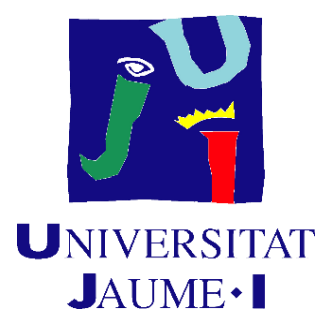

\title{
ESTUDIO DESCRIPTIVO DEL ESPAÑOL NEUTRO DEL DOBLAJE EN SERIES DE FICCIÓN INFANTILES Y JUVENILES: ¿ESTANDARIZACIÓN, POLÍTICA LINGÜÍSTICA O CENSURA?
}

Autora: Gabriela Scandura

Director: Prof. Frederic Chaume

Octubre de 2020 


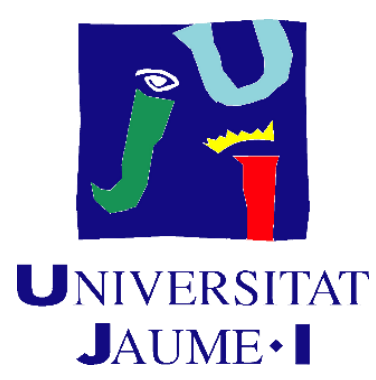

Programa de Doctorado en Lenguas Aplicadas, Literatura y Traducción

Escuela de Doctorado de la Universitat Jaume I

Estudio descriptivo del español neutro del doblaje en series de ficción infantiles y juveniles: ¿Estandarización, política lingüística o censura?

Memoria presentada por Gabriela Scandura para optar al grado de doctora por la Universitat Jaume I

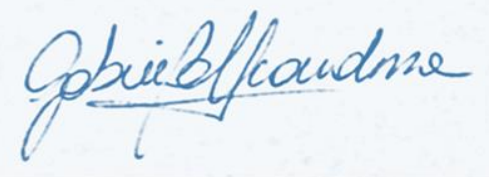

Gabriela Scandura

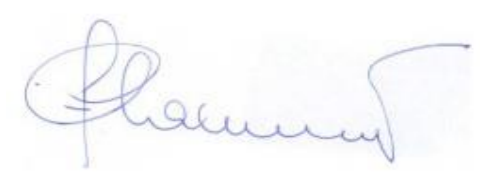

Prof. Frederic Chaume

Castelló de la Plana, octubre de 2020 


\section{Resumen:}

Esta tesis doctoral tiene como finalidad analizar el modelo de lengua conocido como español neutro en el caso del doblaje de series de televisión de imagen real (live-action), dirigidas a un público infantil y juvenil y emitidas entre los años 2006-2016, y determinar si realmente existe un solo español neutro utilizado por los estudios de doblaje de los diferentes países y cuáles son sus principales rasgos lingüísticos. También se propone analizar la influencia de los distintos agentes involucrados directa o indirectamente en el proceso, como distribuidoras, estudios de doblaje, canales de televisión, directores de doblaje o gobiernos, y comprobar si el español neutro que se utiliza es consecuencia solo de las estrategias elegidas por los traductores o también de la influencia de los agentes, que pueden ejercer cierta censura sobre dichas estrategias. El trabajo presenta las características del doblaje y del español neutro, los factores que podrían influir en las decisiones tomadas por los agentes involucrados y los conceptos de ideología, políticas lingüísticas y mecenazgo en la traducción audiovisual, y analiza un corpus paralelo de programas infantojuveniles doblados al español neutro por distintos estudios de diferentes países y disponibles en el sistema de video on demand (VOD), y un corpus comparable con las mismas expresiones extraídas de programas que se producen directamente en español neutro, para poder contrastar lo que se "crea" en español neutro y lo que se dobla a esa misma variedad. Además, se triangulan los datos recogidos en el corpus con las respuestas a encuestas realizadas a directores de doblaje, traductores y actores de doblaje.

Palabras clave: español neutro - doblaje - censura - estandarización - series de TVpolíticas lingüísticas - VOD -mecenazgo 


\section{Agradecimientos}

Me gustaría expresar mi profundo agradecimiento a todas aquellas personas que han colaborado, de un modo u otro, en la realización de esta tesis. En primer lugar, y muy especialmente, al Prof. Frederic Chaume, director de esta investigación, por su ánimo constante, su paciencia infinita, su generosa orientación y su apoyo en todo momento en estos años. También me gustaría agradecer al profesorado del Máster en Investigación en Traducción e Interpretación y a la Escuela de Doctorado de la Universitat Jaume I por su dedicación y por todo lo que me han enseñado. Hago extensiva mi gratitud a los entrevistados, que me permitieron sumar otra arista al análisis del corpus. Y un agradecimiento muy especial a mi familia por su colaboración, comprensión y paciencia, y particularmente a mi hija Sofía y a mi hijo Julián por sus aportes (voluntarios e involuntarios) y su interés en mi tesis. A todos ellos, muchas gracias. 


\section{Contenidos}

INTRODUCCIÓN

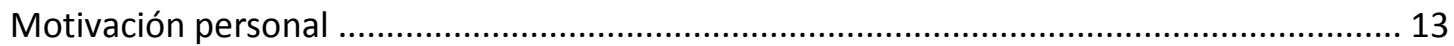

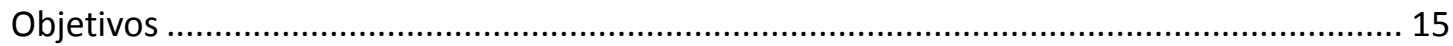

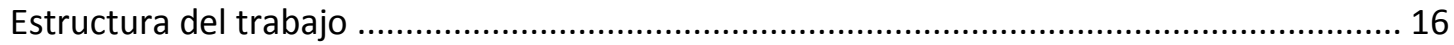

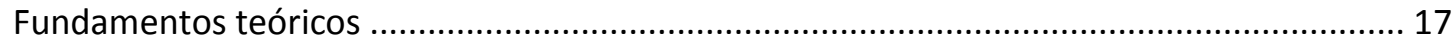

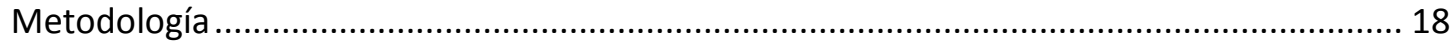

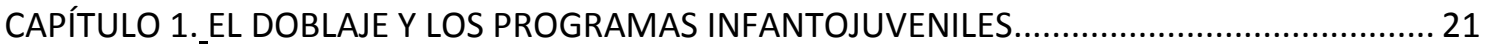

1.1. EL DOBLAJE: UNA MODALIDAD DE TRADUCCIÓN RESTRINGIDA .................................... 21

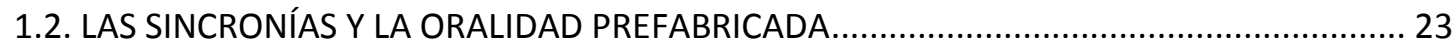

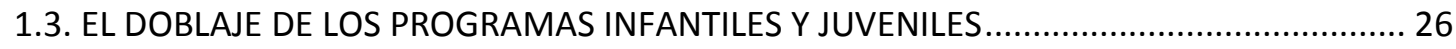

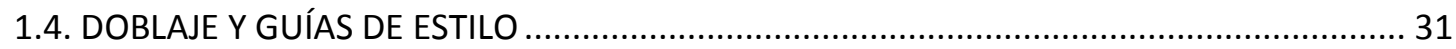

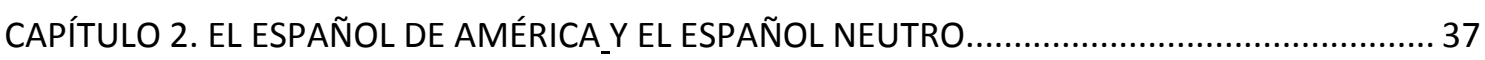

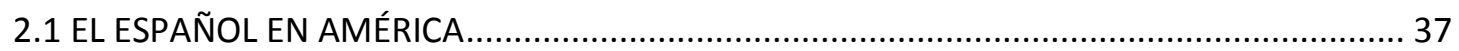

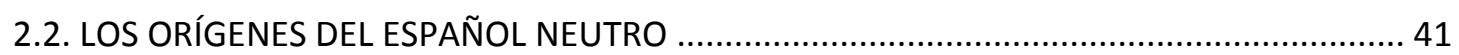

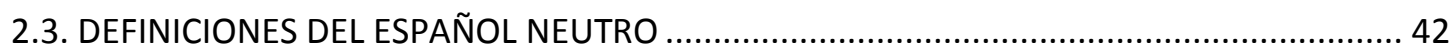

2.4. CARACTERÍSTICAS DEL ESPAÑOL NEUTRO DEL DOBLAJE.................................................... 48

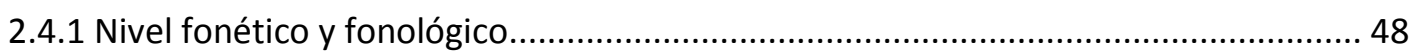

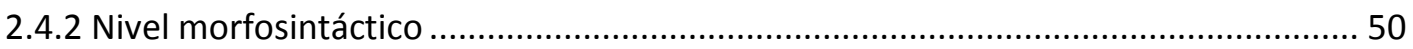

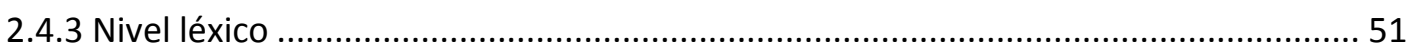

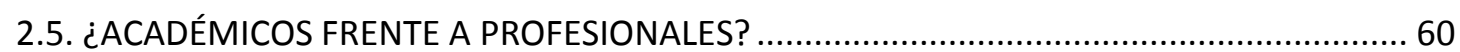

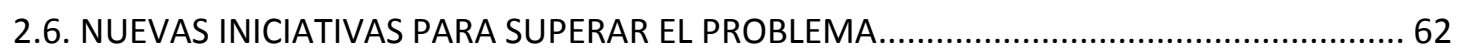

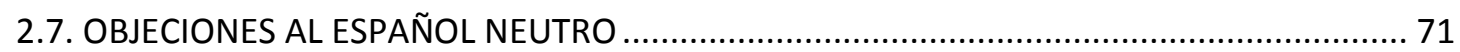

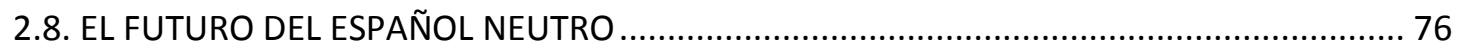

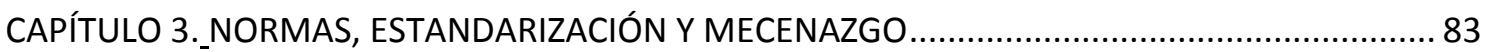

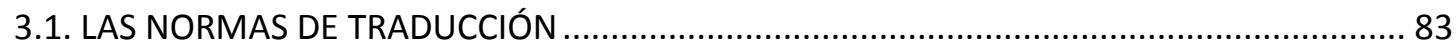

3.2. ESPAÑOL NEUTRO DEL DOBLAJE, DUBBESE Y TERCERA NORMA ….............................. 85

3.3 TÉCNICAS Y NORMAS EN LA TRADUCCIÓN AUDIOVISUAL................................................. 86

3.4. TRADUCCIÓN, MECENAZGO Y ESTANDARIZACIÓN LINGÜÍSTICA .................................. 89

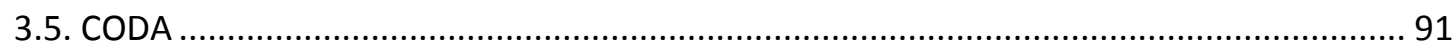

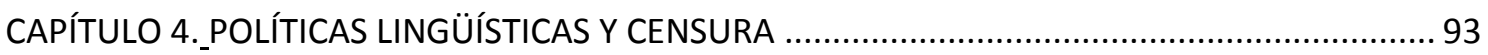

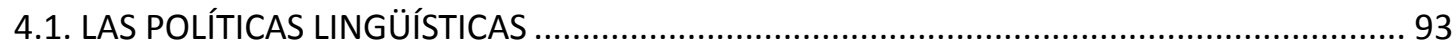

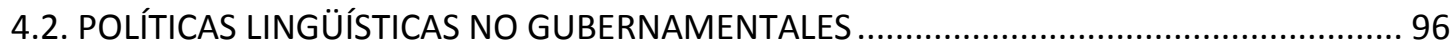

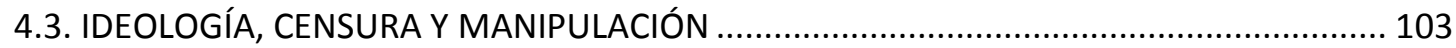

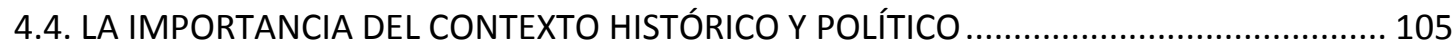

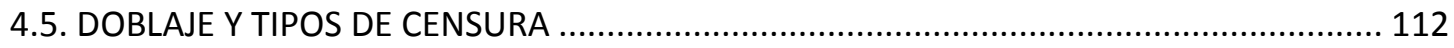


CAPÍTULO 5._METODOLOGÍA Y CORPUS

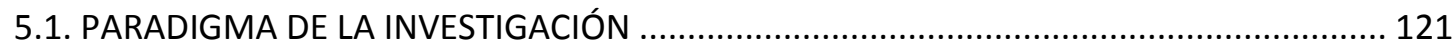

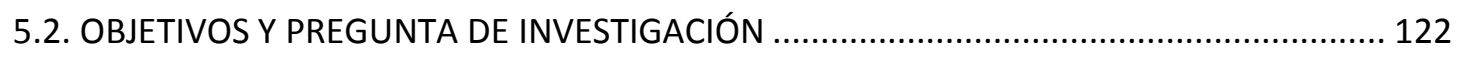

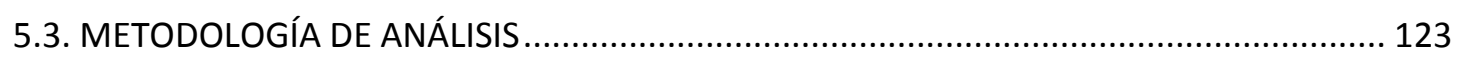

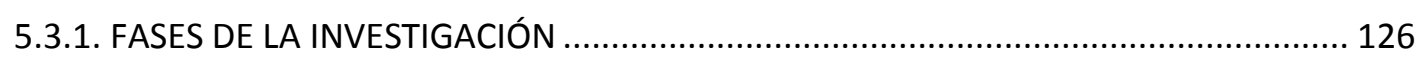

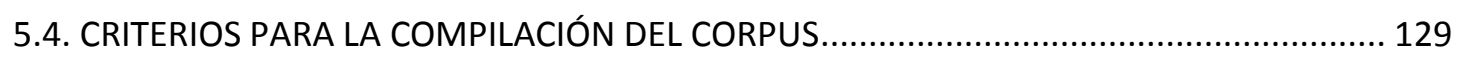

CAPÍTULO 6._ANÁLISIS DE LAS ENTREVISTAS_Y DE LOS CORPUS PARALELO Y COMPARABLE... 137

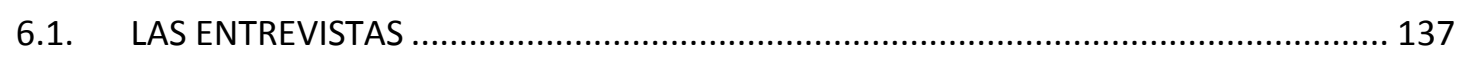

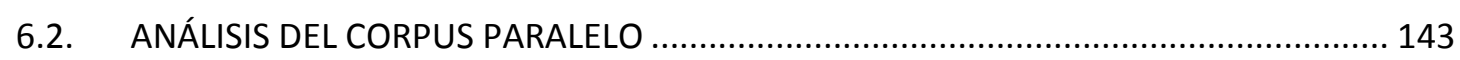

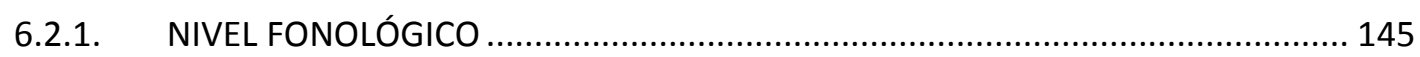

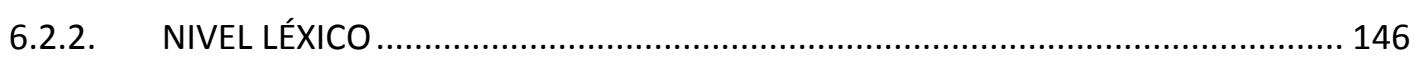

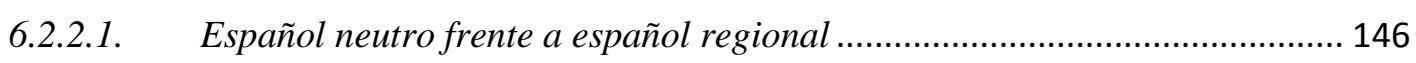

6.2.2.2. Comparación por técnica de traducción ....................................................... 152

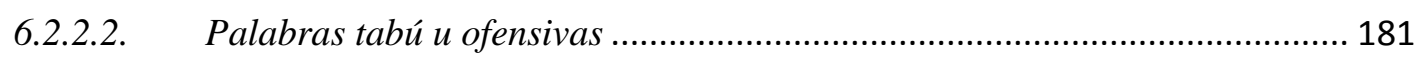

6.2.2.3. Referencias religiosas y culturales (culturemas) ........................................ 184

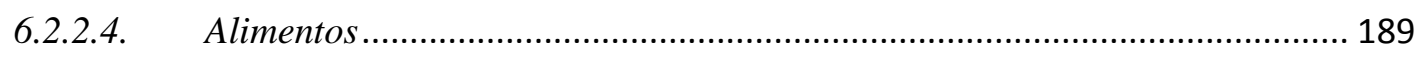

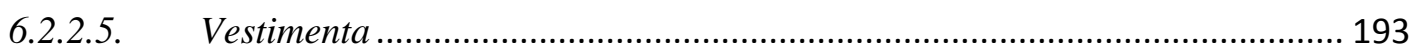

6.2.2.6. Neologismos relacionados con la tecnología ................................................. 196

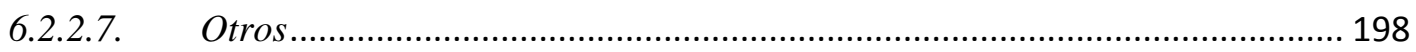

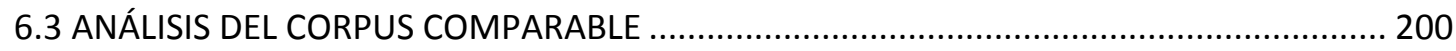

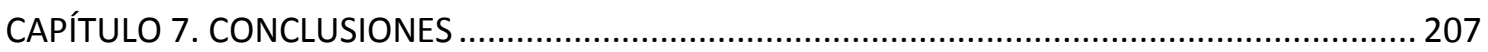

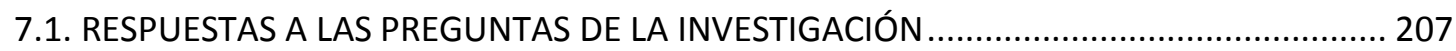

7.2. RESULTADOS: HACIA UN MAPA PROVISIONAL DE LAS NORMAS DE TRADUCCIÓN PARA

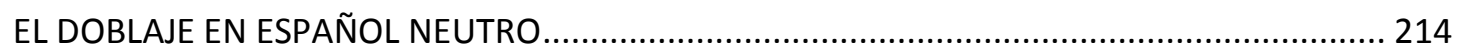

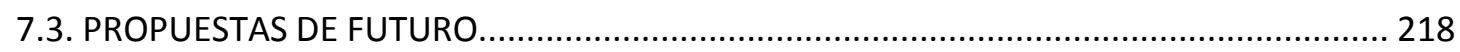

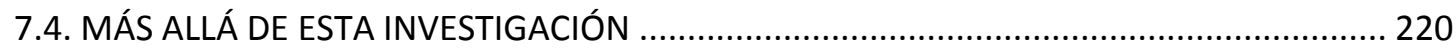

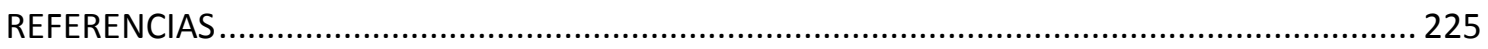




\section{LISTADO DE TABLAS}

Tabla 1 - Taxonomía de restricciones en traducción audiovisual según Martí Ferriol ................ 23

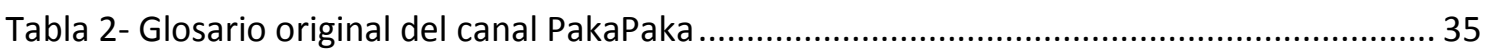

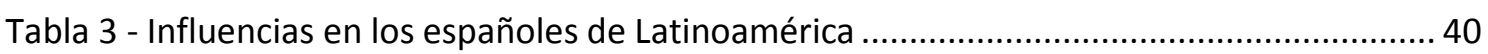

Tabla 4 - Algunas diferencias entre el modelo de lengua del doblaje y el subtitulado de la serie

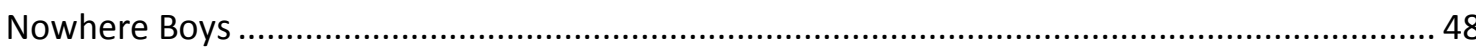

Tabla 5 - Algunos rasgos del español hispanoamericano en el español neutro de doblaje (nivel

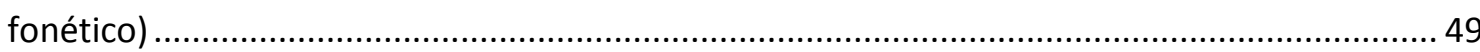

Tabla 6 - Ejemplos de términos utilizados en El Chavo del 8, comparados con las variedades neutra y argentina.

Tabla 7- Comparación entre español mexicano, argentino y peninsular de vocabulario

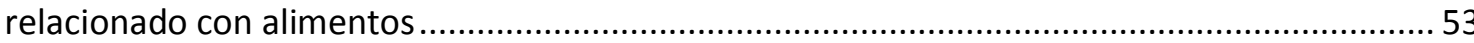

Tabla 8 - Ejemplos de términos que han cambiado en el español neutro del doblaje ................ 55

Tabla 9 - Países con mayor población hispanohablante en América (las cifras son aproximadas)

/ Fuente: El español: una lengua viva (Instituto Cervantes, 2020) ........................................... 56

Tabla 10 - Sinónimos de diferentes términos en los distintos países hispanohablantes,

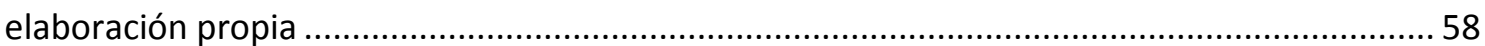

Tabla 11 - Técnicas de traducción según Martí Ferriol (2010) ................................................ 87

Tabla 12 - Comparación del número de funciones con versión subtitulada y doblada de Star

Wars en la semana de su estreno - Fuente: La Nación, 18 de diciembre de 2015 ...................... 98

Tabla 13 - Datos de algunas de las canciones más escuchadas en Latinoamérica en el verano

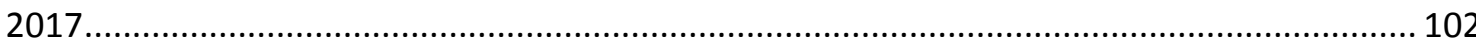

Tabla 14 - Traducciones de Santa Claus según los distintos países latinoamericanos ............. 119

Tabla 15 - Listado de series que componen el corpus paralelo, con sus datos respectivos ..... 133

Tabla 16 - Detalle de los 25 episodios que componen el corpus paralelo.................................. 134

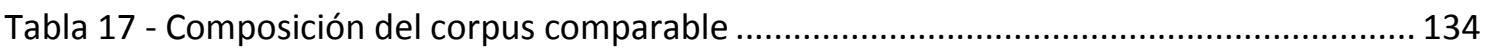

Tabla 18 - Traducciones y acentuación de términos relacionados con el deporte..................... 145

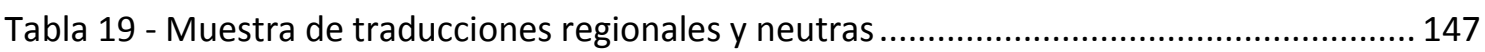

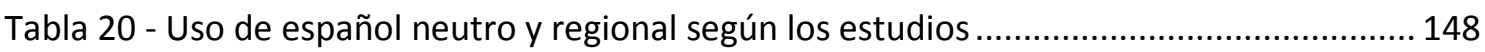

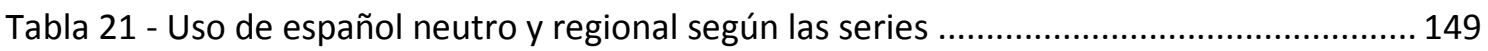

Tabla 22 - Ejemplos de regionalismos hallados en el corpus .................................................... 149

Tabla 23 - Traducción literal por país, en número de casos..................................................... 155

Tabla 24 - Traducción literal por estudio, en número de casos ................................................ 156

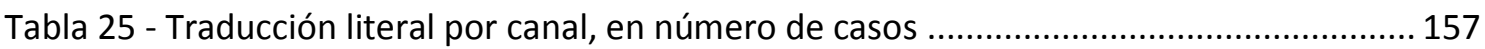

Tabla 26 - Traducción literal según serie, estudio, país y canal ............................................... 157

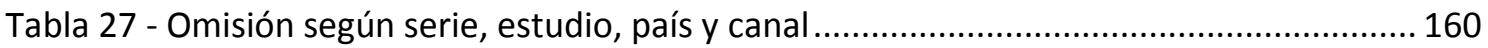

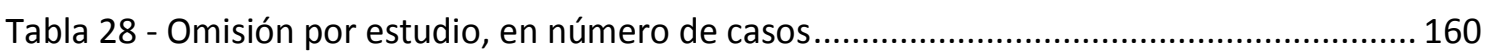

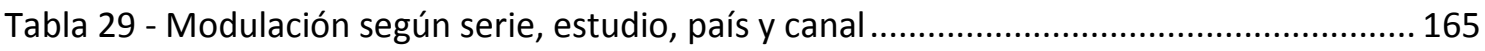

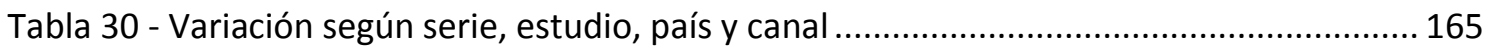

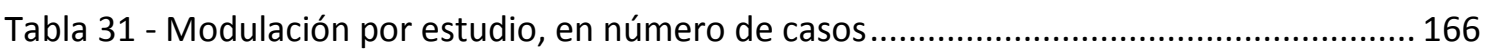

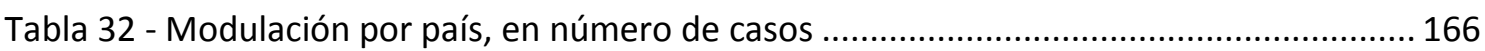

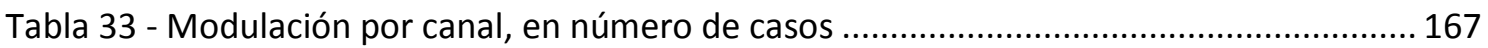

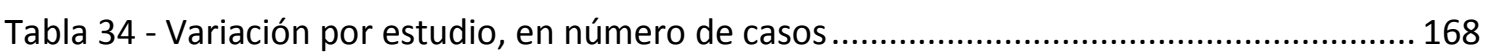

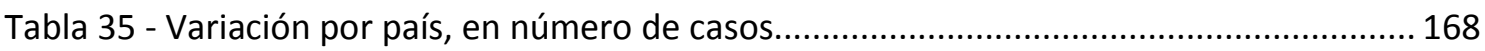


Tabla 36 - Variación por canal, en número de casos

Tabla 37 - Préstamo según serie, estudio, país y canal..................................................... 172

Tabla 38 - Préstamo por estudio, en número de casos...................................................... 172

Tabla 39 - Préstamos por país, en número de casos.......................................................... 173

Tabla 40 - Préstamo por canal, en número de casos .......................................................... 174

Tabla 41 - Generalización según serie, estudio, país y canal ............................................... 176

Tabla 42 - Generalización por estudio, en número de casos .............................................. 177

Tabla 43 - Generalización por país, en número de casos................................................... 178

Tabla 44 - Generalización por canal, en números de casos ................................................ 179

Tabla 45 - Otras técnicas por serie, estudio, país y canal, en número de casos ...................... 180

Tabla 46 - Otras técnicas por serie, estudio, país y canal, en número de casos ...................... 181

Tabla 47 - Traducciones de palabras relacionadas con los conceptos de muerte o agresión .. 182

Tabla 48 -Técnicas utilizadas para los conceptos tabú (en casos) según el campo semántico 183

Tabla 49 - Técnicas utilizadas para los conceptos tabú (en casos), según su relación con la

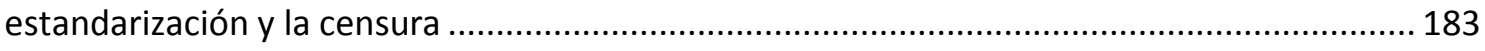

Tabla 50 - Traducciones de algunas referencias religiosas ............................................... 185

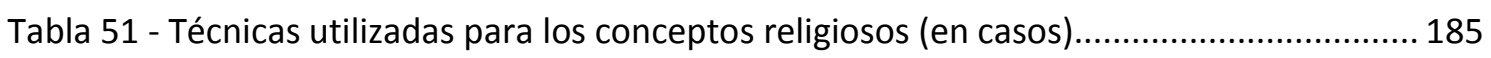

Tabla 52 - Programas doblados con referencias navideñas y sin ellas ................................ 186

Tabla 53 - Técnicas utilizadas para la traducción de alimentos .......................................... 191

Tabla 54 -Distintas traducciones de alimentos según el país y el año .................................. 191

Tabla 55 - Técnicas de traducción de artículos de vestir ..................................................... 194

Tabla 56 - Traducciones de artículos de vestir ............................................................. 194

Tabla 57 - Términos regionales y neutros para traducir alimentos y vestimenta ................... 196

Tabla 58 - Traducción, técnica y variedad utilizada para traducir términos relacionados con la

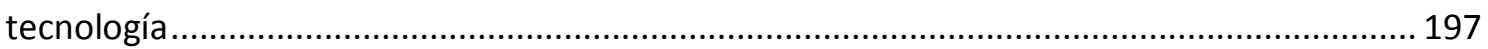

Tabla 59 - Comparación de casos de español neutro y regional....................................... 209

Tabla 60 - Porcentajes máximos y mínimos de utilización de técnicas ................................. 210

Tabla 61 - Técnicas utilizadas (en cantidad de casos) .......................................................... 211 


\section{LISTADO DE ILUSTRACIONES}

Ilustración 1 - Meet \& Greet de un concierto de Big Time Rush - Fuente: www.btr.com .......... 29

Ilustración 2 - Comentario de una abuela en la página de IMDB de la serie Bunk'd ................... 30

Ilustración 3 - Tuits sobre el streaming actual de la serie Big Time Rush ..................................... 30

Ilustración 4 - Guía de estilo de subtitulado del ECl, agosto 2006............................................. 32

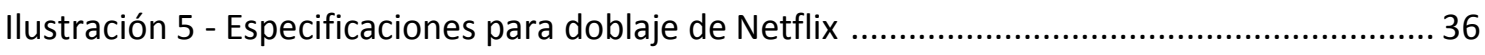

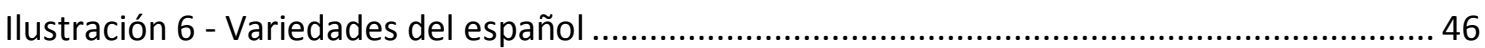

Ilustración 7 - Frecuencia de uso de la palabra "brillantina" en los países de habla hispana ... 53

Ilustración 8 - Nombres que se da al popcorn en Latinoamérica ............................................... 58

Ilustración 9 - Ejemplo de casting de actores latinoamericanos para serie de TV grabada en

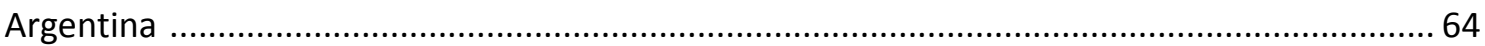

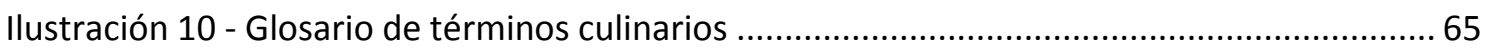

llustración 11 - Traducciones de flush the toilet sugeridas por usuarios en

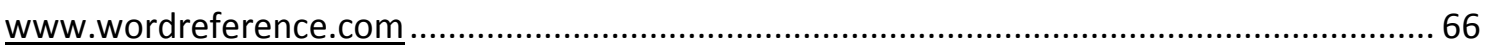

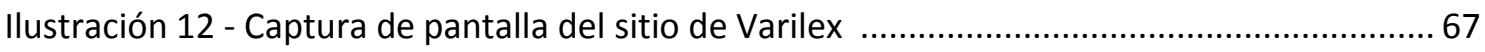

Ilustración 13 - Captura de pantalla de https://carmenchacon.shinyapps.io/PCIC/, basado en

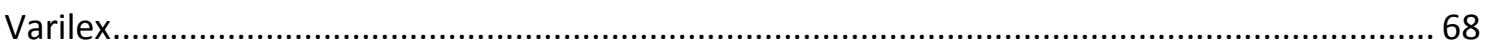

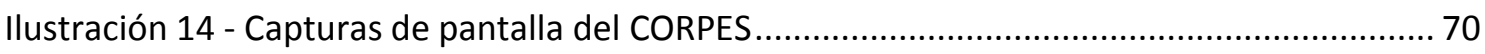

Ilustración 15 - Factores que influyen en la recepción de los programas doblados.................... 71

Ilustración 16 - Tuit de Nickelodeon Latinoamérica - Diciembre de 2018 …................................ 73

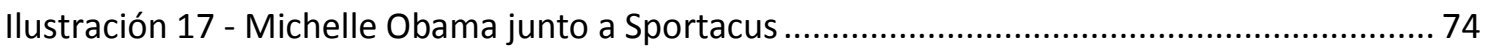

Ilustración 18- Youtubers (dos argentinos y uno colombiano) que forman parte del elenco de

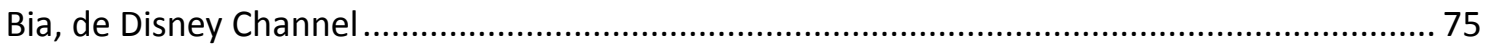

Ilustración 19- Tuits de queja por la falta de diversidad en la nueva serie Bia de Disney Channel

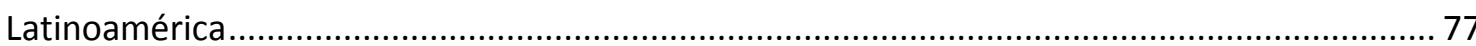

Ilustración 20 - Ejemplo de ideología de género en traducción audiovisual y de la influencia del

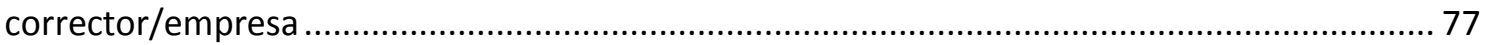

Ilustración 21- Ejemplos extraídos de cadenas de Whatsapp en Argentina- 2017-18 ............... 78

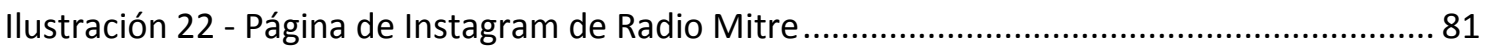

Ilustración 23 - Página web de Radio Mitre (www.radiomitre.cienradioscom) ......................... 81

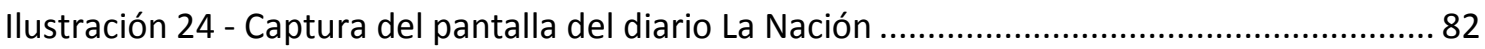

Ilustración 25 - Comparación de la página institucional del canal estatal argentino Pakapaka. 95

Ilustración 26 - Resultados de la votación 2017 en Gran Buenos Aires..................................... 99

Ilustración 27 - Comentarios negativos y positivos sobre Disney ............................................ 105

Ilustración 28 - Captura de pantalla de los comentarios sobre el video de Kermit en YouTube

Ilustración 29 - Flujo de censura en las traducciones para el doblaje infantil y juvenil............. 117

Ilustración 30 - Captura de pantalla del sitio de partners de Netflix ........................................ 120

Ilustración 31 - Países con estudios de doblaje que en la actualidad doblan al español neutro la

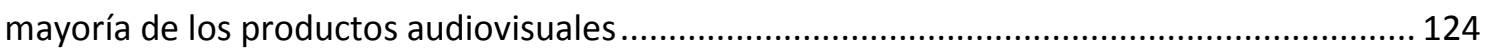

Ilustración 32 - Fuentes de los datos utilizados en esta tesis ................................................. 127

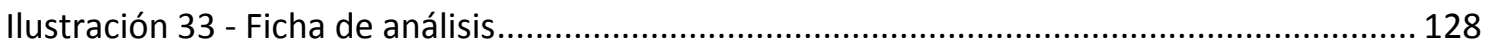

Ilustración 34 - Metodología de análisis: Comparación de las versiones ................................ 128

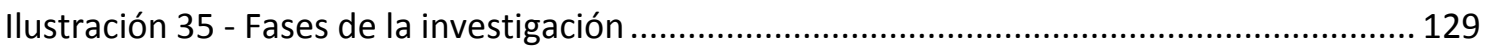


Ilustración 36 - Criterios de selección del corpus paralelo

Ilustración 37 - Capturas de pantalla del sitio Doblaje Wiki (www.doblaje.wikia.com)......

Ilustración 38 - Ficha del doblaje de la versión en español neutro de Odd Squad, de Netflix . 144

Ilustración 39 - Comentario en Twitter sobre la corrección política en ocasión del estreno de

Toy Story 4.

Ilustración 40 - Técnicas utilizadas para la traducción de alimentos (porcentajes) .................. 193

Ilustración 41 - Técnicas utilizadas para la traducción de vestimenta (porcentajes) ................ 195

Ilustración 42 - Tuits en ocasión del final de la serie Soy Luna, de Disney Channel, en protesta

por haber transmitido de inmediato un adelanto de su nueva serie, Bia .............................. 205

Ilustración 43- Proporción de técnicas utilizadas en el corpus .................................................... 211

Ilustración 44 - Flujo de relaciones entre los agentes e instituciones que influyen en la

configuración discursiva del español neutro 
Translation practice is never a neutral act of communication.

Translation is not, and never has been, an innocent activity.

Jorge Díaz Cintas (2012)

\section{INTRODUCCIÓN}

\section{Motivación personal}

Como parte del Máster de Investigación en Traducción e Interpretación de la Universitat Jaume I, tuve la oportunidad de realizar un trabajo final cuyo objetivo fue analizar la influencia de los distintos agentes involucrados directa o indirectamente en el proceso de doblaje latinoamericano de programas infantiles y juveniles de televisión (traductores, distribuidoras, estudios de doblaje, canales de televisión, directores y dobladores, gobiernos, etc.) e intentar determinar si el español neutro que se utiliza en el doblaje de este género audiovisual es producto solo de estrategias recurrentes de traducción o también de la influencia de los demás agentes, que podrían ejercer cierta censura sobre dichas estrategias. Evalué los factores que podían influir en las decisiones tomadas por los distintos agentes e intenté determinar si realmente existe un solo español neutro utilizado para el doblaje, en concreto, el de las series de televisión. Durante mi investigación quedó claro que el tema era mucho más vasto de lo que sospechaba, dado que los diferentes canales de televisión disponían de producciones propias dobladas por sus propios estudios o por estudios externos y también de producciones que ya compraban dobladas. A eso se sumaban otros factores de gran importancia: los estudios estaban ubicados en distintos países de Latinoamérica, e incluso en Estados Unidos; los gobiernos y distribuidoras tenían políticas lingüísticas específicas; existe una gran movilidad entre los directores de doblaje y dobladores debido a cuestiones políticas como la crisis en Venezuela; la tecnología avanzaba a pasos agigantados y modificaba tanto el proceso del doblaje en sí como el léxico utilizado, y otros aspectos que afectaban al doblaje de un modo u otro.

Las conclusiones de mi investigación confirmaron mi hipótesis original: se notaba la influencia de quienes realizaban el encargo de traducción, de los gobiernos y de quienes se ocupaban luego del doblaje. Así como en algunos casos se utilizaba la estandarización en pos de un español comprensible en toda América (y sumo aquí a Estados Unidos, ya que algunos canales norteamericanos transmiten la versión española en su sistema SAP Second Audio Program), también existían casos de censura por parte de algunos de los agentes involucrados. 
Desde la presentación de mi Trabajo Final de Máster hubo otros cambios significativos, como distintas elecciones presidenciales en varios países y el uso cada vez más masivo del sistema de Video On Demand, o VOD ${ }^{1}$, como es el caso de la plataforma Netflix ${ }^{2}$, en detrimento de los canales de televisión por aire o por cable. Por ese motivo, decidí profundizar mi investigación concentrándome en dos aspectos primordiales: por un lado, el léxico del español neutro que se usa en el doblaje de programas de ficción infantojuveniles, y por otro, la influencia de los distintos agentes involucrados en dicho proceso, utilizando un corpus compuesto por programas live-action para niños $\mathrm{y}$ adolescentes que se pueden ver mediante el sistema de VOD, o de TV a la carta, y que suele ofrecer el mismo doblaje que los canales por aire o por cable, para que el estudio resultara lo más representativo posible.

La elección de un corpus compuesto por programas de ficción, o imagen real, se debió a que en mi Trabajo Final de Máster analicé tanto series de animación como de imagen real, y resultó evidente que no se utilizaban los mismos criterios en la traducción y el doblaje de unas y otras. Además, el género de las series live-action atraviesa una época de rápida expansión:

As the proliferation of devices and platforms continues to shape kids' viewing behavior, the long-form live-action renaissance shows no sign of slowing down. Buyer demand for binge-worthy scripted children's programming is higher than ever. Netflix alone is expected to spend upwards of US $\$ 15$ billion on content this year, according to Wall Street analysts, with a significant proportion undoubtedly heading to the kids and family space. In particular, demand for sophisticated, single-cam dramas for tweens, teens and the family co-viewing audience is leading many animation-focused companies to expand their remits with live-action content. ${ }^{3}$

${ }^{1}$ Plunkett, J. (2016): "Third of TV watching among younger viewers is via on-demand services", The Guardian, 11 de julio de 2016 (https://www.theguardian.com/media/2016/jul/11/third-of-tvwatching-among-younger-viewers-done-on-demand-services, consultado el 23 de enero de 2017); Easton, J. (2020): Disney+ exceeded 30 million downloads in Q4, 16 de enero de 2020, https://www.digitaltveurope.com/2020/01/15/disney-exceeded-30-million-downloads-in-q4/ (consultado el 23 de enero de 2020)

${ }^{2}$ La plataforma Netflix contaba en 2017 con 100 millones de suscriptores en todo el mundo: 49,4 millones en Estados Unidos y 44,4 millones en el resto del mundo, y con 20 millones de suscriptores en Latinoamérica a fines de 2018. (Spangler, T. "Netflix Beats Q4 Subscriber Forecasts With Largest Quarterly Gain in Its History", Variety, 31 de enero de 2017, http://variety.com/2017/digital/news/netflix-q4-2016-earnings-1201962823/; Fry, A. "Lat-Am SVOD growing fast, Netflix to maintain lead", Digital TV Europe.com, 4 de abril de 2019, https://www.digitaltveurope.com/2019/04/04/lat-am-sVOD-growing-fast-netflix-to-maintain-lead/, consultados el 8 de abril de 2019)

${ }^{3}$ Dickson, J. (2019): "Why Animation Prodcos Are Trying Out Live Action", 18 de abril de 2019, Kidscreen (http://kidscreen.com/2019/04/18/why-animation-prodcos-are-trying-out-live-action/, consultado el 13 de julio de 2019) 


\section{Objetivos}

Este trabajo tiene como objetivo principal analizar los rasgos léxicos del español neutro que se utiliza en el doblaje de series de televisión infantojuveniles de imagen real (liveaction) que pueden verse a través del sistema de VOD (Netflix, Cablevisión On Demand, FoxPlay, HBO, etc.) en Latinoamérica, así como el grado de influencia de los agentes involucrados en el proceso industrial del doblaje, que acaban conformando y decidiendo ese modelo de lengua.

Con ese fin se llevará a cabo una detallada descripción del español neutro y se intentará:

a) investigar si existe un español específico para el doblaje de programas infantojuveniles, y en particular de programas de imagen real, y describir los rasgos lingüísticos del mismo, en especial, el nivel léxico y el nivel fonético de dicho español neutro;

b) demostrar que el español neutro que se utiliza en el doblaje de programas infantojuveniles no solo es consecuencia de las estrategias utilizadas por los traductores (y de la herencia recibida), sino también de la influencia de los agentes involucrados, y determinar qué tan fuerte es dicha influencia sobre las estrategias traductoras, hasta el punto de preguntarnos si se podría hablar de censura;

c) evaluar los factores políticos, sociales, empresariales, comerciales, ideológicos, traductológicos, etc. que influyen en el proceso de doblaje, desde el encargo de traducción hasta el producto final que sale al aire.

Lamentablemente, resulta imposible hacer una radiografía del español neutro del doblaje en su totalidad, ya que por un lado se necesitaría un corpus ingente del que no disponemos y que sería demasiado amplio para poder analizar en una tesis doctoral, y que, por otro, dado que los doblajes al español neutro se realizan en varios países diferentes, tendríamos que tener acceso a un número significativo de producciones dobladas en cada uno de esos países, lo que dificulta realizar una radiografía completa de este fenómeno. Por lo tanto, en esta tesis me ceñiré al nivel léxico del español neutro, y en concreto, a una serie de palabras que por mi experiencia profesional como traductora para doblaje resultan conflictivas, así como especialmente a los campos semánticos a los que pertenecen. Del mismo modo, indagaremos en cuáles son las técnicas de traducción de esas palabras y de las frases en las que se encuentran. Asimismo, describiremos brevemente el nivel fonético de las producciones estudiadas. 


\section{Estructura del trabajo}

El trabajo está estructurado de la siguiente manera:

El capítulo 1 presenta el doblaje como modalidad de traducción audiovisual y describe algunas de sus características específicas, como las restricciones y las sincronías, y particularmente la oralidad prefabricada y el modelo de lengua del doblaje. También ofrece una breve descripción de los programas infantojuveniles y su doblaje.

El capítulo 2 está dedicado a los orígenes, definiciones y particularidades del español neutro en general y del español neutro del doblaje en particular.

El capítulo 3 analiza la relación entre el doblaje y la estandarización y entre la traducción y el mecenazgo, y presenta las normas y técnicas de traducción aplicadas al doblaje y la dicotomía domesticación-extranjerización.

El capítulo 4 describe los conceptos de ideología, políticas lingüísticas y censura aplicados a la traducción audiovisual en general y al doblaje en particular.

El capítulo 5 presenta la metodología utilizada y contiene una descripción detallada del corpus (especificaciones de cada programa, años de emisión, país de origen, estudio de doblaje, etc.).

El capítulo 6 presenta el análisis de los datos obtenidos, y finalmente, en el capítulo 7 encontraremos las conclusiones a las que se arriba con los datos que arroja el análisis del corpus.

Esta tesis incluye además 6 anexos. El Anexo 1 contiene las fichas del corpus paralelo y del corpus comparable o de contraste; el Anexo 2 muestra las estadísticas derivadas de los datos obtenidos en el análisis del corpus paralelo; el Anexo 3 detalla las preguntas formuladas a los entrevistados; el Anexo 4 presenta una amplia lista de términos utilizados en el español neutro y los compara con los vocablos utilizados en los distintos países latinoamericanos; en el Anexo 5 se reproducen las leyes y decretos argentinos relacionados con el doblaje, y el Anexo 6 presenta la variedad de españoles en la programación musical de una radio de Argentina.

\section{Corpus}

Goris (1993: 187) sostiene que:

dubbing is culturally linked. Thus, every aspect should be examined in different cultural situations (different countries, time periods, etc.) and in relation to the circumstances of specific cultural settings. 
El corpus de trabajo de esta tesis se ha confeccionado, por lo tanto, teniendo en cuenta los distintos países y estudios que doblan al español neutro el material audiovisual para niños y adolescentes en lengua inglesa que se transmite a través del sistema de VOD y que se produjo y dobló entre los años 2006 y 2016. Se ha creado un corpus paralelo TOTM (inglés-español) en el que se han utilizado dos o tres episodios (según su duración) de nueve series dobladas en distintos estudios de los países de habla hispana que realizan doblaje (Argentina, Colombia, Chile, Estados Unidos ${ }^{4}$, México y Venezuela) ${ }^{5}$, lo que da al trabajo una representatividad significativa -al menos de tipo cualitativo-, y se ha analizado un léxico determinado. Para seleccionarlo, se recurrió a las palabras y expresiones que durante el año 2016 habían resultado problemáticas en el trabajo diario de traducción audiovisual para doblaje de la autora (una temporada completa de cuatro series infantojuveniles) y que habían llevado a correcciones o a consultas con los supervisores. También se incluyeron los términos que pueden considerarse tabú para los niños, para lo cual se recurrió a una taxonomía específica de conceptos tabú y el léxico relacionado (Allan y Burridge, 2006).

Asimismo se creó un corpus comparable, o de contraste, con los mismos vocablos (o vocablos de las mismas categorías) extraídos de programas que se producen directamente en español neutro (Violetta, de Disney Channel; O11CE, de Disney XD y Yo soy Franky, de Nickelodeon $)^{6}$, como posibilidad de contrastar lo que se "crea" en español neutro y lo que se dobla a esa misma variedad. Además, se triangularon los datos recogidos en el corpus con las respuestas a encuestas realizadas a directores de doblaje, traductores y actores de doblaje.

\section{Fundamentos teóricos}

Esta tesis se enmarca dentro de los Estudios Descriptivos de la Traducción (EDT), pues su finalidad es describir las características del español neutro que se utiliza en las traducciones para doblaje de programas infantojuveniles en los distintos países de América (diferente del español neutro que podemos encontrar en otros tipos de

\footnotetext{
${ }^{4}$ Estados Unidos no es un país de habla hispana, pero lo debemos incluir en este estudio, pues es uno de los centros neurálgicos del doblaje al español neutro. Se considera que el mayor centro de doblaje es Miami, aunque existen algunos estudios o sedes de estudios de otros países en otras ciudades, como Nueva York, Los Ángeles y Connecticut. En Los Ángeles se doblaron varias series familiares en los años 80 , pero en la actualidad los estudios angelinos se dedican, por lo general, a películas, documentales, animé y series para adultos (ver www.doblaje.wikia.com)

${ }^{5}$ No se ha incluido a países como Cuba o Puerto Rico porque ya no realizan doblajes televisivos.

${ }^{6}$ Violetta, Martín Saban-Jorge Nisco, 2012-2015; Yo soy Franky, William Barragán, 2015-2016; O11CE, Jorge Edelstein, 2017-presente
} 
traducciones, como las literarias o las comerciales, por ejemplo), y una vez realizado ese análisis, investigar los motivos que hay detrás de la elección de ciertos términos. Se basa también en la Teoría de los Polisistemas, dado que se concentra en un subsistema (programas doblados para niños y adolescentes) dentro del sistema audiovisual de la cultura meta (en general considerada una sola a pesar de su diversidad lingüística, social y cultural y de su extensión geográfica), al que se suma, a modo de comparación, otro subsistema compuesto por textos audiovisuales infantojuveniles producidos en la cultura meta directamente en español. Además, posee un enfoque sociológico, pues cuenta con información extraída a los agentes del proceso, que luego se triangula con los datos textuales obtenidos y con la bibliografía sobre esta cuestión.

El trabajo se basa en tres pilares fundamentales. En primer lugar, la lengua española y el español neutro en particular. A pesar de que se ha escrito ya una buena cantidad de artículos y libros sobre el tema, no existen diccionarios de español neutro; sí existen diccionarios de regionalismos, pero de ese modo el español neutro termina por definirse por lo que no debe usarse. El segundo pilar es el doblaje en sí, con sus características específicas, como las sincronías o la oralidad prefabricada. Y el tercer pilar lo componen algunos aspectos relacionados con la traducción (nociones de traductología, según Hurtado Albir, 2001) que resultan de importancia significativa para el análisis de los ejemplos: técnicas de traducción aplicadas al doblaje, aspectos tabú del lenguaje, ideología, mecenazgo, censura, iniciadores y encargos de traducción, etc.

Es necesario resaltar que descriptivismo e ideología no son dos conceptos opuestos ni excluyentes. Como señalan Chaume y Richart-Marset (2015: 17), el análisis ideológico "se puede llevar a cabo con muchas más garantías si los datos que se someten a la lupa de la ideología proceden de un estudio descriptivo sistemático y coherente", y esa es, precisamente, la finalidad de esta tesis.

\section{Metodología}

Chaume y Richart-Marset (2015: 18) explican que:

la confección de catálogos y posteriores corpora, los datos cuantitativos obtenidos tras el análisis, la búsqueda de normas de traducción en esos datos, el cruce necesario con los datos extraídos de las encuestas pertinentes o de la información extratextual disponible, la triangulación de ambos tipos de datos con la bibliografía existente, todos ellos pasos metodológicos clave del método descriptivista, deben ser ahora solamente el primer escalón que nos lleve a realizar un segundo análisis ideológico, una valoración que contemple los casos de manipulación, intencionados o no, y que nos permita saber más sobre los procesos de traducción audiovisual y sobre la agenda de sus ejecutores.

El léxico analizado en esta tesis está compuesto por palabras iguales, similares o de las mismas categorías de las que resultaron problemáticas a la hora de traducirlas del original inglés al español neutro. Dichas expresiones fueron detectadas en los episodios de una 
temporada completa de cuatro series infantojuveniles, y la expresión española correspondiente resultó problemática por la ausencia del término en español (porque el concepto no existía, por ejemplo), porque ese concepto recibe distintos nombres en las diferentes regiones de América (como sucede con la ropa o los alimentos), por la informalidad del término fuente, es decir, por su adscripción a un registro informal, coloquial o vulgar (y la consecuente dificultad de encontrar una palabra informal que sirva para todas las regiones), por la posibilidad de que resultara ofensivo, por tratarse de una referencia cultural o religiosa, etc.

Se analizó la estrategia de traducción utilizada, de acuerdo con lo expuesto en los capítulos teóricos, y se compararon las traducciones según la serie, el país, el canal de emisión original y el estudio. También se analizó si la traducción elegida correspondía al español neutro o a un español más regional, es decir, si se trataba de un término más local que no se utilizaba en la mayoría de los países latinoamericanos.

La revisión teórica del trabajo y el análisis del léxico estudiado se basó en artículos académicos y periodísticos, conferencias, blogs, publicaciones en redes sociales y libros sobre el tema, tanto académicos como profesionales (escritos por dobladores y directores). 


\section{CAPÍtUlO 1.}

\section{EL DOBLAJE Y LOS PROGRAMAS INFANTOJUVENILES}

\subsection{EL DOBLAJE: UNA MODALIDAD DE TRADUCCIÓN RESTRINGIDA}

El doblaje es una de las dos modalidades más antiguas de traducción audiovisual, junto con la subtitulación, y "consiste en la traducción y ajuste de un guion de un texto audiovisual y la posterior interpretación de esa traducción por parte de los actores, bajo la dirección del director de doblaje y los consejos del asesor lingüístico, cuando esa figura existe" (Chaume, 2004b: 32).

En 1928 dos ingenieros de la Paramount consiguieron grabar un diálogo sincrónico con los labios de los actores de la película The Flyer en Estados Unidos. Enseguida se vio la viabilidad comercial de esta modalidad de traducción. En 1929, Radio Pictures dobló Río Rita al español (con una mezcolanza significativa de acentos y registros), al alemán y al francés. La Metro, United Artists, Paramount y Fox empezaron de inmediato a realizar doblajes. La mala calidad de éstos, junto con las objeciones artísticas de que cara y voz eran inseparables, produjo una reacción adversa ante estos primeros intentos (Chaume, 2012).

A principios de los años 30, la industria del doblaje se traslada a Europa para cubrir las traducciones a las grandes lenguas europeas; es entonces cuando la compañía Paramount realiza en Francia el primer doblaje de una película al español peninsular ${ }^{7}$ : Entre la espada y la pared (Devil and the Deep, Marion Hering, 1932) en los estudios de Joinville, en París. Pronto el doblaje al español peninsular comienza a llevarse a cabo en territorio español de forma definitiva. Se cree que el primer doblaje se realizó en Barcelona, también en 1932 (en plena Segunda República), en los estudios Trilla-la Riva, donde se dobló el filme Rasputin, Dämon der Frauen (Adolf Trotz, 1932).

Un poco más tarde, en la década del 40, Estados Unidos comienza a realizar doblajes al español con elencos y estudios mexicanos, mientras que Disney encarga el doblaje de varias películas (Pinocho, Bambi, Dumbo) al director argentino Luis César Amadori. En

\footnotetext{
${ }^{7}$ La expresión "español peninsular" será utilizada en esta tesis para referirse a la variedad que se utiliza en España ya que, a pesar de que engloba distintas sub-variedades, implica una descripción geográfica como "latinoamericano". También se lo conoce con otros nombres, como castellano, español de España, español ibérico o español de Europa, que es un término más común en la industria de la localización que en lo académico.
} 
Europa, el doblaje cobra gran importancia en países como España o Italia, mientras que otros países prefieren la subtitulación. En Latinoamérica, el doblaje crece principalmente en los estudios mexicanos, aunque también hay mercados pequeños en países como Cuba o Puerto Rico, y décadas más tarde se expande a otros mercados, como Venezuela en los años 60, Argentina a partir de la década del 80 o Chile a partir de la del 90. Al promediar los años 2000, la disminución del nivel educativo en algunos países y el surgimiento de una corriente populista en gran parte de Latinoamérica dan lugar a un cambio radical en la televisión por cable: muchos canales cambian su tradicional método de traducción audiovisual, la subtitulación, por el doblaje. Lo mismo ocurre con muchas películas para cine (antes solo se doblaban las que eran para niños), y el crecimiento del doblaje aún continúa. ${ }^{8}$

A diferencia de los subtítulos, el doblaje es, en cierto sentido, una modalidad de traducción más restringida (Mayoral et al. 1988). Mientras que en ambos casos resulta fundamental prestar atención a todos los sistemas sígnicos transmitidos a través del canal acústico y del canal visual, el doblaje tiene la particularidad de requerir del traductor un nivel de adaptación aún mayor (Richart-Marset, 2012). Quien subtitula sabe que a veces es difícil reducir el contenido de las oraciones para que quepa en un subtítulo o que un subtítulo no alcanza para explicar un concepto que no tiene fácil traducción. Sin embargo, quienes traducen para doblaje son conscientes de las dificultades extra que enfrentan. En primer lugar, no es sencillo aceptar que, después de aprender que no se debe traducir literalmente, que la traducción debe sonar natural en la lengua meta y que la voz pasiva no se utiliza tanto en español como en inglés, etc., uno tiene que renunciar a muchas de las estrategias aprendidas para hacer todo lo contrario en pos de que haya una bilabial en la lengua meta donde hay una en la lengua origen, o de hacer coincidir una palabra en el momento justo en que se pronuncia en la lengua origen. Quienes se dedican tanto a la subtitulación como al doblaje suelen concordar en que el doblaje resulta más complicado como tarea de traducción. Esto siempre y cuando sea el mismo traductor quien realiza el ajuste, como requieren muchos estudios de doblaje (aunque el proceso difiere en los distintos países, Chaume 2012).

El doblaje suele ser un trabajo en equipo: el traductor inicia el proceso (después de recibir el encargo de traducción), y le seguirá la labor del ajustador (si no es él mismo), el/los supervisor/es (del estudio de doblaje/canal o del cliente), el director, el técnico y los doblajistas (en Argentina y en España se los llama "actores y actrices de doblaje"). Finalmente, el doblaje terminado es evaluado por los departamentos de calidad de la empresa o el cliente. Dada la intervención de tantos agentes en el proceso (RichartMarset, 2012), el producto terminado con frecuencia es distinto a la traducción original. El traductor puede conocer los cambios de sus supervisores anteriores al doblaje en sí, pero una vez que el guion entró en cabina, pocas veces se recurre al traductor antes de modificarlo. Por ejemplo, los directores de doblaje son expertos en cambiar frases para respetar la sincronía fonética tratando de no modificar los sentidos. Pero si el traductor

\footnotetext{
${ }^{8}$ www.iadacargentina.org (consultado el 2 de abril de 2018)
} 
no es un buen ajustador y el director de doblaje se ve obligado a hacer grandes cambios, podría ocurrir que cambiara sentidos accidentalmente.

Cuando hablamos de modalidad restringida, nos referimos a que la traducción para el doblaje está sometida a respetar más restricciones que otras modalidades y variedades de traducción. Por ejemplo, las conocidas tres sincronías (vid. infra), el modelo de lengua del doblaje, la coherencia con las imágenes, la coherencia con otros códigos de significación acústicos, etc. Martí Ferriol (2013) ofrece una taxonomía de restricciones en traducción audiovisual que se resumen en este listado:

\begin{tabular}{|l|l|l|}
\hline \multicolumn{1}{|c|}{ RESTRICCIONES } & \multicolumn{1}{|c|}{ DEFINICIÓN } & \multicolumn{1}{c|}{ EJEMPLO } \\
\hline Profesionales & Condiciones laborales & $\begin{array}{l}\text { Guías de estilo, limitaciones de } \\
\text { tiempo, remuneración }\end{array}$ \\
\hline Formales & $\begin{array}{l}\text { Convenciones propias del tipo } \\
\text { de TAV }\end{array}$ & $\begin{array}{l}\text { Sincronía fonética, isocronía, } \\
\text { etc. }\end{array}$ \\
\hline Lingüísticas & De la lengua en sí & Oralidad, idiolectos, etc. \\
\hline Semióticas o icónicas & $\begin{array}{l}\text { Asociadas con códigos de } \\
\text { significación no lingǘsticos }\end{array}$ & $\begin{array}{l}\text { Canciones, iconografía, } \\
\text { proxémica, fotografía, etc. }\end{array}$ \\
\hline Socioculturales & $\begin{array}{l}\text { Asociadas a sistemas culturales } \\
\text { diferentes }\end{array}$ & $\begin{array}{l}\text { Culturemas verbalizados o } \\
\text { icónicos }\end{array}$ \\
\hline Restricción nula & Ausencia de restricción & - \\
\hline
\end{tabular}

Tabla 1 - Taxonomía de restricciones en traducción audiovisual según Martí Ferriol

Cualquier estudio que describa un modelo lingüístico del doblaje o las técnicas de traducción utilizadas en el mismo debe tener en cuenta necesariamente estas restricciones, que a veces son la causa directa del uso de ciertas estrategias de traducción.

\subsection{LAS SINCRONÍAS Y LA ORALIDAD PREFABRICADA}

Para tener éxito, todo doblaje con fines comerciales debe lograr que los distintos códigos que componen el material audiovisual concuerden de forma tal que el producto final cumpla con la misma función en la lengua meta (en los casos de traducción equifuncional, que son los abrumadoramente mayoritarios en la industria). Por ejemplo, el código linguiístico, el código iconográfico, el código de planificación y el código de movilidad interactúan entre sí cuando el traductor se enfrenta a primeros y primerísimos planos de un personaje que articula unas palabras que contengan consonantes labiales o vocales 
abiertas. $\mathrm{O}$ a planos en los que un personaje ejecuta un signo cinésico con un significado convencional en la lengua fuente. En estos casos, es prioritario que la traducción cumpla con una serie de sincronías. Chaume (2004a) explica que existen tres tipos de sincronías:

1) la sincronía fonética o labial, es decir, que el parlamento traducido concuerde con los movimientos articulatorios de la boca de los actores y actrices originales;

2) la isocronía, o ajuste de la duración de cada frase entre pausa y pausa, y

3) la sincronía cinésica, o el ajuste de los parlamentos a los movimientos de los personajes en pantalla.

El doblaje se rige por ciertas prioridades y está sometido a ciertas restricciones (Zabalbeascoa, 1993; Martí Ferriol, 2010). Zabalbeascoa entiende por prioridades, fundamentalmente, la función de la traducción. Pero podríamos entender ambos términos casi como sinónimos: una prioridad de la traducción para el doblaje es cumplir con el ajuste, que a su vez es una de sus grandes restricciones. Por ello, en este trabajo, entenderemos prioridad y restricción como sinónimos, y nos referiremos a ellas de manera global como restricciones. Dichas restricciones se dan a distintos niveles. Por ejemplo, no tienen la misma jerarquía los distintos códigos de significación presentes en los textos audiovisuales (lingüístico, paralingüístico, musical, iconográfico, de movilidad, etc.), ni tampoco todos los códigos emitidos a través de un canal en particular. En el canal acústico, el código principal es normalmente el lingüístico (Chaume, 2001: 77-78). En cuanto a los estándares de calidad relacionados con la traducción, para Chaume (2005) son:

* el ajuste, o sea el respeto a los movimientos bucales y corporales y a la duración de los enunciados, como se acaba de relatar;

* la confección de unos diálogos creíbles y verosímiles;

* la coherencia entre palabras e imágenes y la cohesión de los diálogos; y

* la fidelidad al texto origen (como en la gran mayoría de variedades de la traducción en las que se pretende conseguir el mismo efecto y función en la lengua meta, traducciones equifuncionales, Nord, 1997). Este estándar no se cumple en los comentarios libres, llamados también gag dubbing o parodic dubbing, aunque estos no tienen fines comerciales.

Chaume afirma que la isocronía ocupa "el orden más alto de la jerarquía de normas que configuran el acuerdo tácito entre emisor y receptor" (Chaume, 2005: 8-9), por sobre la sincronía fonética y la cinésica, e incluso por sobre la fidelidad al texto origen. También asevera que "la mayoría de las publicaciones conceden mayor importancia a un diálogo verosímil que a un buen ajuste labial", pero algunos actores del proceso no coinciden: 
enfatizan la importancia de la sincronía fonética ${ }^{9}$ (lo que en la jerga se llama "lip sync") y sostienen que es imprescindible respetar las bilabiales, las labiodentales y las vocales abiertas o cerradas en los parlamentos pronunciados por personajes de imagen real en primeros y primerísimos planos. De hecho, en un mismo estudio hay directores de doblaje que dan prioridad a distintas cosas, o piden al traductor que traduzca de cierta manera. Puede ocurrir, por ejemplo, que para traducir palabras como awesome, un director dé prioridad al sonido " $\mathrm{m}$ " final y prefiera una traducción como "increíble" (por la /b/ en posición final), mientras que otro director puede enfatizar el uso de la vocal "o" y pedir al traductor que utilice una palabra como "grandioso". ${ }^{10}$

El doblaje busca ofrecer diálogos creíbles y verosímiles (Chaume, 2012), pero se ha comprobado que los diálogos originales no siempre suenan naturales en la lengua fuente (Zabalbeascoa, 2008). De hecho, aunque al traducir para doblaje se intente conseguir un registro oral prefabricado que se parezca lo más posible al diálogo espontáneo en la lengua meta, siempre cumpliendo con sus normas gramaticales (Chaume, 2005:9), quienes traducen al español neutro se topan (como otros traductores a otras lenguas) con el problema de que, dado que esa variedad del español no corresponde a ninguna región en particular sino que trata de abarcar a un inmenso conglomerado de países y variedades de lengua mediante un léxico comprensible para todos, los diálogos suenan particularmente falsos y artificiales "porque no coinciden con ninguna variedad lingüística realmente hablada" (Zabalbeascoa, 2008: 161).

Estudiado por Freddi, Valentini y Bruti, entre otros (Chaume, 2013), este lenguaje "artificial" del doblaje (Bucaria, 2008: 162), distante del verdadero lenguaje oral pero lo suficientemente reconocible como para que los espectadores puedan considerarlo un tipo de discurso oral espontáneo, se denomina "oralidad prefabricada" o "dubbese" (en italiano hablamos de doppiaggese; en catalán se ha sugerido "doblatgés" (Marzà y Prats, 2018) y en francés se llama synchronien (von Flotow, 2009)). Se trata de un discurso oral "que puede parecer espontáneo y natural pero que en realidad está muy bien planeado o, como lo llama Chaume (2004b), "prefabricado"' (Baños-Piñero y Chaume, 2009). Para Pavesi (2005), el doppiaggese es una tercera norma, independiente de la lengua fuente y la lengua meta, que se consolida a fuerza de repetición. Es decir que el español neutro sería una especie de "tercera lengua" en el proceso de traducción, similar a la lengua meta (en este caso, el español de Latinoamérica) pero con características propias.

Para las empresas que encargan las traducciones (o producciones en lengua origen), el espectador reconocerá esa tercera norma, el registro oral prefabricado, como sinónimo de oralidad (falsamente) espontánea si se cumplen ciertos requisitos. Chaume (2001: 79-86)

\footnotetext{
9 Chion (1993) denomina "síncresis" (la unión de sincronía y síntesis) a "la soldadura irresistible y espontánea que se produce entre un fenómeno sonoro y un fenómeno visual momentáneo cuando estos coinciden en un mismo momento". ${ }^{10}$ Comunicación personal con directores de doblaje en traducciones realizadas por la autora de esta
tesis
} 
comenta el caso de Televisió de Catalunya, que propuso en 1997 varias recomendaciones al respecto. Entre otras figuran:

- $\quad$ sintaxis poco compleja,

- orden gramatical canónico (sujeto + verbo + complementos),

- léxico corriente y preciso,

- pronunciación clara, y

- huir de dialectalismos, cultismos y anacronismos.

Pero un análisis más exhaustivo revela que, de seguir todas esas recomendaciones al pie de la letra, la espontaneidad desaparecería, tal como sugiere Chaume. Por otro lado, algunas de las recomendaciones favorecen la similitud entre la traducción y el discurso oral espontáneo, como facilitar la creación léxica y la entrada de argot (en el caso que nos compete, el juvenil) o utilizar la intertextualidad (dichos, letras de canciones, etc.). Y aunque las recomendaciones de Televisió de Catalunya se refieren a España y en concreto al doblaje en catalán, uno de los criterios se asemeja a un rasgo significativo del español neutro: el uso de "términos genéricos y comodines, de amplio alcance semántico" (Chaume, 2001: 86). En el capítulo dedicado al español neutro ampliaremos este concepto.

\subsection{EL DOBLAJE DE LOS PROGRAMAS INFANTILES Y JUVENILES}

A diferencia de otros géneros, el de los programas infantojuveniles se define por quiénes son los espectadores y no por el tipo de contenido (Messenger-Davies, 2001a: 96). Se da por sentado que la mayoría de los televidentes son niños, aunque las cifras de los ratings indican que el porcentaje de adultos de más de 18 años que ven estos programas puede llegar casi al 50\%. Esto ocurre por dos razones. Puede suceder que los niños vean los programas acompañados por sus padres, abuelos, personas a cargo, etc., o que los programas resulten atractivos también para un público de mayor edad (García de Toro, 2014; Zabalbaescoa, 2000), dado que, si bien la definición de las Naciones Unidas de "niño" sugiere que la niñez llega hasta los 18 años de edad, la realidad muestra que la adolescencia se ha extendido. Cualquier película infantil o para adolescentes en el cine atrae a niños acompañados por adultos, pero también a los denominados kid adults, que no necesitan llevar a un niño con ellos para simular que esa es la razón por la que fueron a ver una película infantil.

El hecho de que el género infantojuvenil se defina por su (supuesto) público ha implicado que el producto tenga ciertas características particulares. En primer lugar, con el transcurso de los años, surgieron canales de cable específicos para niños, y no ya horarios 
en que los niños podían ver televisión. Por otro lado, la preocupación porque los niños utilizaran su experiencia frente al televisor para aprender y para formar su identidad llevó a presentar actitudes sociales positivas que evitaran que los niños copiaran comportamientos violentos o negativos. Los programas infantojuveniles suelen tener temáticas relativamente sencillas (según si van dirigidos a niños de mayor o menor edad), vocabulario simple, finales felices, chistes sin groserías ni dobles sentidos, abundancia de humor escatológico y físico (slapstick), y referencias intertextuales a otros productos audiovisuales infantojuveniles (como es el caso de la película Descendants (Kenny Ortega, 2015), cuyos protagonistas son hijos de los villanos de otras películas).

Tradicionalmente, los programas audiovisuales infantiles han mantenido esas características, especialmente porque los adultos encargados de escribirlos suelen considerar que deben ejercer un rol protector respecto de los niños, como sucede con la literatura infantojuvenil. Pero con el correr del tiempo, al incrementarse considerablemente la cantidad de televidentes adultos (en especial, los que ven estos programas sin niños), algunas de esas características se fueron modificando. Antes era usual encontrar "guiños" al adulto, fenómeno que Zabalbeascoa (2000: 21) denominó "estrategia de topos negros sobre fondo blanco", pero hoy en día es común encontrar un buen número de frases con doble sentido y chistes groseros, contenidos demasiado elevados para niños ("Heisenberg's uncertainty principle", "By Franz Boas' tie!"11) o imágenes sugerentes que solo los adultos pueden detectar ${ }^{12}$. Estas inclusiones pueden despertar el sentimiento proteccionista del traductor (García de Toro, 2014), que opta por la autocensura (Scandura, 2004) y decide omitir o cambiar dichas frases o referencias, o utilizar eufemismos. También pueden despertar su sentimiento autoprotector, en el sentido de no arriesgarse a cometer un error y que el cliente no vuelva a contar con él o ella. Estas nuevas características también podrían ser de peso cuando el iniciador define el encargo de traducción.

Existen en la actualidad varios canales dedicados a los niños de diferentes edades (Disney Channel, Disney Junior, Disney XD, Nickelodeon, Boomerang, Discovery Kids, Baby TV, Cartoon Network, etc.) que emiten sus programas en la mayoría de los países de Latinoamérica. Si a eso sumamos la producción original de las plataformas de VOD, como Netflix o Amazon, y los contenidos generados para los sitios web y redes sociales de dichos canales, la cantidad de videos para doblar es enorme. También hay que agregar el hecho de que en esta última década muchos canales de cable que ofrecían sus programas subtitulados decidieron optar por el doblaje ${ }^{13}$. Las consecuencias para la industria del doblaje fueron enormes. Como era de esperarse, surgieron estudios que no tenían la experiencia ni los recursos profesionales necesarios para crear doblajes de

\footnotetext{
${ }^{11}$ Billy Dilley, Aaron Springer, 2017

12 Shavit (1981) los denomina "textos ambivalentes", pues operan a distintos niveles de comprensión.

${ }^{13} \mathrm{http}$ //tv.otroscines.com/2011/06/a-partir-de-junio-cinecanal-solo-emitira-peliculas-dobladas/
}

(consultado el 6 de noviembre de 2016) 
calidad $^{14}$, y los estudios existentes comenzaron a verse desbordados por la cantidad de trabajo, lo cual originó problemas en la calidad de los productos. ${ }^{15}$ Por otro lado, algunas empresas subtituladoras que vieron reducido considerablemente su flujo de trabajo, por ejemplo, comenzaron a hacer doblaje sin tener experiencia en la materia. Y algunos canales que hacían sus propios doblajes debieron tercerizar o externalizar su trabajo (como hace Netflix con sus proveedores "preferidos" o preferred vendors). Por otro lado, en la actualidad los niños dedican mucho tiempo a ver televisión ${ }^{16}$ (especialmente VOD, porque para ellos todo debe ser inmediato), y pueden reconocer fácilmente las voces de doblaje (y no hay tantas, porque es una industria que en Latinoamérica creció, o debió crecer, a niveles exponenciales en muy poco tiempo), y también las asocian a los personajes. Y como, además, un alto porcentaje de los televidentes de estos contenidos son adultos, los estudios debieron buscar el modo en que el doblaje no suspendiera la credibilidad, asociándose a otros estudios cuando el mismo actor aparecía en productos de diferentes canales. En la actualidad es muy común el doblaje colaborativo, es decir, aquel que generalmente se realiza para respetar la asignación de la voz de un actor o actriz de doblaje a un actor/actriz específico/a, lo que implica que el trabajo se comparte no ya entre estudios del mismo país sino también entre estudios de diferentes países (México y Argentina para algunos productos Disney, o México, Venezuela y Miami para productos Nickelodeon, por ejemplo ${ }^{17}$ ).

En Latinoamérica, en general es tradición que los programas de televisión para niños sean doblados al español neutro. Esto ha sido así desde hace varias décadas, y por lo tanto es una cuestión de hábito (Ivarsson, 1992: 66), una norma. Y si bien muchos niños podrían leer subtítulos, también hay que tener en cuenta que, al igual que lo que sucede con el concepto de doble lector en la literatura infantojuvenil (García de Toro, 2014), es común que los niños vean los programas acompañados de algún adulto. ${ }^{18}$ Ese doble espectador

${ }^{14}$ Para el director Sebastián Arias, la calidad del producto final y de las traducciones en ciertos estudios no es una prioridad, y hay lugares "donde se hace doblaje como salchichas" (http://tavargentina.com/2015/09/entrevista-a-sebastian-arias/)

${ }^{15}$ Warner (Turner) debió redoblar las primeras cinco temporadas de la serie The Big Bang Theory (Chuck Lorre, Bill Prady, 2007-2019), por ejemplo, por la mala calidad de las traducciones y el doblaje (se puede consultar las razones en la página de la serie en www.doblaje.wikia.com), y enfrentó grandes críticas cuando decidió repentinamente y sin aviso, en 2015, empezar a transmitir la serie doblada en vez de subtitulada.

${ }^{16}$ En 2012, los niños pasaban un promedio de 4 horas delante del televisor, que podía incluso extenderse a 6 o más, ya que no solo los adultos "sufren" del binge watching, es decir, de sentir la necesidad de ver múltiples episodios de una serie porque están disponibles en las plataformas de VOD. (http://healthland.time.com/2012/10/02/background-tv-children-exposed-to-four-hours-a-day/, consultado el 16 de noviembre de 2016)

${ }^{17}$ Fuente: Doblaje Wiki (www.doblaje.wikia.com)

18 De hecho, una de las series estudiadas en esta tesis, Big Time Rush, tiene al final de los créditos la leyenda "Thanks to moms everywhere". 
puede ser un padre o madre, pero también puede ser un abuelo o alguna persona que cuida del niño. Por ejemplo, el artículo “Alex Meets Big Time Rush” describe un fenómeno común: está escrito por la abuela de Alex, que fue con su nieto, su hijo y su nuera a ver dos conciertos del grupo y que además es fanática de esta serie para niños. Y Netflix realizó una encuesta que, entre otras conclusiones, sostiene que " $77 \%$ of moms also end up watching shows their kids introduce them to". ${ }^{19}$

Luyken (1991) afirmaba hace ya 30 años que tanto las personas de mayor edad como las de menor nivel cultural prefieren el doblaje. Hoy en día, sin embargo, el fenómeno es más complejo: la preferencia del doblaje ya no solo se debe a estas dos razones.

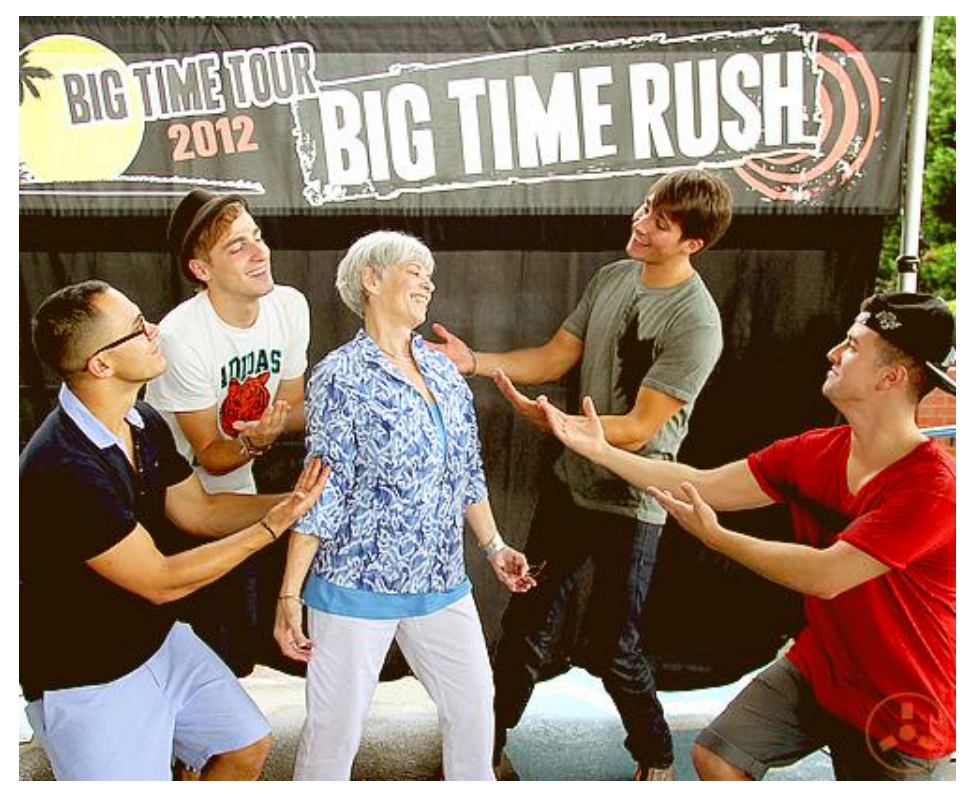

Ilustración 1 - Meet \& Greet de un concierto de Big Time Rush - Fuente: www.btr.com (ya no está disponible)

${ }^{19}$ http://forumhome.org/alex-meets-big-time-rush-p20116-77.htm?smenu=77\&mad=No (consultado el 29 de marzo de 2019); http://kidscreen.com/2015/06/17/netflix-study-shows-dads-actively-introclassic-toons-to-their-kids/ (consultado el 9 de abril de 2018) 


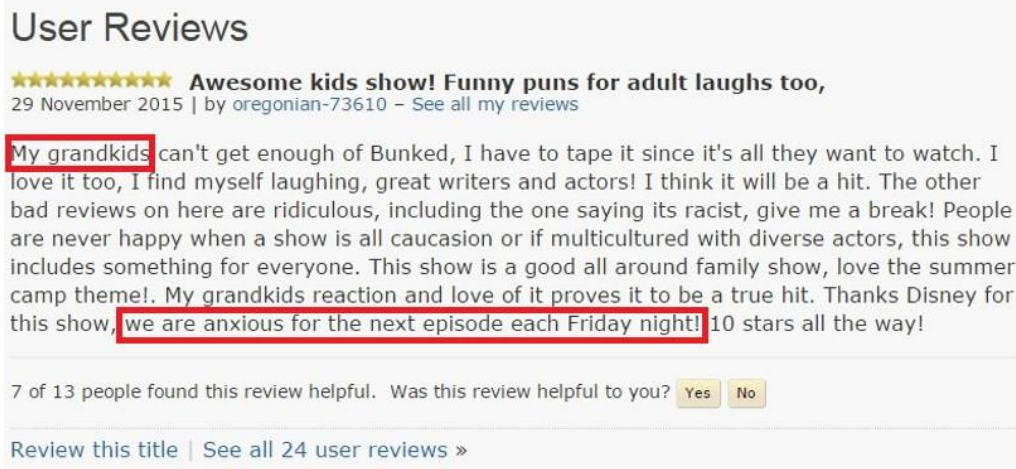

Ilustración 2 - Comentario de una abuela en la página de IMDB de la serie Bunk'd / Fuente: www.imdb.com

El fenómeno del streaming ha provocado que quienes veían programas infantiles de niños o adolescentes, los vean ahora en formato VOD. Por lo tanto, también puede ocurrir que sean estos adultos sin niños los que vean los programas infantojuveniles, como se pudo comprobar en ocasión de los 9 años del estreno de Big Time Rush, cuando parte del público, que tenía más de 20 años en ese momento, seguía viendo la serie a través del streaming:

\section{En respuesta a @HeffronDrive \\ @B2utyfulEXOtic no joke I was legit}

streaming btr the other day

\author{
Okay first of all, babies! Second, how has \\ it been 9 years?! I'm old. Third, thank you \\ for all the BTR memories! Y'all were my \\ first major concert for my sweet 16 back \\ in 2012 and fourth, I'm glad y'all are \\ down for a reunion tour cause l'll \\ soooooo be there
}

Ilustración 3 - Tuits sobre el streaming actual de la serie Big Time Rush

También ha sucedido que, con los años, un porcentaje relativamente amplio del público juvenil no quiere leer subtítulos, por diversos motivos. A veces esto se asocia a un menor nivel educativo y cultural en general ${ }^{20}$, y por lo tanto las películas que se exhiben en cine destinadas a adolescentes también se doblan. Otro factor significativo ha sido la creciente

20 "Todos los países latinoamericanos que son parte de este nuevo estudio [pruebas PISA] están muy por debajo de la media de la OCDE en rendimiento escolar", en "La OCDE advierte sobre los pésimos resultados de estudiantes argentinos en las pruebas PISA", BBC Mundo, 10 de febrero de 2016, http://www.lanacion.com.ar/1869867-pesimos-resultados-de-estudiantes-argentinos-en-laspruebas-pisa (consultado el 10 de febrero de 2017); Oppenheimer, A. (2019): "El atraso educativo en la región", La Nación, 26 de diciembre de 2019 
importancia otorgada a la accesibilidad a los medios (Romero-Fresco, 2013). En consecuencia, los sistemas de VOD ofrecen en Latinoamérica los programas para niños y jóvenes tanto en su versión doblada como con subtítulos. Y el crítico de cine Diego Lerer, que trabaja para Clarín, uno de los dos periódicos más populares de Argentina, plantea otra posible causa, más que interesante: el público (infantil, juvenil o adulto), al que no le molesta dedicar horas a leer textos en las redes sociales, siente que pierde mucha información visual al tener que leer los subtítulos:

El nivel de recorrido visual que se puede hacer en un plano si no se lee es impresionante. (...) Esto se hace más notorio cuando los planos son cortos. (...) Cortes veloces, mucha información, leer y mirar todo lo que pasa en el cuadro puede llegar a transformarse en un ejercicio mentalmente agotador. (Lerer, 2012)

Las series infantojuveniles actuales tienen un ritmo visual mucho más rápido que las de hace una o dos décadas, y los niños están acostumbrados a detectar hasta el más mínimo detalle (Scandura, 2016). Además, presentan mucho texto original en la pantalla (chats, comentarios, etc.), e incluso hay versiones emojified, o sea, con emojis y comentarios agregados, de las películas para niños, lo que fomenta el gusto por el doblaje de niños y adolescentes.

\subsection{DOBLAJE Y GUÍAS DE ESTILO}

El gran problema del español neutro para doblaje es que no existe un manual o un libro que reúna todas las palabras que son realmente neutras, y por supuesto que existe un motivo justificado para eso: es la cantidad de personas que hablan distintas variedades de español en América y la extensión geográfica del territorio donde se hablan dichas variedades. Decidir qué es neutro y qué no es un esfuerzo ciclópeo (tal vez imposible), y pocos se han embarcado en ello, y en todo caso se ha empezado a hacer muy recientemente, aunque no con una finalidad prescriptiva sino más bien con el objeto de establecer qué términos se utilizan en qué lugar.

Por lo general, el español neutro no es abordado en detalle a nivel universitario. Los profesores comentan cuáles son los términos neutros cuando corrigen traducciones, según su experiencia (editorial $\mathrm{u}$ otra), pero la carrera de Traductorado no tiene una asignatura específica al respecto, a pesar de que a la mayoría de los profesionales se les pide que traduzcan al español neutro (de hecho, en algunos países de Latinoamérica ni siquiera existe una carrera universitaria de Traducción, por lo que quienes traducen no tienen formación académica específica).

Existe, por otro lado, una especie de "tradición" respecto de qué vocablos conforman el español neutro, y en general suelen ser las más mexicanas (aunque no siempre) porque durante muchos años la industria del doblaje se desarrolló casi exclusivamente en México. Así quedaron en la lista de "términos aceptados" palabras como "lonchera" (de "lonche", término prestado del inglés), que es un mexicanismo según la Academia Mexicana de la 
Lengua. Por otro lado, en las empresas de doblaje no suelen tener un criterio específico para elegir los términos, o desconocen cuál es ese criterio porque ha pasado de generación en generación y simplemente se lo respeta. ${ }^{21}$ Esto sucede, por ejemplo, con la utilización de "campana" en vez de "timbre" cuando hablamos del dispositivo que uno presiona y se ubica junto a las puertas (la Real Academia Española define con claridad estos dos términos, y se trata de conceptos muy diferentes).

Algunas empresas de doblaje (y de subtitulado) cuentan con guías de estilo, pero si las tienen, no siempre son muy detalladas, y sus recomendaciones son vagas e imprecisas. Tampoco ofrecen sitios web o diccionarios que realmente sean útiles para traducir al español neutro. Véanse, a modo de ejemplo, las siguientes recomendaciones para el español neutro que proponía el European Captioning Institute en 2006 para el caso de la subtitulación:

\footnotetext{
4.3.1 Grammar

Two of the biggest differences, are the 'leismo' of Spain and the use of the pronoun 'vos' in some areas instead of 'tu''. Another major difference is that 'vosotros' is often used as the plural of 'tú' (the singular familiar "you") in

Spain, while in Latin American 'ustedes' is usually 'usted'. There are also numerous small differences, many involving colloquial usage. Be aware of the 'voseo', just in certain areas of Latin American countries is used in instead of 'tư'.

\subsubsection{Vocabulary}

Other than slang, probably the biggest class of vocabulary differences you'll come across is in the use of suffixes. A 'lápiz' is a pencil everywhere, but a 'lapicero' is a pencil holder in some areas, a mechanical pencil in others, and a ball-point pen in still others. There are also fair number of blatant differences, such as a computer being an 'ordenador' in Spain but a 'computadora' in Latin America, but they are probably no more common than the British-American differences. Of course, every area also has its quirky words. For example, a Chinese restaurant in Chile or Peru is called a 'chifa', but you won't run across that word in many other places.

*Taken from: http://spanish. about.com/cs/historyofspanish/f/varieties.htm
}

\subsubsection{Different dialects of Latin American Spanish}

Latin American Spanish has variants in the diverse zones where it is spoken; this tendency toward differentiation is almost imposed by the very magnitude of the territory. Be aware of the deep differences within LA Spanish (Amazon, Bolivian, Caribbean, Central American, Andean, Chilean, ColombianEcuatorian, Mexican, Northern Mexican, Paraguayan, Peruvian, Puerto Rican, Spanish from the River Plate, Uruguayan, etc.) However, try to be as neutral as possible.

\subsubsection{Useful LA Spanish websites}

Diccionario panhispánico de dudas: http://uww.rae.es/

Ortografia de la Lengua Española (Ed. revisada por las Academias de la Lengua Española)

Diccionario conciso de modismos: inglés-español, español-inglés.

\footnotetext{
${ }^{21}$ Experiencia profesional de la autora
} 
Algunas compañías ofrecen al traductor (y al ajustador, de no ser la misma persona) una lista de palabras "correctas" en español neutro, que deben usar, y otra de palabras "prohibidas" por considerarlas vulgares, ofensivas o simplemente "regionales". Otras empresas se limitan a decir que se debe traducir "al español neutro", y no lo definen de ningún modo. ${ }^{22}$ En general los estudios suelen mantener cierto secretismo respecto del proceso de doblaje, y por lo tanto es difícil acceder a sus guías de estilo; otras compañías, como Netflix, tienen sus pautas en Internet, aunque demasiado generales para ser realmente útiles. Si pensamos en esta diversidad, sería lógico suponer que esto debe reflejarse en el español que utilizan en sus doblajes.

A veces es el iniciador del encargo de traducción, o el encargo del doblaje (un canal, por ejemplo) el que impone las reglas. Por ejemplo, en sus comienzos, el canal estatal argentino Pakapaka, dedicado a los niños, no solo exigía que los diálogos finales de las traducciones a cargo de las empresas de doblaje contratadas por el canal estuvieran "aprobados por Canal Pakapaka" sino que además incluía en su Manual de estilo para doblajes ${ }^{23}$ una descripción bastante detallada del lenguaje a utilizar y de los términos "prohibidos":

- La traducción deberá respetar el acento, el voseo y los términos propios de la región, pero deberá excluir jerga y modismos.

- No se utilizará ningún vocablo ni expresión que pueda afectar la integridad emocional de los televidentes, tanto de los adultos como de los chicos y las chicas.

- No se utilizarán vocablos ni expresiones que puedan derivar en interpretaciones soeces, hirientes, discriminatorias, difamatorias $\mathrm{u}$ obscenas. Por ejemplo, adjetivos como "estúpido", "idiota" o similar; vocablos como "gordo", "petiso" cuando se utilicen con la intención de ofender o discriminar por apariencia física.

- Para referirse al amamantamiento, se utilizará la frase "dar la teta".

- Se podrán incluir términos escatológicos siempre y cuando se utilicen para denominar procesos corporales naturales que los chicos conocen por dichos nombres. No se utilizarán eufemismos. salvo que por razones editoriales sea imprescindible.

- No se utilizarán eufemismos respecto del cuerpo humano, salvo en casos especiales.

- Se privilegiará el uso de los sustantivos en femenino y masculino, en vez del masculino genérico.

${ }^{22}$ Netflix, por ejemplo, (https://partnerhelp.netflixstudios.com/hc/en-us/articles/214807888-DubbedAudio-Style-Guide-Lip-Sync-Dubbing), tiene una guía de subtitulado compartida para el "Castillian Spanish" y el "Latin American Spanish" (que también llaman "neutro" en su sitio de Internet) que solo recomienda consultar el diccionario de la RAE y el Panhispánico de dudas ante cualquier problema lingüístico (https://partnerhelp.netflixstudios.com/hc/en-us/articles/217349997-Castilian-LatinAmerican-Spanish-Timed-Text-Style-Guide, consultado el 4 de diciembre de 2018); Turner tenía a mediados de los años 2000 un glosario de español neutro que contenía solo unos 100 términos.

${ }^{23}$ Se puede consultar en https://docplayer.es/20762615-Pliego-de-bases-y-condiciones-particulareseduc-ar-sociedad-del-estado-tipo-contratacion-directa-no66-ejercicio-2012.html (consultado el 4 de diciembre de 2018) 
- Se favorecerá la inclusión de términos específicos a las diferentes regiones geográficas de la Argentina y América hispanoparlante.

Por otro lado, a veces existen inconsistencias entre los pliegos de licitación, por ejemplo, y las guías de estilo. En el caso de Pakapaka, en la licitación del año 2012 para doblar sus programas se solicitaba que "la traducción y adaptación de los scripts" fuera "al español versión argentino neutro", una descripción vaga e incoherente (el español argentino dista mucho de ser neutro) que además era opuesta a lo que planteaba su manual de estilo, que fomentaba "la diversidad de acentos, modismos y entonaciones del territorio nacional argentino".

Entre otros términos que la guía indicaba no usar figuraban "negro" o "persona de color", "indio" (recomendaba usar "pueblos originarios"), "raza" (que solo se podía usar "en referencia a animales" y debía reemplazarse por "etnias o culturas") y "discapacitado", que debía ser reemplazado por "persona/niño/adulto con discapacidad/es". ${ }^{24}$

Esto no ocurre solo con el español neutro. De un modo similar, la Secretaría de Audiovisual del Ministerio de Cultura de Brasil creó una Guía para producciones audiovisuales accesibles que indica que se debe "evitar el lenguaje rebuscado, los términos groseros y las jergas" (Bahiense et al, 2016: 22). Resulta evidente que los gobiernos pueden ser (o son), de un modo u otro y en distinto grado, agentes partícipes en el proceso de traducción y doblaje.

Mientras que algunos glosarios sugeridos por las empresas tienen páginas y páginas, otros son increíblemente acotados u ofrecen soluciones confusas, como el uso de "resorte" en vez de "elástico de calzoncillo"25. El de Pakapaka, por ejemplo, llamaba a privilegiar los términos rioplatenses "o de uso común en Hispanoamérica por sobre los términos en español ibérico" 26 , pero no solo no reconocía que Hispanoamérica no tiene un vocabulario homogéneo y que el rioplatense es muy distinto al resto sino que además sugería que las traducciones latinoamericanas neutras utilizaban el español peninsular. Los términos sugeridos contenían grandes errores, como pensar que "campera", "remera" o "pochoclo" son términos cuyo sentido se comprende del mismo modo en toda la región, y era algo ingenuo suponer que este glosario tan breve podía solucionar el problema léxico de la traducción al español en Latinoamérica:

${ }^{24}$ Este tipo de guías de estilo parecen redactadas con fines ideológicos/políticos, ya que no tienen en cuenta, por ejemplo, otras restricciones de la TAV, como la isocronía.

${ }^{25}$ Experiencia profesional de la autora. La palabra "resorte" no tiene la acepción de "elástico".

${ }^{26}$ Como se verá más adelante, estas definiciones tenían que ver más con el hecho de que el español peninsular, al igual que el inglés, eran consideradas "lenguas imperialistas" que con la posibilidad de que los niños malinterpretaran lo que se decía. Extrañamente, varios de los términos que en el manual figuran como de uso frecuente en España en realidad no lo son (por ejemplo, betarraga, carro o polera). 


\begin{tabular}{|l|l|}
\hline \multicolumn{1}{|c|}{ Español rioplatense (preferido) } & \multicolumn{1}{c|}{ Español peninsular } \\
\hline Remolacha & Betarraga \\
\hline Ananá & Piña \\
\hline Banana & Plátano \\
\hline Cajonera & Cómoda \\
\hline Auto & Carro \\
\hline Colectivo / Bus / Micro & Autobús \\
\hline Calesita & Carrusel \\
\hline Valija & Maleta \\
\hline Medialuna & Croissant \\
\hline Budín & Bizcochuelo \\
\hline Abrochadora & Grapadora \\
\hline Bicho bolita & Cochinilla \\
\hline Birome & Bolígrafo \\
\hline Campera & Chaqueta \\
\hline Pollera & Falda \\
\hline Changuito & Carrito \\
\hline Remera / camiseta & Polera \\
\hline Lavarropas & Lavadora \\
\hline Pochoclo & Palomitas de maíz \\
\hline Torta & Pastel \\
\hline Sándwich & Emparedado \\
\hline
\end{tabular}

Tabla 2- Glosario original del canal PakaPaka

Otro agente son las mismas plataformas de VOD. En el caso de Netflix, por ejemplo, se puede acceder a su guía de estilo para doblaje en Internet. En el caso del español, Netflix no indica qué está bien usar y qué no, y sugiere recurrir al diccionario de la Real Academia Española, porque su guía de estilo es tanto para español peninsular como latinoamericano. 


\section{Netflix Dubbed Audio Style Guide - Lip Sync Dubbing}

\section{Objective}

This document contains a list of required practices when creating dubbed audio for Netflix content. Consult your Netflix representative for any specification not covered in this document.

1. Translation Requirements

1.1 Main Dialogue

All main dialogue in the source (original) language should be translated unless specifically noted.

\subsection{Foreign Languages}

Foreign dialogue should be translated in the forced subtitle stream only if it is meant to be understood. If it is unclear whether or not the foreign dialogue is meant to be understood, seek advice from Netflix or the production. Do not dub over foreign dialogue.

\subsection{Character Names}

Leave character names in original language unless translations are approved by Netflix. EXCEPTION: Famous historical/mythical characters and/or nicknames that might vary from language to language.

English: Santa Claus

German: Nikolaus

\subsection{Songs}

For song translation on dialogue track, seek written clearance from the content owner.

\subsection{Censorship}

Dialogue should not be censored or softened - tone \& register should match original dialogue.

Ilustración 5 - Especificaciones para doblaje de Netflix - Fuente: https://partnerhelp.netflixstudios.com/hc/enus/articles/214807888-Dubbed-Audio-Style-Guide-Lip-Sync-Dubbing

Esta disparidad de criterios no condice con un español homogéneo en todas las producciones dobladas, y deja en claro que, más allá de la buscada estandarización del español neutro, existe cierta censura por parte de algunos agentes del proceso de doblaje. Esto es justamente lo que esta tesis se propone investigar. 


\section{CAPÍtUlO 2.}

\section{EL ESPAÑOL DE AMÉRICA \\ Y EL ESPAÑOL NEUTRO}

\subsection{EL ESPAÑOL EN AMÉRICA}

Cuando los españoles llegaron a América, seguramente no imaginaron la extensión del continente americano, aunque con los años terminaron colonizando una gran parte del mismo. En consecuencia, el idioma español se habla en la mayoría de los países de Latinoamérica, además de en Estados Unidos, Canadá y otros países anglófonos, francófonos y lusófonos del continente. Más de 480 millones de personas en todo el mundo tienen el español como lengua materna, de los cuales unos 440 millones viven en América, y casi 42 millones viven en Estados Unidos, prácticamente la misma cantidad de hablantes nativos de español en España, unos 47 millones (Fernández Vítores, 2018).

El español, que deriva principalmente del latín pero que también tiene gran influencia del árabe y de otras lenguas, adoptó en Latinoamérica muchas palabras provenientes de los idiomas nativos. Además, la pronunciación y el léxico suelen variar de un país a otro, especialmente dada la enorme extensión geográfica del continente, lo que lo convierte en una variedad que dista de ser homogénea. Otra característica del español de América es que utiliza préstamos del inglés con más frecuencia (como en el caso de los términos informáticos). Otros rasgos son el yeísmo, en especial en el Río de la Plata (pronunciar tanto la LL como la Y con yeísmo [/3/] con rehilamiento); el uso de "ustedes" en vez de "vosotros" con su correspondiente forma verbal ("ustedes son" en vez de "vosotros sois"), y el uso del voseo ("vos" en vez de "tú") en algunos países o regiones (Río de la Plata, zonas de Colombia y otros países) y del seseo (o sea, no diferenciar entre la pronunciación de las consonantes $\mathrm{C}, \mathrm{S}$ y Z). En las zonas angloparlantes, por ejemplo, quienes hablan español suelen usar palabras del inglés en oraciones en español ("Mira qué bonito alligator"), o traducir literalmente estructuras sintácticas del inglés ("Llámame para atrás", por Call me back). Lo mismo ocurre en las regiones donde la influencia del inglés es muy notoria y se utilizan préstamos naturalizados como "carro" (por car) (Torres Torres, 2016).

El español de América ha sido estudiado por numerosos autores (Torres Torres, 2016; Moreno de Alba, 2015; Marimón Llorca, 2006; Andión Herrero, 2005; Quesada Pacheco, 2002; Sánchez Méndez, 2002; Sánchez Lobato, 1993, entre otros). En general, los estudios focalizan su interés en la descripción de características concretas de las distintas variedades del español de América, pero ofrecen ciertas "características generales", que 
figuran a continuación (aunque algunas, de hecho, no pueden catalogarse como "generales" ya que no son comunes a todas las variedades):

Características fonéticas y fonológicas:

- Intercambio o adición de vocales o consonantes (sobre todo en zonas de población de escaso nivel educativo, que a veces se trasladan a la sociedad en general): *dispertar, *calientito, *vistes (como conjugación del verbo "ver")

- Desplazamiento acentual (*maiz, *sandia, *pasiar)

- Monoptongaciones: *pos (por “pues")

- Pérdida de la /d/ final (*felicidá) e intervocálica (*barbúo) y aspiración de la /s/ final (¿Me *entiende ${ }^{\mathrm{h}}$ ?)

- Seseo: Los fonemas correspondientes a las grafías Z, C y S, es decir, / / / y /s/, suenan ambos como /s/ fricativa sorda dentoalveolar

- Neutralización homofonética (solo en algunas regiones): lambdacismo (/álte/ en vez de /árte/) y rotacismo (/piér/ en vez de /piél/)

- Yeísmo y yeísmo con rehilamiento

Así como existen ciertas coincidencias en varias regiones de Latinoamérica, que Marimón Llorca (2006) atribuye a la influencia del andalucismo, también existen diferencias notorias, como las distintas pronunciaciones para $\mathrm{G}$ y J (como /x/ o h aspirada $\left.{ }^{\mathrm{h}}\right]$ ), y el uso de yeísmo, que no es común a todo el continente. Tampoco es realmente común a todas las regiones el uso de las monoptongaciones o la neutralización homofonética.

Características morfosintácticas:

- Según las regiones: voseo y ustedeo, es decir, la ausencia del "vosotros" y sus respectivas conjugaciones (Torres Torres, 2016: 71); uso tanto del voseo como del tuteo en algunas regiones. El voseo es compartido por varios países: Guatemala, El Salvador, Nicaragua, Costa Rica, Venezuela (noroeste), Colombia (norte), Ecuador (norte), Bolivia, Argentina, Paraguay y Uruguay. También es frecuente en ciertas zonas de Chile, Perú, y hasta en áreas muy específicas de México, Panamá y Cuba (Andión Herrero, 2005)

- Laísmo y loísmo referidos a la tercera persona, a diferencia del leísmo típico de España 
- Uso intercambiable de "le" y "les": "Le hablé a los chicos" o "Les hablé a los chicos” (el primero suele ser más común)

- Uso de "acá” y “allá” por "aquí" y “allí” (aunque no en todas las regiones)

- Uso de "recién" sin participio: "Recién llegan"

- Uso de "hasta" con sentido de "recién a": "Hasta las cinco no voy" (desde México hasta el norte de América del Sur)

- Modificación del orden de frases con "más" (como determinante o como adverbio): "más nunca", "más nadie"

- Preferencia del masculino al femenino para algunos sustantivos: "un llamado" en vez de "una llamada"

- La forma diminutiva más usada es "ito", y se la utiliza incluso en palabras que no suelen llevarla, como "alguito" o "apenitas", y hasta se la duplica ("toditito", "ahoritita") ${ }^{27}$. Cuando la última consonante de un sustantivo es T, en Cuba, Costa Rica, Venezuela y Colombia la forma diminutiva es "tico": "cartica"

- El sufijo "azo" se emplea con valor afectuoso ("amigazo", "madraza"), o para formar superlativos ("un partidazo")

Existen zonas donde incluso se usan construcciones gramaticales medievales que en otras partes de América Latina son inexistentes, como en ciertas zonas de Santo Domingo, donde se utiliza "ello hay": "Ello hay suficiente comida" (Rincón, 2012).

Incluso dentro de los distintos países hay diferencias notorias. En Argentina, por ejemplo, que es un país geográficamente muy amplio, existen diferencias regionales como el uso del "tú" o del "usted", y según la provincia o zona, los hablantes prefieren un "he visto" a un "vi", o aspiran la S, con lo que la palabra "mosca", por ejemplo, suena /móhka/. Y como mencionamos anteriormente, la LL y la Y se convierten en consonantes fricativas postalveolares sonoras o sordas. Estas características del español de Argentina dificultan el trabajo a los actores de doblaje, que deben adecuar su modo de hablar al español neutro, cuya pronunciación se asemeja más a la de México.

\section{Características léxicas:}

El léxico del español hispanoamericano se caracteriza por la falta de homogeneidad y la existencia de variedades dialectales (no necesariamente relacionadas con los límites geopolíticos de los países) de las que dan cuenta las diferentes Academias de la Lengua

\footnotetext{
${ }^{27}$ Este es otro claro ejemplo de que las características que muchos autores marcan como "generales" en realidad no lo son, puesto que la duplicación del "ito" se reduce a ciertas regiones de Latinoamérica.
} 
y los muchos manuales y diccionarios de americanismos y regionalismos. Diversos factores contribuyeron a que en las diferentes regiones se utilicen términos muy distintos. En primer lugar, la enorme extensión y la geografía de un continente que abarca dos hemisferios y es hogar de topografías que promovieron el aislamiento de ciertas comunidades. A eso se suma, según López Morales (1998), la diversidad de lenguas aborígenes y de orígenes dialectales de los colonizadores, más la llegada de una importante cantidad de esclavos africanos que también enriquecieron el vocabulario del español hispanoamericano. Resulta, pues, muy difícil definir las características de un léxico tan dispar, como veremos a continuación. Según las regiones y los orígenes de quienes se establecieron en cada una de ellas y de los inmigrantes que llegaron principalmente a partir del siglo XIX, el español ha recibido distintas influencias, entre las que se destacan:

\begin{tabular}{|l|l|}
\hline \multicolumn{1}{|c|}{ Zona } & \multicolumn{1}{c|}{ Influencia } \\
\hline México $^{28}$ & Náhuatl \\
\hline Caribe, América Central, Venezuela, Colombia ${ }^{29}$ & Africana, andaluza, canaria \\
\hline Paraguay, Uruguay, Brasil, noreste argentino & Guaraní \\
\hline Bolivia, Perú, Ecuador, noroeste argentino & Quechua \\
\hline Rioplatense (Argentina, Uruguay) & $\begin{array}{l}\text { Principalmente de distintas } \\
\text { regiones españolas, italiana, y en } \\
\text { menor medida guaraní y quechua }\end{array}$ \\
\hline Chile & Mapuche, araucano \\
\hline Uruguay & Portuguesa \\
\hline
\end{tabular}

Tabla 3 - Influencias en los españoles de Latinoamérica

Pero incluso dentro de una misma región o país se pueden encontrar diferencias significativas. En Argentina y México, dos de los países más grandes de Latinoamérica, los hablantes utilizan distintas variedades de español. En Argentina, el idioma varía

\footnotetext{
${ }^{28}$ Es la variedad más hablada en Estados Unidos.

${ }^{29}$ También suele ser el más común en algunas ciudades de Estados Unidos.

${ }^{30}$ Los Andes aislaron a Chile, por lo que su español tiene una pronunciación algo diferente y no se asemeja demasiado al español "argentino", a pesar de su ubicación geográfica.
} 
mucho entre el noreste, que tiene influencia guaraní; el noroeste, con influencia quechua $^{31}$; el centro-oeste, con influencia chilena; y el centro-este, principalmente la Ciudad Autónoma de Buenos Aires y sus alrededores. Buenos Aires era la vía de entrada de los barcos que llegaban de Europa, y lógicamente es la zona con mayor influencia de inmigrantes españoles e italianos. La mezcla del español y el italiano de los inmigrantes se llamó "cocoliche", y tuvo tanta influencia en el Río de la Plata que aún se utilizan muchas de las palabras a las que dio origen: bagayo (persona fea), birra (cerveza), chau (de ciao), chanta (estafador, tramposo), laburar (trabajar), manyar (comer), pibe (chico). En México, la Ciudad de México es sede de la mayor parte de los medios de comunicación del país, y por eso se suele identificar el doblaje con la variedad del centro de México. En la península de Yucatán y en la región que limita con Guatemala se habla una variedad similar a la centroamericana, mientras que en las áreas de Veracruz y Tabasco se habla un español más similar al caribeño.

\subsection{LOS ORÍGENES DEL ESPAÑOL NEUTRO}

"El español neutro tiene un claro fundamento comercial", opina Gómez Font (2012). Y es verdad. "El doblaje es, en última instancia, una actividad económica que debe ser viable y productiva" (Cerezo Merchán et al, 2015: 49), y por lo tanto era lógico que se utilizara un solo español para el doblaje, que sirviera para toda Hispanoamérica, en vez de una multitud de doblajes regionales, con los costos que eso conllevaría.

Si bien los orígenes exactos del español neutro son desconocidos, se cree que surgió entre las décadas del 30 y del 50 del siglo pasado. La calificación de "neutro", según afirma Guevara (2013), proviene de la jerga de los medios audiovisuales. Se cree que se lo comenzó a utilizar en los doblajes para que estos pudieran llegar a todos los países de habla hispana (incluida España) en una sola versión (en aquellos años no se utilizaba el subtitulado por el alto grado de analfabetismo de la población). Algunos autores sostienen que los orígenes del español neutro se remontan a las llamadas "versiones multilingües" o "versiones dobles" de los años 30 (Chaume, 2012). Herrero Sendra (2014) cree que Disney fue una de las precursoras en el uso del español neutro, y fue en parte porque sus primeros intentos de doblaje resultaron desastrosos. Películas como Pinocho (Luske y Sharpsteen, 1940) contenían una mezcla tan desordenada de acentos (argentino, mexicano, cubano, norteamericano, español, etc.) en sus doblajes que el público rechazó esas versiones. Incluso se llegó a grabar un doblaje al español en Francia (Iglesias Gómez, 2009) ${ }^{32}$.

\footnotetext{
${ }^{31}$ Por ejemplo, existe el Diccionario de americanismos en Salta y Jujuy (dos provincias argentinas), publicado en Madrid en 2006.

32 El sitio Doblaje Wikia comenta que "el doblaje original al español más viejo que aún se conserva de una producción animada de Disney es el correspondiente al cortometraje Los tres cerditos (de 1933). Este doblaje, que data del mismo año de estreno del corto y fue realizado en el estudio Des Reservoirs,
} 
Desde entonces, el español neutro fue evolucionando y adaptándose (El Halli Obeid, 2012). Durante muchos años tuvo un acento y un léxico más bien portorriqueño y luego mexicano, pero en la actualidad, y dada la diversidad de estudios de doblaje ubicados en diferentes países, se trata de un español realmente neutro en lo fonológico, aunque, como se plantea este trabajo, resta estudiar si el vocabulario utilizado también lo es.

\subsection{DEFINICIONES DEL ESPAÑOL NEUTRO}

El español neutro no es exclusivo de la traducción audiovisual, como se puede creer. Es una variedad que se utiliza tanto en los productos audiovisuales traducidos como en otros ámbitos: las traducciones literarias, las técnicas (García Izquierdo, 2016), las interpretaciones que van dirigidas al público hispanohablante en general (por ejemplo, un congreso con asistentes de distintos países), el telemarketing, etc. Por otro lado, el español neutro para el doblaje se diferencia por tener reglas propias, ya que es un ejemplo de dubbese con la dificultad agregada de que debe ser comprendido por millones de personas de una gran cantidad de países que distan mucho de hablar en forma similar.

Como explica Guevara (2013), el problema de definir el español neutro radica en el hecho de que se lo suele definir por lo que no es. "Neutro sería entonces, el modo de hablar que no es de ningún lugar" (Guevara, 2013: 9). Como indica más adelante, el español neutro implica acotar los términos y quitar los no compartidos. "Más que saber qué hay que usar, entonces, es cuestión de saber qué no hay que usar" (Guevara, 2013: 44).

De modo similar, Gómez Font (2012) lo define como el "español que no es propio de ningún país en concreto y que puede funcionar bien en todo el ámbito hispánico", sin acento de ningún sitio en particular y con un "léxico común completamente comprensible por todos los hablantes". Y Bravo (2009) sostiene que el español neutro "no es de nadie, y por lo tanto [es] una suerte de lengua 'descafeinada' con la que ningún individuo puede identificarse, por lo que no tiene futuro". Para Bravo, la etiqueta de "neutro" se emplea:

con cierto menosprecio, especialmente bajo el argumento de que el adjetivo "neutro" esconde en realidad un español empobrecido, que augura una época de carencia comunicativa e idiomática.

Aira (2015), desde su perspectiva de directora de doblaje, describe el español neutro como "un español que puede entenderse en cualquier país latinoamericano" con un vocabulario común, "un español 'sin identidad', sin referencia, sin territorio, salvo el del mundo de la televisión y el cine”. Para la autora, esta característica "reduce significativamente la

ubicado en París, Francia, resulta muy peculiar, con el cerdito práctico y el lobo hablando castellano ibérico, y los demás personajes hablando obviamente en español, pero con un marcado acento francés". (http://es.doblaje.wikia.com/wiki/Disney en el doblaje, consultado el 6 de abril de 2018) La primera película de Disney doblada al español fue Blancanieves y los siete enanos (1937), y el doblaje se realizó en Los Ángeles. 
cantidad de palabras posibles de utilizar ya que elimina gran cantidad de sinónimos o formas particulares de expresión regionales".

Díaz Fouces (2009: 243) explica que una lengua estándar es una variedad teórica desprovista de marcas dialectales e identificada con un registro culto que debe permitir la comunicación entre individuos de diverso origen. Según esta definición, se podría decir que el español neutro es una "supravariedad artificial", distinta de las demás, pero representativa de ellas.

Para El Halli Obeid (2012), el español neutro es "una especie de mínimo factor común" basado "en decisiones intuitivas, sondeos de marketing y el más puro método de prueba y error", (...) "una lengua que todo hispanoparlante comprende pero que ninguno habla". Pero Miquel Cortés (2004) lo define como "la variedad de español que contiene rasgos y características de los distintos dialectos del continente americano para que sea comprensible en todos los países de habla hispana".

Fernando Fagnani, editor de Edhasa Argentina, resumió con claridad el dilema del español neutro. ${ }^{33}$ Para él, se puede ver el español neutro desde dos perspectivas opuestas: la del vaso medio lleno, según la cual el español neutro es el corazón del español latinoamericano (aunque es muy difícil describir ese corazón con exactitud), y la del vaso medio vacío, cuya base es que el español neutro es un ente inexistente y artificial que hace que las traducciones parezcan "malas".

Bravo (2009) sostiene que:

la renuncia a lo particular no crea necesariamente un código artificial de lenguaje, sino una estandarización mayor que se utiliza para medios o productos en los que podría tener cabida lo dialectal. (...) La empatía lingüística mejor lograda no es la que selecciona únicamente rasgos comunes a los consumidores finales de un producto, sino la que nos hace sentir como próximos rasgos que en realidad no pertenecen a nuestra modalidad, pero que se introducen en sus variantes afines, concomitantes con usos pasivos o próximos que no resultan ajenos para el espectador y no provocan rechazo. Esta es la primera de las virtudes que debe tener un buen neutro.

Fagnani también favorece un "mestizaje" de la lengua, es decir, un español que no abuse de los coloquialismos pero que vaya incluyendo cada vez más las marcas idiomáticas de cada región. En su visión, el español neutro es una variedad artificial, lavada, que no resulta natural para nadie -y por ende un tanto "sosa", como una paella que solo tuviera arroz- y que por lo tanto debe incorporar rasgos lingüísticos de las distintas regiones en pizcas, sin atiborrar el plato de distintos sabores o favorecer una forma de "cocinar la paella" en particular.

\footnotetext{
33 Jornadas internacionales de traducción comparada - Variedades regionales en las lenguas de traducción, Biblioteca Nacional, Buenos Aires, 20 al 22 de septiembre de 2018
} 
Andión Herrero (2008a) ofrece un concepto similar:

En los márgenes del estándar se encuentra el español neutro, "modelo estandarizado que sin perder los filtros restrictivos de lo común, toma 'muestras' de normas asociadas a núcleos o comunidades de prestigio más concretos dentro del mundo hispánico y las expande por todos sus usuarios" (Andión Herrero, 2008b). El español neutro, resultado de la tan denostada globalización, reina en los medios de comunicación del mundo hispánico y tiene una documentada presencia en Internet. El español neutro, con mucho de sentido común, se dirige a una audiencia mundializada apelando a su mancomunidad lingüística internacional, afinando su hilo para caber por el ojo de todas las agujas.

El director de doblaje Sebastián Arias comenta en $\operatorname{su} \operatorname{blog}^{34}$ que el español neutro es "una convención, tanto el acento utilizado como los términos elegidos", y que va evolucionando, al igual que cualquier otra lengua. "Antes de Internet, era probable que si en un país no le decían de esa forma, no se entendiese qué significaba una gaseosa o un inodoro, pero hoy la solución es inmediata y siempre hay un contexto que termina de completar la idea y todos comprendemos de qué se trata".

Castro (2004), que no está de acuerdo con la existencia de un español realmente neutro, opina que "como cualquier lengua artificial, el español castrado, que nadie habla, sería una lengua sin coloquialismos ni vulgarismos", y que "los engendros supuestamente neutros" no son "ni chicha ni limonada". Villegas (2006), por el contrario, cree en la utilidad del español neutro: "Es una especie de esperanto intraespañol en el cual se usan o inventan formas léxicas y gramaticales lo más exentas de regionalismos que se pueda, con el ánimo de generar un solo producto que no resulte agraviante a nadie, en lugar de tener que producir diferentes copias de lo mismo".

La Ley del Doblaje argentina, de $1988^{35}$, estipulaba que “el doblaje deberá ser realizado en idioma castellano neutro, según su uso corriente en nuestro país, pero comprensible para todo el público de la América hispanohablante". Para dicha ley, se trataba del "hablar puro, fonética, sintáctica y semánticamente, conocido y aceptado por todo el público hispanohablante, libre de modismos y expresiones idiomáticas de sectores" (Petrella, 2001). Si bien esta definición contiene términos vagos como "hablar puro" o "su uso corriente", también reconoce ciertas características particulares del español neutro.

Mientras que algunos académicos opinan que el español neutro existe (Llorente Pintos, 2006), otros lo critican con vehemencia y sostienen que entorpece la tarea de los traductores. Cabanellas (2015) utiliza palabras muy fuertes para describirlo: "imposible, inexistente e inútil", "papilla idiomática", "versión lavada y empobrecida del español",

34 http://doblajeenargentina.blogspot.com.ar/

35 Decreto 933/2013, publicado en el Boletín Oficial de la Argentina (http://servicios.infoleg.gob.ar/infolegInternet/anexos/215000-219999/217418/norma.htm, consultado el 6 de mayo de 2016) 
"engendro", "idea prescriptiva". Se pregunta, con cierto humor, si la versión neutra entre "durazno" y "melocotón" debería ser "melazno" o "duracotón", si nos propusiéramos decidir las opciones correctas en español neutro midiendo porcentajes de cantidad de hablantes que las usan o cantidad de países donde son más comunes y estableciendo una regla matemática para la mezcla. ${ }^{36}$ Además, asevera que:

El español neutro no es hijo de la cultura y el conocimiento, sino de la pobreza intelectual, la ignorancia y su pariente, la soberbia. Viene a recortar nuestra lengua y para "facilitar" la comunicación no encuentra mejor camino que empobrecer nuestro vocabulario y borrar las múltiples formas que nuestras historias han desarrollado para expresar ámbitos culturales de enorme diversidad (Cabanellas, 2015).

Como se ve, no hay acuerdo respecto de lo que es el español neutro. Para unos, es una lengua artificial o inexistente; para otros, se trata de una variedad sin rasgos regionales, mientras que, para otros, se trata justamente de una colección de rasgos de los distintos dialectos. No obstante, todos coinciden en que debe ser una variante que cualquier hispanoamericano pueda comprender. Tras la revisión de todas estas aportaciones, podríamos decir que el español neutro suele definirse como "lo que no es", pero se trata de una variedad del español que busca ser comercialmente viable en toda Latinoamérica (y entre la población de habla hispana de Norteamérica) mediante el uso de estructuras gramaticales, pronunciación y léxico que deberían ser comprensibles para todos los hablantes de esta región y que no sean representativos de una región en particular. Dados la diversidad léxica y el hecho de que no existe una autoridad lingüística específica como la RAE que defina cuáles son las opciones "neutras", y que los corpus que estudian estadísticamente la frecuencia de aparición de los términos en los distintos países de América son reducidos y relativamente nuevos, el español neutro termina siendo diseñado por los diferentes actores involucrados (editoriales, locutores y escuelas de locución, estudios de doblaje, traductores, empresas de subtitulado o telemarketing, etc.), quienes imponen reglas que no siempre se basan en estudios estadísticos o lingüísticos sino en criterios personales que pueden ser correctos o no. Esto da lugar a que el español neutro resulte o más heterogéneo de lo que se pretende o, por el contrario, totalmente restringido en su léxico.

Según lo que hemos visto, podemos clasificar las distintas variedades de español de la siguiente manera:

${ }^{36}$ Que de hecho es lo que proponen autores como Ávila (1998). 


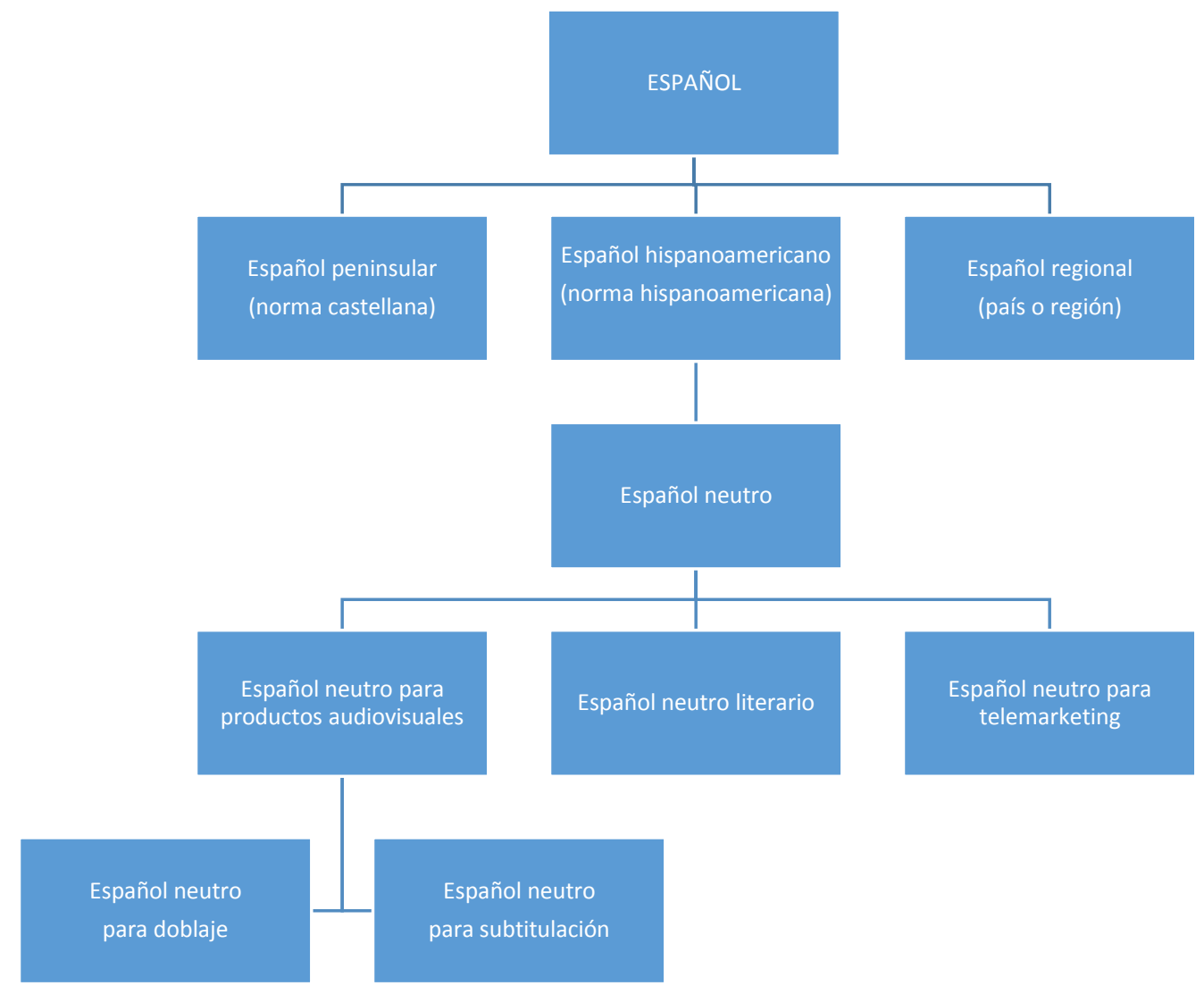

Ilustración 6 - Variedades del español

Hemos marcado una diferencia entre el español neutro para el doblaje y el español neutro para subtitulado por dos razones específicas. En primer lugar, como ejemplo de dubbese, el español para doblaje (y sucede lo mismo con el español peninsular) adquiere ciertos rasgos particulares debido a que por cuestiones de sincronía labial se suelen preferir ciertos términos o frases a otros (por ejemplo, utilizar "eso no suena alentador" en vez de "eso no suena bien" como traducción de "That doesn't sound good" para evitar las bilabiales, cuando la palabra "alentador" no tiene el mismo nivel de uso que "bien" en el habla diaria). En la tabla siguiente, donde se comparan las versiones doblada y subtitulada del primer episodio de la serie Nowhere Boys - Los chicos sin destino (Tony Ayres, 20132018), se puede ver claramente en la elección de "¡Te sostienes!" como traducción de "You can stand!”, dado que el "¡Puedes pararte!” del subtitulado, que es mucho más lógico y suena más natural, contiene bilabiales que de seguro el ajustador intentó evitar (el actor que interpreta al personaje que pronuncia esa frase habla marcando mucho las bilabiales). Y en segundo lugar, también es común que en el doblaje se simplifiquen o expliciten los conceptos ("eso que huele-ese hedor") y se baje el nivel de agresividad ("te voy a ponchar a golpes-te poncharé los testículos"), y que las empresas de subtitulado no sean tan restrictivas respecto del léxico que el traductor puede usar, por ejemplo, en el 
caso de los insultos o palabras soeces, como se puede ver en la guía de subtitulado de Netflix, por ejemplo, que habla de no censurar las expresiones vulgares. ${ }^{37}$

\begin{tabular}{|c|c|}
\hline DOBLAJE & SUBTITULADO \\
\hline Nerd & Cerebrito \\
\hline Estúpido & Tonto \\
\hline Pluma & Bolígrafo \\
\hline Leyes & Derecho \\
\hline Andadera & Andador \\
\hline Banquete & Festín \\
\hline Salsa barbecue & Salsa barbacoa \\
\hline Hermano & Idiota \\
\hline Guapo & Apuesto \\
\hline Tarado & Imbécil \\
\hline Excursionistas & Senderistas \\
\hline Zombi & Fenómeno \\
\hline Eso que huele & Ese hedor \\
\hline Oscuros & Marginados \\
\hline Regresemos caminando & Pidamos un aventón \\
\hline Estos dos perdedores & Estas dos niñitas \\
\hline Patas de pollo & Pies de pollo \\
\hline Hoyo & Agujero \\
\hline Te voy a ponchar a golpes & Te "poncharé” los testículos \\
\hline Qué gran falla, amigo & Fracasaste, viejo \\
\hline ¡Demonios! & Vaya. \\
\hline Eso no suena alentador & Eso no suena bien \\
\hline Eso significa que eres egoísta & Significa que eres un maldito egoísta \\
\hline
\end{tabular}

${ }^{37}$ https://partnerhelp.netflixstudios.com/hc/en-us/articles/217349997-Castilian-Latin-AmericanSpanish-Timed-Text-Style-Guide (consultado el 18 de marzo de 2019) 


\begin{tabular}{|l|l|}
\hline Páneles solares & Paneles solares \\
\hline Los cuentos para dormir & Hay historias aborígenes \\
\hline Raro & Extraño \\
\hline Zoquetes & Perdedores \\
\hline Oscar & Oscie \\
\hline Dr. Seuss & Dr. Dolittle \\
\hline ¡Te sostienes! & ¡Puedes pararte! \\
\hline
\end{tabular}

Tabla 4 - Algunas diferencias entre el modelo de lengua del doblaje y el subtitulado de la serie Nowhere Boys

Por otro lado, el español neutro del doblaje podría definirse como una variedad artificial del español neutro general que se usa únicamente en las versiones dobladas de productos audiovisuales extranjeros para su emisión en cine, TV, DVD o plataformas de Internet o VOD. Sus rasgos generales básicos son una gramática que tiende a simplificar las estructuras, un léxico que busca ser comprensible en toda Latinoamérica y una fonética no marcada por ninguna de las variedades locales del español de América, como se verá a continuación.

\subsection{CARACTERÍSTICAS DEL ESPAÑOL NEUTRO DEL DOBLAJE}

Como mencionamos anteriormente, además del español neutro con sus características particulares, se puede hablar de un español neutro oral y prefabricado del doblaje, con rasgos particulares y no siempre idénticos a los de español neutro general. Tiene una gramática de estructuras simples, un léxico específico y una norma ortofónica especial.

\subsubsection{Nivel fonético y fonológico}

Desde el punto de vista fonético y fonológico, el español neutro del doblaje mantiene los rasgos típicos generales del español de América, pero no los más locales o regionales. Su objetivo es la correcta pronunciación de todos los fonemas para evitar cualquier tipo de confusión o ambigüedad, dado que, como en cualquier producto audiovisual, el espectador debe comprender el sentido de inmediato, ya que no tiene la posibilidad de "releer" el texto. Por este motivo, se hace gran hincapié en que "suenen todas las letras". En primer lugar, las grafías S, Z y C suenan casi idénticas, igual que la Y y la LL. Palabras como "vaya" o "lluvia" tienen el mismo fonema, que suena parecido a una I (/bája/ /júbia/). La S nunca se aspira ni se pierde, en especial al final de la palabra, y se evita el 
sonido aspirado /h/ de la S media o en posición implosiva (/móska/ vs. /móh ka/). Las /x/ no son fuertes, y no se eliden las consonantes al final de las palabras. Por ejemplo, crack $/ \mathrm{krak} /$ nunca se pronuncia /krá/ como en el español de Argentina. También se pone énfasis en que se oigan bien las $\mathrm{D}$ finales y las dos vocales de los diptongos y los hiatos, como en el caso de /kuída/ (para evitar la caída vocálica o la reducción de diptongos del mexicano, por la que, respectivamente, un "ahorita" suena /oríta/ o un "pues" suena /pos/). Además, la V se convierte en bilabial y se pronuncia igual que la B (fenómeno conocido como betacismo).

Los acentos, o variaciones regionales que enfatizan ciertas palabras o partes de una palabra también se evitan, y por supuesto se dejan de lado el estiramiento de las vocales y las subidas y bajadas de tono (que en la jerga del doblaje llamamos "canto") en las frases, como en el caso del español de la provincia de Córdoba en Argentina. No se trata de que sea un discurso monótono, sino de que no tenga marcas de ninguna región en particular. Esto se aplica también a temas de velocidad (los chilenos son los que hablan más rápido, los argentinos son los que hablan con un tono de voz más elevado, hecho que se achaca a la influencia de la inmigración italiana, etc.) y de pronunciación (como el fonema $/ \mathrm{J} /$, que los chilenos dan al dígrafo $\mathrm{CH}$ ). Sí se nota, a veces, una diferencia en la pronunciación de las palabras inglesas, por ejemplo, en las palabras que contienen una U que en inglés tiene un sonido entre /a/ y /o/, por ejemplo lunch. Según el país o el estudio de origen del doblaje, dicha palabra suena /lant// o /lont// (esta última suele ser la pronunciación mexicana).

\begin{tabular}{|l|l|}
\hline \multicolumn{2}{|c|}{ ALGUNOS RASGOS DISTINTIVOS } \\
\hline \multicolumn{2}{|c|}{ DEL ESPAÑOL NEUTRO DE DOBLAJE (Nivel fonético) } \\
\hline S, Z y C suenan idénticas: /s/ (seseo) & $\begin{array}{l}\text { La Y y la LL suenan igual, pero parecidas a } \\
\text { una I (/bája/) }\end{array}$ \\
\hline V y B se pronuncian igual: /B/ (betacismo) & $\begin{array}{l}\text { No se aspira ni se elide ninguna consonante ni } \\
\text { vocal, ni al final ni dentro de las palabras } \\
\text { (articulación tensa) }\end{array}$ \\
\hline No se fusionan vocales en diptongos o hiatos; más bien se exagera el acento (/kuída/)
\end{tabular}

Tabla 5 - Algunos rasgos del español hispanoamericano en el español neutro de doblaje (nivel fonético)

Ávila (2008) sostiene que el español neutro de los medios (al que llama "español internacional") sigue lo que él denomina "la norma alfa" en cuanto a la pronunciación. Según el autor, esta norma alfa se oye en doblajes de películas y series de televisión, y es el español más aceptado en Hispanoamérica (incluyendo a Estados Unidos). Ávila (2008) describe la norma alfa de la siguiente manera: 
Se parece a como se habla en ciudad de México, no en todo el país. Pero también en ciudad de Bogotá, de La Paz, de Cuzco, de Quito... La norma es una norma estándar, pero los medios transmiten a hablantes muy buenos, o sea, que articulan muy bien, no necesariamente cultos.

\subsubsection{Nivel morfosintáctico}

Guevara (2013: 30-33) menciona varios rasgos sociolingüísticos interesantes del español neutro actual, y es el tercero el que nos da pie a intentar describir su nivel morfosintáctico:

- Entre los involucrados en los procesos relacionados con esta variedad, algunos pueden escribir español neutro, pero no lo hablan (los traductores, por ejemplo), pero aunque sea oral, nadie es hablante nativo de español neutro;

- El español neutro americano es percibido como cercano en América pero no en España; y

- El español neutro no es necesariamente "correcto" sino que es funcional (por ejemplo, se escogen ciertos tiempos verbales solo porque son más simples para entender, como el indicativo en vez del subjuntivo, aunque no sea correcto).

Este último aspecto es particularmente llamativo en el español neutro del doblaje. Además, en el español neutro utilizado para los libros, por ejemplo, se trata de evitar el uso de la voz pasiva, pero en el caso del doblaje el uso de la voz pasiva es más común, en especial porque al mantenerla se mantiene la relación palabra a palabra y es más sencillo el proceso de lip sync. Esto también ocurre con otras formas sintácticas (he appeared traducido como "él apareció" en vez del más natural "apareció él” o simplemente "apareció") por las mismas razones.

Otro rasgo característico del español neutro del doblaje es la preferencia de ciertas frases. Es común el uso de "descuida" o "tranquilo/a" para don't worry, para evitar las dos bilabiales del "preocupes", o de la frase "te agradezco" (sumamente formal) para evitar la M del "muchas gracias".

En general se suelen utilizar estructuras sencillas, pero a veces resultan complicadas o no suenan naturales porque se ha intentado dejar alguna palabra en el mismo lugar en que estaba en la lengua fuente. Esto es muy frecuente, por ejemplo, cuando en inglés hay una cadena de sustantivos y/o adjetivos y se intenta conservar el mismo orden para facilitar el lip sync. Si tuviéramos que traducir la frase "Argentine Interpreters Association" del inglés al español neutro del doblaje, posiblemente se traduciría como "Asociación de 
Intérpretes de la Argentina" en vez de "Asociación Argentina de Intérpretes" por cuestiones de lip sync. ${ }^{38}$

\subsubsection{Nivel léxico}

Según Ávila, la norma alfa es tan amplia como para tolerar ciertas marcas o matices. Cita el caso de El Chavo del 8 (Roberto Gómez Bolaños, 1972-1984) que, a pesar de estar repleto de mexicanismos y tener un "canto" bien mexicano, podría incluirse en la norma alfa. Al principio, el español neutro se asemejaba más a la variedad que se hablaba en el centro de México, pero aun así el público de toda Latinoamérica lo entendía. De hecho, los televidentes hispanohablantes han visto durante décadas $E l$ chavo del $8^{39}$, y las distintas generaciones conocen bien las pronunciaciones y los términos mexicanos informales utilizados en dicho programa:

\begin{tabular}{|l|l|l|}
\hline \multicolumn{1}{|c|}{ Mexicano } & \multicolumn{1}{c|}{ Neutro Argentino } \\
\hline Chavo & Niño & Chico \\
\hline Torta & Emparedado / Sándwich & Sándwich \\
\hline Platicar & Hablar & Charlar \\
\hline Marco (de fútbol) & Portería & Arco \\
\hline Menso & Tonto & Tonto \\
\hline Hasta ahorita & Ahora & Recién ahora \\
\hline Me late & Me parece & Me parece \\
\hline Pos & Pues & Pues \\
\hline Nevera & Refrigerador & Heladera \\
\hline Nomás & Solo & Solo \\
\hline Padre & Genial & \\
\hline
\end{tabular}

Tabla 6 - Ejemplos de términos utilizados en El Chavo del 8, comparados con las variedades neutra y argentina

38 Justamente por este criterio se ha dejado de lado en el análisis el aspecto morfosintático, puesto que es más posible que sea el resultado de decisiones tomadas con el lip sync como prioridad que por otros motivos.

39 “La voz de Chespirito por todo el continente", BBC Mundo, 28 de noviembre de 2014, http://www.bbc.com/mundo/video fotos/2014/11/140523 video chespirito obit voxpops wbm (consultado el 11 de febrero de 2017) 
La hegemonía del español mexicano como sinónimo de español neutro (García Aguiar y García Jiménez, 2011) ha ido desapareciendo: los doblajes ya no suelen contener expresiones como "lana" en vez de "dinero", por ejemplo. Esto se debe, en parte, a que las nuevas tecnologías y la globalización permitieron que los doblajes se realizaran en otros países ${ }^{40}$, incluso en forma colaborativa entre un país y otro, de modo que el español neutro se fue acomodando a esta nueva realidad y se tornó "más neutro".

Respecto del léxico, las palabras que menos problemas ocasionan son las más formales y las más modernas, muchas veces relacionadas con la tecnología, como "youtuber" o "hashtag". Pero cuando se trata de alimentos, ropa o colores, por ejemplo, resulta difícil "neutralizarlas". Las "championes" de Uruguay se llaman "zapatillas" en Argentina, "zapatos de goma" en Venezuela y "tenis" en otros países. Y el único modo de encontrar un término neutro sería utilizar uno más genérico: "calzado deportivo". Del mismo modo, se elige "ropa interior" para no usar palabras más locales como "calzón”, "calzoncillo", "calzones", "bombacha", "braga”, "sostén”, “corpiño", "sujetador”, etc. Claro que no siempre existe un término genérico. Por ejemplo, en el caso de los alimentos y comidas, los programas de cocina que no se "hacen en neutro" suelen presentar al pie de la imagen los sinónimos de las palabras que utiliza el cocinero. O podemos toparnos con programas argentinos como Morfi (que significa "comida" en cocoliche) donde los conductores usan "refrigerador" en vez de "heladera", que es su versión argentina.

Sonderéguer (2015) sostiene que la variedad mexicana tiene rasgos en común con la argentina. Si analizamos, por ejemplo, la palabra "brillantina", veremos que la frecuencia de uso es muy similar en Argentina y en México, y bien diferente de la de las demás naciones latinoamericanas.

\footnotetext{
40 Por un lado, las productoras no quieren poner "todos los huevos en la misma canasta" y utilizar solo una empresa de doblaje en un solo país; por el otro, la cantidad de contenidos que se generan en la actualidad es tan enorme que un solo estudio no podría doblar todos los programas de un mismo canal o de una misma productora.
} 


\begin{tabular}{|lrr|}
\hline País & Freq & Fnorm. \\
\hline España & 37 & 0,43 \\
\hline México & 19 & 0,62 \\
\hline Argentina & 14 & 0,58 \\
\hline Venezuela & 8 & 0,66 \\
\hline Cuba & 7 & 0,76 \\
\hline República Dominicana & 6 & 1,03 \\
\hline Chile & 5 & 0,32 \\
\hline Colombia & 5 & 0,25 \\
\hline Perú & 5 & 0,58 \\
\hline Ecuador & 4 & 0,63 \\
\hline 1 - 10 de 19 & & página: 12 \\
\hline
\end{tabular}

Sin embargo, el mismo Sonderéguer (2015: 26-27) cita algunos ejemplos de diferencias entre Argentina y México en el vocabulario relacionado con la comida:

\begin{tabular}{|l|l|l|}
\hline \multicolumn{1}{|c|}{ Argentina } & \multicolumn{1}{|c|}{ México } & \multicolumn{1}{c|}{ España } \\
\hline Dulce de batata & Camote & Dulce de boniato \\
\hline Maní & Cacahuate & Cacahuete \\
\hline Dulce de membrillo & Ate de membrillo \\
\hline Frutilla & Fresa & Fresa \\
\hline Poroto & Frijol & Alubia, judía \\
\hline Chupetín & Paleta & Chupete \\
\hline Ananá & Piña & Piña \\
\hline Banana & Plátano & Plátano, banana \\
\hline Papas fritas & Ruffles (por el nombre comercial) & Patatas fritas \\
\hline
\end{tabular}

Tabla 7- Comparación entre español mexicano, argentino y peninsular de vocabulario relacionado con alimentos

Los vocablos que definen alimentos suelen estar entre los más problemáticos. El término "camote", por ejemplo, corresponde a la palabra que se utiliza en América Central y en Perú para la "batata" de la Argentina y España y el "boniato" de México y también de España. Ahora bien, en Venezuela se suele usar "boniato" como sinónimo de "tonto", y "batata" se utiliza en Argentina para calificar a una máquina de mala calidad o lenta ("Ese 
auto es una batata"). Y si buscamos las definiciones que dan la RAE y el Diccionario de americanismos de la ASALE para la palabra "camote", nos topamos con lo siguiente:

- En Chile es una piedra que se puede lanzar o rodar; también es una mentira, un asunto difícil y una persona fastidiosa.

- En Honduras, Puerto Rico, Uruguay y Argentina es una persona tonta.

- En El Salvador es una hinchazón dura y abultada.

- En Puerto Rico, Colombia y Venezuela es sinónimo de "pantorrilla”.

- En México es una persona desvergonzada, pero también es un amante (masculino) y es sinónimo de "pene”, igual que en Uruguay.

- En República Dominicana es una forma vulgar de decir "vulva".

- Para Perú y Uruguay es “enamoramiento”.

- En Perú también significa “amante”, pero de sexo femenino.

- Y en Puerto Rico es sinónimo de un empleado gubernamental bien remunerado pero incompetente, contratado por influencias.

Está claro que hallar un término que signifique lo mismo en toda Latinoamérica es una tarea muy complicada y muchas veces imposible.

Guevara sugiere que para hablar/escribir en español neutro, uno debe usar las acepciones más difundidas, buscar sinónimos formales incluso en situaciones más informales y acudir a los genéricos (Guevara, 2013: 46). Esto, por supuesto, conlleva una significativa reducción de la riqueza del español, reducción criticada por autores como Ávila, que apoyan la unidad pero sin uniformidad: "Los medios no tienen por qué usar un lenguaje limitado o empobrecido. El español de todos [...] debe nutrirse de los usos nacionales y regionales" (Ávila, 1998).

En el español neutro actual que se utiliza en el doblaje es común la ausencia de groserías y el uso de eufemismos, y aunque sería lógico en un producto para niños, no lo es en el caso de material para adultos. Díaz Cintas (2012: 284) plantea que cualquier modificación, omisión o agregado en el texto meta que no obedece a razones técnicas puede ser un ejemplo de manipulación ideológica. $\mathrm{Y}$ en el blog http://salvenlosmuebles.blogspot.com.ar/2013/11/apuntes-sobre-el-doblaje-elespanol.html se critica este tipo de "neutralización":

El "castellano neutro" no neutraliza el país origen del doblaje, pero sí lo hace con las diferencias sociales y los matices culturales. ¿Acaso es lo mismo que Jesse Pinkman le diga a Walter White, agarrándose las partes íntimas, "Speak into the mic, bitch!' que el "¡Háblele al micrófono, maniático!” de la versión doblada en "español latino”? En Neutralandia los yonquis hablan igual que un prolijo profesor de secundaria. 
También es común que se incorporen extranjerismos como cool, nerd o smoothie y se vayan reemplazando palabras que eran consideradas neutras por otras más locales cuyo significado se ha hecho más usual para todos los hispanohablantes. Tal es el caso de términos como "anillo" (antes "sortija"), "sándwich" (antes "emparedado") o "lentes" (antes "gafas").

Petrella (2001) sostenía que en el doblaje "la norma predominante es la culta madrileña", y citaba algunos ejemplos; sin embargo, en la actualidad esos términos ya no forman parte del español neutro:

\begin{tabular}{|l|l|}
\hline \multicolumn{1}{|c|}{$\begin{array}{c}\text { ESPAÑOL NEUTRO ANTIGUO } \\
\text { (NORMA MADRILEÑA) }\end{array}$} & \multicolumn{1}{c|}{ ESPAÑOL NEUTRO ACTUAL } \\
\hline Nevera & Refrigerador \\
\hline Enfadarse & Enojarse \\
\hline Patata & Papa \\
\hline Lavabo & Sanitario / Baño \\
\hline Cartera & Billetera \\
\hline
\end{tabular}

Tabla 8 - Ejemplos de términos que han cambiado en el español neutro del doblaje

Cabe destacar que autores como Gómez Font o Ávila recalcan la importancia que tienen los medios de comunicación en el desarrollo y avance del español neutro, así como de su homogeneización, aunque no todos consideran que esto sea positivo. Ávila opina que "la comunicación masiva promueve la convergencia lingüística y limita, consecuentemente, los usos divergentes" (2001). Es que la norma alfa "propone que se use la variante que tiene más hablantes en más países, o sea, la que tiene más peso demográfico y más dispersión política" (Ávila, 2008). Claro está que esto es un ideal que está lejos de poder ser alcanzado: ¿Sería realmente posible delimitar qué variante tiene más hablantes en más países? Aunque se tuviera en cuenta la cantidad de hablantes de cada país, ¿se podría decir a ciencia cierta cuántas de esas personas utilizan un mismo término? Si nos guiáramos por la cantidad de hablantes de español en los diferentes países de América, el español neutro debería ser el mexicano: 


\begin{tabular}{|c|c|c|}
\hline País & Población & Grupo de dominio nativo \\
\hline México & 127,8 millones & 123,7 millones \\
\hline Colombia & 50,4 millones & 50 millones \\
\hline Argentina & 45,4 millones & 44,5 millones \\
\hline Estados Unidos & 330 millones & 41,5 millones \\
\hline Venezuela & 32,6 millones & 31,7 millones \\
\hline Perú & 32,6 millones & 28,2 millones \\
\hline Chile & 19,5 millones & 18,7 millones \\
\hline
\end{tabular}

Tabla 9 - Países con mayor población hispanohablante en América (las cifras son aproximadas) / Fuente: El español: una lengua viva (Instituto Cervantes, 202041)

Los demás países de América tienen todos menos de 18 millones de hablantes de español. Es interesante resaltar que, a excepción de Chile, los países con mayor población son los que suelen realizar los doblajes al español latino (Perú tiene una incipiente industria del doblaje).

Castro (2004) comenta que, un español neutro "castrado" es imposible, ya que "hay infinidad de objetos que no tienen un nombre común”, y por lo tanto resulta muy difícil decidir cuál es el término que más personas utilizan y que podría ser el más neutro:

${ }^{41}$ https://cvc.cervantes.es/lengua/espanol lengua_viva/pdf/espanol lengua viva 2020.pdf 


\begin{tabular}{|c|c|c|c|c|c|c|c|}
\hline \multicolumn{7}{|c|}{ TÉRMINOS EN LOS DISTINTOS PAÍSES DE LATINOAMÉRICA } & \multirow{2}{*}{$\begin{array}{l}\quad \mathbf{E N} \\
\text { ESPAÑA } \\
\text { Batata, } \\
\text { boniato } \\
\text { (ES) }\end{array}$} \\
\hline $\begin{array}{l}\text { Batata (AR, } \\
\text { NI, PR, CO, } \\
\text { VE) }\end{array}$ & $\begin{array}{l}\text { Boniato } \\
\text { (MX, CO, } \\
\text { UY) }\end{array}$ & $\begin{array}{l}\text { Camote } \\
\text { (Am } \\
\text { Central, } \\
\text { PE) }\end{array}$ & & & & & \\
\hline $\begin{array}{l}\text { Chico / Pibe } \\
\text { (AR) }\end{array}$ & $\begin{array}{l}\text { Chino } \\
\text { (CO) }\end{array}$ & $\begin{array}{l}\text { Chavo } \\
\text { (MX) }\end{array}$ & $\begin{array}{l}\text { Gurí / } \\
\text { Botija } \\
\text { (UY) }\end{array}$ & $\begin{array}{l}\text { Mitaí } \\
\text { (PAR) }\end{array}$ & $\begin{array}{l}\text { Chamo } \\
\text { (VE) }\end{array}$ & $\begin{array}{l}\text { Patojo } \\
\text { (GU) }\end{array}$ & $\begin{array}{l}\text { Chico/ crío } \\
\text { (ES) }\end{array}$ \\
\hline $\begin{array}{l}\text { Choclo } \\
\text { (CH, PE, } \\
\text { UY, AR, } \\
\text { EC) }\end{array}$ & $\begin{array}{l}\text { Elote } \\
\text { (MX) }\end{array}$ & Jojoto (VE) & $\begin{array}{l}\text { Mazorca } \\
(\mathrm{CO})\end{array}$ & $\begin{array}{l}\text { Maíz } \\
\text { (VE, } \\
\text { UY) }\end{array}$ & & & $\begin{array}{l}\text { Mazorca / } \\
\text { Maíz (ES) }\end{array}$ \\
\hline $\begin{array}{l}\text { Cinta } \\
\text { Scotch (AR, } \\
\text { UY) }\end{array}$ & $\begin{array}{l}\text { Durex } \\
\text { (MX) }\end{array}$ & $\begin{array}{l}\text { Escortei } \\
(\mathrm{CU})\end{array}$ & $\begin{array}{l}\text { Cinta } \\
\text { pegante } \\
(\mathrm{CO})\end{array}$ & $\begin{array}{l}\text { Teipe } \\
\text { (VE) }\end{array}$ & & & $\begin{array}{l}\text { Celo, } \\
\text { celofán } \\
\text { (ES) }\end{array}$ \\
\hline $\begin{array}{l}\text { Concheto / } \\
\text { Cheto (AR, } \\
\text { UY) }\end{array}$ & $\begin{array}{l}\text { Cuico } \\
(\mathrm{CH})\end{array}$ & $\begin{array}{l}\text { Sifrino } \\
\text { (VE) }\end{array}$ & $\begin{array}{l}\text { Pituco } \\
\text { (Bol, PE) }\end{array}$ & $\begin{array}{l}\text { Gomelo } \\
\text { (CO) }\end{array}$ & $\begin{array}{l}\text { Fresa } \\
\text { (MX) }\end{array}$ & & Pijo (ES) \\
\hline $\begin{array}{l}\text { Dulce de } \\
\text { leche (AR, } \\
\text { UY, VE) }\end{array}$ & $\begin{array}{l}\text { Cajeta } \\
\text { (MX, } \\
\text { SAL, GU, } \\
\text { HO) }\end{array}$ & $\begin{array}{l}\text { Manjar } \\
(\mathrm{BO}, \mathrm{CH} \text {, } \\
\mathrm{CO})\end{array}$ & $\begin{array}{l}\text { Arequipe } \\
\text { (Bogotá, } \\
\text { VE) }\end{array}$ & $\begin{array}{l}\text { Fanguito } \\
\text { (CU) }\end{array}$ & & & \\
\hline $\begin{array}{l}\text { Flota-flota } \\
\text { (AR) }\end{array}$ & $\begin{array}{l}\text { Flotador } \\
\text { pancho } \\
\text { (UY) }\end{array}$ & $\begin{array}{l}\text { Funnoodles } \\
\text { (PR) }\end{array}$ & & & & & $\begin{array}{l}\text { Fideos o } \\
\text { churros de } \\
\text { piscina }\end{array}$ \\
\hline $\begin{array}{l}\text { Lomo de } \\
\text { burro (AR) }\end{array}$ & $\begin{array}{l}\text { Policía } \\
\text { acostado } \\
\text { (MX) }\end{array}$ & $\begin{array}{l}\text { Lomada } \\
\text { (UY) }\end{array}$ & $\begin{array}{l}\text { Lomo de } \\
\text { toro }(\mathrm{CH})\end{array}$ & $\begin{array}{l}\text { Rompe- } \\
\text { muelles } \\
\text { (PE) }\end{array}$ & & & $\begin{array}{l}\text { Banda de } \\
\text { frenado, } \\
\text { reductor de } \\
\text { velocidad }\end{array}$ \\
\hline $\begin{array}{l}\text { Metegol } \\
\text { (AR) }\end{array}$ & $\begin{array}{l}\text { Futbolito } \\
\text { (UY, VE) }\end{array}$ & $\begin{array}{l}\text { Taca Taca } \\
(\mathrm{CH})\end{array}$ & & & & & $\begin{array}{l}\text { Futbolín } \\
\text { (ES) }\end{array}$ \\
\hline $\begin{array}{l}\text { Pochoclo } \\
\text { (AR) }\end{array}$ & $\begin{array}{l}\text { Flor } \\
\text { (Cuba) }\end{array}$ & $\begin{array}{l}\text { Cotufas } \\
\text { (VE) }\end{array}$ & $\begin{array}{l}\text { Pororó } \\
\text { (PA) }\end{array}$ & $\begin{array}{l}\text { Crispetas } \\
(\mathrm{CO})\end{array}$ & $\begin{array}{l}\text { Cabritas } \\
(\mathrm{CH})\end{array}$ & $\begin{array}{l}\text { Pipoca } \\
\text { (BO) }\end{array}$ & $\begin{array}{l}\text { Palomitas / } \\
\text { Ros(et)as } \\
\text { (MX, ES) }\end{array}$ \\
\hline $\begin{array}{l}\text { Remera } \\
\text { (AR, UY) }\end{array}$ & $\begin{array}{l}\text { Polera } \\
(\mathrm{CH}, \mathrm{BO})\end{array}$ & $\begin{array}{l}\text { Franela } \\
\text { (VE) }\end{array}$ & $\begin{array}{l}\text { Playera } \\
(\mathrm{MX})\end{array}$ & $\begin{array}{l}\text { Camisa } \\
(\mathrm{PR}, \mathrm{VE})\end{array}$ & $\begin{array}{l}\text { Polo } \\
\text { (PE), } \\
\text { chompa } \\
\text { (PE, EC, } \\
\text { BO, PA) }\end{array}$ & & Jersey (ES) \\
\hline $\begin{array}{l}\text { Remolacha } \\
\text { (Sudamérica) }\end{array}$ & $\begin{array}{l}\text { Betabel } \\
\text { (MX) }\end{array}$ & $\begin{array}{l}\text { Betarraga } \\
(\mathrm{PE}, \mathrm{CH})\end{array}$ & & & & & $\begin{array}{l}\text { Remolacha } \\
\text { (ES) }\end{array}$ \\
\hline $\begin{array}{l}\text { Sorbete } \\
\text { (AR, PE, }\end{array}$ & $\begin{array}{l}\text { Popote } \\
\text { (MX, EC, } \\
\text { CH) }\end{array}$ & $\begin{array}{l}\text { Pajilla (CR, } \\
\text { GU, HO, } \\
\text { CH) }\end{array}$ & $\begin{array}{l}\text { Bombilla } \\
\text { (AR, BO, } \\
\mathrm{CH})\end{array}$ & $\begin{array}{l}\text { Pitillo } \\
\text { (VE, } \\
\text { CO) }\end{array}$ & $\begin{array}{l}\text { Carrizo } \\
\text { (PAN) }\end{array}$ & $\begin{array}{l}\text { Absor- } \\
\text { bente } \\
\text { (CU) }\end{array}$ & $\begin{array}{l}\text { Pajilla, } \\
\text { pajita (ES) }\end{array}$ \\
\hline
\end{tabular}




\begin{tabular}{|c|c|c|c|c|c|}
\hline $\begin{array}{l}\text { EC) })^{42}, \\
\text { sorbeto/paja } \\
(P R)\end{array}$ & & & & & \\
\hline $\begin{array}{l}\text { Zapallo } \\
\text { (Sudamérica, } \\
\text { del quechua } \\
\text { sapallu) }\end{array}$ & $\begin{array}{l}\text { Calabaza } \\
\text { (MX, CO, } \\
\text { AR) }\end{array}$ & $\begin{array}{l}\text { Auyama } \\
\text { (Caribe) }\end{array}$ & $\begin{array}{l}\text { Ayote } \\
\text { (CR, } \\
\text { SAL, GU, } \\
\text { HO, NI) }\end{array}$ & $\begin{array}{l}\text { Zapallo } \\
\text { camote } \\
(\mathrm{CH})\end{array}$ & $\begin{array}{l}\text { Calabaza } \\
\text { (ES) }\end{array}$ \\
\hline
\end{tabular}

Tabla 10 - Sinónimos de diferentes términos en los distintos países hispanohablantes, elaboración propia ${ }^{43}$

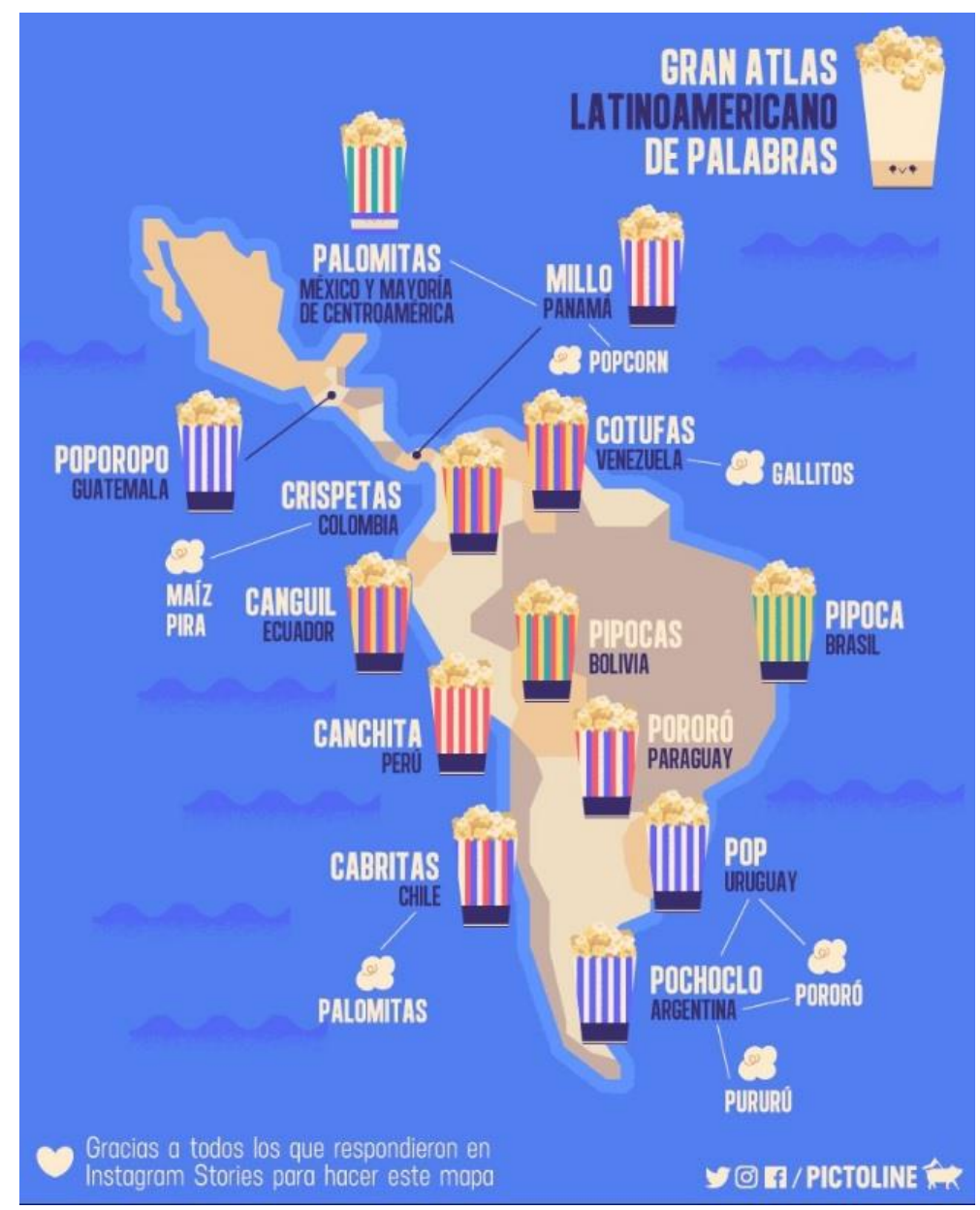

Ilustración 8 - Nombres que se da al popcorn en Latinoamérica / Fuente: pictoline.com

42 Hasta hace unos diez años, en Argentina se la llamaba "pajita", pero ese término se dejó de utilizar cuando se popularizó como una grosería.

${ }^{43}$ Cabe aclarar que en este trabajo se habla de variedades por países para delimitar de alguna forma dichas variedades, pero la realidad es que los límites geopolíticos no son límites lingüísticos, y hay distintas variedades, y muy diferentes, dentro de un mismo país. 
Elegir el término "más usado" es prácticamente imposible, ya que requeriría que el traductor conociera todas las variantes del español en América Latina y además supiera cuántos hablantes usan cada una. Y si bien algunos estudios dan a los traductores una lista de palabras que no pueden utilizar, siempre habrá muchas más que pueden ponerlos en aprietos sin querer. Por ejemplo, es fácil suponer que una mediería vende medias, y que por su similitud con el nombre del objeto que vende podría ser considerado un término genérico (en Argentina se le llama "lencería"; "mediería" es el término uruguayo). Sin embargo, en muchos países las medias se llaman "calcetas" o "calcetines". Con tan solo cruzar el Río de la Plata hasta Uruguay, los argentinos se topan con una enorme cantidad de palabras diferentes (y ambas variedades forman parte del "español rioplatense"). Si algo está "pronto" significa que está listo, y uno deja su abrigo en una "ropería" y no en un guardarropas. En otros casos, sustantivos masculinos como "moño" se convierten en femeninos ("moña")

Hay un hecho muy interesante que no podemos dejar de considerar. Mientras que en los diccionarios figura la palabra "remera" como de uso común en Uruguay para el T-shirt del inglés, y aunque se la utilice en el habla cotidiana, muchos supermercados y tiendas en línea utilizan directamente el término en inglés para que todos comprendan de qué prenda de vestir se trata. Una comparación entre supermercados y tiendas de ropa en línea de varios países ${ }^{45}$ muestra una realidad algo distinta a la de los diccionarios. ${ }^{46} \mathrm{Y}$ si bien confirma que hay palabras que se pueden utilizar con cierta seguridad, incluso sin importar la grafía (como escoba, mochila o rizos; yogur, yogurt o yoghurt; shampoo o champú), también deja a las claras que es fácil equivocarse y usar un término que es directamente ofensivo en otra comunidad lingüística, o que significa algo totalmente distinto. Por ejemplo, lo que en Argentina se llama "manopla", una especie de guante para tomar las asaderas calientes, en Colombia es "coge-ollas", y allí también se venden "almejas en concha", cuando tanto el verbo "coger" como "concha" son términos vulgares de connotación sexual en Argentina. Y sin que sea una palabra ofensiva, en Colombia una consola es un mueble y no un juego de vídeo, lo que podría prestarse a confusión.

Una de las conclusiones más notorias a la que podemos llegar observando las tablas del Anexo 4 es que incluso los países cercanos entre sí (como sería el caso de Argentina, Uruguay y Chile) no necesariamente utilizan los mismos términos, y a veces, por el

${ }^{44}$ Este fenómeno también se da al revés: "el terminal" en vez de "la terminal" (en Venezuela), o "el Internet" y "la Internet" (en diferentes países).

45 Los sitios de venta en línea consultados fueron Tienda Inglesa de Uruguay; Jumbo de Argentina, Colombia y Chile; Walmart de México y Puerto Rico; Makro de Perú, y las tiendas de ropa Dafiti, Falabella y París de los mismos países.

${ }^{46}$ El Anexo 4 contiene una extensa tabla con términos en inglés, en español neutro y en los distintos españoles hablados en los diferentes países hispanófonos, así como comparaciones entre términos de Argentina, Uruguay y España. 
contrario, sí comparten vocabulario países más distantes, como México y Uruguay, o incluso Argentina y España (la palabra "petaca", por ejemplo, significa lo mismo en Argentina y España, pero no en Uruguay).

También llaman la atención otros hechos. En primer lugar, a pesar de la fuerte impronta que supuestamente el español mexicano ha dejado en el español neutro, no siempre se usa la palabra mexicana. Tampoco se utiliza siempre el término común a más países; es más, a veces se opta por el término utilizado por la menor cantidad de hablantes (como "bacinica"), una decisión cuya justificación se desconoce debido al secretismo reinante en la industria del doblaje. Y cuando hay gran variación entre los distintos países, se recurre a un término más genérico (por ejemplo, calzado deportivo), o se inventan nombres como "papel sanitario", que aparentemente no se utiliza en ningún país de Latinoamérica ni en España.

Como se aprecia en esta primera aproximación a la descripción del español neutro del doblaje, las opciones léxicas parecen no seguir un patrón uniforme y parecen predominar criterios subjetivos. Por ello, un trabajo como el presente puede arrojar luz y sobre todo estructurar y organizar, además de describir con criterios más sistemáticos, esta extraña variedad fantasma de la lengua española, quizás la más consumida por todos los hablantes de español del planeta.

\section{5. ¿ACADÉMICOS FRENTE A PROFESIONALES?}

Uno de los grandes problemas que presenta el español neutro, o tal vez el mayor, es que, aunque se coincida en la definición de lo que es (o no es), a la hora de aplicarla no todos opinan lo mismo. Brizuela (en Farina, 2014) sostiene que el mayor desafío del doblaje en español neutro es "lograr que se entienda la frase en todo el territorio, en todos y cada uno de los países de Latinoamérica, manteniendo la frescura y sin quedar formal ni anticuado". Pero, ¿es posible lograrlo? Dado que "todo el territorio" implica hispanohablantes desde Estados Unidos y Canadá hasta Argentina y Chile, resulta bastante obvio que la idea de mantener la frescura y no ser formal ni anticuado es una tarea hercúlea. Y es mucho peor si a eso le sumamos que las distintas partes involucradas tienen diferentes opiniones sobre qué suena natural o qué es gramatical o políticamente correcto. Y este conflicto no solo se da entre académicos y profesionales, sino incluso entre los profesionales mismos. En teoría, eso lleva a que el español neutro utilizado difiera bastante entre los distintos estudios de doblaje ubicados en diferentes países, que se ven afectados por varios factores, como el profesionalismo de los traductores (no en todos los casos han estudiado traducción), las leyes del país, la injerencia del gobierno, la importancia del estudio de doblaje o del iniciador del encargo de traducción, etc. Desarrollaremos estos aspectos en forma más detallada en los capítulos siguientes. Por otro lado, algunos académicos estudian el doblaje terminado, es decir, el producto de la traducción (más el trabajo de todos los eslabones posteriores en la cadena), algo que ha recibido críticas incluso desde los mismos círculos académicos (Richart-Marset, 2012). 
Los profesionales, en cambio, conocen lo que sucede durante todo el proceso. Esto no es un detalle menor, ya que el traductor, que está al inicio del proceso, no siempre es el responsable de lo que finalmente se ve en la pantalla. Ni siquiera los actores de doblaje, que de algún modo son ajenos a la traducción del texto en sí, quedan fuera de este conflicto. Es por ese motivo que este trabajo incluye la perspectiva de gran parte los involucrados.

Petrella (2001) también comenta que cuando se redactó la Ley del Doblaje argentina no se consultó a ningún lingüista, y que es común que algunos agentes del proceso de doblaje no sean expertos en español, aunque tengan la capacidad de tomar decisiones sobre el léxico a utilizar.

Ya el nombre de la variedad de español que estudiamos presenta problemas. Gómez Font sostiene que mientras que los académicos utilizan términos como "español internacional", "norma hispánica" o "español estándar", son los profesionales de la traducción y del doblaje los que lo llaman "español neutro" (Gómez Font, 2003), aunque otros académicos como Petrella sí usan esa denominación.

En cuanto a los rasgos del español neutro, también hay opiniones encontradas. Mientras que Petrella (2001) sostiene que se privilegia el uso del pretérito perfecto compuesto sobre el simple, los productos doblados muestran que no es así (véase el capítulo 6, Análisis). También afirma que se utiliza el diminutivo "-ito", aunque Arias apunta en su blog que "un problema importante reflejado en las traducciones durante muchísimo tiempo fue la creencia equivocada y totalmente fuera de lugar de que el neutro no aceptaba diminutivos o superlativos". Petrella también comenta que "es interesante notar que en doblajes realizados en México podemos encontrar palabras de una norma mexicana que señala dialecto social. Por ejemplo: el término latoso. Lo mismo en los doblajes venezolanos, por ejemplo: lana (dinero), pelarse (huir)". Sin embargo, la evolución del español neutro llevó a que este tipo de palabras más locales no aparezcan (o casi no aparezcan) hoy en día en los doblajes mexicanos o venezolanos.

Para algunos profesionales como el director de doblaje Sebastián Arias, el uso de regionalismos no es un problema:

Muchos de mi generación crecieron escuchando El Chavo del 8 y sus tortas de jamón y/o la falta de pago de la renta, y sin embargo eso no me trajo problemas con el alquiler ni con mi alimentación. ${ }^{47}$

De hecho, Arias cree que el español neutro no existe, porque resultaría imposible conocer cuál es el término más usado o conocido para cada palabra que debemos traducir.

Respecto de los conflictos entre los iniciadores y/o reguladores del encargo de traducción por un lado y los agentes involucrados directamente en el doblaje (traductores, directores

\footnotetext{
${ }^{47}$ Arias, S. “¿De qué estamos hablando? Acento neutro y castellano neutro", en http://doblajeenargentina.blogspot.com.ar/2012/07/espanol-rioplatense-y-espanol-neutro.html
} 
y actores de doblaje) por el otro, durante los años 2015 y 2016 se repitieron las mismas críticas en las jornadas realizadas en la Ciudad de Buenos Aires cuyo tema central era la traducción audiovisual. Durante la jornada Las distintas voces del doblaje ${ }^{48}$, por ejemplo, tanto el director Arias como los dobladores Hernán Palma y Alejandro Graue se quejaron de la imposición de ciertos términos o de la obligación de omitir o cambiar ciertas palabras o expresiones cuando se dobla al español neutro. Los tres coincidieron en que se suelen cambiar algunas referencias culturales, como la Navidad (Arias presentó una interesante discusión sobre el doblete Papá Noel/Santa Claus) o las referencias religiosas, incluido el repetidísimo "Oh my God!" y el juvenil "OMG!" (Este comentario ya había surgido también durante el Simposio Hispanoamericano de Traducción Especializada y Nuevas Tecnologías ${ }^{49}$, también organizado por el Colegio de Traductores Públicos de la Ciudad de Buenos Aires.) Sin embargo, ninguno de los tres pudo indicar quién toma la decisión de imponer esos cambios debido al secretismo que rodea al proceso de doblaje.

La particularidad del español neutro del doblaje es que se suele adaptar a las normas establecidas por los iniciadores del encargo de traducción, ya sea el cliente, el canal, la productora o el estudio de doblaje (o incluso a las normas impuestas por los gobiernos), y no necesariamente al español neutro que el traductor aprende en la universidad (que, por otro lado, no sigue las mismas convenciones porque suele ser el literario o el técnico, escrito, y por ende cumple una función diferente) ${ }^{50}$. Y es por ese motivo que pueden existir diferencias entre los productos terminados de los distintos países y estudios, y que por lo tanto no se podría hablar de un solo español neutro del doblaje, homogéneo y utilizado en toda Latinoamérica.

\subsection{NUEVAS INICIATIVAS PARA SUPERAR EL PROBLEMA}

¿Y qué es lo que puede hacer un traductor a la hora de elegir el término adecuado, que sea comprensible para todos los hispanohablantes? Esta es una pregunta muy difícil de responder. En primer lugar, no existe una materia de "español neutro" en los traductorados, y aunque existiese un diccionario completísimo con todo el vocabulario de toda Latinoamérica, sería prácticamente imposible buscar una significativa cantidad de las palabras que utiliza el traductor. Porque el peor problema no es tanto elegir la palabra que todos entiendan sino más bien elegir una palabra que suene natural, que no modifique el sentido o cause malentendidos, y que no provoque un efecto no deseado. En resumidas

\footnotetext{
${ }^{48}$ http://tavargentina.com/2016/11/doblaje-jornada-taller/

${ }^{49}$ http://tavargentina.com/2015/07/simposio-hispanoamericano/

${ }^{50}$ En las universidades argentinas no existe una asignatura de español neutro. Solamente se aplica en clase en las asignaturas como Traducción Literaria o Traducción Técnico-Científica, pero en forma escueta.
} 
cuentas, un término que cumpla con los requisitos básicos de una traducción de calidad (además de con las restricciones de la traducción audiovisual).

En consecuencia, y dada la imposibilidad de buscar en el diccionario la mayoría de las palabras que se usan al traducir y la posibilidad de usar un término que pueda malinterpretarse o no entenderse, se podría decir que lo más probable es que resulte imposible utilizar un español totalmente neutro.

En este sentido, y retomando el tema de las opiniones encontradas de académicos y profesionales (véase 2.5.), a principios de la década de 2010 algunos canales como Disney, Nickelodeon y otras productoras comenzaron a crear productos que, en vez de estar hablados en español neutro, cuentan con actores de distintas nacionalidades ${ }^{51}$, cada uno con la forma de hablar típica de su país, para que los hispanohablantes reconozcan los acentos y formas de hablar propios y ajenos (incluyendo el español de España). Entre estos nuevos productos (de gran éxito, por cierto) podemos mencionar Violetta (con actores de Argentina, México, España, Italia, Brasil, Ucrania y Francia), Soy Luna (con actores de México, Argentina, Chile, Italia, Brasil, España y Colombia) y Love, Divina. En Variety, John Hopewell explica claramente este nuevo formato: ${ }^{52}$

Allying three of the key independent players in today's teen TV space, Argentina's Polka, producer of Disney juggernauts "Violetta" and "Soy Luna," is teaming with Mexican TV giant Televisa and Paris-based Federation Kids \& Family to produce "Love, Divina," a groundbreaking digital-age, pan-Latin American teen drama. "Love, Divina" toplines Laura Esquivel, an international tween-teen TV icon and pop star after telenovela smash hit "Patito Feo," broadcast from 2008 and reversioned for Mexico by Televisa. (...) Esquivel's new daily teen series reflects a TV revolution. "Patito Feo's" Argentine original had Argentine stars, Televisa's makeover a Mexican key cast. Targeting a new, more globalized generation of TV viewers and an evolving TV landscape, "Love, Divina" will have just one version for the whole of Latin America, sporting characters with clear national accents.

Y esta nueva tendencia ha continuado. En septiembre de 2018 Disney Channel presentó su nueva serie internacional, Bia, con música en español y portugués y experiencias multiplataforma, y así lo comentaba la revista para ti:

"Bia representa la consolidación de nuestra estrategia de producción local de contenidos originales, que se inició con Violetta y continuó con Soy Luna. Volcaremos todo nuestro

\footnotetext{
${ }^{51}$ En la actualidad también se utilizan los doblajes colaborativos, que realizan estudios de distintos países para mantener la ilusión de que la voz del actor de doblaje es la del actor original (más adelante volveremos sobre este tema). Y también han surgido plataformas digitales que permiten a los actores grabar doblajes desde su casa con un director que sí se encuentra físicamente en los estudios. Esto permite trabajar con actores de distintos países en una misma producción.

52 Hopewell, J. (2016): “Televisa, Pol-ka, Federation, Laura Esquivel Team for 'Love, Divina'”, en Variety, 12 de septiembre de 2016 (http://variety.com/2016/digital/global/mipcom-televisa-pol-kafederation-laura-esquivel-love-divina-1201857921/, consultado el 9 de diciembre de 2017)
} 
aprendizaje en este nuevo contenido que veo como superador y -al igual que sus antecesores- absolutamente internacional. Si bien nuestra plataforma de producción y exhibición es Disney Channel, esta es una propuesta multiplataforma que representa no solo una prioridad para Disney Channel en Latinoamérica, sino para toda la compañía a nivel global", expresó Diego Lerner, presidente de The Walt Disney Company Latin America.

El elenco multicultural de Bia está liderado por la actriz brasileña Isabela Souza, el actor español Julio Peña, la actriz mexicana Andrea de Alba y el actor argentino Guido Messina. Completan el reparto los argentinos Fernando Dente, Agustina Palma, Micaela Díaz, Alan Madanes y Rodrigo Rumi; la mexicana Julia Argüelles; los brasileños Gabriella Di Grecco y Rhener Freitas; los colombianos Luis Giraldo y Daniela Trujillo; el venezolano Esteban Velásquez, el ecuatoriano Jandino y la italiana Giulia Guerrini. ${ }^{53}$

En el mismo sentido, el siguiente anuncio muestra la llamada a un casting para la producción de una serie de TV con personajes (y, por tanto, actores y actrices) de varias nacionalidades latinoamericanas:

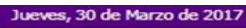

\section{Se busca actores y actrices latinoamericanos para serie de TV}

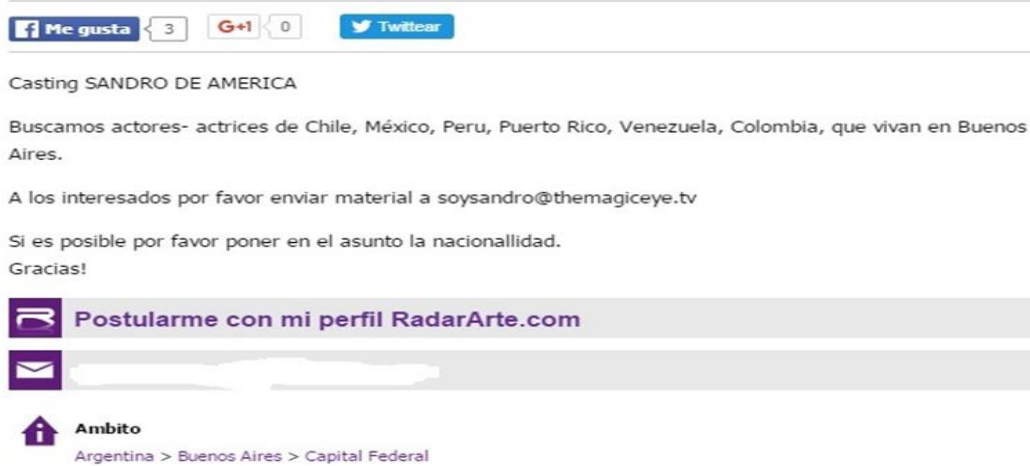

Ilustración 9 - Ejemplo de casting de actores latinoamericanos para serie de TV grabada en Argentina / Fuente: www.alternativateatral.com

53 “Comienza la producción de Bia, la nueva serie multicultural de Disney Channel", para ti, 10 de septiembre de 2018 (https://www.infobae.com/parati/para-teens/2018/09/01/comienza-laproduccion-de-bia-la-nueva-serie-multicultural-de-disney-channel/, consultado el 4 de diciembre de 2018). 
Por el momento, el traductor necesita tomar decisiones informadas, pero no siempre cuenta con toda la información necesaria. Existen, sin embargo, diccionarios de americanismos que se pueden consultar, como www.asale.org/recursos/diccionarios/damer, y glosarios de regionalismos de cada país, como el Diccionario del habla de los argentinos de la Academia Argentina de Letras, o el Diccionario de mexicanismos de la Academia Mexicana de la Lengua, además de glosarios de temas específicos, como la gastronomía.

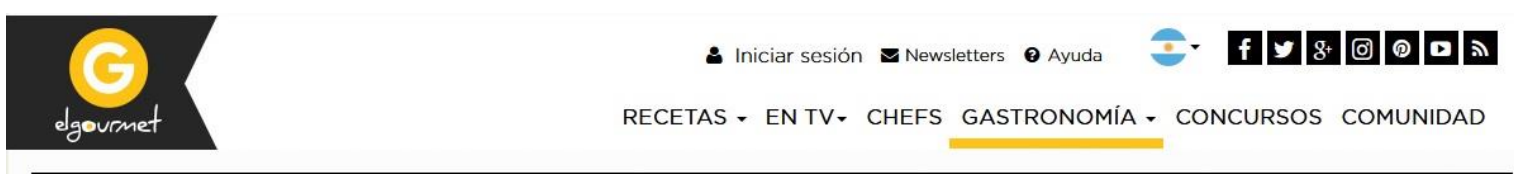

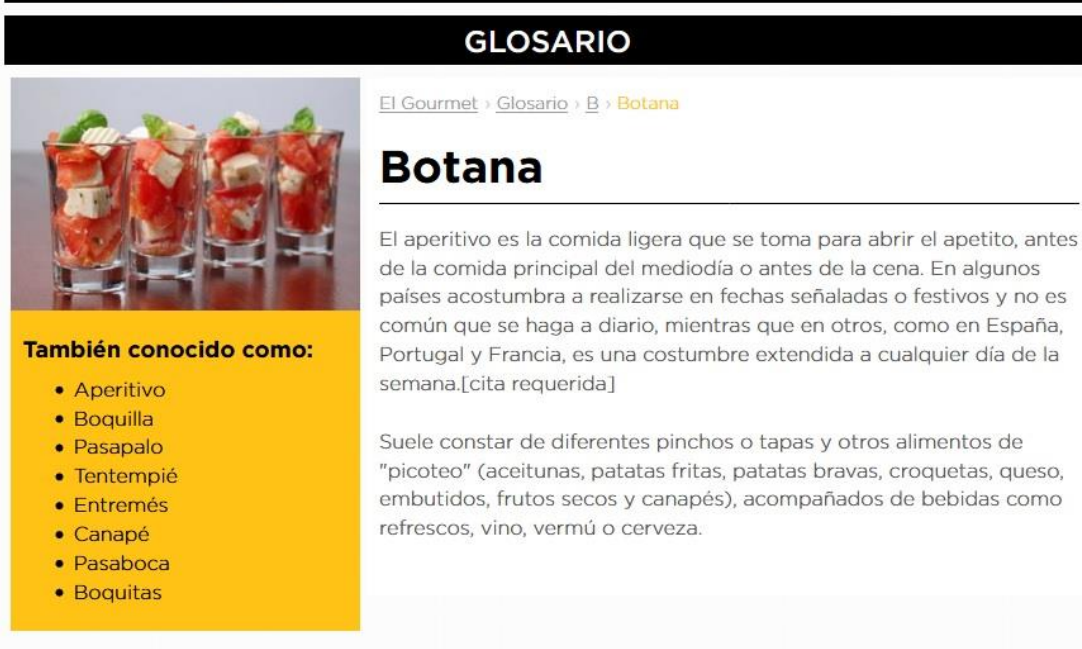

CONSULTA OTROS TÉRMINOS DE NUESTRO GLOSARIO

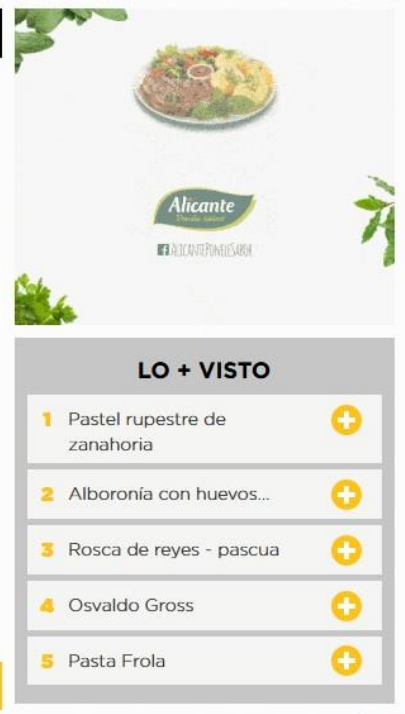

Ilustración 10 - Glosario de términos culinarios / Fuente: www.elgourmet.com

También existen diccionarios online colaborativos, como Word Reference (www.wordreference.com), donde los usuarios pueden contribuir con traducciones para los términos. Y resultan útiles, a pesar de no ser un diccionario formal, los sitios colaborativos como www.asihablamos.com o los grupos de Facebook sobre diferencias linguísticas en Latinoamérica. Pero aun así, a veces no es fácil tomar una decisión. Por ejemplo, si buscamos una traducción para flush the toilet, nos encontraremos con las siguientes propuestas de usuarios: 
Bajarle al agua / al baño

Jalar / Tirar la cadena / Tirar de la cadena

Apretar el botón

Soltar el agua

Descargar el sanitario

Tirar el agua

Jalar al baño

Echar agua

Botar el agua

Soltar el sanitario

Darle a la bomba / a la cisterna

Jalar la palanca del baño

Taza / inodoro / wáter / poceta / excusado / retrete

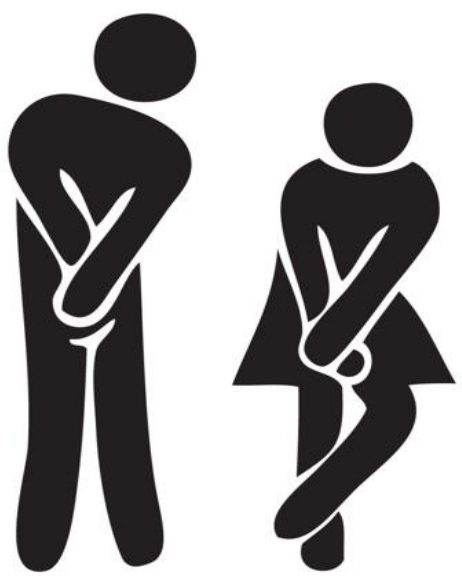

Ilustración 11 - Traducciones de flush the toilet sugeridas por usuarios en www.wordreference.com / Fuente: "El español neutro para el doblaje: mitos y realidades" 54

Además del diccionario de la RAE, que suele especificar en qué país se utiliza cada término, también existe un proyecto interesante denominado VARILEX (Variación léxica del español en el mundo) y organizado entre 1993 y 2005 desde la Universidad de Tokio. VARILEX estudia el léxico separándolo por países, y aunque la división geopolítica no siempre se corresponde con una división lingüística, ofrece los términos que se usan en los distintos países y una página web con mapas que muestran el grado de representatividad léxica de los términos estudiados ${ }^{55}$. En 2015 inició una nueva fase de revisión de los datos reunidos en la primera fase, y si bien los vocablos no tienen contexto y la cantidad de personas encuestadas difiere mucho entre país y país, puede resultar de ayuda a la hora de tomar decisiones lingüísticas.

54 Scandura, G.: "El español neutro para el doblaje: mitos y realidades", ponencia presentada en el I Congreso Hispanoamericano de Traducción Audiovisual, Buenos Aires, mayo de 2018

${ }^{55}$ A diferencia del sitio en sí, la representación léxica está desorganizada y no refleja necesariamente los términos más usados. Por ejemplo, para goalkeeper figura la palabra "golquíper" para Argentina, cuando no es un vocablo que se utilice en ningún medio de comunicación ni que se oiga en los partidos de fútbol. Es posible que en algún lugar de Argentina se utilice, pero no puede tomarse como un término usual. 


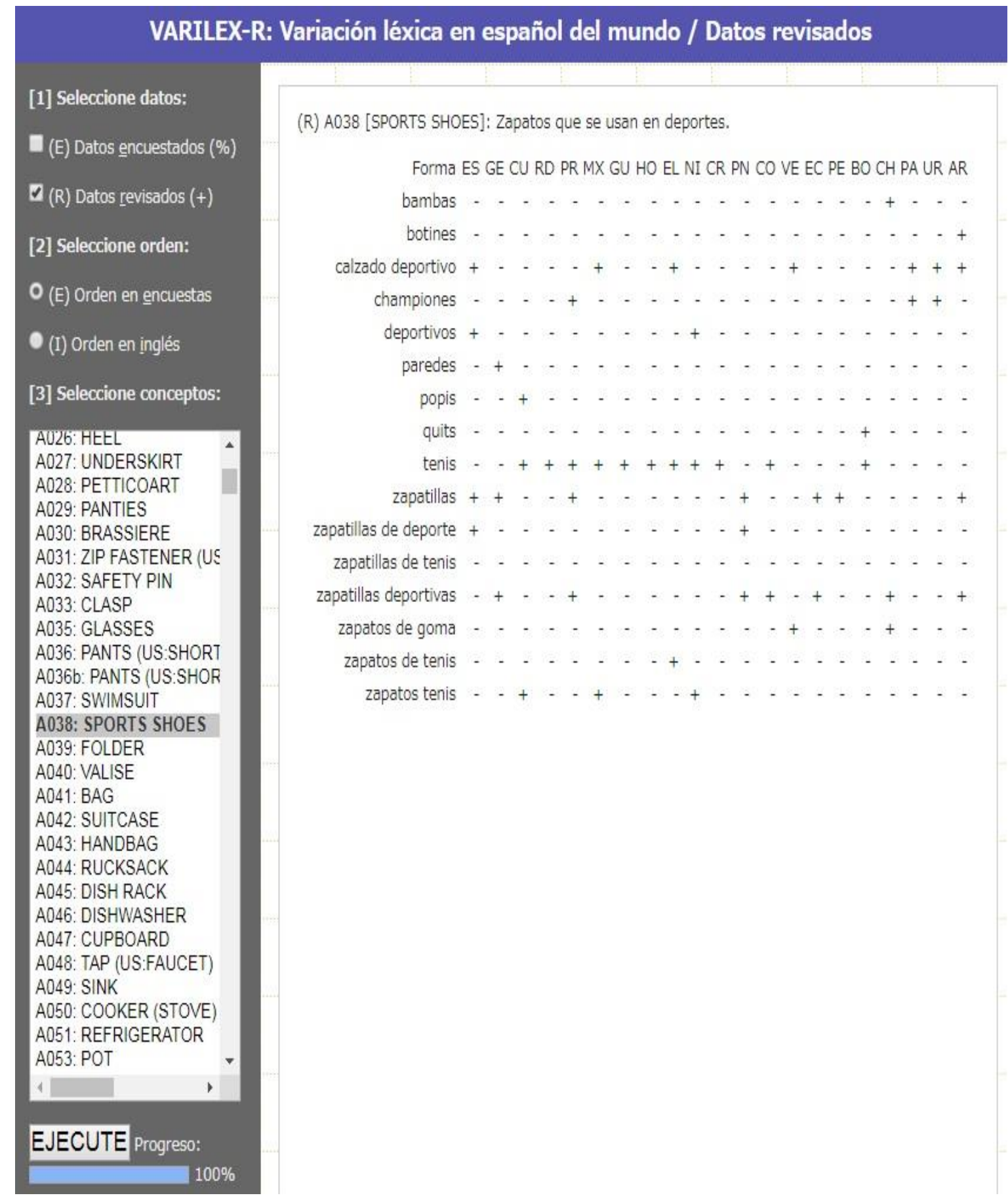

Ilustración 12 - Captura de pantalla del sitio de Varilex - Fuente: https://lecture.ecc.u-tokyo.ac.jp/ cueda/varilex-r/ 


\section{Grado de Representatividad léxica del español}

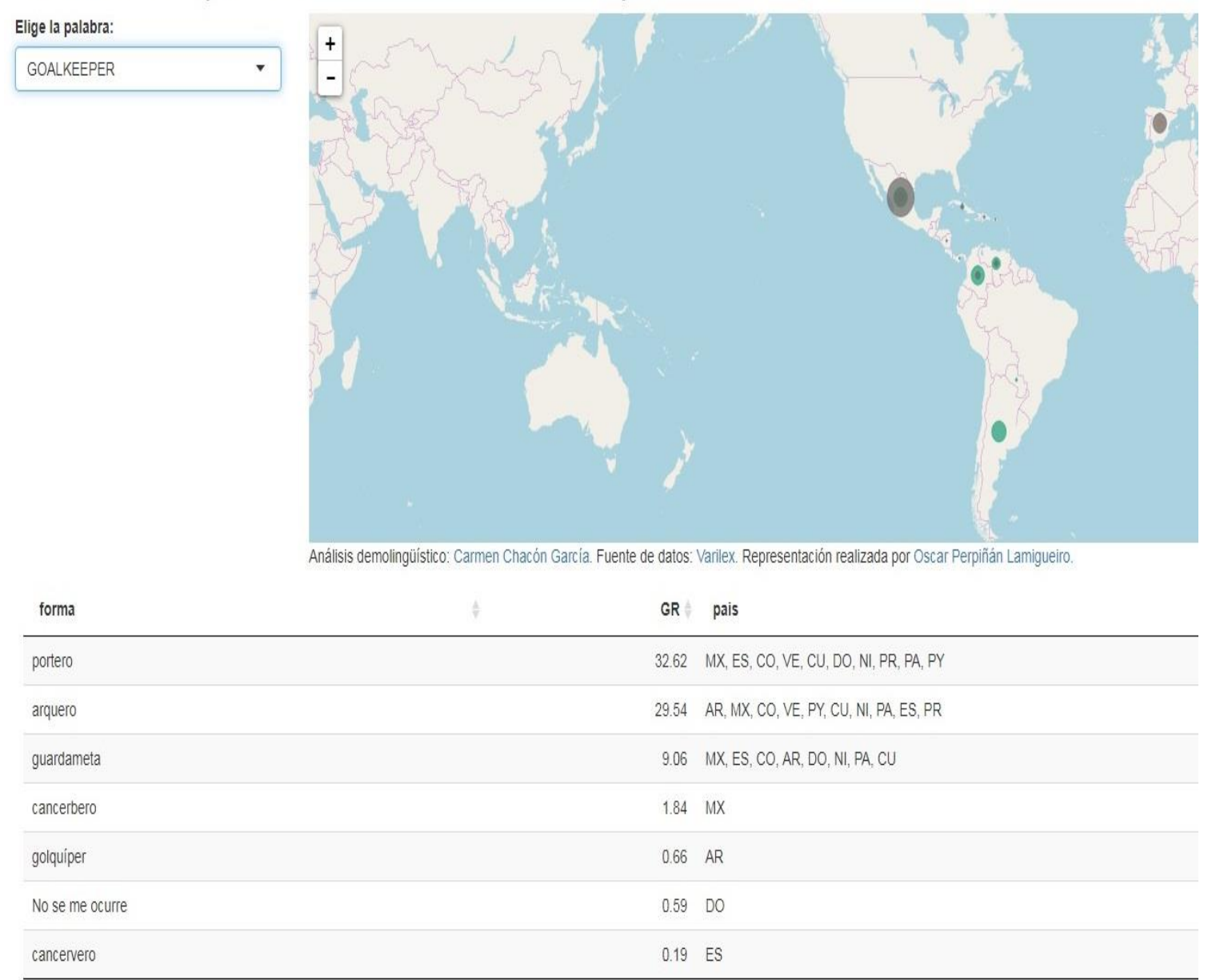

Ilustración 13 - Captura de pantalla de https://carmenchacon.shinyapps.io/PCIC/, basado en Varilex

Otro proyecto interesante y útil es el CORPES (Corpus del Español del siglo XXI), desarrollado por las academias de la lengua española y la RAE. Allí podemos encontrar, en la sección Estadística, la distribución de los términos según la zona, el país, el período, el tema y la tipología. Además, permite visualizar la palabra buscada en contexto, sumado a la fecha y el país de aparición del vocablo. 


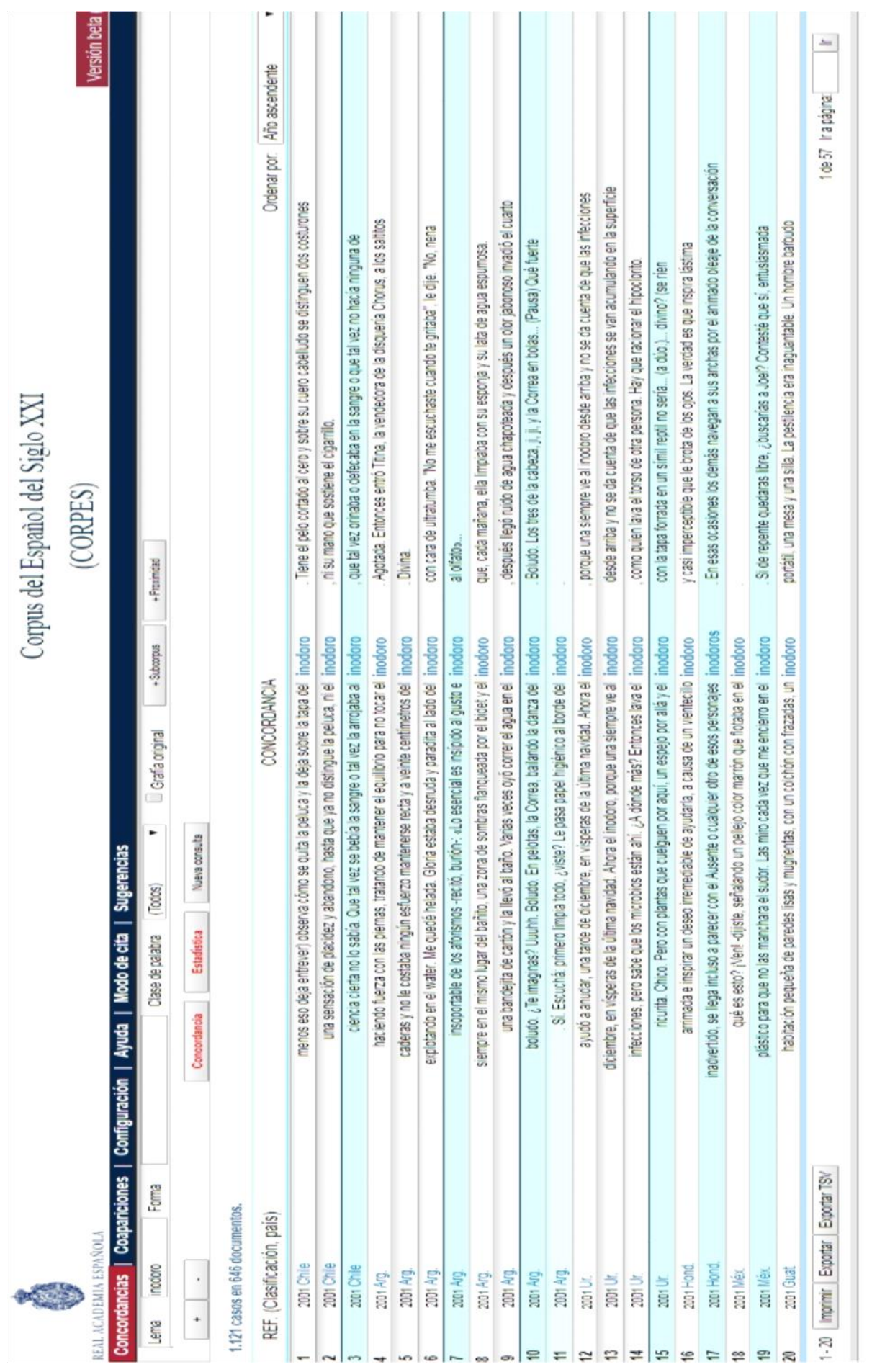




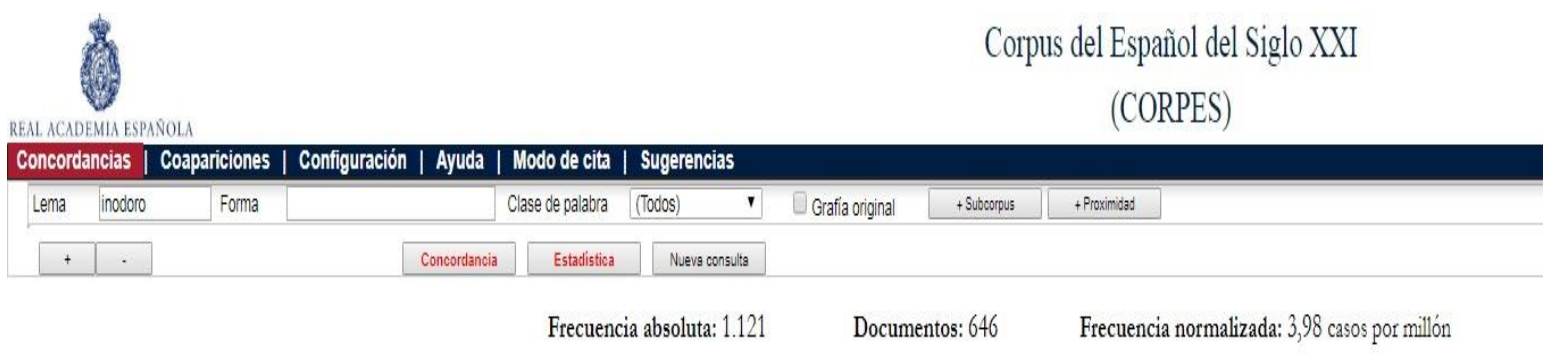

Distribución Zona

\begin{tabular}{|lrr|}
\hline Zona & Freq & Fnorm. \\
\hline Río de la Plata & 302 & 7,79 \\
\hline México y Centroamérica & 221 & 4,06 \\
\hline España & 179 & 1,98 \\
\hline Caribe continental & 145 & 4,17 \\
\hline Antillas & 124 & 6,21 \\
\hline Andina & 92 & 4,27 \\
\hline Estados Unidos & 33 & 9,32 \\
\hline Chilena & 22 & 1,30 \\
\hline Guinea Ecuatorial & 3 & 3,39 \\
\hline 1-9 de 9 & & página: 1 \\
\hline
\end{tabular}

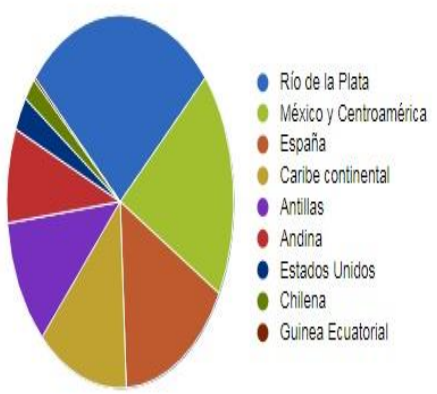

Ilustración 14 - Capturas de pantalla del CORPES / Fuente: http://www.rae.es/recursos/banco-de-datos/corpes-xxi

Finalmente, una forma útil de ver qué término puede ser más neutro que otro consiste en buscar el término en imágenes en Internet y ver a qué región corresponde cada vocablo. Por ejemplo, la palabra "cachucha" es una grosería en Argentina, pero significa "gorra" en México, Venezuela o Colombia, según se ve por el origen de los sitios web que contienen fotos de gorras. Aún sin saber que es un término vulgar en Argentina, se podría pensar que, si solo aparece en sitios de esos tres países, es probable que no sea un término neutro. ${ }^{56}$

En la realidad profesional, por el momento el traductor suele tener que seguir las indicaciones de los iniciadores de los encargos de traducción, y debe desarrollar una especie de radar para intuir qué palabras pueden resultar inadecuadas o causar problemas de sentido. Aun así, y dada la riqueza lingüística de las distintas regiones de Latinoamérica, siempre es posible caer en la trampa de utilizar la palabra incorrecta.

Por ello, esta tesis doctoral pretende radiografiar de forma descriptiva el léxico del español neutro del doblaje, y pretende convertirse en una fuente de consulta para que traductores, adaptadores, actores y actrices, directores de doblaje, y otros agentes del

\footnotetext{
${ }^{56}$ En el doblaje de un episodio de La niñera (The Nanny, Fran Drescher-Peter Marc Jacobson, 1993-1999) se utilizó la palabra "cachucha" como traducción de "cap". Al televidente argentino el término podría sorprenderlo y causarle gracia, o podría causarle pudor.
} 
proceso (correctores, profesionales de los distintos departamentos de Quality Control, Compliance, etc.) puedan utilizar los resultados de esta investigación para contrastar sus intuiciones o decisiones finales.

\subsection{OBJECIONES AL ESPAÑOL NEUTRO}

Es muy común que el público se queje del español neutro del doblaje. Pero ¿a quiénes les molesta en realidad? A los adultos. Los niños toman el español neutro con naturalidad, al extremo de copiarlo y usarlo al jugar sin problemas. En Buenos Aires, por ejemplo, donde se usa el "vos" en vez del "tú", es común que los niños mezclen ambas variedades al jugar ("tú sos" o "vos eres"), y que utilicen palabras del español neutro en vez de la correspondiente en la variedad rioplatense. ${ }^{57}$ Nord (1997) habla de distintos tipos de normas, entre las que se encuentran las normas de expectativa y las convenciones de género. En este caso, el español neutro debería adecuarse a las convenciones del género infantojuvenil, lo que de algún modo podría justificar la elección de quitar ciertas palabras problemáticas, como "cadáver", pero también a lo que esperan los receptores de la traducción, y ahí está el conflicto. El espectador, al igual que en el caso de la literatura infantojuvenil, es tanto el niño como el adulto. Y de allí las críticas al español neutro por parte de los espectadores adultos. Si a eso le sumamos las diferencias entre las culturas de perfil alto y las de perfil bajo ${ }^{58}$ y los cambios que a veces se hacen basándose en ellas, resultará imposible satisfacer a todos.

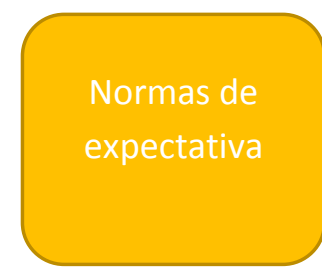

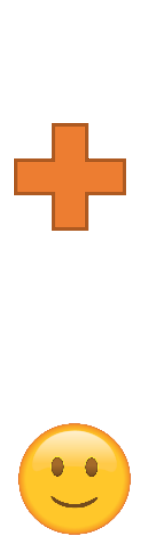

NIÑOS
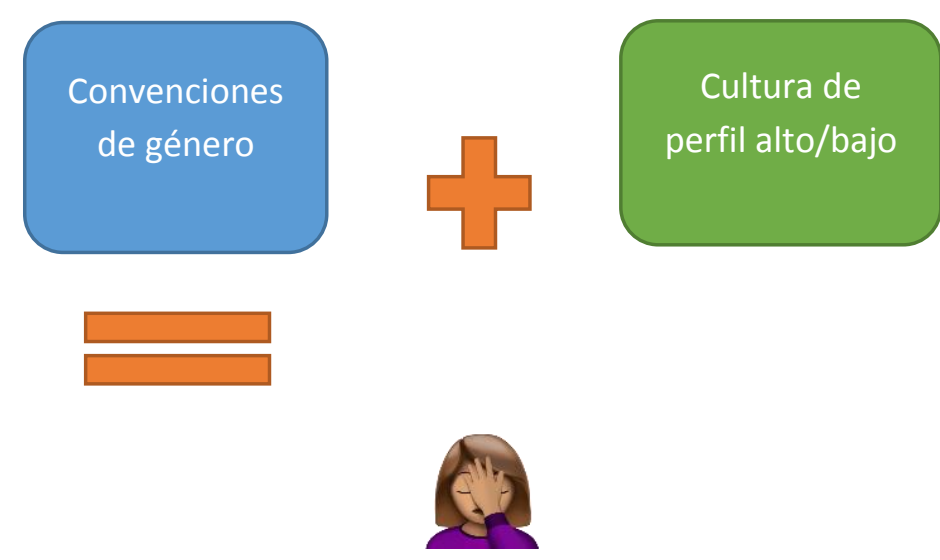

ADULTOS

Ilustración 15 - Factores que influyen en la recepción de los programas doblados

\footnotetext{
${ }^{57}$ Arias comenta en su blog que tiene "un nene chiquito y casi todo lo que ve está doblado en español neutro, y como le pasa a la mayoría, se la pasa hablando con ese acento y esa terminología"; Diaconú (2014) y otros académicos lo confirman en sus artículos.

${ }^{58}$ La diferencia básica entre la cultura anglosajona y la latina es que la primera favorece lo explícito y la segunda, lo implícito. (Ting-Toomey, 1999)
} 
Es de suma importancia analizar la terminología que se utiliza en los doblajes para niños. A veces, en pos de conseguir un producto que pueda comercializarse en toda Latinoamérica, se eligen términos más formales, como comentamos anteriormente, que pueden resultar confusos, y no se tiene en cuenta que los principales espectadores serán niños y que ellos no siempre pueden deducir el significado de ciertas palabras ${ }^{59}$.

Los problemas de comprensión se dan principalmente en los niños más pequeños, que no siempre pueden deducir por contexto (tanto lingüístico como visual) con la misma capacidad que los adultos, o que los niños de mayor edad, que ya han estado expuestos al español neutro durante un tiempo significativo y han aprendido lo que significan los términos que antes desconocían. Por otro lado, es preciso no perder de vista que los niños pequeños entienden todo literalmente. Por ejemplo, los niños pequeños pueden malinterpretar las frases complicadas con palabras que tienen distintos sentidos según el país o región. Si observamos la ilustración, la frase "lavar los trastes" (o "trastos" en algunos países, es decir, los platos) que utiliza la cuenta oficial de Twitter de Nickelodeon Latinoamérica de seguro será malinterpretada por los niños pequeños en cuya variedad de español "trastes" significa "traseros" (como en el Río de la Plata). En general, el español neutro utiliza términos en los que se describe la acción o la función de algún objeto (como "abrelatas"). En este caso, una frase mucho más neutra (y que no causaría gracia) sería "lavar los platos".

59 En un pequeño experimento se pidió a niños de entre 3 y 10 años de dos colegios privados, uno de la Ciudad Autónoma de Buenos Aires y otro del Gran Buenos Aires, que dibujaran "un muñequito con gorra y tenis". De un total de 18 niños, 7 comprendieron correctamente las consignas y 11 las malinterpretaron. Los niños más grandes sabían que "tenis" era calzado deportivo (en Argentina se les llama "zapatillas"), pero los más pequeños pensaron que el muñequito jugaba tenis, y por lo tanto lo dibujaron con pelotita y raqueta. El experimento también demostró la diferencia de comprensión del español neutro entre los niños más pequeños y los de mayor edad. 


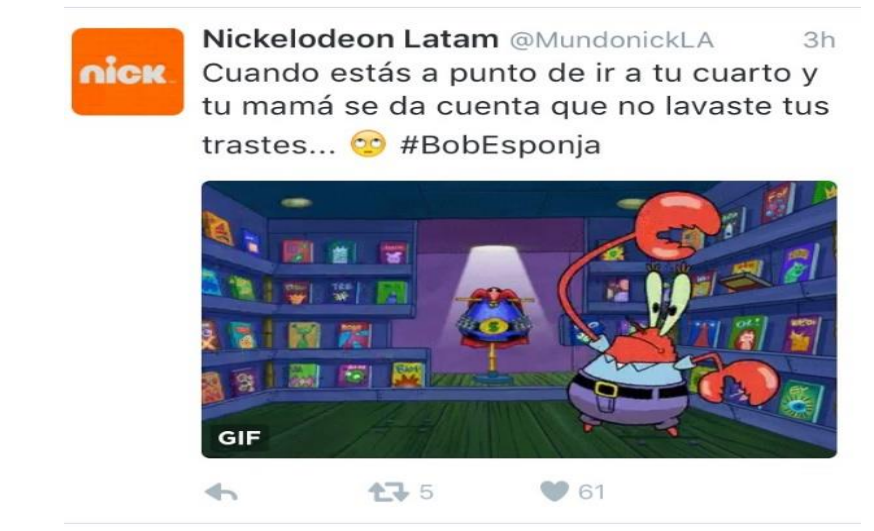

Ilustración 16 - Tuit de Nickelodeon Latinoamérica - Diciembre de 2018

Por otro lado, hay académicos que temen que el español neutro "contamine" el español de los niños de cada región. Diaconú (2014) comenta que los niños "hablan como Mickey Mouse, Lisa Simpson, Tiana, Ben 10 o el Rey León", y considera que no es una tendencia inocua. Y cita a Abel Posse: "La caída del lenguaje precede a la caída de todas las estructuras de una sociedad”. Y continúa justificando su visión fatalista:

Así como el léxico de los jóvenes y de los adultos se ha visto colonizado por el inglés, como consecuencia de la computación y de la cada vez mayor presencia de la tecnología sofisticada en la vida diaria, así también el habla de los niños se ve colonizada constantemente por la invasión del idioma de la televisión y de los juegos electrónicos, donde ellos pasan muchas más horas que en el ámbito de las escuelas. (...) Uno espera que todo esto no sea más que una moda o una etapa (pasajera) que el futuro cercano borrará, aunque -en realidad- no hay indicio alguno para que así ocurra.

Lo que le preocupa es que "los que enseñan a hablar, enseñan a pensar". Y esa preocupación está justificada si tenemos en cuenta que la estandarización del español para el doblaje tiene como consecuencia tanto un empobrecimiento de la lengua -que necesariamente conlleva una reducción de la capacidad de expresión- como un menor acercamiento a los conceptos culturales que permiten al niño conocer y comprender las demás culturas. La televisión para niños es un género definido por quienes la ven y no por las características de los programas en sí (Messenger-Davies, 2001a: 96). Los educadores e investigadores estudian qué cosas aprenden los niños con la televisión, cuál es su contribución cultural y qué actitudes sociales genera, para asegurarse de que ese aprendizaje sea positivo (Messenger-Davies, 2001b: 99). Bravo (2009) sostiene que los medios de comunicación:

forman opinión, educan, definen comportamientos aceptables y tienen valor modélico en muchos aspectos de la vida cotidiana. (...) El niño, igual que el joven, no es solo espectador pasivo sino que incorpora a su vida modos y usos sentidos como novedosos.

Por ejemplo, Lazytown tuvo una influencia tan positiva en los niños más pequeños respecto de hacer ejercicio y comer sano que no solo redujo la obesidad infantil e 
incrementó un $20 \%$ el consumo de frutas y verduras en Islandia ${ }^{60}$, sino que además el fenómeno se investigó en el Departamento de Salud de Gran Bretaña y la Primera Dama de Estados Unidos Michelle Obama se unió a Sprout TV y a Magnus Scheving, el creador de la serie y el personaje principal, en una campaña para fomentar el ejercicio. ${ }^{61}$ Una parte de la enorme influencia positiva de la serie se debió a la asociación que hacía entre la fruta fresca y la palabra "candy" (sports candy en inglés, traducido como "dulces sanos" en español neutro y sport-chuches en España), lo que demuestra la fuerza de la asociación de lo visual con lo lingüístico y su influencia en las actitudes de los telespectadores, en especial si son niños.

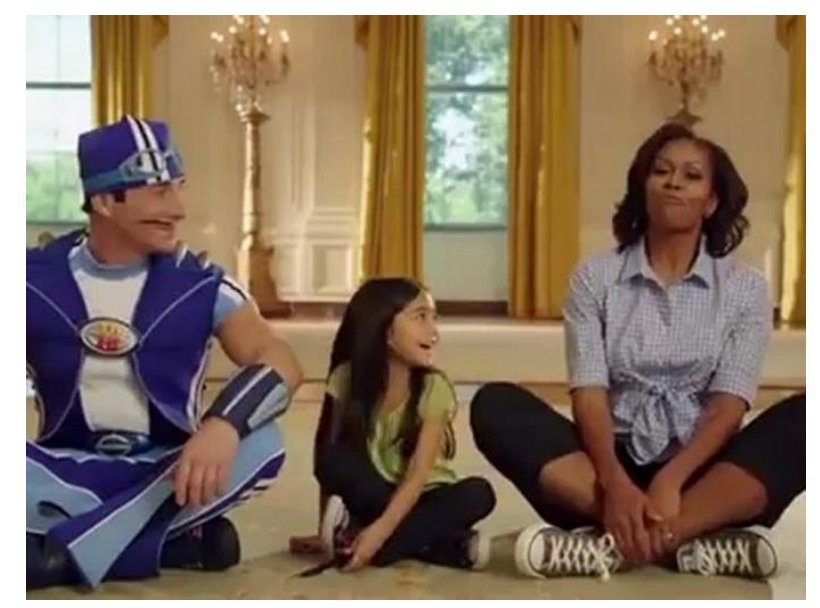

Ilustración 17 - Michelle Obama junto a Sportacus / Fuente: www.dailymotion.com

O’Connell (2003: 225-226) pone el énfasis en que los niños y adolescentes no son espectadores pasivos ( $\mathrm{y}$ menos en la actualidad, cuando gran parte del material audiovisual que consumen es multiplataforma e interactivo). Cuando ven televisión, además de entretenerse, desarrollan un sentido de identidad y aprenden valores y normas. La televisión les ayuda a comprender ironías, a razonar y a entender las conductas, ideas y valores de las demás culturas, y esto último les resultaría imposible si lo quitamos del producto televisivo.

60 Gordon, B. (2006): “Could we move into Lazytown?", The Telegraph, 28 de agosto de 2006, https://www.telegraph.co.uk/news/health/3342731/Could-we-move-into-LazyTown.html

(consultado el 12 de diciembre de 2018)

${ }^{61}$ Para más información sobre este tema: http://www.thensmc.com/sites/default/files/Lazytown\%20strategic\%20development 279694.pdf; https://www.thepacker.com/article/lazytown-incites-kids-be-healthy 
A pesar de que algunos autores sugieren recurrir a un sinónimo formal o a los genéricos para evitar problemas de comprensión (Guevara: 2013: 46) ${ }^{62}$, aunque esto quite naturalidad al texto y reduzca el vocabulario, muchas veces, si el contexto (o la situación) les resulta claro, los niños aprenden sinónimos con las palabras que por lo general no usan pero escuchan en los programas que ven. Y esto se ve magnificado si tenemos en cuenta que, además de los programas, consumen una gran cantidad de videojuegos, videos de Internet y otros contenidos digitales. Los youtubers e influencers más famosos provienen de distintas partes del mundo, donde hablan distintas variedades de español. Y en Latinoamérica los niños no solo ven videos de youtubers latinoamericanos (el chileno Germán Garmendia, el argentino Kevsho, el mexicano Juampa Zurita, el colombiano Sebastián Villalobos, etc.), sino también muchos de España (Willyrex, El Rubius, Vegetta777). Su influencia va más allá de lo audiovisual: muchos han publicado libros de gran éxito que figuran entre los más leídos por los niños y adolescentes (Garmendia, Wigetta, El Rubius y otros). ${ }^{63} \mathrm{Y}$ la nueva tendencia es incorporarlos en las series de televisión.

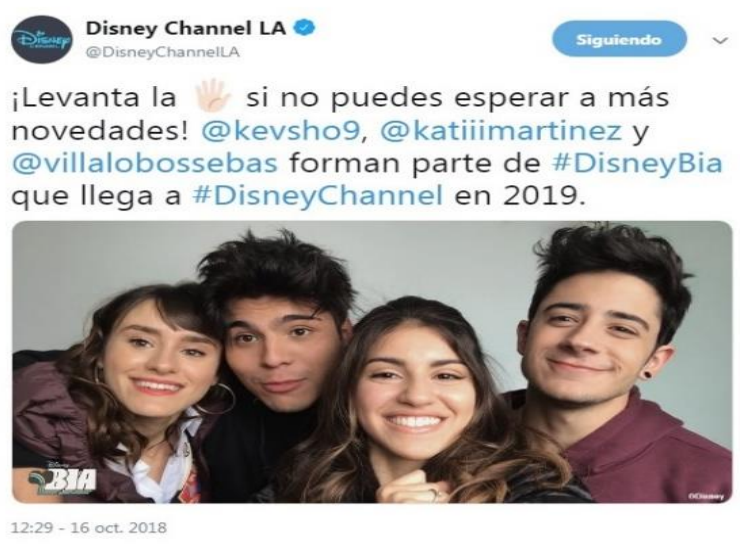

Ilustración 18- Youtubers (dos argentinos y uno colombiano) que forman parte del elenco de Bia, de Disney Channel/ Fuente: Twitter - Noviembre de 2018

La consecuencia de estas nuevas tendencias es que, sumadas a las expresiones locales (como las mexicanas "chido" o "güey"), los niños también incorporan a su vocabulario expresiones españolas como "tío", "chaval" u "ostras". Algunas se vuelven tan comunes que se comparten a ambos lados del océano, como "XD". El Halli Obeid (2012) describe con claridad este fenómeno: el español neutro "esconde grandes batallas económicas, territoriales e identitarias, pero también intercambio, aprendizaje y modificación recíprocos".

62 "Busque sinónimos formales incluso si la situación es informal y, eventualmente, acuda a un genérico". (Guevara: 2013: 46) El autor menciona la elección de "calzado deportivo" por sobre términos más locales como championes, zapatillas o zapatos de goma.

63 Perazo, C. (2016): "Los libros escritos por youtubers, entre los más elegidos por los adolescentes", La Nación, 25 de enero de 2016 


\subsection{EL FUTURO DEL ESPAÑOL NEUTRO}

¿Qué hemos de esperar que suceda en el futuro con el español neutro? De seguro no desaparecerá en un futuro cercano, pero existe la posibilidad de que se modifique en forma considerable. "El neutro, tal como el español, están vivos y en constante crecimiento", afirma Guevara (2013: 43), y El Halli Obeid (2012) sostiene que "el español neutro (...) va siendo reconfigurado permanentemente por los medios de comunicación y la industria del entretenimiento", aunque la dinámica de este proceso de reconfiguración no va en una sola dirección: el público también ejerce presión sobre las decisiones que toma la industria del entretenimiento, principalmente gracias a las redes sociales.

Their increased proficiency and their Internet-enabled global connectivity endow them with a decisional power which would not have been conceivable in previous eras. [...] Viewership 2.0 is often able to play by the same rules as television creators and distributors and even to beat them at their own game if necessary. (Casarini, 2014)

Leppilhalme (1997: 19) asevera que el traductor es "a language and communication expert serving both author and reader, who are equally in need of his/her special skills". A veces el iniciador olvida la calidad de "experto cultural" del traductor y termina censurado por el público, incluso si no es la gran mayoría de su público. ${ }^{64}$

Las campañas a favor de las mujeres como "no princesas" llevó a Disney a cambiar el modelo de princesa y el rol de la mujer en sus productos. Y el movimiento \#MeToo inició una revolución feminista y anti-discriminación en general que ya tiene sus consecuencias a nivel lingüístico y de contenidos. No es extraño encontrar expresiones como mansplaining o patriarchal en los programas infantojuveniles, o toparse con "Sally" Claus. En 2018 se instalaron en Argentina discusiones acaloradas respecto del feminismo y el uso del lenguaje inclusivo, que llegaron hasta a las escuelas, y no sabemos qué tanto podrían afectar al español de la televisión (la primera serie subtitulada con lenguaje inclusivo, Pose, se estrenó en octubre de 2018). Si consideramos que en la década de 2010 los productos televisivos han fomentado la corrección política, es una conclusión lógica que, con la enorme influencia que tienen los medios sobre el público, los televidentes más jóvenes la hayan adoptado plenamente, y que también influya en las elecciones léxicas de los traductores de doblaje.

64 Disney Channel canceló la emisión de un episodio de Jessie en que se burlaban de un niño celíaco por una petición en Change.org firmada por 2.137 personas: "We are removing this particular episode from our regular programming schedule and will re-evaluate its references to gluten restrictions in the character's diet. Please accept our apologies for the upset this episode caused you and your family. We value your feedback and thank you for watching Disney Channel." (http://www.cbsnews.com/news/disney-pulls-jessie-episode-that-makes-fun-of-gluten-free-child/, consultado el 21 de diciembre de 2018) 


\section{0 @ . 4hv \\ En respuesta a @DisneyChannelLA}

Toda gente blanca... la diversidad en nacionalidades no sirve
En respuesta a @DisneyChannelLA

¿por qué no tiene ninguna persona negra en el elenco?

\section{Fuente: Twitter-Noviembre de 2018 \\ Ilustración 19- Tuits de queja por la falta de diversidad en la nueva serie Bia de Disney Channel Latinoamérica}

Por otro lado, cabría estudiar con más profundidad la relación de los traductores con la dicotomía libertad/autocensura. En 2018 se han publicado tuits donde una traductora comentaba que había reemplazado todos los "FAT WOMAN" que aparecían en un guion para denominar a los personajes secundarios como "DIVINA 1", "DIVINA 2", etc. Si bien no era un cambio que se trasladaría al doblaje en sí, implica una decisión tomada por la traductora opuesta a la discriminación del guion en inglés. ¿Habría hecho lo mismo si el guion hubiera contenido un "FAT MAN"? ¿Tal vez en estudios futuros habría que analizar también el género de los traductores y demás agentes involucrados en el proceso de doblaje? Y desde el punto de vista del análisis del discurso, ¿el guion favorecía la discriminación, o eran solo los términos utilizados para denominar a los personajes los que no eran políticamente correctos? ¿La incorrección política (o incluso la excesiva corrección política) destruye la empatía del traductor con el texto/producto audiovisual? ¿Y qué tanto influye la figura del corrector lingüístico en el producto final?
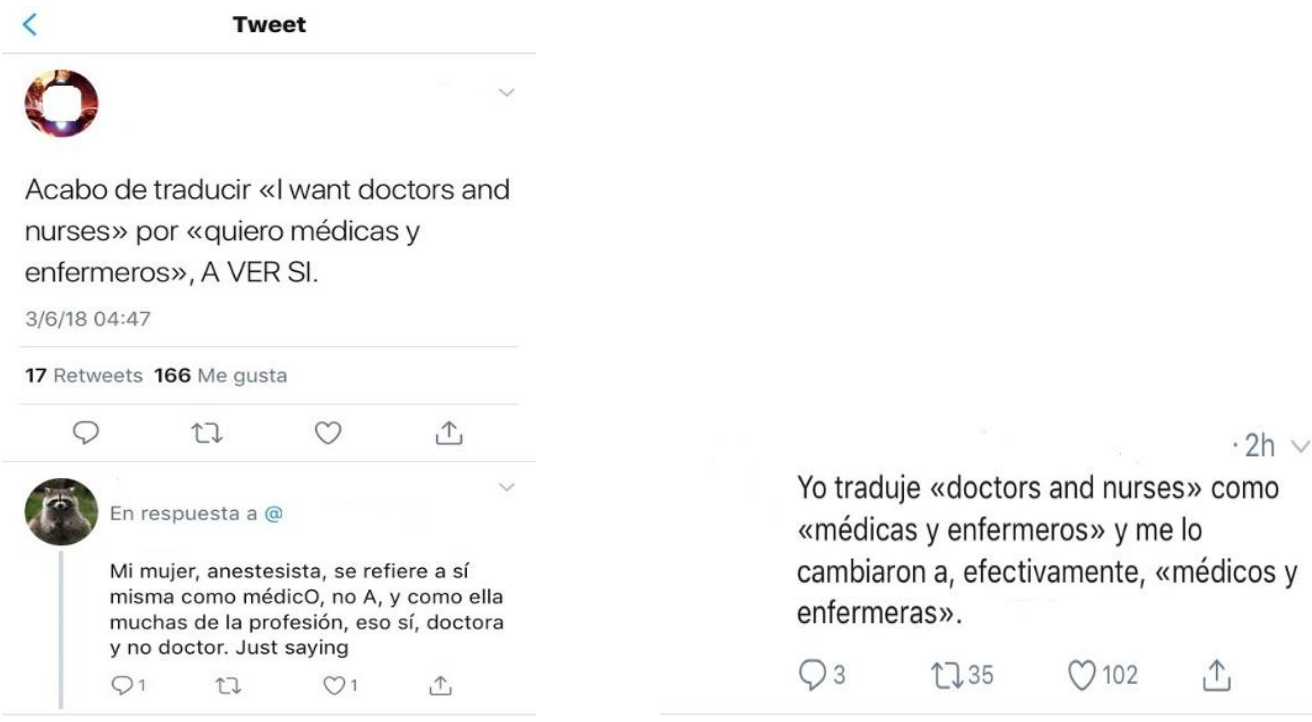
enfermeras». 
Como se ve, la interacción entre texto/producto audiovisual, traductores, correctores, directores de doblaje, estudios, canales e incluso el público crea una situación compleja donde existen cada vez más variables pertinentes que estudiar.

No se puede desestimar tampoco el hecho de que el español neutro está cambiando el habla cotidiana. Así como no es raro oír a niños que usan el español neutro, tampoco lo es oír (o leer) a adultos porteños que utilizan términos que antes eran poco usuales, como "bonito", "dinero", "beber" o "niño/a", tal vez porque los padres muchas veces utilizan las palabras y frases que usan sus hijos, quienes a su vez repiten lo que escuchan en televisión:
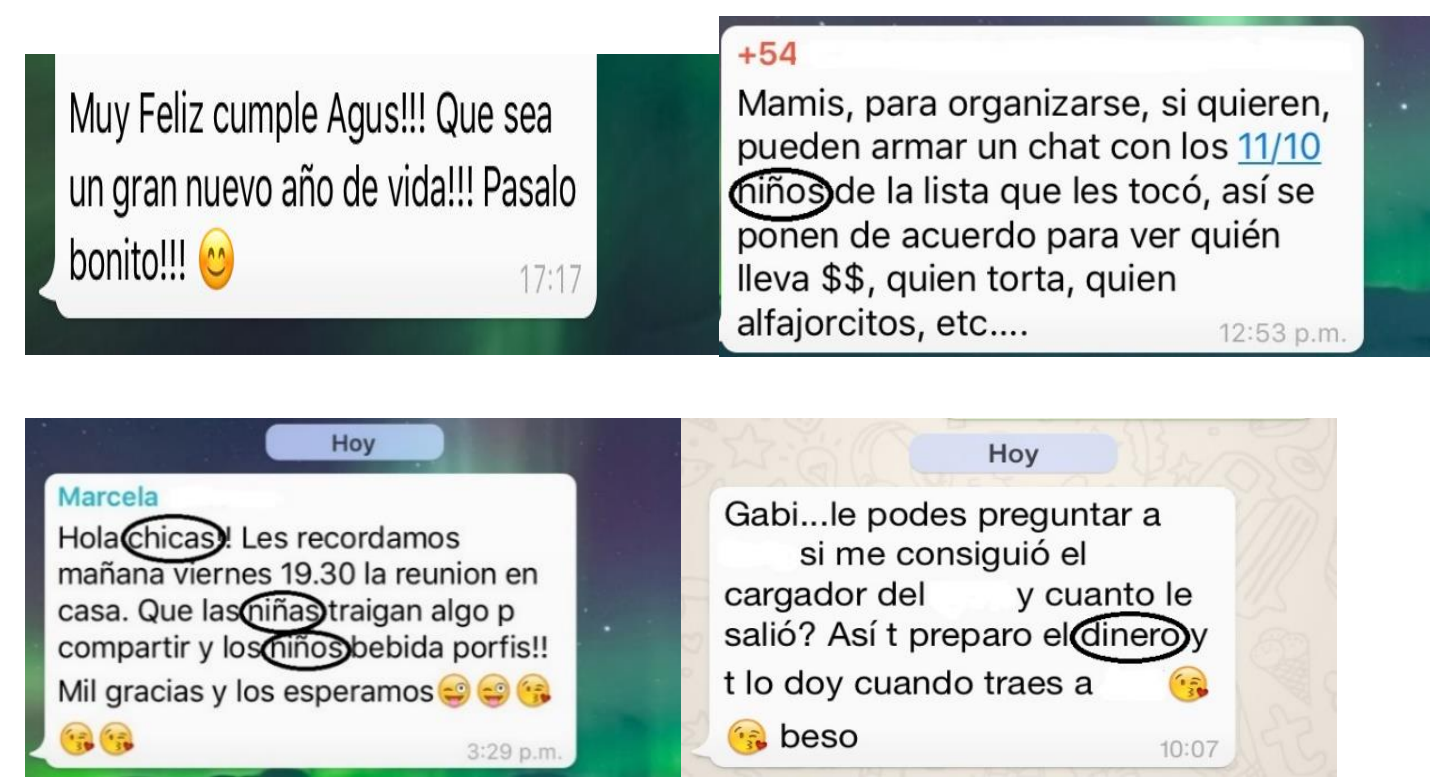

Ilustración 21- Ejemplos extraídos de cadenas de Whatsapp en Argentina-2017-18

Por otro lado, también hay que tener en cuenta los vaivenes naturales del lenguaje, que suele verse afectado por los cambios de generación. Por ejemplo, mientras que en Argentina para las generaciones mayores era común utilizar la palabra "paja" (en vez de "heno") como traducción de hay, para las generaciones de menor edad se convirtió en una grosería, y por lo tanto trataban de no usarla, pero ahora los adolescentes la utilizan de nuevo como sinónimo de "pereza": "Me da paja estudiar". Incluso se dan casos en que se vuelve a términos del pasado. El verbo "chapar" se correspondía, hace varias décadas, con el inglés to get to first base. Luego, en los años 80 y 90, el término era "apretar". Y a partir de los años 2000 se ha vuelto a utilizar "chapar", con un sentido similar al que tenía hace tantos años. Por lo tanto, si para el cool del inglés se utilizaba "de lujo" hace diez años, seguir usando ese vocablo podría no ser la mejor opción. Las empresas suelen poner la excusa de que el lenguaje del producto no debe tener fecha de expiración, pero la realidad es que el contenido de dicho producto también pasará de moda. El doblaje de 
una película como Los cazafantasmas (Ivan Reitman, 1984) es tradicional, pero a los niños seguramente les acabará llamando la atención, por ejemplo, que los personajes fumen, porque ya no se ve gente fumando en ese tipo de productos, y eso no tiene que ver con el lenguaje sino con el contenido (de hecho, en la remake de 2016 y a tono con el resurgimiento del movimiento feminista, los cazafantasmas son mujeres).

Otro aspecto fundamental es el sociocultural, que también hace que los hablantes de cada región comiencen a comprender e incluso a adoptar términos que no les son comunes. Por ejemplo, debido a la crisis en Venezuela, el éxodo de venezolanos hacia Latinoamérica es cada vez más grande. La Organización Internacional para las Migraciones estima que "el número de venezolanos en América Latina creció un 900\% en solo dos años: de 89.000 a 900.000 personas entre 2015 y $2017 " .{ }^{65}$ Se calcula que en Colombia ya viven un millón de venezolanos. Argentina recibió a varios directores y actores de doblaje que debieron dejar su país y que realizan el mismo trabajo que hacían allí. Lo mismo sucedió con algunos que se radicaron en Miami. Por supuesto que eso podría aumentar la riqueza de vocabulario utilizado en el doblaje argentino y en el de Miami. De hecho, es fácil distinguir a la enorme cantidad de inmigrantes en Argentina provenientes de distintos países (Bolivia, Paraguay, Perú, Venezuela, Cuba) por su acento y su vocabulario distintivo. Y lo interesante es que, al ocupar empleos que van desde médico hasta empleado de una gasolinera, es posible que su léxico pueda terminar colándose en el habla típica del rioplatense.

Otro hecho destacable es que quienes trabajan en doblaje no siempre son traductores graduados. De hecho, los perfiles de quienes traducen son muy diferentes. En el sitio Doblaje Wiki se puede ver claramente que quienes traducen tienen una formación muy dispar. Algunos traductores/adaptadores provienen de campos muy diferentes:

Eduardo Garza es un actor, locutor y director de doblaje, y licenciado en publicidad mexicano que también ha tenido una gran experiencia en el doblaje. Comenzó su carrera en la especialidad del doblaje de voz en el año 1990, donde también se desempeña como director, cantante y traductor-adaptador.

Carlos Contreras es el director de Tecnología en la empresa The Kitchen Inc., también trabaja como operador técnico, gerente de producción y traductor al español en dicha empresa. Carlos Contreras, director de Tecnología en el estudio The Kitchen Inc., es el desarrollador del software TM Systems -dos veces ganador del Emmy-, utilizado por el estudio The Kitchen Inc., y también por Discovery Channel y en numerosas empresas de doblaje y subtitulado sudamericanas. Contreras licenció su software a The Kitchen previo a su formación y se trasladó a Miami para administrar la instalación del software y el hardware en los mismos estudios. Además de su experiencia en el campo de la tecnología informática, Contreras es un veterano en el área de servicios de traducción audiovisual

\footnotetext{
65 Lozano, D. (2018): “El imparable éxodo de venezolanos se extiende en la región”, La Nación, 5 de mayo de 2018, https://www.lanacion.com.ar/2131684-el-imparable-exodo-de-venezolanos-se-extiendeen-la-region (consultado el 30 de septiembre de 2018)
} 
con más de 20 años en el negocio, incluyendo la operación de su propio estudio de doblaje y subtitulado en Caracas, Venezuela antes de unirse al equipo de The Kitchen (Doblaje Wikia, www.doblajewiki.com).

Otro ejemplo es el de la empresa colombiana DL Multimedia Internacional (www.dlminternacional.com), que en su cuadernillo sobre tarifas oficiales de doblaje 2015-2016 sostiene que:

Colombia reúne una singularidad que ha hecho difícil unificar criterios estandarizados internacionalmente pues no tiene convenios profesionales ni laborales en los distintos apartados de especialización en la traducción audiovisual, doblaje y multimedia, y cada una de las empresas del sector realiza las actividades en base a regulaciones profesionales internas distintas entre ellas en independencia.

En dicho cuadernillo estipula que, si no se realiza lip sync, no es necesaria la figura del director de doblaje. Por otro lado, el director es el encargado, entre otras cosas, de traducir y ajustar el texto ${ }^{66}$, y también de respetar y añadir todos los términos nuevos al glosario, y solo en algunos casos la traducción será realizada por un especialista:

Las funciones de Adaptador-Ajustador serán desempañadas por el Director de doblaje como responsable artístico traductivo de la obra, pero DL Multimedia puede tomar la opción de que lo realice una tercera persona especialista en lingüística si así lo decide la compañía contratante o en libertad la propia empresa, debiendo acatar el Director las decisiones que en carácter lingüístico genere el especialista designado. ${ }^{67}$

Otro aspecto importante a tener en cuenta es la cantidad significativa de doblajes colaborativos. The Kitchen, por ejemplo, tiene sedes en Caracas, Venezuela, y en Miami. En el caso de Big Time Rush, por ejemplo, cuenta Doblaje Wiki que hay diferencias entre episodios, y dichas diferencias podrían muy bien ser consecuencia del trabajo en distintos países:

La revista "Pop Tiger" fue cambiando de nombre, siendo que primero se llamó "Tigre Pop", luego pasó a llamarse "Tiger y Pop", y actualmente tiene su nombre original.

El episodio "Big Time Pranks" fue traducido como "Jugarretas en grande" aunque el episodio "Big Time Pranks 2" fue traducido como "Bromas en grande" y la palabra jugarreta fue cambiada por bromas. Y aunque la palabra jugarreta haya sido cambiada por broma, Jett menciona a Kendall como el Sr. Lord Jugarretón. ${ }^{68}$

\footnotetext{
${ }^{66}$ Aunque en el cuadernillo se habla de la "rama artística traductiva y adaptación del doblaje", que incluye a los directores y a los "actores traductores artísticos", con lo que no queda claro quién es el responsable final de la traducción (aunque sí queda claro que no es un traductor profesional).

${ }^{67}$ Tarifas oficiales de localización de videojuegos, sonorización y doblaje, Colombia, 2015-2016, https://es.calameo.com/read/0004899626e74d720ba34 (consultado el 13 de julio de 2019)

${ }^{68}$ http://es.doblaje.wikia.com/wiki/Big_Time_Rush (consultado el 20 de septiembre de 2018)
} 
A esto se suma la movilidad de directores y actores, que no siempre son empleados de una empresa de doblaje, sino que se desempeñan como trabajadores independientes, lo que los lleva a trabajar para distintos estudios de un mismo país e incluso de distintos países. En el sitio Doblaje Wikia podemos encontrar ejemplos de directores que han realizado doblajes en México, Argentina, Brasil, Venezuela, Chile, Estados Unidos (Los Ángeles/Miami) y Colombia.

De la mano del aspecto sociocultural va la influencia de los medios de comunicación y de la industria del entretenimiento en sí. En las radios argentinas podemos llegar a oír algunos términos de español neutro. En radio Mitre, por ejemplo, todas las tardes, en el programa Encendidos en la radio, los locutores festejan los cumpleaños de los oyentes cantando "Aquí tiene su pastel, brinde usted con él", a pesar de que la palabra usual en español porteño es "torta".
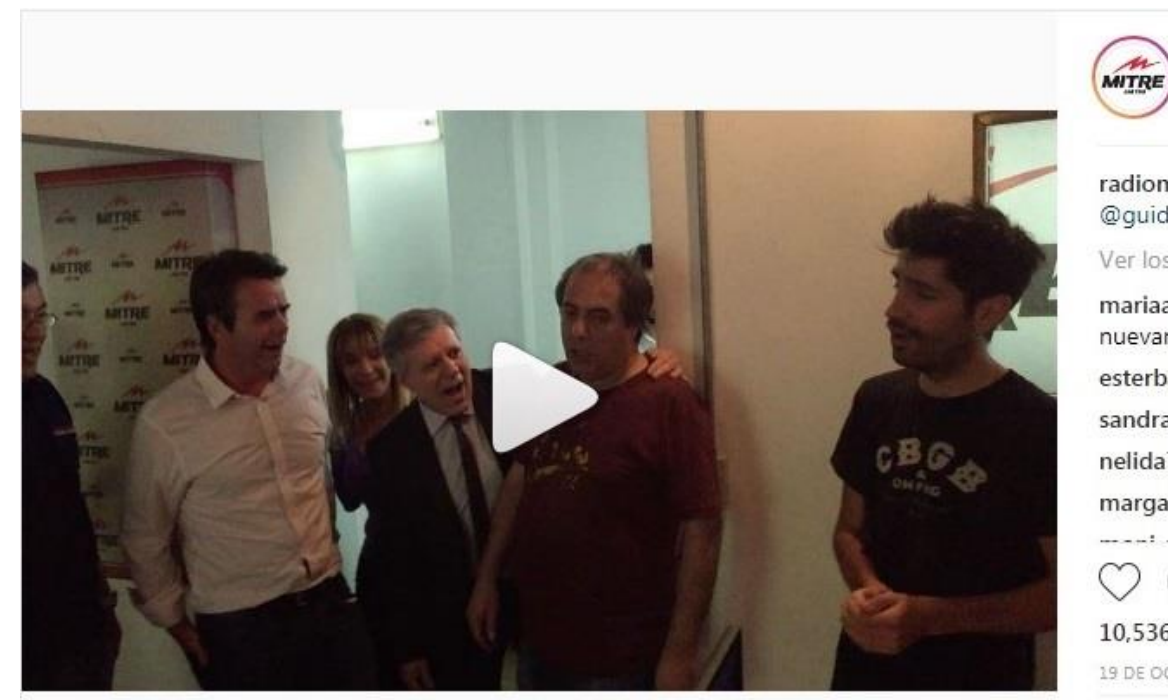

radiomitre $*$ Seguir

radiomitre ¡Le cantamos el pastel a @guido.mtz! \#EncendidosEnLaTarde

Ver los 35 comentarios

mariaadelaetcheberry Felicitaciones nuevamente Guido que grupo bárbaro. esterbarg Felicidades!

sandraemilse -

nelida7891 Felíz Cumple !!! Guido !!!!

margavalentini Feliz cumple $\$$

$\bigcirc \bigcirc$

10,536 reproducciones

19 DE OCTUBRE DE 2017

Ilustración 22 - Página de Instagram de Radio Mitre (https://www.instagram.com/p/Bac/Mj8Bbqr/?hl=es)

Radio Mitre > Nuestro Aire

2 enero, 2017

\section{Rolo Villar festejó su cumpleaños con una torta especial}

El humorista de Cada Mañana y Encendidos en la tarde celebró su natalicio

en el tradicional pase con Diego Leuco. Además, Longobardi comentó sus anécdotas de año nuevo y cerraron con un brindis.

Ilustración 23 - Página web de Radio Mitre (www.radiomitre.cienradioscom) 
Por otro lado, Radio Disney, la tercera radio más escuchada en $\mathrm{FM}^{69}$, transmite canciones que tienen una variedad significativa de españoles regionales. Se analizaron 4 horas de programación de un viernes por la tarde y un sábado por la tarde de febrero de $2018 \mathrm{y}$, con excepción de las canciones en inglés (aproximadamente un 20\% del total de canciones), las cantadas en español provenían de 9 países del Continente Americano (Argentina, Brasil, Canadá, Colombia, Cuba, Estados Unidos, México, Puerto Rico y Venezuela) y de España (ver Anexo 6).

Es lógico suponer, por lo tanto, que todos estos factores que hemos analizado tendrán una influencia considerable tanto en el habla de los habitantes de los países latinoamericanos como en el doblaje.

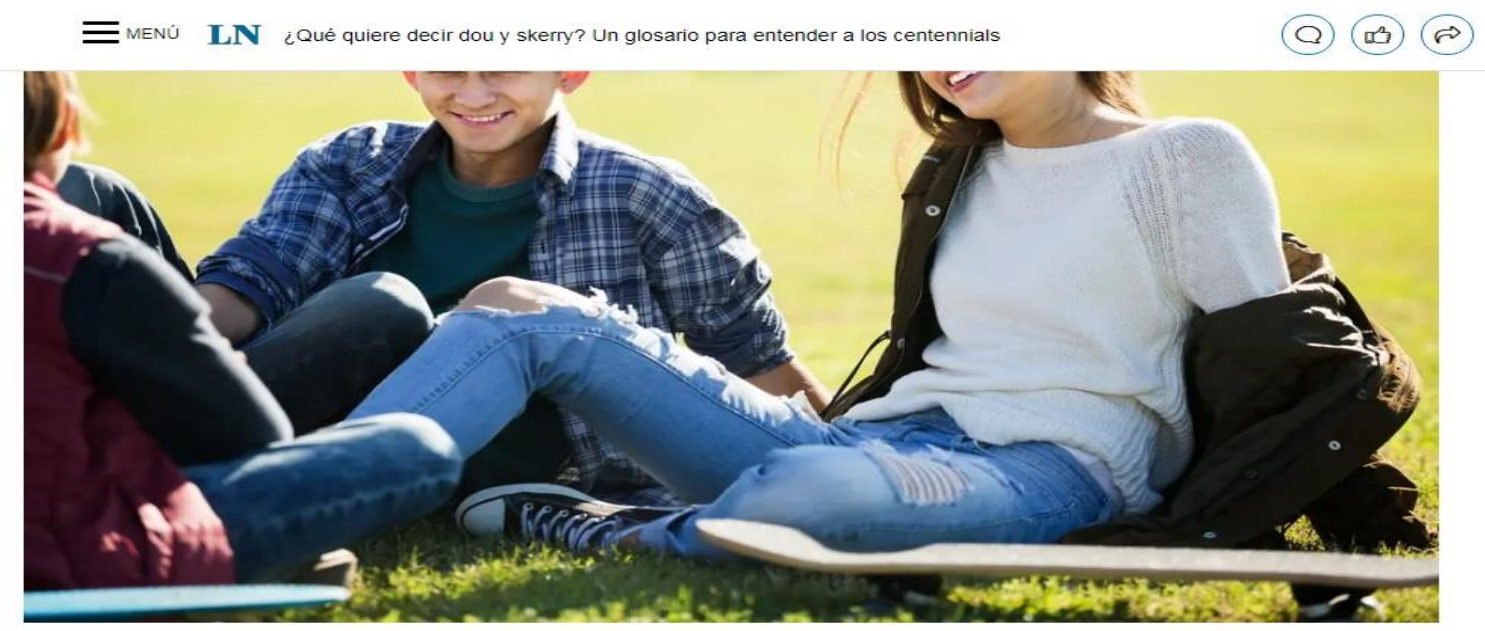

Los adolescentes de hoy se apropian de expresiones de los cantantes del momento y de los influencers; los especialistas reconocen el fenómeno como un proceso de identidad habitual que atraviesan todas las generaciones Crédito: Shutterstock

Federico Acosta Rainis

Ilustración 24 - Captura del pantalla del diario La Nación ${ }^{70}$

${ }^{69}$ http://www.radiodifusiondata.com.ar/ratings-radio.htm (consultado el 21 de diciembre de 2018)

${ }^{70}$ Rainis, F. (2019): “¿Qué quieren decir dou y skerry? Un glosario para entender a los centennials”, $L a$ Nación, 28 de abril de 2019, https://www.lanacion.com.ar/sociedad/que-quiere-decir-dou-skerry-unglosario-nid2242353 (consultado el 13 de julio de 2019) 


\section{CAPÍtULO 3.}

\section{NORMAS, ESTANDARIZACIÓN Y MECENAZGO}

\subsection{LAS NORMAS DE TRADUCCIÓN}

Tanto los Estudios Descriptivos de la Traducción (EDT) como la Escuela de la Manipulación y la Teoría de los Polisistemas tienen un interés especial en las normas y las restricciones relacionadas con la producción y recepción de las traducciones (Hermans, 1985: 11). Martínez Sierra (2010: 156) apunta que "el concepto de norma no es exclusivo de los estudios descriptivos y se trata de una noción común en el campo general de las ciencias humanas y sociales", y que no son "un conjunto de opciones de índole prescriptiva sino una categoría para el análisis descriptivo". Toury (1995: 56-61) distingue tres tipos de normas de traducción, que resultan fundamentales para esta tesis:

- La norma inicial, que determina hacia qué extremo del continuo aceptabilidadadecuación ${ }^{71}$ se inclinará el traductor (o le indicarán que se incline); en otras palabras, se refiere al método de traducción que de forma global permeará en todo el texto;

- Las normas preliminares, relacionadas con las políticas de traducción y los factores y agentes externos que inciden en la traducción, y

- Las normas operacionales, que remiten a las decisiones textuales que toma el traductor. Chesterman (1997: 64-70) suma las normas de expectativa, es decir, lo que esperan los receptores de la traducción, y Nord (1997) habla de otros tipos de normas (que ella denomina "convenciones"), entre las que se encuentran las convenciones de género.

Martínez Sierra (2010: 162), citando a Díaz Cintas (2005), sugiere que:

las normas pueden venir aplicadas no por los traductores de manera individual (operacionales) sino por otros agentes como los estudios, las distribuidoras, los directores de doblaje y ajustadores, etc. (preliminares).

O’Connell (2003: 229), basándose en las afirmaciones de Toury, sostiene que los traductores de textos para niños "often adapt to the norms that prevail in the target culture in relation to a range of linguistic, political, religious, national or other issues". Dado que hemos afirmado que el género de los programas infantojuveniles tiene similitudes con la literatura para niños y adolescentes, sería lógico suponer que debe de ocurrir lo mismo

71 Los extremos de este continuo reciben distintos nombres: familiarización-extrañamiento, domesticación/naturalización-extranjerización, traducción orientada a la lengua/cultura metatraducción orientada a la lengua/cultura origen. 
con las traducciones de dichos programas. Eso implicaría, tanto a nivel lingüístico como de referencias culturales, una clara tendencia hacia el extremo de la familiarización/domesticación y hacia la estandarización lingüística, aunque la decisión de acercarse a dicho extremo no siempre se basa en la idea de comprensión y "protección" del niño (Lorenzo, 2014) sino que a veces tiene que ver con cuestiones ideológicas. Por ejemplo, Goris (1993) ya comentaba que los gobiernos nacionalistas favorecen la estandarización lingüística y utilizan el doblaje como un mecanismo de control.

Según Martínez Sierra (2010: 155), “Toury introdujo la noción de norma para referirse a las regularidades observadas en la conducta traductora dentro de una determinada situación sociocultural". El concepto de norma es especialmente significativo en la traducción audiovisual por dos motivos. En primer lugar, porque la regularidad en la toma de decisiones da lugar a patrones que afectan las expectativas de los receptores de los textos traducidos. Y en segundo lugar, porque, como sostiene Díaz Cintas (2001: 98), "las normas vigentes en un período dado pueden perder esa vigencia con el devenir temporal". Ambos conceptos, sumados a las convenciones de género y a la idea de que el español neutro puede considerarse una tercera norma (Pavesi: 2005), justifican la delimitación del objeto de estudio de este trabajo: el español neutro del doblaje de series de ficción infantojuveniles (convención de género) producidas en un período específico (devenir temporal), en este caso 2006-2016. Resta averiguar, entonces, si ha habido regularidad en la toma de decisiones y, de ser así, cuáles han sido sus consecuencias.

Las normas de expectativa tienen un innegable valor. Como sostiene Franco Aixelá (1996: 53.54):

faced with the difference implied by the other, with a whole series of cultural signs capable of denying and/or questioning our own way of life, translation provides the receiving society with a wide range of strategies, ranging from conservation (acceptance of the difference by means of the reproduction of the cultural signs in the source text), to naturalization (transformation of the other into a cultural replica). The choice between these strategies will show, among other factors, the degree of tolerance of the receiving society and its own solidity.

El hecho de que haya habido casos como los fracasos de las traducciones de películas de Disney dobladas al español argentino $^{72}$ recalca la importancia de las normas de expectativa. ¿Hasta qué punto se puede saber cuál es la norma de expectativa "correcta"? Díaz Cintas (2005: 14-15) y Martínez Sierra (2010: 157) mencionan dos rasgos primordiales de las normas: su especificidad sociocultural y su inestabilidad. En 1998 Disney tuvo que retirar del mercado el VHS redoblado al español peninsular de La sirenita (The Little Mermaid, Ron Clemens-John Musker, 1989) porque al público español no le gustó esa nueva versión (la original se había doblado en español neutro en Los Ángeles en 1989); sin embargo, en la actualidad el DVD y el Blu-Ray incluyen ambas

\footnotetext{
72 Tras las críticas al doblaje al rioplatense de películas como Cars y Los increíbles, Disney volvió a las traducciones en español neutro (ver, por ejemplo, http://es.doblaje.wikia.com/wiki/Los Incre\%C3\%ADbles, consultado el 15 de noviembre de 2017)
} 
versiones. Por otro lado, la compañía tomó la decisión de realizar el redoblaje al español peninsular basada en la opinión de algunos críticos, opinión que no necesariamente reflejaba la del público. ¿Esperaba realmente el público una versión en español peninsular estando acostumbrado al doblaje hispanoamericano y habiendo visto la versión de 1989 ? Según una opinión mayoritaria en Internet: "El público acepta el primer doblaje como válido y rechaza todo lo que destruye el recuerdo original". ${ }^{73}$ Es muy probable que fuera por esta misma razón que no rechazó los siguientes doblajes peninsulares de películas de Disney.

El encargo de traducción (norma preliminar) es lo que determina las estrategias que deberá utilizar el traductor (norma operacional) y que finalmente conformarán un producto aceptable a la cultura meta o adecuado al texto original (normal inicial), algo que se podrá cuantificar y cualificar. Por lo tanto, es posible que un mismo traductor utilice distintas técnicas y terminología según quién sea el iniciador del encargo de traducción. Es decir, un mismo traductor puede utilizar distintas estrategias para los distintos clientes, tal como sostiene Franco Aixelá (1996: 66): "It is not unusual for a publisher to impose homogeneous translation norms which transcend the idiosyncrasy of a translator, who will work in a different way when changing initiator." Por otro lado, se puede considerar el criterio económico como otra norma preliminar que también incide en el doblaje, ya que este "es, en última instancia, una actividad económica que debe ser viable y productiva" (Cerezo Merchán et al, 2015).

\subsection{ESPAÑOL NEUTRO DEL DOBLAJE, DUBBESE Y TERCERA NORMA}

Es necesario hacer una diferenciación entre el dubbese y el español neutro. Pavesi (2005) considera al dubbese una tercera norma, un "modelo estilístico y lingüístico específico de cada cultura para los textos doblados" (Chaume, 2008) que se consolida a fuerza de repetición. ¿Se podría decir, entonces, que el español neutro, en tanto lengua desarrollada principalmente por los medios audiovisuales, es también un ejemplo de dubbese y una tercera norma? La respuesta a esta pregunta es compleja.

Por un lado, se podría decir que sí, pero el español neutro del doblaje es algo más que eso, dado que la cultura meta a la que está orientado es tan amplia como el ámbito geográfico que ocupa, y el nivel de aceptabilidad se convierte en un problema. Como ya hemos señalado, la frase "Don't worry" podría traducirse en el español neutro de un libro como "no te preocupes", pero suele traducirse como "descuida" en doblaje por cuestiones de sincronía labial e isocronía. Los espectadores están acostumbrados a oír ese "descuida", incluso si no es la palabra que usarían habitualmente al hablar. Es decir,

\footnotetext{
${ }^{73}$ http://orgullodeser.com/fan/la-sirenita-y-el-re-doblaje-de-disney-en-espana-por-que-no-se-respetael-original/ (consultado el 15 de noviembre de 2016).
} 
encuentran aceptable el uso de "descuida" en un doblaje, y por lo tanto se podría decir que el uso del término "descuida" es un ejemplo de dubbese.

Por otro lado, a veces se prioriza la búsqueda de una mayor naturalidad, se intenta que esa oralidad prefabricada dé la sensación de espontaneidad en el discurso, y tal vez se utilice "no te preocupes" a pesar de las dos bilabiales que no estaban presentes en la versión inglesa y de que el dubbese indique que "descuida" es la opción "correcta". En el caso del español neutro del doblaje, a veces ocurre que se reniega de la sincronía labial y de la naturalidad por el hecho de buscar un término que sea "inclusivo" y se entienda en las distintas regiones. Por ejemplo, algunos doblajes usan la palabra "soccer" como traducción de football para que todos los hablantes lo comprendan (aunque en la mayoría de los países latinoamericanos lo llaman "fútbol"), es decir que dichos doblajes buscan favorecer el español neutro por sobre el dubbese, que se inclinaría por el préstamo naturalizado "fútbol". 74

Se podría afirmar, entonces, que el español neutro para el doblaje, en tanto $\underline{\text { dubbese, }}$ conforma una tercera norma, puesto que no representa una lengua oral espontánea y auténtica, pero dicha norma tiene dos aspectos diferentes: mientras que el dubbese se centra más en la consolidación del uso de ciertas estructuras gramaticales, términos y clichés de traducción (como las exclamaciones "Oh!" o "Damn!" y el moderno "In your face!" del inglés, que se infiltran en la lengua oral de los hispanohablantes por su constante repetición, que los torna aceptables, o el uso de “¿Puedes?” para reemplazar al "please" del inglés por la bilabial), el español neutro para el doblaje prioriza la aceptabilidad de sus términos a través de una homogeneización inclusiva de la lengua, ya que es un modelo lingüístico de varias culturas que comparten un gigantesco espacio geográfico y el idioma español (en general). Dicho de otro modo, los doblajes en español neutro utilizan un dubbese que intenta buscar un equilibrio entre los clichés de traducción, la estandarización y la deslocalización sacrificando incluso la fidelidad o la coherencia con las imágenes o aún más, la sincronía labial y la isocronía, en pro de la supuesta aceptabilidad de una comunidad heterogénea compuesta por más de 400 millones de hablantes con sus propios dialectos y variedades geográficas y con su propia cultura.

\subsection{TÉCNICAS Y NORMAS EN LA TRADUCCIÓN AUDIOVISUAL}

Los traductores recurren a diferentes procedimientos técnicos, o técnicas de traducción, ante problemas concretos planteados por el texto origen y siguiendo el método consciente o inconsciente que deciden para su encargo de traducción, así como las directrices impuestas por sus clientes. Martí Ferriol (2010: 90-94), basándose en la taxonomía de Hurtado Albir (2001), propone una lista de veinte técnicas de traducción aplicadas a la

\footnotetext{
${ }^{74}$ Ejemplo tomado de la serie animada para niños Backyardigans (Janice Burgees, 2004-2012), que transmite el canal Discovery Kids.
} 
traducción audiovisual que van de un extremo al otro del continuo domesticaciónextranjerización ${ }^{75}$ :

\begin{tabular}{|l|l|l|l|}
\hline Préstamo & $\begin{array}{l}\text { Traducción palabra } \\
\text { por palabra }\end{array}$ & Calco & Traducción uno por uno \\
\hline Traducción literal & Equivalente acuñado & Omisión & Reducción \\
\hline Compresión & Particularización & Generalización & Transposición \\
\hline Descripción & Ampliación & Amplificación & Modulación \\
\hline Variación & Substitución & Adaptación & Creación discursiva \\
\hline
\end{tabular}

Tabla 11 - Técnicas de traducción según Martí Ferriol (2010)

Para esta investigación, sin embargo, hemos centrado nuestra atención en las normas y técnicas que resultan más relevantes para los objetivos de nuestro proyecto. Hemos analizado el corpus en busca de casos de traducción literal, adaptación (naturalización), omisión, préstamo y calco (extranjerización), generalización y ampliación (explicitación). Asimismo, también analizaremos las técnicas que contribuyen a la norma de eufemización, que "cambia o suaviza el signo ético por omisión, adición o sustitución de aspectos ideológicamente inaceptables en la cultura" (Martí Ferriol, 2005), por ejemplo, las técnicas de modulación y variación.

Por otro lado, Chesterman (1997) presenta tres grupos de estrategias que los traductores utilizan para ajustarse a las normas de traducción. La categoría que él denomina "pragmáticas" incluye una estrategia muy importante para este trabajo, la transedición, que implica que el traductor tiene que editar el texto con el que trabaja por algún motivo. Si bien se trata de una estrategia que suele utilizar el traductor para doblaje por las restricciones y prioridades de las que hemos hablado, la transedición también podría abarcar estrategias de censura impuestas por el iniciador del encargo de traducción o algún otro agente del proceso de doblaje, o estrategias de autocensura impuestas por el propio traductor cuando siente que el texto original viola de algún modo la norma de aceptación o su propia idea de qué es correcto que escuchen los niños.

Martí Ferriol asegura que el empleo reiterado de unas técnicas concretas o de un grupo concreto de técnicas a lo largo de un corpus representativo acaba constituyendo una norma de traducción. Las normas de traducción que enuncia el autor, fruto de la repetición de ciertas técnicas, y basándose en autores que ya las habían enunciado en otras

${ }^{75}$ Para las definiciones de estas técnicas, véase Martí Ferriol, 2010. 
investigaciones sobre traducción audiovisual (Goris, 1993; Ballester, 2001) son las siguientes:

1. Estandarización lingüística

2. Naturalización

3. Explicitación

4. Fidelidad lingüística

5. Eufemización

6. Disfemización

Si analizamos esta categorización, veremos que la mayoría de estas normas se acercan más al extremo de la aceptabilidad (excepción hecha de la número 4). De hecho, en el doblaje muchas veces existe cierta tendencia a una domesticación que no responde a ningún criterio de traducción (Goris, 1993). ${ }^{76}$ Existen diversos casos de adaptaciones innecesarias que no parecen tener justificación alguna. Por ejemplo, en el doblaje latinoamericano de Los Simpson (The Simpsons, Matt Groening, 1989-presente), hay alusiones a personajes y personalidades argentinas que no aparecen en el original. En el episodio "El viaje misterioso de nuestro Homero" (1996), Homero habla de los discos de Pimpinela, un dúo de cantantes argentinos, cuando en inglés dice: "It's like you're from Venus...". En otro episodio (“La casita del horror XIII”, 2002), Homero usa las muletillas que utilizaba el actor Mariano Martínez en la novela Son amores (Adrián Suar-Jorge Maestro, 2002-2004) porque, según parece, el doblador Humberto Vélez así se lo había prometido al actor. ${ }^{77}$

La adaptación cultural sin justificación aparente - pero por un motivo encubierto, como veremos más adelante- no es un fenómeno exclusivo de Latinoamérica. En la traducción de la misma serie al árabe es una constante, que incluso llega a cambiar las imágenes que muestran a Homer bebiendo cerveza por zumo o jugo de naranja (Yahiaoui, 2016). En España, Zabalbeascoa (2008) describe la traducción al catalán de dos series francesas para adolescentes en las que se cambiaron los nombres de los personajes y la música fue reemplazada por rock catalán. Y en Italia el doblaje de la serie La niñera (The Nanny, Fran Drescher-Peter Marc Jacobson, 1993-1999) transformó a Fran Fine, una niñera judía de Nueva York, en la italiana Francesca, y convirtió a su mamá en su tía porque, siendo Italia un país mayoritariamente católico, alguien consideró que estaba mal visto que la madre hablara de sexo con su hija (Ferrari, 2010). La cuestión es, entonces, quién es (o

\footnotetext{
${ }^{76}$ Esto es más notorio en algunos doblajes mexicanos que en los de otros países, y cuenta con la aceptación del público.

${ }^{77}$ www.blogdelossimpson.com.ar (consultado el 15 de noviembre de 2016, ya no está disponible)
} 
quiénes son) ese "alguien" que se considera dueño de las normas y las convenciones culturales.

\subsection{TRADUCCIÓN, MECENAZGO Y ESTANDARIZACIÓN LINGÜÍSTICA}

Según Bravo (2009), el español neutro padece una "estandarización artificiosa" vinculada a distintos fenómenos, como "los nuevos modelos lingüísticos más que sugeridos, propuestos por y desde los medios de comunicación”. Y menciona un factor de suma importancia:

la escasa relevancia de la reflexión lingüística sobre este proceso de estandarización mediático, lo cual provoca que muchas decisiones dependan de las propias empresas de comunicación, donde no siempre están a cargo de profesionales de la lengua (Bravo, 2009).

Bravo también cita a McLuhan y Fiore (1967), quienes afirman que "todos los medios [...] son penetrantes en sus consecuencias personales, políticas, económicas, psicológicas, sociales y éticas". El idioma, por supuesto, y el modelo lingüístico de cada idioma que se imponga en cada medio, es una de las formas de penetración más usadas.

Lefevere (1990) acuñó el término patronage, o mecenazgo, para referirse a las personas o instituciones que tienen el poder suficiente para interferir en el proceso de traducción. Díaz Cintas (2001: 100) explica que "se trata de una noción vinculada con el control exógeno que, desde el interior de la estructura socioeconómica e ideológica de cualquier sociedad, se ejerce sobre todo fenómeno traductor". La traducción audiovisual, a diferencia de otros tipos de traducción, involucra a muchos más agentes en el proceso (incluso externos), y algunos de esos agentes detentan un gran poder para influir en las estrategias adoptadas por los traductores. De hecho, el concepto de mecenazgo a menudo va de la mano del concepto de censura, y puede influir en la tensión entre las necesidades y gustos del público y los intereses comerciales de las compañías (Díaz Cintas, 2001: 28). Tanto el mecenazgo como la censura pueden afectar la norma de expectativa del público meta, y ambos están relacionados con los intereses comerciales, económicos, ideológicos y/o políticos de los agentes que pueden influir en las decisiones tomadas por los traductores.

En el caso de una lengua minorizada, como el catalán, por ejemplo, la noción de mecenazgo y su impacto en la traducción son bien visibles y muy perceptibles. Marzà (2016) asegura que:

Ja afirmava Díaz-Cintas que el procés traductor en el marc d'una televisió es troba molt controlat, cosa que facilita la localització de les pautes normatives que el regeixen. Lefevere considera aquest control com a part integrant del "mecenatge" (patronage), i indica els dos factors que sostenen una situació de mecenatge en un sistema literari: d'una banda, els mateixos professionals, i de l'altra, "the powers (persons, institutions) that can 
further or hinder the reading, writing, and rewriting of literature" (Lefevere, 1992: 1415), els quals exerceixen el seu mecenatge a través d'organismes reguladors. Són el que Karamitroglou ha anomenat "agents".

Desde el punto de vista económico, como hemos visto, la creación del español neutro tuvo un fin netamente comercial, ya que se buscaba que el mismo producto se pudiera distribuir en toda Hispanoamérica (España incluida). Con el paso del tiempo, otros factores llevaron a dejar de lado -en parte- ese criterio y a separar a España de ese doblaje neutro general. Sin embargo, se conservó la pretendida estandarización lingüística del español neutro para que los productos pudieran continuar comercializándose en toda Latinoamérica. Al adoptar un nuevo doblaje para España, se modificó la norma de expectativa del público español, que de todos modos espera escuchar una lengua relativamente estándar (un español peninsular 'neutro') y no una variación regional.

En cuanto a los programas infantojuveniles, Di Giovanni (2010) plantea que se utiliza la estandarización con fines "educativos", o un registro formal con alguna que otra palabra informal para que parezca que el texto traducido tiene la misma informalidad que el original, lo que crea cierta incoherencia lingüística. Di Giovanni llama a esta discrepancia "intralingual shift". Cierta estandarización es deseable, ciertamente, para los niños más pequeños, que tienen un vocabulario más simple y acotado, pero si esa misma estrategia se utiliza para los programas juveniles, por ejemplo, llevará a una importante reducción del léxico ${ }^{78}$ y a una estandarización innecesaria, ya que se supone que un adolescente conoce sinónimos, tiene un bagaje léxico mayor e incluso sabe palabras de otras lenguas (como "nerd" o "playlist", en el caso de los jóvenes latinoamericanos, por ejemplo). Por otro lado, los niños y adolescentes conocen expresiones y términos que no son neutros, principalmente a través de las apps, las redes sociales y diferentes plataformas de Internet, y también de algunos libros escritos en españoles locales.

Si bien la estandarización, como afirma Díaz Fouces (2009: 245), es la otra cara de la moneda de la variación lingüística espacial, no solo se lleva a cabo a nivel lingüístico, sino también a nivel cultural (Goris, 1993). Zabalbeascoa (2000: 20) destaca el hecho de que:

todos somos conscientes de la importancia de las industrias que dependen del consumo de los menores, por un lado, y del poder de influencia que en algunos casos se puede llegar a tener sobre su perspectiva del mundo, por otro.

El problema para el traductor es que, a veces, tiene dos jefes a los que debe servir: por un lado, el público infantojuvenil, que está formando su propia perspectiva del mundo, y por otro, los agentes del proceso de doblaje (y también los agentes exógenos) que tienen el poder de influir en dicho proceso por distintos motivos y por distintas causas. Uno de esos motivos es la manipulación ideológica. Franco Aixelá (1996: 54-55) sostiene que:

\footnotetext{
${ }^{78}$ Mourelle de Lema (1998) considera que "se llega hasta grados deplorables de empobrecimiento en léxico y sintaxis".
} 
the constant importation of consumer items (cultural and other) from English-speaking America does not just imply a growing familiarity of many societies with the AngloSaxon world view, but also a clear process of gradual acceptability of its values and specific cultural reality.

Este proceso de aceptación gradual de sus valores y de su realidad socio-cultural debería implicar una menor manipulación del texto meta, y sin embargo no siempre es así, y esto se refleja en las técnicas de traducción elegidas tanto a la hora de trasvasar referencias culturales como al elegir términos en español neutro (vid. Capítulo 6).

\subsection{CODA}

Por tanto, el español neutro del doblaje no es fruto solamente de elecciones subjetivas, o de caprichos individuales, o de la idiosincrasia de los traductores, sino que entran en juego fuerzas de mecenazgo que inciden sobre la traducción y sobre el resultado final del modelo que estudiamos.

Las distribuidoras, cadenas de TV o plataformas online tienen sus propias guías de estilo (vid. capítulos 1 y 4), tanto particulares para cada idioma como generales, y definen el encargo de traducción con mayor o menor detalle. Es probable que las plataformas online tengan más libertad, por ser globales, que una cadena de televisión que transmite en un país determinado, y que esto, a su vez, se refleje en las normas preliminares de la traducción. También puede darse el caso de que los gobiernos u otros agentes con poder (político, religioso, colectivos específicos, etc.) impongan ciertas reglas a los canales o distribuidoras.

Por otro lado, los directores y actores de doblaje prefieren un texto bien ajustado a uno que deban modificar. Los cambios que realizan pueden tener como objetivo mejorar el lip sync (sincronía fonética o labial) o la isocronía, pero no todos los directores y actores de doblaje son conscientes de que no deben alterar los sentidos o del cuidado con el que los traductores escogen las palabras. Lo ideal sería que director y traductor estén en contacto para resolver cualquier duda lingüística que se presente, como por qué se eligió cierto término, y así evitar errores de sentido involuntarios. Por otro lado, los directores y actores no son ajenos a las ideologías, y tal vez no tienen tan en claro que al traducir el público espera que se le ofrezca una versión fiel y no una versión manipulada (recuérdese lo mencionado anteriormente sobre los agregados y cambios en series como The Simpsons vid. 3.3). Los traductores y adaptadores también pueden tener miedo a no cumplir con las expectativas de sus clientes: además de aplicar las guías de estilo que sus clientes les facilitan (e imponen), traductores y adaptadores a veces dudan de sus elecciones y, en caso de duda, es posible que opten por la solución más conservadora, más estándar, o menos conflictiva en términos políticos, ideológicos, sexuales o religiosos.

Y, por último, y no menos importante, el papel del público que, aunque no ejerza un mecenazgo previo a la traducción, de algún modo sí lo ejerce a posteriori, puesto que sus 
reacciones (sobre todo, hoy en día, a través de las redes sociales), y el posible impacto que esas reacciones tengan en el consumo del producto traducido, van a servir de retroalimentación a todos los agentes del proceso. Asimismo, y como en cualquier otro tipo de traducción, el público es el que define las estrategias de traducción. Si comparamos la traducción para doblaje infantojuvenil con la traducción de literatura infantil y juvenil, podemos hacernos eco de la opinión de García de Toro:

El acto de traducir es siempre una actividad lingüística sometida a restricciones a causa de diferentes factores y, en el caso de la traducción de literatura infantil y juvenil, la audiencia es el factor que más claramente incide en el proceso de traducción. Tanto es así que para investigadoras como Oittinen (2000) u O'Connell (2003) es precisamente el rasgo que mejor la define. (García de Toro, 2014) 


\section{CAPÍTULO 4. \\ POLÍTICAS LINGÜÍSTICAS Y CENSURA}

\subsection{LAS POLÍTICAS LINGÜÍSTICAS}

La traducción audiovisual es un tipo de traducción restringida por muchos motivos, como ya se ha tratado en el Capítulo 1 de esta tesis (Titford, 1982; Mayoral et al., 1988; Zabalbeascoa, 1993; Martí Ferriol, 2010). No solo porque tanto en el texto a traducir como en la confección del resultado final siempre hay que sumar aspectos como la información que se transmite por la imagen y sonido (vid. Capítulo 1), sino porque también se inscribe dentro de procesos que afectan el trabajo del traductor en distintos grados (las restricciones profesionales de Martí Ferriol, 2010). Distintos agentes influyen en las decisiones del traductor de doblaje, algunos más cercanos a él (supervisor, director) y otros más distantes ( $\$ 3.5)$. El secretismo que siempre ha envuelto al proceso de doblaje sigue existiendo, y provoca que muchas veces el traductor no sepa quién influye en su tarea y hasta qué punto. En algunos casos, las políticas linguísticas de los estudios son establecidas por un equipo encargado del español neutro o por algún manual de estilo propio, pero en otros casos, dichas políticas trascienden las paredes del estudio y son impuestas por otros agentes, como canales de televisión, distribuidoras, o incluso gobiernos.

Bein (2015: 4) define las políticas lingüísticas como:

las decisiones adoptadas, generalmente por el Estado, sobre el uso público de las lenguas. Incluyen, entre otras, fijar las lenguas oficiales de un país, decidir las lenguas de la escuela, reformar la ortografía, fijar una terminología y determinar qué lenguas se utilizan en los medios de comunicación. [...] Como toda regulación de las prácticas sociales, las políticas lingüísticas están vinculadas con otras políticas: interior, exterior, económica, social, cultural. Por eso, resulta imprescindible analizar las políticas lingüísticas en función de las coyunturas en las que se producen y de los intereses que encarnan.

Por su parte, Varela (2007: 165) definía una política lingüística como:

un conjunto de decisiones y acciones promovidas por el poder público, que tiene por objeto principal una (o más) lengua(s) de su órbita, y está racionalmente orientado hacia objetivos que son tanto lingüísticos (esto es, determinado efecto sobre el corpus de la lengua, su estatuto y/o su adquisición) como no lingüísticos.

Ambos autores coinciden en la importancia de la relación entre las políticas lingüísticas y la situación política, económica, social y cultural en que se producen, pero Varela enfatiza el hecho de que "el factor que determina la forma y la intensidad de la acción en el plano lingüístico es, sin duda alguna, el político". 
Así como algunos países eligieron originalmente el doblaje para su industria cinematográfica o televisiva porque gran parte de su población era analfabeta y no podía leer subtítulos (Chaume, 2012), en otros predominaron las cuestiones políticas (Danan, 1991). Algunos de los países que han preferido el doblaje son grandes defensores de su lengua o han sufrido dictaduras a las que les resultaba muy útil controlar los contenidos de los productos audiovisuales a través del doblaje. Varela (2007: 165) afirma que "la instauración de un régimen autoritario [...] viene siempre acompañada de medidas represivas, más o menos explícitas, también en el campo del lenguaje". Danan se pregunta, por ejemplo: “How did Peron's Argentina, with its large Italian immigrant population, compare to European fascist countries with respect to film production and dubbing?", y Gambier (2002) se pregunta lo mismo respecto de la dictadura de los años 70 y 80 en Argentina.

Sonderéguer (2015: 7) explica que "todos los gobiernos tienen planes y realizan intervenciones lingüísticas", y que los medios de comunicación no utilizan la expresión "política lingüística", pero estas existen, y a veces se las utiliza "para manipular al destinatario y conseguir ciertos fines" (p. 57).

En la década de 2000, Latinoamérica tuvo varios gobiernos populistas -Hugo Chávez en Venezuela, Néstor y Cristina Kirchner en Argentina, Daniel Ortega en Nicaragua, Evo Morales en Bolivia- que fomentaron políticas lingüísticas acordes a sus ideas. En Argentina, por ejemplo, Saavedra (2011) cita a Varela en el periódico Página 12: "La política lingüística está al servicio de un proyecto político de país”. De la misma época son la creación del canal estatal infantil Pakapaka (2010), la Ley de Medios (Ley 26.522 de Servicios de Comunicación Audiovisual), promulgada en 2009, y la actualización de la Ley del Doblaje (vid. Anexo 5). La aprobación de leyes que fomentan y a la vez regulan estrictamente el doblaje en los países de tendencia nacionalista coincide con el crecimiento de la accesibilidad a los medios gracias a estas nuevas leyes, que a veces también buscan manipular los contenidos ofrecidos en pos de una supremacía del "pensamiento nacional"

En la siguiente tabla, que compara la página institucional del canal estatal argentino Pakapaka -dedicado a los niños- de 2014 (gobierno Kirchner) con la de 2016 (gobierno Macri), vemos la diferencia entre el enfoque de los dos gobiernos de esos años, ya que el primero menciona conceptos sociopolíticos que no menciona el segundo ("desigualdades económicas, sociales y culturales").

\footnotetext{
${ }^{79}$ Como la Secretaría de Coordinación Estratégica para el Pensamiento Nacional, creada en Argentina en 2014.
} 
Concebimos esta sección web de la señal PAKAPAKA como un puente que une la televisión pública destinada a la infancia, las aulas y los hogares. Una pasarela entre los distintos espacios de la vida infantil. También entre soportes tradicionales y multimediales. $U n$ aporte al diálogo tanto entre las distintas generaciones como entre la diversidad de infancias que se demarcan a partir de las desigualdades económicas, sociales y culturales.
PAKAPAKA es la señal pública destinada al público joven, chicas y chicos de entre 2 y 12 años. Con temáticas universales y estéticas variadas, garantiza el acceso a contenidos culturales y educativos de calidad que trascienden edades de manera entretenida y audaz. Sus propuestas multiplataforma y transmedia convocan a la participación e interacción a través del desarrollo de contenidos y juegos en su sitio web, y el desarrollo de apps.

\section{PAKAPAKA}

Primer canal educativo y público de la Argentina. Nació en 2010 y es un espacio que permite a los chicos y chicas del país expresarse respetando sus diferencias y particularidades.

Ilustración 25 - Comparación de la página institucional del canal estatal argentino Pakapaka

Si bien a veces las políticas lingüísticas gubernamentales no se traducen en directrices concretas, su impacto se puede ver en la aprobación de leyes que fomentan cierto tipo de doblaje, por ejemplo, o en iniciativas del estilo de este canal estatal, cuyos contenidos propios tenían una ideología muy marcada y cuya guía de estilo hablaba de adaptar los contenidos de los programas extranjeros al enfoque del canal. Del mismo modo, el uso de ciertos términos en los discursos políticos o el hecho de tildar de "imperialista" al español peninsular ${ }^{80}$ podrían considerarse también casos de políticas lingüísticas gubernamentales encubiertas.

Los años analizados en esta tesis coinciden con los gobiernos del matrimonio Kirchner y el inicio del gobierno del presidente Macri. Mendelevich (2016) habla del "mecanismo de las palabras y los conceptos prohibidos" en un artículo publicado en el periódico La Nación titulado "Réquiem para el lenguaje kirchnerista". ${ }^{11}$ Se podría suponer que las "palabras prohibidas" y los "modismos y eufemismos" de la "era K", como afirma Mendelevich, pudieron influir de algún modo en las empresas de doblaje y en la lengua utilizada, dado que, por ejemplo, fue famosa la disputa que tuvo un secretario del gobierno

\footnotetext{
80 Por ejemplo, durante el Congreso Internacional de la Lengua Española realizado en Córdoba, Argentina, en 2019, docentes y estudiantes de la Universidad Nacional de Córdoba organizaron un "Anticongreso de la Lengua contra el imperialismo del idioma español".

${ }^{81}$ Mendelevich, P. (2016): “Réquiem para el lenguaje kirchnerista”, La Nación, 2 de agosto de 2016
} 
con los directivos en Argentina de Disney y Universal por las restricciones impuestas al estreno de sus películas. ${ }^{82}$

\subsection{POLÍTICAS LINGÜÍSTICAS NO GUBERNAMENTALES}

Cabe señalar que las políticas lingüísticas, como mencionamos anteriormente, no solo son establecidas por los gobiernos. Los estudios de doblaje, canales y otros agentes también tienen políticas lingüísticas específicas. Por ejemplo, como mencionamos anteriormente, El Halli Obeid (2012) afirma que el español neutro se basa "en decisiones intuitivas, sondeos de marketing y el más puro método de prueba y error". Más allá de confirmar el hecho de que a veces quienes utilizan el español neutro solo suponen que lo están haciendo bien, El Halli Obeid incluye a otros dos agentes con poder en el proceso de doblaje: los expertos en marketing y el público meta.

La importancia del público meta para un encargo de traducción es innegable. Pero también lo son las decisiones de los expertos en marketing. Además de dejar de lado a los actores de doblaje profesionales en pos de utilizar a los denominados "Star Talents" (como Fernando Alonso en el doblaje de Cars para España) "como gancho comercial para las audiencias" $"$, pueden inmiscuirse en las estrategias traductoras y hacer que Los Increíbles vayan por la avenida Corrientes, en Buenos Aires, por ejemplo. Y aunque, como dice El Halli Obeid, los expertos de marketing realicen sondeos, está claro que los resultados no son siempre los buscados. Es lo que sucedió cuando se realizaron versiones en español de Argentina de algunas películas de Disney, como Cars (Fuentes-Luque, 2019b). El resultado, si bien interesante, no fue el deseado. El público, acostumbrado a décadas de doblaje al español neutro, no se sintió identificado con estas versiones, y hasta sentía "extraña" la variedad argentina en boca de personajes que claramente no lo eran ${ }^{84}$, aunque el español neutro tampoco se correspondiera con el origen de dichos personajes. Las críticas fueron muchas y ya no se hacen doblajes al argentino. El director de doblaje Sebastián Arias lo explica así en su blog ${ }^{85}$ :

\footnotetext{
${ }^{82}$ Burgüeño, C. (2011): “Avanza Ley Moreno: también en el cine dólar por dólar", en Ámbito Financiero, 24 de noviembre de 2011

83 Zurro, J. (2017): “Famosos e intrusos: ¿por qué Fernando Alonso dobla a un personaje de 'Cars 3'?”, El español, 16 de julio de 2017, https://www.elespanol.com/cultura/cine/20170714/231227681 0.html (consultado el 2 de marzo de 2019)

${ }^{84}$ http://tavargentina.com/2017/10/el-doblaje-en-la-argentina/ (consultado el 2 de marzo de 2019)

${ }^{85}$ http://doblajeenargentina.blogspot.com.ar/2012/07/espanol-rioplatense-y-espanol-neutro.html
} 
El neutro como tal no se habla en ninguna parte, y es solo una convención, y es por esa cualidad que podemos "comprar" la fantasía de que hablen así, sin importar dónde trascurre la historia.

Sí hay, de todos modos, programas para niños (como Flopaloo, ¿dónde estás? ${ }^{86}$ ) y documentales doblados al español de Argentina en los dos canales estatales, Pakapaka y Encuentro, pero si bien utilizan rasgos típicos como el uso del pronombre "vos" y los verbos correspondientes, y algún que otro término específico, la variedad utilizada suena a un español neutro con algunos rasgos argentinos. Valdría la pena investigar qué tan fácil les resulta a los traductores, acostumbrados a trabajar en neutro, realizar esta tarea de adaptación a la variedad local. De hecho, a algunos directores de doblaje no les parece una política adecuada cuando atenta contra la estética elegida para la película o programa, como asegura Arias en su blog.

En el caso del doblaje para niños y jóvenes, su consolidación se debe también a cuestiones comerciales y económicas, que pueden haberse visto afectadas también por las políticas lingüísticas gubernamentales. Muchos canales de cable optaron repentinamente por el doblaje para programas juveniles y para adultos a mediados de los años 2000 y dejaron de brindar el servicio de subtitulado (medida resistida ampliamente en Argentina) ${ }^{87}$. La medida podría resultar extraña ya que el doblaje es más costoso y complejo que el subtitulado, pero benefició enormemente a los estudios de doblaje de los distintos países. La justificación fue que quienes veían los programas no tenían el nivel cultural necesario para leer los subtítulos y preferían el doblaje. Cabe preguntarse qué tanto pudieron influir los gobiernos en semejante decisión. Por otro lado, el pobre (pero comprobable) ${ }^{88}$ nivel educativo de los jóvenes y la consiguiente falta de voluntad de leer subtítulos aparentemente llevó a los cines a proyectar películas dobladas que una década atrás habrían sido subtituladas. Sin embargo, la distribución de las copias dobladas o subtituladas de una misma película muestra con claridad que la elección de una u otra depende de la ubicación de la sala de cine. A mayor nivel económico y educativo de una zona, más funciones subtituladas, y viceversa. ${ }^{89}$

${ }^{86}$ Flapacha, où es-tu?, Hugo Gittard y Jean Cayrol, Francia, 2012-2013

${ }^{87}$ http://www.lanacion.com.ar/1382020-cine-doblado-o-con-subtitulos; http://tv.otroscines.com/2011/06/a-partir-de-junio-cinecanal-solo-emitira-peliculas-dobladas/; "Lo cierto es que no nos dejan elegir" (http://www.pagina12.com.ar/diario/suplementos/espectaculos/5-33874-2014-11-02.html); "Películas con subtítulos: ¿una causa perdida?" (http://www.lanacion.com.ar/1732624-peliculascon-subtitulos-una-causa-perdida, consultados el 26 de noviembre de 2015)

${ }^{88}$ Ver nota 21

89 "La oferta de funciones dobladas revela un mapeo digno de análisis, de urgente análisis", recalca Porta Fouz (2016a) en “¿Ustedes conocen la voz de Tom Hanks?”, La Nación, 3 de diciembre de 2016 
En la siguiente tabla se puede observar la disparidad de versiones subtituladas y dobladas $^{90}$ de la misma película según la ubicación de los cines en la Ciudad Autónoma de Buenos Aires (CABA) y en el Gran Buenos Aires:

\begin{tabular}{|c|c|c|c|}
\hline & ZONA & $\begin{array}{c}\text { NÚMERO DE } \\
\text { FUNCIONES } \\
\text { CON VERSIÓN } \\
\text { SUBTITULADA }\end{array}$ & $\begin{array}{c}\text { NÚMERO DE } \\
\text { FUNCIONES } \\
\text { CON VERSIÓN } \\
\text { DOBLADA }\end{array}$ \\
\hline \multirow{3}{*}{$\begin{array}{l}\text { Ciudad Autónoma de } \\
\text { Buenos Aires }\end{array}$} & $\begin{array}{l}\text { Zona norte (Recoleta, Belgrano, } \\
\text { Palermo) }\end{array}$ & 85 & 41 \\
\hline & $\begin{array}{l}\text { Zona centro (Caballito, Villa } \\
\text { Crespo, Almagro) }\end{array}$ & 18 & 48 \\
\hline & $\begin{array}{lll}\text { Zona } & \text { sur/sureste } & \text { (Devoto, } \\
\text { Flores) } & & \end{array}$ & 13 & 19 \\
\hline \multirow{5}{*}{ Gran Buenos Aires } & Zona norte (Martínez, Olivos) & 31 & 13 \\
\hline & Zona sur (San Justo) & 5 & 15 \\
\hline & $\begin{array}{l}\text { Zona suroeste } \\
\text { (González Catán, Ezeiza) }\end{array}$ & - & 17 \\
\hline & Zona noroeste (Morón) & 21 & 5 \\
\hline & $\begin{array}{l}\text { Zona sur (Quilmes, Lanús, } \\
\text { Avellaneda) }\end{array}$ & 32 & 83 \\
\hline
\end{tabular}

Tabla 12 - Comparación del número de funciones con versión subtitulada y doblada de Star Wars en la semana de su estreno - Fuente: La Nación, 18 de diciembre de 2015

Si se echa un vistazo al resultado de las elecciones primarias de 2017, es fácil establecer un vínculo entre los resultados, el nivel económico y educativo y las versiones más comunes en cada distrito o zona: las zonas con votantes de centro-derecha y supuestamente con mayor nivel cultural son las que tienen los cines en los que se proyectan las versiones subtituladas, y las zonas con votantes de partidos populistas, que se supone tienen menor nivel educativo, son aquellas en las que se proyectan las versiones dobladas. Sin embargo, aun en cines de zonas con mayor poder adquisitivo uno puede

90 Porta Fouz, J. (2016b): “El aumento alarmante de las películas con doblaje”, La Nación, 15 de octubre de 2016 
encontrar jóvenes viendo películas prohibidas para mayores de 13 o 16 años en su versión doblada. ${ }^{91}$
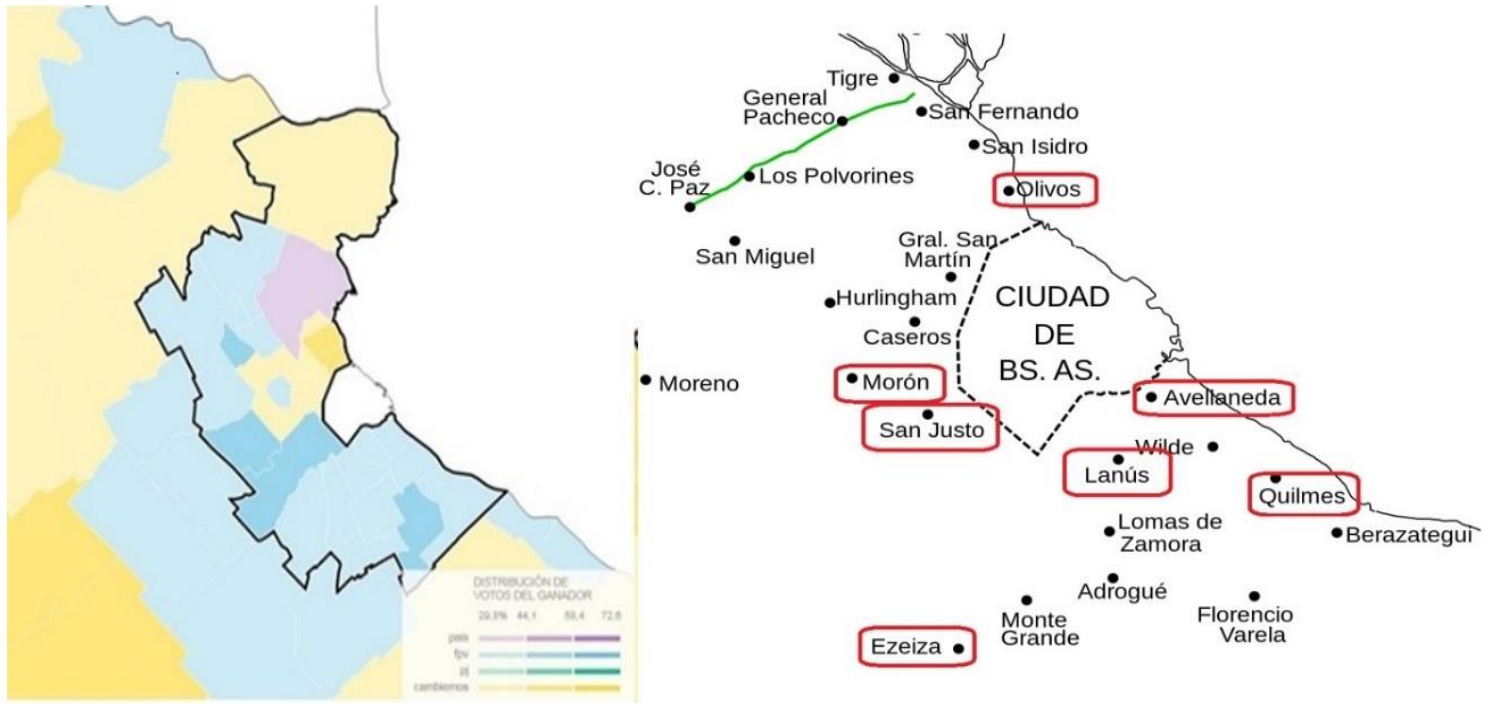

Ilustración 26 - Resultados de la votación 2017 en Gran Buenos Aires

(en azul y celeste, los distritos ganados por el partido populista Frente para la Victoria, y en amarillo, los ganados por el partido conservador Cambiemos) / Fuentes: La Nación, 14 de agosto de 2017, y www.mapoteca.educ.ar

Esta tendencia, según consideran los expertos, es una mezcla de oferta y demanda: el público joven, que prefiere no leer, opta por ver doblaje, algo que las plataformas de VOD les ofrecen siempre, y por lo tantolos cines tratan de satisfacer esa demanda también, pero según la ubicación geográfica de las salas y lo que suponen es el nivel económico y educativo del público de cada zona. Porta Fouz (2016b) sostiene que:

El doblaje es una mutilación a la obra original, y puede verse como una muleta comprensible para aquellos que por edad o educación no sepan leer. Pero es alarmante que cada vez más gente que podría leer subtítulos esté cómoda con esta oferta, y más alarmante aún es pensar que el aumento del doblaje es una respuesta a un estado de situación de la capacidad de lectura de parte de la población adolescente y adulta. (La cursiva es mía.)

Este fenómeno no es exclusivo de Argentina, también está presente en otros países latinoamericanos como Uruguay o México. En Uruguay opinan que la causa original del incremento del doblaje se debió a:

la aceptación pasiva de una política diseñada por los distribuidores internacionales en función de un mercado latinoamericano genérico (es decir, países que, en comparación

\footnotetext{
${ }^{91}$ Experiencia personal de la autora
} 
con Uruguay, tienen mucho menor tasa de alfabetización e inferior calidad educativa). (Quiring, 2017)

Las quejas por el aumento del doblaje también fueron expresadas en Uruguay por asociaciones de críticos y empresarios del cine, que tienen la misma visión que los críticos argentinos y que opinan que "el doblaje analfabetiza e impide acercarse a nuevos idiomas y cultura" (Quiring, 2017):

La Asociación de Críticos de Cine del Uruguay (ACCU) emitió una declaración para expresar su consternación frente a la "creciente y ya desmesurada extensión, en nuestro circuito de exhibición cinematográfica, de funciones con versiones dobladas de películas". Explican que, durante la vigencia de las copias en fílmico, en Uruguay eran casi inexistentes las versiones dobladas, salvo en producciones destinadas al público infantil. (...) La creciente ausencia de la opción de ver una película subtitulada, en un país que, tradicionalmente, respetó el idioma original, parece depender de la ubicación geográfica de las salas, al menos en la política que llevan adelante los shopping: en el Costa Urbana y el Nuevo Centro, los films subtitulados son casi inexistentes, mientras que en Portones, Montevideo Shopping y Punta Carretas su proporción es notoriamente mayor, aunque algunas producciones sólo se puedan ver con subtítulos en horarios posteriores a las 22.00. (La cursiva es mía.)

Álvaro Caso, director de [la distribuidora] ENEC (...) y socio de Life Cinemas, se pregunta si es el público el que demanda el doblaje, o si los distribuidores fueron los que marcaron la tendencia y acostumbraron al público. "¿Las majors generan tendencia al doblaje o responden a la expectativa del público? Lo cierto es que hay complejos de cines que solicitan que las películas populares tengan una versión doblada. (...) Admitió que hay también "un segmento de la sociedad que no mantiene una práctica habitual de lectura", y que eso en algunas ocasiones se convierte en un obstáculo. (Quiring, 2017)

Caso opina que las plataformas VOD "han cambiado el paradigma del negocio". Pero a veces son los agentes del proceso de doblaje más cercanos a la traducción quienes establecen ciertas políticas lingüísticas o censuran, o incluso los traductores mismos, que no siempre son profesionales de la traducción, sino que pueden ser directores de doblaje o técnicos devenidos en traductores. En México, por ejemplo, Jorge Arvizu, un conocido doblajista que era la voz de Maxwell Smart en El superagente 86 (Get Smart, Mel Brooks y Buck Henry, 1965-1970) llegó a inventar a un personaje, la tía de Acapulco, que no existía en el original" ${ }^{92}$. Su opinión era que "el humor es universal, nadie puede adueñarse del humor en una comedia, es un trabajo de equipo". No es difícil imaginar que, así como inventó un personaje, seguramente debe de haber cambiado u omitido muchas otras cosas

92 “Los condenados de mi país, aquí en México, me deberían estar agradecidos, la Secretaría de Turismo, y darme invitación vitalicia a Acapulco", dijo. "El hombre del doblaje: entrevista a Jorge Arvizu”, Clarín, 29 de junio de 2008, https://www.clarin.com/extrashow/hombre-doblaje 0 SJXka20aYl.html (consultado el 30 de octubre de 2016) 
del original. Curiosamente, hay quienes piensan que ser infiel es una forma de mejorar el texto original:

Cuando se piensa en el intenso proceso de colonización que la cultura estadounidense ha ido llevando a cabo en el mundo por medio de sus producciones de cine y televisión, se suele pasar por alto que en el procedimiento de traducción siempre ocurren algunos desvíos del sentido original, recreaciones y modificaciones de esos contenidos que se pretenden unívocos. Si bien para porciones grandes del público el subtitulado es preferido porque supone una menor pérdida del contexto cultural, así como de la calidad actoral en las voces originales, el doblaje mexicano tiene hermosos ejemplos de un sutil trabajo de subversión del mensaje, una sofisticación alcanzada gracias al creativo trabajo de adaptación de sus traductores y sus actores de voz que llegaron a darle un valor agregado a ciertas obras. (El Halli Obeid, 2012; la cursiva es mía)

Si bien este comentario es verdadero en ciertos aspectos (hay actores de doblaje que hacen un trabajo excelente y traductores que adaptan el texto en forma brillante), la elección de la frase "sutil trabajo de subversión del mensaje" y de la palabra "colonización" sugieren que la autora aprueba la manipulación ideológica de los textos.

También ha sucedido que nadie sepa de dónde provino alguna regla respecto del español neutro, como mencionamos anteriormente, y que aun así perdure en los distintos estudios de doblaje. Parini (2012) comenta que existen "codes of rules and guidelines", transmitidos entre traductores o en las empresas de doblaje, de los cuales no existe una versión escrita, pero que son considerados una especie de "Biblia del traductor". Una de estas "reglas no escritas" en español es la traducción de la palabra "purple". Por algún motivo, la versión neutra para el doblaje es "morado", y nunca se utilizan ni "violeta" ni "púrpura", a pesar de que ambos términos se usan en la vida diaria y en los ámbitos académicos (el violeta, por ejemplo, es el séptimo color del arcoíris y del espectro newtoniano de luz visible, además del nombre de la flor de ese color). De hecho, los tres colores son diferentes en su tonalidad.

Arias comenta que existe "un diccionario con términos vedados y palabras que entran y salen siguiendo infinidad de criterios distintos". Cuando habla de "diccionario", no se refiere a un libro sino a los distintos glosarios que utilizan los estudios, canales o distribuidoras para definir qué términos pueden utilizar los traductores. En algunos casos ni siquiera existen, y la guía de estilo simplemente remite al traductor a "consultar el diccionario de la Real Academia".

Uno de los problemas que expone Arias en su blog y que comentamos anteriormente es el de "la creencia errada y totalmente fuera de lugar de que el neutro no aceptaba diminutivos o superlativos", aunque ese es el criterio que siguen algunos estudios de doblaje. Esto tal vez se deba a que en las distintas regiones se utilizan diferentes diminutivos (manito/manita, cartita/cartica), pero sería algo extremo sostener que el público no comprenderá que las terminaciones ito-a, ico-ica o illo-illa son un 
diminutivo. ${ }^{93}$ Y lo mismo sucedía con los superlativos. Ahora bien, ¿realmente es un problema utilizar uno u otro? La realidad es que, como ya vimos respecto de El chavo del 8 , el público meta sabe perfectamente (o puede intuir) de qué se está hablando. Veamos un ejemplo. En los primeros meses de 2017, varias canciones de compositores latinoamericanos tuvieron amplia repercusión en todo el mundo. Todas incluían diminutivos, pero en ninguna red social ni en ningún medio alguien se quejó de no comprender lo que decían o simplemente de la rareza de dichos diminutivos.

\begin{tabular}{|c|c|c|c|c|}
\hline $\begin{array}{l}\text { NOMBRE DE } \\
\text { LA CANCIÓN }\end{array}$ & CANTANTES & ORIGEN & $\begin{array}{c}\text { CANTIDAD DE } \\
\text { VISTAS EN } \\
\text { YOUTUBE }^{94}\end{array}$ & $\begin{array}{c}\text { DIMINUTIVOS } \\
\text { INCLUIDOS EN } \\
\text { LA LETRA }\end{array}$ \\
\hline Despacito & $\begin{array}{c}\text { Luis Fonsi } \\
\text { Daddy Yankee } \\
\text { Justin Bieber }\end{array}$ & $\begin{array}{c}\text { Puerto Rico } \\
\text { Canadá }\end{array}$ & $\begin{array}{l}\text { Más de } 5.000 \\
\text { millones }\end{array}$ & $\begin{array}{c}\text { Despacito } \\
\text { Pasito } \\
\text { Suavecito }\end{array}$ \\
\hline La bicicleta & $\begin{array}{c}\text { Shakira } \\
\text { Carlos Vives }\end{array}$ & Colombia & $\begin{array}{l}\text { Más de } 1.000 \\
\text { millones }\end{array}$ & Cartica \\
\hline La mordidita & $\begin{array}{c}\text { Ricky Martin } \\
\text { Yotuel }\end{array}$ & $\begin{array}{c}\text { Puerto Rico } \\
\text { Cuba }\end{array}$ & $\begin{array}{l}\text { Más de } 970 \\
\text { millones }\end{array}$ & $\begin{array}{c}\text { Orillita } \\
\text { Pica'ita } \\
\text { Mordidita } \\
\text { Todito }\end{array}$ \\
\hline
\end{tabular}

Tabla 13 - Datos de algunas de las canciones más escuchadas en Latinoamérica en el verano $2017^{95}$

Estos ejemplos ponen en entredicho la "prohibición" del uso de diminutivos en el español neutro del doblaje, por razones de desconocimiento o de uso asimétrico en los distintos países latinoamericanos.

\footnotetext{
${ }^{93} \mathrm{Y}$ sin embargo, en general se considera neutro el término "mantequilla de maní".

${ }^{94}$ Al 27 de agosto de 2017

${ }^{95}$ Fuente: www.toplatino.net
} 


\subsection{IDEOLOGÍA, CENSURA Y MANIPULACIÓN}

El Giro Cultural en los Estudios de Traducción enfatizó los factores culturales involucrados en la actividad traductora e incorporó fenómenos culturales como las restricciones ideológicas (Camus Camus, 2017). A su vez, este paradigma se basa en el desarrollo de los EDT y la Teoría de los Polisistemas, según la cual uno de los subsistemas de una cultura es la literatura traducida, que recibe la influencia de otros sistemas y de fuerzas que dirigen los movimientos sociales como la economía, la política, el mecenazgo, etc. (Díaz Cintas y Neves, 2015). Como hemos visto, muchas veces no son los traductores quienes deciden qué estrategias o léxico utilizar, sino que son los iniciadores del encargo $\mathrm{y} / \mathrm{u}$ otros agentes involucrados directa o indirectamente en el proceso de doblaje quienes toman las decisiones. Para Cómitre (2009), la manipulación de los textos no siempre supone una estrategia traductológica sino de otro tipo (comercial/económica, ideológica, etc.). Wolinsky (2014) asevera que "las productoras siempre tienen la última palabra, y eso a veces a los traductores nos parece injusto" 96 , y Chaume (2013: 21) sostiene que ciertos enfoques pragmáticos:

pretenden en última instancia demostrar que las elecciones lingüísticas siempre esconden una postura ideológica, es decir, que los distintos usos lingüísticos obedecen a una agenda por parte de los integrantes del proceso de comunicación.

Queda claro, entonces, que el acto de traducción muchas veces no puede separarse de los conceptos de ideología y manipulación, y por ende, de censura. Aira (2015) sostiene que "el español neutro que se utiliza en doblajes es criticado por tener un léxico más reducido y por cierta censura del idioma español”, y El Halli Obeid (2012) afirma que:

en ciertos periodos políticos, el doblaje sirvió incluso para esconder la censura de contenidos y aún hoy, si se comparan los doblajes españoles con los latinos, se puede notar una mayor tendencia a suprimir "malas palabras" o "tacos" en las versiones latinoamericanas. Esta comparación también puede ser hecha entre el doblaje y el subtitulado, siendo este último mucho más escueto por limitaciones espaciales, pero también menos cuidadoso de las formas y, por ende, menos censurado.

Richart-Marset y Chaume (2015) sostienen que la ideología en la traducción no era un campo muy explorado, pero que sin embargo el componente cultural de la traducción está "inextricablemente unido tanto a los textos objeto del trasvase como a la misma operación de traducir". Lo que comenzó en los años 90 con las aportaciones de Bassnett y Lefevere (1998) o Hatim y Mason (1990) y con la creación del Proyecto TraCe (1997) en la Universidad de León y la Universidad del País Vasco y sus diversas publicaciones, continuó en el nuevo siglo con libros y revistas profesionales con números especiales sobre censura, manipulación y TAV: Gambier (2002), Ferrari (2011), Meta (2004, dirigido por Yves Gambier; 2012, dirigido por Díaz Cintas), Prosopopeya (2015, dirigido

\footnotetext{
96 "Las limitaciones del doblaje" (www.tavargentina.com/limitaciones-en-doblaje/, consultado el 30 de agosto de 2017)
} 
por Chaume y Richart-Marset), Ranzato, (2016), Perspectives (2016, dirigido por McLaughlin y Muñoz-Basols), entre otros. Dichas aportaciones han ido describiendo de qué manera la ideología y la censura están presentes en la TAV. En el caso del doblaje, la influencia de los agentes del proceso puede ser mayor o menor por distintos motivos y en distintas circunstancias. Existen notorias diferencias entre los estudios de doblaje más importantes y los más pequeños; también existen grandes diferencias entre los canales y productoras importantes. Con una simple búsqueda en Google con la frase "críticas a Disney", obtendremos casi 700.000 resultados (Disney es objeto continuo de críticas por ser una especie de "representante del imperio estadounidense" fuera -y a veces también dentro- de Estados Unidos), ${ }^{97}$ mientras que "críticas a Nickelodeon" arroja tan solo 215.000 resultados, a pesar de que Nickelodeon tenía al 25 de diciembre de 2016 un 22\% más de telespectadores que Disney Channel y un $46 \%$ más que Cartoon Network ${ }^{98}$. Resulta lógico que Disney sea mucho más cuidadosa con sus productos y con sus doblajes que otras empresas: se han escrito libros que critican la Disneyfication o Disneyization de la sociedad (Bryman, 2004) (aunque también hay artículos en contra de la Nickelodeonization $)^{99}$, y hasta la ex presidenta de Argentina, Cristina Fernández de Kirchner, se hizo eco de esto:

“Acá también funciona el Canal Encuentro y Pakapaka, me había olvidado. Ahora no nos meten más al Pato Donald. Ahora tenemos a Zamba, a San Martín, a Belgrano, a la Juana Azurduy. Ahora tenemos nuestros propios héroes". ${ }^{100}$

97 Digón Regueiro, P. (2006): “El caduco mundo de Disney: propuesta de análisis crítico en la escuela”, Comunicar, № 26, Grupo Comunicar Ediciones, Huelva. / Es conocida la mala relación entre el CEO de Disney, Bob Iger, y el presidente Donald Trump (“Did Disney CEO Bob Iger Just Compare Donald Trump to Hitler?", 12 de abril de 2019, https://toofab.com/2019/04/12/did-disney-ceo-bob-igerjust-compare-donald-trump-to-hitler/, consultado el 6 de julio de 2019), pero es importante notar que el encono con Iger y Disney no es solo del presidente republicano sino también de los demócratas: Johnson, T. (2016): "Bernie Sanders Continues Attack on Disney Over Worker Pay", Variety, 25 de mayo de 2016, http://variety.com/2016/biz/news/bernie-sanders-disney-robert-iger-

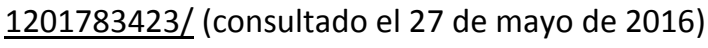

98 "Nickelodeon Wins 2016 with Kids and Total Viewers - Outperforms Competition by Double Digits", www.thefutoncritic.com/ratings/2016/12/28/nickelodeon-wins-2016-with-kids-and-total-viewersoutperforms-competition-by-double-digits-40211/20161228nickelodeon01/\#QAdhejUrSXjTuGuL.99 (consultado el 28 de diciembre de 2016)

99 Por el momento, la Netflixation solo hace alusión al consumo compulsivo de productos audiovisuales, pero no es necesariamente despectiva como las referencias a Disney y Nickelodeon. / Weitz, M. (1996): “Mr. Corn Mo Rising”, Dallas Observer, 10 de octubre de 1996

100 "Ahora no nos meten más al Pato Donald' y otras frases de Cristina Kirchner", La Nación, 2 de diciembre de 2015, https://www.lanacion.com.ar/politica/ahora-no-nos-meten-mas-al-pato-donald-ahoratenemos-a-paka-paka-y-otras-frases-de-cristina-kirchner-nid1850799 (consultado el 2 de marzo de 2019) 
Las críticas a Disney no solo se encuentran en discursos políticos o monografías académicas, sino también en la red:

\section{En respuesta a @DisneyStudios y \\ @andersonDrLJA}

Disney is so into diversity now, why was it not "Marty Poppins the Transgender Au Pair" with a female chimney sweep?
In Marvel cinematic universe, even the aliens are white. Please don't speak to me about diversity. Disney is a white supremacist entity.

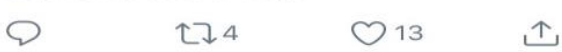

My idea for my final project is the rising diversity in Disney princess movies \#mcomo2

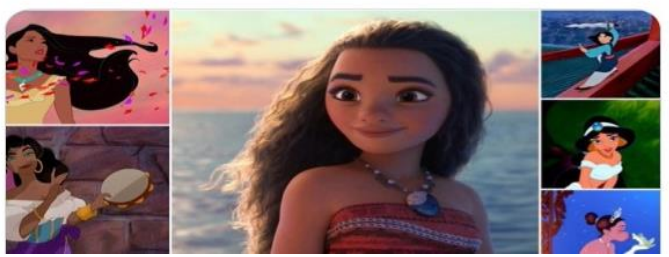

Ilustración 27 - Comentarios negativos y positivos sobre Disney - Fuente: Twitter

\subsection{LA IMPORTANCIA DEL CONTEXTO HISTÓRICO Y POLÍTICO}

Según la Teoría de los Polisistemas, la actividad traductora forma parte de un sistema cultural receptor enmarcado en un determinado momento histórico, y se rige por las normas de dicho sistema en ese momento histórico y socio-político en particular. Díaz Cintas (2012: 283) sugiere que habría que comprender la relación entre las estrategias de los traductores y las cuestiones socio-políticas para elucidar las normas de traducción y tendencias dominantes en ciertos períodos históricos. Por su parte, Chaume (2013: 21) sostiene que:

los Estudios Descriptivos de la Traducción examinan las traducciones como hechos de la cultura en que se originan y, en ese sentido, los EDT consideran las traducciones como productos concretos de las normas y convenciones de la cultura meta. No solo se preocupan de las normas lingüísticas y textuales que dirigen la traducción hacia un lado u otro, sino que también indagan en las razones sociológicas, políticas y económicas que hay detrás de esas normas.

Tanto la cultura fuente como la cultura meta tienen sus propias ideologías y realidades históricas, y el traductor a veces se ve obligado a debatirse entre unas y otras cuando existe disparidad de criterios y circunstancias. A esto se suma que el doblaje se presta a la manipulación ideológica y política y a la censura. Diversos autores (Ballester, 2000; Garnemark, 2015), y en especial los del Grupo TraCe, han comprobado la existencia de censura en el doblaje (vid. Rabadán, 2000) en los períodos franquista y postfranquista de la historia de España. 
Wirnitzer (2003) afirma que "el traductor a menudo está sometido a una ideología dominante a nivel nacional y que influye notoriamente en la práctica y teoría traductoras". Por ejemplo, El Halli Obeid (2012) comenta que "en un momento de la década de los setenta, el gobierno mexicano no dejaba mencionar la palabra 'droga' en TV'. Desde el punto de vista histórico-político, queda claro que el desarrollo del populismo en América Latina, más la mayor importancia otorgada a las minorías y a la accesibilidad a los medios, tuvo su repercusión en la lengua. Surgieron expresiones como "todos y todas" para no generalizar con el masculino (frase que la Real Academia Española tildó de incorrecta) ${ }^{101}$, que dieron lugar a otras frases similares, como "sujetos y sujetas" para hablar de individuos en las Ciencias Sociales o la Psicología (Rosales, 2011) ${ }^{102}$.

En el caso de Argentina en particular, la influencia de las ideologías y censuras ha quedado en claro a lo largo de los años. En 1986, durante el gobierno de Raúl Alfonsín, el primer presidente elegido democráticamente después de la dictadura militar, se promulgó la Ley del Doblaje. Esta Ley 23.316 establecía que "el doblaje para la televisión [...] deberá ser realizado en idioma castellano neutro, según su uso corriente en nuestro país, pero comprensible para todo el público de América hispanohablante". Esta definición contenía varios conceptos muy vagos, y a pesar de que se cumplía con este requisito de traducir al español neutro, en 2013 la presidenta Cristina Fernández de Kirchner decretó ${ }^{103}$ ciertos porcentajes de doblaje que se debían realizar en el país "como medio razonable para la defensa de nuestra cultura e identidad nacional, circunstancia que se garantiza a través de la actividad desarrollada por actores y locutores que posean nuestras características fonéticas" (vid. Anexo 5). Esto era incompatible con el requisito de realizar los doblajes en el "idioma oficial" de Argentina, cuya definición no podía ser más ambigua, dado que el decreto continuaba: "Se considera como idioma oficial al castellano neutro según su uso corriente en la República Argentina, pero garantizando su comprensión para todo el público de la América hispanohablante. Asimismo se establece que su utilización no deberá desnaturalizar las obras, particularmente en lo que se refiere a la composición de personajes que requieran de lenguaje típico". La finalidad secundaria

101 Sack, A. (2012): “La Real Academia Española, contra el 'todos y todas'”, La Nación, 5 de marzo de 2012 (https://www.lanacion.com.ar/sociedad/la-real-academia-espanola-contra-el-todos-y-todasnid1453900); Pérez, A. (2018): “La RAE se reafirma en rechazar el lenguaje inclusivo”, El Mundo, 27 de noviembre de 2018, https://www.elmundo.es/cultura/literatura/2018/11/26/5bfc3577468aebb83e8b45b4.html, (consultados el 2 de marzo de 2019)

102 Algo similar ocurrió en España en 2008 con el uso de la palabra "miembras" por parte de la ministra de Igualdad, Bibiana Aído ("Las 'miembras' de Bibiana Aído", 10 de junio de 2008, https://www.20minutos.es/noticia/387648/0/miembras/bibiana/aido/, consultado el 2 de marzo de 2019)

103 Decreto 933/2013, publicado en el Boletín Oficial de la Argentina (http://servicios.infoleg.gob.ar/infolegInternet/anexos/215000-219999/217418/norma.htm) 
de dicho decreto quedó expuesta en un artículo publicado por la agencia de noticias estatal Télam, que abiertamente lo considera "un proyecto político":

\section{La reglamentación de la Ley de Doblaje es uno de los grandes logros del proyecto nacional}

La reglamentación de la ley se complementa a su vez con la Ley de Servicios de Comunicación, y forma parte de un proyecto nacional que pone a la cultura y a sus gestores por delante de los intereses de quienes aceptan el manoseo político-cultural y permitieron que por décadas Hollywood se entrometa en la actividad del resto del mundo

\section{Por Claudio D. Minghetti}

Es sabido que el doblaje del cine tiene que ver con viejas épocas, finales de la década del 20, cuando nació el cine sonoro y a la alternativa de subtitulado, se intentó en diferentes países imponer el doblaje, en especial en aquellos donde la precaria educación fuera de los centros urbanos, impedía a mucho público potencial ir al cine y leer aquellas traducciones.

Sin embargo, en los países de América latina se dio una circunstancia singular, por ejemplo en la Argentina, donde la gente estaba, y sigue estando, muy acostumbrada a ver el cine en su idioma original. La cosa cambia con la irrupción de los filmes para niños que tiene su primera aparición fuerte con Walt Disney.

Con la llegada de la televisión al promediar la del 50, se produce la segunda aparición del tema doblaje, con series y películas todas dobladas en el exterior, y así Hollywood comenzó un nuevo trabajo fino en la cabeza de los espectadores sentados en sus casas, fijando así la forma en que se debía encarar el tema.

Si el cine estadounidense tuvo como misión golpear a los cada vez más fuertes cines de todo el continente, pero en especial al argentino, la TV tenía como meta ser el ariete que rompería aún más con la idea de industria con identidad que el cine local había alcanzado una década atrás, porque la cuestión era invadir la casas de la gente y amoldarla a su oferta.

Con el golpe que derrocó a Juan Domingo Perón en 1955, y a pesar de la rápida firma de una primera Ley de Cine, la producción local todavía era respetada por su alta calidad, y eso seguía preocupando a los Estados Unidos, que ya habían tomado a la producción de cine como una cuestión más que de estado, aplicando un plan de defensa e invasividad casi militar pero sin uniforme.

La televisión postergó las voces de actores locales, posibles para un filme o serie a verse por TV, presentando otras, principalmente mexicanas, que hicieron del doblaje "neutro" una industria para actores, actrices y locutores de ese país, convirtiendo esa alternativa en un negocio cautivo.

A la idea muy difundida de que "una buena película no parece argentina" había que sumar que las buenas películas extranjeras, cuando llegaban a la TV (por entonces solo abierta), tampoco tenían nada que ver con lo nuestro. No cabía entonces duda alguna de que en el negocio del cine y series de TV, Hollywood debía tener el control y llegar al país con el enlatado terminado.

Algo que hay que tener en cuenta es que aquí se podía hacer un excelente doblaje "neutro", como incluso ya en la década del 50 y 60 se hacía en anuncios publicitarios, con actores conocidos, otros no, 
que más allá de su imagen en off eran tan idóneos y versátiles como los locutores.

Es más: en 1941, Walt Disney recorrió parte de Latinoamérica y llegó a Buenos Aires el 8 de septiembre estrenando al día siguiente "Fantasía" en el cine Broadway, y poco después visitó los estudios de Argentina Sono Film, donde acordó que el joven y ascendente director Luis César Amadori se encargara del doblaje para el mercado hispanohablante de sus próximos filmes.

Amadori, que tenía entonces 39 años, ya había dirigido diez películas para ese sello, y venía de estrenar éxitos como "Hay que educar a Niní" y "Napoleón", con Niní Marshall y Pepe Arias, respectivamente y siete años después alcanzaría su mayor éxito con "Dios se lo pague".

El vínculo había nacido poco antes con "Blancanieves y los siete enanitos", "Pinocho", y "Fantasía", y siguió con "Bambi” y "Dumbo", pero Disney pensó que era mejor controlar esa etapa y llevó la actividad primero a Los Ángeles, y después a México, y así bajar costos, y poder ver más de cerca a sus "empleados".

En esos doblajes locales participaron Miguel Gómez Bao (que fue Gepetto, en "Pinocho" y el Sr. Cigüeña en "Dumbo"), Pablo Palitos (Pepe Grillo, en "Pinocho" y Timoteo en "Dumbo"), Semillita (Polilla, en "Pinocho" y un chico en "Dumbo"), Lalo Malcolm y Cielito (Pinocho); Eduardo Rudy (Bambi joven), Norma Castillo (madre de Bambi, y el Hada Azul en "Pinocho"), Narciso Ibañez Serrador (Peter Behn, en "Bambi"), entre otros.

La relación con Argentina Sono Film y Amadori terminó igual que la del ilustrador Florencio Molina Campos, al ver que su aporte a Disney para convertir a Tribilín en gaucho para un film ambientado aquí, terminó en un breve episodio de "Saludos, amigos!" (1942), parodia de excelente animación pero coherente con la mirada imperialista que Estados Unidos tiene sobre la región.

Después de muchos años y con la globalización Disney volvió en la Argentina a recurrir a actores locales para los doblajes, dejando en claro una vez más que aquí hay talento para que esto ocurra, por ejemplo en "Cars", "Los increíbles" y "Ratatouille", y lo insólito es que fue para dar valor agregado local a sus productos.

Durante décadas los actores y locutores argentinos reclamaron la posibilidad de ampliar su espectro laboral, de hecho asegurar trabajo genuino a un importante grupo de actores nacionales. y devolver a la gente en los personajes de las series estadounidenses y de otros países un sonido algo más cercano.

Dice la reglamentación anunciada en hace un par de semanas que la decisión apunta a "la defensa de nuestra cultura e identidad nacional, circunstancia que se garantiza a través de la actividad desarrollada por actores y locutores que posean nuestras características fonéticas".

¿Por qué habiendo tantos actores y locutores de calidad, algunos con voces memorables o con la capacidad de generar mil voces, como lo hacen habitualmente estos profesionales, no fueron hasta ahora los que doblaban el cine o las series de TV que se veían en la pantalla chica local?

Que a partir de ahora los filmes y series que se vean por los canales de TV locales tengan en buena proporción que ser doblados por argentinos habla a las claras de un proyecto político que incluye a la cultura respaldándola con leyes y otros ejemplos son los decretos que dispusieron considerar a los directores y actores de cine y TV como autores y así recibir derecho de autor.

El doblaje establecido para los filmes y series de TV tiene un efecto respecto a la identidad invisible, pero es reivindicativo para actores y locutores nacionales y, además, promueve la posibilidad de consolidar la idea de nuevas fuentes de trabajo para unos y otros, ampliando la oferta laboral. 
Varios medios comunicadores intentaron confundir a la gente de a pie haciéndole creer que se trataba de una ley como la franquista que forzaría a doblar toda película extranjera, perjudicando a los que prefieren, con todo derecho, escuchar las voces originales con sus expresiones tal cual fueron hechas por los actores en su idioma, en el cine. Pero no es eso.

La TV de aire impuso el doblaje, seguramente por su masividad y llegada a cualquiera que encienda su receptor de TV, y así seguirá siendo, incluso en el cine, muchas películas que estrenan distribuidoras extranjeras, se presentan dobladas, sin excepción por voces muy extranjeras, de caribeños, mexicanos o venezolanos.

"La caridad bien entendida empieza por casa", dice un viejo refrán. Pero en estos casos no se trata de eso sino de justicia, esa que reivindica como autores a directores audiovisuales, a actores dándoles derecho de autor y ahora a estos últimos y locutores permitiéndoles poner sus voces ya sea a personajes como Gregory House, Walter White y, por qué no, a los de Disney. (Agencia Télam) ${ }^{104}$

El artículo, con su visión nacionalista y sesgada y sus datos erróneos ${ }^{105}$, confirma tanto la tendencia de considerar a Disney como una especie de representante mediático del imperialismo del que se acusa a Estados Unidos ${ }^{106}$ como el hecho de que el doblaje no puede separarse de su contexto histórico y político. ¿Cuán significativa es, entonces, la incidencia del contexto histórico y político, tanto del sistema fuente como del sistema meta, en las decisiones de cada agente involucrado en el proceso de doblaje?

En México, por ejemplo, la Ley de la Industria Cinematográfica de 1949, reformada en 1952, establecía que las películas debían verse en idioma original y subtituladas. En 1992, una nueva ley estableció que "las películas serán exhibidas al público en su versión original $y$, en su caso, subtituladas en español, en los términos que establezca el

${ }^{104}$ Agencia Nacional de Noticias Télam (http://www.telam.com.ar/notas/201308/27544-la-
reglamentacion-de-la-ley-de-doblaje-es-uno-de-los-grandes-logros-del-proyecto-nacional.php,

consultado el 3 de diciembre de 2017)

105 Entre los errores que se deslizan más voluntaria que involuntariamente en el artículo (si analizamos con cuidado la terminología del texto, es fácil ver que es muy tendencioso) podemos citar los siguientes: Blancanieves y los siete enanos (David Hand, 1937), por ejemplo, fue doblada en los estudios de Disney en Los Ángeles; los doblajes argentinos de la época moderna de Disney se remontan por lo menos al año 2004, y el decreto es de 2013; los doblajes de cine tienen acento neutro, y no se nota que los dobladores sean "caribeños, mexicanos o venezolanos", etc. Se puede consultar la historia del doblaje argentino en http://www.iadacargentina.org/\#!/-historia/, el sitio de Intérpretes Argentinos de Doblaje.

106 Bravo (2009) cita el caso de Mattelart y Dorfman, que "abogan por extender el espacio audiovisual latino para contrarrestar el inglés." Ambos autores publicaron en 1971 Para leer al Pato Donald, "un trabajo destinado a denunciar desde una perspectiva marxista la 'colonización' americana a través de los cómics y Disney", que se retomó en una exposición de arte en Los Ángeles en 2017 (Chatruc, C. "En Hollywood, el arte latinoamericano opaca la magia de Disney", La Nación, 14 de septiembre de 2017, https://www.lanacion.com.ar/2062887-en-hollywood-el-arte-latinoamericano-opaca-la-magia-dedisney, consultado el 2 de diciembre de 2018) 
reglamento. Las clasificadas para público infantil y los documentales educativos podrán exhibirse dobladas al español". ${ }^{107}$ En 1999 se adicionó a la ley el artículo 23, que expresaba que "con el fin de conservar la identidad lingüística nacional, el doblaje de películas extranjeras se realizará en la República Mexicana, con personal y actores mexicanos o extranjeros residentes en el país, salvo las disposiciones contenidas en convenios o tratados internacionales, y en los precisos términos del Artículo 8o. de esta Ley". 108

En 2005, el senador mexicano Guillermo Herbert Pérez, del Grupo Parlamentario del Partido Acción Nacional, presentó un proyecto de decreto para reformar la Ley Federal del Derecho de Autor y la Ley Federal de Cinematografía. ${ }^{109}$ Los conceptos detrás del proyecto suenan llamativamente similares a los vertidos en el artículo de Télam:

Las compañías productoras de películas norteamericanas se interesaron en México para "doblar" su material debido a la familiaridad con que era recibido en Latinoamérica gracias a la presencia del cine mexicano, además de que el acento mexicano frente a otros acentos hispanoamericanos tiene mayor neutralidad, todo esto sin dejar de lado el gran prestigio y calidad de los actores de nuestro país debido a sus excelentes interpretaciones. (...)

Es necesaria una adición de un artículo, donde contemple la incorporación a la posibilidad de que las películas que se presenten en las salas cinematográficas sean también dobladas al español por actores mexicanos, cuyos beneficios se darían en tres vertientes.

En primer lugar, existen muchas personas que no asisten al cine; porque no saben leer, o el subtitulado es sumamente malo y las letras están muy pequeñas (debilidad visual).

Si se lleva a cabo el doblaje de las películas, se incrementaría de manera notable la asistencia del público a las salas cinematográficas, cabe recalcar que también se seguirían pasando las películas subtituladas, para aquel público que decida ver la cinta cinematográfica que desee.

Se pretende adicionar un artículo en la Ley Federal de Radio y Televisión, donde se estipule que el material de lengua extranjera que se transmita en la televisión abierta y que se pretenda transmitir en español, deba ser doblado exclusivamente en México, y por actores mexicanos y/o extranjeros residentes en México.

Esto con la finalidad de hacer valer y respetar el trabajo de los actores de doblaje mexicanos, así como también respetar nuestro idioma, nuestra cultura, y nuestro lenguaje, para de esta forma evitar el fomento de tecnicismos, modismos y formas de lenguaje que deforman gravemente al de nuestro país.

La reciente apertura de salas de doblaje de voz en diversos países latinoamericanos, de los que destacan Argentina, Colombia, Chile y Venezuela, ha generado un grave daño a la industria mexicana de doblaje de voz en nuestro país, debido a la competencia desleal por parte de las empresas dedicadas a esta actividad en dichas naciones; quienes por su situación económica pueden ofrecer sus servicios por la cuarta o incluso la quinta parte de lo que en

\footnotetext{
${ }^{107}$ Se puede consultar en http://www.uam.mx/difusion/comcul/leyes/leyes10.html

${ }^{108}$ Se puede consultar en https://www.imcine.gob.mx

${ }^{109}$ Se puede consultar en http://www.senado.gob.mx/64/gaceta_del_senado/documento/4606
} 
México se cobra, lo cual se refleja no solo en la industria mexicana de doblaje de voz y en el ataque directo a nuestro idioma, sino que además se violan los artículos fundamentales de nuestra Constitución Política y de las Leyes vinculadas a la actividad, al permitir su introducción y proyección en nuestro país; obviamente la calidad de este doblaje extranjero no cumple con los estándares mínimos nacionales de calidad que el público mexicano merece. $(\ldots)$

Es importante mencionar que el doblaje mexicano de voz utiliza de manera correcta nuestro idioma, y en cuanto a su calidad, cualidades, tonalidad y musicalidad provoca que sea considerado "neutro", además es entendido absolutamente en todos los países de habla hispana, por el contrario el doblaje de las naciones competidoras utiliza localismos incomprensibles y ajenos para los mexicanos, lo cual corrompe de manera directa la utilización, protección, preservación y difusión de nuestro idioma.

El senador justifica su proyecto comparándolo con leyes similares en España y Argentina. $\mathrm{Y}$ vierte ciertos conceptos que resultan de gran importancia para esta tesis. En primer lugar, Pérez afirma que el acento mexicano tiene más neutralidad que los demás de Latinoamérica, para luego decir que los otros doblajes deforman gravemente el idioma, la cultura y el lenguaje de México, con lo que se contradice y confirma que el doblaje mexicano hace uso de la variedad mexicana y no de un español en verdad neutro. Por otro lado, habla de la "competencia desleal" de los estudios de doblaje recientemente establecidos en Argentina, Colombia, Chile y Venezuela (siendo que algunos llevan décadas doblando), y sostiene que dichos estudios están dedicados a un "ataque directo a nuestro idioma", dando otra vez prioridad a la variedad mexicana, que no es neutra. ${ }^{110}$

Mientras tanto, casi 15 años después, la Academia Mexicana de Artes y Ciencias Cinematográficas (AMACC) acaba de proponer reformar la Ley Federal de Cinematografía para prohibir el doblaje al español de las películas extranjeras, ya que en los cines casi todas las versiones que se presentan son dobladas, y no solo las infantiles, como establecía originalmente el Artículo 8 de la ley. ${ }^{111}$ Esto demuestra la importancia del doblaje para la industria audiovisual, la economía y los intereses políticos, y los cambios que conlleva.

Por otro lado, en Argentina, la ley 22.285, o Ley de Radiodifusión, ${ }^{112}$ databa de 1980, año en que gobernaba el presidente de facto Jorge Rafael Videla, y en su artículo 15, la ley estipulaba que:

\footnotetext{
${ }^{110}$ De hecho, las películas como Los increíbles, que contaban con varias versiones, tenían en el DVD la opción de elegir la versión mexicana, la argentina y la neutra.

${ }^{111}$ Gutiérrez, V. (2019): “AMACC pide prohibir doblaje al español de películas de México, El economista, 9 de julio de 2019, https://www.eleconomista.com.mx/arteseideas/AMACC-pide-prohibir-doblaje-alespanol-de-peliculas-en-Mexico-20190709-0188.html (consultado el 10 de julio de 2019)

112 Se puede consultar en http://servicios.infoleg.gob.ar/infolegInternet/anexos/1500019999/17694/texact.htm
} 
los titulares de los servicios de radiodifusión podrán emitir programación en lenguas extranjeras previa autorización del Comité Federal de Radiodifusión, sin perjuicio de lo cual, deberán orientar su programación a la difusión del idioma castellano intentando promover las lenguas aborígenes de nuestro país. Para el doblaje de películas o series habladas en lengua extranjeras que para su difusión por televisión deban ser dobladas al idioma castellano, deberá darse prioridad a los profesionales argentinos.

Como se ve, resulta imposible estudiar el proceso de traducción y doblaje sin tener en cuenta el contexto histórico y político en el que transcurre.

\subsection{DOBLAJE Y TIPOS DE CENSURA}

En el doblaje resulta sencillo utilizar el idioma para manipular e influir. El reemplazo del diálogo original por otro en otra lengua convierte al doblaje en un instrumento ideal para ejercer censura. Díaz Cintas (2012: 287; 281-282) asegura que:

the act of translating is one of the principal and most recurrent ways that cultures have of dealing with foreign influence. In this negotiation of socio-cultural values, censorship is often activated in the domestic arena as a forceful political and ideological means of articulating those representations in a way that would suit the vested interests of those in authority.

Audiovisual media and its translation play a special role in the articulation of cultural concepts such as femininity, masculinity, race, and Otherness, among others. It can contribute greatly to perpetuating certain racial stereotypes, framing ethnic and gender prejudices, and presenting viewers with outdated role models and concepts of good and bad seen as rigid, diametrically opposed. [...] Power and political dominance, rather than the linguistic asymmetries between languages, act as motivating factors and catalysts in the way cultural values are translated.

Danan (1991) argumenta que se han realizado muchos abusos en nombre de la ideología, la moral o la educación, y afirma que:

dubbing is an attempt to hide the foreign nature of a film by creating the illusion that actors are speaking the viewer's language [...] Dubbing, in short, is an assertion of the supremacy of the national language and its unchallenged political, economic and cultural power within the nation's boundaries. (Danan, 1991)

Y ya en 1931, el Primer Congreso Hispanoamericano de Cinematografía, celebrado en Madrid, concluyó que debía impedir el crecimiento de la producción sonora en español en estudios extranjeros, especialmente en Hollywood, porque no podía controlarla ni censurarla (Fuentes-Luque, 2019a).

Existen distintos tipos de censura que se pueden ejercer sobre el material audiovisual, y en especial sobre el doblaje, como cambiar el título del programa, cambiar los contenidos o el argumento, cortar o suprimir parte del metraje, omitir referencias a la cultura local o referencias religiosas, estandarizar las jergas o variedades dialectales, evitar palabras 
soeces, etc. (Carbonell i Cortés, 1999; Pegenaute, 1999; Merino - Grupo TraCe, 2009; Ferrari, 2010; Díaz Cintas, 2012; Ranzato, 2016). También puede existir cierta autocensura por parte del traductor (Scandura, 2004; Chaume, 2008), o "censura preventiva", en terminología de Gambier (2002), para proteger al televidente o para no ofenderle.

Algunos de estos ejemplos de censura están relacionados con los denominados “conceptos tabú". Allan y Burridge (2006) establecen una clasificación de términos tabú, que incluye palabras y frases relacionadas con partes del cuerpo y funciones corporales; enfermedades, muertes, agresión y asesinatos; personas, objetos y lugares sagrados; preparación y consumo de ciertos alimentos, y obscenidades. Por lo tanto, en esta tesis se analizaron términos y expresiones relacionados con:

- Palabras relativas al concepto de muerte (die, dead, death, kill y similares),

- Referencias a festividades religiosas (Christmas, Santa, etc.) y vocabulario relacionado con la religión ( $G o d$, Hell y similares),

- Referencias culturales (Halloween, etc.),

- Palabras consideradas ofensivas o soeces (turd, fat, idiot y similares), y

- Términos relacionados con alimentos y ropa.

Otros tipos de censura son las regulaciones institucionales de las autoridades públicas, como hemos visto, y los imperativos financieros y comerciales, y el traductor:

relève souvent du non-dit: au traducteur d'en tenir compte, selon sa perception de la compagnie pour laquelle il travaille, selon ses affinités avec les traditions et les orientations de cette compagnie, selon ses représentations des récepteurs devant leur écran. (Gambier, 2002: 203).

La obligación de usar términos políticamente correctos también puede considerarse censura. Mayoral (1994) lo define como el hecho de evitar "el uso de palabras y expresiones que puedan resultar ofensivas, discriminatorias o perjudiciales para grupos sociales, raciales, étnicos, mujeres, animales, etc." Y en una entrevista concedida al diario El País, Darío Villanueva, director de la RAE, calificó a la corrección política como "una forma de censura perversa". ${ }^{113}$ Debido a esta exigencia de cuidar que todo sea políticamente correcto, muchas veces se ha recurrido a una eufemización o estandarización extrema. Por ejemplo, se han dejado de utilizar los acentos en español cuando algún personaje proviene de un país no angloparlante (Rusia, la India, Alemania) y tiene un acento muy marcado en inglés, como el que tenía Siegfried en El Superagente 86. La página de The Big Bang Theory (Chuck Lorre-Bill Prady, 2007-2019) en Doblaje

113 García Testa, V. (2018): “Idioma y política: lenguaje para todEs”, en Noticias, 17 de agosto de 2018, Buenos Aires 
Wikia comprueba que se trató de un exceso de corrección política por parte del canal, que tuvo que corregir, junto con otra enorme cantidad de errores, con un redoblaje:

Otra especificación del cliente fue eliminar el acento de Raj, que originariamente se había grabado con acento, y regresaron los primeros 6 episodios pues tenía que ser neutro, ya que según ellos era racista ponerle ese acento, a pesar de que en la versión original lo tenía como parte de la esencia del personaje. ${ }^{114}$

Y Lozano Miralles (2013) argumenta que, aunque los niños entendían perfectamente el léxico o el voseo de los primeros doblajes de las películas de Disney al español, que contenían una gran variedad de acentos, ahora esa tendencia ha desaparecido y solo se mantiene en escasas ocasiones, como ocurrió con las palomas de la película Bolt (Byron Howard-Chris Williams, 2008) dobladas con acento argentino por los integrantes de Les Luthiers. Incluso se ha recurrido a censurar frases ya dobladas, como cambiar un "Te maldigo" por un "Te odio"115, para no utilizar expresiones religiosas.

También puede ocurrir que sea el mismo traductor quien se autocensure a la hora de traducir programas infantojuveniles, en especial los de estos últimos años, que suelen incluir términos vulgares, bullying lingüístico, dobles sentidos, groserías, etc. Lorenzo (2014) denomina a este fenómeno "paternalismo traductor". Por ejemplo, en una serie para chicos podemos toparnos con diálogos como este:

HAZEL: Or we can rip its horn off and put it right where that doodle doodies!

RAVI: Is it wrong that I am scared and titillated?

TIFFANY: Ew, yes! $!^{116}$

El traductor podría plantearse que este diálogo no es adecuado para un niño, con la misma necesidad de proteger que a veces guía a los adultos que escriben o traducen literatura para niños, y podría decidir modificarlo, del mismo modo que en otros casos podría inclinarse por usar eufemismos. Chaume (2005: 11) confirma la existencia tanto de censura en general como de autocensura:

Si bien el espectador no consentiría cambios en el argumento y contenido de una obra audiovisual [...] sí los consiente y tolera en otros ámbitos, como en la censura y

\footnotetext{
${ }^{114}$ https://doblaje.fandom.com/es/wiki/La teor\%C3\%ADa del Big Bang\#Discrepancias de adaptaci.C3 .B3n.2Ftraducci.C3.B3n

115 Si bien en el sitio web Doblaje Wiki se menciona que el redoblaje probablemente se produjo por "la carga peyorativa" de la frase, es posible que se debiera a que "maldecir" es un verbo relacionado con cuestiones religiosas o místicas (Phineas y Ferb, Dan Povenmire y Jeff Marsh, 2007-2015)

${ }^{116}$ La idea de "meterle el cuerno por el trasero" es comprensiblemente objetable en una serie infantil, al igual que la connotación sexual del comentario de Ravi ("I am titillated", o excitado), hecho que de alguna manera queda demostrado en la respuesta de Tiffany (“Ew!”). El ejemplo pertenece a la serie Bunk'd.
} 
autocensura lingüística (practicada por todas las cadenas de televisión y estudios de doblaje y subtitulación en mayor o menor medida, así como por el propio traductor).

A veces el traductor se ve obligado a convertirse en censor lingüístico por indicación del cliente (sea este un canal, un estudio u otro agente del proceso de doblaje), que le encarga que omita o reemplace cualquier elemento que pueda resultar inapropiado (transedición). A veces esta faceta del encargo queda explícita en la guía de estilo, como en el caso de Pakapaka:

- Los diálogos finales serán aprobados por Pakapaka.

- Se deben trabajar los conceptos centrales de las series a doblar. En muchos casos, la traducción textual del material a doblar podría no coincidir con el enfoque que canal Pakapaka busca para dicho producto.

- Cuando una producción incluya una referencia cultural a un personaje célebre que esté al servicio de una temática general, se la reemplazará por una referencia cultural afín a la audiencia infantil argentina. Esto no quiere decir que se eliminarán las referencias culturales extranjeras en el proceso de adaptación, solo se usarán cuando estas referencias sirvan como ejemplo y no estén directamente vinculadas a la trama.

- No se utilizarán expresiones como “¡Mi Dios!”, “¿Que Dios se lo pague!” o similares para expresar asombro, gratitud, sorpresa, etc., sino que se privilegiarán otras expresiones que no incluyan términos religiosos. ${ }^{117}$

Esta última indicación concuerda con lo que sostiene Parini (2012) respecto de la traducción de anime en Italia: al traductor se le pide que modifique el argumento, que domestique las referencias culturales, que evite las referencias a la muerte y utilice verbos más neutros, como "pasar a mejor vida", y que omita los insultos y términos soeces, entre otras indicaciones que debe cumplir. Y Ranzato (2016) comenta que Disney pide a los adaptadores italianos que no utilicen expresiones como “¡Dios mío!”.

Por otro lado, el público tampoco ve con buenos ojos cuando las productoras o los estudios deciden que de ahora en adelante se utilizarán los nombres originales de los personajes en vez de las traducciones que se usaron durante años (Bruce Wayne Batman- en vez de Bruno Díaz, por ejemplo). Excepto raras excepciones (como un video en el que Kermit, la rana de Los Muppets, da una explicación graciosa -y ficticia- de por qué antes se llamaba René en Latinoamérica), las productoras o los estudios simplemente empiezan a utilizar los nombres originales sin dar explicaciones. Este cambio de nombres

117 https://docplayer.es/20762615-Pliego-de-bases-y-condiciones-particulares-educ-ar-sociedad-delestado-tipo-contratacion-directa-no66-ejercicio-2012.html (consultado el 4 de diciembre de 2018) 
suele ser resistido por el público de mayor edad, que ya conocía a los personajes por su nombre traducido y que lo ve como un tipo de censura: ${ }^{118}$

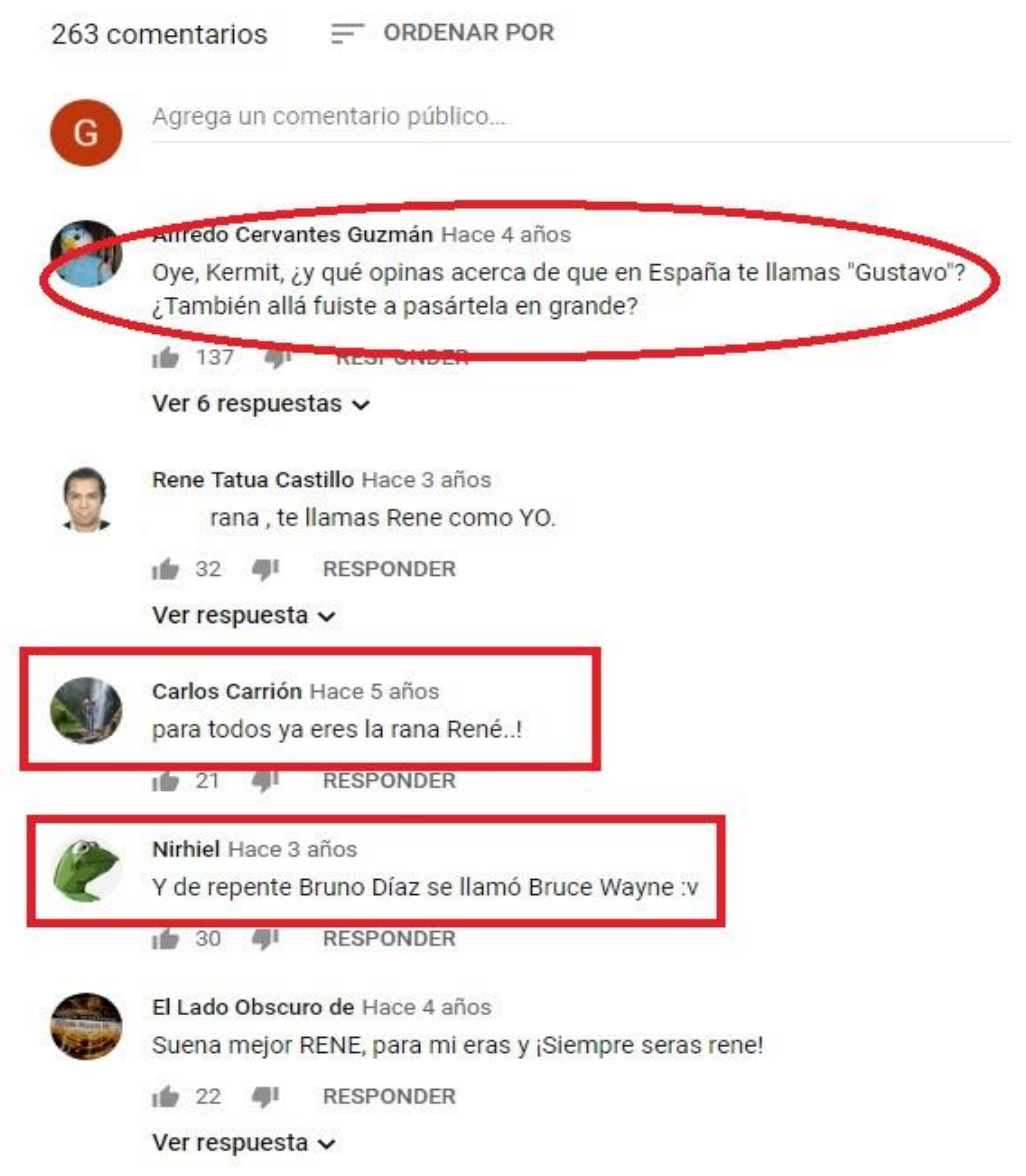

Ilustración 28 - Captura de pantalla de los comentarios sobre el video de Kermit en YouTube (https://www.youtube.com/watch? $v=V p R E 4-l P 86 Y$ )

Existe otro tipo de censura, impuesta por el propio público ${ }^{119}$, que podría definirse como "la influencia que tiene la cultura meta en las decisiones tomadas por los iniciadores del encargo de traducción. Así, el traductor podría dejar de ser un mediador cultural (y como tal, el más idóneo para determinar las estrategias a seguir en casos de brechas culturales y en el uso de vocabulario, estructuras, etc.) y convertirse en un simple redactor de un

${ }^{118}$ Entrevista a Francisco Colmenero (https://www.youtube.com/watch?v=KcCeVxZXNGw); https://www.youtube.com/watch?v=VpRE4-IP86Y (versión para México) y https://www.youtube.com/watch?v=j70h2rvwSyg (versión para Buenos Aires)

119 Bollettieri, Di Giovanni y Rossato (2014) sostienen que "audiences beyond screens are becoming increasingly heterogeneous, but also progressively more specialized and demanding." 
texto nivelado y llano que respeta las convenciones técnicas del doblaje, las necesidades lingüísticas y comerciales de los iniciadores de la traducción y las (supuestas) necesidades del público meta. En el caso de la censura por parte del público, es el espectador el que influye en el iniciador, y éste a su vez influye en el traductor, probablemente sin tener en cuenta la calidad de 'experto' del traductor en cuestiones culturales, incluso si las críticas representan un porcentaje pequeño de la población. ${ }^{120 "}$ (Scandura, 2015) Este flujo de censura podría representarse de este modo:

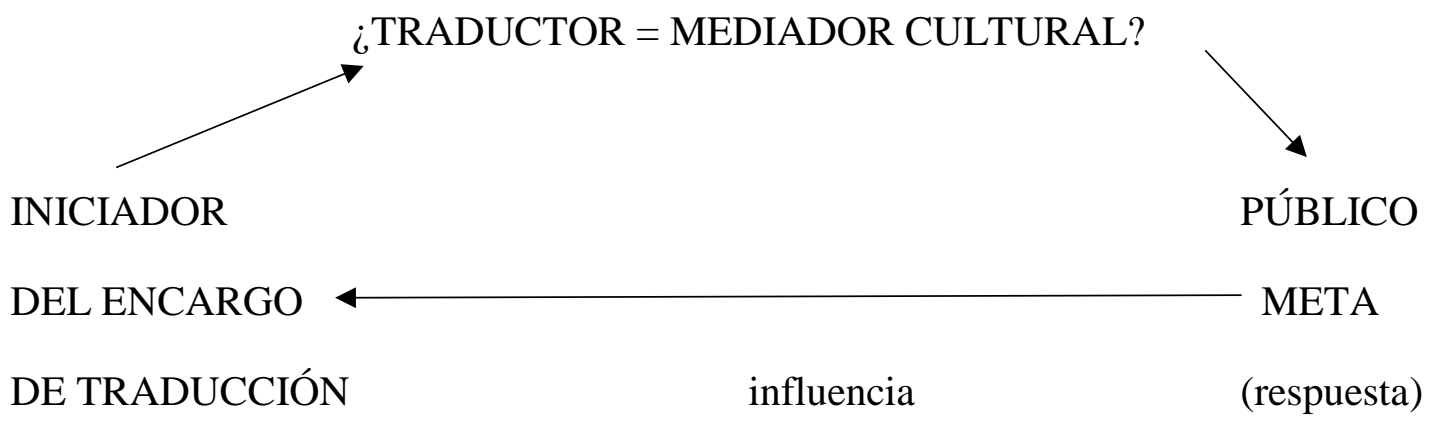

Ilustración 29 - Flujo de censura en las traducciones para el doblaje infantil y juvenil

Finalmente, las nuevas tecnologías presentan nuevos desafíos y restricciones al doblaje, que también pueden considerarse una forma de manipulación. Como afirman McLaughlin y Muñoz-Basols:

today's technology offers increasingly sophisticated and efficient mechanisms for communicating both historical and current events, disseminating ideological agendas, and censoring and manipulating ideas in translation. (McLaughlin y Muñoz-Basols, 2016)

Chaume y Richart-Marset explican que:

Díaz Cintas (2012) distingue dos tipos de manipulación en traducción audiovisual: la manipulación técnica y la manipulación ideológica. Por manipulación técnica, entiende el autor aquellas operaciones de traducción que son esenciales para cumplir con los requerimientos técnicos de las distintas modalidades de traducción audiovisual: por ejemplo, las modificaciones del texto meta para conseguir un ajuste labial o un ajuste isocrónico en el caso del doblaje. [...] Es decir, las manipulaciones (obligatorias) para

120 Disney Channel canceló la emisión de un episodio de Jessie en el que se burlaban de los niños celíacos por una petición en Change.org firmada por 2.137 personas: "We are removing this particular episode from our regular programming schedule and will re-evaluate its references to gluten restrictions in the character's diet. Please accept our apologies for the upset this episode caused you and your family. We value your feedback and thank you for watching Disney Channel." (http://www.cbsnews.com/news/disney-pulls-jessie-episode-that-makes-fun-of-gluten-free-child/ 
cumplir con las normas profesionales de las distintas modalidades de la traducción audiovisual, según unas coordenadas de espacio y tiempo determinadas, es decir, según el encargo de un cliente concreto, en una sociedad o país determinado, y en un momento concreto. El autor habla de manipulación ideológica para aquellos casos en que los motivos técnicos no son los únicos culpables de las manipulaciones observadas en la traducción, aquellos casos en que los agentes implicados en el proceso de traducción y distribución de los textos audiovisuales trasladan al producto audiovisual su visión sobre la relación que debe existir entre texto original y texto meta. (Chaume y Richart-Marset, 2015: 19-20)

La sincronía fonética que favorecía Fodor (1976) parece cobrar más importancia en estos últimos años ${ }^{121}$ con los televisores de alta definición y de gran tamaño. Y en la actualidad, las películas televisivas infantiles más importantes suelen tener su pre-estreno en algún cine, lo que hace que el traductor-adaptador deba prestar mayor atención al detalle de la imagen y al ajuste o adaptación ${ }^{122}$. Agost (1999: 81) ya mencionaba la influencia del tamaño de las pantallas en el trabajo del traductor:

Respecto a las condiciones de recepción, éstas pueden influir en el ajuste, en el sentido que la pantalla de la televisión es más pequeña y «disimula» los problemas de sincronía visual, mientras que el tamaño de la pantalla de cine hace que el ajuste sea más importante y tenga que recibir una atención especial.

En Argentina, hace 20 años los directores de doblaje se concentraban solo en las vocales abiertas o cerradas, pero en la actualidad se enfatiza la necesidad de mantener la misma ubicación en la frase de las bilabiales, las labiodentales y las vocales abiertas, aunque eso signifique perder la fidelidad al sentido, el humor, el orden sintáctico más natural o incluso la coherencia en los diálogos (Chaume, 2005). El traductor debe hacer un gran esfuerzo por supeditar la fidelidad (como le han enseñado a hacer durante su formación) a la sincronía labial.

\subsubsection{IDEOLOGÍA Y REFERENCIAS CULTURALES}

Otro de los factores que enfrenta a los profesionales (traductores, actores de doblaje, directores) con los agentes que controlan las políticas lingüísticas es el hecho de que se modifiquen u omitan ciertas referencias culturales.

Es verdad que la arista cultural no puede separarse del acto de traducir. Chaume (2015: 8) sostiene que:

con el giro cultural hemos aprendido (...) que traducir no es simplemente un acto de reproducción fiel, sino un acto consciente y deliberado de selección y estructuración, y a

\footnotetext{
${ }^{121}$ Experiencia profesional de la autora

122 "Traducción y adaptación para doblaje: ¿Una única tarea o dos etapas de un proceso?", http://tavargentina.com (consultado el 27 de octubre de 2017)
} 
veces de falsificación, o incluso de suplantación. Como ocurre con los periodistas, políticos, escritores, comunicadores, publicistas y otras profesiones, los traductores participan en un movimiento que crea opinión, que crea conocimiento, y que crea y modela una cultura. Las maneras de traducir los referentes culturales, el humor, los discursos ideológicos, los sistemas de valores o las miradas sobre el mundo no dependen solo de las asimetrías entre lenguas sino de las decisiones cruciales que se toman cada vez que el traductor se enfrenta a cuestiones de poder, dominación o ideología, algo habitual en los textos audiovisuales, y no solo en los de ficción.

Entre los temas sobre los que los traductores tienen que decidir figuran, como menciona Chaume, los referentes culturales. En el corpus de esta tesis aparece, por ejemplo, Santa Claus. Para Ranzato (2016), por ejemplo, se trataría de una "referencia intercultural", que pueden ser las referencias que originalmente pertenecían a una cultura fuente y que fueron absorbidas por la cultura meta, o las que son consideradas propias tanto por la cultura fuente como por la cultura meta, sin importar su origen.

Además de las diferencias en sustantivos comunes, adjetivos, verbos, etc. entre los distintos españoles regionales, también existen diferentes nombres propios para un mismo concepto o persona/personaje. Según el país, este viejito regordete vestido de rojo y blanco recibe distintos nombres:

\begin{tabular}{|c|c|}
\hline NOMBRE UTILIZADO & PAÍSES \\
\hline Papá Noel & $\begin{array}{l}\text { Argentina, Paraguay, Uruguay } \\
\text { Bolivia, Colombia, Ecuador y Perú (a veces utilizan "Santa } \\
\text { Claus", pero no es muy frecuente) }\end{array}$ \\
\hline Viejito Pascuero & Chile \\
\hline Colacho & Costa Rica (a veces utilizan "Santa Claus") \\
\hline Santa Claus & $\begin{array}{l}\text { Cuba, Puerto Rico, República Dominicana, El Salvador, } \\
\text { Guatemala, Nicaragua, Panamá } \\
\text { México (también Papá Noel) }{ }^{123}\end{array}$ \\
\hline San Nicolás & Honduras y Venezuela (también Santa Claus) \\
\hline
\end{tabular}

Tabla 14 - Traducciones de Santa Claus según los distintos países latinoamericanos

Algunas guías de estilo, como la de Netflix, instruyen a los traductores a usar "languagespecific translations" para los nombres de personajes históricos o míticos.

\footnotetext{
${ }^{123}$ Arias comenta en su blog que en la película El expreso polar (Robert Zemeckis, 2004), se usa Papá Noel a pesar de que la película se dobló en México, mientras que en Argentina nunca decimos "Santa Claus" pero debemos usar "Santa" en las traducciones.
} 


\section{NETFLIX PARRNER HELP CENTER}

4. Character Names

- Do not translate proper names (e.g., Peter, Suzanne), unless Netflix provides approved translations.

- Nicknames should only be translated if they convey a specific meaning.

- Use language-specific translations for historical/mythical characters (e.g., Papá Noel, San Nicolás).

Ilustración 30- Captura de pantalla del sitio de partners de Netflix (https://partnerhelp.netflixstudios.com/hc/enus/articles/217349997-Castilian-Latin-American-Spanish-Timed-Text-Style-Guide)

¿Cuál sería el correcto en el caso de Latinoamérica, entonces? En español neutro se suele recurrir al nombre "Santa" para homogeneizar y hacerlo comprensible para todos. No se suelen modificar, por ejemplo, las referencias a ciertas festividades no religiosas como Halloween, pero sí se recurre a veces a cambios para evitar nombrar ciertas festividades religiosas como la Navidad, ${ }^{124}$ que termina convirtiéndose en " 25 de diciembre" o simplemente "Fiestas". Para el traductor esto se transforma en una pesadilla, ya que hablar del "árbol de las Fiestas" no suena natural, y tampoco puede usar frases como "la fiesta de las Fiestas" para Christmas party. ${ }^{125}$ Por otro lado, sí son aceptadas otras fiestas religiosas, como Kwanzaa o Jánuca, lo que lleva a pensar que hay algo más detrás de esa política lingüística. Sonderéguer (2015: 69) afirma que "se pueden marcar diferencias ideológicas con el uso de distintas palabras para designar un mismo referente, con el uso de eufemismos, etc." De hecho, en los programas infantiles también se ha hecho uso de cambios de imagen en las tradiciones, con fines antirracistas o profeministas, por ejemplo, como que Papá Noel sea afroamericano ${ }^{126}$ o de sexo femenino ${ }^{127}$, pero no se utilizan expresiones como "Oh my God" sino que se las reemplaza con términos como "Damn" u "OMG". Sería interesante estudiar este mismo fenómeno en unos años para ver cómo ha continuado.

124 Como se mencionó anteriormente, esta tendencia fue objeto de fuertes críticas por parte de los oradores y el público por igual en la jornada Las distintas voces del doblaje, y fue confirmada por los oradores en el Simposio Hispanoamericano de Traducción Especializada y Nuevas Tecnologías.

125 Aunque sí lo hizo una escuela en Italia en 2017, que invitaba a celebrar, para no utilizar la palabra "Navidad" y así ofender a quienes no son católicos, "la Gran Fiesta de las Felices Fiestas" (vid. Piqué, E. 2017 y Capítulo 6).

${ }^{126}$ Bunk'd (Pamela Eells, 2015-presente), episodio de Navidad 2015

${ }^{127}$ Bizaardvark (Josh Lehrman y Kyle Stegina, 2016-presente), episodio de Navidad 2018: "Hi, I'm Sally Claus. There's no reason Santa can't be a woman. Why does Christmas have to be patriarchal?" 


\section{CAPÍTULO 5. METODOLOGÍA Y CORPUS}

\subsection{PARADIGMA DE LA INVESTIGACIÓN}

La presente investigación se inscribe en los Estudios Descriptivos de la Traducción y en la Teoría de los Polisistemas, según la cual el polisistema audiovisual en español latino incluye un subsistema (Baños-Piñero y Chaume, 2009) compuesto por los programas infantojuveniles y este, a su vez, otro subsistema de dichos programas doblados al español neutro (frente a programas que se graban originalmente en español).

Williams y Chesterman (2011) explican que existen distintos tipos de investigaciones: cualitativas y cuantitativas, conceptuales (o teóricas) y experimentales, etc. Dado que estas dicotomías no son necesariamente excluyentes, sino que las consideramos complementarias para corroborar las hipótesis planteadas, esta tesis no puede reducirse a un solo tipo de investigación. Es, en primer lugar, descriptiva, porque se inicia con una amplia descripción del español de América en general y del español neutro en particular, descripción que resulta necesaria tanto para la elaboración y el análisis del corpus como para las conclusiones. También se describen las circunstancias políticas, sociales, económicas, culturales y profesionales que rodean al doblaje como proceso y como encargo de traducción, y las técnicas que los traductores (y/u otros agentes del proceso de doblaje) han utilizado para llegar a la versión final en español neutro. Asimismo, la tesis muestra una clara vocación polisistémica, pues confronta dos sistemas audiovisuales: el de las series extranjeras dobladas al español neutro con el de las series del mismo género producidas originariamente en español.

Por otro lado, se trata también de un estudio empírico y observacional, puesto que recopila datos y los analiza sin interferir en el proceso. Es, además, una investigación exploratoria, ya que pretende ofrecer un panorama inicial o tentativo del doblaje al español neutro de las series infantojuveniles de imagen real.

Finalmente, consideramos que era pertinente complementar el aspecto cuantitativo de esta investigación con un análisis interpretativo y cualitativo, que incluye las entrevistas realizadas a profesionales del doblaje para contrastar sus respuestas con los datos de los corpus. 


\subsection{OBJETIVOS Y PREGUNTA DE INVESTIGACIÓN}

Esta tesis surge de la necesidad de profundizar una investigación anterior (Scandura, 2015) respecto del español neutro utilizado en el doblaje de programas infantojuveniles, que presuponía la influencia de otros agentes del proceso de doblaje e incluso de agentes exógenos al proceso en sí, como los gobiernos, en las estrategias y técnicas de traducción utilizadas por los traductores. Dicha influencia se plasmaba en estandarización, omisiones y hasta en censura.

Debido a que desde la realización de la investigación anterior hasta ahora ha habido cambios políticos y sociales significativos, y un uso cada vez más masivo del sistema de VOD en detrimento de los canales de televisión por aire o por cable, resultaba necesario profundizar dicha investigación estudiando dos aspectos primordiales, que dan lugar a nuestras preguntas de investigación, a saber: ¿cuáles son los rasgos léxicos del español neutro que se usa en el doblaje en Latinoamérica? ¿Y en qué medida la influencia de los distintos agentes involucrados en el proceso industrial del doblaje incide en las elecciones léxicas de dicho español neutro? La utilización de un corpus compuesto por programas infantojuveniles que se pueden ver mediante el sistema de VOD y que ofrecen el mismo doblaje que los canales por aire o por cable, además de otro corpus que comparara dichos hallazgos con el español de los programas infantojuveniles latinoamericanos, junto con las entrevistas a los agentes del proceso, nos ayuda a tratar de dar respuesta a estas dos preguntas de la manera más representativa posible.

La tesis tiene como objetivo principal analizar las características del español neutro que se utiliza en el doblaje de series de televisión de imagen real (live-action) infantojuveniles que pueden verse a través del sistema de VOD (Netflix, Cablevisión On Demand, FoxPlay, HBO, Amazon, etc.) en Latinoamérica, así como el papel de los agentes que acaban conformando y decidiendo ese modelo de lengua.

Con ese fin se llevó a cabo una detallada descripción del español neutro, como objetivo principal, y se ha intentado, como objetivos específicos:

a) investigar si existe un español específico para el doblaje de programas infantojuveniles, y en particular de programas live-action, y describir los rasgos lingüísticos de este género audiovisual, en especial, el nivel léxico de dicho español neutro (junto con algunos apuntes tentativos del nivel fonológico);

b) demostrar que el español neutro que se utiliza en el doblaje de programas para niños y jóvenes no solo es consecuencia de las estrategias utilizadas por los traductores (y de la herencia recibida), sino también de la influencia de los agentes involucrados, y determinar qué tan fuerte es dicha influencia sobre las estrategias traductoras, hasta el punto de preguntarnos si se podría hablar de censura;

c) evaluar los factores políticos, sociales, empresariales, comerciales, ideológicos, traductológicos, etc. que influyen en el proceso de doblaje, desde el encargo de traducción hasta el producto final que sale al aire. 


\subsection{METODOLOGÍA DE ANÁLISIS}

Para corroborar las hipótesis planteadas en los objetivos de esta tesis, se recurrió a un análisis descriptivo del español neutro utilizado en ese subsistema de programas para niños y adolescentes que han sido doblados, y, como medio de emisión, se escogieron las plataformas de VOD por dos motivos: en primer lugar, porque son cada vez más utilizadas, tanto que suelen superar a las mismas series transmitidas en televisión abierta o por cable ${ }^{128}$; y en segundo lugar, por su disponibilidad, ya que nos permiten analizar los programas que corresponden a algo más de una década (2006-2016) para poder estudiar si el español neutro se modificó a lo largo de esos once años. En consecuencia, se compiló un corpus compuesto por programas para niños y adolescentes que ofrecen los sistemas de VOD y que fueron doblados en estudios de los países latinoamericanos que realizan más doblajes (México, Argentina, Venezuela, Estados Unidos, Chile y Colombia), que representan a tres regiones diferentes del continente: dos están al Sur (Chile y Argentina), dos al norte de Sudamérica (Venezuela y Colombia) y dos pertenecen al Hemisferio Norte (Estados Unidos y México). Algunos países, como Perú y Paraguay, tienen una incipiente industria del doblaje, principalmente de películas y series de animación ${ }^{129}$, y Perú forma parte de doblajes colaborativos con estudios de otros países, como en el caso de The Secret Life of Pets, en el que participaron estudios y actores de México, Los Ángeles, Perú, Chile, Argentina y Venezuela. Sin embargo, el único programa de imagen real de Nickelodeon doblado en Perú (en colaboración con México y Venezuela) es Knight Squad, pero fue doblado en 2018 y por lo tanto no podemos incluirlo en nuestro corpus.

El siguiente mapa muestra los países del continente americano que realizan la gran mayoría de los doblajes al español neutro:

\footnotetext{
${ }^{128}$ Esta es una de las razones por las que Disney lanzará en 2019 Disney+, una plataforma de SVOD. // "Los niños de hoy ya no quieren ver televisión", El Tiempo, Colombia, 23 de junio de 2018, https://www.eltiempo.com/cultura/cine-y-tv/ninos-prefieren-ver-programas-en-internet-quetelevision-tradicional-234920 (consultado el 12 de abril de 2019)

${ }^{129}$ Se puede ver un ejemplo del doblaje paraguayo de una película animada en https://doblaje.fandom.com/es/wiki/El_pr\%C3\%ADncipe_encantador
} 


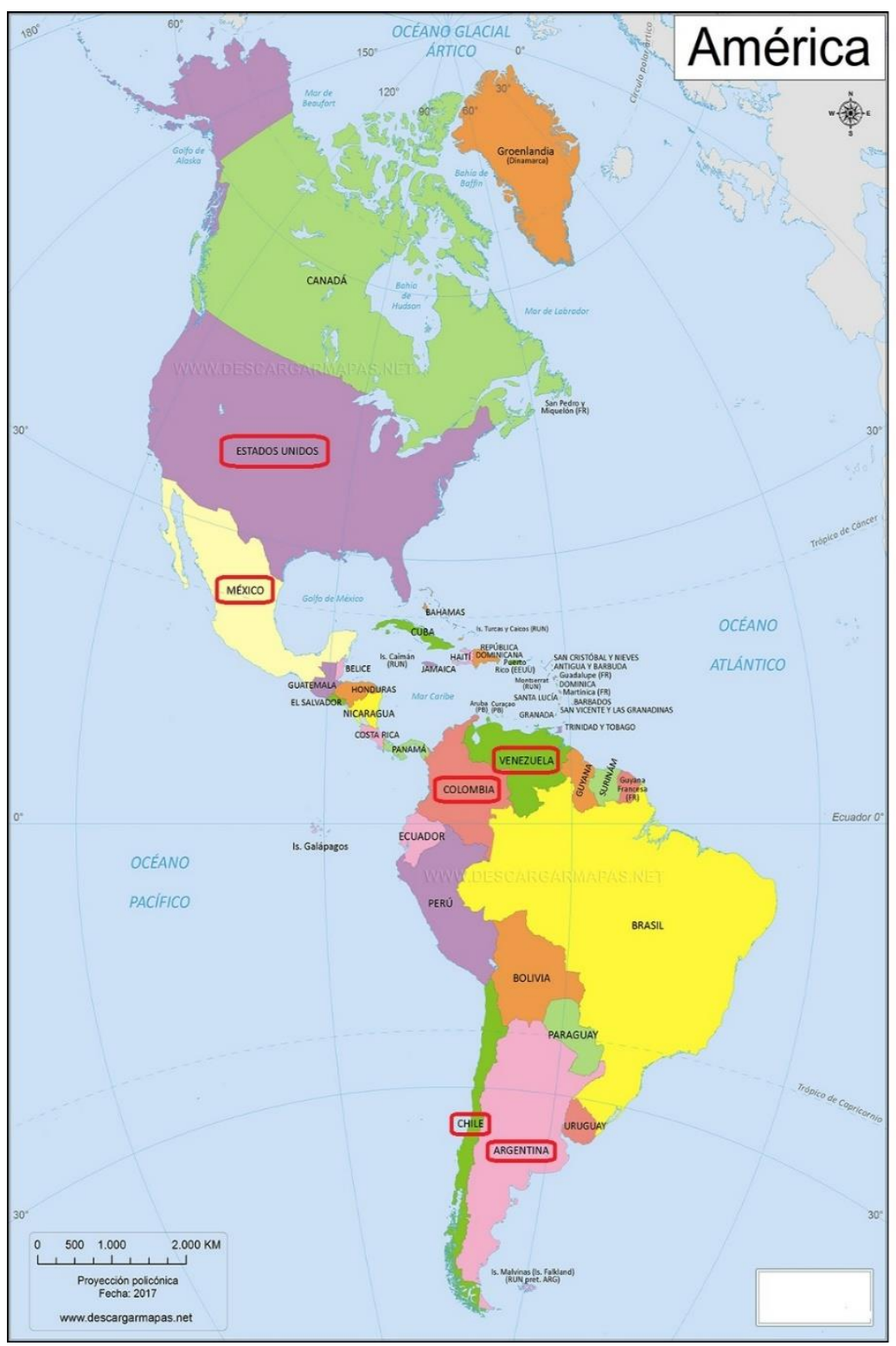

Ilustración 31 - Países con estudios de doblaje que en la actualidad doblan al español neutro la mayoría de los productos audiovisuales

Para el análisis lingüístico del modelo de lengua de las traducciones para el doblaje (dubbese), Chaume (2004) propone un marco analítico basado en la detección y enunciación de las normas microtextuales que conforman la lengua del doblaje, estructurado en los cuatro niveles tradicionales del lenguaje (prosodia, morfología, sintaxis y lexis) y compara el discurso oral real, el escrito y el dubbese. Un detallado análisis posterior realizado por Marzà, Chaume, Torralba y Alemany (2005) mostró varias características del dubbese, como el uso de estructuras sintácticas sencillas y compactas y oraciones cortas, la combinación de expresiones formales e informales, y el uso de un vocabulario poco variado pero creativo y adaptable al contexto comunicativo. Sin embargo, también reconoció una fuerte tendencia hacia la estandarización linguiística. 
A pesar de que nos basamos en este modelo de análisis, se decidió dejar de lado el nivel morfosintáctico porque en el doblaje muchas veces se elige una estructura sintáctica en particular para simplificar el texto o en pos de la sincronía labial. Conde (2011), por ejemplo, sostiene que en el doblaje muchas veces se conserva la sintaxis inglesa, y explica que "los sintagmas ingleses se organizan de lo particular a lo general, exactamente al revés que el castellano, que formula la realidad de lo general a lo particular", lo que da lugar a estructuras como "Greenfield Hermanos" (por Greenfield Brothers). Otro rasgo que Conde reconoce como común en la sintaxis del doblaje es el abuso de adjetivos posesivos, y comenta que "los niños ya hablan así: 'Mira mi espalda', le dice mi hija a mi mujer cuando algo le molesta en esa zona del cuerpo" (vid. Capítulo 7). Conde opina que estos mimetismos suelen colarse "por los intersticios de la mala traducción". No obstante, lo más probable es que se cuelen para conservar la sincronía labial, y ese es el motivo por el cual se descartó el análisis de la sintaxis, ya que no creemos que los factores que se deseaba estudiar (estandarización, políticas lingüísticas, censura) estuvieran relacionados con la sintaxis en particular sino más bien con el léxico. Sí se realizó, en cambio, desde el plano fonológico, un sucinto análisis del acento neutro utilizado por los actores de doblaje, para confirmar si incorporaban pronunciaciones típicas de alguna región o no. Y obviamente se analizó el nivel léxico, el de mayor importancia en esta tesis. Arias corrobora en su blog este concepto de que los rasgos más significativos del español neutro son el léxico y el fonológico: "El neutro es una convención, tanto el acento utilizado como los términos elegidos. Una convención más, como tantas otras que existen en el cine”. Una convención, según el mismo Arias, determinada por las preferencias del público y del cliente.

En cuanto al léxico, se creó un corpus paralelo (TO en inglés y TM en español neutro) compuesto por ciertos términos (en contexto) elegidos según criterios específicos, como el trabajo profesional de un traductor. Se utilizaron las palabras y expresiones que durante el año 2016 habían resultado problemáticas para la traducción para doblaje del inglés al español neutro realizada por la autora (una temporada completa de cuatro series infantojuveniles) y que habían llevado a consultas con los supervisores y/o correctores, y otros términos similares, correspondientes a las mismas categorías de palabras. En general, la palabra o expresión había resultado problemática por la ausencia del término o del concepto en español, porque el concepto recibe distintos nombres en las diferentes regiones de América, por la informalidad del término o por tratarse de una referencia cultural o religiosa. También se incluyeron las expresiones que podían resultar vulgares o conflictivas para los niños, y las expresiones tabú (Allan y Burridge, 2006) mencionadas anteriormente: palabras y frases relacionadas con partes del cuerpo y funciones corporales; enfermedades, muerte, agresión y asesinatos; personas, objetos y lugares sagrados; preparación y consumo de ciertos alimentos, y obscenidades (vid. Capítulo 4).

Asimismo, se creó un corpus comparable con expresiones y pronunciaciones extraídas de programas que se producen directamente en español, para poder contrastar los contenidos que se crean en español latinoamericano con los que se doblan a esa misma variedad en lo que respecta al grado de regionalismo de los mismos. 
Finalmente, se triangularon los datos recogidos en el corpus con las respuestas a encuestas realizadas a directores de doblaje, traductores y actores de doblaje, para contrastar los datos cuantitativos extraídos del análisis del corpus con los datos cualitativos extraídos de las entrevistas con los agentes del proceso.

En cuanto al análisis del corpus, por un lado, se distinguió entre expresiones del español neutro y vocablos más regionales, y por otro utilizamos las normas de la fase de traducción y la lista de técnicas de traducción aplicadas al doblaje y la subtitulación que proponen Martí Ferriol (2010), basándose en la taxonomía de Hurtado Albir (2001), mencionadas anteriormente, y Molina y Hurtado Albir (2002) (vid. Capítulo 3).

Para esta tesis hemos elegido las normas y técnicas que resultan más relevantes para los objetivos de esta investigación. Analizamos el corpus en busca de casos de traducción literal, omisión, calco y préstamo (extranjerización), generalización, explicitación y eufemización (en este caso, incluida en las técnicas de modulación y variación).

\subsubsection{FASES DE LA INVESTIGACIÓN}

La primera fase de esta investigación consistió en la revisión teórica de los temas necesarios para abordar esta tesis. En primer lugar, la traducción audiovisual en general y el doblaje en particular (Capítulo 1), y el español neutro (Capítulo 2). También realizamos una revisión de las normas y técnicas de traducción en busca de las más adecuadas para cumplir con los objetivos que nos propusimos, es decir, las que pueden revelar la influencia de las políticas lingüísticas y actitudes de censura ideológica o linguiística (Capítulos 3 y 4). De ese modo sería posible analizar la influencia de los agentes involucrados en el proceso de doblaje (y también los exógenos, como los gobiernos) en las decisiones tomadas por el traductor o impuestas sobre su trabajo.

La segunda fase de la investigación consistió en la compilación de un catálogo de series para niños y adolescentes, procedentes de países anglófonos o habladas en inglés en su versión original, que fueron dobladas al español neutro y emitidas originalmente en canales de cable o aire entre 2006 y 2016, y que están disponibles en plataformas de VOD. Luego se filtró dicho catálogo según otros criterios pertinentes para incluir la mayor cantidad de variables posible (país de origen de la serie, país donde se realizó el doblaje, temática de los programas, distintos estudios de un mismo país, episodios de distintas temporadas, doblaje colaborativo, series originales de una plataforma de VOD) y se seleccionó un total de 25 episodios de nueve series. La finalidad de dicha compilación fue realizar un estudio sincrónico y analizar las similitudes o diferencias del español neutro utilizado en sus doblajes para intentar corroborar las hipótesis planteadas en los objetivos de esta tesis (Capítulo 6).

También se elaboró un corpus comparable, más pequeño, compuesto por un episodio de tres series grabadas en español directamente para toda Latinoamérica, transmitidas por 
los mismos canales de cable que fueron objetos de estudio y con un elenco que incluye a actores de distintos países latinoamericanos, e incluso europeos (España e Italia). Dicho corpus describe las características fonológicas, gramaticales y léxicas de dichos programas, divididas en neutras y regionales.

La tercera fase de la investigación consistió en realizar una serie de entrevistas a profesionales que participan del proceso de doblaje (traductores, directores de doblaje, dobladores), procedentes de Argentina, México y Venezuela, cuyas respuestas podrían corroborar (o refutar) lo planteado en las hipótesis de esta tesis y los datos obtenidos en el análisis de los textos audiovisuales seleccionados. Consideramos que la mejor metodología para asegurarnos de llegar a conclusiones válidas era triangular la información, es decir, cruzar los datos de tres fuentes distintas: las aportaciones académicas sobre español neutro y el modelo de lengua del doblaje, los datos empíricos del análisis y las entrevistas con los agentes.

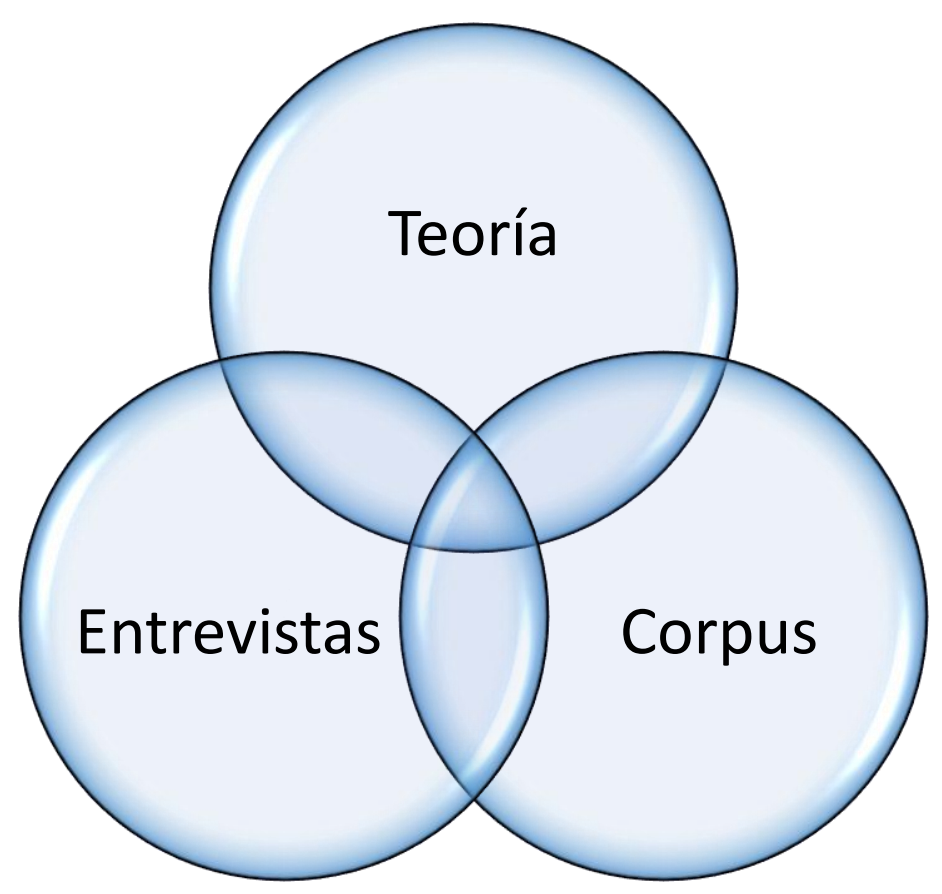

Ilustración 32 - Fuentes de los datos utilizados en esta tesis 
En cuanto a las fichas de análisis para estudiar cada ejemplo, están constituidas por los siguientes campos:

\begin{tabular}{|c|c|c|c|c|}
\hline TÉRMINO & CONTEXTO & TRADUCCIÓN & TÉCNICA & $\begin{array}{c}\text { VARIEDAD DEL } \\
\text { ESPAÑOL }\end{array}$ \\
\hline $\begin{array}{c}\text { Término conflictivo } \\
\text { (susceptible de } \\
\text { censura según la } \\
\text { clasificación } \\
\text { propuesta) }\end{array}$ & $\begin{array}{c}\text { Sintagma u } \\
\text { oración en la } \\
\text { que aparece el } \\
\text { término }\end{array}$ & $\begin{array}{c}\text { Traducción } \\
\text { ofrecida por las } \\
\text { plataformas } \\
\text { analizadas }\end{array}$ & $\begin{array}{c}\text { Se utilizó la taxonomía } \\
\text { de las técnicas de } \\
\text { traducción propuesta } \\
\text { en el Capítulo 3 }\end{array}$ & Regional o neutro \\
\hline
\end{tabular}

Ilustración 33 - Ficha de análisis

Finalmente, para el análisis microtextual se ha procedido como se ilustra en la figura siguiente:

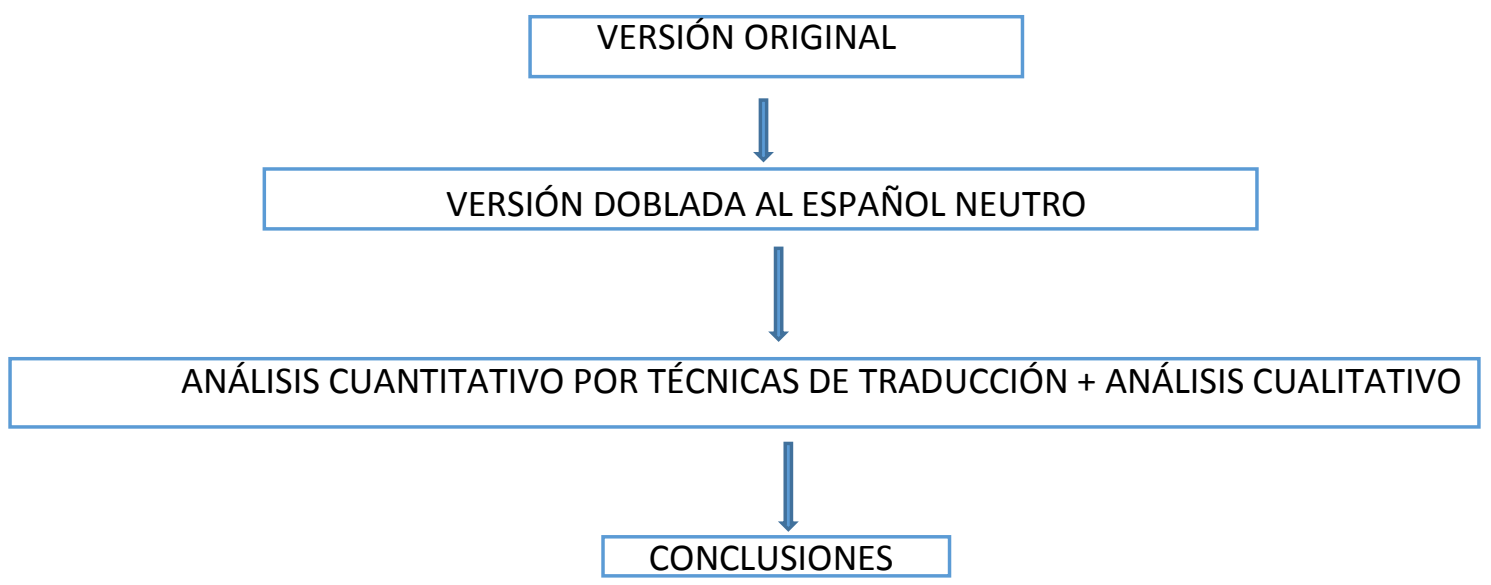

Ilustración 34 - Metodología de análisis: Comparación de las versiones 
En resumen, las fases de la investigación fueron las siguientes:

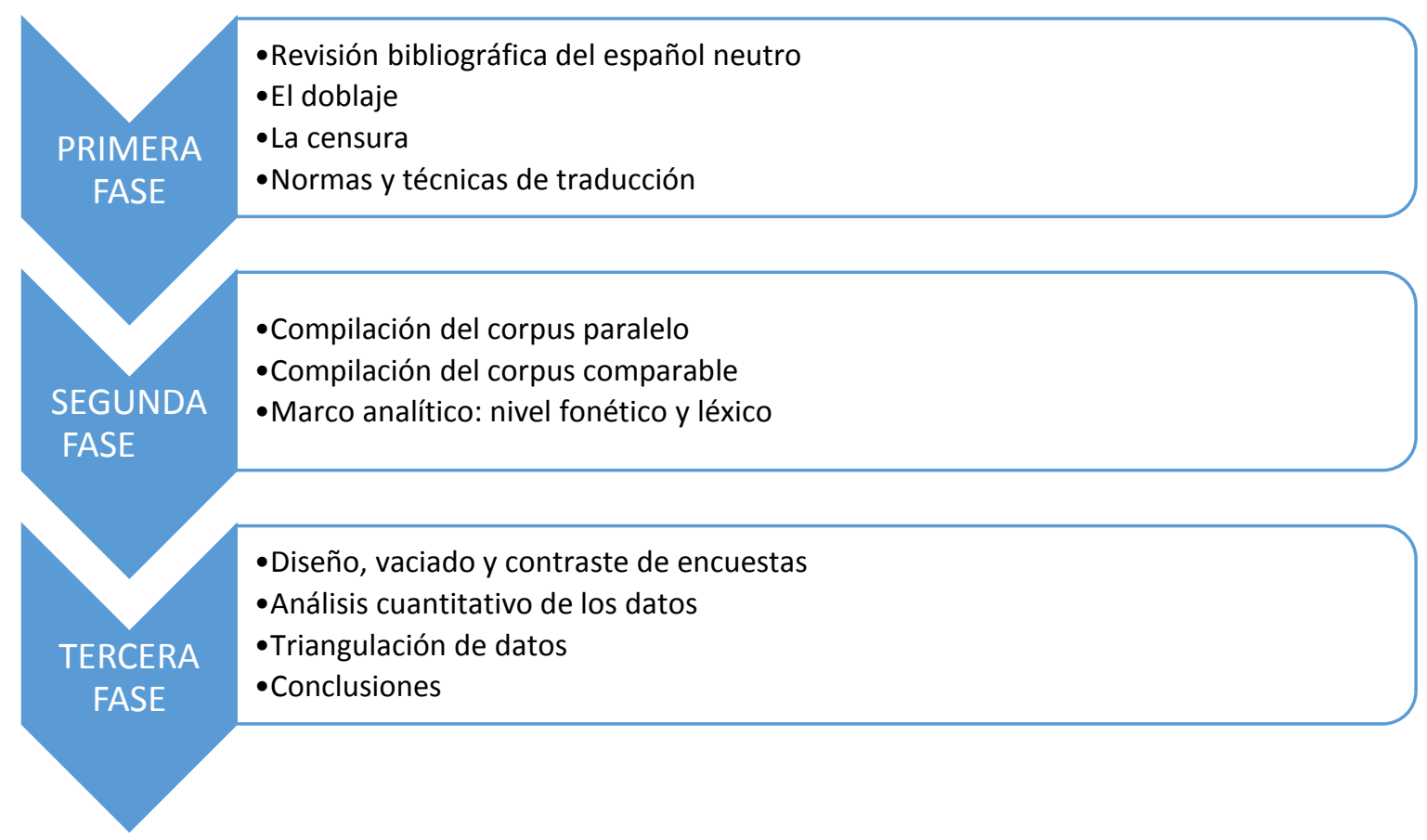

Ilustración 35 - Fases de la investigación

\subsection{CRITERIOS PARA LA COMPILACIÓN DEL CORPUS}

Con el propósito de estudiar un corpus que fuera representativo para poder extraer conclusiones válidas, se decidió trabajar con material disponible en las plataformas de VOD, dado que, como hemos comentado, la transmisión de programas por este medio no solo ha avanzado a pasos agigantados en la última década, sino que ofrece una amplísima disponibilidad de material audiovisual de distintos orígenes y con diferentes modalidades de traducción. Eso nos permitiría no solo confeccionar un corpus paralelo inglés-español sino también uno comparable para contrastar el español neutro del doblaje con el que se utiliza en los programas grabados originalmente en español latinoamericano y disponibles en todo el continente a través de plataformas de VOD.

Decidimos estudiar los once años transcurridos entre 2006 y 2016 porque queríamos averiguar si había habido cambios en el neutro debido a que en ese tiempo no solo hubo grandes avances tecnológicos y proliferaron las plataformas de VOD, sino que la situación política y social en Latinoamérica (y en gran parte del mundo) se fue modificando considerablemente. Resultaba importante averiguar si dichos cambios habían influido en las prácticas de doblaje de algún modo, como a través de la censura, la estandarización, las políticas lingüísticas, etc. 
Por otro lado, también era necesario analizar la influencia del enorme crecimiento de empresas como Netflix, con el consiguiente y significativo incremento en la cantidad y el origen de los contenidos y, por lo tanto, en la necesidad de presentar dichos productos doblados. Eso implicaba, además, la posibilidad de incluir en el corpus programas originarios de distintos países y doblados en diferentes países.

Aquí es necesario detenernos para analizar un término que las empresas de esta industria suelen utilizar y que resultaba poco práctico a la hora de realizar esta tesis. Las empresas suelen asignar las traducciones según lo que ellos denominan "territorios". No hablan de países. Si bien esto sería adecuado, ya que el habla no cambia automáticamente con las fronteras políticas, y que dentro de un mismo país puede haber regiones donde se hablen distintas variedades de español, para las empresas, el "territorio" del español neutro es toda Latinoamérica (más Estados Unidos y Canadá). Eso implica una simplificación poco real. A pesar de que se utiliza el español neutro como una especie de "lengua franca" para los hispanohablantes de América, cada región difiere de las demás, tanto lingüística como política y socialmente (vid. Capítulo 2).

Para el análisis desarrollado en esta tesis se decidió dividir el "territorio del español neutro" en los diferentes países porque, aunque se trata de una división arbitraria que no suele tenerse en cuenta en la industria audiovisual, se puede suponer que existen diferencias entre los estudios de los distintos países, e incluso entre estudios del mismo país, por ejemplo:

a) estudios de países con una larga tradición de doblaje, principalmente México, y su voluntad de diferenciarse de los países que recién se incorporan a la industria o cuya experiencia es menor; ${ }^{130}$

b) estudios que dependen (o no) de alguna empresa audiovisual, canal o plataforma importante (como los partners de Netflix ${ }^{131}$, que tienen distintas categorías);

c) estudios que son más pequeños pero que se encargan de los productos que terceriza (en formato partnership) alguna empresa de doblaje multinacional, y

d) estudios que surgieron recientemente por la enorme demanda provocada por el crecimiento exponencial del doblaje a raíz de la mayor creación de contenidos por parte de las empresas de SVOD (video a la carta por suscripción), que necesitan comercializar dichos contenidos en todo el mundo en distintos idiomas; estos estudios se caracterizan por su falta de experiencia en comparación con los que llevan varias décadas en la industria.

\footnotetext{
130 "El doblaje abaratado quita a México terreno", El Heraldo de México, 14 de enero de 2019, (https://heraldodemexico.com.mx/escena/el-doblaje-abaratado-quita-a-mexico-terreno/, consultado el 15 de enero de 2019)

${ }^{131}$ https://np3.netflixstudios.com/dubbing
} 
Aunque todos estos tipos de estudios de doblaje pretenden utilizar el español neutro, resulta lógico suponer que, dada la inexistencia de una autoridad en español neutro como lo es la RAE, por ejemplo, respecto del español en general, deben existir diferencias lingüísticas en sus productos. Por lo tanto, teniendo en cuenta estas circunstancias, el corpus se delimitó según los siguientes criterios:

1. Todos los programas analizados, series de ficción de imagen real para público infantil y juvenil, debían haber sido transmitidos y doblados originalmente entre 2006 y 2016, y debían estar disponibles en alguna plataforma de VOD.

2. Debían ser programas de los canales más populares entre los niños y jóvenes: Disney Channel y XD, Nickelodeon, Discovery Kids y Boomerang ${ }^{132}$. La popularidad se basó en la medición de rating de los canales de cable donde se habían transmitido originalmente. También se incluyeron dos series originales de Netflix. Todas las series seleccionadas se encontraban en la sección "Niños" de las plataformas de streaming utilizadas para la investigación.

3. Se tuvo en cuenta que las series provinieran de distintos países de habla inglesa (o que fueran habladas en inglés originalmente), y que incluyeran tanto programas para niños más pequeños como para adolescentes. Se eligió material original en inglés porque una gran parte de los programas infantojuveniles no animados provienen de países de habla inglesa (Estados Unidos, Canadá, Reino Unido y Australia).

4. Se intentó que las series cubrieran distintas temáticas. Lost and Found Music Studios y Big Time Rush se centran en la música; Lab Rats, Project MC2, The Odd Squad y iCarly giran en torno a la tecnología; Jessie es la típica historia de una familia con niñera; $\mathrm{Hi}-5$ es una serie para niños más pequeños, cuyo propósito es enseñar (algo que comparte con The Odd Squad, que hace hincapié en las matemáticas), y Lazytown, también para niños de menor edad, busca transmitir la importancia de una vida saludable a través del ejercicio y de los alimentos naturales. Todas las series tenían protagonistas femeninos y masculinos. ${ }^{133}$

5. Los doblajes debían haber sido realizados por estudios de los principales países que en la actualidad producen doblajes al español neutro. En los casos en los que había más de un estudio en un país, se incluyeron por lo menos dos para una mayor representatividad y para poder cotejar si había similitudes o no entre estudios del

\footnotetext{
${ }^{132}$ A pesar de que Boomerang no tiene tanto rating como los otros canales, se incluyó un programa de dicho canal porque se trataba de una serie de imagen real para público de menor edad, que es una categoría con menos ejemplos porque los programas para niños más pequeños suelen ser de dibujos animados. (www.boomerangla.com)

${ }^{133}$ Con excepción de Project MC2, donde las protagonistas principales son mujeres, pero la temática es para ambos sexos.
} 
mismo país. Se intentó elegir estudios con diferente nivel de experiencia en la industria.

6. Se incluyeron también programas que habían sido doblados por más de un estudio (del mismo país o de otro), otra vez en busca de similitudes o diferencias en las elecciones lingüísticas de los distintos estudios, y también uno con doblaje colaborativo (pero traducción de un solo país, Venezuela).

7. Finalmente, se eligieron también episodios de distintas temporadas del mismo programa para verificar si existían diferencias entre los doblajes, aunque el traductor hubiera sido el mismo, lo que indicaría una clara intervención de algún otro agente en el proceso (empresa, gobierno, etc.).

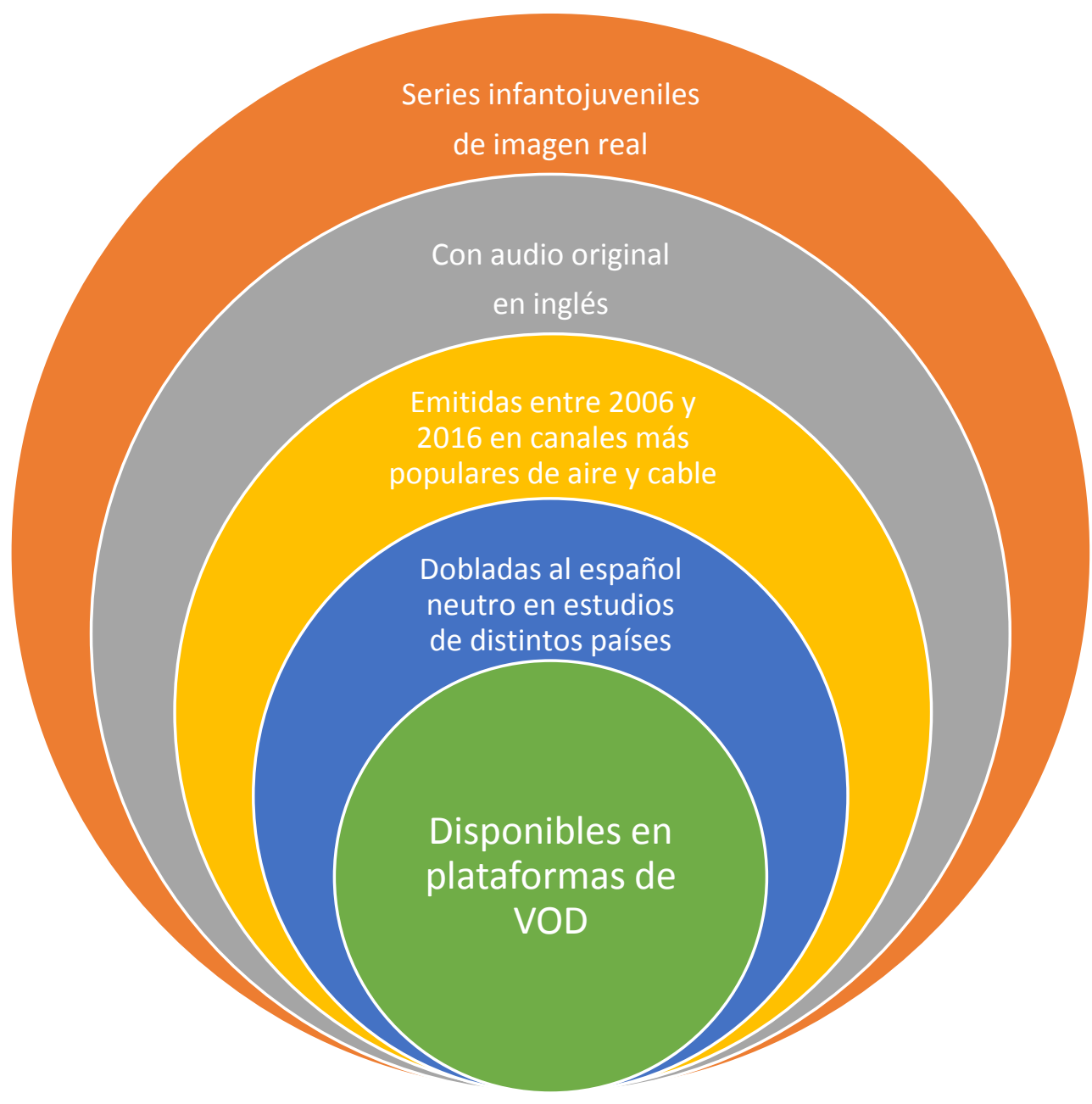

Ilustración 36 - Criterios de selección del corpus paralelo 
En total se analizaron 25 textos, correspondientes a las nueve series siguientes:

\begin{tabular}{|c|c|c|c|c|c|c|}
\hline SERIE & $\begin{array}{l}\text { EMISIÓN } \\
\text { ORIGINAL }\end{array}$ & $\begin{array}{l}\text { GRABA- } \\
\text { CIÓN }\end{array}$ & $\begin{array}{l}\text { PAÍS DE } \\
\text { ORIGEN }\end{array}$ & $\begin{array}{l}\text { PAÍS DE } \\
\text { DOBLAJE }\end{array}$ & $\begin{array}{c}\text { ESTUDIO } \\
\text { DE DOBLAJE }\end{array}$ & TRADUCTOR \\
\hline $\begin{array}{c}\text { Lost and } \\
\text { Found Music } \\
\text { Studios (Frank } \\
\text { van Keeken) } \\
\end{array}$ & Netflix & $\begin{array}{l}2015- \\
2017\end{array}$ & Canadá & Argentina & $\begin{array}{c}\text { Polaco Audio } \\
\text { Studio }\end{array}$ & $\begin{array}{l}\text { Agostina } \\
\text { Sueldo }\end{array}$ \\
\hline $\begin{array}{c}\text { Jessie } \\
\text { (Pamela Eells, } \\
\text { Phil Baker, } \\
\text { Drew Vaupen) }\end{array}$ & $\begin{array}{l}\text { Disney } \\
\text { Channel }\end{array}$ & $\begin{array}{c}2011- \\
2015\end{array}$ & EE.UU. & Argentina & Media Pro & $\begin{array}{l}\text { Sandra } \\
\text { Brizuela }\end{array}$ \\
\hline $\begin{array}{l}\text { Odd Squad / } \\
\text { El escuadrón } \\
\text { de lo increíble } \\
\text { (Timothy } \\
\text { McKeon, } \\
\text { Adam } \\
\text { Peltzman) }\end{array}$ & $\begin{array}{l}\text { Discovery } \\
\text { Kids }\end{array}$ & $\begin{array}{c}2014 \text { - } \\
\text { presente }\end{array}$ & Canadá & Colombia & $\begin{array}{c}\text { Centauro } \\
\text { (BTI Studios) }\end{array}$ & $N / D$ \\
\hline $\begin{array}{c}\text { Hi-5 } \\
\text { (Jonathan } \\
\text { Geraghty) }\end{array}$ & $\begin{array}{l}\text { Discovery } \\
\text { Kids }\end{array}$ & 2009 -- & Australia & Chile & $\begin{array}{l}\text { DINT - Doblajes } \\
\text { Internacionales }\end{array}$ & N/D \\
\hline $\begin{array}{l}\text { Lazytown } \\
\text { (Magnus } \\
\text { Scheving) }\end{array}$ & Boomerang & $\begin{array}{l}2006- \\
2014\end{array}$ & Islandia & $\begin{array}{l}\text { EE.UU. } \\
\text { (Miami) }\end{array}$ & The Kitchen & N/D \\
\hline $\begin{array}{l}\text { Project MC2 } \\
\text { (Jordana } \\
\text { Arkin) }\end{array}$ & Netflix & $\begin{array}{c}2015- \\
2017\end{array}$ & EE.UU. & México & $\begin{array}{l}\text { Dubbing House } \\
\text { (temp. 1) } \\
\text { SDI Media de } \\
\text { México } \\
\text { (temp. 2) }\end{array}$ & $\begin{array}{l}\text { Francisco } \\
\text { Rocha } \\
\text { Francisco } \\
\text { Tinoco }\end{array}$ \\
\hline $\begin{array}{c}\text { Lab Rats } \\
\text { (Bryan Moore, } \\
\text { Chris } \\
\text { Peterson) }\end{array}$ & Disney XD & $\begin{array}{l}2012- \\
2016\end{array}$ & EE.UU. & México & $\begin{array}{l}\text { Producciones } \\
\text { Grande } \\
\text { (temp. 1) } \\
\text { Diseño en Audio } \\
\text { (temp. 2-4) }\end{array}$ & $\begin{array}{l}\text { Carolina } \\
\text { Fierro }\end{array}$ \\
\hline $\begin{array}{c}\text { iCarly } \\
\text { (Dan } \\
\text { Schneider) }\end{array}$ & Nickelodeon & $\begin{array}{l}2007- \\
2013\end{array}$ & EE.UU. & México & $\begin{array}{l}\text { Art Sound } \\
\text { México }\end{array}$ & $\begin{array}{l}\text { Eduardo } \\
\text { Garza }\end{array}$ \\
\hline $\begin{array}{l}\text { Big Time Rush } \\
\text { (Scott } \\
\text { Fellows) }\end{array}$ & Nickelodeon & $\begin{array}{c}2009- \\
2013\end{array}$ & EE.UU. & Venezuela & $\begin{array}{l}\text { Etcétera Group } \\
\text { (doblaje } \\
\text { colaborativo } \\
\text { con México) }\end{array}$ & $N / D$ \\
\hline
\end{tabular}




\begin{tabular}{|c|c|c|c|}
\hline SERIE & $\begin{array}{c}\text { CANTIDAD DE EPISODIOS } \\
\text { ANALIZADOS }\end{array}$ & AÑO DE EMISIÓN & $\begin{array}{l}\text { DURACIÓN } \\
\text { PROMEDIO }\end{array}$ \\
\hline $\mathrm{Hi}-5$ & 3 & 2009, 2010, 2010 & 20 minutos \\
\hline Jessie & 3 & 2011, 2014, 2014 & 20 minutos \\
\hline Lazytown & 3 & 2006, 2006, 2014 & 20 minutos \\
\hline The Odd Squad & 3 & 2014, 2014, 2015 & 20 minutos \\
\hline Lab Rats & 3 & 2012, 2015, 2016 & 20 minutos \\
\hline iCarly & 3 & 2007, 2010, 2012 & 20 minutos \\
\hline Big Time Rush & 3 & 2009, 2009, 2011 & 20 minutos \\
\hline Project MC2 & 2 & 2015, 2016 & 30 minutos \\
\hline $\begin{array}{l}\text { Lost and Found Music } \\
\text { Studios }\end{array}$ & 2 & 2016, 2016 & 30 minutos \\
\hline
\end{tabular}

Tabla 16 - Detalle de los 25 episodios que componen el corpus paralelo

El corpus comparable está compuesto por un episodio de tres series de distintos canales, todas grabadas directamente en español para su transmisión en toda Latinoamérica:

\begin{tabular}{|c|c|c|}
\hline PROGRAMA & CANAL DE TRANSMISIÓN & INICIO DE TRANSMISIÓN \\
\hline Violetta & Disney Channel & 2012 \\
\hline Yo soy Franky & Nickelodeon & 2015 \\
\hline O11CE & Disney XD & 2017 \\
\hline
\end{tabular}

Tabla 17 - Composición del corpus comparable 
La información para la selección se obtuvo del sitio Doblaje Wiki (www.doblaje.wikia.com):
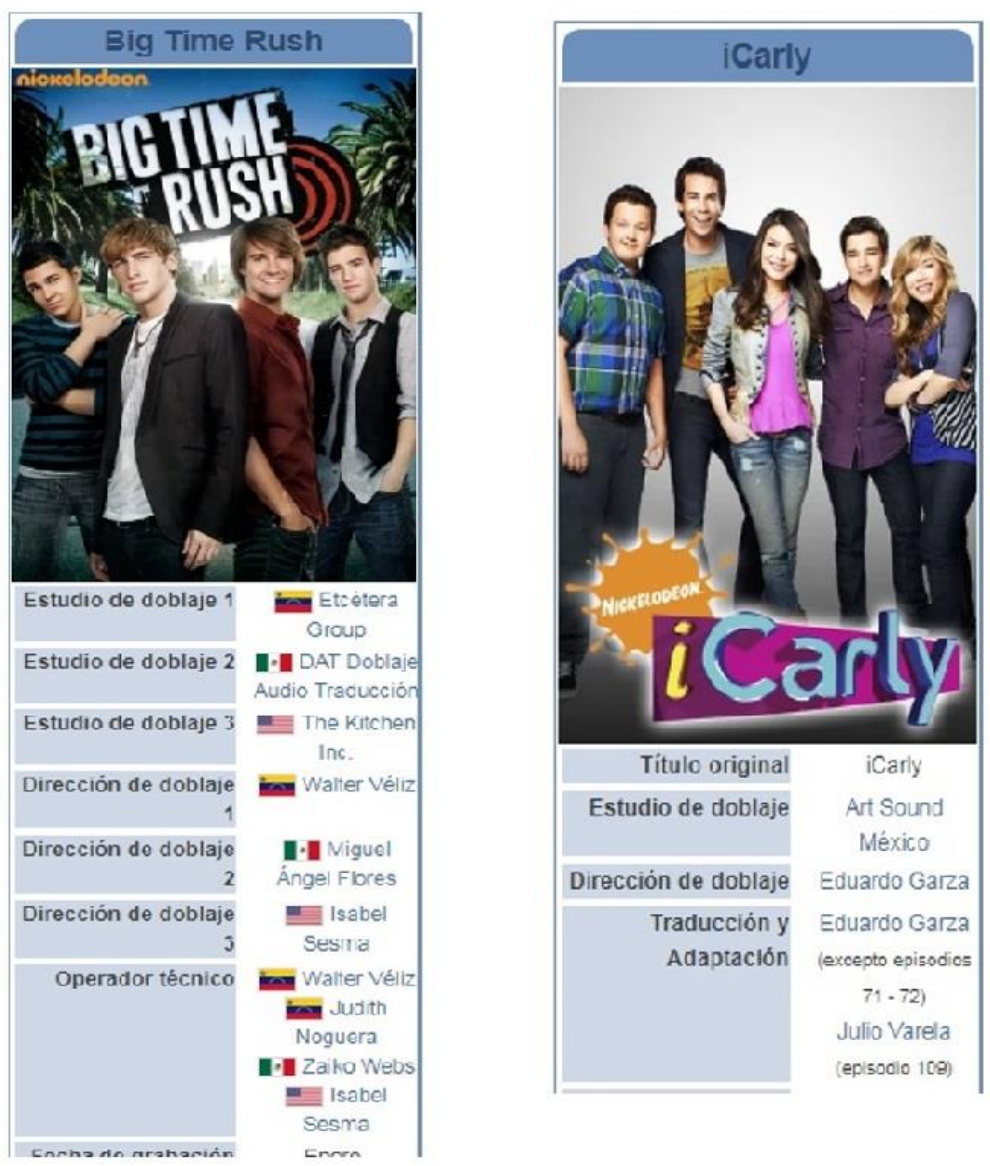

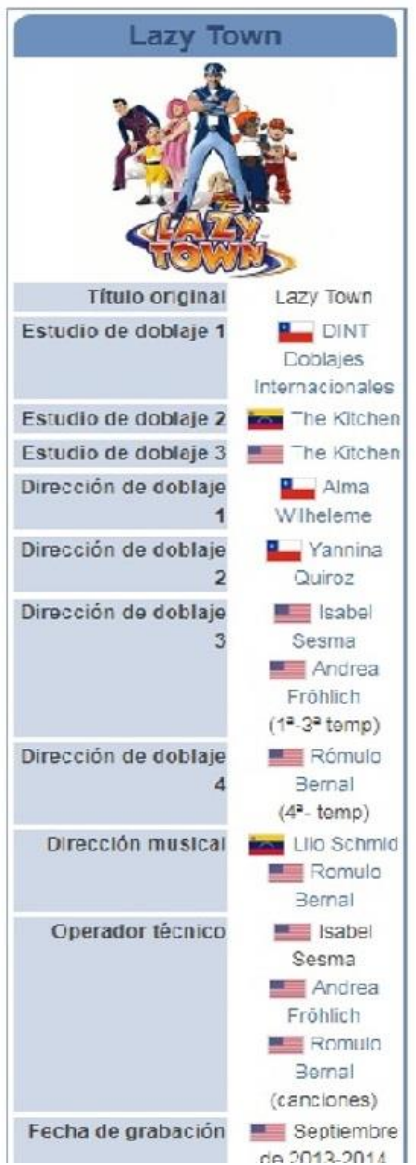

Ilustración 37 - Capturas de pantalla del sitio Doblaje Wiki (www.doblaje.wikia.com)

Por tanto, en esta tesis trabajaremos con 25 textos en versión original y sus correspondientes 25 versiones dobladas al español y 3 textos de producción propia como banco de pruebas con el que comparar el español neutro del doblaje (53 textos). 


\section{CAPÍTULO 6.}

\section{ANÁLISIS DE LAS ENTREVISTAS \\ Y DE LOS CORPUS PARALELO Y COMPARABLE}

\subsection{LAS ENTREVISTAS}

El doblaje es un campo "en el que siempre ha habido mucho secretismo profesional" (Cerezo Merchán et al., 2015). Resulta muy difícil lograr hablar con los agentes involucrados en el proceso de doblaje y obtener respuestas a preguntas básicas para comprender qué tanto influye cada uno de los participantes de ese proceso en las decisiones y elecciones lingüísticas. Por eso, era de sumo interés contar con datos cualitativos que ellos pudieran proporcionar. A tal fin, se enviaron cuestionarios a traductores, directores y dobladores que trabajan en doblaje para el público infantojuvenil, para intentar descubrir qué grado de influencia tenía cada agente del proceso de doblaje en su trabajo. De un total de 11 encuestados de Argentina, Venezuela y México, 7 respondieron el cuestionario (una tasa relativamente alta, teniendo en cuenta el alto grado de secretismo). Tres de ellos trabajaron o trabajan también para clientes de varios países latinoamericanos (incluido Brasil) y del resto del mundo (Israel, Estados Unidos, Reino Unido) y 5 lo hacen para distintos estudios. De los 11 encuestados, 7 hombres y 4 mujeres, respondieron 6 hombres y una mujer ${ }^{134}$.

Las preguntas se elaboraron teniendo en cuenta los resultados de la investigación llevada a cabo por la autora en su Trabajo de Fin de Máster (Scandura, 2015) y su experiencia profesional personal.

Las respuestas a las preguntas fueron muy similares, y en algunos casos el encuestado se explayó dando ejemplos concretos.

El cuestionario se encuentra en el Anexo 3. En él se invitaba a los agentes mencionados a responder -en forma anónima- las siguientes preguntas:

\footnotetext{
${ }^{134} \mathrm{Si}$ bien mencionamos el género de los entrevistados, las respuestas de todos los encuestados fueron similares, y por lo tanto no creemos pertinente marcar una diferencia de género. Sin embargo, la diferencia entre hombres y mujeres dispuestos a responder las preguntas, incluso en forma anónima, podría ser objeto de futuros estudios, dado que, como hemos mencionado, la industria del doblaje se ha movido hasta el momento en un secretismo muy particular. Sería interesante estudiar también si con la nueva apertura a las redes sociales, tanto de los profesionales como de las empresas mismas, la situación se modifica.
} 
Pregunta número 1: ¿Sus clientes tienen una lista de palabras que usted no puede usar en el doblaje?

Casi todos se refirieron a palabras que no se pueden usar por ser consideradas regionalismos, aunque ninguno de ellos disponía de una guía formal que seguir respecto de esto, sino que simplemente se trata de palabras o expresiones que fueron pasando "de boca en boca" (agente 7) desde que se realizan doblajes en cada país. También mencionaron palabras que podrían resultar ofensivas para algún sector (sin determinar a qué se referían por "sector") o religión (hay clientes que no les permiten usar nada relacionado con Dios o con el cristianismo, como Navidad o los santos). Entre los ejemplos mencionados figuran sustantivos como "raza" e "indio", y adjetivos como "gordo-flaco", "negro", "discapacitado", “estúpido-idiota-tonto" (agentes 1, 2, 3, 4, 6 y 7), etc.

Sin embargo, uno de los encuestados refirió que solo uno de sus clientes tenía una lista de palabras que no pueden usar, aunque no es muy extensa (agente 5).

Otro entrevistado mencionó el hecho de que hay que tener mucho cuidado respecto del término que eligen las empresas. Mencionó el ejemplo de la elección del término "cocer" (que un niño pequeño puede confundir con "coser"), en vez de buscar alguna alternativa como "cocción" (cambiando la estructura) o "cocinar" (agente 2). También se habló de la elección del "muy" en vez del "bien" ("muy buena" en vez de "bien buena"), a pesar de que "bien" es utilizado como sinónimo de "muy" en varios países (agente 7).

Una respuesta echó luz a una razón para las diferencias entre doblajes de un mismo estudio o cliente: "Las listas se manejan por programa o por película, y sobre todo se usan en series de caricaturas o películas y programas infantiles" (agente 2). Esta respuesta justifica la elección del tema de esta tesis, ya que confirma que el doblaje para programas infantojuveniles difiere de otros tipos de doblaje.

Pregunta número 2: Si tienen prohibido usar ciertas palabras, ¿son similares o varían mucho entre cliente y cliente?

Estas respuestas fueron interesantes porque, si bien algunos encuestados coincidieron en que "son similares" (agentes 1 y 5), otros sostuvieron que cada cliente "tiene su glosario", que "varía según el público" (y aquí podemos dar por sentado que se está haciendo la distinción público infantil-público adulto), que "la lista se amplía según el nivel de autocensura del cliente" y que "son listas muy arbitrarias" (agentes 1, 3, 4, 6 y 7). El uso de la palabra "arbitrarias" indica disconformidad, pero también puede verse como un indicador de la influencia ejercida por una persona que, a los ojos del profesional que utilizó dicho adjetivo, no tiene una capacidad lingüística equiparable al poder que detenta en el proceso de doblaje. También llama la atención el uso de la palabra 
"autocensura". En este caso, el entrevistado habla de la autocensura del cliente, y eso implica que él o ella no está de acuerdo, pero también existe la autocensura del traductor mismo, y sería lógico suponer que, si un traductor ejerce autocensura sobre sus traducciones para adultos, es probable que ejerza más sobre sus traducciones para niños, especialmente teniendo en cuenta que algunos programas para niños contienen cada vez más chistes y referencias que un adulto puede considerar "subidas de tono" (agente 4). A veces, por ejemplo, la autocensura ocurre por el proteccionismo que siente el traductor respecto del público principal al que va dirigido el texto: los niños. El agente 4 mencionó que una vez se rehusó a usar un término porque había habido una tragedia con un niño relacionada con el producto al que hacía referencia, pero que su supervisor le indicó que lo usara igual porque ese era el término neutro. La duda del traductor respecto de usar el término neutro se basaba en su idea de proteger al público infantil. Por supuesto que el contenido seguirá allí, es decir, en todo caso se podría acusar a quienes escriben o producen la serie original de no tener en cuenta y "cuidar" a su público, y realmente no se puede saber (y el traductor lo comentó) si el cambio de palabra puede modificar la percepción de los niños (o de los adultos que también forman parte del público) respecto del riesgo, pero sentía que era su forma de contribuir a proteger a los niños.

\section{Pregunta número 3: ¿Varían según el país de origen del cliente o entre estudios del mismo país?}

Aquí las respuestas fueron diversas, y tocaron temas significativos para este trabajo. Tres de los encuestados coincidieron en que varían entre estudios del mismo país (agentes 1, 3 y 6). Otro afirmó que cada cliente tiene su terminología y "cada estudio, su forma de doblar. Algunos priorizan la dicción y el lip sync, y otros, la actuación" (agente 3). Esta respuesta resulta de sumo interés, dado que, como afirma Chaume (2014), en España la principal prioridad es la sincronía labial o ajuste. Por otro lado, una de las respuestas dejó en claro que el concepto de "cliente" difiere según el rol que el encuestado desempeña en el proceso de doblaje. Mientras que, para los traductores y actores de doblaje, el cliente suele ser el estudio de doblaje (ya que la mayoría trabaja en forma freelance), para los directores, el cliente es la empresa que solicita el doblaje al estudio (pues los directores son empleados de los estudios). Este es un dato significativo, porque quienes forman parte del proceso de doblaje no siempre conocen el lugar de procedencia del material o del cliente.

Pregunta número 4: ¿En todos los casos son palabras relacionadas con el español neutro? ¿O también tienen que ver con cuestiones culturales? (Por ejemplo, nombres de comidas o verbos problemáticos frente a groserías o referencias muy locales o específicas)

En este caso hubo una abrumadora mayoría que opinó que los términos más conflictivos tienen que ver con lo cultural y con "insultos o cuestiones que puedan ofender a otros" 
(agentes 1, 2, 3, 4, 5, 6), pues "el neutro ya lo tenemos muy en cuenta" (agente 2). Los encuestados opinaron que no compartían el criterio de muchos clientes de evitar groserías o cuestiones religiosas, porque dependen de la "estética" del material y por lo tanto están justificadas. También se mencionaron las exigencias de Netflix, aunque sin explicitarlas ni citar ejemplos (agentes 3 y 5).

Un caso singular es el que citó uno de los encuestados respecto de "términos vedados por haberse usado demasiado, como el caso de la palabra 'genial'" (agente 7).

Y otro de los profesionales consultados comentó que, como se pide no usar regionalismos, en el caso de nombres de frutas, vegetales, cortes de carne, mariscos, etc., que cambian de país a país, es difícil crear un consenso y normalmente es el cliente quien define los términos que se van a utilizar (agente 3).

\section{Pregunta número 5: ¿Notó algún cambio con el correr de los años en este aspecto?}

Todos coincidieron en que el vocabulario que se les permite utilizar se fue flexibilizando con los años. Entre los cambios mencionados figuran la aceptación de expresiones más informales, como "tipo" en vez de "sujeto", y más regionales, como "inodoro" y "gaseosa", y de palabras que no se usaban porque en algunas regiones podían malinterpretarse, como "acá" (aunque nadie es capaz de dar la razón real para evitar este adverbio) (agentes 4 y 7). Uno de los encuestados resumió esta tendencia como el uso de "muchos términos "callejeros"” (agente 3).

A pesar de que uno de los profesionales consultados consideró que estos cambios fueron una "evolución" (agente 7), otros expresaron sus dudas al respecto, e incluso su abierto rechazo a ciertos cambios. Por ejemplo, se habló de la aceptación de términos provenientes de otros idiomas, como cool, chance u $O K$, y uno de los encuestados indicó que él prefiere evitarlos porque le parece que "esto colabora con la pérdida de identidad de nuestro idioma, que es tan rico y potente en sus expresiones" (agente 1).

También se citaron casos en los que "se retrocede algunos casilleros para después arrepentirse" (agente 2). Uno de los encuestados relató que "hace un par de años hubo una corriente de pedir 'carro' en reemplazo de 'auto' o 'automóvil', y después de unos meses hubo una contraorden y todo volvió a la normalidad" (agente 7). ${ }^{135}$ Otro ejemplo fue el cambio de "heroína" por "héroe" (agente 1). También mencionaron que algunas empresas cambiaron el uso de "tenis" por "calzado deportivo", pero que no siempre es posible generalizar de ese modo (agente 6).

Y hubo encuestados que cuestionaron a sus clientes por sus elecciones: "Hay clientes que introducen nuevas maneras de trabajar, como Netflix, que tienen requerimientos de uso

135 Énfasis de la autora. Esta expresión habla claramente del rechazo a los cambios de lo "ya establecido". 
de lenguaje muy absurdos, que tienden a empobrecer el lenguaje y la creatividad en la traducción para doblaje" (agente 3).

El concepto de "empobrecer el lenguaje y la creatividad" revela la frustración del traductor respecto de las limitaciones impuestas a su tarea, y en realidad podría provocar el desgano del profesional ante su lucha infructuosa contra criterios impuestos por el encargo de traducción que no comparte y la consiguiente reducción de la calidad en sus traducciones.

Pregunta número 6: ¿Hay diferencias en las pronunciaciones del español neutro que le piden los distintos clientes?

La mayoría de los encuestados coincidieron en que no suelen existir diferencias en las pronunciaciones del español neutro, salvo en algún que otro caso, aunque algunos clientes exigen "más naturalidad" que otros (pero sin indicar qué sería "más natural”). No obstante, una de las respuestas hizo hincapié en varios aspectos muy significativos a la hora de analizar los doblajes. En primer lugar, debemos reiterar y resaltar que lo que los trabajos académicos muchas veces analizan es el resultado de dicho proceso, lo que implica que resulta primordial estudiar la influencia de cada uno de los agentes que participan en él, así como quiénes son, qué formación tienen, etc. Por ejemplo, sería muy interesante poder acceder a las personas que trabajan en el departamento de Control de Calidad de los estudios de doblaje para tener una visión más completa de las razones en que basan sus decisiones respecto de ciertos términos, pero es casi imposible por el secretismo del que hablaba Chaume. Respecto del rol que desempeña cada agente del proceso de doblaje y su influencia, el encuestado mencionado se explayó sobre este tema:

No noto diferencias según el cliente. En todo caso, las diferencias las hacemos los directores, en su gran mayoría. En los estudios que trabajan sin directores, un operador técnico que no tiene mucha idea del español neutro y de la actuación deja al actor o actriz de doblaje la decisión de adaptar y hablar como le parezca o le salga. El resultado es que vemos una película con personajes que hablan con distintos acentos, cadencias y formas de emitir la voz. (agente 2)

Este comentario arroja luz sobre la realidad del doblaje y sobre la influencia de los distintos agentes que participan de dicho proceso. Tal vez el traductor escogió ciertos términos que le parecían adecuados, pero alguien más decidió cambiarlos, y ese "alguien más" puede ser una persona capacitada para tomar decisiones lingüísticas o no. Vale la pena aclarar nuevamente que, en Argentina, por ejemplo, no existe la figura del ajustador, y por lo tanto no puede culpabilizarse al ajustador de los cambios a la traducción, ya que es el mismo traductor quien ajusta su texto. Por otro lado, resulta obvio que la calidad de los doblajes debe necesariamente variar mucho cuando se trabaja con tanta informalidad en algunos casos. 
Volviendo a las pronunciaciones en sí, a partir de los datos de las encuestas se podría afirmar que la incidencia de la calidad del doblaje (y del estudio que lo realiza) podría estar relacionada con las diferencias en las pronunciaciones.

Pregunta número 7: ¿Diría que algún cliente ejerce algún tipo de censura sobre la traducción?

Los encuestados coincidieron en sostener vehementemente que todos los clientes censuran sus traducciones, en mayor o menor medida. Algunos explicaron que lo dejan claro en las guías de estilo, y otros, que existe mucha autocensura, a veces fundamentada en la posibilidad de "futuros conflictos judiciales" (agente 5), y prejuicios, por los que a veces se llega hasta a evitar temas, y no solo palabras. Otros hablaron de la modulación como recurso: usar "no ganar" en vez de "perder" o "no me fue bien" en vez de "me fue mal" (agente 1). Pero también indicaron que esto se debe a que el producto infantojuvenil es distinto de los demás materiales audiovisuales que se doblan. Esto resulta de suma importancia, porque los niños son mucho más vulnerables que los adultos ante ciertas situaciones, como el acoso, y los conceptos negativos pueden impresionarlos en mayor medida.

Pregunta número 8: ¿Todos los estudios tienen una guía de estilo? De tenerla, ¿hablan específicamente de temas de español neutro, o solo indican que "hay que usar un español neutro"?

Aquí las respuestas difieren. Algunos encuestados sostienen que pocos clientes tienen una guía de estilo, y que suelen contener lineamientos muy generales. Otros opinan que las guías que tienen son "muy restrictivas" y que no hablan estrictamente de español neutro sino de "qué palabras se pueden usar o no y para qué público" (agente 3). En general, las guías apuntan a "evitar que alguien pueda ofenderse" y "solo indican que hay que usar español neutro y no mucho más" (agente 5 y 6). Los encuestados citaron el caso de MTV, que ya envía los guiones traducidos, y Netflix, que corrige las traducciones de sus producciones originales porque exige "palabras específicas" (agente 3 ).

Cabe destacar la similitud de respuestas dadas por profesionales de México y de Argentina en un aspecto crucial: "los verdaderos encargados de homologar estilo y lenguaje son los directores" (agente 2). Uno de los encuestados comentó: "En mi caso, algunos hicieron comentarios y sugerencias que yo adoptaba para todas las traducciones que hacía... Hasta que llegó Netflix" (agente 3). Resulta muy interesante que varios profesionales de distintos países hablaran de la influencia de Netflix en el doblaje, porque no se les indicó que este trabajo era sobre material que se podía ver en plataformas de VOD. Netflix, como hemos señalado, es un gigante de este tipo de entretenimiento digital, y recurre a muchos estudios de doblaje del mundo, por lo que sería lógico suponer que las decisiones lingüísticas no las toma cada director en particular sino la empresa (a través 
del departamento correspondiente), para poder homogeneizar las traducciones que encarga. De hecho, Netflix utiliza más de 60 estudios de doblaje ubicados en distintas partes del mundo ${ }^{136}$. Por otro lado, Netflix también se destaca por diferenciarse de lo

habitual; por ejemplo, "hace grabaciones en grupo, algo inusual en la industria"137 (agente 3), lo que confirmaría esa "revolución" de la que habla el encuestado al decir "hasta que llegó Netflix" como un jugador de peso en la industria del doblaje.

Muchas de las respuestas a esta encuesta confirman las hipótesis de este trabajo, pero para poder validarlas por completo era necesario triangular los datos obtenidos con los procedentes del análisis del material audiovisual detallado en el Capítulo 5.

\subsection{ANÁLISIS DEL CORPUS PARALELO}

Una vez recogidos los datos del corpus, se procedió al análisis correspondiente, que arrojó resultados muy interesantes.

En primer lugar, solo figuraban en los créditos los nombres de los traductores de los doblajes realizados en Argentina y México. Eso genera un mayor reconocimiento de la labor del traductor, que no figura en las producciones de otros países. Un caso llamativo es el de la serie The Odd Squad. El estudio encargado de los doblajes a los distintos idiomas es BTI Studios. Sin embargo, como BTI terceriza algunos de estos doblajes, los créditos al final de la serie mencionan al traductor en algunos idiomas y en otros no, como en el caso del español (realizado en Colombia).

${ }^{136}$ Página oficial de Netflix, https://np3.netflixstudios.com/dubbing (consultado el 25 de noviembre de 2018)

137 Vega, W. (2018): “La odisea tecnológica de llevar Netflix a docenas de idiomas", El Tiempo, 16 de marzo de 2018, Colombia, https://www.eltiempo.com/tecnosfera/novedades-tecnologia/como-se-doblany-subtitulan-las-series-y-peliculas-de-netflix-194996 (consultado el 25 de noviembre de 2018) 


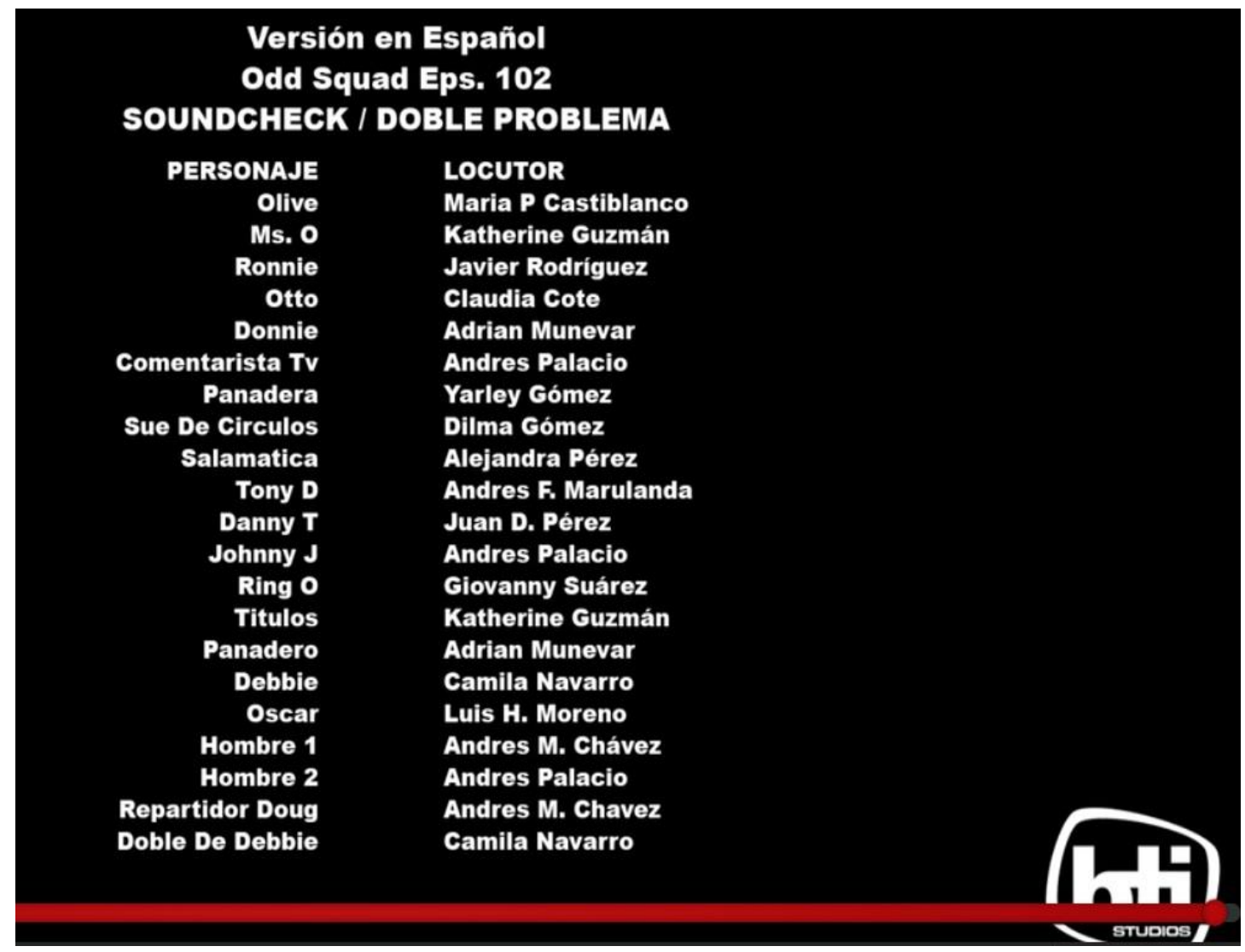

Ilustración 38 - Ficha del doblaje de la versión en español neutro de Odd Squad, de Netflix ${ }^{138}$

Por lo tanto, aquí no se trata de una política del canal o de la plataforma VOD, como queda claro también cuando comparamos las dos series de Nickelodeon: figuran los créditos solo en el doblaje mexicano (y no en el venezolano).

Los datos obtenidos en el estudio del material audiovisual se compararon por año, serie, país, estudio y canal, y según las categorías descritas en la Metodología del presente trabajo (véase Cap. 5.):

i) Nivel fonológico

ii) Nivel léxico:

- Palabras tabú u ofensivas

- Referencias culturales

138 También es extraño el uso de la palabra "locutor" para referirse a los actores de doblaje, ya que en Latinoamérica se suele llamar locutor a quien habla en off o a quien tiene una matrícula profesional para participar en publicidades. 
- Referencias religiosas

- Alimentos

- Vestimenta

- Neologismos relacionados con la tecnología

- Otros

Teniendo en cuenta los resultados de la investigación del Trabajo de Fin de Máster (Scandura, 2015) y la experiencia profesional de la autora, se eligieron los términos que habían resultado problemáticos en la traducción de una temporada completa de cuatro series (tal como se detalla en el Capítulo 5). Las clases de términos problemáticas coincidieron con las respuestas de los entrevistados: por lo general, se trataba de palabras tabú u ofensivas, conceptos culturales y religiosos, y términos relacionados con alimentos, vestimenta o tecnología (véase 6.1.).

Además, los resultados se dividieron en dos grupos: los términos que correspondían a un español neutro y los regionales. Tras analizar todas estas variables y compararlas, se detectaron los patrones que figuran a continuación.

\subsubsection{NIVEL FONOLÓGICO}

La pronunciación detectada en las distintas series era prácticamente neutra en su totalidad. No es posible detectar el origen del doblaje con solo escucharlo, a pesar de que sí se detectaron algunas diferencias muy leves tanto en pronunciación como en acentuación. En algunos casos se registró una pronunciación distinta de la $\mathrm{J}$ (/h/ aspirada versus /x/ velar), y también se comprobó que en algunas series se utilizaba la acentuación normal para préstamos naturalizados relacionados con el deporte (fútbol, básquetbol) mientras que en otras se usaba una acentuación regional (futból, basquetból), es decir, un desplazamiento acentual.

\begin{tabular}{|c|c|c|}
\hline $\begin{array}{c}\text { Básquetbol (The Odd Squad, } \\
\text { Colombia, 2014) }\end{array}$ & $\begin{array}{c}\text { *Basquetból (Jessie, Argentina, } \\
\text { 2014) }\end{array}$ & $\begin{array}{c}\text { Baloncesto (Lab Rats, } \\
\text { México, 2012) }\end{array}$ \\
\hline $\begin{array}{c}\text { Fútbol (Project MC2, México, } \\
\text { 2016) }\end{array}$ & $\begin{array}{c}\text { *Futból (Big Time Rush, } \\
\text { Venezuela, 2011) }\end{array}$ & \\
\hline Béisbol (Lazytown, Chile, 2014) & & \\
\hline
\end{tabular}


También se registró una diferencia en la pronunciación de la U de la palabra "Rush" en Big Time Rush. Esto seguramente se debe a que se trata de un doblaje colaborativo: los personajes principales son doblados por actores de Venezuela y de México, y en el caso de esta U del inglés, en México se utiliza el sonido /o/ en vez de /a/. ${ }^{139}$

No se presentó ninguna instancia de intercambio o adición de vocales o consonantes, monoptongaciones, pérdida de la $\mathrm{D}$ final o intervocálica, aspiración de la $\mathrm{S}$ final, lambdacismo o rotacismo. Por el contrario, cada fonema se pronuncia claramente, y se exageran los hiatos y diptongos. Sí es común a todos los doblajes analizados el seseo, el betacismo y el yeísmo con rehilamiento $(/ / 3 /)$ de la LL y la Y.

No se registran casos de acento rioplatense (derivado del napolitano) en los doblajes argentinos, ni pronunciaciones o acentos típicos de otras regiones (la combinación $\mathrm{CH}$ pronunciada / $/$ / de Chile o el acento mexicano, por ejemplo ${ }^{140}$ ).

\subsubsection{NIVEL LÉXICO}

\subsubsection{Español neutro frente a español regional}

Uno de los análisis realizados fue la categorización de las traducciones halladas en el material estudiado en términos de español neutro o de español regional. A medida que fuimos analizando el material, comenzaron a surgir algunos vocablos que claramente no eran neutros sino más locales, propios de alguna región en particular. Por ejemplo, si hubiese aparecido la palabra "pirulín", o "chupetín", como traducción de lollipop, sabríamos que muy posiblemente se tratara de una traducción rioplatense. Si, en cambio, la traducción era "paleta", se podría decir que se trata de una traducción neutra, pues es la que suele oírse en los doblajes desde hace décadas, a pesar de que en general se la asocia con la variedad mexicana, por lo cual también se la podría calificar de regional. Veamos tres ejemplos que ilustran bien esta diferencia, sustancial para nuestro análisis:

\footnotetext{
${ }^{139} Y$ aunque no se registró en ningún caso en el corpus, también es común que, según el canal, en los doblajes se escuche tanto "doble V" como "doble U" para nombrar a la letra W.

140 Sin embargo, en el congreso Media for All 8, realizado en Estocolmo en junio de 2019, algunos profesionales latinoamericanos de países como Puerto Rico y Colombia comentaron que ellos podían darse cuenta de si el doblaje había sido realizado en Argentina o en México porque en ambos casos es posible detectar un leve acento que revela el origen del doblaje. Corroborar o descartar dicho punto de vista requiere de una investigación mucho más exhaustiva del nivel fonológico del doblaje al español neutro que la realizada para esta tesis.
} 


\begin{tabular}{|c|c|c|c|c|}
\hline TÉRMINO & CONTEXTO & TRADUCCIÓN & TÉCNICA & ESPAÑOL \\
\hline Rope & $\begin{array}{l}\text { Focus the } \\
\text { light on the } \\
\text { rope }\end{array}$ & $\begin{array}{l}\text { Enfoca la luz } \\
\text { sobre la cuerda }\end{array}$ & Traducción literal & $\begin{array}{l}\text { Neutro } \\
\text { (regional: } \\
\text { soga) }\end{array}$ \\
\hline Cake & $\begin{array}{l}\text { I do need } \\
\text { cake for my } \\
\text { party }\end{array}$ & $\begin{array}{l}\text { Yo necesito una } \\
\text { torta para mi } \\
\text { fiesta }\end{array}$ & Traducción literal & $\begin{array}{l}\text { Regional } \\
\text { (neutro: } \\
\text { pastel) }\end{array}$ \\
\hline Pacifier & $\begin{array}{l}\text {...l used a } \\
\text { scorpion as } \\
\text { a pacifier }\end{array}$ & $\begin{array}{l}\text {...usaba un } \\
\text { escorpión como } \\
\text { chupete }\end{array}$ & Traducción literal & $\begin{array}{l}\text { Regional } \\
\text { (neutro: } \\
\text { chupón) }\end{array}$ \\
\hline
\end{tabular}

Tabla 19 - Muestra de traducciones regionales y neutras

En el primer caso, rope se ha traducido por "cuerda", que es el término considerado neutro; si se hubiera utilizado "soga", se trataría de un término más regional. Por el contrario, en el caso del uso de "torta" como traducción de cake, "pastel" habría sido el término neutro; sin embargo, quien realizó la traducción para el estudio colombiano se inclinó por el vocablo que se utiliza en ese país y en otros, como Argentina, a pesar de que no se lo considera neutro (puesto que, por ejemplo, "torta" es un tipo de sándwich en México). El tercer ejemplo es el más interesante. Durante más de 20 años ${ }^{141}$, la palabra pacifier se tradujo como "chupón", ya que según la tradición de los estudios de doblaje, ese era el término neutro ${ }^{142}$. Pero hace unos pocos años, en algunos estudios de Argentina (país del que proviene el ejemplo) se comenzó a utilizar la palabra "chupete", como en España, (seguramente porque alguien descubrió que "chupón" tiene connotaciones muy negativas en varios países, como Argentina o México). Sin embargo, sigue siendo mucho más común encontrar la palabra "chupón" en los doblajes que no son argentinos, y por lo tanto lo catalogamos como regionalismo.

Si comparamos las cifras de regionalismos y traducciones neutras veremos que, a pesar de tratarse de un corpus que en teoría debería contener solo términos neutros, se registró una significativa cantidad de regionalismos $(25,40 \%)$. Las siguientes tablas son el resumen cuantitativo de los ejemplos en español neutro y en los distintos españoles americanos presentes en el corpus:

\footnotetext{
${ }^{141}$ Experiencia profesional de la autora

${ }^{142}$ Es la palabra que se utiliza principalmente en Venezuela, Perú y Bolivia.
} 


\begin{tabular}{|l|c|c|c|c|c|c|}
\hline \multirow{2}{*}{ ESTUDIO } & \multicolumn{2}{|c|}{ ESPAÑOL NEUTRO } & \multicolumn{2}{c|}{$\begin{array}{c}\text { ESPAÑOL } \\
\text { REGIONAL }\end{array}$} & \multirow{2}{*}{} \\
\cline { 2 - 6 } & CANTIDAD & $\%$ & CANTIDAD & $\%$ & TOTAL & \multirow{2}{*}{ OMISIONES } \\
\hline Argentina 1 & 6 & $60 \%$ & 4 & $40 \%$ & 10 & \\
\hline Argentina 2 & 47 & $84 \%$ & 9 & $16 \%$ & 56 & 9 \\
\hline Colombia & 20 & $69 \%$ & 9 & $31 \%$ & 29 & \\
\hline Chile & 20 & $71 \%$ & 8 & $29 \%$ & 28 & 2 \\
\hline $\begin{array}{l}\text { EE.UU. } \\
\text { (Miami) }\end{array}$ & 18 & $75 \%$ & 6 & $25 \%$ & 24 & \\
\hline México 1 & 13 & $87 \%$ & 2 & $13 \%$ & 15 & \\
\hline México 2 & 10 & $55 \%$ & 8 & $45 \%$ & 18 & \\
\hline México 3 & 9 & $82 \%$ & 2 & $18 \%$ & 11 & \\
\hline México 4 & 8 & $100 \%$ & & - & 8 & \\
\hline México 5 & 32 & $74 \%$ & 11 & $26 \%$ & 43 & 1 \\
\hline Venezuela & 14 & $74 \%$ & 8 & $36 \%$ & 22 & 1 \\
\hline
\end{tabular}

\begin{tabular}{|c|c|c|}
\hline ESPAÑOL NEUTRO & TOTAL: 197 & $\mathbf{7 4 , 6 0 \%}$ \\
\hline ESPAÑOL REGIONAL & TOTAL: 67 & $\mathbf{2 5 , 4 0 \%}$ \\
\hline
\end{tabular}

Tabla 20 - Uso de español neutro y regional según los estudios

Para la comparación entre estudios, hemos analizado los porcentajes por separado. En los casos de comparaciones entre series, hemos tomado ambos estudios como un todo cuando los dos habían doblado una sola serie. Se escogieron series con más de un estudio para poder evaluar si las técnicas utilizadas eran diferentes, lo que podría suponer que no todos los estudios son igual de estrictos respecto del español neutro utilizado por el traductor o traductora. 


\begin{tabular}{|c|c|c|c|c|c|c|}
\hline \multirow[b]{2}{*}{ PROGRAMA } & \multicolumn{2}{|c|}{ ESPAÑOL NEUTRO } & \multicolumn{2}{|c|}{ ESPAÑOL REGIONAL } & \multirow[b]{2}{*}{ TOTAL } & \multirow[b]{2}{*}{ OMISIONES } \\
\hline & CANTIDAD & $\%$ & CANTIDAD & $\%$ & & \\
\hline Lost and Found Music Studios & 6 & $60 \%$ & 4 & $40 \%$ & 10 & \\
\hline Jessie & 47 & $84 \%$ & 9 & $16 \%$ & 56 & 9 \\
\hline Odd Squad & 20 & $69 \%$ & 9 & $31 \%$ & 29 & \\
\hline $\mathrm{Hi}-5$ & 20 & $71 \%$ & 8 & $29 \%$ & 28 & 3 \\
\hline Lazytown & 18 & $75 \%$ & 6 & $25 \%$ & 24 & \\
\hline Project MC2 & 23 & $70 \%$ & 10 & $30 \%$ & 33 & \\
\hline Lab Rats & 17 & $89 \%$ & 2 & $11 \%$ & 19 & \\
\hline iCarly & 32 & $74 \%$ & 11 & $26 \%$ & 43 & 1 \\
\hline Big Time Rush & 14 & $64 \%$ & 8 & $36 \%$ & 22 & 1 \\
\hline TOTAL & 197 & $74.6 \%$ & 67 & $25.4 \%$ & & \\
\hline
\end{tabular}

Tabla 21 - Uso de español neutro y regional según las series

Entre los ejemplos de regionalismos hallados en el corpus podemos mencionar $^{143}$ :

\begin{tabular}{|c|c|c|c|c|}
\hline \multirow{2}{*}{ REGIONALISMO } & $\begin{array}{c}\text { TÉRMINO } \\
\text { NEUTRO }\end{array}$ & SERIE & ESTUDIO & A NO \\
\hline Botar & Arrojar & The Odd Squad & Colombia & 2015 \\
\hline Pasabocas & Bocadillo & The Odd Squad & Colombia & 2014 \\
\hline Balde & Cubeta & Hi-5 & Chile & 2010 \\
\hline Torta & Pastel & The Odd Squad & Colombia & 2014 \\
\hline Aparcar & Estacionar & Hi-5 & Chile & 2010 \\
\hline Bubis & Senos ${ }^{144}$ & iCarly & México 5 & 2007 \\
& & & & 2012 \\
\hline Patatas & Papas & Lost and Found & Argentina 1 & 2016 \\
\hline Receso & Recreo & Lazytown & EE.UU. & 2014 \\
\hline
\end{tabular}

Tabla 22 - Ejemplos de regionalismos hallados en el corpus

\footnotetext{
143 Para un análisis detallado, ver Anexo 1.

${ }^{144}$ Cabe destacar que, a pesar de que se considera que esta palabra es neutra, en general se la intenta evitar por tratarse de un vocablo demasiado formal.
} 
Es interesante resaltar que las distintas temporadas de un mismo programa dobladas en distintos estudios pueden tener un porcentaje significativamente diferente de regionalismos, como se ve en los estudios de México que doblaron la misma serie (55\% frente al $87 \%$, por ejemplo). Eso podría indicar que los estudios en cuestión no son igual de estrictos en el uso del español neutro.

Resulta llamativo que los programas que tienen una mayor proporción de términos neutros en comparación con los términos regionales son los programas de Disney (Jessie y Lab Rats), con un promedio de $86,50 \%$ de español neutro y un $13,50 \%$ de español regional, aunque fueron doblados en distintos países (Argentina y México). Las demás series tienen proporciones más similares, todas entre el $60 \%$ y el $75 \%$ de neutro, incluso las dobladas en estos mismos países, pero en otros estudios. De todos modos, los dos extremos de ese rango tienen una considerable diferencia. Por otro lado, la traducción argentina realizada en un estudio más pequeño y no tan conocido tiene una proporción de $60 \%$ de neutro frente al $40 \%$ de regional, dato que resulta sugerente comparado con el doblaje argentino para Disney Channel ( $84 \%$ y $16 \%$ respectivamente). Recordemos que los dos doblajes de Disney, a pesar de tener una proporción neutro-regional similar, fueron realizados en países diferentes: Argentina y México. Este dato resulta interesante por dos razones. En primer lugar, porque sugiere que esos porcentajes pueden tener que ver con políticas lingüísticas del canal (a su vez debidas al alto grado de exposición al que se ve sometido por la importancia de la empresa a la que pertenece); $y$, en segundo lugar, por lo que sostiene Sonderéguer: que el español de Argentina tiene similitudes con el de México. Si consideramos que el español mexicano es la base del español neutro, se podría afirmar que el argentino se acerca más al neutro que los demás por este motivo. Tampoco se puede dejar de mencionar que, dado que los argentinos son muy conscientes de que su habla es la que más difiere de la norma hispánica, es probable que los traductores argentinos pongan un mayor énfasis en utilizar términos que les parezcan neutros.

También hay que resaltar el caso de México, donde el porcentaje de español neutro utilizado varía significativamente entre el $55 \%$ y el $100 \%$. Es posible que las mismas razones entren en juego: que los estudios o los traductores mexicanos consideren que el neutro se basa en su variedad y que por lo tanto no necesitan buscar otros términos que sean comprensibles para el resto de Latinoamérica. También podría haber influido en esta desproporción el hecho de que el 55\% corresponde a la serie de Netflix, que, como hemos visto, parece dar más libertad a sus traductores y directores respecto del español neutro a utilizar.

Otra cuestión primordial es que los programas y doblajes de Disney (por ser esta una de las empresas más reconocidas del mundo y por representar, para muchos, al "imperio" 
estadounidense) reciben más críticas que los de otros canales. ${ }^{145}$ Por lo tanto, es común leer comentarios sobre la dedicación que ponen quienes realizan los doblajes de productos Disney y el cuidado de la empresa para que el doblaje resulte lo más neutro posible. Alejandro Nogueras, que era responsable de los doblajes de Disney en España, dictó una conferencia en $2012^{146}$ donde confirmó que:

Disney es una empresa que cuida bastante sus productos y siempre busca la excelencia y transmitir la sensación de magia, por lo que sus doblajes son especiales. [...] El doblaje es enviado al responsable, que analiza el producto terminado y pide las correcciones pertinentes.

Se cuidan rigurosamente los diálogos y las canciones, ajustándolos a los movimientos de la boca y asesorando al estudio original en cuestiones que pueden resultar incómodas para el país receptor, como en Cars 2, que algunos personajes tuvieron que ser alterados pues podían resultar ofensivos para el público francés.

Zabalbeascoa (2000: 27) hace un comentario similar:

Disney "es famosa por el cuidado y las ganas que pone en el proceso y el control de calidad de los doblajes de sus películas, y suele imponer una serie de condiciones que deberían conducir a un producto de doblaje bastante o muy satisfactorio". (Zabalbeascoa, 2000: 27)

Disney no es la única en recibir críticas. Las plataformas como Netflix o Amazon también están recibiendo críticas, tanto por sus doblajes y subtitulados al español neutro como por sus doblajes al español peninsular, ${ }^{147}$ como el famoso caso del "sicansíos" en el doblaje de Game of Thrones (David Benioff y D.B. Weiss, 2011-2019), y dada la influencia que actualmente tiene el público en la industria audiovisual, ponen gran empeño en superarlas. Aun así, la proporción neutro-regional sigue siendo muy despareja.

${ }^{145}$ Abbott, M. (2017): “Stop Blaming Disney for Your Insatiable Appetite for Entertainment", The Christian Post, 12 de agosto de 2017 (https://www.christianpost.com/news/stop-blaming-disney-for-yourinsatiable-appetite-for-entertainment-195186/, consultado el 2 de julio de 2018); “Algunos españoles se quejan del doblaje en español latinoamericano de Coco, 29 de noviembre de 2017 (https://www.radioformula.com.mx/notas.asp?ldn=722942\&idFC=2017, consultado el 29 de agosto de 2018); Míguez, M. (2011): "La larga 'lista negra' de Disney”, El Mundo, 12 de noviembre de 2011, http://www.elmundo.es/elmundo/2011/11/11/cultura/1321031223.html (consultado el 29 de agosto de 2018); "Doblaje de Enredados", 26 de noviembre de 2010, https://salvemosdisneymexico.blogspot.com/2010/11/doblaje-de-enredados.html (consultado el 29 de agosto de 2018)

146 http://www.bandasonoraonline.com/news/news bso/?p=419 (consultado el 23 de septiembre de 2016)

147 García, A. (2017): “Huelga de dobladores: lista de series paralizadas sin doblaje en español” (https://www.adslzone.net/2017/04/17/huelga-de-dobladores-lista-de-series-paralizadas-sindoblaje-en-espanol/, consultado el 29 de agosto de 2018) 


\subsubsection{Comparación por técnica de traducción}

Se compararon los resultados por país, canal, estudio y programa para las técnicas de traducción utilizadas para los tipos de términos mencionados anteriormente. Estos son los resultados más llamativos por su disparidad: ${ }^{148}$

i. $\quad$ Traducción literal

La traducción literal estaba presente en proporciones muy dispares en el material analizado (80\% frente a 21,54\%). A continuación figuran ejemplos extraídos del corpus y la cantidad de casos encontrados. ${ }^{149}$ La categoría traducción literal se aplica únicamente al término seleccionado:

\section{PAÍS DE DOBLAJE: CHILE}

CASOS: 11

PROGRAMA: HI-5

TEMPORADA 11 - EPISODIO 26 "Christmas"

AÑO: 2010

\begin{tabular}{|c|c|c|c|c|}
\hline TÉRMINO & CONTEXTO & TRADUCCIÓN & TÉCNICA & ESPAÑOL \\
\hline Drive & $\begin{array}{c}\text { One of us can drive } \\
\text { the sleigh }\end{array}$ & $\begin{array}{c}\text { Alguien podría manejar } \\
\text { el trineo }\end{array}$ & $\begin{array}{c}\text { Traducción } \\
\text { literal }\end{array}$ & Regional \\
\hline
\end{tabular}

${ }^{148}$ No figuran en este apartado los resultados más homogéneos; los datos completos pueden encontrarse en el Anexo 1.

149 Todos los ejemplos pueden consultarse en el Anexo 1. 


\begin{tabular}{|c|c|c|c|c|}
\hline \multicolumn{5}{|c|}{ PAÍS DE DOBLAJE: ARGENTINA } \\
\hline \multicolumn{5}{|l|}{ CASOS: 22} \\
\hline \multicolumn{5}{|c|}{ PROGRAMA: JESSIE } \\
\hline \multicolumn{5}{|c|}{ TEMPORADA 3 - EPISODIOS 26 Y 27 “Jessie’s Aloha-Holidays with Parker and Joey” } \\
\hline \multicolumn{5}{|l|}{ ANO: 2014} \\
\hline TÉRMINO & CONTEXTO & TRADUCCIÓN & TÉCNICA & ESPAÑOL \\
\hline Dumb & $\begin{array}{c}\text { They are too dumb } \\
\text { to live. }\end{array}$ & $\begin{array}{c}\text { Son muy torpes para } \\
\text { vivir. }\end{array}$ & $\begin{array}{c}\text { Traducción } \\
\text { literal }\end{array}$ & Neutro \\
\hline
\end{tabular}

\begin{tabular}{|l|}
\hline PAÍS DE DOBLAJE: ESTADOS UNIDOS \\
\hline CASOS: 17 \\
\hline
\end{tabular}

\begin{tabular}{|l|}
\hline PROGRAMA: LAZYTOWN \\
\hline TEMPORADA 2 - EPISODIO 1 "Rockin Robbie" \\
\hline AÑO: 2006 \\
\hline
\end{tabular}

\begin{tabular}{|c|c|c|c|c|}
\hline TÉRMINO & CONTEXTO & TRADUCCIÓN & TÉCNICA & ESPAÑOL \\
\hline \multirow{2}{*}{ Cool } & $\begin{array}{c}\text { Johnny B. Bad was } \\
\text { the coolest } \\
\text { musician in the } \\
\text { world! }\end{array}$ & $\begin{array}{c}\text { iJohnny C. Malo fue el } \\
\text { músico más fabuloso } \\
\text { del mundo! }\end{array}$ & $\begin{array}{c}\text { Traducción } \\
\text { literal }\end{array}$ & Neutro \\
\hline
\end{tabular}

\begin{tabular}{|c|c|c|c|c|}
\hline \multicolumn{5}{|c|}{ PAÍS DE DOBLAJE: COLOMBIA } \\
\hline \multicolumn{5}{|l|}{ CASOS: 14} \\
\hline \multicolumn{5}{|c|}{ PROGRAMA: THE ODD SQUAD } \\
\hline \multicolumn{5}{|c|}{ TEMPORADA 1 - EPISODIO 1 "Zero Effect - Bad Luck Bears” } \\
\hline \multicolumn{5}{|l|}{ ANO: 2014} \\
\hline TÉRMINO & CONTEXTO & TRADUCCIÓN & TÉCNICA & ESPAÑOL \\
\hline Gum & $\begin{array}{l}\text {...the giant ball of } \\
\text { gum... }\end{array}$ & $\begin{array}{l}\text {...la bola gigante de } \\
\text { goma de mascar... }\end{array}$ & $\begin{array}{c}\text { Traducción } \\
\text { literal }\end{array}$ & Neutro \\
\hline
\end{tabular}




\begin{tabular}{|l|}
\hline PAÍS DE DOBLAJE: MÉXICO \\
\hline CASOS: 53 \\
\hline PROGRAMA: iCARLY \\
\hline TEMPORADA 1 - EPISODIO 1 "iPilot" \\
\hline AÑO: 2007 \\
\hline
\end{tabular}

\begin{tabular}{|c|c|c|c|c|}
\hline TÉRMINO & CONTEXTO & TRADUCCIÓN & TÉCNICA & ESPAÑOL \\
\hline Doof & $\begin{array}{c}\text { You invited the } \\
\text { doof }\end{array}$ & Invitaste al tonto & $\begin{array}{c}\text { Traducción } \\
\text { literal }\end{array}$ & Neutro \\
\hline
\end{tabular}

\section{PAÍ́S DE DOBLAJE: VENEZUELA}

CASOS: 10

PROGRAMA: BIG TIME RUSH

TEMPORADA 1 - EPISODIOS 1 y 2 "Big Time Audition"

AÑO: 2009

\begin{tabular}{|c|c|c|c|c|}
\hline TÉRMINO & CONTEXTO & TRADUCCIÓN & TÉCNICA & ESPAÑOL \\
\hline Butt & $\begin{array}{c}\text { The CEO of all of } \\
\text { our butts }\end{array}$ & $\begin{array}{c}\text { El presidente de todos } \\
\text { nuestros traseros }\end{array}$ & $\begin{array}{c}\text { Traducción } \\
\text { literal }\end{array}$ & Neutro \\
\hline
\end{tabular}




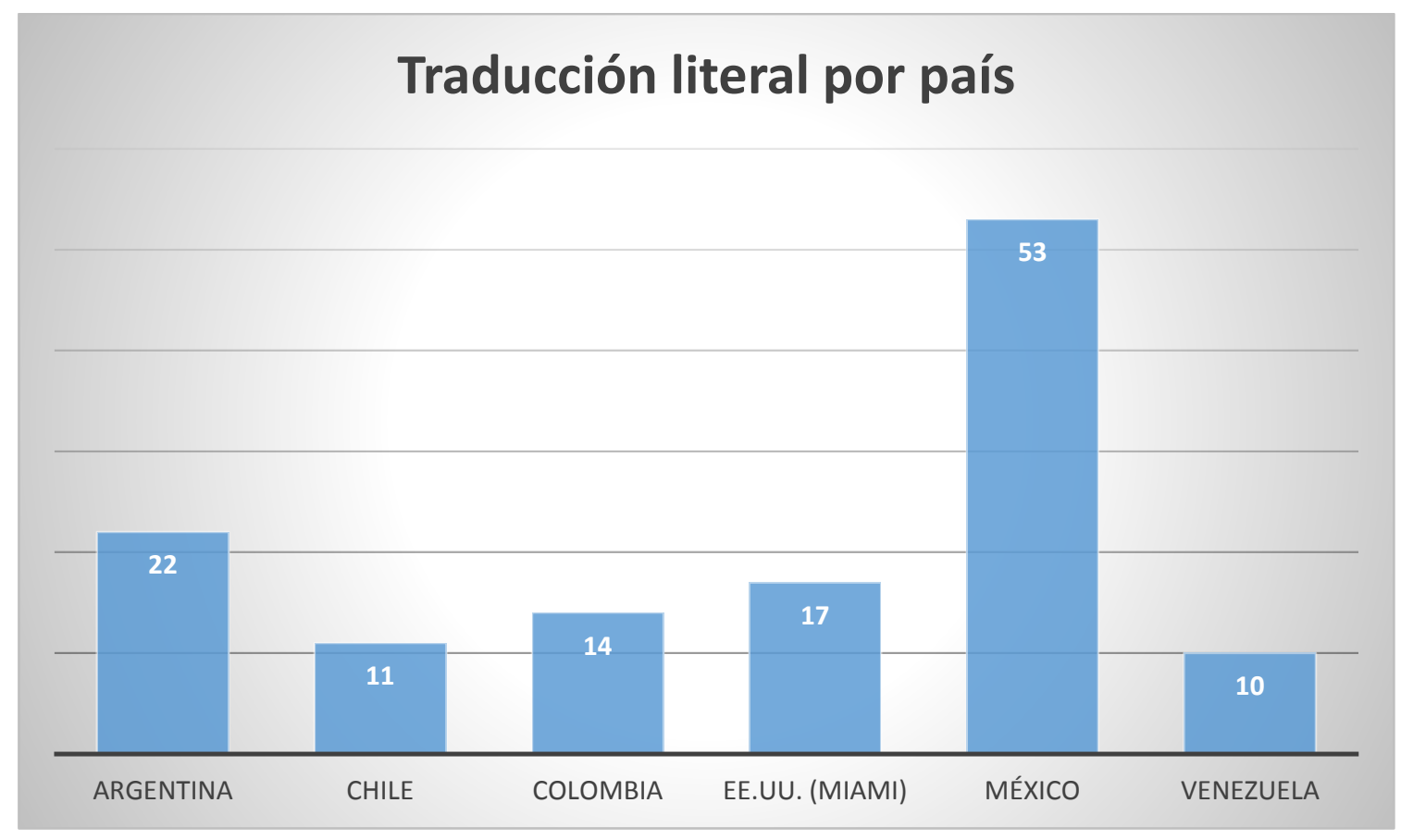

Tabla 23 - Traducción literal por país, en número de casos

En el análisis de la traducción literal según el país, Estados Unidos tiene casi la misma cantidad de casos que México (que tiene un promedio de 18 por programa, dado que los 53 casos abarcan las tres series estudiadas dobladas en México). Los demás países tienen cifras muy similares y menores (11 Argentina y Chile, 10 Venezuela), excepto Colombia (14). 


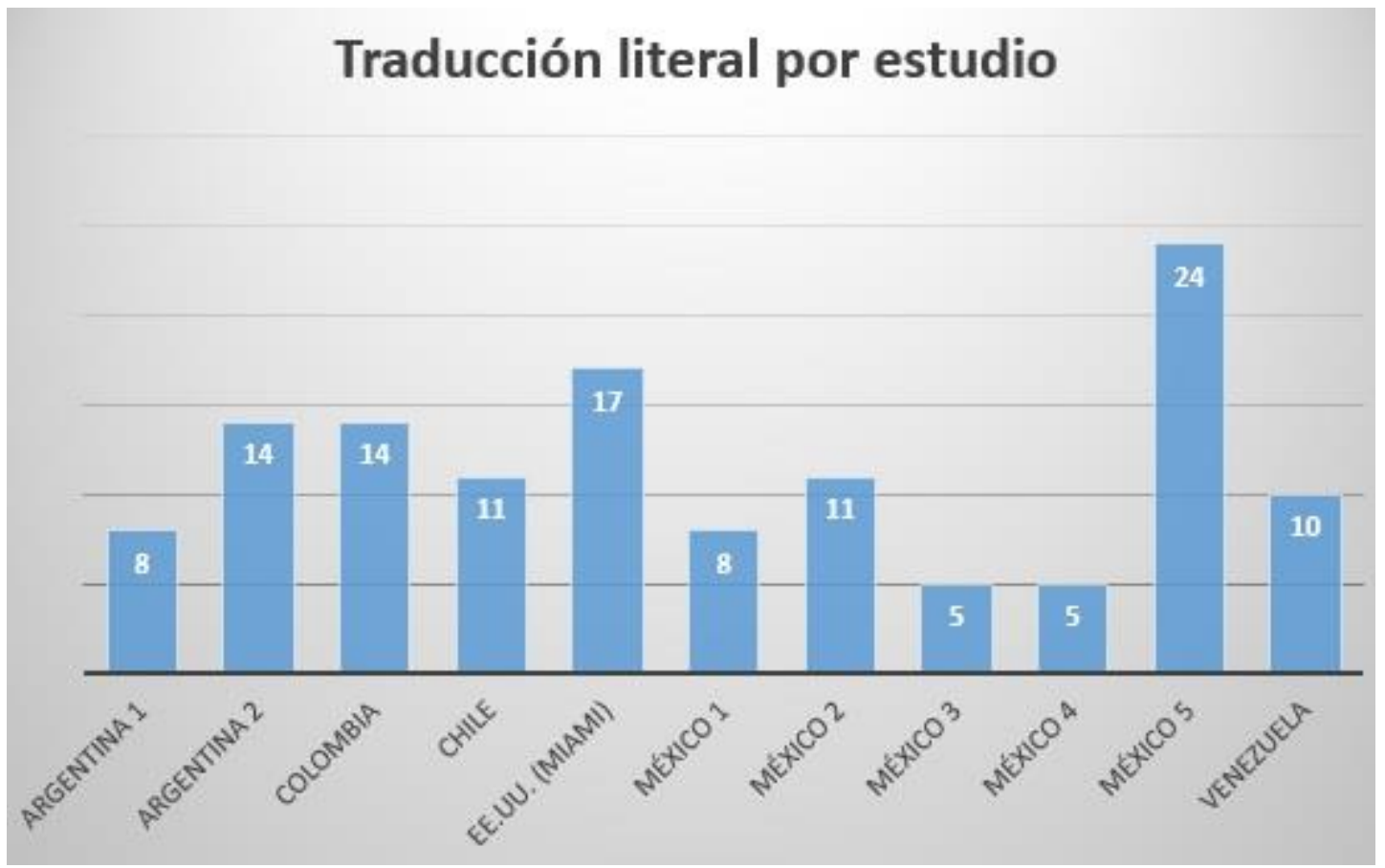

Tabla 24 - Traducción literal por estudio, en número de casos

En el caso de las diferencias según el estudio, si bien son notorias entre los dos estudios de Argentina (8-14), son aún más notorias entre los estudios mexicanos (24 casos frente a $10^{150}$, por ejemplo).

150 Sumamos las traducciones literales de los estudios de México 3 y 4 porque entre ambos conforman tres episodios de una misma serie, y entonces sí se los puede comparar con los 24 casos de otra serie traducida enteramente por un solo estudio. 


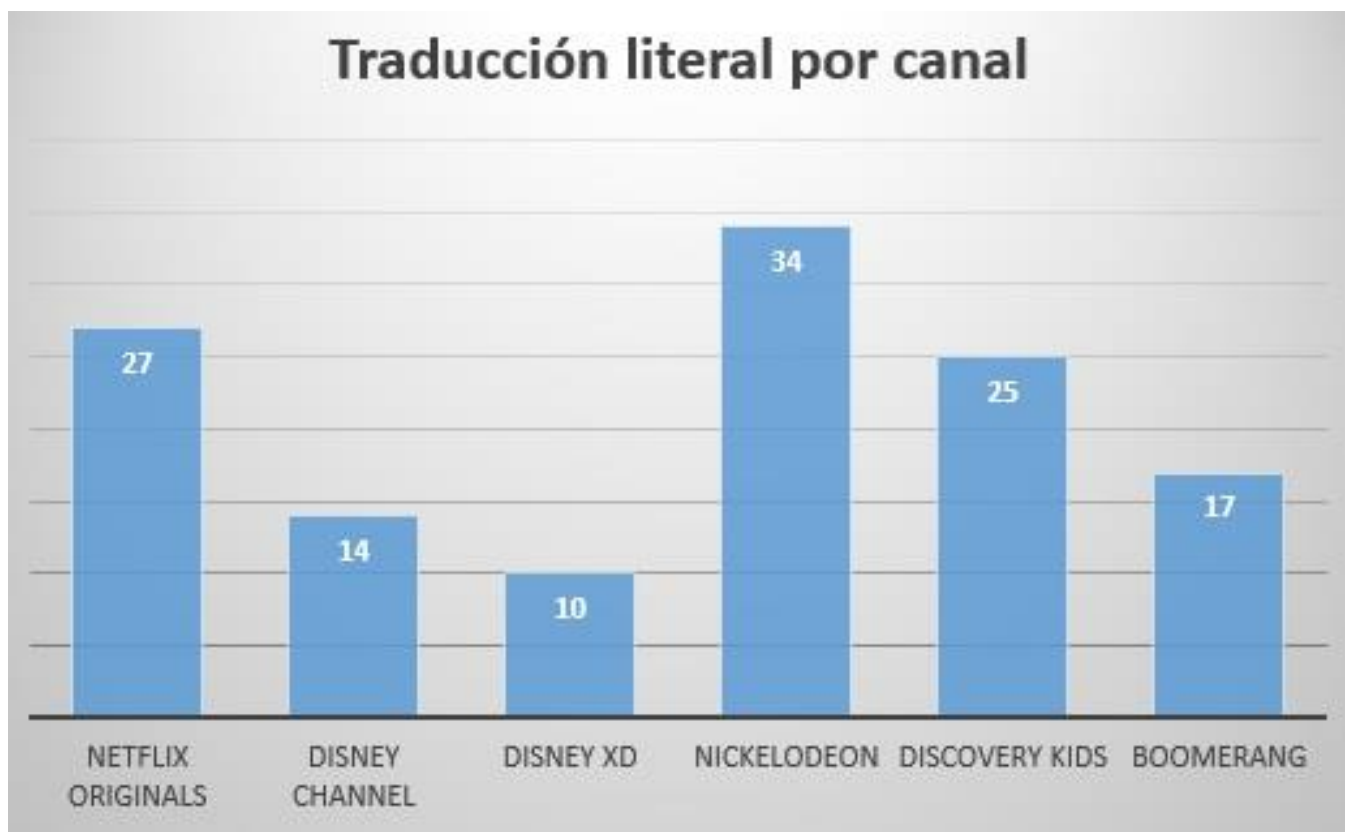

Tabla 25 - Traducción literal por canal, en número de casos

Los casos de traducción literal hallados en el corpus se repartieron de la siguiente manera:

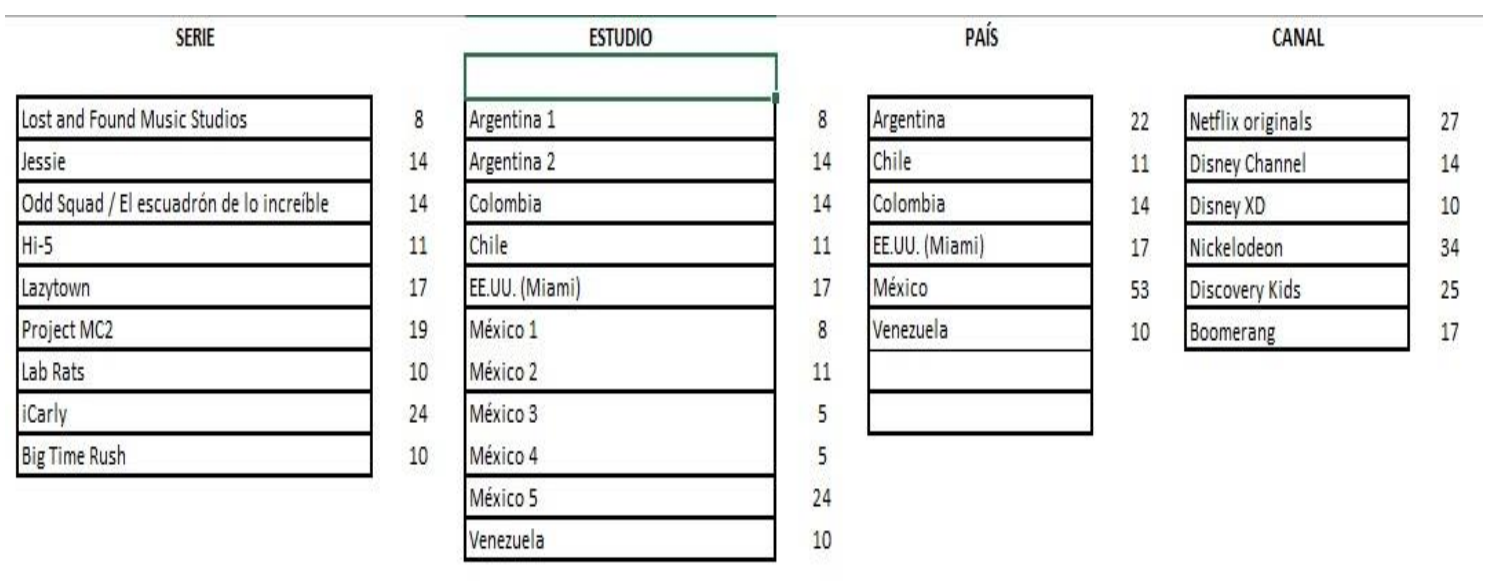

Tabla 26 - Traducción literal según serie, estudio, país y canal

En cuanto a las series, casi todas tienen un promedio de aproximadamente un $50 \%$ de traducciones literales, exceptuando Jessie, con un 21,54\%, y Lost and Found Music Studios, con un $80 \%$. Dado que ambos programas son doblados en Argentina, se podría inferir que el estudio, como agente del proceso de doblaje, tiene mayor influencia que cualquier otra directriz a nivel nacional. En el Anexo 1 se pueden observar todos los ejemplos de traducción literal extraídos del corpus. 


\section{ii. Omisión}

Dado lo discutido en capítulos anteriores respecto de la posibilidad de que exista cierta censura en este tipo de traducción audiovisual, el estudio de la omisión nos parecía sumamente pertinente, ya que la censura muchas veces se expresa a través de las omisiones realizadas adrede y no por cuestiones de ajuste o isocronía.

Veamos algunos ejemplos extraídos del corpus:

\section{PAÍS DE DOBLAJE: ARGENTINA}

CASOS: 9

PROGRAMA: JESSIE

TEMPORADA 3 - EPISODIOS 26 y 27 "Jessie's Aloha-Holidays with Parker and Joey"

\begin{tabular}{|c|l|l|l|l|}
\hline \multicolumn{1}{|c|}{$\begin{array}{c}\text { AÑO: } \\
\text { 2014TÉRMINO }\end{array}$} & \multicolumn{1}{|c|}{ CONTEXTO } & TRADUCCIÓN & TÉCNICA & ESPAÑOL \\
\hline Murder & $\begin{array}{l}\text { I'm going to } \\
\text { make Jessie the } \\
\text { most important } \\
\text { character in the } \\
\text { entire murder } \\
\text { mystery }\end{array}$ & $\begin{array}{l}\text { Convertiré a Jessie en } \\
\text { el personaje más } \\
\text { importante de todo } \\
\text { este misterio }\end{array}$ & Omisión & Neutro \\
\hline
\end{tabular}

\section{PAÍS DE DOBLAJE: CHILE}

CASOS: 2

PROGRAMA: HI-5

AÑO: 2009

\begin{tabular}{|c|l|l|l|l|}
\hline TÉRMINO & \multicolumn{1}{|c|}{ CONTEXTO } & \multicolumn{1}{|c|}{ TRADUCCIÓN } & \multicolumn{1}{c|}{ TÉCNICA } & ESPAÑOL \\
\hline Ride a bike & Ride my bike & -- & Omisión & -- \\
\hline
\end{tabular}




\begin{tabular}{|l|}
\hline PAÍS DE DOBLAJE: VENEZUELA \\
\hline CASOS: 1 \\
\hline PROGRAMA: BIG TIME RUSH \\
\hline TEMPORADA 1 - EPISODIOS 1 y 2 "Big Time Audition" \\
\hline AÑO: 2009 \\
\hline
\end{tabular}

\begin{tabular}{|c|l|l|l|l|}
\hline \multicolumn{1}{|c|}{ TÉRMINO } & \multicolumn{1}{|c|}{ CONTEXTO } & TRADUCCIÓN & TÉCNICA & ESPAÑOL \\
\hline Turd & $\begin{array}{l}\text { Oh, you're such } \\
\text { a turd }\end{array}$ & [canción no traducida] & Omisión & -- \\
\hline
\end{tabular}

\begin{tabular}{|c|c|c|c|c|}
\hline \multicolumn{5}{|c|}{ PAÍS DE DOBLAJE: MÉXICO } \\
\hline \multicolumn{5}{|l|}{ CASOS: 1} \\
\hline \multicolumn{5}{|c|}{ PROGRAMA: iCARLY } \\
\hline \multicolumn{5}{|c|}{ TEMPORADA 6 - EPISODIO 5 “iPear Store" } \\
\hline \multicolumn{5}{|l|}{ AÑO: 2012} \\
\hline TÉRMINO & CONTEXTO & TRADUCCIÓN & TÉCNICA & ESPAÑOL \\
\hline Butt & $\begin{array}{l}\text { I hope my foot } \\
\text { doesn't hurt } \\
\text { your butt when } \\
\text { I do this }\end{array}$ & $\begin{array}{l}\text { Espero que mi pie no } \\
\text { te lastime cuando } \\
\text { haga esto }\end{array}$ & Omisión & -- \\
\hline
\end{tabular}


El total de casos obtenidos para esta técnica fue de 13, repartidos de la siguiente manera:

SERIE
\begin{tabular}{|l|}
\hline Lost and Found Music Studios \\
\hline lessie \\
\hline Odd Squad/El escuadrón de lo increible \\
\hline Hi-5 \\
\hline Laztown \\
\hline Project MC2 \\
\hline Lab Rats \\
\hline Carly \\
\hline Big Time Rush \\
\hline
\end{tabular}

ESTUDIO

\begin{tabular}{|l|l|}
\hline Argentina 1 \\
\hline Argentina 2 \\
\hline Colombia \\
\hline Chile \\
\hline EE.UU. (Miami) \\
\hline México 1 \\
\hline México 2 \\
\hline México 3 \\
\hline México 4 \\
\hline México 5 \\
\hline Venezuela \\
\hline
\end{tabular}

Tabla 27 - Omisión según serie, estudio, país y canal
CANAL

\begin{tabular}{|c|c|c|}
\hline Argentina & 9 & Netflix originals \\
\hline Chile & 2 & Disney Channel \\
\hline Colombia & & Disney XD \\
\hline EEEU. (Miami) & & Nickelodeon \\
\hline México & 1 & Discovery Kids \\
\hline Venezula & 1 & Boomerang \\
\hline
\end{tabular}

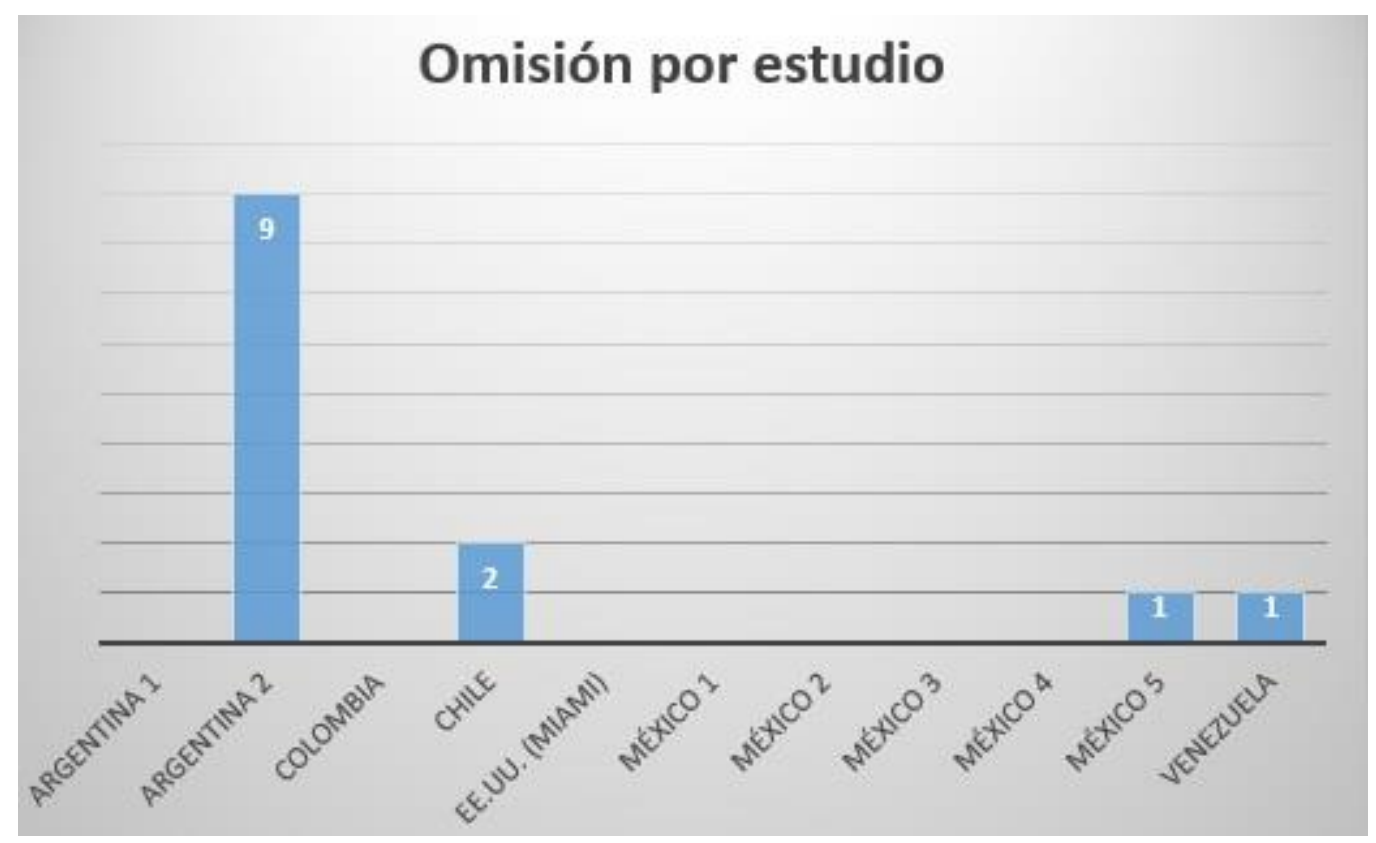

Tabla 28 - Omisión por estudio, en número de casos 
En el caso de la omisión, si bien esta técnica no resultó tan usual como esperábamos, la diferencia entre los estudios de Argentina, Chile, México y Venezuela es notoria, como también lo es entre estudios del mismo país en el caso de Argentina (relación 9:0) y en comparación con estudios de otros países que no presentan ningún caso de omisión. Por otro lado, también llama la atención que la mayor cantidad de omisiones, que corresponde a Argentina, sea del año 2014, mientras que la cifra que le sigue, la de Chile, es del 2009. En este caso, sería necesario ampliar el corpus para poder extraer conclusiones fiables.

En su mayoría, las omisiones tenían que ver con palabras que podían resultar ofensivas, como butt o turd; verbos problemáticos que pueden malinterpretarse, como "montar"; expresiones relacionadas con la muerte, y términos religiosos o relacionados con la Navidad.

Las omisiones más llamativas son las de los términos relacionados con Navidad entre episodios de distintas temporadas de la misma serie, lo cual lleva a pensar que alguna política lingüística nueva (en el nivel de la empresa, canal o país) fue responsable de este cambio.

iii. Modulación y variación

A pesar de que la modulación y la variación son técnicas con ciertos rasgos en común, existen diferencias entre ambas. Molina y Hurtado Albir (2002) sostienen que la variación es "un cambio de elementos lingüísticos o paralingüísticos que afectan aspectos de la variación lingüística, como cambios de tono, de estilo, de dialecto social o geográfico, etc.". Molina (2001), en su tesis doctoral, cita como ejemplo los "cambios de tono en adaptaciones de novelas para niños". Este mismo concepto podría aplicarse a la traducción para doblaje de programas infantiles. Un ejemplo de variación es evitar palabras soeces y cambiarlas por otras más aceptables (como varios casos de Big Time Rush).

Por modulación, entendemos aquí "une variation dans le message, obtenue en changeant de point de vue, d'éclairage" (Vinay y Darbelnet, 1958: 51). Entre los distintos ejemplos de modulación que ofrecen estos autores en su clasificación, hay dos que son los que más nos interesan: la metonimia, que consiste en designar una cosa con el nombre de otra con la que existe cierta relación, y la sinécdoque, en cuyo caso la relación es de inclusión. Esta técnica ha recibido otros nombres en la bibliografía de los Estudios de Traducción, como generalización (vid. infra) o explicitación (como en el ejemplo de Lazy Town, para dotar de coherencia a la traducción con las imágenes).

En el ámbito audiovisual, la modulación y la variación, junto con la omisión, la generalización, la explicitación y la creación discursiva, están muy relacionadas con la norma de eufemización y, por lo tanto, también con la censura.

Veamos algunos ejemplos de modulación del corpus: 
PAÍS DE DOBLAJE: ARGENTINA

CASOS: 5

PROGRAMA: JESSIE

TEMPORADA 3 - EPISODIOS 26 y 27 "Jessie's Aloha-Holidays with Parker and Joey"

AÑO: 2014

\begin{tabular}{|l|l|l|l|l|}
\hline \multicolumn{1}{|c|}{ TÉRMINO } & \multicolumn{1}{|c|}{ CONTEXTO } & \multicolumn{1}{c|}{ TRADUCCIÓN } & \multicolumn{1}{c|}{ TÉCNICA } & EÑ̃OL \\
\hline Corpse & $\begin{array}{l}\text { Right, because } \\
\text { you're a corpse }\end{array}$ & $\begin{array}{l}\text { Claro, porque eres la } \\
\text { víctima }\end{array}$ & Modulación & Neutro \\
\hline
\end{tabular}

Es necesario aclarar que las modulaciones relacionadas con la muerte suelen cambiar la perspectiva para reducir el impacto del término original (eufemización). Por ejemplo, el cambio de corpse por "víctima" o "cuerpo" quita la idea de muerte del vocablo español (se puede ser víctima de un robo sin necesidad de que eso implique una muerte, y un cuerpo no necesariamente no tiene vida).

\section{PAÍS DE DOBLAJE: CHILE}

\section{CASOS: 1}

PROGRAMA: HI-5

TEMPORADA 11 - EPISODIO 27 "Celebrations Around the World"

AÑO: 2010

\begin{tabular}{|c|l|l|l|l|}
\hline \multicolumn{1}{|c|}{ TÉRMINO } & \multicolumn{1}{|c|}{ CONTEXTO } & TRADUCCIÓN & TÉCNICA & ESPAÑOL \\
\hline Bow & $\begin{array}{l}\text { A pretty } \\
\text { bow }\end{array}$ & Una linda cinta & Modulación & Neutro \\
\hline
\end{tabular}




\begin{tabular}{|l|}
\hline PAÍS DE DOBLAJE: MÉXICO \\
\hline CASOS: 2 \\
\hline PROGRAMA: LAB RATS \\
\hline TEMPORADA 4 - EPISODIO 2 "Bionic Rebellion Part 2" \\
\hline AÑO: 2016 \\
\hline
\end{tabular}

\begin{tabular}{|c|c|c|c|c|}
\hline TÉRMINO & CONTEXTO & TRADUCCIÓN & TÉCNICA & ESPAÑOL \\
\hline Doorbell & $\begin{array}{l}\text { Don't ring my } \\
\text { doorbell! }\end{array}$ & No tocar a mi puerta & $\begin{array}{l}\text { Modulación } \\
\text { (por timbre) }\end{array}$ & Neutro \\
\hline
\end{tabular}

Y ahora veamos algunos ejemplos de variación del corpus:

\begin{tabular}{|l|}
\hline PAÍS DE DOBLAJE: MÉXICO \\
\hline CASOS: 11 \\
\hline PROGRAMA: iCARLY \\
\hline TEMPORADA 1 - EPISODIO 1 "iPilot" \\
\hline AÑO: 2007 \\
\hline
\end{tabular}

\begin{tabular}{|l|l|l|l|l|}
\hline \multicolumn{1}{|c|}{ TÉRMINO } & \multicolumn{1}{|c|}{ CONTEXTO } & \multicolumn{1}{|c|}{ TRADUCCIÓN } & TÉCNICA & ESPAÑOL \\
\hline Idiots & $\begin{array}{l}\text { We were being } \\
\text { all goofy and } \\
\text { acting like } \\
\text { idiots all day! }\end{array}$ & $\begin{array}{l}\text { Hicimos tonterías y } \\
\text { actuamos como tontos }\end{array}$ & Variación & Neutro \\
\hline
\end{tabular}




\begin{tabular}{|l|}
\hline PAÍS DE DOBLAJE: ARGENTINA \\
\hline CASOS: 6 \\
\hline PROGRAMA: JESSIE \\
\hline TEMPORADA 3 - EPISODIOS 26 y 27 “Jessie's Aloha-Holidays with Parker and Joey” \\
\hline AÑO: 2014 \\
\hline
\end{tabular}

\begin{tabular}{|l|l|l|l|l|}
\hline \multicolumn{1}{|c|}{ TÉRMINO } & \multicolumn{1}{|c|}{ CONTEXTO } & \multicolumn{1}{|c|}{ TRADUCCIÓN } & TÉCNICA & ESPAÑOL \\
\hline Die & $\begin{array}{l}\text { I can't believe } \\
\text { I'm going to die } \\
\text { with the } \\
\text { frizzies! }\end{array}$ & $\begin{array}{l}\text { iTerminaré mis días } \\
\text { con este pelo! }\end{array}$ & Variación & Neutro \\
\hline
\end{tabular}

\begin{tabular}{|l|}
\hline PAÍS DE DOBLAJE: VENEZUELA \\
\hline CASOS: 4 \\
\hline PROGRAMA: BIG TIME RUSH \\
\hline TEMPORADA 1 - EPISODIOS 1 y 2 "Big Time Audition" \\
\hline AÑO: 2009 \\
\hline
\end{tabular}

\begin{tabular}{|l|l|l|l|l|}
\hline \multicolumn{1}{|c|}{ TÉRMINO } & \multicolumn{1}{|c|}{ CONTEXTO } & \multicolumn{1}{c|}{ TRADUCCIÓN } & TÉCNICA & ESPAÑOL \\
\hline Turd & $\begin{array}{l}\text {...with a giant } \\
\text { turd producer }\end{array}$ & $\begin{array}{l}\text {...con un cerdo } \\
\text { productor }\end{array}$ & Variación & Neutro \\
\hline
\end{tabular}

El total de casos obtenidos para la modulación fue de 8, y para la variación, de 22, repartidos de la siguiente manera: 
SERIE

\begin{tabular}{|l|}
\hline Lost and Found Music Studios \\
\hline Lessie \\
\hline Odd Squad / El escuadrón de lo increible \\
\hline Hi-5 \\
\hline Lazytown \\
\hline Project MC2 \\
\hline Lab Rats \\
\hline CCarly \\
\hline BigTime Rush \\
\hline
\end{tabular}

ESTUDIO

\begin{tabular}{|c|}
\hline Argentina 1 \\
\hline Argentina 2 \\
\hline Colombia \\
\hline Chile \\
\hline EE.UU. (Miami) \\
\hline México 1 \\
\hline México 2 \\
\hline México 3 \\
\hline México 4 \\
\hline México 5 \\
\hline Venezuela \\
\hline
\end{tabular}

PAÍS

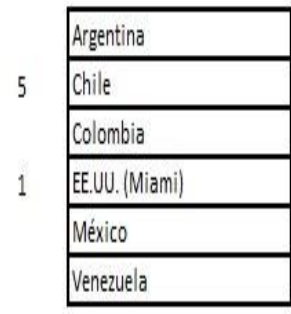

CANAL

Tabla 29 - Modulación según serie, estudio, país y canal

\section{SERIE}

\begin{tabular}{|l|}
\hline Lost and Found Music Studios \\
\hline Jessie \\
\hline Odd Squad / El escuadrón de lo increible \\
\hline Hi-5 \\
\hline Lazytown \\
\hline Project MC2 \\
\hline Lab Rats \\
\hline iCarly \\
\hline Big Time Rush \\
\hline
\end{tabular}

ESTUDIO

\begin{tabular}{|l|}
\hline Argentina 1 \\
\hline Argentina 2 \\
\hline Colombia \\
\hline Chile \\
\hline EE.UU. (Miami) \\
\hline México 1 \\
\hline México 2 \\
\hline México 3 \\
\hline México 4 \\
\hline México 5 \\
\hline Venezuela \\
\hline
\end{tabular}

PAÍS

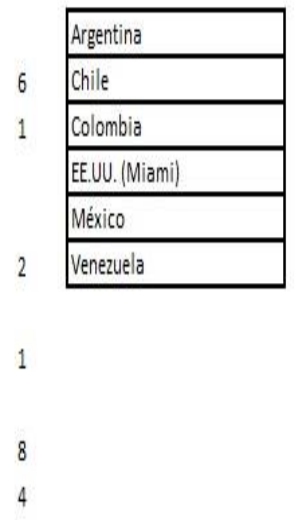

CANAL

Netflix originals

Disnev Channel.

Disney XD

Nickelodeon

2

Discovery Kids

Boomerang

Tabla 30 - Variación según serie, estudio, país y canal

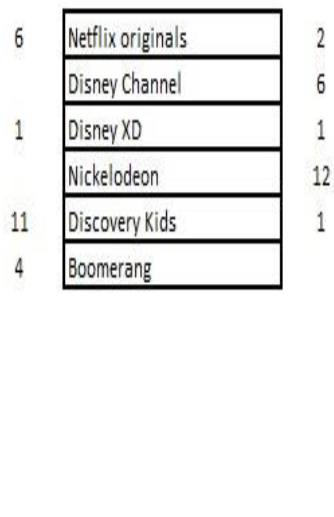




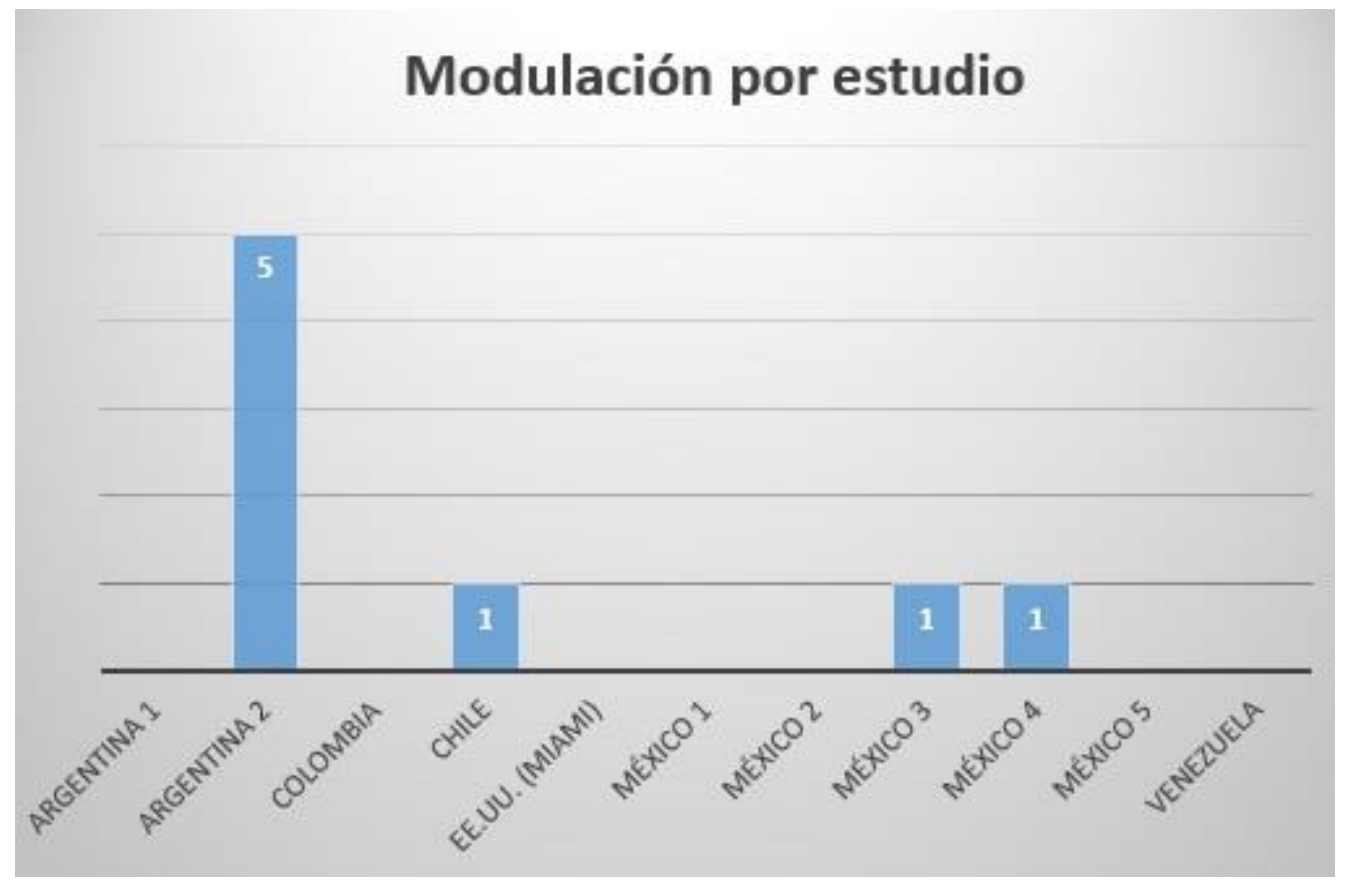

Tabla 31 - Modulación por estudio, en número de casos

Existe una diferencia significativa entre los casos de modulación de los dos estudios de Argentina (5:0) y entre un estudio de Argentina y los demás estudios (del mismo o de otro país) por otro. Estas diferencias son muy marcadas.

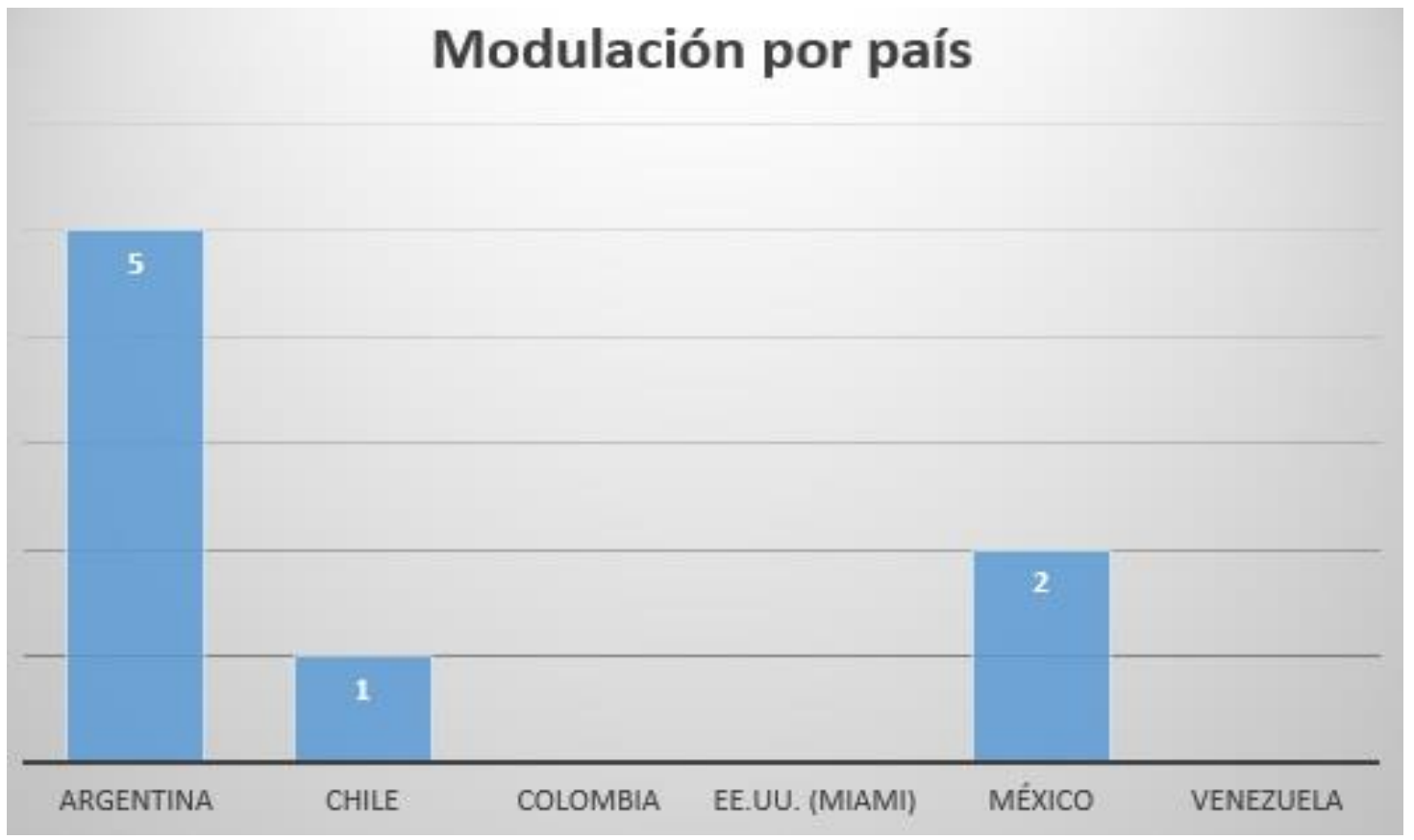

Tabla 32 - Modulación por país, en número de casos 


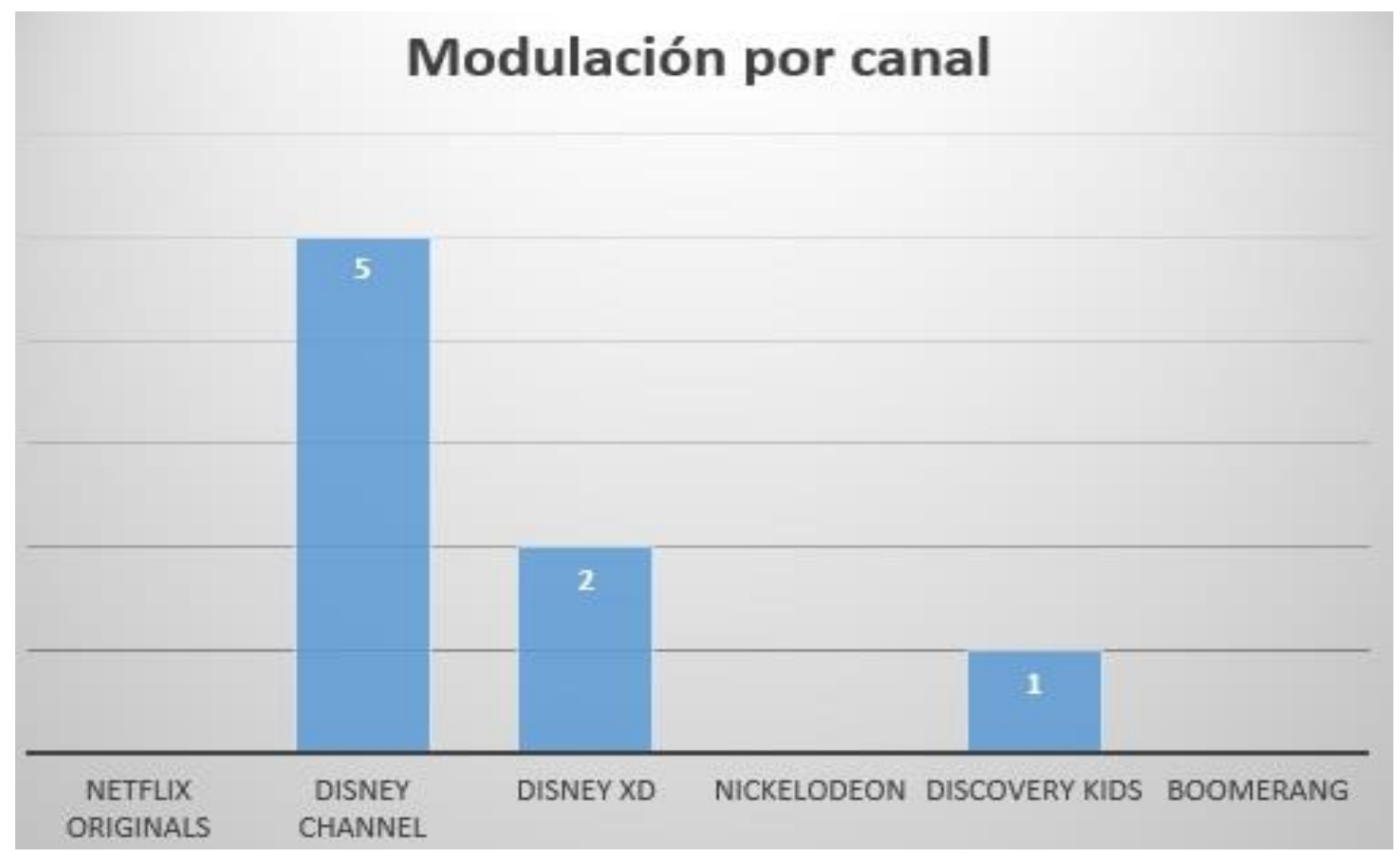

Tabla 33 - Modulación por canal, en número de casos

Resulta llamativo que haya canales sin casos de modulación. Pero dado que la modulación está tan ligada a la variación, más adelante compararemos las cifras de ambas técnicas combinadas. También llama la atención que Boomerang no tenga ningún caso de modulación ni de variación, pero dado que el programa de Boomerang es para niños más pequeños (Lazytown), es probable que no fueran requeridas debido a que los términos utilizados en dicho tipo de contenidos no necesitan ser suavizados. Lo mismo ocurre con la variación: hay solo un caso en Discovery Kids, comparado con 12 casos de Nickelodeon, cuya programación es para niños de mayor edad (ver tabla debajo). 


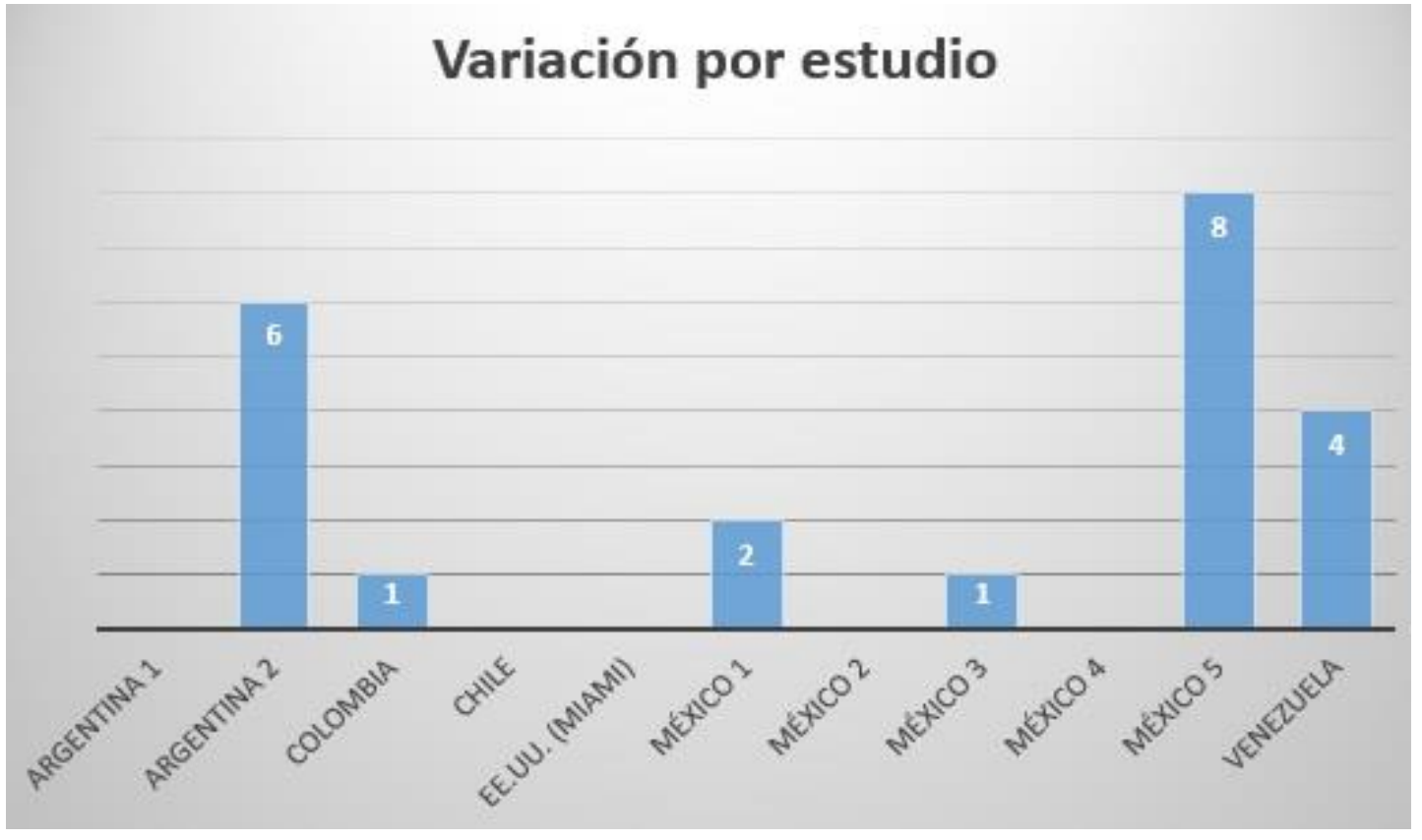

Tabla 34 - Variación por estudio, en número de casos

Aquí llama la atención la diferencia entre los estudios de México, y también entre uno y otro estudio de Argentina. En cuanto a las diferencias entre países, no existe entre México (promedio de 4) y Venezuela, y es significativa con los demás (con Argentina 4:3).

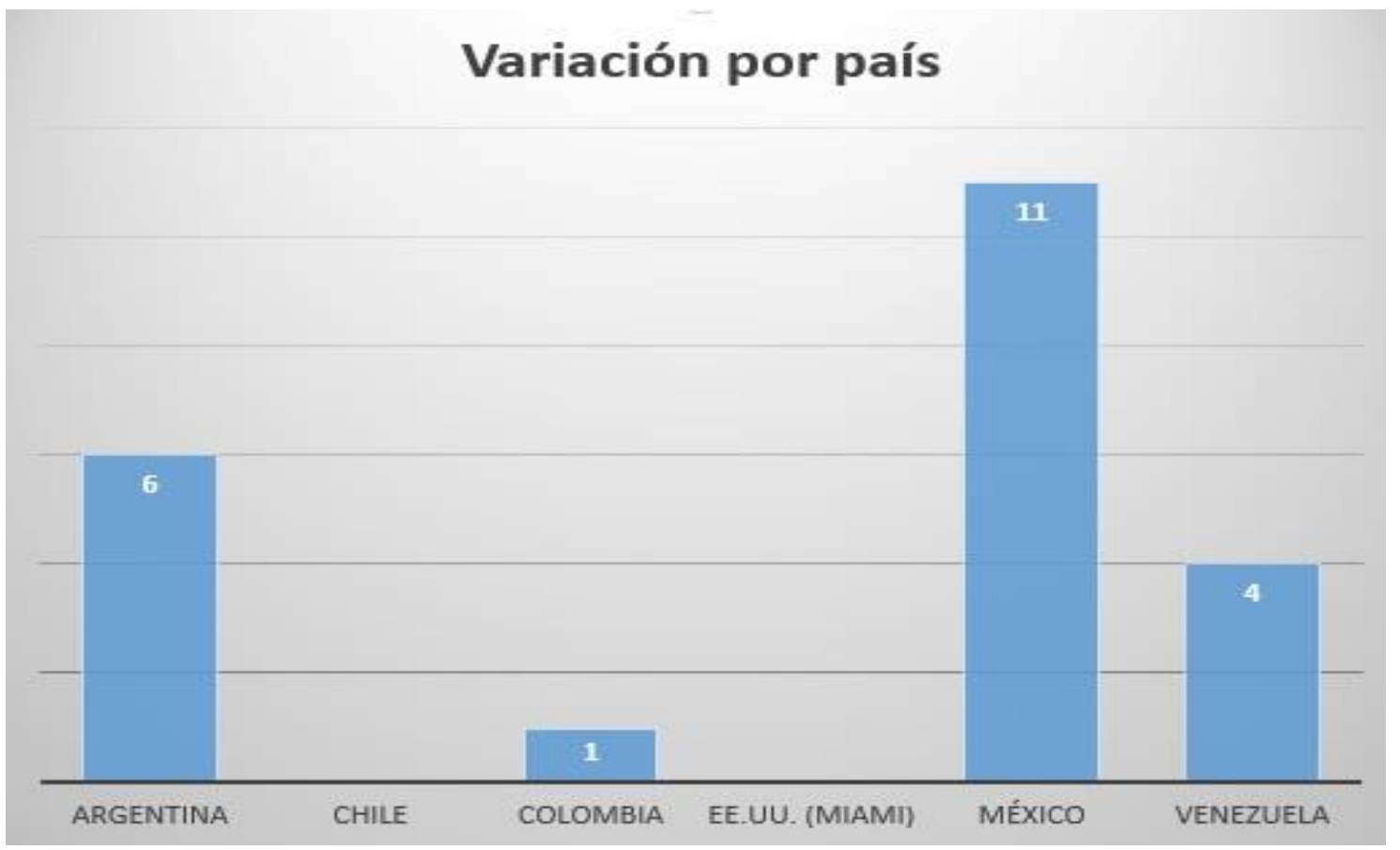

Tabla 35 - Variación por país, en número de casos 


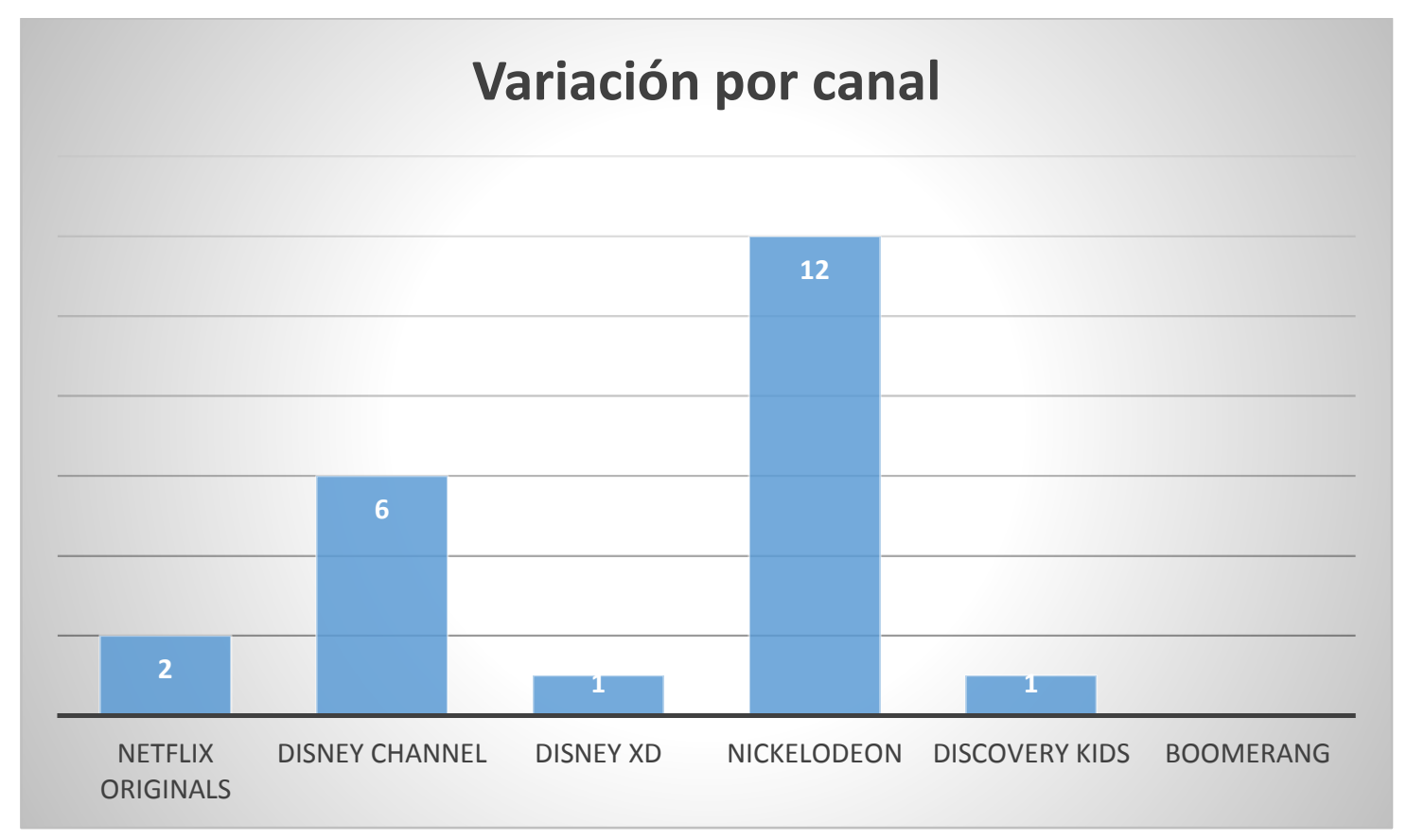

Tabla 36 - Variación por canal, en número de casos

Las diferencias por canal parecen relacionadas con el contenido o el público destinatario. Por ejemplo, Disney Channel es el canal más general de Disney, mientras que Disney XD nació como un canal "para varones"151 (aunque ya no sea tan así), ${ }^{152}$ y tal vez a eso se deba la diferencia en el uso de estas técnicas (6 casos de variación y 1, respectivamente). Pero si unimos los resultados de modulación y variación, Argentina y México tienen cifras muy similares (11 y 13 casos, respectivamente), al igual que si comparamos los programas de Nickelodeon con los de ambos canales de Disney (12 casos de Nickelodeon y 14 casos de Disney).

Por otro lado, también es notorio que en algunos programas la variación tenga porcentajes tan altos. En Big Time Rush, la variación representa el 20\% de las técnicas de traducción utilizadas, frente al $50 \%$ de traducción literal en la misma serie.

151 Haugsted, L. (2009): “ Disney XD Unwraps On Friday The $13^{\text {th" }}$, Multichannel News, 7 de enero de 2009 https://web.archive.org/web/20110616202259/http://www.multichannel.com/article/161701Disney XD Unwraps On Friday The 13 th.php (consultado el 9 de abril de 2019)

152 Por ejemplo, la serie de fútbol de Disney, O11CE, se transmite solo en Disney XD, y esto puede deberse a que se da por sentado que el fútbol interesa mayoritariamente a los varones. Mientras tanto, Soy Luna, sobre una niña que patina, se transmite por Disney Channel, pero en realidad su público es mixto. 
La mayoría de los casos de modulación y variación estaban relacionados con conceptos que puedan perturbar a un niño, como corpse o murder, y con palabras ofensivas como stupid, idiot o butt. También hay, pero en menor medida, casos relacionados con cuestiones religiosas (Christmas Eve, oi).

\section{iv. Préstamo}

En general, es bastante usual que todo tipo de español neutro (no solo el audiovisual) incluya cierta cantidad de préstamos, es decir, que tome palabras prestadas de otra lengua en lugar de traducirlas, acuñe nuevas cuando el concepto no existe en la lengua meta, o las calque. La mayor cantidad de préstamos en el español neutro provienen del inglés. En el caso de México, la cercanía geográfica es fundamental para entender este fenómeno. En el caso de Argentina, cabe recordar que su léxico, como se explicó anteriormente, es más similar al de México que el de otros países. Por ejemplo, mientras que en España se utiliza la palabra "ratón" para el mouse de la computadora, en Argentina se utiliza el préstamo. Los préstamos son más comunes en los textos de ciertos temas, como los de tecnología.

Veamos algunos ejemplos de préstamos extraídos del corpus:

\begin{tabular}{|l|}
\hline PAÍS DE DOBLAJE: ARGENTINA \\
\hline CASOS: 8 \\
\hline PROGRAMA: LOST AND FOUND MUSIC STUDIOS \\
\hline TEMPORADA 1 - EPISODIO 2 - "See through me" \\
\hline AÑO: 2016 \\
\hline
\end{tabular}

\begin{tabular}{|l|l|l|l|l|}
\hline \multicolumn{1}{|c|}{ TÉRMINO } & \multicolumn{1}{|c|}{ CONTEXTO } & TRADUCCIÓN & TÉCNICA & ESPAÑOL \\
\hline Bromance & $\begin{array}{l}\text { Like a } \\
\text { bromance thing }\end{array}$ & Como un bromance & Préstamo & Regional \\
\hline
\end{tabular}




\begin{tabular}{|l|}
\hline PAÍ́S DE DOBLAJE: COLOMBIA \\
\hline CASOS: 3 \\
\hline PROGRAMA: THE ODD SQUAD \\
\hline TEMPORADA 1 - EPISODIO 2 - "Soundcheck - Double Trouble" \\
\hline AÑO: 2014 \\
\hline
\end{tabular}

\begin{tabular}{|l|l|l|l|l|}
\hline \multicolumn{1}{|c|}{ TÉRMINO } & \multicolumn{1}{|c|}{ CONTEXTO } & \multicolumn{1}{|c|}{ TRADUCCIÓN } & ESPAÑOL \\
\hline Minivan & $\begin{array}{l}\text { I'm driving around in } \\
\text { my minivan... }\end{array}$ & $\begin{array}{l}\text { Iba conduciendo mi } \\
\text { minivan... }\end{array}$ & Préstamo & Regional \\
\hline
\end{tabular}

\begin{tabular}{|c|c|c|c|c|}
\hline \multicolumn{5}{|c|}{ PAÍS DE DOBLAJE: MÉXICO } \\
\hline \multicolumn{5}{|l|}{ CASOS: 18} \\
\hline \multicolumn{5}{|c|}{ PROGRAMA: PROJECT MC2 } \\
\hline \multicolumn{5}{|c|}{ TEMPORADA 1 - EPISODIO 1 "New Girl in Town”, y } \\
\hline \multicolumn{5}{|c|}{ TEMPORADA 2 - EPISODIO 1 "Back to Basics" } \\
\hline \multicolumn{5}{|c|}{ AÑO: 2015 - 2016} \\
\hline TÉRMINO & CONTEXTO & TRADUCCIÓN & TÉCNICA & ESPAÑOL \\
\hline Aliens & $\begin{array}{l}\text {...and fight } \\
\text { aliens... }\end{array}$ & ...y pelear con aliens... & Préstamo & Neutro \\
\hline Trending & $\begin{array}{l}\text { We're so } \\
\text { trending now! }\end{array}$ & $\begin{array}{l}\text { ¡Somos tan trending } \\
\text { ahora! }\end{array}$ & Préstamo & Regional \\
\hline
\end{tabular}


Los casos de préstamos hallados en el corpus fueron 34, distribuidos de la siguiente manera:

SERIE
\begin{tabular}{|l|}
\hline Lostand Found Music Studios \\
\hline Lessie \\
\hline Odd Squad/El esccuadrón de lo increible \\
\hline Hi-5 \\
\hline Laztown \\
\hline Project MC2 \\
\hline Lab Rats \\
\hline iCarly \\
\hline Big Time Rush \\
\hline
\end{tabular}

ESTUDIO

PAÍS

CANAL

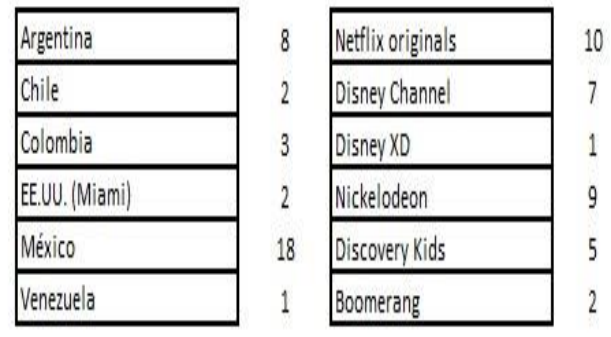

Tabla 37 - Préstamo según serie, estudio, país y canal

\section{Préstamo por estudio}

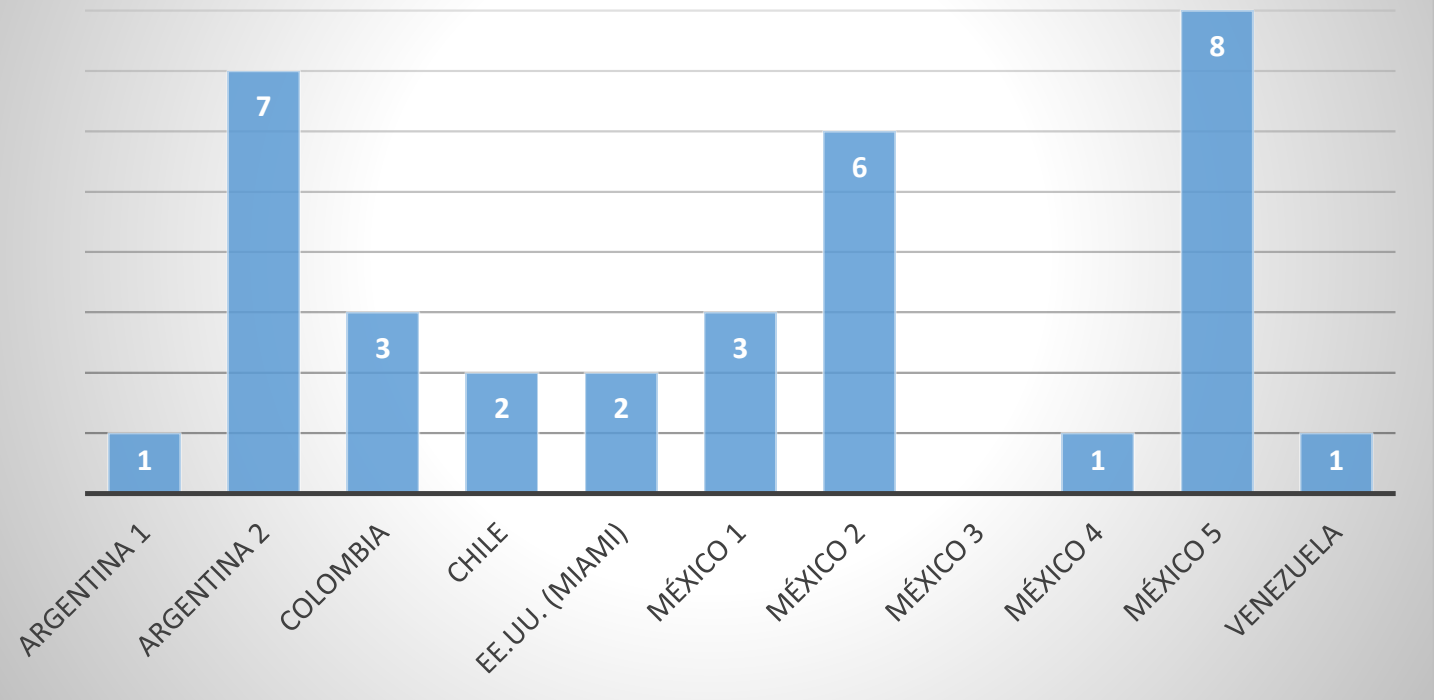

Tabla 38 - Préstamo por estudio, en número de casos 
A pesar de observar grandes diferencias entre un estudio y otro, nuevamente dos estudios de México tienen un nivel similar de préstamos al de uno de los argentinos, mientras que los demás tienen considerablemente menos instancias de préstamos. También es llamativo el hecho de que, de los dos estudios mexicanos que doblaron Project MC2, uno utilizó más préstamos que el otro, por lo que en una temporada, por ejemplo, podemos encontrar el término trending y en la otra, "tendencia".

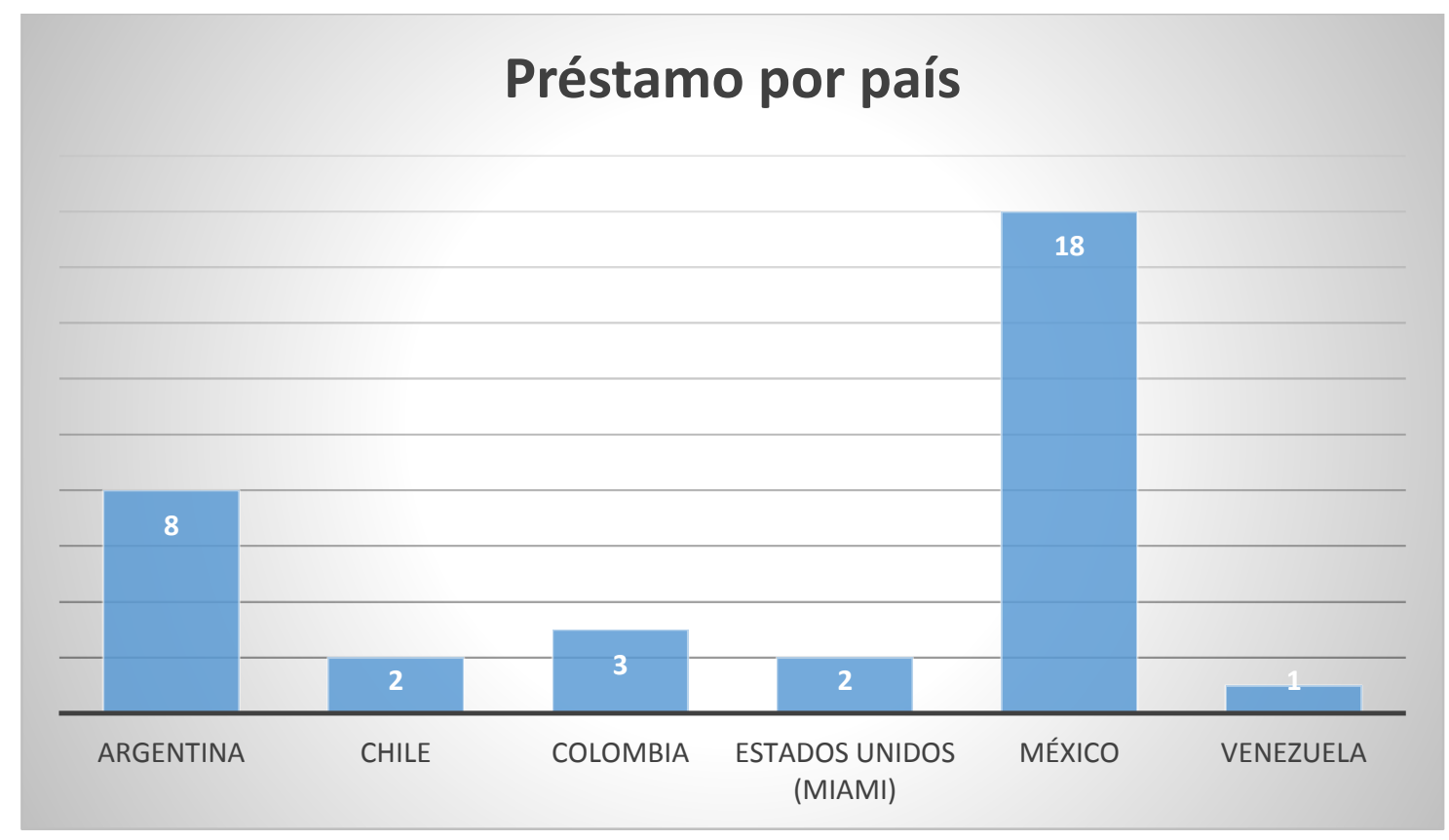

Tabla 39 - Préstamos por país, en número de casos

No obstante, al comparar estos datos por país, queda claro que el doblaje de México contiene más préstamos (un promedio de 6) que el de los demás países. Sería lógico considerar que esto también podría deberse a la cercanía del país con los Estados Unidos y la obvia influencia del inglés en el español, y aquí sí se comprobaría la influencia del país (y su ubicación y estatus frente al país de origen) en el proceso de doblaje. 


\section{Préstamo por canal}

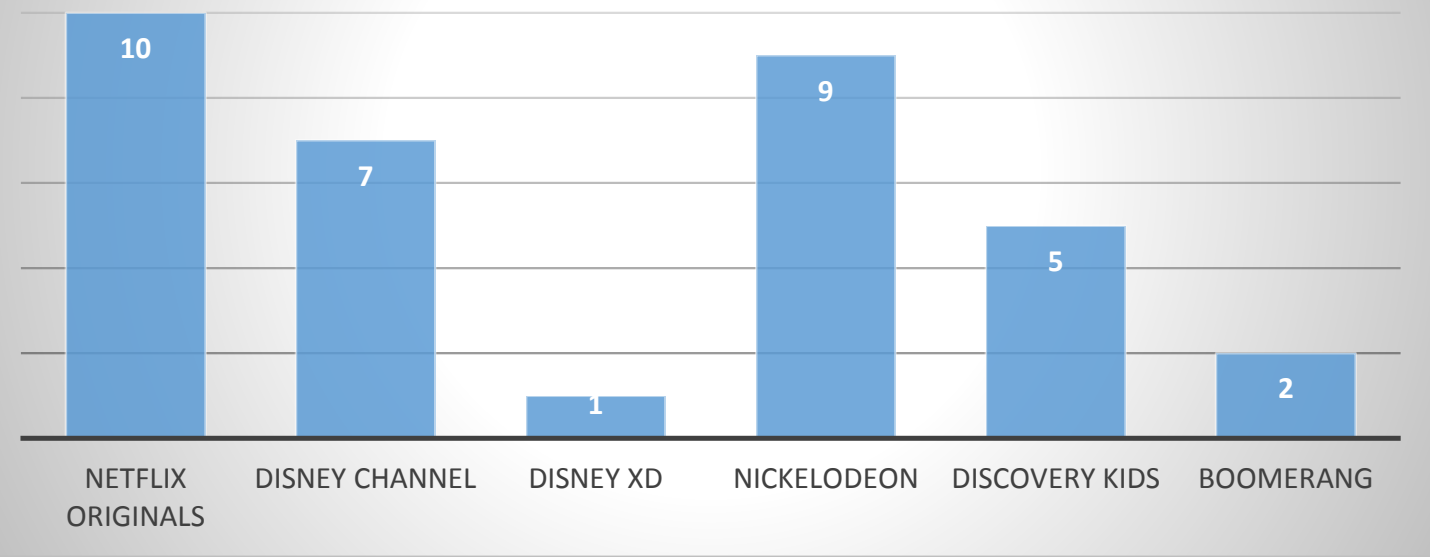

Tabla 40 - Préstamo por canal, en número de casos

Aquí llama la atención la gran cantidad de préstamos del programa Project MC2 de Netflix (27,27\% del total de técnicas para ese programa). Por tratarse de niñas que usan la tecnología continuamente, es lógico que incluya préstamos; sin embargo, varios de los préstamos que se usan en el doblaje de esta serie tienen traducción al español, como trending-tendencia, y la traducción se ve con frecuencia en las publicaciones de personas latinoamericanas en las redes sociales, por ejemplo. Todos los ejemplos de préstamo pueden consultarse en el Anexo 1.

\section{v. Generalización}

La generalización está íntimamente ligada a la modulación, porque se trata (como veremos más adelante) de casos en los que se tiende a cambiar el término inglés original, ya sea para una mejor comprensión o para evitar alguna referencia cultural o concepto problemático.

Veamos algunos ejemplos: 


\begin{tabular}{|l}
\hline PAÍS DE DOBLAJE: ARGENTINA \\
\hline CASOS: 10 \\
\hline PROGRAMA: JESSIE \\
\hline TEMPORADA 3 - EPISODIOS 26 y 27 “Jessie's Aloha-Holidays with Parker and Joey" \\
\begin{tabular}{|l|l|l|l|l|}
\hline \multicolumn{2}{|c|}{ CONTEXTO } & \multicolumn{2}{|c|}{ TRADUCCIÓN } & ESPAÑOL \\
\hline TÉRMINO & $\begin{array}{l}\text { I'm gonna put your } \\
\text { bra in hot water }\end{array}$ & $\begin{array}{l}\text { Pondré tu ropa en } \\
\text { agua caliente }\end{array}$ & Generalización & Neutro \\
\hline \multirow{2}{*}{ Bra } & $\begin{array}{l}\text { That explains } \\
\text { the sports bra }\end{array}$ & Eso explica tu ropa & Generalización & Neutro \\
\hline
\end{tabular}
\end{tabular}

\begin{tabular}{|c|c|c|c|c|}
\hline \multicolumn{5}{|c|}{ PAÍS DE DOBLAJE: COLOMBIA } \\
\hline \multicolumn{5}{|l|}{ CASOS: 3} \\
\hline \multicolumn{5}{|c|}{ PROGRAMA: THE ODD SQUAD } \\
\hline \multicolumn{5}{|c|}{ TEMPORADA 1 - EPISODIO 1 "Zero Effect - Bad Luck Bears” } \\
\hline \multicolumn{5}{|l|}{ AÑ: 2014} \\
\hline TÉRMINO & CONTEXTO & TRADUCCIÓN & TÉCNICA & ESPAÑOL \\
\hline Cupcake & $\begin{array}{l}\text { A cupcake } \\
\text { shop? }\end{array}$ & ¿Una pastelería? & Generalización & Neutro \\
\hline
\end{tabular}

\begin{tabular}{|c|c|c|c|c|}
\hline \multicolumn{5}{|c|}{ PAÍS DE DOBLAJE: CHILE } \\
\hline \multicolumn{5}{|c|}{ CASOS: 2} \\
\hline \multicolumn{5}{|c|}{ PROGRAMA: HI-5 } \\
\hline \multicolumn{5}{|c|}{ TEMPORADA 11 - EPISODIO 27 "Celebrations around the world" } \\
\hline \multicolumn{5}{|c|}{ AÑO: 2010} \\
\hline TÉRMINO & CONTEXTO & TRADUCCIÓN & TÉCNICA & ESPAÑOL \\
\hline Lollies & $\begin{array}{l}\text { We can go get } \\
\text { lollies }\end{array}$ & $\begin{array}{l}\text { ¡Podemos ir juntos a } \\
\text { pedir caramelos! }\end{array}$ & Generalización & Regional \\
\hline
\end{tabular}




\begin{tabular}{|c|c|c|c|c|}
\hline \multicolumn{5}{|c|}{ PAÍS DE DOBLAJE: MÉXICO } \\
\hline \multicolumn{5}{|l|}{ CASOS: 3} \\
\hline \multicolumn{5}{|c|}{ PROGRAMA: iCARLY } \\
\hline \multicolumn{5}{|c|}{ TEMPORADA 6 - EPISODIO 5 "iPear Store" } \\
\hline \multicolumn{5}{|l|}{ AÑO: 2012} \\
\hline TÉRMINO & CONTEXTO & TRADUCCIÓN & TÉCNICA & ESPAÑOL \\
\hline Brownies & $\begin{array}{c}\text { Would a jerk } \\
\text { bring you guys } \\
\text { brownies? }\end{array}$ & $\begin{array}{c}\text { ¿Un tonto les traería } \\
\text { pastelillos? }\end{array}$ & Generalización & Neutro \\
\hline
\end{tabular}

Los casos de esta técnica hallados en el corpus fueron 21, distribuidos de la siguiente manera:

\section{SERIE}

\begin{tabular}{|l|}
\hline Lost and Found Music Studios \\
\hline Jessie \\
\hline Odd Squad / El escuadrón de lo increible \\
\hline Hi-5 \\
\hline Lazytown \\
\hline Project MC2 \\
\hline Lab Rats \\
\hline iCarly \\
\hline Big Time Rush \\
\hline
\end{tabular}

ESTUDIO

\begin{tabular}{|l|}
\hline Argentina 1 \\
\hline Argentina 2 \\
\hline Colombia \\
\hline Chile \\
\hline EE.UU. (Miami) \\
\hline México 1 \\
México 2 \\
\hline México 3 \\
México 4 \\
\hline México 5 \\
\hline Venezuela \\
\hline
\end{tabular}

PAÍS

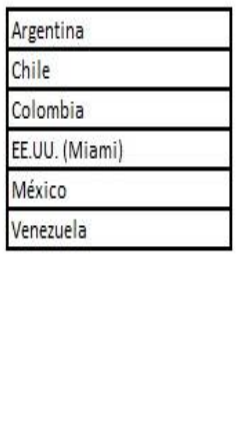

CANAL

\begin{tabular}{|c|}
\hline Netflix originals \\
\hline Disney Channel \\
\hline Disney XD \\
\hline Nickelodeon \\
\hline Discovery Kids \\
\hline Boomerang \\
\hline
\end{tabular}

Tabla 41 - Generalización según serie, estudio, país y canal 


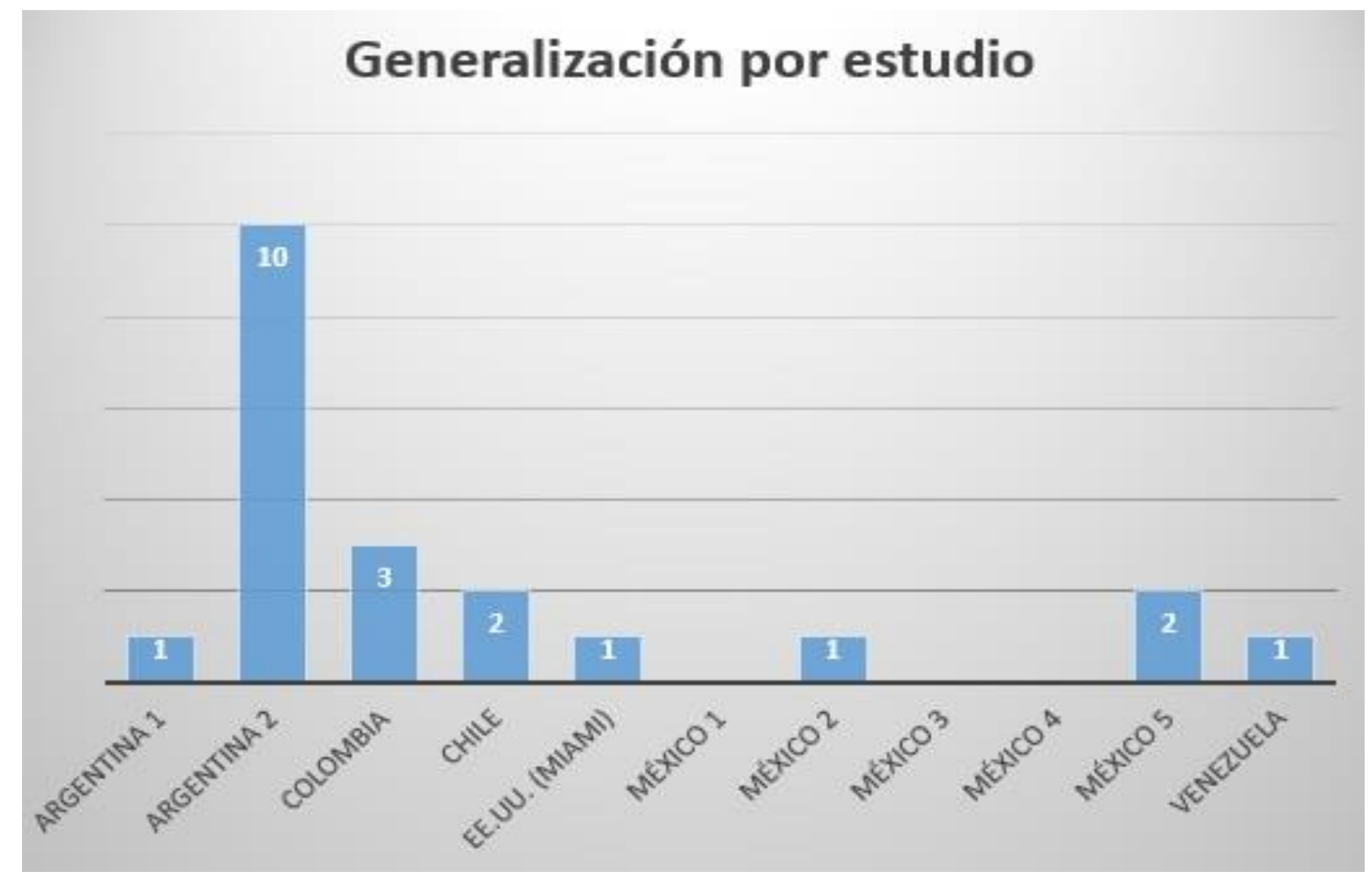

Tabla 42 - Generalización por estudio, en número de casos

Otra vez resulta notoria la diferencia entre un estudio argentino y los demás. Eso no significa necesariamente que sea el estudio el que determina la técnica que utiliza el traductor; bien podría significar que el canal, la distribuidora o los responsables de la serie en sí han determinado las normas que regirán el encargo de traducción, como comentaban los entrevistados. O podría tratarse simplemente de una elección personal del traductor, siempre y cuando sea la misma persona la que tradujo los tres episodios de cada una de las series escogidas (algo que no siempre podemos comprobar dado que no todos los responsables de la traducción figuran en los créditos finales). 


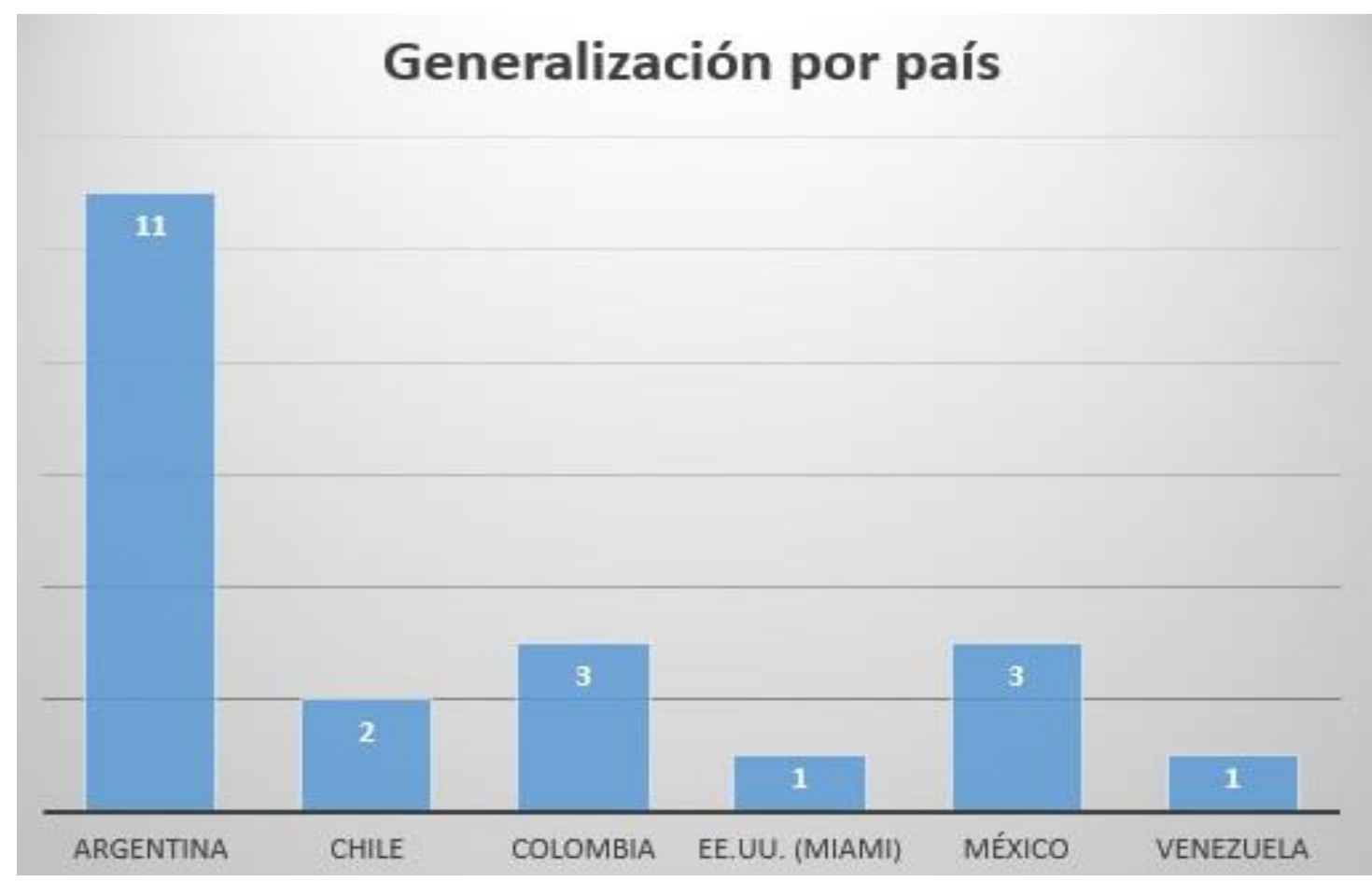

Tabla 43 - Generalización por país, en número de casos

Nuevamente Argentina se destaca por utilizar la técnica de generalización el doble de veces que Colombia y México (6:3), y mucho más que los demás países (6:2 y 6:1). Es posible que los profesionales del doblaje en Argentina tal vez sean demasiado conscientes de que el español argentino es muy distinto del resto de las variedades de español en Latinoamérica, y que por lo tanto exageren en el uso de la generalización para no ser tildados de "localistas". Por ejemplo, en el corpus aparecen casos de doblaje argentino donde se usan términos como "ropa" para no elegir una de las tantas palabras españolas que son la traducción de bra, ya que la traducción argentina, "corpiño", podría no entenderse en otros países. Esta tradición de generalizar probablemente provenga de las traducciones literarias, pero no se puede aplicar el mismo criterio en las traducciones escritas que en las audiovisuales, porque no podemos perder de vista el hecho de que la palabra a menudo viene acompañada de un contexto visual además del lingüístico. 


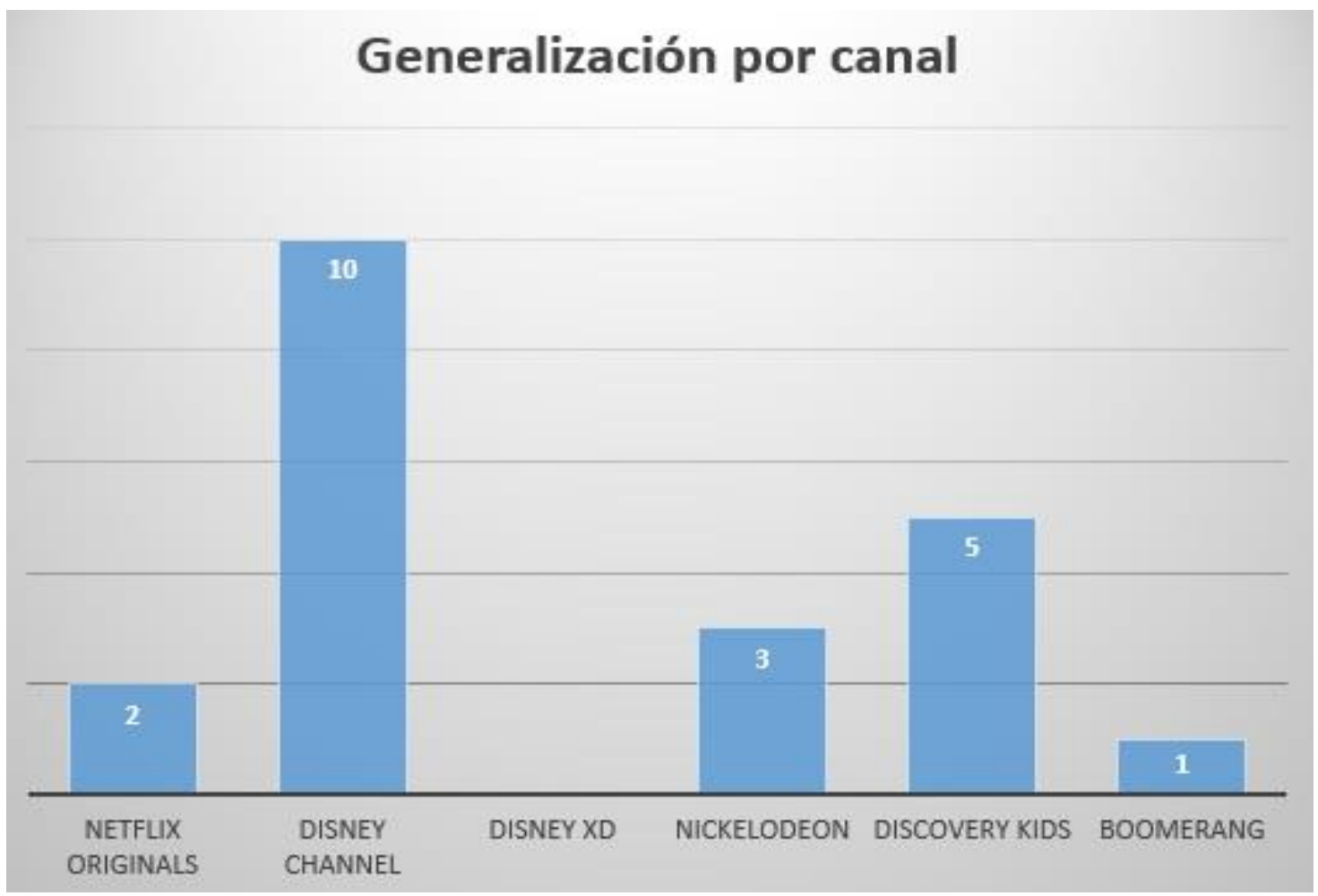

Tabla 44 - Generalización por canal, en números de casos

Si observamos las diferencias por canal, veremos que Discovery Kids también tiene una tasa relativamente alta de generalización, quizá porque sus contenidos son para niños más pequeños. En futuras investigaciones se debería analizar si existen diferencias léxicas aun dentro de la categoría "doblaje de material infantil", dado que no es lo mismo un niño pequeño que uno de más edad. También es notoria la diferencia entre Disney Channel y Disney XD, lo que sugiere, otra vez, que los contenidos y el público meta pueden definir las estrategias y técnicas de traducción.

\section{vi. Comentarios del análisis}

En cuanto a las demás técnicas de traducción analizadas (explicitación, creación discursiva, calco, particularización y equivalente acuñado), los resultados no varían significativamente entre países, estudios o canales. Sin embargo, sí existe una mayor cantidad de casos de creación discursiva en un programa que en otros, y en general están relacionadas con eliminar palabras tabú, como suckers, butt o death, y con alimentos. También resulta lógico que haya una razonable cantidad de casos de explicitación y equivalentes acuñados, dado que se trata de programas para niños.

En las siguientes tablas podemos ver los casos hallados en el corpus según la serie, el estudio, el país y el canal: 


\section{EXPLICITACIÓN}

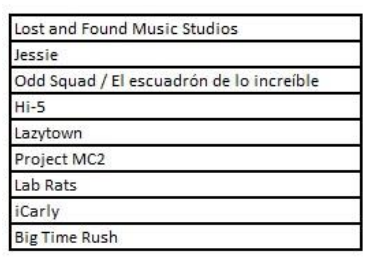

\begin{tabular}{|l|}
\hline Argentina 1 \\
\hline Argentina 2 \\
\hline Colombia \\
\hline Chile \\
\hline EE.UU. (Miami) \\
\hline México 1 \\
México 2 \\
\hline México 3 \\
México 4 \\
\hline México 5 \\
\hline Venezuela \\
\hline
\end{tabular}

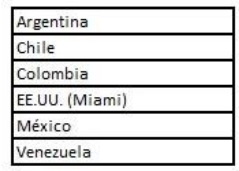

Netflix originals

Disney Channel

Disney XD

Nickelodeon

Discovery Kids

Boomerang

Venezuela

\section{CREACIÓN DISCURSIVA}

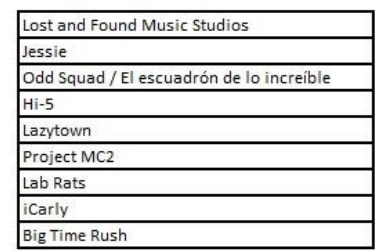

\begin{tabular}{|c|}
\hline Argentina 1 \\
\hline \begin{tabular}{|l|} 
Argentina 2 \\
\end{tabular} \\
\hline $\begin{array}{l}\text { Colombia } \\
\end{array}$ \\
\hline Chile \\
\hline EE.UU. (Miami) \\
\hline \begin{tabular}{|l|} 
México 1 \\
\end{tabular} \\
\hline México 2 \\
\hline México 3 \\
\hline México 4 \\
\hline México 5 \\
\hline
\end{tabular}

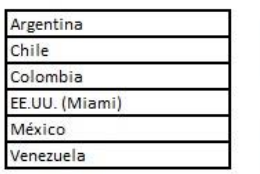

\begin{tabular}{|l|}
\hline Netflix originals \\
\hline Disney Channel \\
\hline Disney XD \\
\hline Nickelodeon \\
\hline Discovery Kids \\
\hline Boomerang \\
\hline
\end{tabular}

Big Time Rush

Venezuela

\section{CALCO}

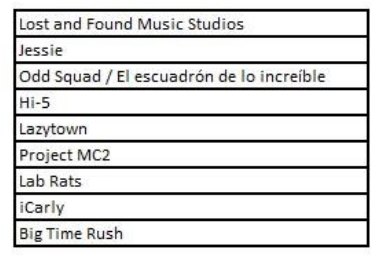

\begin{tabular}{|l|}
\hline Argentina 1 \\
\hline Argentina 2 \\
\hline Colombia \\
\hline Chile \\
\hline EE.UU. (Miami) \\
\hline México 1 \\
México 2 \\
\hline México 3 \\
México 4 \\
\hline México 5 \\
\hline Venezuela \\
\hline
\end{tabular}

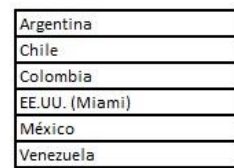

\begin{tabular}{|l|}
\hline Netflix originals \\
\hline Disney Channel \\
\hline Disney XD \\
\hline Nickelodeon \\
\hline Discovery Kids \\
\hline Boomerang \\
\hline
\end{tabular}
1

Boomerang

\section{PARTICULARIZACIÓN}

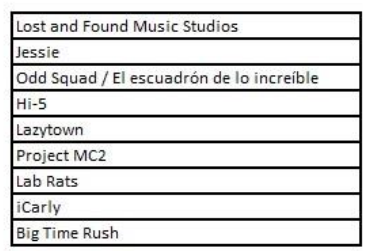

\begin{tabular}{|l|}
\hline Argentina 1 \\
\hline Argentina 2 \\
\hline Colombia \\
\hline Chile \\
\hline EE.UU. (Miami) \\
\hline México 1 \\
México 22 \\
\hline México 3 \\
México 4 \\
\hline México 5 \\
\hline Venezuela \\
\hline
\end{tabular}
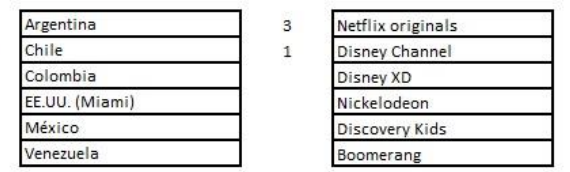

\section{EQUIVALENTE ACUÑADO}

\begin{tabular}{|l|}
\hline Lost and Found Music Studios \\
\hline Jessie \\
\hline Odd Squad / El escuadrón de lo increíble \\
\hline Hi-5 \\
\hline Lazytown \\
\hline Project MC2 \\
\hline Lab Rats \\
\hline iCarly \\
\hline Big Time Rush \\
\hline
\end{tabular}

\begin{tabular}{|l|}
\hline Argentina 1 \\
\hline Argentina 2 \\
\hline Colombia \\
\hline Chile \\
\hline EE.UU. (Miami) \\
\hline México 1 \\
México 2 \\
\hline México 3 \\
México 4 \\
\hline México 5 \\
\hline Venezuela \\
\hline
\end{tabular}
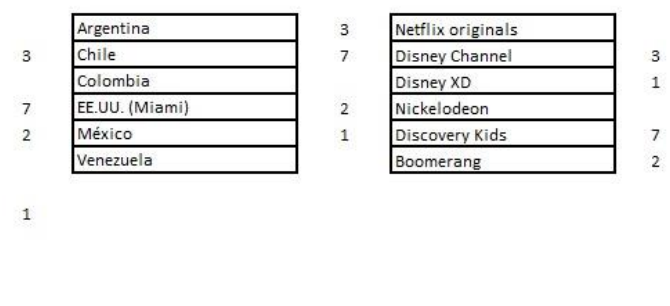

Tabla 45 - Otras técnicas por serie, estudio, país y canal, en número de casos 
Por otro lado, es necesario considerar la diferencia entre una serie y otra. Si bien todas son series infantojuveniles, al tener distintas temáticas, pueden aparecer más términos de alguno de los buscados que en otras. Por ejemplo, como dijimos anteriormente, Project $M C 2$ contiene mucha terminología relacionada con la tecnología porque las protagonistas son espías, pero también contiene muchas palabras asociadas a la comida porque una de las chicas tiene un café y es chef. Eso podría justificar la aparición de una cantidad importante de préstamos o generalizaciones en ciertas series, pero no explica el uso de la modulación (principalmente en forma de metonimia) en otras. Por lo tanto, agruparemos los términos que corresponden a las categorías mencionadas anteriormente, según la clasificación ofrecida en el capítulo 4 y 6.1. (palabras, tabú, vestimenta, etc.) para analizarlos.

\subsubsection{Palabras tabú u ofensivas}

Si bien no apareció ninguna palabra estrictamente tabú o soez, justamente por tratarse de contenido infantojuvenil, sí se encontraron, sin embargo, palabras como idiot, stupid, turd o butt, y también algunos términos ligeramente despectivos como nerd o geek.

En el caso de turd, que entre todos esos términos resulta el más vulgar, se lo tradujo como "cerdo" en el doblaje venezolano (2009).

Para los términos idiot, stupid y jerk, las opciones más comunes, compartidas en los distintos doblajes, fueron "torpe" y mayoritariamente "tonto", que no son tan impactantes como el ocasional "estúpido", "idiota" o "cretino". Las traducciones literales se correspondieron con los insultos más suaves en inglés, como dumb o goofy.

En una escala del más suave al más fuerte, los términos utilizados en las traducciones de idiot, stupid y jerk fueron los siguientes:

\begin{tabular}{|l|l|l|}
\hline \multicolumn{1}{|c|}{ Traducción } & \multicolumn{1}{c|}{ País } & Año \\
\hline (Omisión)(1) & Argentina & 2014 \\
\hline Ridículo (1) & Argentina & 2014 \\
\hline \multirow{4}{*}{ Tonto (5) } & México & 2007 \\
\cline { 2 - 3 } & Venezuela & 2009 \\
\cline { 2 - 3 } & México & 2010 \\
\cline { 2 - 3 } & México & 2012 \\
\cline { 2 - 3 } & Argentina & 2014 \\
\hline \multirow{5}{*}{ Torpe (2) } & Venezuela & 2009 \\
\cline { 2 - 3 } & Argentina & 2014 \\
\hline Cretino (1) & Venezuela & 2009 \\
\hline Estúpido (1) & México & 2007 \\
\hline Idiota (2) & Venezuela & 2009 \\
\cline { 2 - 3 } & México & 2016 \\
\hline
\end{tabular}

Tabla 46 - Otras técnicas por serie, estudio, país y canal, en número de casos 
Como se ve, Argentina es el país que utiliza las versiones más "suavizadas", mientras que Venezuela utiliza la mayor gama de opciones. Tampoco se puede sostener que estas elecciones tengan que ver con una mayor corrección política en estos últimos años, dado que el término "idiota" aparece tanto en 2009 como en 2016.

El uso de préstamos del inglés que son despectivos parece haberse modificado con el tiempo. En el mismo programa con doblaje mexicano se tradujo la palabra "geek" en 2010 pero se utilizó el préstamo "nerd" en 2012. Esto sugiere que tal vez exista una tendencia a utilizar más préstamos a medida que van resultado más conocidos para el público latinoamericano.

En cuanto a las palabras butt y booty, se las tradujo como "trasero" o se las omitió en igual cantidad, a pesar de que "trasero" no es un término vulgar en español, sino más bien coloquial. Por otro lado, la palabra "bubis" es un préstamo naturalizado de boobs, y es un término regional. En cambio, la expresión "popó" como traducción de boom boom parece la opción más neutra para ese concepto, ya que es la que solemos ver en los doblajes.

En el caso de las palabras relacionadas con la muerte o con agresión se recurrió frecuentemente a la modulación (y también a la omisión y a la traducción literal).

\begin{tabular}{|l|l|l|l|}
\hline \multicolumn{1}{|c|}{$\begin{array}{c}\text { Término } \\
\text { en inglés }\end{array}$} & \multicolumn{1}{c|}{ Praducción } & Año \\
\hline Murder & (Omisión) & Argentina & 2014 \\
\hline Corpse & Víctima / sin vida / cuerpo & Argentina & 2014 \\
\hline Die & Terminar mis días & Argentina & 2014 \\
\hline \multirow{2}{*}{ Death } & Muerte & Argentina & 2011 \\
\cline { 2 - 4 } & (Omisión) & Argentina & 2014 \\
\hline \multirow{2}{*}{ Kill } & Matar & Venezuela & 2009 \\
\cline { 3 - 4 } & & México & 2010 \\
\cline { 3 - 4 } & & México & 2015 \\
\cline { 3 - 4 } & & Colombia & 2015 \\
\hline Stab & Pelear & México & 2012 \\
\hline
\end{tabular}

Tabla 47 - Traducciones de palabras relacionadas con los conceptos de muerte o agresión

En este caso vuelve a notarse la diferencia en las traducciones argentinas entre $2011 \mathrm{y}$ 2014. México, Venezuela y Colombia no parecen tener problema en utilizar la palabra "matar" entre 2009 y 2015. La única excepción es la de la palabra stab, modulada como "pelear". Este ejemplo podría confirmar la influencia de los canales, dado que se trata del mismo canal de las traducciones argentinas. Obviamente, no es posible generalizar ni buscar tendencias o representatividad con un corpus tan pequeño, y sin un estudio verdaderamente longitudinal. 
Es interesante mencionar que, en este sentido, lo que ocurre en Argentina es similar a lo que ocurre en Italia. ${ }^{153}$ Parini (2012) comenta un fenómeno similar con la traducción de anime, y Ranzato (2016) señala que Disney pide a sus adaptadores italianos que no utilicen groserías, expresiones irrespetuosas o racistas, bromas sobre sacerdotes o la Iglesia, exclamaciones como: “Dios mío!”, términos como “estúpido” o “idiota” o nombres de marcas muy conocidas (Coca-Cola, PlayStation, marcas de cigarrillos, etc.), y que eviten la palabra "muerte" y otras palabra relacionadas con ese concepto. ${ }^{154}$

\begin{tabular}{c|c|c|c|c|c|c|c|c|}
\hline CONCEPTO TABÚ & TRADUCCIÓN LITERAL & EQUIVALENTEACUÑADO & MODULACIÓN & OMIIIÓN & GENERALIZACIÓN & VARIACIÓN & CRECIÓN DISCURSIVA & PRÉSTAMO \\
\hline Muerte/ Agresión & 7 & & 4 & 2 & & 3 & 1 & \\
\hline Insultos & 11 & & & 2 & & 12 & 4 & 3 \\
\hline Religión/Festividades & 3 & 7 & 1 & 5 & 5 & & 1 & 4 \\
\hline Partes/funciones del cuerpo & 6 & 1 & & 1 & 1 & 2 & 1 & 2 \\
\hline
\end{tabular}

Tabla 48 -Técnicas utilizadas para los conceptos tabú (en casos) según el campo semántico

Como se ve claramente en la tabla anterior, la cantidad de traducciones literales o equivalentes acuñados, a excepción del caso de las partes y funciones del cuerpo, es menor que la suma de las soluciones que suavizan el texto o lo censuran (modulación, omisión, generalización, variación y creación discursiva). Por ejemplo, en el caso de los insultos, contamos 11 traducciones literales frente a un total de 18 instancias de técnicas asociadas a la censura (12 variaciones, 2 omisiones y 4 creaciones discursivas).

\begin{tabular}{|c|c|c|}
\hline CONCEPTO TABÚ & $\begin{array}{c}\text { TÉCNICAS DE } \\
\text { ESTANDARIZACIÓN }\end{array}$ & $\begin{array}{c}\text { TÉCNICAS ASOCIADAS } \\
\text { A LA CENSURA }\end{array}$ \\
\hline Muerte / Agresión & 7 & 10 \\
\hline Insultos & 11 & 18 \\
\hline Religión / festividades & 10 & 12 \\
\hline $\begin{array}{c}\text { Partes / funciones } \\
\text { del cuerpo }\end{array}$ & 7 & 5 \\
\hline
\end{tabular}

Tabla 49 - Técnicas utilizadas para los conceptos tabú (en casos), según su relación con la estandarización y la censura

153 Se estima que entre un $40 \%$ y $50 \%$ de la población argentina desciende de italianos, y la religión mayoritaria en el país es la católica.

154 Serena Paccagnella, la adaptadora de Disney (Ranzato, 2016), comenta que Disney es una empresa muy cuidadosa de no herir la sensibilidad de nadie. 


\subsubsection{Referencias religiosas y culturales (culturemas)}

Los culturemas suelen presentar un dilema para el traductor, porque debe decidir qué tan conocidos son en la cultura meta y en base a eso mantenerlos o adaptarlos. Tanto en España como en México, muchos televidentes ven con buenos ojos la adaptación a su cultura. En Twitter existen numerosos hilos con comentarios de espectadores a favor de estos cambios de referencias culturales estadounidenses por referencias locales.

En los casos de nuestro corpus, en la mayoría de las traducciones se mantuvieron las referencias culturales como Halloween, Luau o el Día de San Patricio, e incluso nombres de productos como Winnebago (que ciertamente no es un nombre familiar en toda Latinoamérica). Sin embargo, esto no ocurrió con muchas de las referencias al cristianismo. ${ }^{155} \mathrm{Si}$ bien se mantuvieron algunos conceptos religiosos, como Pascua (Chile 2010 y Argentina 2011) o Satán (Venezuela 2009), otros desaparecen en algunas traducciones, principalmente el nombrar a Dios o la festividad de la Navidad. Esta tendencia fue confirmada por los encuestados (véase 6.1.) y también figura en artículos de sitios cristianos de Internet como el de ACI Prensa y en entrevistas con directores de doblaje. ${ }^{156}$

${ }^{155}$ En la actualidad, también se omiten referencias a otras religiones, como Janucá (Fiesta de las Luminarias). Las referencias religiosas no se omitían ni se modulaban en general antes del 2006. El doblaje de Barney's Christmas Star (Jim Rowley, 2002), por ejemplo, mencionaba la Navidad y todo lo asociado a ella, como el árbol, y también festividades de otras religiones, como Jánuca con su dréidel o Kwanzaa con su típico candelabro.

156 “En Disney está prohibida la palabra 'Dios', admiten compositores de música de Frozen”, Redacción ACI Prensa/EWTN Noticias, 25 de abril de 2014 (https://www.aciprensa.com/noticias/en-disneyesta-prohibida-la-palabra-dios-admiten-compositores-de-musica-de-frozen-62933, consultado el 2 de mayo de 2018). "En el caso de Disney puntualmente, hay un departamento que se llama 'Compliance'. Ellos son los que supervisan previamente todas las letras de las canciones. Hay palabras que no se pueden utilizar, como por ejemplo 'Dios' (consideran que es una falta de respeto nombrarlo en vano y a cada rato), 'pisar' (tiene connotaciones sexuales: el gallo pisa a la gallina), y obviamente ninguna clase de insultos". (Irene Guiser, entrevistada por Sebastián Arias en http://doblajeenargentina.blogspot.com.ar) 


\begin{tabular}{|c|c|c|c|}
\hline $\begin{array}{l}\text { Término } \\
\text { en inglés }\end{array}$ & Traducción & País & Año \\
\hline \multirow[t]{2}{*}{ Easter } & \multirow{2}{*}{$\begin{array}{l}\text { Pascua (huevos de) } \\
\text { Pascua (conejo de) }\end{array}$} & Chile & 2010 \\
\hline & & Argentina & 2011 \\
\hline \multirow[t]{3}{*}{ Santa } & \multirow[t]{3}{*}{ Santa $^{157}$} & Chile & 2010 \\
\hline & & Argentina & 2011 \\
\hline & & Argentina & 2014 \\
\hline \multirow[t]{5}{*}{ Christmas } & \multirow[t]{2}{*}{ Navidad (equivalente acuñado) } & Chile & 2010 \\
\hline & & Argentina & 2011 \\
\hline & (Omisión) & Argentina & 2014 \\
\hline & Fiestas & Argentina & 2014 \\
\hline & 24 de diciembre & Argentina & 2014 \\
\hline \multirow[t]{2}{*}{ Miracle } & Milagro & Argentina & 2011 \\
\hline & (Omisión) & Argentina & 2014 \\
\hline \multirow[t]{6}{*}{ God } & \multirow[t]{4}{*}{ Dios } & México & 2007 \\
\hline & & Argentina & 2011 \\
\hline & & Colombia & 2014 \\
\hline & & Argentina & 2016 (estudio 1) \\
\hline & (Omisión) & Argentina & 2014 (estudio 2) \\
\hline & ¡Ay, por Dios! (Come on! en inglés) & México & 2010 \\
\hline Rock & Adorar & México & 2012 \\
\hline
\end{tabular}

Tabla 50 - Traducciones de algunas referencias religiosas

En esta tabla se ve claramente que en Argentina hubo un cambio entre 2011 y 2014 respecto del uso de "Dios" y "Navidad", que se nota en la utilización de omisiones y de modulaciones como "24 de diciembre" y "Fiestas" en las traducciones. Sin embargo, dicho cambio solo se dio en uno de los estudios, dado que el otro utilizó la palabra "Dios" en 2016.

\begin{tabular}{|c|c|c|c|c|c|c|c|c|}
\hline CONCEPTO TABÚ & TRADUCCIÓN LITERAL & EQUIVALENTEACUÑAD & MODULACIÓN & OMIIIÓN & GENERALIZACIÓN & VARIACIÓN & CRECIÓN DISCURSIVA & PRÉSTAMO \\
\hline Religión/ Festividades & 3 & 7 & 1 & 5 & 5 & & 1 & 4 \\
\hline
\end{tabular}

Tabla 51 - Técnicas utilizadas para los conceptos religiosos (en casos)

Es importante remarcar aquí el hecho de que la cantidad de omisiones es igual a la cantidad de traducciones literales. Si a eso le sumamos las modulaciones y generalizaciones, está claro que se tiende a suprimir de algún modo las referencias religiosas. Los préstamos se utilizaron solo para nombrar a Santa Claus (Santa).

${ }^{157}$ En este caso, el préstamo evita los regionalismos como "Viejito Pascuero" o "Papá Noel". 
Para intentar determinar si esta tendencia a no incluir la referencia a la Navidad era común como habían sugerido los entrevistados y habíamos visto en la teoría (ya que en nuestro corpus solo había aparecido en un episodio), se visualizaron los episodios de Navidad de las series del corpus y de otras series infantojuveniles no animadas. Como se ve en la tabla siguiente, algunos estudios dejaron de utilizar las referencias navideñas en programas del mismo canal, pero de años posteriores, y otros utilizaron las referencias en unos programas y en otros no (pero esto también fue en años posteriores). Se podría suponer que el requisito de quitar las referencias no fue decisión del traductor (aunque fueran distintos) porque cualquiera de los agentes del proceso de doblaje que realizan un trabajo posterior a la traducción (revisor, supervisor, director, etc.) podría haber modificado el texto e incluir nuevamente las referencias.

\begin{tabular}{|c|c|c|c|c|c|}
\hline SERIE & $\begin{array}{c}\text { AÑOS DE } \\
\text { EMISIÓN } \\
\text { ORIGINAL }\end{array}$ & CANAL & DOBLAJE & PAÍS & $\begin{array}{c}\text { ¿INCLUYE } \\
\text { REFERENCIAS } \\
\text { NAVIDEÑAS? }\end{array}$ \\
\hline Hi-5 & $2009-2012$ & $\begin{array}{l}\text { Discovery } \\
\text { Kids }\end{array}$ & DINT & Chile & Sí \\
\hline Lazytown & $2006-2014$ & Boomerang & The Kitchen & Miami & Sí \\
\hline $\begin{array}{l}\text { The Suite Life } \\
\text { on Deck }\end{array}$ & $2008-2011$ & Disney & $\begin{array}{l}\text { Diseño en } \\
\text { Audio }\end{array}$ & México & $\begin{array}{c}\text { Sí (episodio de } \\
\text { 2008) }\end{array}$ \\
\hline $\begin{array}{l}\text { K.C. } \\
\text { Undercover }\end{array}$ & $2015-2018$ & Disney & $\begin{array}{l}\text { Diseño en } \\
\text { Audio }\end{array}$ & México & $\begin{array}{c}\text { No (episodio } \\
\text { de 2015) }\end{array}$ \\
\hline $\begin{array}{l}\text { Big Time } \\
\text { Rush }\end{array}$ & $2009-2013$ & Nickelodeon & $\begin{array}{l}\text { Etcétera } \\
\text { Group }\end{array}$ & Venezuela & Sí \\
\hline A.N.T. Farm & $2011-2014$ & Disney & $\begin{array}{l}\text { Media Pro } \\
\text { Com }\end{array}$ & Argentina & $\begin{array}{l}\text { Sí (episodio } \\
\text { de 2013) }\end{array}$ \\
\hline Jessie & $2011-2015$ & Disney & $\begin{array}{l}\text { Media Pro } \\
\text { Com }\end{array}$ & Argentina & $\begin{array}{l}\text { Sí (episodio } \\
\text { de 2011) } \\
\text { No (episodio } \\
\text { de 2014) }\end{array}$ \\
\hline $\begin{array}{l}\text { Some } \\
\text { Assembly } \\
\text { Required }\end{array}$ & $2014-2018$ & Netflix & $\begin{array}{l}\text { SDI Media } \\
\text { México }\end{array}$ & México & Sí \\
\hline Odd Squad & $\begin{array}{l}2014- \\
\text { presente }\end{array}$ & Netflix & Centauro & Colombia & Sí \\
\hline Henry Danger & $\begin{array}{l}2014- \\
\text { presente }\end{array}$ & Nickelodeon & Sebastians & México & Sí \\
\hline Fuller House & $\begin{array}{l}2016- \\
\text { presente }\end{array}$ & Netflix & $\begin{array}{l}\text { Polaco } \\
\text { Audio } \\
\text { Studio } \\
\end{array}$ & Argentina & Sí \\
\hline Nailed it! & $\begin{array}{l}2018 \text { - } \\
\text { presente }\end{array}$ & Netflix & $\begin{array}{l}\text { SDI Media } \\
\text { México }\end{array}$ & México & Sí \\
\hline
\end{tabular}

Tabla 52 - Programas doblados con referencias navideñas y sin ellas 
La discrepancia entre un estudio o país y otro queda bien clara si analizamos uno de los típicos episodios crossover de Disney. Los episodios crossover, en los que se cruzan personajes de una y otra serie, suelen tener doblajes colaborativos, ya que a menudo las series son dobladas en distintos estudios. En el episodio crossover de Navidad de Jessie y Buena suerte, Charlie de 2013 (Disney Channel, 2010-2014), la palabra "Christmas" se convierte en "Fiestas" cuando el personaje que habla está doblado en Argentina, pero es "Navidad" cuando el personaje está doblado en México. Este mismo estudio mexicano (Diseño en Audio) dejó de utilizar la palabra Navidad con posterioridad en sus doblajes. Es decir, dos estudios estaban doblando el mismo episodio de una serie, pero cada uno usó un término diferente para el mismo concepto. Esto podría sugerir que la censura al término "Navidad" se inició en Argentina y pasó luego a México. Asimismo, resulta sugestivo el hecho de que el decreto 933/2013 que reguló la antigua ley del doblaje se haya firmado en julio de ese mismo año en Argentina.

También se investigó y comprobó que las mismas series en las que no se utilizan términos navideños en español latino sí los incluyen en su doblaje francés, italiano, portugués (de Brasil) y español peninsular, y hasta en la versión de la India (Oye Jassie). Y llama la atención que las publicidades navideñas de los canales Disney y Nickelodeon de principios de la década de 2010 nombraban la Navidad, pero la publicidad de 2017 de Kally's Mashup, de Nickelodeon en coproducción con un canal argentino, habla de "Felices Fiestas". Esto sugiere que la omisión de los términos navideños en los doblajes infantiles podría ser un fenómeno exclusivo de Latinoamérica.

Sabemos que los factores ideológicos tienen injerencia en el léxico elegido y las técnicas utilizadas. La omisión de la palabra "Dios", por ejemplo, podría entenderse como un intento de no ofender a nadie evitando un concepto religioso. Pero la Navidad con el sentido en que se la suele utilizar (con Santa Claus, los regalos, etc.) no es estrictamente cristiana sino pagana. ¿Por qué no quitar toda referencia a cualquier religión, entonces? ${ }^{158}$ En 2010, Di Giovanni se preguntaba si el uso de un registro más formal en las traducciones para niños "has its roots in a Catholic-driven socio-cultural attitude" (en Italia, pero puede aplicarse a Latinoamérica también, dado que la mayoría de la población latinoamericana es cristiana). ${ }^{159}$ Sin embargo, también en Italia, el país que alberga al

158 También ha habido recientemente un relativo incremento de las referencias a la religión judía en algunos programas infantojuveniles de Disney, con frases como our little blond gefilte fish, my Little matzo balls o Mazel tov (Bizaardvark, Josh Lehrman y Kyle Stegina, temporada 2018), tal vez para hacer los textos más inclusivos. Y el doblador Alejandro Graue planteaba en la jornada Las distintas voces del doblaje que "censuran el cristianismo pero no el Bar Mitzvah", http://tavargentina.com/2016/11/doblaje-jornada-taller/(consultado el 12 de abril de 2019). Sin embargo, en nuestro corpus desaparece un Oi! de la versión latina de iCarly de 2010, cuyo doblaje no fue realizado por los estudios que quitaron las referencias a la Navidad.

159 Prácticamente un $80 \%$ de la población de Latinoamérica es cristiana (60\% de católicos y $19 \%$ de protestantes), frente a un $51 \%$ de población protestante en Estados Unidos. (El papa Francisco y la religión en Chile y América Latina, Latinobarómetro.org; 
Vaticano, pero en 2017, algunas escuelas decidieron cancelar pesebres, villancicos y actos navideños, e incluso llegaron a censurar la palabra "Navidad" para evitar "malestar en niños no católicos", ${ }^{160}$ decisión que -además de causar el enojo de los padres de las escuelas- es consistente con la tendencia a hacer lo mismo en los doblajes de los programas infantojuveniles. Esta tendencia podría ser la consecuencia de una ola antiNavidad que surgió a principios o mediados de los años $2000^{161}$ y que llegó más tarde a los países más católicos, como vimos en el ejemplo de Italia, y que podría estar detrás del fenómeno de no mencionar la Navidad en algunos doblajes, a pesar de que es extraño, como mencionamos antes, que este fenómeno se dé solo en el doblaje latinoamericano.

El alto perfil de ciertos canales, plataformas o contenidos (y por lo tanto su mayor exposición a las críticas del público en las redes sociales) y la importancia que cobró la corrección política en los últimos años podrían ser la razón detrás de la utilización de las omisiones, o la modulación en los casos de términos problemáticos como los relacionados con la religión o la agresión, más allá de que sepamos que algunos canales no quieren utilizarlos para no herir sensibilidades. El director de doblaje Sebastián Arias criticó "la corrección política con calzador" en el doblaje de Toy Story 4 en su cuenta de Twitter. Y los críticos de cine Javier Porta Fouz y Santiago García hicieron alusión a cómo se adaptan los productos audiovisuales (en este caso, una película para niños) a "los discursos de la época" y resaltan la importancia actual que se le da a la opinión del público:

"A este cine ya no lo hacen personas; lo hacen, como nunca antes, unas corporaciones [...] que dicen lo que suponen $-\mathrm{y}$ hacen estudios y estudios- que se quiere escuchar". (Porta Fouz, 2019)

"Forky surge por ser un juguete creado por una nena y no un juguete de fabricación industrial. Un guiño 'progre' frente los reclamos que ha sufrido la saga con respecto a ese tema y que en otra época hubieran sido simplemente ignorados. [...] Más el toque feminista que todos los films industriales agregan -no siempre con sinceridad- en los últimos dos o tres años”. (García, 2019)

http://www.cooperativa.cl/noticias/site/artic/20180112/asocfile/20180112124342/f00006494 religi on chile america latina 2017.pdf, consultado el 28 de septiembre de 2018)

160 Piqué, E. (2017): “Italia y una Navidad 'políticamente correcta' que exacerba los ánimos”, en La Nación, 14 de diciembre de 2017

161 John Gibson cuenta en su libro The War on Christmas (2005) que en algunas escuelas de Estados Unidos celebraban Jánuca y Kwanzaa, pero no la Navidad, y que habían rebautizado al Christmas tree como Friendship tree. 
Sebastián Arias@doblajearias.Jul 4

Leo críticas antes y después de ver una película y me fascina cuando fesan y

fundamentan las sensaciones que viví. La falta de cohesión y la corrección política

con calzador son ideas de esta nota con las que estoy MUY de acuerdo.

asalallena.com.ar/cine/critica-t...de@JavierPortaFouz

(6) Translate Tweet

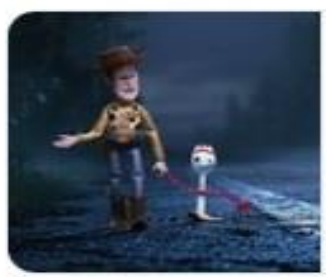

Critica: Toy Story 4, por Javier Porta Fouz - A Sala ...

(Estados Unidos, 2019) Dirección: Josh Cooley. Guion: Andrey Stanton, Stephany Folsom. Voces: Tom Hanks, Tim Allen, Annie Potts, Joan Cusack, Tony Hale. Músic.. asalallena.com.ar

Ilustración 39 - Comentario en Twitter sobre la corrección política en ocasión del estreno de Toy Story 4

Si tenemos en cuenta estos comentarios, y a eso le sumamos las campañas contra la Navidad, como las quejas por los dibujos de los vasos de café navideños en Starbucks, que ya llevan varios años (Stack, 2017), resulta lógico pensar que tal vez la desaparición de los términos navideños y religiosos de algunos doblajes se deba a la actitud proactiva del público respecto de lo que considera políticamente correcto.

¿Pero se puede considerar el eliminar las referencias culturales y religiosas como un caso de corrección política? "The aim of watching TV is not only being entertained but also learning [...]", sosteníamos en un trabajo anterior (Scandura, 2004), en especial si se trata de niños. Pero, a veces, lo que algunos agentes consideran "no discriminación" puede causar el efecto contrario, ya que es necesario conocer al otro para no discriminarlo. Puurtinen (1998) asevera que los textos para niños tienen como fin el entretenimiento, el desarrollo de habilidades lingüísticas, la socialización y la adquisición de conocimiento del mundo. Ciertamente, la omisión de culturemas obstaculiza que se puedan concretar esas finalidades.

\subsubsection{Alimentos}

Esta es una de las categorías que más problemas presenta, junto con la de vestimenta, como ya se había anticipado en el capítulo sobre español neutro, y la disparidad de criterios se pudo comprobar en nuestro corpus. 


\begin{tabular}{|c|c|c|c|}
\hline $\begin{array}{l}\text { TÉRMINO } \\
\text { EN INGLÉS }\end{array}$ & TRADUCCIÓN & TÉCNICA & VARIEDAD \\
\hline Bacon & Tocino & Traducción literal & Neutro \\
\hline Bagel & Bagel & Préstamo & Regional \\
\hline Bagels & Panecillos & Traducción literal & Neutro \\
\hline Banana & Banana & Traducción literal & Neutro \\
\hline Banana & Banana & Traducción literal & Neutro \\
\hline Bananas & Bananas & Traducción literal & Neutro \\
\hline Bananas & Bananas & Traducción literal & Neutro \\
\hline Berry & Frutos & Generalización & Neutro \\
\hline Brownies & Pastelillos & Generalización & Neutro \\
\hline Cake & Pastel & Traducción literal & Neutro \\
\hline Cake & Torta & Traducción literal & Regional \\
\hline Candy cane & Dulce & Generalización & Neutro \\
\hline Candy wrapper & Caramelo & Traducción literal & Neutro \\
\hline Caramel corn & Palomitas de caramelo & Traducción literal & Neutro \\
\hline Cheesy Curls & Pasabocas & Generalización & Regional \\
\hline Chewing gum & Chicle & Traducción literal & Regional \\
\hline Churro & Churro & Préstamo & Neutro \\
\hline Cookies & Galletas & Traducción literal & Neutro \\
\hline Crackers & Galletas & Generalización & Neutro \\
\hline Cupcake & Panquecito & Traducción literal & Regional \\
\hline Cupcake shop & Pastelería & Generalización & Neutro \\
\hline Donuts & Panecillos & Creación discursiva & Neutro \\
\hline Fries & Patatas & Traducción literal & Regional \\
\hline Fudge nut & Chocolate & Traducción literal & Neutro \\
\hline Gum & Goma de mascar & Traducción literal & Neutro \\
\hline Hard-boiled eggs & Huevos cocidos & Traducción literal & Neutro \\
\hline Hot dog & Perros calientes & Calco & Regional \\
\hline
\end{tabular}




\begin{tabular}{|l|l|l|l|}
\hline Ketchup & Salsa & Generalización & Neutro \\
\hline Ketchup & Salsa de tomate & Explicitación & Neutro \\
\hline Lollies & Caramelos & Explicitación & Regional \\
\hline Lollipop & Paleta & Traducción literal & Regional \\
\hline Lollipop & Paletita & Traducción literal & Regional \\
\hline Meatball sub & Sándwich de albóndiga & Generalización & Neutro \\
\hline Muffin & Muffin & Préstamo & Regional \\
\hline Muffin & Pastelillo & Generalización & Neutro \\
\hline Potato & Papas & Traducción literal & Neutro \\
\hline Sandwich & Sándwich & Préstamo & Neutro \\
\hline Smoothie & Batidos & Traducción literal & Neutro \\
\hline Smoothie & Sorbete & Traducción literal & Regional \\
\hline Smoothie & Malteadas & Creación discursiva & Regional \\
\hline Snacks & Pasabocas & Traducción literal & Regional \\
\hline Snacks & Bocadillos & Traducción literal & Neutro \\
\hline Steak & Conos de helado & Traducción literal & Neutro \\
\hline Waffle cones & & & Neutro \\
\hline
\end{tabular}

Tabla 53 - Técnicas utilizadas para la traducción de alimentos

Se encontraron distintas versiones para una misma palabra en inglés, y en general se utilizaron distintos términos en distintos países, pero incluso en algunos casos los estudios de un mismo país utilizaron vocablos diferentes. Estos son algunos ejemplos:

\begin{tabular}{|l|l|l|}
\hline \multicolumn{1}{|c|}{$\begin{array}{c}\text { Término } \\
\text { en inglés }\end{array}$} & \multicolumn{1}{c|}{ Traducción 1 } & \multicolumn{1}{c|}{ Traducción 2 } \\
\hline Potato & Papa (Colombia, 2015) & Patata (Argentina, 2016) \\
\hline Smoothie & Batido (Colombia, 2014) & Malteada (México 2012, Venezuela, 2011) \\
\hline Gum & Goma de mascar (Colombia 2014) & Chicle (Argentina, 2014) \\
\hline Snack & Pasabocas (Colombia, 2014) & Bocadillos (Argentina, 2016) \\
\hline Bagel & Panecillo (Colombia, 2014) & Bagel (México, 2007) \\
\hline Muffin & Muffin (México, 2016) & Pastelillo (Argentina, 2016) \\
\cline { 2 - 3 } & & Panquecito (México, 2007) \\
\hline Cake & Torta (Colombia, 2014) & Pastel (Chile, 2006) \\
\hline
\end{tabular}


En algunos casos se utilizaron las traducciones neutras usuales como "albóndiga", pero también se presentaron casos interesantes y hasta absurdos. El término "emparedado", por ejemplo, hace años que ya no se usa en el español neutro, y por lo tanto apareció en el corpus la palabra "sándwich". Sin embargo, también se encontró "perros calientes" como traducción para hot dogs, expresión que no es considerada neutra y que además podría ser malinterpretada por un niño pequeño (la traducción más usual en estos últimos años es "salchichas").

También se recurrió a la creación discursiva (steak = hamburguesas) y a la generalización (cupcake shop $=$ pastelería).

Un párrafo aparte merecen las referencias a panes y distintos tipos de comidas dulces horneadas. Para no usar algún término que pueda no comprenderse, los traductores con frecuencia recurren a dos palabras "neutras": panecillo y pastelillo. La palabra "panecillo" fue la traducción elegida tanto para bagels como para donuts, ambas versiones en un mismo episodio (doblaje colombiano, 2014) ${ }^{162}$. De la misma manera, la palabra "pastelillo" se utilizó tanto para brownies (México, 2012) como para muffin (Argentina, 2016). Siguiendo este criterio, sería imposible traducir frases como Would you like a brownie or a muffin? Incluso en un mismo episodio (doblaje mexicano, 2007) se dejó bagel como "bagel" y muffin como "panquecito". Podría tratarse de algún cambio posterior a la traducción, introducido por alguno de los agentes que intervienen en el proceso de doblaje, dado que resulta difícil suponer que el traductor decidió usar un préstamo en un caso y en el otro, no.

La técnica más utilizada fue la traducción literal (57\%), pero también hubo un número significativo de préstamos (9\%), y la generalización, la explicitación y la creación discursiva sumaron un 32\%. Estas técnicas borran el sabor local de la traducción.

162 En la misma traducción aparecen "perros calientes" y "pasabocas”, que son términos regionales. 


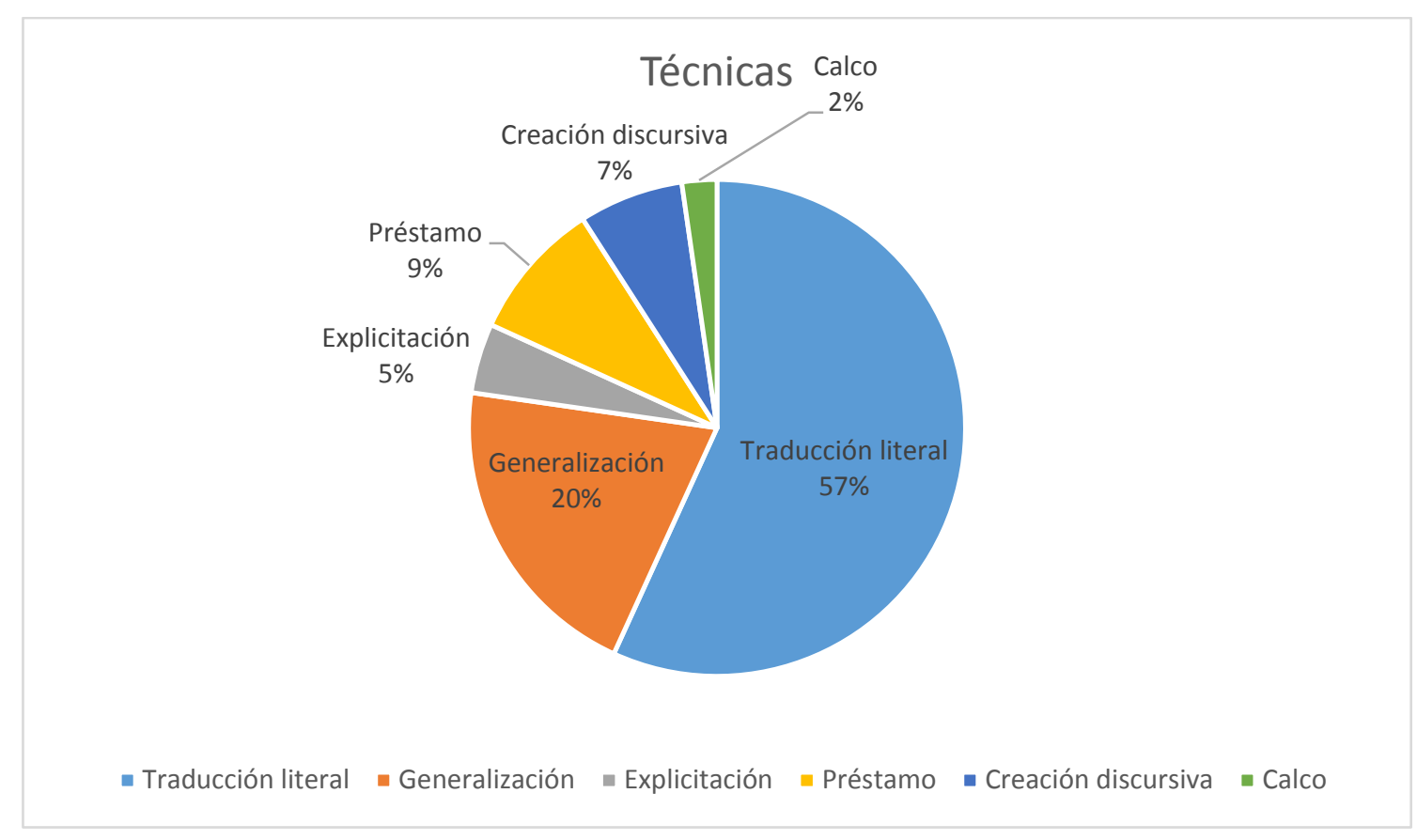

Ilustración 40 - Técnicas utilizadas para la traducción de alimentos (porcentajes)

\subsubsection{Vestimenta}

La vestimenta es otra de las categorías problemáticas en cuanto al neutro. Como ya hemos visto, la mayoría de las prendas reciben nombres muy diferentes en las distintas regiones. Esto se nota en las diferentes opciones para un mismo término, o en la generalización para no tener que elegir entre palabras que seguramente son regionales. 


\begin{tabular}{|l|l|l|l|}
\hline \multicolumn{1}{|c|}{ TÉRMINO } & \multicolumn{1}{|c|}{ TRADUCCIÓN } & \multicolumn{1}{c|}{ TÉCNICA } & \\
\hline Bra & & & \\
\hline Bra & Sostén & Traducción literal & Regional \\
\hline Bra & Sostén & Traducción literal & Regional \\
\hline Bra & Ropa & Generalización & Neutro \\
\hline Bra & Brassiere & Préstamo & Regional \\
\hline Sports bra & Brassiere & Préstamo & Regional \\
\hline Jeans & Ropa & Generalización & Neutro \\
\hline Shirt & Jean & Préstamo & Regional \\
\hline Sneakers & Camiseta & Traducción literal & Neutro \\
\hline Drawers & Piernas & Modulación & Neutro \\
\hline Robe & Calzoncillos & Traducción literal & Neutro \\
\hline Socks & Bata & Traducción literal & Neutro \\
\hline Socks & Medias & Traducción literal & Regional \\
\hline Stocking & Medias & Traducción literal & Regional \\
\hline
\end{tabular}

Tabla 55 - Técnicas de traducción de artículos de vestir

Aquí vemos de nuevo que las diferencias de términos no solo se dan entre países sino también entre estudios de un mismo país, como en el caso de bra en México:

\begin{tabular}{|l|l|l|l|}
\hline $\begin{array}{l}\text { Término } \\
\text { en inglés }\end{array}$ & \multicolumn{1}{|c|}{ Traducción 1 } & \multicolumn{1}{c|}{ Traducción 2 } & \multicolumn{1}{c|}{ Traducción 3 } \\
\hline Bra & $\begin{array}{l}\text { Brassiere (México, 2007 y } \\
\text { 2010) }\end{array}$ & $\begin{array}{l}\text { Sostén (Argentina, 2011; México, } \\
\text { 2012) }\end{array}$ & $\begin{array}{l}\text { Ropa (Argentina, } \\
\text { 2014) }\end{array}$ \\
\hline Sock & Calceta (Chile, 2010) & Media (Colombia, 2016) & \\
\hline
\end{tabular}

Tabla 56 - Traducciones de artículos de vestir 
Y también se aprecia que la técnica más utilizada es la traducción literal (57\%), que en este caso también se podría categorizar como equivalentes acuñados, y es un porcentaje muy similar al obtenido para las palabras relacionadas con alimentos, aunque con una significativa mayoría de regionalismos, mientras la suma de modulación y generalización representa un $21 \%$. Por otro lado, los préstamos (22\%) son numerosos, y eso podría deberse a que se utiliza la palabra en inglés para evitar usar un término regional ya que, debido a la gran cantidad de opciones de las distintas variedades, resulta imposible elegir un término neutro. Es muy posible que eso haya ocurrido también con la elección del préstamo como técnica para traducir nombres de alimentos.

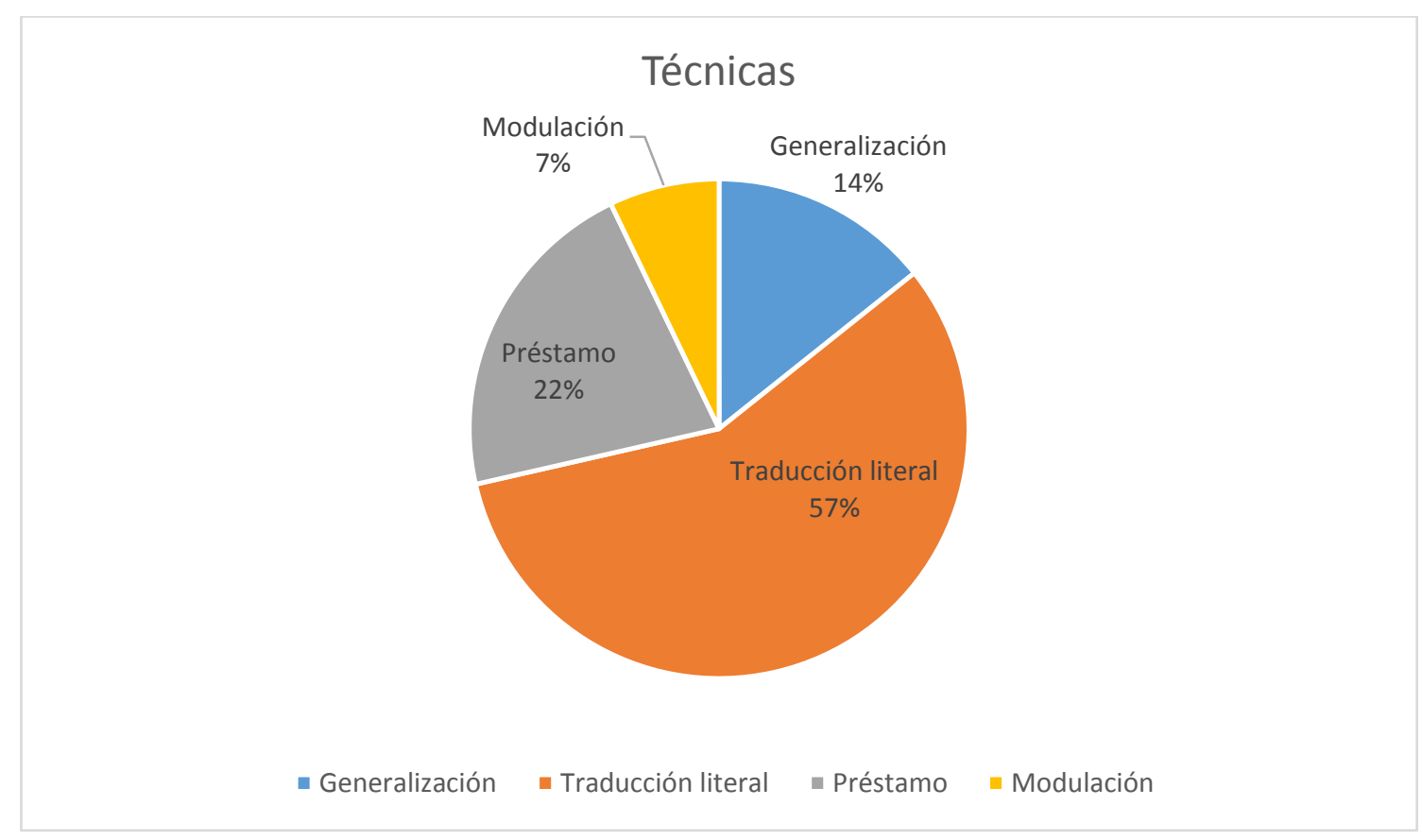

Ilustración 41 - Técnicas utilizadas para la traducción de vestimenta (porcentajes)

A pesar de que tanto la categoría de alimentos como la de ropa resultan conflictivas a la hora de traducir, es notoria la diferencia de elección entre términos neutros y regionales entre ambas. 


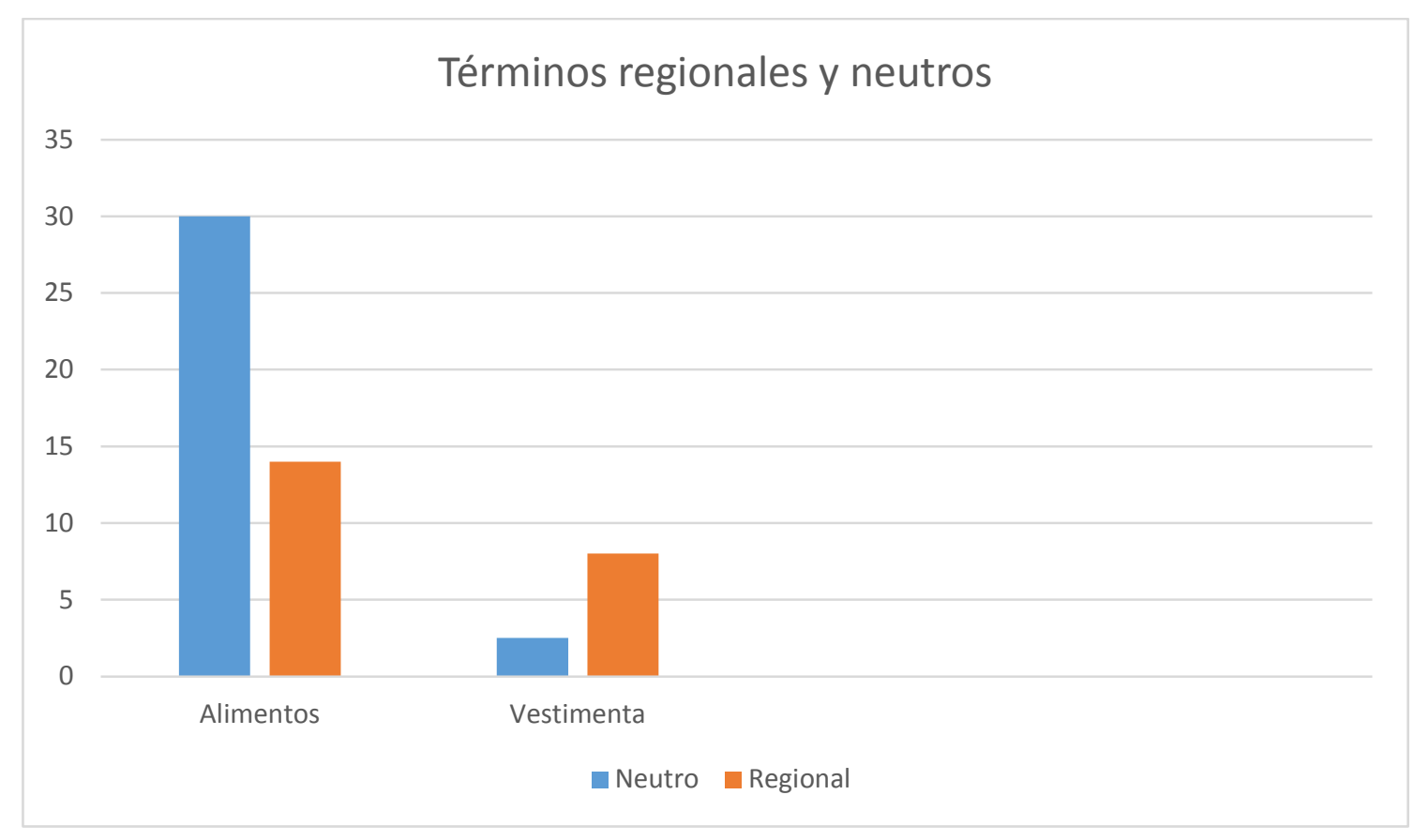

Tabla 57 - Términos regionales y neutros para traducir alimentos y vestimenta

\subsubsection{Neologismos relacionados con la tecnología}

En general, en el caso de los términos relacionados con la tecnología se suele recurrir a la técnica del préstamo. En el corpus aparecieron términos como hackear, trending o hashtag. No obstante, también aparecieron términos traducidos literalmente y como préstamo (tendencia-trending). Eso habla de cierta incoherencia en cuanto a la actitud frente a los neologismos asociados con las nuevas tecnologías, dado que en el mismo episodio se utilizan tres préstamos (hashtag, hack y trending) pero luego se utiliza una traducción literal, "odiosos", como traducción de haters. 


\begin{tabular}{|l|l|l|l|}
\hline \multicolumn{1}{|c|}{ TÉRMINO } & \multicolumn{1}{|c|}{ TRADUCCIÓN } & \multicolumn{1}{|c|}{ TÉCNICA } & \\
\hline Ear buds & & & \\
\hline Firewall & Audífonos & Traducción literal & Neutro \\
\hline Hacker & Protección & Traducción literal & Neutro \\
\hline Trending & Hacker & Préstamo & Neutro \\
\hline Trending & Tendencia & Traducción literal & Neutro \\
\hline Hashtag & Trending & Préstamo & Regional \\
\hline Haters & Hashtag & Préstamo & Neutro \\
\hline Hack & Odiosos & Traducción literal & Neutro \\
\hline
\end{tabular}

Tabla 58 - Traducción, técnica y variedad utilizada para traducir términos relacionados con la tecnología

En esta categoría se nota claramente la diferencia de criterios entre estudios, por ejemplo, en la serie Project MC2, de Netflix, traducida en dos temporadas distintas por dos estudios diferentes del mismo país:

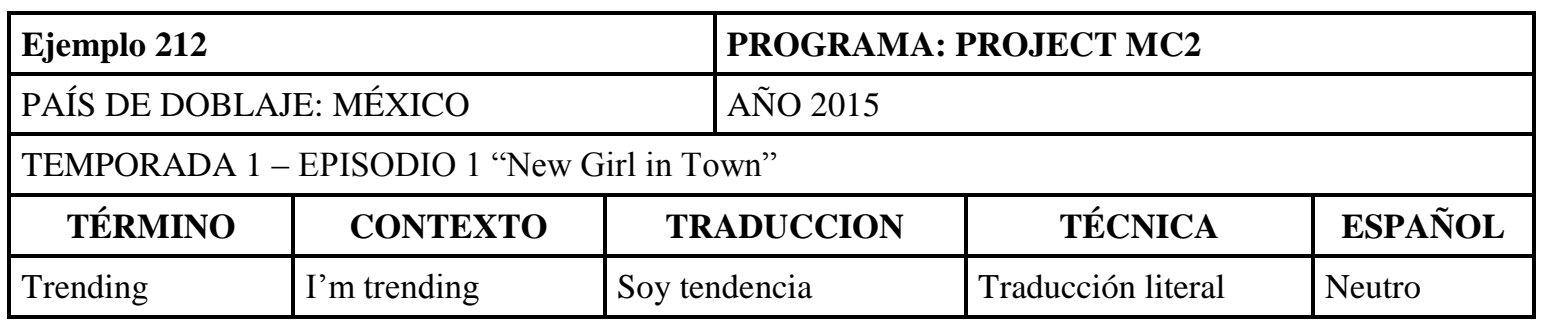

\begin{tabular}{|c|c|c|c|c|}
\hline \multicolumn{2}{|l|}{ Ejemplo 214} & \multicolumn{3}{|c|}{ PROGRAMA: PROJECT MC2 } \\
\hline \multicolumn{2}{|c|}{ PAÍS DE DOBLAJE: MÉXICO } & \multicolumn{3}{|l|}{ AÑO 2016} \\
\hline \multicolumn{5}{|c|}{ TEMPORADA 2 - EPISODIO 1 "Back to Basics" } \\
\hline TÉRMINO & CONTEXTO & TRADUCCION & TÉCNICA & ESPAÑOL \\
\hline Trending & $\begin{array}{l}\text { We're so trending } \\
\text { now! }\end{array}$ & $\begin{array}{l}\text { ¿Somos tan trending } \\
\text { ahora! }\end{array}$ & Préstamo & Regional \\
\hline
\end{tabular}




\subsubsection{Otros}

Se registraron también algunos usos interesantes de diferentes términos:

- Uso de "balón" (México, 2012) y "pelota" (México, 2016), aunque no se trata de doblajes del mismo estudio.

- Uso de "libreta" (México, 2015) y "cuaderno" (México, 2016) en la misma serie, pero doblada en distintos estudios.

- Uso del acrónimo "MAPS" (Mejores Amigas Para Siempre), muy poco frecuente en español, en vez de "BFF" (Best Friends Forever), que es el préstamo que se suele utilizar. Lo extraño es que se traduce esta expresión en el mismo episodio en que luego se utiliza el préstamo trending.

- Uso de "chicas" como traducción de girls cuando se trata de adolescentes y de "niñas" cuando son más pequeñas, con excepción de un caso en el que el personaje utiliza "niñas" en forma despectiva para referirse a una adolescente. Los vocablos "chicos" y "chicas" no formaban parte del español neutro tradicional de los estudios de doblaje. Se les ha añadido recientemente, dado que durante años se utilizó "niños" y "niñas".

- Uso de los sinónimos "manejar" y "conducir" (manejar un trineo, licencia de conducir) en el mismo episodio (Chile, 2010), y también del verbo "aparcar" (regionalismo, Chile, México, español peninsular) y de "estacionamiento".

\begin{tabular}{|c|c|c|c|c|}
\hline \multicolumn{2}{|l|}{ Ejemplo 25} & \multicolumn{3}{|l|}{ PROGRAMA: HI-5 } \\
\hline \multicolumn{2}{|c|}{ PAÍS DE DOBLAJE: CHILE } & \multicolumn{3}{|l|}{ AÑO 2010} \\
\hline \multicolumn{5}{|c|}{ TEMPORADA 11 - EPISODIO 26 “Christmas" } \\
\hline TÉRMINO & CONTEXTO & TRADUCCION & TÉCNICA & ESPAÑOL \\
\hline Drive & $\begin{array}{l}\text { One of us can } \\
\text { drive the sleigh }\end{array}$ & $\begin{array}{l}\text { Alguien podría manejar } \\
\text { el trineo }\end{array}$ & $\begin{array}{l}\text { Traducción } \\
\text { literal }\end{array}$ & Regional \\
\hline \multicolumn{2}{|l|}{ Ejemplo 26} & \multicolumn{3}{|l|}{ PROGRAMA: HI-5 } \\
\hline \multicolumn{2}{|c|}{ PAÍS DE DOBLAJE: CHILE } & AÑO 2010 & & \\
\hline \multicolumn{5}{|c|}{ TEMPORADA 11 - EPISODIO 26 “Christmas” } \\
\hline TÉRMINO & CONTEXTO & TRADUCCION & TÉCNICA & ESPAÑOL \\
\hline $\begin{array}{l}\text { Driver's } \\
\text { license }\end{array}$ & $\begin{array}{l}\text { I don't have my } \\
\text { driver's license }\end{array}$ & $\begin{array}{l}\text { Yo no tengo licencia de } \\
\text { conducir }\end{array}$ & $\begin{array}{l}\text { Equivalente } \\
\text { acuñado }\end{array}$ & Neutro \\
\hline
\end{tabular}




\begin{tabular}{|l|l|l|l|l|}
\hline \multicolumn{2}{|l|}{ Ejemplo 27 } & \multicolumn{1}{l|}{ PROGRAMA: HI-5 } \\
\hline \multicolumn{4}{|l|}{ PAÍS DE DOBLAJE: CHILE } & AÑO 2010 \\
\hline \multicolumn{4}{|l|}{ TEMPORADA 11 - EPISODIO 26 “Christmas” } \\
\hline TÉRMINO & CONTEXTO & \multicolumn{1}{|l|}{ TRADUCCION } & TÉCNICA & ESPAÑOL \\
\hline Park & $\begin{array}{l}\text { And I haven’t } \\
\text { learnt to park on } \\
\text { the roof yet }\end{array}$ & $\begin{array}{l}\text { Yo aún no aprendo a } \\
\text { aparcar en el techo }\end{array}$ & $\begin{array}{l}\text { Traducción } \\
\text { literal }\end{array}$ & Regional \\
\hline
\end{tabular}

\begin{tabular}{|l|c|l|c|l|}
\hline Ejemplo 46 & \multicolumn{1}{l|}{ PROGRAMA: JESSIE } \\
\hline PAÍS DE DOBLAJE: & AÑO 2014 \\
\hline TEMPORADA 3 - EPISODIOS 26 Y 27 “Jessie's Aloha-Holidays with Parker and Joey" \\
\hline TÉRMINO & CONTEXTO & \multicolumn{1}{|l|}{ TRADUCCION } & TÉCNICA & ESPAÑOL \\
\hline Parking & $\begin{array}{l}\text { Much like our } \\
\text { resort guests when } \\
\text { they find out about } \\
\text { the parking fee }\end{array}$ & $\begin{array}{l}\text { Como los huéspedes } \\
\text { del hotel cuando ven } \\
\text { la tarifa del } \\
\text { estacionamiento }\end{array}$ & $\begin{array}{l}\text { Traducción } \\
\text { literal }\end{array}$ & Neutro \\
\hline
\end{tabular}

- A pesar de que Sonderéguer (2015) habla de la similitud entre el español de México y el de la Argentina en comparación con los demás, en el corpus se registraron varias similitudes entre términos utilizados en Argentina y Colombia, como "timbre" y "torta". No es de extrañar que Chile utilice palabras similares a las del habla argentina (como "balde", por ejemplo), pero dada la distancia geográfica entre Argentina y Colombia, esta similitud resulta cuanto menos curiosa (aunque no hay que olvidar que hay zonas de Colombia donde se usa el "vos" como en Argentina).

- Como mencionó uno de los profesionales entrevistados, a veces sucede que se comienza a evitar el uso de un término cuando ya se lo ha utilizado hasta el hartazgo. Eso podría ser lo que sucede con la palabra cool. En estos últimos años se la ha traducido ad nauseam como "genial". En el corpus aparece siete veces como traducción de cool entre 2007 y 2016 en México, Chile, Venezuela y Argentina. Otras traducciones son "fabuloso", "súper", "lindo", "bueno" e "interesante", e incluso se la utiliza como préstamo (Argentina, 2014). Otro término que corre el mismo riesgo es "torpe".

- La forma tradicional del diminutivo en español neutro es la terminada en “illo", como en el caso de "bocadillo" o "mantequilla" (términos, por otra parte, ya lexicalizados). No obstante, en el corpus se registraron distintos tipos de diminutivos, algunos provenientes del mismo país e incluso del mismo estudio: "pastelillo" (Argentina, 2016; México, 2012), "paletita” (México, 2010) y "panquecito" (México, 2007). 


\subsection{ANÁLISIS DEL CORPUS COMPARABLE}

Luego del análisis del corpus paralelo, realizamos la compilación de un corpus comparable, o de contraste, para estudiar si las producciones que se graban directamente en español en algún país de la región, pero que se transmiten en todo el continente, contenían un léxico similar al que encontramos en el doblaje de las series de imagen real, y si se asemejaban las estructuras sintácticas y el aspecto fonológico y fonético. Además, nos interesaba comparar la proporción de características regionales y neutras entre ambos tipos de programas.

Tanto las series dobladas como las originales suelen estar protagonizadas por adolescentes. En el caso de las series de este corpus comparable, las tres (Violetta, Yo soy Franky y O11CE) tienen protagonistas adolescentes, pero tienen otra particularidad: el elenco proviene de distintos países y los productores buscaron que cada actor mantuviera su pronunciación y léxico (vid. Capítulo 2). Estas series se producen directamente con hispanohablantes (e incluso hablantes de otras lenguas, como portugués o italiano) provenientes de distintos países, pues, tal como afirma Chaume (2001: 87), el discurso prefabricado no solo aparece en los textos audiovisuales traducidos sino también en los de producción original, en este caso en español neutro. Baños Piñero (2009) sostiene que el dubbese y el discurso oral de las producciones originales intentan parecerse al discurso oral real, pero que el doblaje está mucho más estandarizado y es mucho más estricto. Y el análisis de estos programas lo confirmó. A diferencia de los productos doblados, $Y o$ soy Franky, O11CE y Violetta presentan una interesante variedad, ya que cada personaje utiliza el español de su país de origen. 


\begin{tabular}{|c|c|c|}
\hline Ejemplo 240 & \multicolumn{2}{|l|}{ PROGRAMA: VIOLETTA } \\
\hline $\begin{array}{l}\text { CANAL: } \\
\text { CHANNEL }\end{array}$ & \multicolumn{2}{|l|}{ AÑO 2012} \\
\hline \multicolumn{3}{|c|}{ ORIGEN DEL PROGRAMA: Argentina } \\
\hline \multicolumn{3}{|c|}{ ORIGEN DEL ELENCO: Argentina, España, México, Italia, Brasil, Estados Unidos, etc. } \\
\hline \multicolumn{2}{|c|}{$\begin{array}{l}\text { CARACTERÍSTICAS LÉXICAS } \\
\end{array}$} & VARIEDAD DE ESPAÑOL \\
\hline \multicolumn{2}{|l|}{ Necesitamos tener una plática } & Regional \\
\hline \multicolumn{2}{|l|}{ ¿Eres repartidor? } & Regional \\
\hline \multicolumn{2}{|l|}{ Nena (vocativo) } & Regional \\
\hline \multicolumn{2}{|l|}{ Niña (vocativo) } & Neutro \\
\hline \multicolumn{2}{|l|}{ Eso me da coraje } & Regional \\
\hline \multicolumn{2}{|l|}{ Dame tu valija? } & Regional \\
\hline \multicolumn{2}{|l|}{ ¿Qué os pasa? } & Regional \\
\hline \multicolumn{2}{|l|}{ Bajá un cambio } & Regional \\
\hline \multicolumn{2}{|c|}{ CARACTERÍSTICAS GRAMATICALES } & VARIEDAD DE ESPAÑOL \\
\hline \multicolumn{2}{|c|}{ Tuteo: "No puedo olvidarme de ti" } & Neutro \\
\hline \multicolumn{2}{|c|}{ Voseo: "Vos sabés que somos un referente" } & Regional \\
\hline \multicolumn{2}{|c|}{ ¡Falsa que sos! (estructura sin "qué") } & Regional \\
\hline \multicolumn{2}{|c|}{ CARACTERÍSTICAS FONOLÓGICAS } & VARIEDAD DE ESPAÑOL \\
\hline \multicolumn{2}{|c|}{$\begin{array}{l}\text { Pronunciación marcada que difiere entre los personajes } \\
\text { según el origen del actor. Por ejemplo, la } \mathrm{S} \text { puede sonar } \\
\text { como /s/ o como /z/ (actor español). Pronunciación a veces } \\
\text { incorrecta por parte de los actores que no tienen el español } \\
\text { como lengua materna. }\end{array}$} & Regional \\
\hline
\end{tabular}




\begin{tabular}{|c|c|c|}
\hline Ejemplo 241 & \multicolumn{2}{|c|}{ PROGRAMA: YO SOY FRANKY } \\
\hline CANAL: NICKELODEON & \multicolumn{2}{|c|}{ AÑO 2015} \\
\hline \multicolumn{3}{|c|}{ ORIGEN DEL PROGRAMA: Colombia } \\
\hline \multicolumn{3}{|c|}{ ORIGEN DEL ELENCO: Venezuela, Cuba, Colombia, etc. } \\
\hline \multicolumn{2}{|c|}{ CARACTERÍSTICAS LÉXICAS } & VARIEDAD DE ESPAÑOL \\
\hline \multicolumn{2}{|l|}{ Guapa (vocativo) } & Regional \\
\hline \multicolumn{2}{|l|}{ ¿Traes una cubeta? } & Neutro \\
\hline \multicolumn{2}{|l|}{ Bonita (vocativo) } & Regional \\
\hline \multicolumn{2}{|l|}{ Sube al carro } & Regional \\
\hline \multicolumn{2}{|c|}{ ¡Qué rico está! (como sinónimo de "bonito") } & Regional \\
\hline \multicolumn{2}{|c|}{ CARACTERÍSTICAS GRAMATICALES } & VARIEDAD DE ESPAÑOL \\
\hline \multicolumn{2}{|l|}{ Uso de tuteo exclusivamente } & Neutro \\
\hline \multicolumn{2}{|c|}{ Una vez esté mojado el papel (estructura sin "qué") } & Regional \\
\hline \multicolumn{2}{|c|}{ Uso generalizado del pretérito perfecto compuesto } & Regional \\
\hline \multicolumn{2}{|c|}{ CARACTERÍSTICAS FONOLÓGICAS } & VARIEDAD DE ESPAÑOL \\
\hline \multicolumn{2}{|c|}{$\begin{array}{l}\text { Pronunciación marcada que difiere entre los personajes } \\
\text { según el origen del actor. Por ejemplo: la G puede sonar /h/ } \\
\mathrm{o} / \mathrm{x} / \text {. }\end{array}$} & Regional \\
\hline
\end{tabular}




\begin{tabular}{|c|c|c|}
\hline Ejemplo 242 & \multicolumn{2}{|l|}{ PROGRAMA: O11CE } \\
\hline CANAL: DISNEY XD & \multicolumn{2}{|l|}{ AÑO 2017} \\
\hline \multicolumn{3}{|c|}{ ORIGEN DEL PROGRAMA: Argentina } \\
\hline \multicolumn{3}{|c|}{ ORIGEN DEL ELENCO: Argentina, México, Colombia, Brasil, Italia, etc. } \\
\hline \multicolumn{2}{|c|}{ CARACTERÍSTICAS LÉXICAS } & VARIEDAD DE ESPAÑOL \\
\hline \multicolumn{2}{|c|}{ Se dedican a hackear } & Neutro \\
\hline \multicolumn{2}{|l|}{ ¿Tienes tu tablet? } & Neutro \\
\hline \multicolumn{2}{|l|}{ Chicos (vocativo) } & Regional \\
\hline \multicolumn{2}{|l|}{ Quédate en la portería } & Neutro \\
\hline \multicolumn{2}{|l|}{ Vengo a platicar } & Regional \\
\hline \multicolumn{2}{|c|}{ No me molesta quedarme en la banca } & Regional \\
\hline \multicolumn{2}{|l|}{ Voy a estar en el banco } & Regional \\
\hline \multicolumn{2}{|l|}{ Apenitas } & Regional \\
\hline \multicolumn{2}{|c|}{ ¿Me habrá comprado la camiseta? } & Neutro \\
\hline \multicolumn{2}{|l|}{ Ya quiero esa playera } & Regional \\
\hline \multicolumn{2}{|c|}{ Aumentativos terminados en azo/aza: "un partidazo" } & Regional \\
\hline \multicolumn{2}{|c|}{ CARACTERÍSTICAS GRAMATICALES } & VARIEDAD DE ESPAÑOL \\
\hline \multicolumn{2}{|l|}{ Tuteo } & Neutro \\
\hline \multicolumn{2}{|c|}{ Voseo: No podés ser tan irresponsable } & Regional \\
\hline \multicolumn{2}{|c|}{ Uso del pretérito perfecto simple y compuesto } & Neutro \\
\hline \multicolumn{2}{|c|}{ CARACTERÍSTICAS FONOLÓGICAS } & VARIEDAD DE ESPAÑOL \\
\hline \multicolumn{2}{|l|}{ Jugar fútbol } & Neutro \\
\hline \multicolumn{2}{|l|}{ Jugar futból } & Regional \\
\hline \multicolumn{2}{|c|}{ Jugar futebol (del portugués) } & Regional \\
\hline \multicolumn{2}{|c|}{$\begin{array}{l}\text { Tanto la pronunciación como la entonación (acento) difieren } \\
\text { entre los personajes según el origen del actor. Por ejemplo: } \\
\text { /pesadídas/ y /pesadíjas/ }\end{array}$} & Regional \\
\hline
\end{tabular}

Como se puede ver, las tres series utilizan en gran medida las variedades regionales del español. Lo que más diferencia a estas producciones de las dobladas no es tanto el léxico (que en general puede deducirse por el contexto, la situación o la imagen) sino justamente dos características que, o no están presentes, o están muy atenuadas en el español neutro: las pronunciaciones (y el acento) y las estructuras gramaticales regionales. La finalidad de incluirlas, según los productores, es llegar a una nueva generación de telespectadores, más globalizada y multiplataforma, que no solo comprende las expresiones de otros países, sino que además las utiliza en su comunicación diaria, ya sea oral como a través de las redes sociales. De hecho, la combinación de nacionalidades y variedades de español en los elencos promueve también una mayor comprensión entre los fans (incluso con los 
de Brasil), que empiezan a compartir ciertos términos que deberían resultarles foráneos. Véanse como ejemplo estos tuits de fans de diferentes países:

En respuesta a @DisneyChannelLA

Aguante soy luna

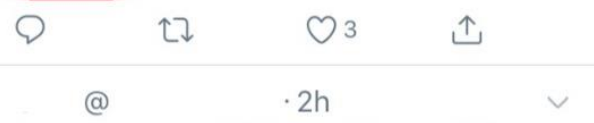

En respuesta a @DisneyChannelLA

A Soy Luna no le queda ni un dia, y ya se pusieron a Promocionar la nueva serie, osea todo bien con eso pero Esperense tantitono?

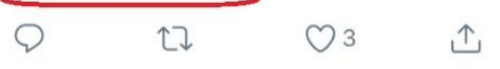

\section{8曰@ $2 \mathrm{~h}$}

En respuesta a @DisneyChannelLA No jodan, dejen culminar este proyecto de soy luna como debe y luego promocionen la próxima. Que no se les note la desesperacion. Yo por mi parte y con todo lo que me dañaron la trama de soy luna y con solo 60caps y nada de película. No les vuelvo a ver una serie ni siendo cierto

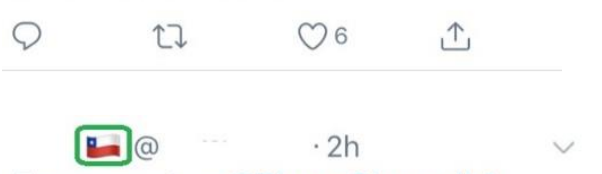

En respuesta a @DisneyChannelLA Nada pero nada reemplaza violetta oyeronnnn????!??! Ahre

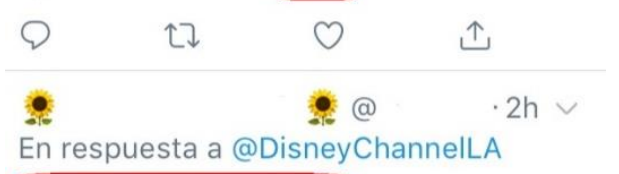

Qué poca madre tienen, RESPETEN A

LOS FANS SENSIBLES POR EL FINAL

DE SOY LUNA.

No esperaba menos de ti Disney

$Q \quad$ 证 0 个

@ $\cdot 2 \mathrm{~h}$

En respuesta a @DisneyChannelLA

Não queremos saber de nova série, estamos sofrendo, RESPEITEM NOSSA DORAHRE

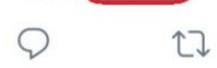




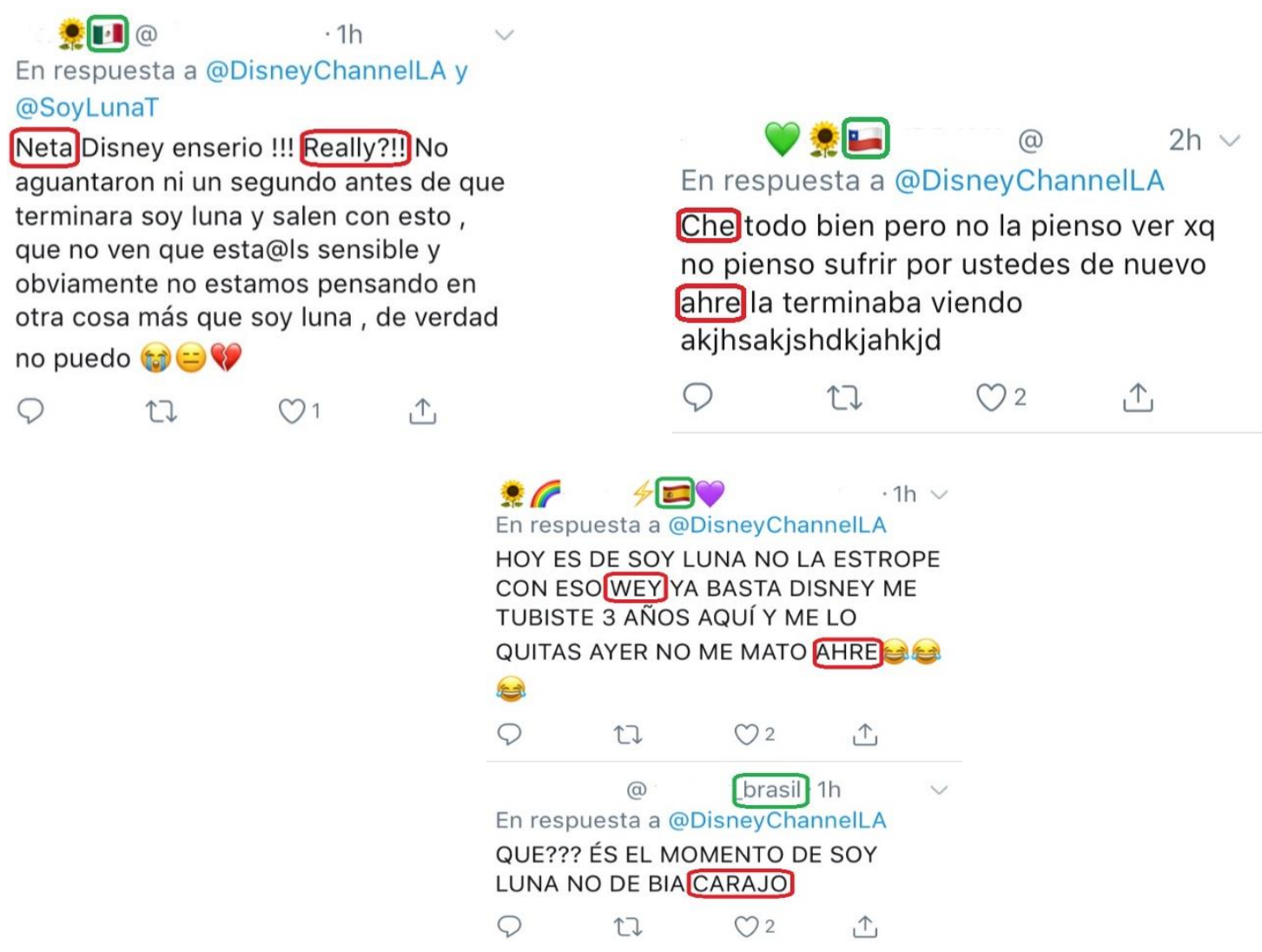

Ilustración 42 - Tuits en ocasión del final de la serie Soy Luna, de Disney Channel, en protesta por haber transmitido de inmediato un adelanto de su nueva serie, Bia / Fuente: Twitter-Agosto de 2018

Cabe aclarar que los fans eran tanto chicas como chicos, lo que iría en contra del concepto de Disney de transmitir programas como Soy Luna en su canal general (que tiene un enfoque más para niñas) y otros como Lab Rats u O11CE en su canal XD (dedicado a los varones). ${ }^{163}$ También cabe resaltar el uso de ciertas palabras groseras en las redes sociales ("boludo", “jodan", "carajo") que contrasta con la terminología "santurrona” del español neutro para los programas infantojuveniles, donde ni siquiera se habla de la muerte. ${ }^{164}$ Pero lo más interesante es la difusión del vocabulario informal y local más allá de las fronteras y su aceptación y replicación por parte de los hablantes de otras regiones: "ahre" (Chile, España, Brasil), "boludo" (Colombia), "WTF" (México), "carajo" (Brasil), "really" (México), “che” (Chile) y güey/wey (España). Todas estas expresiones las usan

163 Basta con observar, por ejemplo, el increíble aumento de la popularidad del fútbol femenino (el Mundial 2019 fue noticia en todo el mundo) para darse cuenta de que un programa como O11CE no pertenece necesariamente a un canal "para varones".

${ }^{164}$ Es interesante resaltar que, si bien estos programas tienen como público meta a preadolescentes y adolescentes, muchos niños pequeños los ven también, aunque no son los destinatarios originales. Por otro lado, la eufemización es mucho menor en los programas animados, para la edad que sea (experiencia profesional de la autora). 
también los adolescentes argentinos. ${ }^{165}$ Por el contrario, otras frases y palabras son locales y no suelen replicarse por algún motivo particular, como "qué pedo" (frase mexicana que significa "qué onda" y que, por ejemplo, no se usa en Argentina porque "pedo" es un sinónimo más vulgar de "gas"), "espérense tantito" o "qué poca madre", otra frase de México con el sentido de "qué vergüenza" (siempre que se escriba separada, porque "pocamadre" es un adjetivo sinónimo de "excelente"). Estos términos nos proporcionan datos sobre el origen del hablante, y aunque no necesariamente se repliquen, son comprendidos con facilidad.

En cuanto a la comparación de ambos corpus y la proporción de características regionales y neutras entre ambos subsistemas (programas infantojuveniles doblados y en español), la tendencia promovida por los productores de estas series resultó obvia: mientras que en el corpus paralelo se registran 197 instancias de español neutro frente a 67 de español regional, las variedades regionales son mucho más utilizadas en los programas hablados en español, como demuestra el corpus comparable. Aunque el número total de palabras de ambos corpus no sea idéntica ni cercana (no era esa la intención ni el objetivo de esta tesis), la cata hecha en el corpus comparable nos permite afirmar que el número de regionalismos en los tres episodios analizados es muy significativo.

Si bien esto no indica que el español neutro del doblaje vaya a desaparecer, sí es muy posible que vaya ampliando cada vez más su léxico, aunque no se prevé que pierda su estandarización en el nivel gramatical o fonético-fonológico e incluya las particularidades del habla de cada actor de doblaje.

\footnotetext{
${ }^{165}$ En un artículo que habla sobre la jerga adolescente española aparecen muchos términos, como cringe, crush, okis, pro, hater, retuit, shippear o viciarse, de uso muy común en Argentina (Fernández, J. y N. Marrón (2019): “En plan... mi crush me putoflipa: diccionario de la jerga adolescente”, El periódico, 6 de julio de 2019, https://www.elperiodico.com/es/mas-periodico/20190706/en-plan-crush-putoflipadiccionario-de-argot-adolescente-7538640 (consultado el 7 de julio de 2019)
} 


\section{CAPÍTULO 7. \\ CONCLUSIONES}

\subsection{RESPUESTAS A LAS PREGUNTAS DE LA INVESTIGACIÓN}

Al inicio de esta tesis nos preguntábamos cuáles eran los rasgos léxicos del español neutro que se usa en el doblaje en Latinoamérica y en qué medida la influencia de los distintos agentes involucrados en el proceso industrial del doblaje incidía en las elecciones léxicas de dicho español neutro. El análisis del español neutro de las series estudiadas llevado a cabo para esta tesis nos permite establecer conclusiones de diversa índole respecto de estas dos preguntas.

En primer lugar, está comprobado que la lengua varía según el género, pero también según el uso (Marzà et al, 2009). El análisis realizado confirmó que el español neutro no es homogéneo, sino que varía según la región o país, y también cuando los diferentes agentes involucrados en el proceso de doblaje ejercen su poder sobre los demás, poder que a veces se traduce en forma de políticas lingüísticas o de censura. Lamentablemente, el secretismo que rodea al proceso de doblaje no contribuye a que podamos conocer exactamente qué porcentaje de influencia tiene cada agente. Incluso los involucrados directos en el proceso, como los directores de doblaje, a veces no saben quién es responsable de las políticas lingüísticas que deben cumplir. Sin embargo, las entrevistas que forman parte de esta investigación confirmaron que hay otros agentes con poder sobre las decisiones del traductor. Incluso los mismos directores aceptaron que a veces son ellos quienes determinan el español que se utilizará (vid. Capítulo 6).

Los objetivos que se describieron al principio de esta tesis planteaban que en esta investigación se procuraría:

a) investigar si existe un español específico para el doblaje de programas infantojuveniles, en particular de programas de ficción de imagen real, y describir los rasgos lingüísticos del mismo, en especial, el nivel léxico de dicho español neutro;

b) demostrar que el español neutro que se utiliza en el doblaje de programas infantojuveniles no solo es consecuencia de las estrategias utilizadas por los traductores, sino también de la influencia de los agentes involucrados, y determinar qué tan fuerte es dicha influencia sobre las estrategias traductoras y si se podría hablar de censura; 
c) evaluar los factores políticos, sociales, empresariales, comerciales, ideológicos, traductológicos, etc. que influyen en el proceso de doblaje, desde el encargo de traducción hasta el producto final que sale al aire.

Respecto del primer objetivo, pudimos describir los rasgos lingüísticos del español neutro del doblaje de programas infantojuveniles de imagen real, si bien sería necesario complementar el corpus paralelo de esta tesis comparándolo con un corpus de doblaje de dibujos animados para establecer claramente las diferencias entre uno y otro tipo de doblaje.

A pesar de que los artículos académicos no hablaban de un español neutro para el doblaje específico de los programas infantojuveniles, el análisis del corpus nos permitió describir rasgos lingüísticos distintivos de dicha variedad. En un análisis futuro, sería posible ahora comprobar si algunos rasgos de los aquí descritos son comunes al español neutro para doblaje en general (como, probablemente, el uso de la modulación, la variación o la omisión para "bajar el tono" de lo que se dice en la lengua fuente), o si se dan en mayor grado o en forma más exagerada en este género (como la omisión de términos como "cadáver" o "muerto"). Otras técnicas, como el uso de la generalización o la explicitación, también forman parte de este registro del español neutro para doblaje de programas infantiles y juveniles y tal vez lo sean también del español neutro en general, aunque probablemente en menor medida. También se comprobó la utilización de términos más “juveniles”, como cool, que apuntan a un público de cierta edad.

El español neutro utilizado en los programas estudiados resultó relativamente homogéneo, ya que es muy constante en sus aspectos fonético-fonológicos, pero presenta una significativa variedad en el léxico, principalmente en las palabras conflictivas como las relacionadas con la vestimenta y los alimentos. Las opciones elegidas no siempre son las que utiliza la mayor cantidad de hablantes (vid. Anexo 4), y aún con los comentarios de los entrevistados no siempre se sabe exactamente quién determina qué palabra se debe usar, aunque sí comprobamos que no es necesariamente el traductor quien toma la decisión, ya que en episodios traducidos por la misma persona había diferencias notorias de terminología, como el uso y la omisión de términos religiosos o traducciones diferentes para el mismo alimento (por lo que suponemos que otro agente de la cadena intervino en la traducción).

El uso de regionalismos varía entre un $11 \%$ y un $40 \%$, y no coincide entre estudios de un mismo país. Si partimos de la base de que estamos estudiando el español neutro del doblaje, resulta un tanto sorprendente que haya programas en los que los regionalismos alcanzan un $40 \%$. Esto confirma el concepto de la heterogeneidad del español neutro por la inexistencia de un glosario o diccionario que sirva de base al traductor, al menos para consultar cuando tenga dudas respecto de si un término es neutro. 


\begin{tabular}{|c|c|c|c|c|c|c|}
\hline \multirow[b]{2}{*}{ PROGRAMA } & \multicolumn{2}{|c|}{ ESPAÑOL NEUTRO } & \multicolumn{2}{|c|}{ ESPAÑOL REGIONAL } & \multirow[b]{2}{*}{ TOTAL } & \multirow[b]{2}{*}{ OMISIONES } \\
\hline & CASOS & $\%$ & CASOS & $\%$ & & \\
\hline $\begin{array}{l}\text { Lost and Found } \\
\text { Music Studios }\end{array}$ & 6 & $60 \%$ & 4 & $40 \%$ & 10 & \\
\hline Jessie & 47 & $84 \%$ & 9 & $16 \%$ & 56 & 9 \\
\hline Odd Squad & 20 & $69 \%$ & 9 & $31 \%$ & 29 & \\
\hline $\mathrm{Hi}-5$ & 20 & $71 \%$ & 8 & $29 \%$ & 28 & 2 \\
\hline Lazytown & 18 & $75 \%$ & 6 & $25 \%$ & 24 & \\
\hline Project MC2 & 23 & $70 \%$ & 10 & $30 \%$ & 33 & \\
\hline Lab Rats & 17 & $89 \%$ & 2 & $11 \%$ & 19 & \\
\hline iCarly & 32 & $74 \%$ & 11 & $26 \%$ & 43 & 1 \\
\hline Big Time Rush & 14 & $64 \%$ & 8 & $36 \%$ & 22 & 1 \\
\hline
\end{tabular}

Tabla 59 - Comparación de casos de español neutro y regional

Resulta interesante la diferencia de uso de español neutro y regional entre los dos estudios de Argentina (60-40\% frente a 84-16\%), la gran cantidad de omisiones en el mismo programa y la similitud de porcentajes de los dos programas de Disney que, a pesar de estar doblados en distintos países (Argentina y México), presentan porcentajes muy similares en la relación neutro-regional (84-16\% y 89-11\%).

También hallamos gran amplitud entre los porcentajes de uso de las distintas técnicas de traducción entre países, estudios y canales. La traducción literal es la técnica con más variación (mínimo de $22 \%$ y máximo de $80 \%$ ), y excepto el calco, que tiene una variación de tan solo $5 \%$, todas las demás tienen diferencias de entre un $10 \%$ y un $23 \%$. 


\begin{tabular}{|l|c|c|}
\hline \multicolumn{1}{|c|}{ TÉCNICA } & MÁXIMO $^{\mathbf{1 6 6}}$ & MÍNIMO \\
\hline Traducción literal & $80 \%$ & $22 \%$ \\
\hline Omisión & $14 \%$ & $0 \%$ \\
\hline Modulación & $10 \%$ & $5 \%$ \\
\hline Préstamo & $27 \%$ & $0 \%$ \\
\hline Creación discursiva & $15 \%$ & $0 \%$ \\
\hline Generalización & $15 \%$ & $0 \%$ \\
\hline Equivalente acuñado & $23 \%$ & $0 \%$ \\
\hline Calco & $5 \%$ & $0 \%$ \\
\hline Explicitación & $14 \%$ & $0 \%$ \\
\hline Variación & $20 \%$ & \\
\hline
\end{tabular}

Tabla 60 - Porcentajes máximos y mínimos de utilización de técnicas

Hay algunos porcentajes que resultan llamativos. En primer lugar, la cantidad de omisiones no es tan grande como la de modulaciones, variaciones, creaciones discursivas y generalizaciones, lo que nos lleva a pensar que la censura comprobada no se traduce en omisiones, sino que se "disfraza" mediante las otras técnicas de traducción recién mencionadas. Por otro lado, en algunos programas las cifras de traducción literal no distan mucho de las de las técnicas útiles para ejercer algún tipo de manipulación. Por ejemplo, Jessie cuenta con 59 casos de estas técnicas frente a 22 de traducción literal; Lab Rats, con 37 casos de estas técnicas y 53 de traducción literal, y Big Time Rush con 45 casos frente a 50 .

En segundo lugar, no parece lógico encontrar una cantidad tan elevada de préstamos en programas infantojuveniles, dado que se supone que los niños no conocen términos como "Winnebago" o "minivan", que no son neutros y pueden resultar difíciles de comprender. Si comparamos los préstamos con los calcos, la proporción es más que llamativa (34 préstamos frente a 4 calcos), en especial porque el préstamo se acerca más a la extranjerización que a la domesticación, que podríamos asociar más con los programas infantojuveniles por su condición de "acercarse al espectador".

Por otro lado, la cantidad de ejemplos de creación discursiva, variación/modulación, omisión y generalización es considerablemente alta pues, a excepción del préstamo, son

${ }^{166}$ Los porcentajes fueron redondeados para simplificar la lectura. Los porcentajes exactos se encuentran en el Anexo 1. 
las técnicas que presentan los mayores números de casos. Estas cuatro técnicas suelen estar relacionadas con la eufemización y la manipulación.

\begin{tabular}{|l|r|}
\hline Traducción literal & 127 \\
\hline Equivalente acuñado & 13 \\
\hline Omisión & 13 \\
\hline Modulación & 8 \\
\hline Préstamo & 34 \\
\hline Calco & 4 \\
\hline Creación discursiva & 16 \\
\hline Explicitación & 11 \\
\hline Generalización & 21 \\
\hline Variación & 22 \\
\hline Particularización & 4 \\
\hline & \\
\hline TOTAL & $\mathbf{2 7 3}$ \\
\hline
\end{tabular}

Tabla 61 - Técnicas utilizadas (en cantidad de casos)

Técnicas:

literal frente a relacionadas potencialmente con la censura

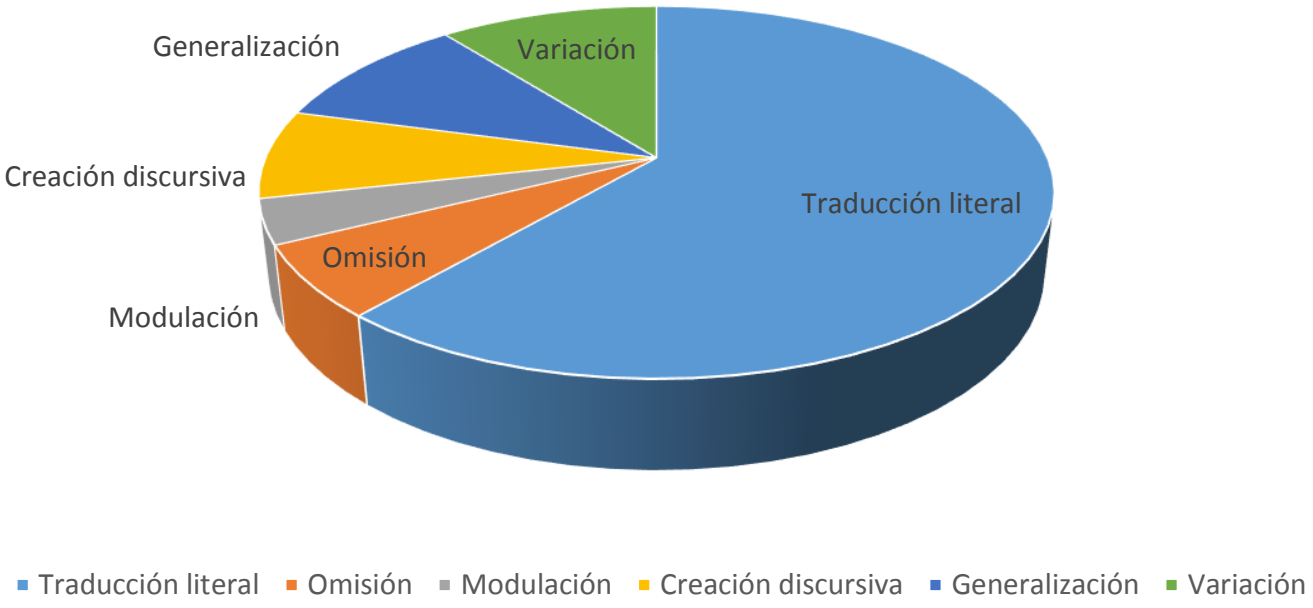

Ilustración 43- Proporción de técnicas utilizadas en el corpus 
Se comprobó que, por lo general, las palabras tabú se suavizaban u omitían. También se las reemplazaba con creaciones discursivas. Esto es común a cualquier tipo de doblaje para niños, e incluso en otros tipos de programas. Sin embargo, algunas omisiones, modulaciones y variaciones, como la de Navidad, no resultaban necesarias y sugerían cierto tipo de intervención o manipulación.

En cuanto a los términos conflictivos analizados en particular, es decir, los alimentos y vestimentas, se corroboró que no hay criterios que apliquen todos los estudios, puesto que encontramos distintos términos para el mismo concepto, incluso en estudios del mismo país. La disparidad de resultados también se reflejó en los vocablos relacionados con la tecnología.

Quedó claro que la corrección política a veces es una fachada para la manipulación y la censura, como opina Richart-Marset (2012). Estos datos se relacionan con la falta de homogeneidad del español neutro utilizado, pues las diferencias entre estudios, canales y países apuntan a la injerencia de otros agentes. Por supuesto que no se descarta el hecho de que no hay dos traductores que traduzcan igual, pero por lo revelado por los entrevistados, no son necesariamente los traductores quienes marcan las diferencias entre "los españoles neutros" de los distintos estudios, canales o países.

En cuanto al segundo objetivo, que planteaba que el español neutro de estos doblajes es consecuencia tanto de las estrategias de los traductores como de la influencia de los demás agentes involucrados, quedó comprobada con lo que sostenían algunos artículos y libros y especialmente con las respuestas de los entrevistados: tanto los traductores como los directores y actores hablaron de la injerencia de otros agentes del proceso de doblaje. Sin embargo, no se pudo determinar qué tan fuerte es dicha influencia, aunque podemos entrever en sus respuestas que la influencia es considerable. Sí pudimos comprobar que existe censura, tanto a través de la revisión teórica como de las entrevistas (y de las técnicas de traducción que la fomentan), y determinamos la importancia de las políticas lingüísticas en relación al doblaje. No obstante, debido al secretismo que rodea al doblaje, no pudimos determinar con exactitud quién ejerce qué tipo de manipulación o censura y a qué nivel. El caso de la Navidad dejó en claro que a veces las políticas lingüísticas de una empresa o canal no son iguales para todos los idiomas, lo que nos llevaría a pensar que existe algún otro agente cuyas decisiones tienen peso en el proceso de doblaje específicamente para ciertos idiomas o variedades. Resulta evidente que hay factores de importancia, como las políticas gubernamentales, pero no podemos dejar de considerar, por ejemplo, la influencia del público adulto de los programas para niños y adolescentes como factor en la toma de decisiones respecto de los doblajes. Tampoco podemos dejar de tener en cuenta la posibilidad de que algunas opciones elegidas por el traductor sean producto de autocensura, especialmente porque se trata de programas para niños y adolescentes, y eso puede generar cierto deseo de proteger al público meta por parte del traductor. 
Descubrir el nivel de influencia de cada agente requeriría una investigación mucho más exhaustiva, pero también sería necesario contar con la colaboración de los estudios de doblaje, principalmente para encontrar respuestas que no hemos podido obtener en esta tesis, ni siquiera a través de las entrevistas. No existe una clara definición del rol de cada agente, y por lo tanto tampoco de quién es "el cliente" (estudio de doblaje, canal, etc.). Sigue existiendo una superposición de tareas de los agentes que impide que se pueda realizar una descripción clara del rol de cada uno (técnicos que son directores, actores o directores que traducen, etc.). Por otro lado, no se ha podido comprobar que quienes toman las decisiones linguiísticas estén profesionalmente preparados para hacerlo. Y si a eso sumamos la diversidad de españoles regionales en Latinoamérica y la imposibilidad (al menos hasta ahora) de determinar cuáles serían los términos realmente neutros, resulta lógica la disparidad de criterios hallada en nuestro corpus.

El tercer objetivo buscaba evaluar los factores políticos, sociales, empresariales, comerciales, ideológicos, traductológicos, etc. que influyen en el proceso de doblaje. Se pudo llevar a cabo una exhaustiva evaluación de dichos factores mediante una extensa revisión bibliográfica que abarcó no solo libros y aportaciones académicas, sino también artículos de periódicos, blogs, leyes, sitios web especializados, publicaciones de redes sociales, etc. Es importante destacar que Chaume (2013: 16) sostiene que:

la TAV -y, por tanto, la traducción para el doblaje- es una subdisciplina de los Estudios de Traducción, directamente relacionada con los Estudios de Comunicación, los Estudios Fílmicos y los Estudios sobre Medios Audiovisuales. Pero también con disciplinas afines vinculadas necesariamente a los Estudios de Traducción, como la Sociología, Filosofía, Lingüística, Semiótica, Pragmática, Teoría de la Literatura, etc.

Esto implica que, como se ha visto, no podemos dejar de lado aspectos tales como el mecenazgo o las políticas lingüísticas al momento de desarrollar cualquier análisis de material audiovisual, y muy especialmente del material doblado donde, como se ha comprobado, cada participante del proceso puede modificar el resultado final, que para la gran mayoría de los espectadores es solo responsabilidad del traductor (y a lo sumo del adaptador). Esto tiene gran importancia a la hora de iniciar cualquier investigación sobre el doblaje. Resulta imposible evaluar la traducción como resultado si no conocemos la traducción como proceso, que involucra no solo al traductor sino a las personas que modifican o tienen la influencia necesaria para modificar-directa o indirectamente- dicha traducción. 


\subsection{RESULTADOS: HACIA UN MAPA PROVISIONAL DE LAS NORMAS DE TRADUCCIÓN PARA EL DOBLAJE EN ESPAÑOL NEUTRO}

A partir del análisis de nuestro corpus, y sin poder generalizar a otros corpus, podemos concluir que el español neutro del doblaje de series de ficción infantojuveniles no es homogéneo. Las estrategias traductoras y normas subyacentes están relacionadas con los resultados obtenidos:

En cuanto a los comentarios de los entrevistados, afirmaron que:

- Aunque no siempre hay una guía de estilo o una lista de palabras prohibidas/aprobadas, hay términos que no les permiten utilizar (palabras ofensivas, religiosas, etc.)

- Las listas se manejan por programa o por película, y sobre todo se usan en series de caricaturas o películas y programas infantiles. Son muy arbitrarias.

- Las palabras "prohibidas" varían según el público y el nivel de "autocensura" del cliente.

- Las diferencias no solo se dan entre países sino también entre estudios del mismo país.

- Algunos estudios priorizan la actuación y otros, el lip sync.

- No existe una clara definición del rol de cada agente, y por lo tanto tampoco de quién es "el cliente" (estudio de doblaje, canal, etc.).

- Los términos más conflictivos tienen que ver con lo cultural y con insultos o cuestiones que puedan ofender a otros (aunque los encuestados no siempre estaban de acuerdo con las indicaciones del cliente en este tema).

- El vocabulario que se les permite utilizar se fue flexibilizando con los años.

- No suelen existir diferencias en las pronunciaciones del español neutro.

- Todos los clientes censuran sus traducciones, en mayor o menor medida, pero esto se debe a que el producto infantojuvenil es distinto de los demás materiales audiovisuales que se doblan.

- El método de trabajo varía mucho entre estudios y entre clientes.

En lo que respecta a los rasgos del español neutro:

- La pronunciación detectada en las distintas series es prácticamente neutra en su totalidad.

- No se presentó ninguna instancia de intercambio o adición de vocales o consonantes, monoptongaciones, pérdida de la /d/ final o intervocálica, aspiración de la /s/ final, lambdacismo o rotacismo. Cada fonema se pronuncia claramente, y se exageran los hiatos y diptongos. Sí es común a todos los doblajes analizados el seseo, el betacismo y el yeísmo con rehilamiento de la LL y la Y.

- No se registran casos de acento rioplatense (derivado del napolitano) en los doblajes argentinos, ni pronunciaciones o acentos típicos de otras regiones (la combinación $\mathrm{CH}$ pronunciada / $/$ / de Chile o el acento mexicano, por ejemplo).

- Se utilizan términos más "juveniles", como "cool”.

- Se registró la presencia de distintos tipos de sufijos de diminutivo: -illo, -ito, -cito. 
En cuanto a los regionalismos:

- Si bien los traductores tienden a evitar regionalismos, se registró una significativa cantidad $(25,40 \%)$ que el sistema meta parece aceptar.

- Las distintas temporadas de un mismo programa dobladas en distintos estudios pueden tener un porcentaje significativamente diferente de regionalismos.

- Los programas que tienen una mayor proporción de términos neutros en comparación con los términos regionales son los programas de Disney, con un promedio de $86,40 \%$ de español neutro y un $13,50 \%$ de español regional, aunque fueron doblados en distintos países (Argentina y México).

- La proporción regional/neutro de dos estudios distintos en Argentina y en México es significativamente diferente.

- El uso de regionalismos varía entre un $11 \%$ y un $40 \%$, y no coincide entre estudios de un mismo país.

En lo que respecta a las técnicas utilizadas:

- La traducción literal estaba presente en proporciones muy dispares en el material analizado ( $80 \%$ frente a $21,54 \%$ ). Casi todas las series tienen un promedio de aproximadamente un $50 \%$ de traducciones literales.

- En el caso de la omisión, si bien esta técnica no resultó tan usual como esperábamos, la diferencia entre los estudios es marcada. En su mayoría, las omisiones tenían que ver con palabras que podían resultar ofensivas, verbos problemáticos que pueden malinterpretarse, expresiones relacionadas con la muerte, y términos religiosos o relacionados con la Navidad.

- Existen diferencias entre estudios, canales y países en la cantidad de casos de modulación y variación. México y Venezuela tienen más variaciones en comparación con los demás países, y Argentina es el país que presenta más casos de modulación, más del doble que México y Chile.

- Las diferencias por canal parecen relacionadas con el contenido o el público destinatario. Los programas para niños más pequeños casi no tenían casos de modulación o variación (apenas uno), frente a, por ejemplo, 8 casos de otros programas. Esto podría deberse a que el contenido para niños más pequeños no presenta términos que deban suavizarse.

- En algunos programas, el nivel de variación es muy alto (20\% frente a un $50 \%$ de traducción literal).

- La mayoría de los casos de modulación y variación estaban relacionados con conceptos que puedan perturbar a un niño, como los relacionados con la muerte, y con palabras ofensivas. También hay, pero en menor medida, casos relacionados con cuestiones religiosas.

- La mayor cantidad de préstamos se presentó en los doblajes de México, seguido por Argentina, pero igual existe una amplia diferencia entre uno y otro (México, 
un promedio de 6 casos; Argentina, 4), tal vez justificada por la cercanía de México y Estados Unidos y la obvia influencia del inglés en su español. Colombia registró 3 casos.

- Argentina se destaca por utilizar la técnica de generalización más que los demás países, aunque Colombia y México también la utilizan con frecuencia (4:3).

- Hallamos gran amplitud entre los porcentajes de uso de las distintas técnicas de traducción entre países, estudios y canales.

- La cantidad de omisiones no es tan grande como la de modulaciones, variaciones, creaciones discursivas y generalizaciones, lo que nos lleva a pensar que la censura comprobada no se traduce en omisiones, sino que se "disfraza" mediante las otras técnicas de traducción.

- En algunos programas, el porcentaje de las técnicas que facilitan la manipulación combinadas es muy similar al de la traducción literal (por ejemplo, 45 casos frente a 50).

- A pesar de que la traducción de los programas infantojuveniles suele acercarse más a la domesticación que a la extranjerización, la cantidad de préstamos hallados en el corpus es significativa.

En cuanto a la traducción de palabras tabú u ofensivas:

- Las traducciones literales se correspondieron con los insultos más suaves en inglés. La mayor parte de las palabras tabú u ofensivas fueron suavizadas, es decir, se cumplió la norma de eufemización.

- Argentina es el país que utiliza las versiones más "suavizadas", mientras que Venezuela utiliza la mayor gama de opciones.

- El uso de préstamos del inglés que son despectivos parece haberse modificado con el tiempo.

- En el caso de las palabras relacionadas con la muerte o con agresión se recurrió frecuentemente a la modulación y a la omisión, pero también a la traducción literal. No hay patrones que indiquen que hay una mayor eufemización en los últimos años estudiados en esta tesis, pero sí se comprobó que algunos canales piden a sus traductores que suavicen la traducción y que eviten ciertas palabras religiosas o relacionadas con la muerte.

- La cantidad de traducciones literales o equivalentes acuñados, a excepción del caso de las partes y funciones del cuerpo, es menor que la suma de las soluciones que suavizan el texto o lo censuran (modulación, omisión, generalización, variación y creación discursiva).

En lo que respecta a las referencias culturales:

- En la mayoría de las traducciones se mantuvieron las referencias culturales, pero no siempre se mantuvieron las relacionadas con el cristianismo y la Navidad.

- La omisión de culturemas podría deberse tanto a un intento de realizar un doblaje políticamente correcto como a la actitud proactiva del público respecto de la corrección política. 
En los casos de alimentos y vestimenta:

- Existe una disparidad de criterios respecto de cómo traducir los nombres de alimentos y prendas de vestir. Se encontraron distintas versiones para una misma palabra en inglés, y en general se utilizaron distintos términos en distintos países, o incluso en el mismo país.

- La técnica más utilizada es la traducción literal (57\%), aunque con una significativa mayoría de regionalismos en el caso de la vestimenta y de términos neutros en el caso de los alimentos. Los préstamos son numerosos, y eso podría deberse a que se utiliza la palabra en inglés para evitar usar un término regional.

En cuanto a los términos relacionados con la tecnología:

- En general se recurrió a la técnica del préstamo. No obstante, también aparecieron términos traducidos literalmente y como préstamo (tendencia-trending). Eso habla de cierta incoherencia en cuanto a la actitud frente a los neologismos asociados con las nuevas tecnologías.

Otros:

- Existe una similitud de los términos utilizados en Argentina y en México y Colombia, a pesar de la distancia geográfica.

- Se comprobó que, tal como afirma Baños Piñero (2009), el dubbese y el discurso oral de las producciones originales intentan parecerse al discurso oral real, pero el doblaje está mucho más estandarizado y es mucho más estricto. Las producciones en español contienen una mayor cantidad de términos regionales que neutros, así como también una variedad de pronunciaciones, acentos y estructuras gramaticales regionales.

Respecto de la influencia de los distintos agentes:

- No existen criterios claros respecto de quién toma las decisiones en todos los casos. Mientras que algunos doblajes parecen haber recibido la influencia del canal o plataforma, es probable que en otros las decisiones las haya tomado cada estudio de doblaje (por ejemplo, cuando dos estudios se habían encargado del doblaje de diferentes temporadas del mismo programa). Tampoco podemos establecer cuándo ciertas decisiones fueron del traductor y cuándo no, aunque podemos sospechar que, si el mismo traductor se encargó de dos temporadas del mismo programa y hay diferencias de criterio significativas, como en el caso de omisiones, modulaciones o variaciones, es probable que algún otro agente del proceso de doblaje haya sido el responsable, ya sea de definir el encargo de traducción o una vez que el traductor terminó su tarea.

En cuanto a la censura y la norma de eufemización:

- El uso repetido de ciertas técnicas genera una norma de traducción, la eufemización.

- La abundancia de casos de variación, modulación, omisión, creación discursiva y generalización nos hace pensar que a veces existe un propósito de censura. 
- La cantidad de casos de creación discursiva, variación/modulación, omisión y generalización es considerablemente alta pues, a excepción del préstamo, son las técnicas que presentan los mayores números de casos. Estas cuatro técnicas suelen estar relacionadas con la eufemización y la manipulación.

- La corrección política a veces es una fachada para la manipulación y la censura.

- Pudimos comprobar que existe censura, tanto a través de la revisión teórica como de las entrevistas, y determinamos la importancia de las políticas lingüísticas en relación al doblaje.

- Es evidente que hay factores de importancia, como las políticas gubernamentales, pero no podemos dejar de considerar, por ejemplo, la influencia del público adulto de los programas para niños y adolescentes como factor en la toma de decisiones respecto de los doblajes.

- La elección de ciertas técnicas y estrategias puede ser producto del deseo del traductor de proteger a su público meta, compuesto por niños y adolescentes (autocensura), pero también puede ser consecuencia de la censura ejercida por el público adulto que también ve estos programas.

- Resulta imposible evaluar la traducción como resultado si no conocemos la traducción como proceso, que involucra no solo al traductor sino a las personas que modifican o tienen la influencia necesaria para modificar - directa o indirectamente- dicha traducción.

\subsection{PROPUESTAS DE FUTURO}

Del resultado del análisis realizado en este trabajo se desprenden ciertas realidades de la traducción para doblaje de programas infantojuveniles, que listamos ahora como propuestas elaboradas a partir de esta tesis doctoral:

1) Para no empobrecer el lenguaje y la creatividad, tal como afirmó uno de los entrevistados, es necesario que el traductor tenga una mayor libertad de expresión y más poder de decisión (o al menos de discusión) dentro del proceso de doblaje. El doblaje es tanto una técnica como un arte, y por lo tanto se debería considerar al traductor como uno de los artistas que contribuyen a que el producto tenga la mayor calidad posible, o al menos considerarlo un asesor de peso en la toma de decisiones, ya que el traductor, además de dominar la lengua, suele ser experto en las culturas con las que trabaja. Por otro lado, en tanto arte, el doblaje puede sufrir la misma censura que cualquier otro tipo de obra.

2) Todos los involucrados en el proceso de doblaje de material infantojuvenil (incluyendo al traductor) deberían tener conocimientos específicos sobre los niños, como psicología infantil básica y desarrollo cognitivo, o saber qué leen, qué actividades realizan, a qué juegan, cómo piensan. Por supuesto que es imposible generalizar, pero sí se pueden conocer las tendencias. Por ejemplo, mientras que a algunos traductores no les permiten poner palabras que tengan que ver con la muerte para evitar la violencia, hay asociaciones que se dedican a crear 
videos para niños que han perdido a algún ser querido en los que recomiendan decir las cosas por su nombre. Y los mismos niños que no escuchan la palabra "matar" pasan horas jugando juegos en los que el objetivo es matar (extraterrestres, soldados o lo que sea).

3) Ese conocimiento de los niños no tiene que ser necesariamente enciclopédico. Leer revistas especializadas o sitios web como Kidscreen permite conocer los gustos de los niños más pequeños; asistir a alguna convención de cómics o películas y series para adolescentes, o informarse sobre los invitados y expositores también resulta útil para conocer a los de más edad. Prestar atención a cómo hablan los adolescentes en toda Latinoamérica es imprescindible para evitar que el dubbese del doblaje de programas infantojuveniles se vuelva obsoleto. Si insistimos en utilizar las frases que se usan tradicionalmente desde hace años, el dubbese terminará siendo una variedad vetusta (que hasta cierto punto ya lo es), con el consiguiente riesgo de que los jóvenes comiencen a rechazarla. Con la debida investigación linguiística de los usos de la lengua se puede comenzar a incluir términos más modernos que comparten los niños y adolescentes hispanohablantes (incluyendo a los de España, como hemos visto). A principios de los años 2010, Disney Channel transmitía una serie que se llamaba Qué onda, que era la traducción habitual para el What's up? Casi diez años después, sería totalmente anacrónico traducir un $S^{\prime}$ up? con el mismo "¿Qué onda?" cuando existen frases (como "Hola, ¿qué hace?") que son habituales entre los adolescentes de toda Latinoamérica. ${ }^{167}$ Pero por supuesto, para estar al tanto de las frases típicas de niños y jóvenes no solo es necesario dedicar tiempo a conocerlos, sino compilar un corpus de lengua oral espontánea en dicho segmento de la población. Después de todo, los traductores no pueden perder de vista al público al que va dirigida su traducción.

4) Existe la necesidad de un diálogo más fluido entre académicos, profesionales y empresas, que debe ser una instancia diaria dentro del proceso de doblaje, en especial porque se manifestó entre los traductores encuestados cierto resentimiento respecto de su imposibilidad de participar en ciertas tomas de decisiones y utilizar su creatividad y conocimientos lingüísticos (vid. Capítulo 6). Si bien es verdad que modificar las políticas lingüísticas de un país o de una empresa es difícil, tal vez sea posible un acuerdo entre los distintos agentes involucrados en el doblaje para que el producto que crean tenga la mayor calidad posible y se adecue al público al que va dirigido.

5) Debería existir un debate entre las partes involucradas, respaldado por datos pertinentes, respecto de cuándo y por qué omitir, modular o estandarizar. Cualquier decisión tomada sin un fundamento claro se convierte en censura a los ojos del que la padece, y crea resentimiento. Quienes detentan el poder de decidir

${ }^{167}$ Los memes son muchas veces una buena fuente de términos utilizados por los jóvenes. 
en el proceso de doblaje deben estar bien informados lingüística y culturalmente, además de tener los conocimientos específicos antes mencionados. Por ejemplo, un estudio comprobó que aquellos adolescentes que vieron la serie 13 Reasons Why sobre una joven que se suicida tenían un riesgo más elevado de suicidarse. ${ }^{168}$ Los resultados de este estudio justificarían la decisión de quitar toda referencia a la muerte en los programas infantojuveniles. Pero una cosa es un suicidio o un asesinato, y otra muy distinta la muerte en sí, el fin natural de la vida, en especial cuando se la menciona en tono de comedia. Del mismo modo, quitar toda referencia a otras religiones o tradiciones reduce las posibilidades del niño de conocer otras culturas y de tener una mente abierta. Es decir, que el mismo hecho de crear textos políticamente correctos desde lo lingüístico en la lengua meta utilizando técnicas como la omisión o la generalización atenta contra la posibilidad de que el niño o el adolescente abra su mente a las distintas realidades existentes.

6) Es muy probable que el español neutro continúe siendo la variedad utilizada en la traducción audiovisual, a pesar de cierta resistencia por parte de algunos académicos e incluso de algún grupo de traductores. Lo que se debe tener en cuenta es que quienes se quejan de que el español neutro no suena natural son los adultos y no los niños. Por otro lado, también es importante recordar que es bueno que los niños aprendan sinónimos, para no reducir su vocabulario, pero siempre que comprendan por contexto (lingüístico o visual) el sentido de cada término. Tal vez sería necesario que no se hicieran tantas generalizaciones respecto del español neutro como un todo y se tuviera más en consideración la edad del público consumidor de cada producto.

\subsection{MÁS ALLÁ DE ESTA INVESTIGACIÓN}

El propósito de esta tesis era llevar a cabo una investigación lo más exhaustiva posible sobre el español neutro del doblaje de programas infantojuveniles de imagen real, pero a partir de los resultados obtenidos, sería posible emprender otras investigaciones relacionadas, como:

- estudiar los niveles que aquí no se han tratado, como el morfosintáctico o el fraseológico, o incluso el paralingüístico, es decir, de qué modo se "doblan" los gestos en inglés, qué entonaciones se utilizan, etc.;

168 Gander, K. (2018): "Netflix's '13 Reasons Why' linked to raised suicide risk in study", Newsweek, 26 de noviembre de 2018, https://www.newsweek.com/netflixs-13-reasons-why-linked-raised-suicide-riskstudy-1223990 (consultado el 26 de noviembre de 2018) 
- llevar a cabo un estudio contrastivo entre el español neutro y el español peninsular;

- comparar el español neutro del doblaje con aquel que se utiliza en la traducción literaria;

- ampliar el corpus a programas para adultos, o a dibujos animados, de modo que se pueda comparar los resultados obtenidos aquí con los que se extraigan de esos nuevos corpus;

- comparar el español neutro del doblaje con el español neutro de la subtitulación;

- analizar exhaustivamente la diferencia entre el español neutro del doblaje de series de ficción y las animadas;

- realizar un estudio polisistémico más exhaustivo de comparación de la producción doblada con la producción propia del mismo género infantojuvenil;

- investigar si, dado que la categoría de "series infantojuveniles" es muy amplia, se la debería dividir en subgéneros (para niños pequeños, para adolescentes, musicales, etc.) y analizar si se utilizan opciones diferentes según su público y temática, y si son las adecuadas;

- llevar a cabo un estudio exhaustivo de las preferencias, la respuesta y la influencia del público en el doblaje, tanto del público infantil y adolescente como adulto, pues es posible que existan diferencias en la recepción por parte del público de distintas edades; por otro lado, también sería útil estudiar de aquí a unos años la recepción y aceptación del español neutro por parte de quienes serán adultos pero habrán crecido con una influencia mucho mayor del español neutro debido al incremento en la disponibilidad de productos doblados en cine y plataformas VOD, y no solamente en canales de televisión para niños;

- estudiar con mayor profundidad alguno de los aspectos de la censura descritos en esta investigación, como su relación con las ideologías, las religiones, etc.;

- analizar el género y la formación académica o técnica de los traductores para ver cómo influyen en su tarea;

- comprobar qué tanto influye la figura del corrector lingüístico en el producto final;

- analizar si es significativo que, incluso en forma anónima, los traductores dispuestos a responder las preguntas fueron mayoritariamente hombres y qué 
implica eso respecto del temor a perder el empleo, el trabajo independiente, etc.; e

- investigar si la influencia del español neutro del doblaje en los niños es perjudicial o no. Di Giovanni (2010) se pregunta: "Can they somehow resist the impact on themselves of not-always-appropriate translation strategies and linguistic choices?"

- Finalmente, sería pertinente también, dados los hallazgos relacionados con las diferencias de criterios respecto de las variedades a las que traducen las empresas, investigar si tal vez existe algún agente específico en el proceso de doblaje que tiene peso en las decisiones tomadas pero cuyo rol es desconocido debido al secretismo que rodea al doblaje.

El español neutro del doblaje para programas infantojuveniles está expuesto a fuerzas que intentan modificarlo o conservarlo, moverlo por el continuo aceptación-adecuación, o incluso erradicarlo, y cada uno de los agentes involucrados en el proceso de doblaje ejerce dichas fuerzas, a las que se suma la influencia del público, compuesto tanto por adultos como por niños, cada vez menos pasivos en sus experiencias audiovisuales.

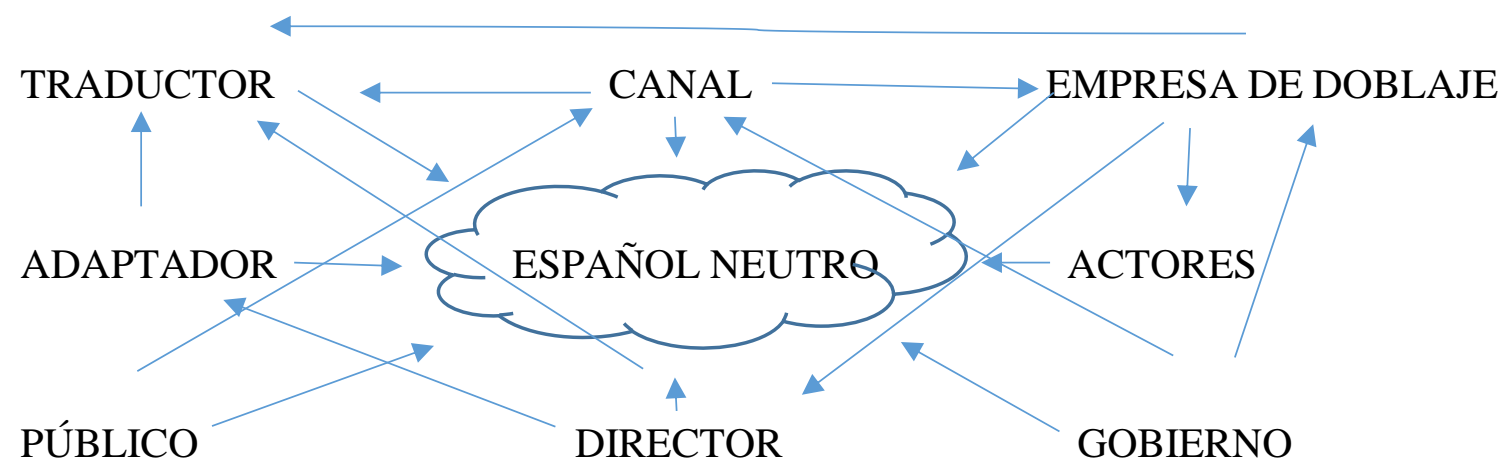

Ilustración 44 - Flujo de relaciones entre los agentes e instituciones que influyen en la configuración discursiva del español neutro

El español neutro es, pues, una variedad que depende de las políticas lingüísticas y es propensa a la estandarización y la censura. Está compuesto en gran medida por términos que a lo largo de los años han sido considerados neutros y que supuestamente son comprendidos en toda Latinoamérica, y en menor medida por regionalismos, incluidos en forma consciente o inconsciente por quienes utilizan esta variedad, ante la imposibilidad de conocer todas las variantes de español de esta enorme región. El español neutro, por lo tanto, no suele sonar natural, no solo porque contiene regionalismos sino porque además contiene palabras que pueden ser comprendidas en todas las regiones pero que 
no son necesariamente utilizadas en el habla cotidiana. Sin embargo, como hemos visto, la democratización del español hispanoamericano podría llevar a que el español neutro sea, en un futuro, un poco menos soso. Gracias a la tecnología, a las audiencias activas y a la convergencia propiciada por la digitalización, el hispanohablante reconoce (y algunas veces termina adoptando) la terminología de otras regiones, que empezará a parecerle cada vez menos ajena. Y en la medida que los niños que escuchen este español neutro más variado vayan creciendo, tal vez sea posible que desaparezca la resistencia que sí sienten hacia él los adultos en la actualidad.

Esta tesis doctoral no ha sido más que un primer intento de describir ese modelo de lengua artificial, y por ello ha sido necesario no restringirse a un solo país, ni a un sola serie de televisión, ni a un solo estudio de doblaje, sino intentar cubrir todos los países que traducen a español neutro en América, y ello obviamente supone también haber tenido que restringir el análisis del español neutro a un solo nivel lingüístico, el léxico (con algunas pinceladas sobre el nivel fonológico) y a ciertos campos semánticos que en la experiencia de la autora de esta tesis y de los profesionales encuestados son aquellos que presentan mayores problemas de traducción y los más sujetos a formas de manipulación. Sirva esta tesis doctoral como una primera cata de la descripción del español neutro del doblaje, preliminar, tentativa, incompleta, pero humildemente pionera en la exploración de un tema fascinante y apenas tratado en los círculos académicos con rigor metodológico. 


\section{REFERENCIAS}

\section{Bibliografía}

ABBOTT, M. (2017): "Stop Blaming Disney for Your Insatiable Appetite for Entertainment", https://www.christianpost.com/news/stop-blaming-disney-for-yourinsatiable-appetite-for-entertainment-195186/

AGOST, R. (1999): Traducción y doblaje: palabras, voces e imágenes, Barcelona: Ariel

AIRA, S. (2015): Doblaje. Sugerencias para el aprendizaje del oficio, Buenos Aires: Editorial Autores de Argentina

ALLAN, K.; K. BURRIDGE (2006): Forbidden Words: Taboo and the Censoring of Language, Cambridge y New York: Cambridge University Press

ANDIÓN HERRERO, M. A. (2005). Las variedades del español en América: una lengua y 19 países. Apuntes para profesores de E/LE, Brasilia: Consejería de Educación de la Embajada de España en Brasilia

ANDIÓN HERRERO, M. A. (2008a): "La diversidad lingüística del español: la compleja relación entre estándar, norma y variedad", VIII Congreso de Lingüística General 2008, Universidad Autónoma de Madrid, http://elvira.1llf.uam.es/clg8/actas/pdf/paperCLG10.pdf

ANDIÓN HERRERO, M. A. (2008b): "Modelo, estándar y norma... conceptos imprescindibles en el español L2/LE”, Revista española de Lingüística Aplicada, Asociación Española de Lingüística Aplicada, Castellón de la Plana: Universitat Jaume I

ARIAS, S. (N/D): “¿De qué estamos hablando? Acento neutro y castellano neutro”, http://doblajeenargentina.blogspot.com.ar/2012/07/espanol-rioplatense-y-espanolneutro.html

ÁVILA, R. (1998): “Televisión internacional, lengua internacional”, en CORTÉS BARGALLÓ, L. (ed): La lengua española y los medios de comunicación, volumen 2 , México: Siglo XXI Editores

ÁVILA, R. (2008): "Español internacional y normas regionales", http://www.elcastellano.org/ns/edicion/2008/septiembre/avila_r.html

BAHIENSE, S. et al. (2016): Guía para producciones audiovisuales accesibles, Ministerio de Cultura de Brasil, Secretaría de Audiovisual 
BALLESTER CASADO, A. (2000): Traducción y nacionalismo: la recepción del cine americano en España a través del doblaje, Granada: Universidad de Granada

BALLESTER CASADO, A. (2001): "Doblaje y nacionalismo. El caso de Sangre y arena”, en CHAUME, F. y R. AGOST (eds.): La traducción en los medios audiovisuales, Castelló de la Plana: Universitat Jaume I

BAÑOS PIÑERO, R. (2009): “La oralidad prefabricada en la traducción para el doblaje. Estudio descriptivo-contrastivo del español de dos comedias de situación: Friends y Siete Vidas", tesis doctoral, Universidad de Granada

BAÑOS-PIÑERO, R.; F. CHAUME (2009): "Prefabricated Orality", InTRAlinea, http://www.intralinea.org/specials/article/1714

BASSNETT, S.; A. LEFEVERE (1998): Constructing Cultures: Essays on Literary Translation, Clevedon: Multilingual Matters

BEIN, R. (ed.) (2015): Legislación sobre lenguas en la Argentina: manual para docentes, Proyecto UBACyT 2011-2017,

http://www.linguasur.com.ar/panel/archivos/8e 7b4dd361b63f707ab820a8c595f447ma nual-para-docentes.pdf

BOLLETTIERI, R.M.; E. DI GIOVANNI; L. ROSSATO (2014): Across Screens Across Boundaries, inTRAlinea, http://www.intralinea.org/specials/across_screens

BRAVO, E. (2009): "Español de América, español internacional”, en CAMACHO TABOADA, M.J.; J.J. RODRÍGUEZ TORO; J. SANTANA

MARRERO (eds.): Estudios de Lengua Española: Descripción, Variación y UsoHomenaje a Humberto López Morales, Madrid y Frankfurt am Main:

Iberoamericana/Vervuert

BRYMAN, A. (2004): The Disneyization of Society, Londres: SAGE Publications

BUCARIA, C. (2008): "Acceptance of the norm or suspension of disbelief?", en BUCARIA, C.; D. CHIARO; C. HEISS (eds): Between Text and Image: Updating Research in Screen Translation, Amsterdam: John Benjamins, pp. 149-164

BURGÜEÑO, C. (2011): “Avanza Ley Moreno: también en el cine dólar por dólar”, en Ámbito Financiero, 24 de noviembre de 2011

CABANELLAS, G. (2015): "El llamado español neutro", Revista CTPCBA, № 126, Colegio de Traductores Públicos de la Ciudad de Buenos Aires

CAMUS CAMUS, C.; C. GÓMEZ CASTRO; J. WILLIAMS CAMUS (eds.) (2017): Translation, Ideology and Gender, Cambridge: Cambridge Scholars

CARBONELL I CORTÉS, O. (1999): Traducción y cultura, Salamanca: Colegio de España

CASARINI, A. (2014): "Viewership 2.0: New forms of television consumption and their impact on audiovisual translation", inTRAlinea, www.intralinea.org 
CASTRO, L. (2004): "Nadie puede ser neutral", La Nación, 19 de noviembre de 2004, Buenos Aires

CEREZO MERCHÁN, B. et al. (2015): La traducción para el doblaje en España. Mapa de convenciones, Castelló de la Plana: Universitat Jaume I

CHATRUC, C.: "En Hollywood, el arte latinoamericano opaca la magia de Disney", La Nación, 14 de septiembre de 2017, https://www.lanacion.com.ar/2062887-enhollywood-el-arte-latinoamericano-opaca-la-magia-de-disney

CHAUME, F. (2001): "La pretendida oralidad de los textos audiovisuales y sus implicaciones en traducción", en AGOST, R.; CHAUME, F. (eds.) La traducción en los medios audiovisuales, Castelló de la Plana: Universitat Jaume I

CHAUME, F. (2004a): "Synchronization in dubbing: A translational approach", en ORERO, P. (ed.): Topics in Audiovisual Translation, Amsterdam: John Benjamins, pp. $35-52$

CHAUME, F. (2004b): Cine y traducción, Madrid: Cátedra

CHAUME, F. (2005): "Los estándares de calidad y la recepción de la traducción audiovisual", Puentes $\mathrm{N}^{\circ}$ 6, pp. 5-12

CHAUME, F. (2008): "El papel de la TAV en la creació i difusió de models de llengua", Revista del Collegi Oficial de Doctors i Llicenciats en Filosofia i Lletres i en Ciències de Catalunya, 129, pp. 62-77

CHAUME, F. (2012): Audiovisual translation: Dubbing, Manchester: St. Jerome

CHAUME, F. (2013): "Panorámica de la investigación en traducción para el doblaje", Trans: Revista de traductología, $\mathrm{N}^{\circ} 17$

CHAUME, F. y M. RICHART-MARSET (2015): "Del paradigma descriptivista al giro cultural en traducción audiovisual", en CHAUME, F. y M. RICHART-MARSET (eds.) (2015): "Traducción, ideología y poder en la ficción audiovisual", Prosopopeya $\mathrm{N}^{\mathrm{o}}$ 9, Tirant lo Blanch, Universitat de Valencia

CHESTERMAN, A. (1997): Memes of Translation. The spread of ideas in translation theory, Amsterdam: John Benjamins

CHION, M. (1993): La audiovisión, Madrid: Paidós

CÓMITRE NARVÁEZ, I. (2009): "Doblaje audiovisual y publicidad. Reflexiones en torno al concepto de manipulación", www.redit.uma.es

CONDE, J. L. (2011): "Castellano doblado. Interferencias del inglés en el castellano contemporáneo", Puntoycoma: Boletín de los traductores españoles de las instituciones de la Unión Europea, $\mathrm{N}^{\mathrm{o}}$ 122, pp. 14-21 
DANAN, M. (1991): "Dubbing as an Expression of Nationalism", Meta 36:4, Montreal: Les Presses de l'Université de Montréal, pp. 606-614

DI GIOVANNI, E. (2010): "Shifts in Audiovisual Translation for Children: Reviving Linguistic-Driven Analyses", en DI GIOVANNI, E.; C. ELEFANTE; R. PEDERZOLI (eds.) Ecrire Et Traduire Pour Les Enfants Writing and Translating for Children: Voix, Images Et Mots Voices, Images and Texts, Bruselas: Presses Interuniversitaires Europeennes

DIACONÚ, A. (2014): "Los riesgos del lenguaje neutro", La gaceta literaria, 20 de julio de 2014, https://www.lagaceta.com.ar/nota/600104/la-gaceta-literaria/riesgoslenguaje-neutro.html

DÍAZ CINTAS, J. (2001): "Los Estudios sobre Traducción y la traducción fílmica", en DURO, M. (Coord): La traducción para el doblaje y la subtitulación, Madrid: Cátedra, pp. 91-102

DÍAZ CINTAS, J. (2005): “Teoría y traducción audiovisual”, en La traducción audiovisual. Investigación, enseñanza y profesión, Granada: Comares

DÍAZ CINTAS, J. (2012): "Clearing the Smoke to See the Screen: Ideological Manipulation in Audiovisual Translation", Meta, 57:2, Montreal: Les Presses de l'Université de Montréal, pp. 279-293

DÍAZ CINTAS, J.; J. NEVES (eds.) (2015): Audiovisual Translation: Taking Stock, Newcastle Upon Tyne: Cambridge Scholars

DÍAZ CINTAS, J.; I. PARINI; I. RANZATO (2016): "The Discreet Charm of Manipulation", Altre Modernità, Università degli Studi di Milano, 2016,

DÍAZ FOUCES, O. (2009): "Estándar, variación y traducción en la lengua española", Diacrítica, Ciencias Da Linguagem 23:1, pp. 243-260

DICKSON, J. (2019): "Why Animation Prodcos Are Trying Out Live Action", 18 de abril de 2019, Kidscreen, http://kidscreen.com/2019/04/18/why-animation-prodcosare-trying-out-live-action/

DIGÓN REGUEIRO, P. (2006): "El caduco mundo de Disney: propuesta de análisis crítico en la escuela", Comunicar, No 26, Huelva: Grupo Comunicar Ediciones

EASTON, J. (2020): Disney+ exceeded 30 million downloads in Q4, 16 de enero de 2020, https://www.digitaltveurope.com/2020/01/15/disney-exceeded-30-milliondownloads-in-q4/

EL HALLI OBEID, L. (2012): "La normalidad de Frankenstein: El español neutro y el doblaje", Revista Nexos, http://www.nexos.com.mx/?p=14931

FARINA, M. (2014): Entrevista a Sandra Brizuela y Natalia Rosminati, http://tavargentina.com/entrevista-a-sandra-brizuela-y-natalia-rosminati/ 
FERNÁNDEZ, J.; N. MARRÓN (2019): “En plan... mi crush me putoflipa: diccionario de la jerga adolescente", El periódico, 6 de julio de 2019, https://www.elperiodico.com/es/mas-periodico/20190706/en-plan-crush-putoflipadiccionario-de-argot-adolescente- 7538640

FERNÁNDEZ VÍTORES, D. (2018): “El español: una lengua viva. Informe 2020”, Instituto Cervantes, https://cvc.cervantes.es/lengua/espanol_lengua_viva/pdf/espanol_lengua_viva_2020.p $\underline{\mathrm{df}}$

FERRARI, C. (2010): Since When is Fran Drescher Jewish?, Austin: University of Texas Press

FISHER, D. (2015): "Netflix study shows dads actively intro classic toons to their kids", Kidscreen, http://kidscreen.com/2015/06/17/netflix-study-shows-dads-activelyintro-classic-toons-to-their-kids/

FODOR, I. (1976): Film Dubbing: Phonetic, Semiotic, Esthetic and Psychological Aspects, Hamburgo: Buske

FRANCO AIXELÁ, J. (1996): "Culture-Specific Items in Translation", en ÁLVAREZ, R.; M. VIDAL (eds.): Translation, Power, Subversion, Clevedon: Multilingual Matters, pp. 52-78

FRY, A. "Lat-Am SVOD growing fast, Netflix to maintain lead", Digital TV Europe.com, 4 de abril de 2019, https://www.digitaltveurope.com/2019/04/04/lat-amsvod-growing-fast-netflix-to-maintain-lead/

FUENTES-LUQUE, A. (2019a): "Silence, sound, accents: Early film translation in the Spanish-speaking world", Proceedings of the British Academy, 218, The British Academy

FUENTES-LUQUE, A. (2019b): “An Approach to Audio-Visual Translation and the Film Industry in Spain and Latin America”, Bulletin of Spanish Studies, 96:5, University of Glasgow

GAMBIER, Y. (2002): "Les censures dans la traduction audiovisuelle", TTR:

Traduction, terminologie, rédaction, 15:2, pp. 203-221

GAMBIER, Y. (ed.) (2004): Meta 49:1, Montréal: Les Presses de l'Université de Montréal

GANDER, K. (2018): “Netflix's '13 Reasons Why' linked to raised suicide risk in study", Newsweek, 26 de noviembre de 2018, https://www.newsweek.com/netflixs-13reasons-why-linked-raised-suicide-risk-study-1223990

GARCÍA, A. (2017): "Huelga de dobladores: lista de series paralizadas sin doblaje en español", https://www.adslzone.net/2017/04/17/huelga-de-dobladores-lista-de-seriesparalizadas-sin-doblaje-en-espanol/

GARCÍA, S. (2019): Crítica de Toy Story 4, http://www.leercine.com.ar/toy-story-4/ 
GARCÍA AGUIAR, L.; R. GARCÍA JIMÉNEZ (2011): "La influencia del sistema meta en traducción: el doblaje de Los Picapiedra al español neutro", Estudios de Traducción, 1, 127-138

GARCÍA DE TORO, C. (2014): "Traducir literatura para niños: de la teoría a la práctica", Trans - Revista de Traductología, № 18, Málaga: Universidad de Málaga, pp. 123-137

GARCÍA IZQUIERDO, I. (2016): "El español neutro y la traducción de los lenguajes de especialidad", Sendebar, Vol. 27, Universidad de Granada

GARCÍA TESTA, V. (2018): "Idioma y política: lenguaje para todEs", Noticias, 17 de agosto de 2018, Buenos Aires: Editorial Perfil

GARNEMARK, R. (2015): Ingmar Bergman y la censura cinematográfica franquista, Santander: Asociación Shangrila

GIBSON, J. (2005): The War on Christmas, Nueva York: Sentinel

GIL BARDAJÍ, A. (2003): Procedimientos, técnicas, estrategias: operadores del proceso traductor, https://www.recercat.cat/bitstream/handle/2072/8998/TREBALL\%20DE\%20RECER CA\%20ANNA\%20GIL.pdf?sequence $=1$

GÓMEZ FONT, A. (2003): "El español internacional y la prensa hispana en Estados Unidos", Simposios de Chicago,

http://cvc.cervantes.es/lengua/espanol_eeuu/comunicacion/agomez.htm

GÓMEZ FONT, H. (2012): "Español neutro, global, general, estándar o internacional", Ómnibus 8:39, http://www.omni-

bus.com/n39/sites.google.com/site/omnibusrevistainterculturaln39/especial/espanolinternacional.html

GORDON, B. (2006): “Could we move into Lazytown?", The Telegraph, 28 de agosto de 2006, https://www.telegraph.co.uk/news/health/3342731/Could-we-move-intoLazyTown.html

GORIS, O. (1993): "The Question of French Dubbing", Target, 5:2, Amsterdam: John Benjamins, pp. 169-190

GUEVARA, A. (2013): El español neutro - Realización hablada en audiovisuales, doblaje, web y telemarketing, Editorial Iberoamericana / Comunicación

GUTIÉRREZ, V. (2019): “AMACC pide prohibir doblaje al español de películas de México, El economista, México, 9 de julio de 2019, https://www.eleconomista.com.mx/arteseideas/AMACC-pide-prohibir-doblaje-alespanol-de-peliculas-en-Mexico-20190709-0188.html

HATIM, B.; I. MASON (1990): Discourse and the Translator, Nueva York y

Londres: Routledge 
HAUGSTED, L. (2009): “Disney XD Unwraps On Friday The $13^{\text {th", } \text {, Multichannel }}$ News, 7 de enero de 2009,

https://web.archive.org/web/20110616202259/http://www.multichannel.com/article/16 1701-Disney_XD_Unwraps_On_Friday_The_13 th.php

HERMANS, T. (ed.) (1985): The Manipulation of Literature, Nueva York y Londres: Routledge

HERRERO SENDRA, A. (2014): "El español neutro en el doblaje de Los Aristogatos: un estudio de caso", trabajo final de grado en Traducción e Interpretación, Universitat Jaume I

HOPEWELL, J. (2016): "Televisa, Pok-ka, Federation, Laura Esquivel Team for 'Love, Divina'", Variety, 12 de septiembre de 2016, http://variety.com/2016/digital/global/mipcom-televisa-pol-ka-federation-lauraesquivel-love-divina-1201857921/

HURTADO ALBIR, A. (2001): Traducción y traductología, Madrid: Cátedra

IGLESIAS GÓMEZ, L.A. (2009): "Los doblajes en español de los clásicos de Disney", tesis doctoral, Salamanca: Universidad de Salamanca

IVARSSON, J. (1992): Subtitling for the Media, Stockholm: TransEdit

JOHNSON, T. "Bernie Sanders Continues Attack on Disney Over Worker Pay", Variety, 25 de mayo de 2016, http://variety.com/2016/biz/news/bernie-sanders-disneyrobert-iger-1201783423/

LEFEVERE, A.; S. BASSNETT (1990): Translation, History, Culture, London: Pinter LEFEVERE, A. (1992): Translation, Rewriting, and the Manipulation of Literary Fame, Nuea York y Londres: Routledge

LEPPILHALME, R. (1997): Culture Bumps: An Empirical Approach to the Translation of Allusions, Clevedon: Multilingual Matters

LERER, D. (2012): "¿Doblada o subtitulada? Un problema más complejo de lo que parece", 7 de enero de 2012, http://www.micropsiacine.com/2012/01/\%C2\%BFdoblada-o-subtitulada-un-problemamas-complejo-de-lo-que-parece/

LLORENTE PINTO, M. (2006): "¿Qué es el español neutro?", Cuadernos del Lazarillo: Revista literaria y cultural, 31, pp. 77-81, http://dialnet.unirioja.es/servlet/revista?codigo $=1983$

LÓPEZ, P. (2015): "Internet explota por transmisión de The Big Bang Theory doblada al español", 2 de noviembre de 2105, https://www.sdpnoticias.com/geek/transmisioninternet-explota-big-the.html 
LÓPEZ MORALES, H. (1998): La aventura del español en América, Madrid: EspasaCalpe

LORENZO, L. (2014) "Paternalismo traductor en las traducciones del género infantil y juvenil", en Trans - Revista de Traductología, No18, Málaga: Universidad de Málaga, pp. 35-48

LOZANO, D. (2018): "El imparable éxodo de venezolanos se extiende en la región", La Nación, 5 de mayo de 2018, https://www.lanacion.com.ar/2131684-el-imparableexodo-de-venezolanos-se-extiende-en-la-region

LOZANO MIRALLES, H. (2013): "La enunciación imperfecta del español neutro", inTRAlinea, www.intralinea.org

LUYKEN, G. (1991): Overcoming Language Barriers in Television, Manchester: European Institute for the Media

MARIMÓN LLORCA, C. (2006): "El español en América: de la conquista a la Época Colonial", Biblioteca Virtual Miguel de Cervantes, http://www.cervantesvirtual.com/obra-visor/el-espaol-en-amrica-de-la-conquista-a-lapoca-colonial-0/html/00f4b922-82b2-11df-acc7-002185ce6064_2.html\#I_0_

MARTÍ FERRIOL, J.L. (2005): "Estudio descriptivo y comparativo de las normas de traducción", Puentes, № 6 ,

https://www.researchgate.net/publication/306361137_Estudio_descriptivo_y_compara tivo_de_las_normas_de traduccion_en_las_versiones_doblada_y_subtitulada_al_espa nol_del_filme_Monsters'_Ball

MARTÍ FERRIOL, J.L. (2010): Cine independiente y traducción, Valencia: Tirant Lo Blanch

MARTÍ FERRIOL, J. L. (2013): El método de traducción: doblaje y subtitulación frente a frente, Castelló de la Plana: Publicaciones de la Universitat Jaume I

MARTÍNEZ SIERRA, J.J. (2010): "De normas, tendencias y otras regularidades en traducción audiovisual", Estudios de Traducción, 1, pp. 151-170

MARZÀ, A.; F. CHAUME; G. TORRALBA; A. ALEMANY (2005): "The Language We Watch: An Approach to the Linguistic Model of Catalan in Dubbing", en JONES, G. (ed.) Mercator Media Forum, Cardiff: University of Wales Press

MARZÀ, A. (2016): "La naturalitat en la traducció per al doblatge. El cas dels marcadors d'intensificació", tesis doctoral, Universitat Jaume I, https://www.tesisenred.net/bitstream/handle/10803/398396/2016_Tesis_Marza\%20Iba $\% \mathrm{C} 3 \%$ B1ez_Anna.pdf?sequence $=1 \&$ isAllowed $=\mathrm{y}$

MARZÀ, A.; A. M. PRATS (2018): La llengua perifèrica. El doblatge a les televisions públiques valenciana i balear, Vic: Eumo 
MATTELART, A.; A. DORFMAN (1971): Para leer al Pato Donald. Comunicación de masa y colonialismo, Valparaíso: Ediciones Universitarias

MAYORAL, R. (1994): "La traducción de la variación lingüística”, tesis doctoral, Universidad de Granada,

http://www.ugr.es/ rasensio/docs/La_traduccion_variacion_linguistica.pdf

MAYORAL, R.; D. KELLY; N. GALLARDO (1988): "Concept of Constrained Translation. Non-linguistic Perspectives of Translation", Meta 33:3, Montréal: Les Presses de l'Université de Montréal

MCLAUGHLIN, M.; J. MUÑOZ-BASOLS (2016): "Introduction", Perspectives in Translation Theory and Practice, Censorship and Translation Across Genres: Past and Present, 24:1, Nueva York y Londres: Routledge/Taylor \& Francis, https://doi.org/10.1080/0907676X.2016.1095579

MCLUHAN, M.; Q. FIORE (1967): El medio es el masaje, Barcelona: Paidós Ibérica

MENDELEVICH, P. (2016): "Réquiem para el lenguaje kirchnerista", La Nación, 2 de agosto de 2016

MERINO ÁLVAREZ, R. (ed.) (2009): Traducción y censura en España (1939-1985). Estudios sobre corpus TRACE: cine, narrativa, teatro, Universidad de León/Universidad del País Vasco

MESSENGER-DAVIES, M. (2001a): "Studying Children's Television", en CREEBER, G. (ed.): The Television Genre Book, London: British Film Institute, pp. 96-97

MESSENGER-DAVIES, M. (2001b): "The Child Audience", en CREEBER, G. (ed.): The Television Genre Book, London: British Film Institute, pp. 97-99

MíGUEZ, M. (2011): "La larga 'lista negra' de Disney", http://www.elmundo.es/elmundo/2011/11/11/cultura/1321031223.html

MINGHETTI, C. (2013): "La reglamentación de la Ley de Doblaje es uno de los grandes logros del proyecto nacional", Télam, 4 de agosto de 2013, http://www.telam.com.ar/notas/201308/27544-la-reglamentacion-de-la-ley-de-doblajees-uno-de-los-grandes-logros-del-proyecto-nacional.html

MOLINA MARTÍNEZ, L. (2001): Análisis descriptivo de la traducción de los culturemas árabe-español, tesis doctoral, Bellaterra: Universidad Autònoma de Barcelona

MOLINA MARTÍNEZ, L. y A. HURTADO ALBIR (2002): “Translation Techinques Revisited: A Dynamic and Functionalist Approach”, Meta, 47:4, Montreal: Les Presses de l'Université de Montréal

MORENO DE ALBA, J. (2015): El español en América, México D. F.: Fondo de Cultura Económica 
MOURELLE DE LEMA, M. (1998). "El periodismo como vehículo de penetración de extranjerismos en el léxico común", La lengua española y los medios de comunicación, Vol. I, Siglo XXI Editores, Secretaría de Educación Pública de México e Instituto Cervantes (México)

NORD, C. (1997): Translating as a Purposeful Activity: Functionalist Approaches Explained, Londres y Nueva York: Routledge

O'CONNELL, E. (2003): "What Dubbers of Children's Television Programmes Can Learn from Translators of Children's Books", Meta 48:2, Montréal: Les Presses de l'Université de Montréal, pp. 222-232

OITTINEN, R. (2000): Translating for Children, Nueva York: Garland Publishing OPPENHEIMER, A. (2019): “El atraso educativo en la region”, La Nación, 26 de diciembre de 2019

PARINI, I. (2012): "Censorship of Anime in Italian Distribution", Meta Vol. 57:2, Montréal: Les Presses de l'Université de Montréal pp. 325-337, https://doi.org/10.7202/1013948ar

PAVESI, M. (2005): La traduzione filmica. Aspetti del parlato doppiato dall'inglese all'italiano, Roma: Carocci

PEGENAUTE, L. (1999): "Censoring Translation and Translation as Censorship: Spain under Franco", El Trujamán, Centro Virtual Cervantes

PERAZO, C. (2016): “Los libros escritos por youtubers, entre los más elegidos por los adolescentes", La Nación, 25 de enero de 2016

PÉREZ, A. (2018): "La RAE se reafirma en rechazar el lenguaje inclusivo", El Mundo, 27 de noviembre de 2018, https://www.elmundo.es/cultura/literatura/2018/11/26/5bfc3577468aebb83e8b45b4.ht $\mathrm{ml}$

PETRELLA, L. (2001): "El español 'neutro' de los doblajes: intenciones y realidades", Congreso de Zacatecas, Centro Virtual Cervantes, http://cvc.cervantes.es/actcult/congreso/television/comunicaciones/petre.htm

PIQUÉ, E. (2017): “Italia y una Navidad 'políticamente correcta' que exacerba los ánimos”, en La Nación, 14 de diciembre de 2017

PLUNKETT, J. "Third of TV watching among younger viewers is via on-demand services", The Guardian, 11 de julio de 2016, https://www.theguardian.com/media/2016/jul/11/third-of-tv-watching-amongyounger-viewers-done-on-demand-services

PORTA FOUZ, J. (2016a): “¿Ustedes conocen la voz de Tom Hanks?”, La Nación, 3 de diciembre de 2016 
PORTA FOUZ, J. (2016b): "El aumento alarmante de las películas con doblaje", La Nación, 15 de octubre de 2016

PORTA FOUZ, J. (2019): Crítica de Toy Story 4, http://www.asalallena.com.ar/cine/critica-toy-story-4-javier-porta-fouz/

PUURTINEN, T. (1998): "Syntax, Readability and Ideology in Children's Literature", Meta, 43:4, Montréal: Les Presses de l'Université de Montréal, pp. 524-533

QUESADA PACHECO, M. A. (2002): El español de América, Cartago: Editorial Tecnológica de Costa Rica

QUIRING, D. (2017): “Críticos de cine cuestionan el creciente doblaje de películas”, La Diaria, Uruguay, 19 de octubre de 2017, https://ladiaria.com.uy/articulo/2017/10/criticos-de-cine-cuestionan-el-crecientedoblaje-de-peliculas/

RABADÁN, R. (2000): Traducción y censura inglés-español: 1939-1985. Estudio preliminar, León: Universidad de León

RAINIS, F. (2019): “¿Qué quieren decir dou y skerry? Un glosario para entender a los centennials", La Nación, 28 de abril de 2019,

https://www.lanacion.com.ar/sociedad/que-quiere-decir-dou-skerry-un-glosario-nid2242353

RANZATO, I. (2016) Translating Culture Specific References on Television: The Case of Dubbing, Nueva York y Londres: Routledge/Taylor \& Francis

REGUEIRO DIGÓN, P. (2006): "El caduco mundo de Disney: propuesta de análisis crítico en la escuela", Comunicar, $\mathrm{N}^{\circ} 26$, Huelva: Grupo Comunicar Ediciones

RICHART-MARSET, M. (2012): Ideología y Traducción. Por un análisis genético del doblaje, Madrid: Biblioteca Nueva

RINCÓN, M. J. (2012): "Ello hay mucha' folma de hablai español", 15 de marzo de 2012, https://www.diariolibre.com/actualidad/ello-hay-mucha-folma-de-hablai-espaorLJd1328164

ROMERO-FRESCO, P. (2013): "Accessible filmmaking: Joining the dots between audiovisual translation, accessibility and filmmaking", The Journal of Specialised Translation, 20, http://www.jostrans.org/issue20/art_romero.php

ROSALES, M. B. (2011): "Comunicación, género y políticas universitarias: una articulación necesaria hacia el cambio social", Revista de Ciencias Sociales desde la Comunicación y la Cultura, 1:26, La Plata: Universidad Nacional de la Plata, http://perio.unlp.edu.ar/ojs/index.php/oficiosterrestres/index

SAAVEDRA, A. (2011): "Sobre las lenguas de la educación", Página 12, 15 de noviembre de 2011

SACK, A. "La Real Academia Española, contra el 'todos y todas'", La Nación, 5 de 
marzo de 2012, https://www.lanacion.com.ar/sociedad/la-real-academia-espanolacontra-el-todos-y-todas-nid1453900

SÁNCHEZ LOBATO, J. (1993): "El español en América”, Actas del IV Congreso de la ASELE, Centro Virtual Cervantes, https://cvc.cervantes.es/ensenanza/biblioteca_ele/asele/pdf/04/04_0553.pdf

SÁNCHEZ MÉNDEZ, J. (2002): Historia de la lengua española en América, Valencia: Tirant Lo Blanch

SCANDURA, G. (2004): "Sex, Lies and TV: Censorship and Subtitling", Meta, 49:1, Montréal: Les Presses de l'Université de Montréal, pp. 125-134

SCANDURA, G. (2015): "El español neutro del doblaje de programas infantiles y juveniles: ¿un caso de estandarización o de censura?”, trabajo final de Máster, Universidad Jaume I

SCANDURA, G. (2016): "El efecto 'mariposa azul': cambios en la traducción de programas infantiles y juveniles", Actas del VI Congreso Latinoamericano de Traducción e Interpretación, Buenos Aires: Colegio de Traductores Públicos de la Ciudad de Buenos Aires

SHAVIT, Z. (1981): "Translation of children's literature as a function of its position in the literary polysystem", Poetics today, 2:4, Durham: Duke University Press, pp.171179

SONDERÉGUER, P. (2015): Lenguajes y manipulación lingüística. Lenguajes en contacto, intervenciones lingüísticas y medios de comunicación, Buenos Aires: Biblos

SPANGLER, T. "Netflix Beats Q4 Subscriber Forecasts With Largest Quarterly Gain in Its History", Variety, 31 de enero de 2017, http://variety.com/2017/digital/news/netflix-q4-2016-earnings-1201962823/

STACK, L. (2017): "Starbucks is Criticized for Its Holidays Cups. Yes, again.", The New York Times, 20 de noviembre de 2017, https://www.nytimes.com/2017/11/20/style/starbucks-gay-agenda.html

TING-TOOMEY, S. (1999): Communicating Across Cultures, New York: The Guildford Press

TITFORD, C. (1982): "Subtitling-Constrained Translation", Lebende Sprachen III, pp. 113-116

TORRES TORRES, A. (2016): El español de América, Barcelona: Universitat de Barcelona

TOURY, G. (1995): Descriptive Translation Studies -and beyond, Amsterdam: John Benjamins

VARELA, L. (2007): "Política lingüística: ¿qué está pasando en la Argentina?", Indicadores culturales, Buenos Aires: Universidad de Tres de Febrero 
VEGA, W. (2018): "La odisea tecnológica de llevar Netflix a docenas de idiomas", El Tiempo, Colombia, 16 de marzo de 2018, https://www.eltiempo.com/tecnosfera/novedades-tecnologia/como-se-doblan-ysubtitulan-las-series-y-peliculas-de-netflix-194996

VILLAFRANCO, G. (2019): "Empresarios del doblaje buscan reforzar industria pionera en México", Forbes México, 23 de abril de 2019, https://www.forbes.com.mx/empresarios-del-doblaje-buscan-reforzar-industriapionera-en-mexico/

VILLEGAS, A. (2006): "El espanglés y la utilidad del español neutro", en Panacea, 7:24, http://www.tremedica.org/panacea/IndiceGeneral/n24_tribuna-villegas.pdf

VINAY, J. P.; J. DARBELNET (1958): Stylistique compare du français et de l'anglais, Paris, Didier y Montréal: Beauchemin

VON FLOTOW, L. (2009): "Frenching the feature film twice. Or le synchronien au débat", en DÍAZ CINTAS, J. (ed.) New Trends in Audiovisual Translation, Bristol, Buffalo, Toronto: Multilingual Matters, pp. 83-98

WEITZ, M. (1996): "Mr. Corn Mo Rising", Dallas Observer, 10 de octubre de 1996WILLIAMS, J.; CHESTERMAN, A. (2011): The Map: A Beginner's Guide to Doing Research in Translation Studies, Manchester: St. Jerome

WIRNITZER, G. (2003): "Tipos de intervencionismo en la traducción de la literatura infantil y juvenil", Actas del Primer Congreso Internacional de la Asociación Ibérica de Estudios de Traducción e Interpretación, Granada: AIETI, pp. 633-639

WOLINSKY, N. (2014): "Las limitaciones del doblaje", http://tavargentina.com/limitaciones-en-doblaje/

YAHIAOUI, R. (2016): "Ideological Constraints in Dubbing The Simpsons into Arabic", Altre Modernità, Università degli Studi di Milano, https://riviste.unimi.it/index.php/AMonline/article/view/6855/6795

ZABALBEASCOA, P. (1993): "Developing translation studies to better account for audiovisual texts and other new forms of text production", tesis doctoral, Universidad de Lérida

ZABALBEASCOA, P. (2000): "Contenidos para adultos en el género infantil: el caso del doblaje de Walt Disney", en VELIJKA R. et al. (eds.): Literatura infantil y juvenil: tendencias actuales en investigación, Vigo: Universidad de Vigo, p. 19-31

ZABALBEASCOA, P. (2008): "La credibilidad de los diálogos traducidos para audiovisuales", en BRUMME, J. (ed.): La oralidad fingida: descripción y traducción, Madrid: Iberoamericana 
ZURRO, J. "Famosos e intrusos: ¿por qué Fernando Alonso dobla a un personaje de 'Cars 3'?", El español, 16 de julio de 2017,

https://www.elespanol.com/cultura/cine/20170714/231227681_0.html 


\section{Sitios web consultados}

http://www.imcine.gob.mx [última consulta: 8 de mayo de 2019; página original no disponible] http://archivo.pilardetodos.com.ar/index.php/component/k2/item/2481-por-videoconferenciacristina-kirchner-inaugur\%C3\%B3-el-hipermercado-walmart-de-pilar

http://doblajeenargentina.blogspot.com.ar/

http://doblajeenargentina.blogspot.com.ar/2012/07/espanol-rioplatense-y-espanol-neutro.html http://es.doblaje.wikia.com/wiki/Disney_en_el_doblaje

http://es.doblaje.wikia.com/wiki/Doblaje_Wiki:Portada

http://es.doblaje.wikia.com/wiki/Los_Incre\%C3\%ADbles

http://forumhome.org/alex-meets-big-time-rush-p20116-77.htm?smenu=77\&mad=No

http://healthland.time.com/2012/10/02/background-tv-children-exposed-to-four-hours-a-day/

http://kidscreen.com/2015/06/17/netflix-study-shows-dads-actively-intro-classic-toons-to-theirkids/

http://orgullodeser.com/fan/la-sirenita-y-el-re-doblaje-de-disney-en-espana-por-que-no-serespeta-el-original/

http://salvenlosmuebles.blogspot.com.ar/2013/11/apuntes-sobre-el-doblaje-el-espanol.html http://servicios.infoleg.gob.ar/infolegInternet/anexos/15000-19999/17694/texact.htm http://servicios.infoleg.gob.ar/infolegInternet/anexos/215000-219999/217418/norma.htm http://tavargentina.com/2015/07/simposio-hispanoamericano/ http://tavargentina.com/2015/09/entrevista-a-sebastian-arias/ http://tavargentina.com/2016/11/doblaje-jornada-taller/ http://tv.otroscines.com/2011/06/a-partir-de-junio-cinecanal-solo-emitira-peliculas-dobladas/ [última consulta: 6 de noviembre de 2016; página original no disponible]

http://www.asale.org/obras-y-proyectos/diccionarios/diccionario-de-americanismos http://www.iadacargentina.org/\#!/-historia/, el sitio de Intérpretes Argentinos de Doblaje http://www.lanacion.com.ar/1382020-cine-doblado-o-con-subtitulos http://www.rae.es/recursos/banco-de-datos/corpes-xxi 
http://www.senado.gob.mx/64/gaceta_del_senado/documento/4606

https://carmenchacon.shinyapps.io/PCIC/

https://docplayer.es/20762615-Pliego-de-bases-y-condiciones-particulares-educ-ar-sociedaddel-estado-tipo-contratacion-directa-no66-ejercicio-2012.html

https://lecture.ecc.u-tokyo.ac.jp/ cueda/varilex-r/

https://np3.netflixstudios.com/dubbing

https://np3.netflixstudios.com/dubbing

https://partnerhelp.netflixstudios.com/hc/en-us/articles/214807888-Dubbed-Audio-Style-GuideLip-Sync-Dubbing

https://partnerhelp.netflixstudios.com/hc/en-us/articles/217349997-Castilian-Latin-AmericanSpanish-Timed-Text-Style-Guide

https://www.youtube.com/watch?v=j70h2rvwSyg

https://www.youtube.com/watch?v=KcCeVxZXNGw

https://www.youtube.com/watch?v=VpRE4-1P86Y

www.alternativateatral.com

www.asale.org/recursos/diccionarios/damer

www.asihablamos.com

www.billboard.com

www.blogdelossimpson.com.ar [última consulta: 15 de noviembre de 2016; página original no disponible]

www.boomerangla.com

www.clarin.com/diccionario

www.doblaje.wikia.com

www.elgourmet.com

www.iadacargentina.org

www.imdb.com

www.mapoteca.educ.ar 
www.toplatino.net

www.wordreference.com

“Ahora no nos meten más al Pato Donald' y otras frases de Cristina Kirchner", La Nación, 2 de diciembre de 2015, https://www.lanacion.com.ar/politica/ahora-no-nos-meten-mas-al-patodonald-ahora-tenemos-a-paka-paka-y-otras-frases-de-cristina-kirchner-nid1850799

"Algunos españoles se quejan del doblaje en español latinoamericano de Coco, 29 de noviembre de 2017, https://www.radioformula.com.mx/notas.asp?Idn=722942\&idFC=2017

“Comienza la producción de Bia, la nueva serie multicultural de Disney Channel", para ti, $1^{\circ}$ de septiembre de 2018, https://www.infobae.com/parati/para-teens/2018/09/01/comienza-laproduccion-de-bia-la-nueva-serie-multicultural-de-disney-channel/

"Doblaje de Enredados", 26 de noviembre de 2010, https://salvemosdisneymexico.blogspot.com/2010/11/doblaje-de-enredados.html

"El doblaje abaratado quita a México terreno", El Heraldo de México, 14 de enero de 2019, https://heraldodemexico.com.mx/escena/el-doblaje-abaratado-quita-a-mexico-terreno/

"El hombre del doblaje: entrevista a Jorge Arvizu", Clarín, 29 de junio de 2008, https://www.clarin.com/extrashow/hombre-doblaje_0_SJXka20aY1.html

“En mi país se dice así. ¿En el tuyo?”, http://www.taringa.net/posts/offtopic/7340439/En-mipais-se-dice-asi-En-el-tuyo-post-latino.html

"La OCDE advierte sobre los pésimos resultados de estudiantes argentinos en las pruebas PISA", BBC Mundo, 10 de febrero de 2016, http://www.lanacion.com.ar/1869867-pesimosresultados-de-estudiantes-argentinos-en-las-pruebas-pisa

"La voz de Chespirito por todo el continente", BBC Mundo, 28 de noviembre de 2014, http://www.bbc.com/mundo/video_fotos/2014/11/140523_video_chespirito_obit_voxpops_wbm

“Las 'miembras' de Bibiana Aído", 10 de junio de 2008, https://www.20minutos.es/noticia/387648/0/miembras/bibiana/aido/

“Lo cierto es que no nos dejan elegir", Página 12, 2 de noviembre de 2014, http://www.pagina12.com.ar/diario/suplementos/espectaculos/5-33874-2014-11-02.html

"Los niños de hoy ya no quieren ver televisión”, El Tiempo, Colombia, 23 de junio de 2018, https://www.eltiempo.com/cultura/cine-y-tv/ninos-prefieren-ver-programas-en-internet-quetelevision-tradicional-234920

"Nickelodeon Wins 2016 with Kids and Total Viewers - Outperforms Competition by Double Digits", www.thefutoncritic.com/ratings/2016/12/28/nickelodeon-wins-2016-with-kids-andtotal-viewers-outperforms-competition-by-double-digits-

40211/20161228nickelodeon01/\#QAdhejUrSXjTuGuL.99

“Películas con subtítulos: ¿una causa perdida?”, La Nación, 4 de octubre de 2014, http://www.lanacion.com.ar/1732624-peliculas-con-subtitulos-una-causa-perdida

“Third of TV now watched on demand", 3 de septiembre de 2015, http://www.digitaltveurope.net/420901/third-of-tv-now-watched-on-demand/ 


\section{Filmografía}

A.N.T. Farm, Dan Signer, 2011-2014

Backyardigans, Janice Burgees, 2004-2012

Bambi, Ben Sharpsteen-Hamilton Luske, 1940

Billy Dilley, Aaron Springer, 2017

Bolt, Byron Howard-Chris Williams, 2008

Bunk'd, Pamela Eells, 2015-presente

Cars, John Lasseter, Joe Rankft, 2006

Descendants, Kenny Ortega, 2015

Devil and the Deep, Marion Hering, 1932

Dumbo, Ben Sharpsteen, 1941

El Chavo del 8, Roberto Gómez Bolaños, 1972-1984

Fuller House, Jeff Franklin, 2016-presente

Game of Thrones, David Benioff y D.B. Weiss, 2011-2019

Get Smart, Mel Brooks y Buck Henry, 1965-1970

Good Luck, Charlie, Phil Baker y Drew Vaupen, 2010-2014

Henry Danger, Dana Olsen y Dan Schneider, 2014-presente

K.C. Undercover, Corinne Marshall, 2015-2018

Nailed it!, 2018-presente

Nowhere Boys, Tony Ayres, 2013-2018

O11CE, Jorge Edelstein, 2017-presente

Phineas \& Ferb, Dan Povenmire-Jeff Marsh, 2007-2015

Pinocchio, Hamilton Luske-Ben Sharpsteen, 1940

Rasputin, Dämon der Frauen, Adolf Trotz, 1932

Snow White and the Seven Dwarfs, David Hand, 1937

Some Assembly Required, 2014-2018

Son amores, Adrián Suar-Jorge Maestro, 2002-2004

The Big Bang Theory, Chuck Lorre-Bill Prady, 2007-2019 
The Incredibles, Brad Bird, 2004

The Little Mermaid, Ron Clemens-John Musker, 1989

The Nanny, Fran Drescher-Peter Marc Jacobson, 1993-1999

The Polar Express, Robert Zemeckis, 2004

The Simpsons, Matt Groening, 1989-presente

The Suite Life on Deck, Jim Geoghan, Danny Kallis y Pamela Eells, 2008-2011

Violetta, Martín Saban-Jorge Nisco, 2012-2015

Yo soy Franky, William Barragán, 2015-2016 


\section{ANEXO 1: FICHAS DE ANÁLISIS}

\begin{tabular}{|l|c|l|l|l|}
\hline Ejemplo 1 & \multicolumn{3}{l|}{ PROGRAMA: HI-5 } \\
\hline PAÍS DE DOBLAJE: CHILE & AÑO 2009 \\
\hline TEMPORADA 11 - EPISODIO 1 “On Safari” & \multicolumn{1}{l|}{ TÉCNICA } & ESPAÑOL \\
\hline TÉRMINO & CONTEXTO & TRADUCCION & $\begin{array}{l}\text { Traducción } \\
\text { literal }\end{array}$ & Neutro \\
\hline Cool & Cool things & Cosas fabulosas &
\end{tabular}

\begin{tabular}{|l|c|l|l|l|}
\hline Ejemplo 2 & PROGRAMA: HI-5 \\
\hline PAÍ́S DE DOBLAJE: CHILE & AÑO 2009 \\
\hline TEMPORADA 11 - EPISODIO 1 “On Safari” & \multicolumn{1}{l|}{ TÉCNICA } & ESPAÑOL \\
\hline TÉRMINO & CONTEXTO & \multicolumn{1}{l|}{ TRADUCCION } & $\begin{array}{l}\text { Equivalente } \\
\text { acuñado }\end{array}$ & Neutro \\
\hline Bless & Bless you! & ¡Salud! & \\
\hline
\end{tabular}

\begin{tabular}{|l|c|l|l|l|}
\hline Ejemplo 3 & \multicolumn{2}{l|}{ PROGRAMA: HI-5 } \\
\hline PAÍ́S DE DOBLAJE: CHILE & AÑO 2009 \\
\hline TEMPORADA 11 - EPISODIO 1 “On Safari” & TÉCNICA & ESPAÑOL \\
\hline TÉRMINO & CONTEXTO & TRADUCCION & $\begin{array}{l}\text { Traducción } \\
\text { literal }\end{array}$ & Neutro \\
\hline Swing & Ready to swing? & ¿Listos para columpiarse? \\
\hline
\end{tabular}

\begin{tabular}{|l|c|l|l|l|}
\hline Ejemplo 4 & PROGRAMA: HI-5 \\
\hline PAÍS DE DOBLAJE: CHILE & AÑO 2009 \\
\hline TEMPORADA 11 - EPISODIO 1 “On Safari” & \multicolumn{1}{l|}{ TŔCNICA } & ESPAÑOL \\
\hline TÉRMINO & CONTEXTO & TRADUCION & $\begin{array}{l}\text { Traducción } \\
\text { literal }\end{array}$ & Neutro \\
\hline Bananas & Bananas! & ¡Bananas! &
\end{tabular}

\begin{tabular}{|l|c|l|c|c|}
\hline Ejemplo 5 & \multicolumn{2}{l|}{ PROGRAMA: HI-5 } \\
\hline PAÍS DE DOBLAJE: CHILE & AÑO 2009 \\
\hline TEMPORADA 11 - EPISODIO 1 “On Safari” & \multicolumn{1}{l|}{} \\
\hline TÉRMINO & CONTEXTO & TRADUCCION & TÉCNICA & ESPAÑOL \\
\hline Ride a bike & Ride my bike & -- & Omisión & -- \\
\hline
\end{tabular}




\begin{tabular}{|l|l|l|c|c|}
\hline Ejemplo 6 & \multicolumn{1}{l|}{ PROGRAMA: HI-5 } \\
\hline PAÍS DE DOBLAJE: CHILE & AÑO 2010 & \multicolumn{1}{l|}{} \\
\hline TEMPORADA 11 - EPISODIO 27 “Celebrations Around the World” & \multicolumn{1}{|l|}{ TRADUCCION } & TÉCNCA & ESPAÑOL \\
\hline TÉRMINO & CONTEXTO & $\begin{array}{l}\text { Creación } \\
\text { discursiva }\end{array}$ & Neutro \\
\hline $\begin{array}{l}\text { Ride on a } \\
\text { bike }\end{array}$ & I'll ride on a bike & Iré a navegar &
\end{tabular}

\begin{tabular}{|l|c|c|c|c|}
\hline Ejemplo 7 & \multicolumn{1}{l|}{ PROGRAMA: HI-5 } \\
\hline PAÍS DE DOBLAJE: CHILE & AÑO 2010 \\
\hline TEMPORADA 11 - EPISODIO 27 “Celebrations Around the World” \\
\hline TÉRMINO & \multicolumn{1}{|l|}{ CONTEXTO } & \multicolumn{1}{|l|}{ TRADUCCION } & TÉCNICA & ESPAÑOL \\
\hline Bucket & $\begin{array}{l}\text { That bucket would be } \\
\text { perfect! }\end{array}$ & Ese balde está perfecto. & $\begin{array}{l}\text { Traducción } \\
\text { literal }\end{array}$ & Regional \\
\hline
\end{tabular}

\begin{tabular}{|c|c|c|c|c|}
\hline \multicolumn{2}{|l|}{ Ejemplo 8} & \multicolumn{3}{|l|}{ PROGRAMA: HI-5 } \\
\hline \multicolumn{2}{|c|}{ PAÍS DE DOBLAJE: CHILE } & \multicolumn{3}{|l|}{ AÑO 2010} \\
\hline \multicolumn{5}{|c|}{ TEMPORADA 11 - EPISODIO 27 "Celebrations Around the World" } \\
\hline TÉRMINO & CONTEXTO & TRADUCCION & TÉCNICA & ESPAÑOL \\
\hline Drum & \multirow[b]{2}{*}{$\begin{array}{l}\text { Good for a rain dance } \\
\text { drum }\end{array}$} & \multirow[b]{2}{*}{ Ideal como tambor de lluvia. } & $\begin{array}{l}\text { Traducción } \\
\text { literal }\end{array}$ & Neutro \\
\hline Rain & & & & $\begin{array}{l}\text { Neutro } \\
\text { (Pronunciación } \\
\text { palatal de la } \\
\text { LL) }\end{array}$ \\
\hline
\end{tabular}

\begin{tabular}{|l|c|l|l|l|}
\hline Ejemplo 9 & PROGRAMA: HI-5 \\
\hline \multicolumn{4}{|l|l|}{ PAÍ́S DE DOBLAJE: CHILE } & AÑO 2010 \\
\hline \multicolumn{4}{|l|}{ TEMPORADA 11 - EPISODIO 27 “Celebrations Around the World” } \\
\hline TÉRMINO & CONTEXTO & \multicolumn{1}{l|}{ TRADUCCION } & TÉCNICA & ESPAÑOL \\
\hline \multirow{3}{*}{ Cool } & Hey! Cool banner! & ¡Oye! ¡Lindo cartel! & $\begin{array}{l}\text { Traducción } \\
\text { literal }\end{array}$ & Neutro \\
\cline { 2 - 5 } & Cool! & ¡Súper! & $\begin{array}{l}\text { Traducción } \\
\text { literal }\end{array}$ & Neutro \\
\hline
\end{tabular}

\begin{tabular}{|l|c|l|l|l|}
\hline Ejemplo 10 & \multicolumn{1}{l|}{ PROGRAMA: HI-5 } \\
\hline PAÍ́S DE DOBLAJE: CHILE & AÑO 2010 & TÉCNICA & ESPAÑOL \\
\hline TEMPORADA 11 - EPISODIO 27 “Celebrations Around the World” & \multicolumn{1}{|l|}{ TRADUCCION } & $\begin{array}{l}\text { Creación } \\
\text { discursiva }\end{array}$ & Neutro \\
\hline TÉRMINO & CONTEXTO & iFelices y locos pies! &
\end{tabular}




\begin{tabular}{|l|c|l|l|l|}
\hline Ejemplo 11 & \multicolumn{1}{l|}{ PROGRAMA: HI-5 } \\
\hline PAÍS DE DOBLAJE: CHILE & AÑO 2010 & \multicolumn{1}{l|}{ TÉCNICA } & ESPAÑOL \\
\hline TEMPORADA 11 - EPISODIO 27 “Celebrations Around the World” & \multicolumn{1}{|c|}{ TRADUCCION } & $\begin{array}{l}\text { TRuivalente } \\
\text { acuñado }\end{array}$ & Neutro \\
\hline TÉRMINO & CONTEXTO & ¡Huevos de Pascua! &
\end{tabular}

\begin{tabular}{|c|c|c|c|c|}
\hline \multicolumn{2}{|l|}{ Ejemplo 12} & \multicolumn{3}{|l|}{ PROGRAMA: HI-5 } \\
\hline \multicolumn{2}{|c|}{ PAÍS DE DOBLAJE: CHILE } & \multicolumn{3}{|l|}{ AÑO 2010} \\
\hline \multicolumn{5}{|c|}{ TEMPORADA 11 - EPISODIO 27 "Celebrations Around the World" } \\
\hline TÉRMINO & CONTEXTO & TRADUCCION & TÉCNICA & ESPAÑOL \\
\hline Bow & A pretty bow & Una linda cinta & Modulación & Neutro \\
\hline
\end{tabular}

\begin{tabular}{|l|l|l|l|l|}
\hline Ejemplo 13 & \multicolumn{1}{l|}{ PROGRAMA: HI-5 } \\
\hline PAÍS DE DOBLAJE: CHILE & AÑO 2010 \\
\hline TEMPORADA 11 - EPISODIO 27 “Celebrations Around the World” \\
\hline TÉRMINO & \multicolumn{1}{|l|}{ CONTEXTO } & \multicolumn{1}{|l|}{ TRADUCCION } & TÉCNICA & ESPAÑOL \\
\hline Halloween & $\begin{array}{l}\text { Just in time for } \\
\text { Halloween }\end{array}$ & $\begin{array}{l}\text { Justo a tiempo para la Noche } \\
\text { de Brujas }\end{array}$ & $\begin{array}{l}\text { Equivalente } \\
\text { acuñado }\end{array}$ & Neutro \\
\hline
\end{tabular}

\begin{tabular}{|c|c|c|c|c|}
\hline \multicolumn{2}{|l|}{ Ejemplo 14} & \multicolumn{3}{|l|}{ PROGRAMA: HI-5 } \\
\hline \multicolumn{2}{|c|}{ PAÍS DE DOBLAJE: CHILE } & \multicolumn{3}{|l|}{ AÑO 2010} \\
\hline \multicolumn{5}{|c|}{ TEMPORADA 11 - EPISODIO 27 "Celebrations Around the World" } \\
\hline TÉRMINO & CONTEXTO & TRADUCCION & TÉCNICA & ESPAÑOL \\
\hline Lollies & \multirow{2}{*}{$\begin{array}{l}\text { We can go get lollies! } \\
\text { And go trick or } \\
\text { treating! }\end{array}$} & \multirow{2}{*}{$\begin{array}{l}\text { ¡Podemos ir juntos a pedir } \\
\text { caramelos! } \\
\text { ¡Y a hacer travesuras! }\end{array}$} & Generalización & Regional \\
\hline $\begin{array}{l}\text { Trick or } \\
\text { treat }\end{array}$ & & & Explicitación & Neutro \\
\hline
\end{tabular}

\begin{tabular}{|l|c|c|c|c|}
\hline Ejemplo 15 & \multicolumn{2}{l|}{ PROGRAMA: HI-5 } \\
\hline PAÍS DE DOBLAJE: CHILE & AÑO 2010 \\
\hline TEMPORADA 11 - EPISODIO 27 “Celebrations Around the World” \\
\hline TÉRMINO & CONTEXTO & TRADUCCION & TÉCNICA & ESPAÑOL \\
\hline $\begin{array}{l}\text { St. Patrick's } \\
\text { Day }\end{array}$ & It's St. Patrick's Day & Es el día de San Patricio & $\begin{array}{l}\text { Equivalente } \\
\text { acuñado }\end{array}$ & Neutro \\
\hline
\end{tabular}




\begin{tabular}{|l|c|c|c|c|}
\hline Ejemplo 16 & \multicolumn{2}{l|}{ PROGRAMA: HI-5 } \\
\hline PAÍS DE DOBLAJE: CHILE & AÑO 2010 \\
\hline TEMPORADA 11 - EPISODIO 26 “Christmas” & TÉCNICA & ESPAÑOL \\
\hline TÉRMINO & CONTEXTO & TRADUCCION & TÉC & Neutro \\
\hline Santa Claus & Santa Claus is coming & Santa Claus pronto vendrá & Préstamo & \\
\hline
\end{tabular}

\begin{tabular}{|l|l|l|l|l|}
\hline Ejemplo 17 & \multicolumn{1}{l|}{ PROGRAMA: HI-5 } \\
\hline PAÍS DE DOBLAJE: CHILE & AÑO 2010 \\
\hline TEMPORADA 11 - EPISODIO 26 “Christmas” & \multicolumn{1}{l|}{ TÉCNICA } & ESPAÑOL \\
\hline TÉRMINO & \multicolumn{1}{|l}{ CONTEXTO } & \multicolumn{1}{l|}{ TRADUCCION } & Omisión & -- \\
\hline Stockings & $\begin{array}{l}\text { Time to hang your } \\
\text { stockings up }\end{array}$ & -- & & \\
\hline
\end{tabular}

\begin{tabular}{|l|l|l|l|c|}
\hline Ejemplo 18 & PROGRAMA: HI-5 \\
\hline PAÍS DE DOBLAJE: CHILE & AÑO 2010 \\
\hline TEMPORADA 11 - EPISODIO 26 “Christmas” & \multicolumn{1}{l|}{} \\
\hline TÉRMINO & CONTEXTO & TRADUCCION & TÉCNICA & ESPAÑOL \\
\hline Christmas & $\begin{array}{l}\text { Tomorrow's } \\
\text { Christmas Day }\end{array}$ & Mañana es Navidad & $\begin{array}{l}\text { Equivalente } \\
\text { acuñado }\end{array}$ & Neutro \\
\hline
\end{tabular}

\begin{tabular}{|c|c|c|c|c|}
\hline \multicolumn{2}{|l|}{ Ejemplo 19} & \multicolumn{3}{|l|}{ PROGRAMA: HI-5 } \\
\hline \multicolumn{2}{|c|}{ PAÍS DE DOBLAJE: CHILE } & \multicolumn{3}{|l|}{ AÑO 2010} \\
\hline \multicolumn{5}{|c|}{ TEMPORADA 11 - EPISODIO 26 “Christmas” } \\
\hline TÉRMINO & CONTEXTO & \begin{tabular}{|l|} 
TRADUCCION \\
\end{tabular} & TÉCNICA & ESPAÑOL \\
\hline Stocking & \multirow{2}{*}{$\begin{array}{l}\text { I can use this instead } \\
\text { of my Christmas } \\
\text { stocking }\end{array}$} & \multirow{2}{*}{$\begin{array}{l}\text { Usaré esto en lugar de mi } \\
\text { calceta }\end{array}$} & \begin{tabular}{|l|} 
Traducción \\
literal
\end{tabular} & \multirow{2}{*}{ Regional } \\
\hline $\begin{array}{l}\text { Christmas } \\
\text { stocking }\end{array}$ & & & Generalización & \\
\hline
\end{tabular}

\begin{tabular}{|l|l|l|l|l|}
\hline Ejemplo 20 & \multicolumn{1}{l|}{ PROGRAMA: HI-5 } \\
\hline PAÍ́S DE DOBLAJE: CHILE & AÑO 2010 \\
\hline TEMPORADA 11 - EPISODIO 26 “Christmas” & TÉCNICA & ESPAÑOL \\
\hline TÉRMINO & \multicolumn{1}{|c|}{ CONTEXTO } & TRADUCCION & Regional \\
\hline Glitter pens & $\begin{array}{l}\text { I'm going to draw with } \\
\text { these sparkly glitter } \\
\text { pens }\end{array}$ & $\begin{array}{l}\text { Voy a dibujar con estos } \\
\text { lápices de escarcha brillante }\end{array}$ & $\begin{array}{l}\text { Particulariza- } \\
\text { ción }\end{array}$ \\
\hline
\end{tabular}




\begin{tabular}{|c|c|c|c|c|}
\hline \multicolumn{2}{|l|}{ Ejemplo 21} & \multicolumn{3}{|l|}{ PROGRAMA: HI-5 } \\
\hline \multicolumn{2}{|c|}{ PAÍS DE DOBLAJE: CHILE } & AÑO 2010 & & \\
\hline \multicolumn{5}{|c|}{ TEMPORADA 11 - EPISODIO 26 “Christmas" } \\
\hline TÉRMINO & CONTEXTO & TRADUCCION & TÉCNICA & ESPAÑOL \\
\hline Santa & Like Santa & Como Santa & Préstamo & Neutro \\
\hline
\end{tabular}

\begin{tabular}{|l|c|l|c|l|}
\hline Ejemplo 22 & \multicolumn{1}{l|}{ PROGRAMA: HI-5 } \\
\hline PAÍS DE DOBLAJE: CHILE & AÑO 2010 \\
\hline TEMPORADA 11 - EPISODIO 26 “Christmas” & TÉCNICA & ESPAÑOL \\
\hline TÉRMINO & CONTEXTO & TRADUCCION & $\begin{array}{l}\text { Traducción } \\
\text { literal }\end{array}$ & $\begin{array}{l}\text { Regional } \\
\text { (diminutivo no } \\
\text { neutro) }\end{array}$ \\
\hline Jingle bells & And jingle bells & Y las campanitas &
\end{tabular}

\begin{tabular}{|l|c|l|c|c|}
\hline Ejemplo 23 & \multicolumn{3}{l|}{ PROGRAMA: HI-5 } \\
\hline PAÍS DE DOBLAJE: CHILE & AÑO 2010 & \\
\hline TEMPORADA 11 - EPISODIO 26 “Christmas” & TÉCNICA & ESPAÑOL \\
\hline TÉRMINO & CONTEXTO & TRADUCCION & Regional \\
\hline Cow bell & This cow bell-- & Esta campana de vaca & Calco & Region \\
\hline
\end{tabular}

\begin{tabular}{|l|c|l|l|l|}
\hline Ejemplo 24 & \multicolumn{2}{l|}{ PROGRAMA: HI-5 } \\
\hline PAÍS DE DOBLAJE: CHILE & AÑO 2010 \\
\hline TEMPORADA 11 - EPISODIO 26 “Christmas” & TÉCNICA & ESPAÑOL \\
\hline TÉRMINO & CONTEXTO & TRADUCCION & Neutro \\
\hline $\begin{array}{l}\text { Christmas } \\
\text { Eve }\end{array}$ & It's Christmas Eve & Es Nochebuena & $\begin{array}{l}\text { Equivalente } \\
\text { acuñado }\end{array}$ & Nando \\
\hline
\end{tabular}

\begin{tabular}{|l|c|l|l|l|}
\hline Ejemplo 25 & \multicolumn{1}{l|}{ PROGRAMA: HI-5 } \\
\hline PAÍS DE DOBLAJE: CHILE & AÑO 2010 \\
\hline TEMPORADA 11 - EPISODIO 26 “Christmas” & \multicolumn{1}{|l|}{ TRADUCCION } & TÉCNICA & ESPAÑOL \\
\hline TÉRMINO & CONTEXTO & $\begin{array}{l}\text { Traducción } \\
\text { literal }\end{array}$ & Regional \\
\hline Drive & $\begin{array}{l}\text { One of us can drive the } \\
\text { sleigh }\end{array}$ & $\begin{array}{l}\text { Alguien podría manejar el } \\
\text { trineo }\end{array}$ &
\end{tabular}




\begin{tabular}{|l|l|l|l|l|}
\hline Ejemplo 26 & PROGRAMA: HI-5 \\
\hline PAÍS DE DOBLAJE: CHILE & AÑO 2010 \\
\hline \multicolumn{1}{|l|}{ TEMPORADA 11 - EPISODIO 26 “Christmas” } \\
\hline TÉRMINO & \multicolumn{1}{|l|}{ CONTEXTO } & \multicolumn{1}{l|}{ TRADUCCION } & TÉCNICA & ESPAÑOL \\
\hline $\begin{array}{l}\text { Driver's } \\
\text { license }\end{array}$ & $\begin{array}{l}\text { I don't have my } \\
\text { driver's license }\end{array}$ & $\begin{array}{l}\text { Yo no tengo licencia de } \\
\text { conducir }\end{array}$ & $\begin{array}{l}\text { Equivalente } \\
\text { acuñado }\end{array}$ & Neutro \\
\hline
\end{tabular}

\begin{tabular}{|l|c|l|c|c|}
\hline Ejemplo 27 & \multicolumn{3}{l|}{ PROGRAMA: HI-5 } \\
\hline PAÍS DE DOBLAJE: CHILE & AÑO 2010 \\
\hline TEMPORADA 11 - EPISODIO 26 “Christmas” & \multicolumn{1}{l|}{ TRADUCCION } & TÉCNICA & ESPAÑOL \\
\hline TÉRMINO & CONTEXTO & $\begin{array}{l}\text { TRAducción } \\
\text { literal }\end{array}$ & Regional \\
\hline Park & $\begin{array}{l}\text { And I haven't learnt to } \\
\text { park on the roof yet }\end{array}$ & $\begin{array}{l}\text { Yo aún no aprendo a aparcar } \\
\text { en el techo }\end{array}$ & \begin{tabular}{l} 
Tradol \\
\hline
\end{tabular}
\end{tabular}

\begin{tabular}{|l|c|l|c|c|}
\hline Ejemplo 28 & \multicolumn{3}{l|}{ PROGRAMA: JESSIE } \\
\hline PAÍS DE DOBLAJE: ARGENTINA & AÑO 2011 \\
\hline TEMPORADA 1 - EPISODIO 8 “Christmas Story” & \multicolumn{1}{l|}{ TÉCNICA } & ESPAÑOL \\
\hline TÉRMINO & CONTEXTO & TRADUCCION & $\begin{array}{l}\text { Creación } \\
\text { discursiva }\end{array}$ & Neutro \\
\hline Suckers & Adiós, suckers! & iAdiós, hasta nunca! &
\end{tabular}

\begin{tabular}{|l|l|l|c|c|}
\hline Ejemplo 29 & \multicolumn{2}{l|}{ PROGRAMA: JESSIE } \\
\hline PAÍS DE DOBLAJE: ARGENTINA & AÑO 2011 \\
\hline TEMPORADA 1 - EPISODIO 8 “Christmas Story” & \multicolumn{1}{l|}{ TÉCNICA } & ESPAÑOL \\
\hline TÉRMINO & \multicolumn{1}{|l|}{ CONTEXTO } & \multicolumn{1}{|l|}{ TRADUCCION } & Neutro \\
\hline Santa & $\begin{array}{l}\text { Want to make our list } \\
\text { for Santa? }\end{array}$ & $\begin{array}{l}\text { ¿Escribimos las listas a } \\
\text { Santa? }\end{array}$ & Préstamo \\
\hline
\end{tabular}

\begin{tabular}{|l|c|l|l|l|}
\hline Ejemplo 30 & \multicolumn{2}{l|}{ PROGRAMA: JESSIE } \\
\hline PAÍS DE DOBLAJE: ARGENTINA & AÑ̃ 2011 \\
\hline TEMPORADA 1 - EPISODIO 8 “Christmas Story” & \multicolumn{1}{l|}{} \\
\hline TÉRMINO & CONTEXTO & TRADUCCION & TÉCNICA & ESPAÑOL \\
\hline Chubby & $\ldots$ he's chubby and he & $\begin{array}{l}\text {...y regordete y tiene una } \\
\text { has a cool beard }\end{array}$ & $\begin{array}{l}\text { Traducción } \\
\text { literal }\end{array}$ & Neutro \\
\cline { 4 - 5 } Cool & $\begin{array}{l}\text { Traducción } \\
\text { literal }\end{array}$ & Neutro \\
\hline
\end{tabular}




\begin{tabular}{|c|c|c|c|c|}
\hline \multicolumn{2}{|l|}{ Ejemplo 31} & \multicolumn{3}{|l|}{ PROGRAMA: JESSIE } \\
\hline \multicolumn{2}{|c|}{ PAIIS DE DOBLAJE: ARGENTINA } & AÑO 2011 & & \\
\hline \multicolumn{5}{|c|}{ TEMPORADA 1 - EPISODIO 8 "Christmas Story" } \\
\hline TÉRMINO & CONTEXTO & TRADUCCION & TÉCNICA & ESPAÑOL \\
\hline $\begin{array}{l}\text { God of } \\
\text { death }\end{array}$ & $\begin{array}{l}\text {...like Yama, the god } \\
\text { of death! }\end{array}$ & $\begin{array}{l}\text {...como Yama, el dios de la } \\
\text { muerte }\end{array}$ & $\begin{array}{l}\text { Traducción } \\
\text { literal }\end{array}$ & Neutro \\
\hline
\end{tabular}

\begin{tabular}{|l|c|l|l|l|}
\hline Ejemplo 32 & \multicolumn{3}{l|}{ PROGRAMA: JESSIE } \\
\hline PAÍS DE DOBLAJE: ARGENTINA & AÑO 2011 \\
\hline \multicolumn{2}{|l|}{ TEMPORADA 1 - EPISODIO 8 “Christmas Story” } \\
\hline TÉRMINO & CONTEXTO & TRADUCCION & TÉCNICA & ESPAÑOL \\
\hline $\begin{array}{l}\text { Easter } \\
\text { Bunny }\end{array}$ & $\begin{array}{l}\text {... when the Easter } \\
\text { Bunny comes to town }\end{array}$ & $\begin{array}{l}\text {...cuando el Conejo de } \\
\text { Pascua venga a la ciudad }\end{array}$ & $\begin{array}{l}\text { Equivalente } \\
\text { acuñado }\end{array}$ & Neutro \\
\hline
\end{tabular}

\begin{tabular}{|l|l|l|l|l|}
\hline Ejemplo 33 & \multicolumn{1}{l|}{ PROGRAMA: JESSIE } \\
\hline PAÍS DE DOBLAJE: ARGENTINA & AÑO 2011 \\
\hline TEMPORADA 1 - EPISODIO 8 “Christmas Story” & \multicolumn{1}{l|}{ TÉCNICA } & ESPAÑOL \\
\hline TÉRMINO & CONTEXTO & TRADUCCION & $\begin{array}{l}\text { Particulariza- } \\
\text { ción }\end{array}$ & Neutro \\
\hline Bugs & Bugs! & iInsectos! &
\end{tabular}

\begin{tabular}{|c|c|c|c|c|}
\hline \multicolumn{2}{|l|}{ Ejemplo 34} & \multicolumn{3}{|l|}{ PROGRAMA: JESSIE } \\
\hline \multicolumn{2}{|c|}{ PAIIS DE DOBLAJE: ARGENTINA } & AÑO 2011 & & \\
\hline \multicolumn{5}{|c|}{ TEMPORADA 1 - EPISODIO 8 “Christmas Story" } \\
\hline TÉRMINO & \begin{tabular}{|c|} 
CONTEXTO \\
\end{tabular} & \begin{tabular}{|l|} 
TRADUCCION \\
\end{tabular} & TÉCNICA & ESPAÑOL \\
\hline Bra & $\begin{array}{l}\text {...my dad took me } \\
\text { shopping for my first } \\
\text { training bra }\end{array}$ & $\begin{array}{l}\text {...mi papá me llevó a } \\
\text { comprar mi primer sostén }\end{array}$ & Generalización & Regional \\
\hline
\end{tabular}

\begin{tabular}{|l|l|l|c|l|}
\hline \multicolumn{2}{|l|}{ Ejemplo 35 } & \multicolumn{2}{l|}{ PROGRAMA: JESSIE } \\
\hline PAÍS DE DOBLAJE: ARGENTINA & AÑO 2011 \\
\hline \multicolumn{4}{|l|}{ TEMPORADA 1 - EPISODIO 8 “Christmas Story” } \\
\hline TÉRMINO & \multicolumn{1}{|l|}{ CONTEXTO } & \multicolumn{1}{|l|}{ TRADUCCION } & TÉCNICA & ESPAÑOL \\
\hline \multirow{2}{*}{ Prom } & $\begin{array}{l}\text { I don't want a prison } \\
\text { prom! }\end{array}$ & $\begin{array}{l}\text { ¡No quiero graduarme en } \\
\text { prisión! }\end{array}$ & Explicitación & Neutro \\
\cline { 2 - 5 } & $\begin{array}{l}\text { There will be no } \\
\text { prison prom }\end{array}$ & No habrá baile en prisión & Explicitación & Neutro \\
\hline
\end{tabular}




\begin{tabular}{|c|c|c|c|c|}
\hline \multicolumn{2}{|l|}{ Ejemplo 36} & \multicolumn{3}{|l|}{ PROGRAMA: JESSIE } \\
\hline \multicolumn{2}{|c|}{ PAÍS DE DOBLAJE: ARGENTINA } & AÑO 2011 & & \\
\hline \multicolumn{5}{|c|}{ TEMPORADA 1 - EPISODIO 8 "Christmas Story" } \\
\hline TÉRMINO & CONTEXTO & TRADUCCION & TÉCNICA & ESPAÑOL \\
\hline Candy cane & $\begin{array}{l}\text { That's why no one } \\
\text { tunneled out of jail } \\
\text { with a candy cane }\end{array}$ & $\begin{array}{l}\text { Por eso nadie cavó un túnel } \\
\text { con un dulce }\end{array}$ & Generalización & Neutro \\
\hline
\end{tabular}

\begin{tabular}{|c|c|c|c|c|}
\hline \multicolumn{2}{|l|}{ Ejemplo 37} & \multicolumn{3}{|l|}{ PROGRAMA: JESSIE } \\
\hline \multicolumn{2}{|c|}{ PAIIS DE DOBLAJE: ARGENTINA } & AÑO 2011 & & \\
\hline \multicolumn{5}{|c|}{ TEMPORADA 1 - EPISODIO 8 "Christmas Story" } \\
\hline TÉRMINO & CONTEXTO & \begin{tabular}{|r|} 
TRADUCCION \\
\end{tabular} & TÉCNICA & ESPAÑOL \\
\hline Christmas & $\begin{array}{l}\text { We need a Christmas } \\
\text { miracle }\end{array}$ & $\begin{array}{l}\text { Necesitamos un milagro de } \\
\text { Navidad }\end{array}$ & $\begin{array}{l}\text { Equivalente } \\
\text { acuñado }\end{array}$ & Neutro \\
\hline
\end{tabular}

\begin{tabular}{|c|c|c|c|c|}
\hline \multicolumn{2}{|l|}{ Ejemplo 38} & \multicolumn{3}{|l|}{ PROGRAMA: JESSIE } \\
\hline \multicolumn{2}{|c|}{ PAÍS DE DOBLAJE: ARGENTINA } & AÑO 2011 & & \\
\hline \multicolumn{5}{|c|}{ TEMPORADA 1 - EPISODIO 8 "Christmas Story" } \\
\hline TÉRMINO & CONTEXTO & TRADUCCION & TÉCNICA & ESPAÑOL \\
\hline Jingles & $\begin{array}{l}\text { Jingles, the police just } \\
\text { called }\end{array}$ & Cascabel, la policía llamó & $\begin{array}{l}\text { Traducción } \\
\text { literal }\end{array}$ & Neutro \\
\hline
\end{tabular}

\begin{tabular}{|c|c|c|c|c|}
\hline \multicolumn{2}{|l|}{ Ejemplo 39} & \multicolumn{3}{|l|}{ PROGRAMA: JESSIE } \\
\hline \multicolumn{2}{|c|}{ PAÍS DE DOBLAJE: ARGENTINA } & \multicolumn{3}{|l|}{ AÑO 2014} \\
\hline \multicolumn{5}{|c|}{ TEMPORADA 3 - EPISODIOS 26 Y 27 “Jessie’s Aloha-Holidays with Parker and Joey” } \\
\hline TÉRMINO & CONTEXTO & \begin{tabular}{|l|} 
TRADUCCION \\
\end{tabular} & TÉCNICA & \begin{tabular}{|l} 
ESPAÑOL \\
\end{tabular} \\
\hline Santa & $\begin{array}{l}\text {...Santa magically } \\
\text { delivers presents... }\end{array}$ & $\begin{array}{l}\text {...Santa mágicamente } \\
\text { entrega presentes... }\end{array}$ & Préstamo & Neutro \\
\hline
\end{tabular}

\begin{tabular}{|c|c|c|c|c|}
\hline \multicolumn{2}{|l|}{ Ejemplo 40} & \multicolumn{3}{|l|}{ PROGRAMA: JESSIE } \\
\hline \multicolumn{2}{|c|}{ PAÍS DE DOBLAJE: ARGENTINA } & \multicolumn{3}{|l|}{ AÑO 2014} \\
\hline \multicolumn{5}{|c|}{ TEMPORADA 3 - EPISODIOS 26 Y 27 “Jessie's Aloha-Holidays with Parker and Joey” } \\
\hline TÉRMINO & CONTEXTO & \begin{tabular}{|c|} 
TRADUCCION \\
\end{tabular} & TÉCNICA & ESPAÑOL \\
\hline Miracles & $\begin{array}{l}\text {...but some miracles, } \\
\text { even he can't pull off }\end{array}$ & $\begin{array}{l}\text {...pero ni siquiera él puede } \\
\text { conseguir ciertas cosas }\end{array}$ & Omisión & \\
\hline
\end{tabular}




\begin{tabular}{|c|c|c|c|c|}
\hline \multicolumn{2}{|l|}{ Ejemplo 41} & \multicolumn{3}{|l|}{ PROGRAMA: JESSIE } \\
\hline \multicolumn{2}{|c|}{ PAÍS DE DOBLAJE: ARGENTINA } & AÑO 2014 & & \\
\hline \multicolumn{5}{|c|}{ TEMPORADA 3 - EPISODIOS 26 Y 27 “Jessie's Aloha-Holidays with Parker and Joey” } \\
\hline TÉRMINO & CONTEXTO & TRADUCCION & TÉCNICA & ESPAÑOL \\
\hline Christmas & $\begin{array}{l}\text {... we should all spend } \\
\text { Christmas in Hawaii } \\
\text { together }\end{array}$ & $\begin{array}{l}\text {...debemos pasar las Fiestas } \\
\text { en Hawái juntos }\end{array}$ & Generalización & Neutro \\
\hline
\end{tabular}

\begin{tabular}{|c|c|c|c|c|}
\hline \multicolumn{2}{|l|}{ Ejemplo 42} & \multicolumn{3}{|l|}{ PROGRAMA: JESSIE } \\
\hline \multicolumn{2}{|c|}{ PAIIS DE DOBLAJE: ARGENTINA } & AÑO 2014 & & \\
\hline \multicolumn{5}{|c|}{ TEMPORADA 3 - EPISODIOS 26 Y 27 “Jessie's Aloha-Holidays with Parker and Joey” } \\
\hline TÉRMINO & CONTEXTO & \begin{tabular}{|c|} 
TRADUCCION \\
\end{tabular} & TÉCNICA & ESPAÑOL \\
\hline Pacifier & $\begin{array}{l}\text {...I used a scorpion as } \\
\text { a pacifier }\end{array}$ & $\begin{array}{l}\text {...usaba un escorpión como } \\
\text { chupete }\end{array}$ & $\begin{array}{l}\text { Traducción } \\
\text { literal }\end{array}$ & Regional \\
\hline
\end{tabular}

\begin{tabular}{|l|l|l|c|l|}
\hline \multicolumn{2}{|l|}{ Ejemplo 43 } & \multicolumn{4}{l|}{ PROGRAMA: JESSIE } \\
\hline \multicolumn{4}{|l|}{ PAÍS DE DOBLAJE: ARGENTINA } & AÑO 2014 \\
\hline \multicolumn{4}{|l|}{ TEMPORADA 3 - EPISODIOS 26 Y 27 “Jessie's Aloha-Holidays with Parker and Joey” } \\
\hline TÉRMINO & \multicolumn{1}{|c|}{ CONTEXTO } & \multicolumn{1}{|l|}{ TRADUCCION } & TÉCNICA & ESPAÑOL \\
\hline \multirow{3}{*}{ Bra } & $\begin{array}{l}\text { I'm gonna put your bra } \\
\text { in hot water }\end{array}$ & $\begin{array}{l}\text { Pondré tu ropa en agua } \\
\text { caliente }\end{array}$ & Generalización & Neutro \\
\cline { 2 - 5 } & $\begin{array}{l}\text { That explains the } \\
\text { sports bra }\end{array}$ & Eso explica tu ropa & Generalización & Neutro \\
\hline
\end{tabular}

\begin{tabular}{|c|c|c|c|c|}
\hline \multicolumn{2}{|l|}{ Ejemplo 44} & \multicolumn{3}{|l|}{ PROGRAMA: JESSIE } \\
\hline \multicolumn{2}{|c|}{ PAÍS DE DOBLAJE: ARGENTINA } & AÑO 2014 & & \\
\hline \multicolumn{5}{|c|}{ TEMPORADA 3 - EPISODIOS 26 Y 27 "Jessie's Aloha-Holidays with Parker and Joey" } \\
\hline TÉRMINO & CONTEXTO & TRADUCCION & TÉCNICA & ESPAÑOL \\
\hline $\begin{array}{l}\text { Christmas } \\
\text { Eve }\end{array}$ & $\begin{array}{l}\text {...you'll have to come } \\
\text { back Christmas Eve }\end{array}$ & ...regresen el 24 & Modulación & Neutro \\
\hline
\end{tabular}

\begin{tabular}{|l|c|l|c|c|}
\hline Ejemplo 45 & \multicolumn{1}{l|}{ PROGRAMA: JESSIE } \\
\hline \multicolumn{2}{|l|}{ PAÍS DE DOBLAJE: ARGENTINA } & AÑO 2014 \\
\hline TEMPORADA 3 - EPISODIOS 26 Y 27 “Jessie's Aloha-Holidays with Parker and Joey” \\
\hline TÉRMINO & CONTEXTO & \multicolumn{1}{|c|}{ TRADUCCION } & TÉCNICA & ESPAÑOL \\
\hline $\begin{array}{l}\text { Merry } \\
\begin{array}{l}\text { Christmas } \\
\text { Eve }\end{array}\end{array}$ & $\begin{array}{l}\text { Merry Christmas Eve, } \\
\text { everyone! }\end{array}$ & $\begin{array}{l}\text { ¡Felices Fiestas para todos } \\
\text { los presentes! }\end{array}$ & Generalización & Neutro \\
\hline
\end{tabular}




\begin{tabular}{|c|c|c|c|c|}
\hline \multicolumn{2}{|l|}{ Ejemplo 46} & \multicolumn{3}{|l|}{ PROGRAMA: JESSIE } \\
\hline \multicolumn{2}{|c|}{ PAÍS DE DOBLAJE: ARGENTINA } & AÑO 2014 & & \\
\hline \multicolumn{5}{|c|}{ TEMPORADA 3 - EPISODIOS 26 Y 27 “Jessie's Aloha-Holidays with Parker and Joey” } \\
\hline TÉRMINO & CONTEXTO & TRADUCCION & TÉCNICA & ESPAÑOL \\
\hline Parking & $\begin{array}{l}\text { Much like our resort } \\
\text { guests when they find } \\
\text { out about the parking } \\
\text { fee }\end{array}$ & $\begin{array}{l}\text { Como los huéspedes del hotel } \\
\text { cuando ven la tarifa del } \\
\text { estacionamiento }\end{array}$ & $\begin{array}{l}\text { Traducción } \\
\text { literal }\end{array}$ & Neutro \\
\hline
\end{tabular}

\begin{tabular}{|c|c|c|c|c|}
\hline \multicolumn{2}{|l|}{ Ejemplo 47} & \multicolumn{3}{|l|}{ PROGRAMA: JESSIE } \\
\hline \multicolumn{2}{|c|}{ PAIÍS DE DOBLAJE: ARGENTINA } & \multicolumn{3}{|l|}{ AÑO 2014} \\
\hline \multicolumn{5}{|c|}{ TEMPORADA 3 - EPISODIOS 26 Y 27 “Jessie's Aloha-Holidays with Parker and Joey” } \\
\hline TÉRMINO & CONTEXTO & TRADUCCION & TÉCNICA & ESPAÑOL \\
\hline $\begin{array}{l}\text { Christmas } \\
\text { Eve }\end{array}$ & \multirow{2}{*}{$\begin{array}{l}\text {...for our Christmas } \\
\text { Eve Luau }\end{array}$} & \multirow{2}{*}{$\begin{array}{l}\text {...para nuestro Luau de las } \\
\text { Fiestas }\end{array}$} & Generalización & Neutro \\
\hline Luau & & & Préstamo & Neutro \\
\hline
\end{tabular}

\begin{tabular}{|c|c|c|c|c|}
\hline \multicolumn{2}{|l|}{ Ejemplo 48} & \multicolumn{3}{|l|}{ PROGRAMA: JESSIE } \\
\hline \multicolumn{2}{|c|}{ PAIIS DE DOBLAJE: ARGENTINA } & AÑ̃ 2014 & & \\
\hline \multicolumn{5}{|c|}{ TEMPORADA 3 - EPISODIOS 26 Y 27 "Jessie's Aloha-Holidays with Parker and Joey" } \\
\hline TÉRMINO & CONTEXTO & TRADUCCION & TÉCNICA & ESPAÑOL \\
\hline Suckers & $\begin{array}{l}\text {...and see if these } \\
\text { suckers bite. }\end{array}$ & $\begin{array}{l}\text {..y veamos si estos torpes } \\
\text { los compran }\end{array}$ & Variación & Neutro \\
\hline
\end{tabular}

\begin{tabular}{|c|c|c|c|c|}
\hline \multicolumn{2}{|l|}{ Ejemplo 49} & \multicolumn{3}{|l|}{ PROGRAMA: JESSIE } \\
\hline \multicolumn{2}{|c|}{ PAÍS DE DOBLAJE: ARGENTINA } & AÑO 2014 & & \\
\hline \multicolumn{5}{|c|}{ TEMPORADA 3 - EPISODIOS 26 Y 27 “Jessie’s Aloha-Holidays with Parker and Joey” } \\
\hline TÉRMINO & CONTEXTO & TRADUCCION & TÉCNICA & ESPAÑOL \\
\hline Basketball & $\begin{array}{l}\text { I learned how to play } \\
\text { basketball from my } \\
\text { sister, Maddie. }\end{array}$ & $\begin{array}{l}\text { Aprendí a jugar basquetból } \\
\text { con mi hermana Maddie }\end{array}$ & Préstamo & $\begin{array}{l}\text { Regional } \\
\text { (variación } \\
\text { dialectal } \\
\text { /basquetból/) }\end{array}$ \\
\hline
\end{tabular}

\begin{tabular}{|l|c|l|c|l|}
\hline Ejemplo 50 & \multicolumn{2}{l|}{ PROGRAMA: JESSIE } \\
\hline PAÍS DE DOBLAJE: ARGENTINA & AÑO 2014 & \multicolumn{2}{l|}{} \\
\hline TEMPORADA 3 - EPISODIOS 26 Y 27 “Jessie's Aloha-Holidays with Parker and Joey” \\
\hline TÉRMINO & CONTEXTO & TRADUCCION & TÉCNICA & ESPAÑOL \\
\hline Stupid & Stupid, stupid! & ¡Torpe, torpe! & Variación & Neutro \\
\hline
\end{tabular}




\begin{tabular}{|l|c|l|l|l|}
\hline \multicolumn{2}{|l|}{ Ejemplo 51 } & \multicolumn{1}{l|}{ PROGRAMA: JESSIE } \\
\hline PAÍS DE DOBLAJE: ARGENTINA & AÑO 2014 \\
\hline TEMPORADA 3 - EPISODIOS 26 Y 27 “Jessie's Aloha-Holidays with Parker and Joey” \\
\hline TÉRMINO & CONTEXTO & TRADUCCION & TÉCNICA & ESPAÑOL \\
\hline Pen & Gonna go get a pen & Voy por un lápiz & $\begin{array}{l}\text { Particulariza- } \\
\text { ción }\end{array}$ & Neutro \\
\hline
\end{tabular}

\begin{tabular}{|l|c|l|l|l|}
\hline Ejemplo 52 & \multicolumn{1}{l|}{ PROGRAMA: JESSIE } \\
\hline PAÍS DE DOBLAJE: ARGENTINA & AÑO 2014 \\
\hline \multicolumn{1}{|l|}{ TEMPORADA 3 - EPISODIOS 26 Y 27 “Jessie's Aloha-Holidays with Parker and Joey” } \\
\hline TÉRMINO & CONTEXTO & \multicolumn{1}{|c|}{ TRADUCCION } & TÉCNICA & ESPAÑOL \\
\hline Boom-boom & $\begin{array}{l}\text {... after I made boom- } \\
\text { boom. }\end{array}$ & ...después de hacer popó & $\begin{array}{l}\text { Equivalente } \\
\text { acuñado }\end{array}$ & Neutro \\
\hline
\end{tabular}

\begin{tabular}{|l|l|l|l|l|}
\hline \multicolumn{2}{|l|}{ Ejemplo 53 } & \multicolumn{2}{l|}{ PROGRAMA: JESSIE } \\
\hline PAÍS DE DOBLAJE: ARGENTINA & AÑO 2014 \\
\hline TEMPORADA 3 - EPISODIOS 26 Y 27 “Jessie's Aloha-Holidays with Parker and Joey” \\
\hline TÉRMINO & CONTEXTO & \multicolumn{1}{|l|}{ TRADUCCION } & TÉCNICA & ESPAÑOL \\
\hline Christmas & $\begin{array}{l}\text { Get your Christmas } \\
\text { sandy canes here! }\end{array}$ & $\begin{array}{l}\text { ¡Compren sus recuerdos de } \\
\text { arena aquí! }\end{array}$ & Omisión & -- \\
\cline { 4 - 6 } & & Omisión & -- \\
\hline
\end{tabular}

\begin{tabular}{|l|c|l|c|c|}
\hline \multicolumn{2}{|l|}{ Ejemplo 54 } & \multicolumn{1}{l|}{ PROGRAMA: JESSIE } \\
\hline PAÍS DE DOBLAJE: ARGENTINA & AÑO 2014 \\
\hline \multicolumn{2}{|l|}{ TEMPORADA 3 - EPISODIOS 26 Y 27 “Jessie's Aloha-Holidays with Parker and Joey” } \\
\hline TÉRMINO & \multicolumn{1}{|c|}{ CONTEXTO } & \multicolumn{1}{|c|}{ TRADUCCION } & TÉCNICA & ESPANOLL \\
\hline Ketchup & $\begin{array}{l}\text { These are just empty } \\
\text { ketchup bottles. }\end{array}$ & $\begin{array}{l}\text { Son solo botellas vacías de } \\
\text { salsa. }\end{array}$ & Generalización & Neutro \\
\hline
\end{tabular}

\begin{tabular}{|l|l|l|l|l|}
\hline \multicolumn{2}{|l|}{ Ejemplo 55 } & \multicolumn{1}{l|}{ PROGRAMA: JESSIE } \\
\hline \multicolumn{2}{|l|}{ PAÍS DE DOBLAJE: ARGENTINA } & AÑO 2014 \\
\hline \multicolumn{1}{|l|}{ TEMPORADA 3 - EPISODIOS 26 Y 27 “Jessie's Aloha-Holidays with Parker and Joey” } \\
\hline TÉRMINO & \multicolumn{1}{|c|}{ CONTEXTO } & \multicolumn{1}{|l|}{ TRADUCCION } & TÉCNICA & ESPANOLL \\
\hline Bugs & $\begin{array}{l}\text { I told Joey Emma } \\
\text { loves bugs }\end{array}$ & $\begin{array}{l}\text { Le dije a Joey que Emma } \\
\text { ama los insectos }\end{array}$ & $\begin{array}{l}\text { Particulariza- } \\
\text { ción }\end{array}$ & Neutro \\
\hline
\end{tabular}




\begin{tabular}{|l|c|l|c|l|}
\hline \multicolumn{2}{|l|}{ Ejemplo 56 } & \multicolumn{1}{l|}{ PROGRAMA: JESSIE } \\
\hline \multicolumn{2}{|l|}{ PAÍS DE DOBLAJE: ARGENTINA } & AÑO 2014 \\
\hline TEMPORADA 3 - EPISODIOS 26 Y 27 “Jessie's Aloha-Holidays with Parker and Joey” \\
\hline TÉRMINO & \multicolumn{1}{|c|}{ CONTEXTO } & \multicolumn{1}{|c|}{ TRADUCCION } & TÉCNICA & ESPAÑOL \\
\hline Jeans & $\begin{array}{l}\text { You're, like, the high- } \\
\text { waisted jeans of } \\
\text { people! }\end{array}$ & $\begin{array}{l}\text { Eres como un jean pasado de } \\
\text { moda }\end{array}$ & Préstamo & Regional \\
\hline
\end{tabular}

\begin{tabular}{|l|l|l|l|l|}
\hline \multicolumn{2}{|l|}{ Ejemplo 57 } & \multicolumn{1}{l|}{ PROGRAMA: JESSIE } \\
\hline \multicolumn{4}{|l|}{ PAÍS DE DOBLAJE: ARGENTINA } & AÑO 2014 \\
\hline TEMPORADA 3 - EPISODIOS 26 Y 27 “Jessie's Aloha-Holidays with Parker and Joey” \\
\hline TÉRMINO & \multicolumn{1}{|c|}{ CONTEXTO } & \multicolumn{1}{|c|}{ TRADUCCION } & TÉCNICA & ESPAÑOL \\
\hline Glitter & $\begin{array}{l}\text { Throw a little glitter } \\
\text { on this thing, and it's } \\
\text { my dream pet! }\end{array}$ & $\begin{array}{l}\text { Con brillo es ideal como } \\
\text { mascota }\end{array}$ & $\begin{array}{l}\text { Traducción } \\
\text { literal }\end{array}$ & Neutro \\
\hline
\end{tabular}

\begin{tabular}{|c|c|c|c|c|}
\hline \multicolumn{2}{|l|}{ Ejemplo 58} & \multicolumn{3}{|l|}{ PROGRAMA: JESSIE } \\
\hline \multicolumn{2}{|c|}{ PAÍS DE DOBLAJE: ARGENTINA } & \multicolumn{3}{|l|}{ AÑO 2014} \\
\hline \multicolumn{5}{|c|}{ TEMPORADA 3 - EPISODIOS 26 Y 27 “Jessie's Aloha-Holidays with Parker and Joey" } \\
\hline TÉRMINO & CONTEXTO & TRADUCCION & TÉCNICA & ESPAÑOL \\
\hline Murder & $\begin{array}{l}\text { I'm going to make } \\
\text { Jessie the most } \\
\text { important character in } \\
\text { the entire murder } \\
\text { mystery }\end{array}$ & $\begin{array}{l}\text { Convertiré a Jessie en el } \\
\text { personaje más importante de } \\
\text { todo este misterio }\end{array}$ & Omisión & Neutro \\
\hline
\end{tabular}

\begin{tabular}{|c|c|c|c|c|}
\hline \multicolumn{2}{|l|}{ Ejemplo 59} & \multicolumn{3}{|l|}{ PROGRAMA: JESSIE } \\
\hline \multicolumn{2}{|c|}{ PAÍS DE DOBLAJE: ARGENTINA } & \multicolumn{3}{|l|}{ AÑO 2014} \\
\hline \multicolumn{5}{|c|}{ TEMPORADA 3 - EPISODIOS 26 Y 27 "Jessie's Aloha-Holidays with Parker and Joey" } \\
\hline TÉRMINO & CONTEXTO & TRADUCCION & TÉCNICA & ESPAÑOL \\
\hline \multirow{3}{*}{ Corpse } & $\begin{array}{l}\text { Right, because you're a } \\
\text { corpse }\end{array}$ & Claro, porque eres la víctima & Modulación & Neutro \\
\hline & $\begin{array}{l}\text {...you're a little too } \\
\text { high-strung to be a } \\
\text { corpse }\end{array}$ & $\begin{array}{l}\text {...estás un poco nerviosa } \\
\text { para estar sin vida }\end{array}$ & Modulación & Neutro \\
\hline & $\begin{array}{l}\text { So they needed } \\
\text { another corpse and no } \\
\text { one called me? }\end{array}$ & $\begin{array}{l}\text { ¿Necesitaban otro cuerpo y } \\
\text { nadie me llamó? }\end{array}$ & Modulación & Neutro \\
\hline
\end{tabular}




\begin{tabular}{|l|c|l|c|c|}
\hline \multicolumn{2}{|l|}{ Ejemplo 60 } & \multicolumn{1}{l|}{ PROGRAMA: JESSIE } \\
\hline PAÍS DE DOBLAJE: ARGENTINA & AÑO 2014 \\
\hline \multicolumn{1}{|l|}{ TEMPORADA 3 - EPISODIOS 26 Y 27 “Jessie's Aloha-Holidays with Parker and Joey” } \\
\hline TÉRMINO & CONTEXTO & \multicolumn{1}{|c|}{ TRADUCCION } & TÉCNICA & ESPAÑOL \\
\hline Diaper & $\begin{array}{l}\text { And yet, you put me in } \\
\text { a diaper! }\end{array}$ & $\begin{array}{l}\text { ¡Y fue tu idea ponerme esta } \\
\text { ropa! }\end{array}$ & Generalización & Neutro \\
\hline
\end{tabular}

\begin{tabular}{|l|l|l|l|l|}
\hline \multicolumn{2}{|l|}{ Ejemplo 61 } & \multicolumn{1}{l|}{ PROGRAMA: JESSIE } \\
\hline PAÍS DE DOBLAJE: ARGENTINA & AÑO 2014 \\
\hline TEMPORADA 3 - EPISODIOS 26 Y 27 “Jessie's Aloha-Holidays with Parker and Joey” \\
\hline TÉRMINO & CONTEXTO & \multicolumn{1}{|l|}{ TRADUCCION } & TÉCNICA & ESPAÑOL \\
\hline Dumb & $\begin{array}{l}\text { They're too dumb to } \\
\text { live }\end{array}$ & Son muy torpes para vivir & $\begin{array}{l}\text { Traducción } \\
\text { literal }\end{array}$ & Neutro \\
\hline
\end{tabular}

\begin{tabular}{|l|l|l|l|l|}
\hline \multicolumn{2}{|l|}{ Ejemplo 62 } & \multicolumn{1}{l|}{ PROGRAMA: JESSIE } \\
\hline PAÍS DE DOBLAJE: ARGENTINA & AÑO 2014 \\
\hline \multicolumn{2}{|l|}{ TEMPORADA 3 - EPISODIOS 26 Y 27 “Jessie's Aloha-Holidays with Parker and Joey” } \\
\hline TÉRMINO & CONTEXTO & \multicolumn{1}{|l|}{ TRADUCCION } & TÉCNICA & ESPAÑOL \\
\hline $\begin{array}{l}\text { Christmas } \\
\text { tree }\end{array}$ & \multirow{2}{*}{$\begin{array}{l}\text { Christmas trees don't } \\
\text { usually wear sneakers? }\end{array}$} & $\begin{array}{l}\text { Los árboles no tienen } \\
\text { piernas, ¿o sí? }\end{array}$ & Omisión & -- \\
\cline { 4 - 5 } Sneakers & $\begin{array}{l}\text { Creación } \\
\text { discursiva }\end{array}$ & Neutro \\
\hline
\end{tabular}

\begin{tabular}{|l|c|l|l|l|}
\hline \multicolumn{2}{|l|}{ Ejemplo 63 } & \multicolumn{1}{l|}{ PROGRAMA: JESSIE } \\
\hline PAÍS DE DOBLAJE: ARGENTINA & AÑO 2014 \\
\hline \multicolumn{2}{|l|}{ TEMPORADA 3 - EPISODIOS 26 Y 27 “Jessie's Aloha-Holidays with Parker and Joey” } \\
\hline TÉRMINO & \multicolumn{1}{|c|}{ CONTEXTO } & \multicolumn{1}{|l|}{ TRADUCCION } & TÉCNICA & ESPAÑOL \\
\hline Fart & $\begin{array}{l}\text { It's like we're trapped } \\
\text { inside a hot fart! }\end{array}$ & $\begin{array}{l}\text { Es como estar atrapados en } \\
\text { un gas por frijoles. }\end{array}$ & $\begin{array}{l}\text { Traducción } \\
\text { literal }\end{array}$ & Neutro \\
\hline
\end{tabular}

\begin{tabular}{|c|c|c|c|c|}
\hline \multicolumn{2}{|l|}{ Ejemplo 64} & \multicolumn{3}{|l|}{ PROGRAMA: JESSIE } \\
\hline \multicolumn{2}{|c|}{ PAÍS DE DOBLAJE: ARGENTINA } & \multicolumn{3}{|l|}{ AÑO 2014} \\
\hline \multicolumn{5}{|c|}{ TEMPORADA 3 - EPISODIOS 26 Y 27 “Jessie’s Aloha-Holidays with Parker and Joey” } \\
\hline TÉRMINO & CONTEXTO & TRADUCCION & TÉCNICA & ESPAÑOL \\
\hline Zipper & \multirow{2}{*}{$\begin{array}{l}\text { The zipper on my } \\
\text { sleeping bag } \\
\text { jammed... }\end{array}$} & \multirow{2}{*}{$\begin{array}{l}\text { El cierre de mi saco de } \\
\text { dormir se atascó... }\end{array}$} & $\begin{array}{l}\text { Traducción } \\
\text { literal } \\
\end{array}$ & Regional \\
\hline $\begin{array}{l}\text { Sleeping } \\
\text { bag }\end{array}$ & & & $\begin{array}{l}\text { Traducción } \\
\text { literal } \\
\end{array}$ & Neutro \\
\hline
\end{tabular}




\begin{tabular}{|l|c|l|l|l|}
\hline \multicolumn{2}{|l|}{ Ejemplo 65 } & \multicolumn{1}{l|}{ PROGRAMA: JESSIE } \\
\hline PAÍS DE DOBLAJE: ARGENTINA & AÑO 2014 \\
\hline \multicolumn{2}{|l|}{ TEMPORADA 3 - EPISODIOS 26 Y 27 “Jessie's Aloha-Holidays with Parker and Joey” } \\
\hline TÉRMINO & CONTEXTO & \multicolumn{1}{|l|}{ TRADUCCION } & TÉCNICA & ESPAÑOL \\
\hline Pig & ..the pig! & $\ldots$ el cerdito! & $\begin{array}{l}\text { Traducción } \\
\text { literal } \\
\text { (diminutivo no } \\
\text { neutro) }\end{array}$ & $\begin{array}{l}\text { Regional } \\
\text { (diminutivo no } \\
\text { neutro) }\end{array}$ \\
\hline
\end{tabular}

\begin{tabular}{|c|c|c|c|c|}
\hline \multicolumn{2}{|l|}{ Ejemplo 66} & \multicolumn{3}{|l|}{ PROGRAMA: JESSIE } \\
\hline \multicolumn{2}{|c|}{ PAÍS DE DOBLAJE: ARGENTINA } & AÑO 2014 & & \\
\hline \multicolumn{5}{|c|}{ TEMPORADA 3 - EPISODIOS 26 Y 27 “Jessie's Aloha-Holidays with Parker and Joey" } \\
\hline TÉRMINO & CONTEXTO & TRADUCCION & TÉCNICA & ESPAÑOL \\
\hline $\begin{array}{l}\text { Supes / } \\
\text { Forgivsies }\end{array}$ & $\begin{array}{l}\text { We're supes sorry! } \\
\text { Forgivsies? }\end{array}$ & ¡Lo súper siento! ¿Listo? & Variación & Neutro \\
\hline
\end{tabular}

\begin{tabular}{|l|l|l|c|l|}
\hline \multicolumn{2}{|l|}{ Ejemplo 67 } & \multicolumn{1}{l|}{ PROGRAMA: JESSIE } \\
\hline \multicolumn{4}{|l|}{ PAÍS DE DOBLAJE: ARGENTINA } & AÑO 2014 \\
\hline TEMPORADA 3 - EPISODIOS 26 Y 27 “Jessie's Aloha-Holidays with Parker and Joey” \\
\hline TÉRMINO & \multicolumn{1}{|c|}{ CONTEXTO } & \multicolumn{1}{|l|}{ TRADUCCION } & TÉCNICA & ESPAÑOL \\
\hline Gods & $\begin{array}{l}\text { Dear gods, it is } \\
\text { erupting! }\end{array}$ & ¡Está haciendo erupción! & Omisión & -- \\
\hline
\end{tabular}

\begin{tabular}{|c|c|c|c|c|}
\hline \multicolumn{2}{|l|}{ Ejemplo 68} & \multicolumn{3}{|l|}{ PROGRAMA: JESSIE } \\
\hline \multicolumn{2}{|c|}{ PAÍS DE DOBLAJE: ARGENTINA } & \multicolumn{3}{|l|}{ AÑO 2014} \\
\hline \multicolumn{5}{|c|}{ TEMPORADA 3 - EPISODIOS 26 Y 27 "Jessie's Aloha-Holidays with Parker and Joey" } \\
\hline TÉRMINO & CONTEXTO & \begin{tabular}{|l|} 
TRADUCCION \\
\end{tabular} & TÉCNICA & ESPAÑNL \\
\hline Kids & \multirow{2}{*}{$\begin{array}{l}\text { I mean I have to go } \\
\text { save my kids, who for } \\
\text { some incredibly stupid } \\
\text { reason, went up there! }\end{array}$} & \multirow{2}{*}{$\begin{array}{l}\text { ¡Hablo de que tengo que } \\
\text { salvar a mis chicos, quienes } \\
\text { por alguna razón subieron } \\
\text { ahí! }\end{array}$} & $\begin{array}{l}\text { Traducción } \\
\text { literal }\end{array}$ & Regional \\
\hline Stupid & & & Omisión & -- \\
\hline
\end{tabular}




\begin{tabular}{|c|c|c|c|c|}
\hline \multicolumn{2}{|l|}{ Ejemplo 69} & \multicolumn{3}{|l|}{ PROGRAMA: JESSIE } \\
\hline \multicolumn{2}{|c|}{ PAÍS DE DOBLAJE: ARGENTINA } & \multicolumn{3}{|l|}{ AÑO 2014} \\
\hline \multicolumn{5}{|c|}{ TEMPORADA 3 - EPISODIOS 26 Y 27 “Jessie's Aloha-Holidays with Parker and Joey” } \\
\hline TÉRMINO & CONTEXTO & TRADUCCION & TÉCNICA & ESPAÑOL \\
\hline \multirow{3}{*}{ Stupid } & $\begin{array}{l}\text { Stupid fake snake } \\
\text { didn't even pop out }\end{array}$ & $\begin{array}{l}\text { La tonta serpiente falsa ni se } \\
\text { asomó }\end{array}$ & Variación & Neutro \\
\hline & $\begin{array}{l}\text {...wasting so much } \\
\text { time on this stupid } \\
\text { dream... }\end{array}$ & $\begin{array}{l}\text {...desperdiciar tanto tiempo } \\
\text { en un sueño imposible... }\end{array}$ & $\begin{array}{l}\text { Creación } \\
\text { discursiva }\end{array}$ & Neutro \\
\hline & $\begin{array}{l}\text { I saw enough fire } \\
\text { when we flew over } \\
\text { that stupid volcano }\end{array}$ & $\begin{array}{l}\text { Vi suficiente fuego cuando } \\
\text { volamos sobre ese volcán } \\
\text { ridículo }\end{array}$ & $\begin{array}{l}\text { Creación } \\
\text { discursiva }\end{array}$ & Neutro \\
\hline
\end{tabular}

\begin{tabular}{|c|c|c|c|c|}
\hline \multicolumn{2}{|l|}{ Ejemplo 70} & \multicolumn{3}{|l|}{ PROGRAMA: JESSIE } \\
\hline \multicolumn{2}{|c|}{ PAÍS DE DOBLAJE: ARGENTINA } & AÑO 2014 & & \\
\hline \multicolumn{5}{|c|}{ TEMPORADA 3 - EPISODIOS 26 Y 27 "Jessie's Aloha-Holidays with Parker and Joey" } \\
\hline TÉRMINO & CONTEXTO & TRADUCCION & TÉCNICA & ESPAÑOL \\
\hline \multirow[b]{2}{*}{ Die } & $\begin{array}{l}\text {...my character got } \\
\text { pushed out and died }\end{array}$ & $\begin{array}{l}\text { A mi personaje lo empujan y } \\
\text { cae }\end{array}$ & $\begin{array}{l}\text { Modulación + } \\
\text { Variación }\end{array}$ & Neutro \\
\hline & $\begin{array}{l}\text { I can't believe I'm } \\
\text { going to die with the } \\
\text { frizzies! }\end{array}$ & $\begin{array}{l}\text { ¡Terminaré mis días con este } \\
\text { pelo! }\end{array}$ & Variación & Neutro \\
\hline
\end{tabular}

\begin{tabular}{|l|l|l|l|l|}
\hline \multicolumn{2}{|l|}{ Ejemplo 71 } & \multicolumn{2}{l|}{ PROGRAMA: JESSIE } \\
\hline \multicolumn{2}{|l|}{ PAÍS DE DOBLAJE: ARGENTINA } & AÑO 2014 \\
\hline TEMPORADA 3 - EPISODIOS 26 Y 27 “Jessie's Aloha-Holidays with Parker and Joey” \\
\hline TÉRMINO & \multicolumn{1}{|c|}{ CONTEXTO } & \multicolumn{1}{|c|}{ TRADUCCION } & TÉCNICA & ESPAÑOL \\
\hline $\begin{array}{l}\text { Chewing } \\
\text { gum }\end{array}$ & $\begin{array}{l}\ldots \text { and what appears to } \\
\text { be very old chewing } \\
\text { gum }\end{array}$ & $\begin{array}{l}\text {...y lo que parece ser un } \\
\text { viejo chicle }\end{array}$ & $\begin{array}{l}\text { Traducción } \\
\text { literal }\end{array}$ & Regional \\
\hline
\end{tabular}

\begin{tabular}{|l|l|l|c|c|}
\hline \multicolumn{2}{|l|}{ Ejemplo 72 } & \multicolumn{1}{l|}{ PROGRAMA: JESSIE } \\
\hline PAÍS DE DOBLAJE: ARGENTINA & AÑO 2014 \\
\hline \multicolumn{4}{|l|}{ TEMPORADA 3 - EPISODIOS 26 Y 27 “Jessie's Aloha-Holidays with Parker and Joey” } \\
\hline TÉRMINO & \multicolumn{1}{|c|}{ CONTEXTO } & \multicolumn{1}{|c|}{ TRADUCCION } & TÉCNICA & ESPANOL \\
\hline $\begin{array}{l}\text { Christmas } \\
\text { spirit }\end{array}$ & $\begin{array}{l}\text { Where is your } \\
\text { Christmas spirit? }\end{array}$ & $\begin{array}{l}\text { ¿Dónde está tu espíritu de las } \\
\text { Fiestas? }\end{array}$ & Generalización & Neutro \\
\hline
\end{tabular}




\begin{tabular}{|l|c|l|l|l|}
\hline Ejemplo 73 & \multicolumn{2}{l|}{ PROGRAMA: JESSIE } \\
\hline \multicolumn{2}{|l|}{ PAÍS DE DOBLAJE: ARGENTINA } & AÑO 2014 & \multicolumn{2}{l|}{} \\
\hline TEMPORADA 3 - EPISODIOS 26 Y 27 “Jessie's Aloha-Holidays with Parker and Joey” \\
\hline TÉRMINO & CONTEXTO & TRADUCCION & TÉCNICA & ESPAÑOL \\
\hline Cool & Cool, babe & Cool, bebé & Préstamo & Regional \\
\hline
\end{tabular}

\begin{tabular}{|l|c|l|c|l|}
\hline Ejemplo 74 & \multicolumn{3}{l|}{ PROGRAMA: JESSIE } \\
\hline \multicolumn{3}{|l|}{ PAÍS DE DOBLAJE: ARGENTINA } & AÑO 2014 & \\
\hline TEMPORADA 3 - EPISODIOS 26 Y 27 “Jessie's Aloha-Holidays with Parker and Joey” \\
\hline TÉRMINO & CONTEXTO & TRADUCCION & TÉCNICA & ESPAÑOL \\
\hline Nerd & Well, I'm the nerd. & Y yo soy el nerd. & Préstamo & Neutro \\
\hline
\end{tabular}

\begin{tabular}{|l|l|l|l|l|}
\hline \multicolumn{2}{|l|}{ Ejemplo 75 } & \multicolumn{1}{l|}{ PROGRAMA: JESSIE } \\
\hline \multicolumn{2}{|l|}{ PAÍS DE DOBLAJE: ARGENTINA } & AÑO 2014 \\
\hline \multicolumn{4}{|l|}{ TEMPORADA 3 - EPISODIOS 26 Y 27 “Jessie's Aloha-Holidays with Parker and Joey” } \\
\hline TÉRMINO & \multicolumn{1}{|c|}{ CONTEXTO } & \multicolumn{1}{|l|}{ TRADUCCION } & TÉCNICA & ESPAÑOL \\
\hline Death & $\begin{array}{l}\text {.. flying into the fiery } \\
\text { jaws of death... }\end{array}$ & $\begin{array}{l}\text {..volar a la mandíbula del } \\
\text { volcán... }\end{array}$ & $\begin{array}{l}\text { Creación } \\
\text { discursiva }+ \\
\text { Omisión }\end{array}$ & Neutro \\
\hline
\end{tabular}

\begin{tabular}{|l|l|l|l|l|}
\hline \multicolumn{2}{|l|}{ Ejemplo 76 } & \multicolumn{1}{l|}{ PROGRAMA: JESSIE } \\
\hline PAÍS DE DOBLAJE: ARGENTINA & AÑO 2014 \\
\hline TEMPORADA 3 - EPISODIOS 26 Y 27 “Jessie's Aloha-Holidays with Parker and Joey” \\
\hline TÉRMINO & \multicolumn{1}{|c|}{ CONTEXTO } & \multicolumn{1}{|l|}{ TRADUCCION } & TÉCNICA & ESPAÑOL \\
\hline $\begin{array}{l}\text { Christmas } \\
\text { miracle }\end{array}$ & $\begin{array}{l}\text { It's a Christmas } \\
\text { miracle! }\end{array}$ & No sabía que nevaba aquí & $\begin{array}{l}\text { Omisión + } \\
\text { Creación } \\
\text { discursiva }\end{array}$ & Neutro \\
\hline
\end{tabular}

\begin{tabular}{|c|c|c|c|c|}
\hline \multicolumn{2}{|l|}{ Ejemplo 77} & \multicolumn{3}{|c|}{ PROGRAMA: LAZYTOWN } \\
\hline \multicolumn{2}{|c|}{$\begin{array}{lll}\text { PAÍS DE DOBLAJE: ESTADOS } \\
\text { UNIDOS } & & \\
\end{array}$} & \multicolumn{3}{|c|}{ AÑO 2006} \\
\hline \multicolumn{5}{|c|}{ TEMPORADA 1 - EPISODIO 32 "Dancing Duel” } \\
\hline TÉRMINO & CONTEXTO & TRADUCCION & TÉCNICA & ESPAÑOL \\
\hline Cake & The cake! & $\begin{array}{l}\text { 1) ¡El pastel! } \\
\text { 2) ¡El pastel!!69 }\end{array}$ & $\begin{array}{l}\text { Traducción } \\
\text { literal }\end{array}$ & Neutro \\
\hline
\end{tabular}

169 La traducción 1 corresponde al doblaje original realizado en Chile por DINT, y la traducción 2 corresponde al redoblaje realizado con posterioridad en Miami por The Kitchen. Solo tendremos en cuenta el doblaje realizado por The Kitchen en esta tesis, pero presentamos el de DINT con fines comparativos. 


\begin{tabular}{|c|c|c|c|c|}
\hline \multicolumn{2}{|l|}{ Ejemplo 78} & \multicolumn{3}{|c|}{ PROGRAMA: LAZYTOWN } \\
\hline \multicolumn{2}{|c|}{$\begin{array}{l}\text { PAÍS DE DOBLAJE: } \\
\text { UNIDSTADOS }\end{array}$} & \multicolumn{3}{|l|}{ AÑO 2006} \\
\hline \multicolumn{5}{|c|}{ TEMPORADA 1 - EPISODIO 32 "Dancing Duel" } \\
\hline TÉRMINO & CONTEXTO & TRADUCCION & TÉCNICA & ESPAÑOL \\
\hline Kids & $\begin{array}{l}\text {... and stop those kids } \\
\text { from making noise }\end{array}$ & $\begin{array}{l}\text { 1) ...y haz que esos niños } \\
\text { dejen de hacer ruido } \\
\text { 2) ...y haz que esos niños } \\
\text { dejen de hacer ruido }\end{array}$ & $\begin{array}{l}\text { Traducción } \\
\text { literal }\end{array}$ & Neutro \\
\hline
\end{tabular}

\begin{tabular}{|l|l|l|l|l|}
\hline \multicolumn{2}{|l|}{ Ejemplo 79 } & \multicolumn{1}{l|}{ PROGRAMA: LAZYTOWN } \\
\hline $\begin{array}{l}\text { PAÍS DE DOBLAJE: ESTADOS } \\
\text { UNIDOS }\end{array}$ & AÑO 2006 & \multicolumn{1}{l|}{} \\
\hline TEMPORADA 1 - EPISODIO 32 “Dancing Duel” & \multicolumn{1}{|l|}{ TRADUCCION } & TÉCNCA & ESPAÑOL \\
\hline TÉRMINO & CONTEXTO & $\begin{array}{l}\text { 1) ¡No te preocupes, } \\
\text { caramelo! } \\
\text { Lollipop }\end{array}$ Don’t worry, lollipop! Tranquila, paleta! & $\begin{array}{l}\text { Traducción } \\
\text { literal }\end{array}$ & Regional \\
\hline
\end{tabular}

\begin{tabular}{|c|c|c|c|c|}
\hline \multicolumn{2}{|l|}{ Ejemplo 80} & \multicolumn{3}{|c|}{ PROGRAMA: LAZYTOWN } \\
\hline \multicolumn{2}{|c|}{$\begin{array}{l}\text { PAÍS DE DOBLAJE: ESTADOS } \\
\text { UNIDOS }\end{array}$} & \multicolumn{3}{|c|}{ AÑO 2006} \\
\hline \multicolumn{5}{|c|}{ TEMPORADA 1 - EPISODIO 32 "Dancing Duel” } \\
\hline TÉRMINO & CONTEXTO & TRADUCCION & TÉCNICA & ESPAÑOL \\
\hline Disco & $\begin{array}{l}\text { They're gonna turn } \\
\text { Lazytown into a disco! }\end{array}$ & $\begin{array}{l}\text { 1) Convertirán a Lazytown } \\
\text { en una discoteca } \\
\text { 2) Van a transformar a } \\
\text { Lazytown en una disco }\end{array}$ & Préstamo & Neutro \\
\hline
\end{tabular}

\begin{tabular}{|c|c|c|c|c|}
\hline \multicolumn{2}{|l|}{ Ejemplo 81} & \multicolumn{3}{|c|}{ PROGRAMA: LAZYTOWN } \\
\hline \multicolumn{2}{|c|}{$\begin{array}{l}\text { PAÍS DE DOBLAJE: ESTADOS } \\
\text { UNIDOS }\end{array}$} & \multicolumn{3}{|c|}{ AÑO 2006} \\
\hline \multicolumn{5}{|c|}{ TEMPORADA 1 - EPISODIO 32 “Dancing Duel” } \\
\hline TÉRMINO & CONTEXTO & \begin{tabular}{|l|} 
TRADUCCION \\
\end{tabular} & TÉCNICA & ESPAÑOL \\
\hline Split & And a split & $\begin{array}{l}\text { 1) Y un split } \\
\text { 2) Y me abro de piernas }\end{array}$ & Explicitación & Neutro \\
\hline
\end{tabular}




\begin{tabular}{|c|c|c|c|c|}
\hline \multicolumn{2}{|l|}{ Ejemplo 82} & \multicolumn{3}{|c|}{ PROGRAMA: LAZYTOWN } \\
\hline \multicolumn{2}{|c|}{$\begin{array}{l}\text { PAÍS DE DOBLAJE: ESTADOS } \\
\text { UNIDOS }\end{array}$} & \multicolumn{3}{|l|}{ AÑO 2006} \\
\hline \multicolumn{5}{|c|}{ TEMPORADA 1 - EPISODIO 32 "Dancing Duel" } \\
\hline TÉRMINO & CONTEXTO & TRADUCCION & TÉCNICA & ESPAÑOL \\
\hline Oh dear & Oh dear! & $\begin{array}{l}\text { 1) ¡Vaya, vaya! } \\
\text { 2) ¡Oh, cielos! }\end{array}$ & $\begin{array}{l}\text { Equivalente } \\
\text { acuñado }\end{array}$ & Neutro \\
\hline
\end{tabular}

\begin{tabular}{|c|c|c|c|c|}
\hline \multicolumn{2}{|l|}{ Ejemplo 83} & \multicolumn{3}{|c|}{ PROGRAMA: LAZYTOWN } \\
\hline \multicolumn{2}{|c|}{$\begin{array}{l}\text { PAÍS DE DOBLAJE: ESTADOS } \\
\text { UNIDOS }\end{array}$} & \multicolumn{3}{|c|}{ AÑO 2006} \\
\hline \multicolumn{5}{|c|}{ TEMPORADA 1 - EPISODIO 32 "Dancing Duel” } \\
\hline TÉRMINO & CONTEXTO & TRADUCCION & TÉCNICA & ESPAÑOL \\
\hline Stiff & I'm... stiff! & $\begin{array}{l}\text { 1) Estoy algo.. ¡rígida! } \\
\text { 2) Estoy... ¡entumida! }\end{array}$ & $\begin{array}{l}\text { Traducción } \\
\text { literal }\end{array}$ & Regional \\
\hline
\end{tabular}

\begin{tabular}{|c|c|c|c|c|}
\hline \multicolumn{2}{|l|}{ Ejemplo 84} & \multicolumn{3}{|c|}{ PROGRAMA: LAZYTOWN } \\
\hline \multicolumn{2}{|c|}{$\begin{array}{l}\text { PAÍS DE DOBLAJE: ESTADOS } \\
\text { UNIDOS }\end{array}$} & \multicolumn{3}{|l|}{ AÑO 2006} \\
\hline \multicolumn{5}{|c|}{ TEMPORADA 1 - EPISODIO 32 "Dancing Duel” } \\
\hline TÉRMINO & CONTEXTO & TRADUCCION & TÉCNICA & ESPAÑOL \\
\hline Oh my & Oh my! & $\begin{array}{l}\text { 1) ¡Vaya, vaya! } \\
\text { 2) ¡Oh! }\end{array}$ & $\begin{array}{l}\text { Equivalente } \\
\text { acuñado }\end{array}$ & Neutro \\
\hline
\end{tabular}

\begin{tabular}{|c|c|c|c|c|}
\hline \multicolumn{2}{|l|}{ Ejemplo 85} & \multicolumn{3}{|c|}{ PROGRAMA: LAZYTOWN } \\
\hline \multicolumn{2}{|c|}{$\begin{array}{l}\text { PAÍS DE DOBLAJE: } \\
\text { ENTADADOS }\end{array}$} & \multicolumn{3}{|c|}{ AÑO 2006} \\
\hline \multicolumn{5}{|c|}{ TEMPORADA 2 - EPISODIO 1 "Rockin Robbie" } \\
\hline TÉRMINO & CONTEXTO & TRADUCCION & TÉCNICA & ESPAÑOL \\
\hline Sportscandy & Sportscandy! & $\begin{array}{l}\text { 1) Dulces sanos } \\
\text { 2) Fruta sana }\end{array}$ & Explicitación & Neutro \\
\hline
\end{tabular}

\begin{tabular}{|c|c|c|c|c|}
\hline \multicolumn{2}{|l|}{ Ejemplo 86} & \multicolumn{3}{|c|}{ PROGRAMA: LAZYTOWN } \\
\hline \multicolumn{2}{|c|}{$\begin{array}{l}\text { PAÍS DE DOBLAJE: ESTADOS } \\
\text { UNIDOS }\end{array}$} & \multicolumn{3}{|c|}{ AÑO 2006} \\
\hline \multicolumn{5}{|c|}{ TEMPORADA 2 - EPISODIO 1 "Rockin Robbie" } \\
\hline TÉRMINO & CONTEXTO & TRADUCCION & TÉCNICA & ESPAÑOL \\
\hline Drums & $\begin{array}{l}\text { Can you play the } \\
\text { drums? }\end{array}$ & $\begin{array}{l}\text { 1) ¿Sabes tocar la batería? } \\
\text { 2) Ídem }\end{array}$ & $\begin{array}{l}\text { Traducción } \\
\text { literal }\end{array}$ & Neutro \\
\hline
\end{tabular}




\begin{tabular}{|c|c|c|c|c|}
\hline \multicolumn{2}{|l|}{ Ejemplo 87} & \multicolumn{3}{|c|}{ PROGRAMA: LAZYTOWN } \\
\hline \multicolumn{2}{|c|}{$\begin{array}{lll}\text { PAÍS DE } & \text { DOBLAJE: } & \text { ESTADOS } \\
\text { UNIDOS } & & \\
\end{array}$} & \multicolumn{3}{|l|}{ AÑO 2006} \\
\hline \multicolumn{5}{|c|}{ TEMPORADA 2 - EPISODIO 1 "Rockin Robbie" } \\
\hline TÉRMINO & CONTEXTO & TRADUCCION & TÉCNICA & ESPAÑOL \\
\hline \multirow{3}{*}{ Cool } & $\begin{array}{l}\text { Johnny B. Bad was the } \\
\text { coolest musician in the } \\
\text { world! }\end{array}$ & $\begin{array}{l}\text { 1) Johnny C. Malo fue el } \\
\text { músico más fabuloso del } \\
\text { mundo } \\
\text { 2) Ídem }\end{array}$ & $\begin{array}{l}\text { Traducción } \\
\text { literal }\end{array}$ & Neutro \\
\hline & $\begin{array}{l}\text { Do people still think } \\
\text { I'm cool? }\end{array}$ & $\begin{array}{l}\text { 1) ¿Aún creen que soy el } \\
\text { mejor? } \\
\text { 2) ¿Aún creen que soy } \\
\text { genial? }\end{array}$ & $\begin{array}{l}\text { Traducción } \\
\text { literal }\end{array}$ & Neutro \\
\hline & You look cool, man! & $\begin{array}{l}\text { 1) Se ve genial, viejo } \\
\text { 2) Se ve genial, viejo }\end{array}$ & $\begin{array}{l}\text { Traducción } \\
\text { literal }\end{array}$ & Neutro \\
\hline
\end{tabular}

\begin{tabular}{|c|c|c|c|c|}
\hline \multicolumn{2}{|l|}{ Ejemplo 88} & \multicolumn{3}{|l|}{ PROGRAMA: LAZYTOWN } \\
\hline \multicolumn{2}{|c|}{$\begin{array}{ll}\text { PAÍS DE DOBLAJE: } & \text { ESTADOS } \\
\text { UNIDOS } & \\
\end{array}$} & \multicolumn{3}{|l|}{ AÑO 2006} \\
\hline \multicolumn{5}{|c|}{ TEMPORADA 2 - EPISODIO 1 "Rockin Robbie" } \\
\hline TÉRMINO & CONTEXTO & TRADUCCION & TÉCNICA & ESPAÑOL \\
\hline Purple & $\begin{array}{l}\text { If Johnny B. Bad wore } \\
\text { purple shoes... }\end{array}$ & $\begin{array}{l}\text { 1) Si Johnny C. Malo usaba } \\
\text { zapatos morados... } \\
\text { 2) Si Johnny C. Malo usaba } \\
\text { zapatos violeta... }\end{array}$ & $\begin{array}{l}\text { Traducción } \\
\text { literal }\end{array}$ & Regional \\
\hline
\end{tabular}

\begin{tabular}{|c|c|c|c|c|}
\hline \multicolumn{2}{|l|}{ Ejemplo 89} & \multicolumn{3}{|l|}{ PROGRAMA: LAZYTOWN } \\
\hline \multicolumn{2}{|c|}{$\begin{array}{l}\text { PAÍS DE DOBLAJE: } \text { ESTADOS } \\
\text { UNIDOS }\end{array}$} & \multicolumn{3}{|l|}{ AÑO 2006} \\
\hline \multicolumn{5}{|c|}{ TEMPORADA 2 - EPISODIO 1 "Rockin Robbie" } \\
\hline TÉRMINO & CONTEXTO & TRADUCCION & TÉCNICA & $\overline{\text { ESPAÑOL }}$ \\
\hline Bananas & $\begin{array}{l}\text { If Johnny B. Bad ate } \\
\text { bananas... }\end{array}$ & $\begin{array}{l}\text { 1) Si Johnny C. Malo comía } \\
\text { bananas... } \\
\text { 2) Si Johnny C. Malo comía } \\
\text { bananas ... }\end{array}$ & $\begin{array}{l}\text { Traducción } \\
\text { literal }\end{array}$ & Neutro \\
\hline
\end{tabular}




\begin{tabular}{|c|c|c|c|c|}
\hline \multicolumn{2}{|l|}{ Ejemplo 90} & \multicolumn{3}{|c|}{ PROGRAMA: LAZYTOWN } \\
\hline \multicolumn{2}{|c|}{$\begin{array}{l}\text { PAÍS DE DOBLAJE: } \\
\text { UNIDTADOS } \\
\text { UNIDOS }\end{array}$} & \multicolumn{3}{|l|}{ AÑO 2006} \\
\hline \multicolumn{5}{|c|}{ TEMPORADA 2 - EPISODIO 1 "Rockin Robbie" } \\
\hline TÉRMINO & CONTEXTO & TRADUCCION & TÉCNICA & ESPAÑOL \\
\hline Rubber duck & Rubber ducky & $\begin{array}{l}\text { 1) Un pato de hule } \\
\text { 2) Un pato de goma }\end{array}$ & $\begin{array}{l}\text { Traducción } \\
\text { literal }\end{array}$ & Neutro \\
\hline
\end{tabular}

\begin{tabular}{|c|c|c|c|c|}
\hline \multicolumn{2}{|l|}{ Ejemplo 91} & \multicolumn{3}{|l|}{ PROGRAMA: LAZYTOWN } \\
\hline \multicolumn{2}{|c|}{$\begin{array}{l}\text { PAÍS DE DOBLAJE: ESTADOS } \\
\text { UNIDOS }\end{array}$} & \multicolumn{3}{|l|}{ AÑO 2006} \\
\hline \multicolumn{5}{|c|}{ TEMPORADA 2 - EPISODIO 1 "Rockin Robbie" } \\
\hline TÉRMINO & CONTEXTO & \begin{tabular}{|r|} 
TRADUCCION \\
\end{tabular} & TÉCNICA & ESPAÑOL \\
\hline Dumbest & & & $\begin{array}{l}\text { Traducción } \\
\text { literal }\end{array}$ & Regional \\
\hline $\begin{array}{l}\text { I've ever } \\
\text { done }\end{array}$ & $\begin{array}{l}\text { That was the dumbest } \\
\text { thing I've ever done! }\end{array}$ & $\begin{array}{l}\text { 1) Esa fue la cosa más tonta } \\
\text { que jamás hice en mi vida } \\
\text { 2) Esa fue la cosa más tonta } \\
\text { que jamás hice }\end{array}$ & $\begin{array}{l}\text { Traducción } \\
\text { literal }\end{array}$ & $\begin{array}{l}\text { Regional } \\
\text { ("hice" en vez } \\
\text { de "he hecho" } \\
\text { y orden en el } \\
\text { uso del } \\
\text { adverbio } \\
\text { "jamás") }\end{array}$ \\
\hline
\end{tabular}

\begin{tabular}{|c|c|c|c|c|}
\hline \multicolumn{2}{|l|}{ Ejemplo 92} & \multicolumn{3}{|c|}{ PROGRAMA: LAZYTOWN } \\
\hline \multicolumn{2}{|c|}{$\begin{array}{l}\text { PAÍS DE DOBLAJE: } \\
\text { ESTADOS } \\
\text { UNIDOS }\end{array}$} & \multicolumn{3}{|c|}{ AÑO 2014} \\
\hline \multicolumn{5}{|c|}{ TEMPORADA 4 - EPISODIO 5 "Time to Learn" } \\
\hline TÉRMINO & CONTEXTO & TRADUCCION & TÉCNICA & ESPAÑOL \\
\hline Baseball bat & Baseball bat & Bate de béisbol & Préstamo & Neutro \\
\hline
\end{tabular}

\begin{tabular}{|c|c|c|c|c|}
\hline \multicolumn{2}{|l|}{ Ejemplo 93} & \multicolumn{3}{|c|}{ PROGRAMA: LAZYTOWN } \\
\hline \multicolumn{2}{|c|}{$\begin{array}{lll}\text { PAÍS DE DOBLAJE: ESTADOS } \\
\text { UNIDOS }\end{array}$} & \multicolumn{3}{|c|}{ AÑO 2014} \\
\hline \multicolumn{5}{|c|}{ TEMPORADA 4 - EPISODIO 5 “Time to Learn” } \\
\hline TÉRMINO & CONTEXTO & TRADUCCION & TÉCNICA & ESPAÑOL \\
\hline Cool & That's so cool! & ¡Es genial! & $\begin{array}{l}\text { Traducción } \\
\text { literal }\end{array}$ & Neutro \\
\hline
\end{tabular}

\begin{tabular}{|c|c|c|c|c|}
\hline \multicolumn{2}{|l|}{ Ejemplo 94} & \multicolumn{3}{|c|}{ PROGRAMA: LAZYTOWN } \\
\hline \multicolumn{2}{|c|}{$\begin{array}{l}\text { PAÍS DE DOBLAJE: } \\
\text { UNIDOSADOS } \\
\text { UNIDOS }\end{array}$} & \multicolumn{3}{|c|}{ AÑO 2014} \\
\hline \multicolumn{5}{|c|}{ TEMPORADA 4 - EPISODIO 5 "Time to Learn" } \\
\hline TÉRMINO & CONTEXTO & TRADUCCION & TÉCNICA & ESPAÑOL \\
\hline Recess! & Recess! & ¡Receso! & \begin{tabular}{|l|} 
Traducción \\
literal
\end{tabular} & Regional \\
\hline
\end{tabular}




\begin{tabular}{|c|c|c|c|c|}
\hline \multicolumn{2}{|l|}{ Ejemplo 95} & \multicolumn{3}{|c|}{ PROGRAMA: LAZYTOWN } \\
\hline \multicolumn{2}{|c|}{$\begin{array}{l}\text { PAÍS DE DOBLAJE: } \\
\text { UNIDSTADOS }\end{array}$} & \multicolumn{3}{|l|}{ AÑO 2014} \\
\hline \multicolumn{5}{|c|}{ TEMPORADA 4 - EPISODIO 5 "Time to Learn" } \\
\hline TÉRMINO & CONTEXTO & TRADUCCION & TÉCNICA & ESPAÑOL \\
\hline Banana & I brought this banana & Traje esta banana & $\begin{array}{l}\text { Traducción } \\
\text { literal }\end{array}$ & Neutro \\
\hline
\end{tabular}

\begin{tabular}{|l|l|l|l|l|}
\hline \multicolumn{2}{|l|}{ Ejemplo 96 } & \multicolumn{1}{l|}{ PROGRAMA: LAZYTOWN } \\
\hline $\begin{array}{l}\text { PAÍS DE DOBLAJE: ESTADOS } \\
\text { UNIDOS }\end{array}$ & AÑO 2014 \\
\hline \multicolumn{2}{|l|}{ TEMPORADA 4 - EPISODIO 5 “Time to Learn” } & \multicolumn{1}{l|}{ TÉCNICA } & ESPAÑOL \\
\hline TÉRMINO & CONTEXTO & TRADUCCION & $\begin{array}{l}\text { Traducción } \\
\text { literal }\end{array}$ & Neutro \\
\hline Cold & How's your cold? & ¿Qué tal tu resfriado? &
\end{tabular}

\begin{tabular}{|c|c|c|c|c|}
\hline \multicolumn{2}{|l|}{ Ejemplo 97} & \multicolumn{3}{|c|}{ PROGRAMA: LAZYTOWN } \\
\hline \multicolumn{2}{|c|}{$\begin{array}{l}\text { PAÍS DE DOBLAJE: } \\
\text { ENTIDOS }\end{array}$} & \multicolumn{3}{|c|}{ AÑO 2014} \\
\hline \multicolumn{5}{|c|}{ TEMPORADA 4 - EPISODIO 5 "Time to Learn" } \\
\hline TÉRMINO & CONTEXTO & TRADUCCION & TÉCNICA & ESPAÑOL \\
\hline $\mathrm{F}$ & I got an F! & ¡Reprobé! & Generalización & Neutro \\
\hline
\end{tabular}

\begin{tabular}{|l|l|l|l|l|}
\hline Ejemplo 98 & \multicolumn{1}{l|}{ PROGRAMA: THE ODD SQUAD } \\
\hline PAÍS DE DOBLAJE: COLOMBIA & AÑO 2014 \\
\hline \multicolumn{1}{|l|}{ TEMPORADA 1 - EPISODIO 1 “Zero Effect - Bad Luck Bears” } \\
\hline TÉRMINO & CONTEXTO & \multicolumn{1}{|l|}{ TRADUCCION } & TÉCNICA & ESPAÑOL \\
\hline Kids & $\begin{array}{l}\text {.. an organization run } \\
\text { by kids... }\end{array}$ & $\begin{array}{l}\text {...una organización dirigida } \\
\text { por niños... }\end{array}$ & $\begin{array}{l}\text { Traducción } \\
\text { literal }\end{array}$ & Neutro \\
\hline
\end{tabular}

\begin{tabular}{|l|l|l|c|c|}
\hline Ejemplo 99 & \multicolumn{1}{l|}{ PROGRAMA: THE ODD SQUAD } \\
\hline PAÍS DE DOBLAJE: COLOMBIA & AÑO 2014 \\
\hline TEMPORADA 1 - EPISODIO 1 “Zero Effect - Bad Luck Bears” \\
\hline TÉRMINO & \multicolumn{1}{|c|}{ CONTEXTO } & \multicolumn{1}{l|}{ TRADUCCION } & TÉCNICA & ESPAÑOL \\
\hline Ketchup & $\begin{array}{l}\ldots \text { with ketchup } \\
\text { centers... }\end{array}$ & $\ldots$ y salsa de tomate... & Explicitación & Neutro \\
\hline
\end{tabular}




\begin{tabular}{|l|l|l|l|l|}
\hline Ejemplo 100 & \multicolumn{1}{l|}{ PROGRAMA: THE ODD SQUAD } \\
\hline PAÍS DE DOBLAJE: COLOMBIA & AÑO 2014 \\
\hline \multicolumn{1}{|l|}{ TEMPORADA 1 - EPISODIO 1 “Zero Effect - Bad Luck Bears” } \\
\hline TÉRMINO & \multicolumn{1}{|l|}{ CONTEXTO } & \multicolumn{1}{|l|}{ TRADUCCION } & TÉCNICA & ESPAÑOL \\
\hline Gum & $\begin{array}{l}\text {..the giant ball of } \\
\text { gum... }\end{array}$ & $\begin{array}{l}\text {..la bola gigante de goma de } \\
\text { mascar... }\end{array}$ & $\begin{array}{l}\text { Traducción } \\
\text { literal }\end{array}$ & Neutro \\
\hline
\end{tabular}

\begin{tabular}{|l|l|l|l|l|}
\hline Ejemplo 101 & \multicolumn{1}{l|}{ PROGRAMA: THE ODD SQUAD } \\
\hline PAÍS DE DOBLAJE: COLOMBIA & AÑO 2014 \\
\hline TEMPORADA 1 - EPISODIO 1 “Zero Effect - Bad Luck Bears” \\
\hline TÉRMINO & \multicolumn{1}{|l|}{ CONTEXTO } & \multicolumn{1}{|l|}{ TRADUCCION } & TÉCNICA & ESPAÑOL \\
\hline Diapers & $\begin{array}{l}\text { Tomorrow I'm gonna } \\
\text { be in diapers! }\end{array}$ & $\begin{array}{l}\text { ¡Mañana tendré que usar } \\
\text { pañales! }\end{array}$ & $\begin{array}{l}\text { Traducción } \\
\text { literal }\end{array}$ & Neutro \\
\hline
\end{tabular}

\begin{tabular}{|l|l|l|c|c|}
\hline Ejemplo 102 & \multicolumn{3}{l|}{ PROGRAMA: THE ODD SQUAD } \\
\hline PAÍS DE DOBLAJE: COLOMBIA & AÑO 2014 & \\
\hline TEMPORADA 1 - EPISODIO 1 “Zero Effect - Bad Luck Bears” \\
\hline TÉRMINO & CONTEXTO & TRADUCCION & TÉCNICA & ESPAÑOL \\
\hline Cupcake & A cupcake shop? & ¿Una pastelería? & Generalización & Neutro \\
\hline
\end{tabular}

\begin{tabular}{|l|l|l|c|c|}
\hline Ejemplo 103 & \multicolumn{1}{l|}{ PROGRAMA: THE ODD SQUAD } \\
\hline PAÍS DE DOBLAJE: COLOMBIA & AÑO 2014 \\
\hline \multicolumn{1}{|l|}{ TEMPORADA 1 - EPISODIO 1 “Zero Effect - Bad Luck Bears” } \\
\hline TÉRMINO & \multicolumn{1}{|c|}{ TRADUEXTO } & \multicolumn{1}{|l|}{ TRECNICA } & ESPAÑOL \\
\hline Cake & $\begin{array}{l}\text { I do need cake for my } \\
\text { party }\end{array}$ & $\begin{array}{l}\text { Yo necesito una torta para mi } \\
\text { fiesta }\end{array}$ & $\begin{array}{l}\text { Traducción } \\
\text { literal }\end{array}$ & Regional \\
\hline
\end{tabular}

\begin{tabular}{|l|c|l|c|c|}
\hline Ejemplo 104 & \multicolumn{1}{l|}{ PROGRAMA: THE ODD SQUAD } \\
\hline PAÍS DE DOBLAJE: COLOMBIA & AÑO 2014 \\
\hline TEMPORADA 1 - EPISODIO 1 “Zero Effect - Bad Luck Bears” \\
\hline TÉRMINO & CONTEXTO & \multicolumn{1}{l|}{ TRADUCCION } & TÉCNICA & ESPAÑOL \\
\hline Basketball & $\begin{array}{l}\text { He coaches the Bears } \\
\text { basketball team }\end{array}$ & $\begin{array}{l}\text { Él entrena al equipo de } \\
\text { básquetbol de los Osos }\end{array}$ & Préstamo & Neutro \\
\hline
\end{tabular}

\begin{tabular}{|l|l|l|l|l|}
\hline Ejemplo 105 & \multicolumn{3}{l|}{ PROGRAMA: THE ODD SQUAD } \\
\hline PAÍ́S DE DOBLAJE: COLOMBIA & AÑO 2014 & \\
\hline TEMPORADA 1 - EPISODIO 1 “Zero Effect - Bad Luck Bears” \\
\hline TÉRMINO & CONTEXTO & TRADUCCION & TÉCNICA & ESPAÑOL \\
\hline Oh my & Oh my! & ¡Oh, Dios! & Explicitación & Neutro \\
\hline
\end{tabular}




\begin{tabular}{|l|l|l|c|c|}
\hline Ejemplo 106 & \multicolumn{1}{l|}{ PROGRAMA: THE ODD SQUAD } \\
\hline PAÍS DE DOBLAJE: COLOMBIA & AÑO 2014 \\
\hline TEMPORADA 1 - EPISODIO 2 “Soundcheck - Double Trouble” \\
\hline TÉRMINO & CONTEXTO & \multicolumn{1}{l|}{ TRADUCCION } & TÉCNICA & ESPAÑOL \\
\hline Cheesy curls & $\begin{array}{l}\text { You keep eating those } \\
\text { cheesy curls... }\end{array}$ & $\begin{array}{l}\text { Si sigues comiendo } \\
\text { pasabocas de queso }\end{array}$ & Generalización & Regional \\
\hline
\end{tabular}

\begin{tabular}{|l|l|l|l|l|}
\hline Ejemplo 107 & \multicolumn{1}{l|}{ PROGRAMA: THE ODD SQUAD } \\
\hline PAÍS DE DOBLAJE: COLOMBIA & AÑO 2014 \\
\hline TEMPORADA 1 - EPISODIO 2 “Soundcheck - Double Trouble” \\
\hline TÉRMINO & CONTEXTO & TRADUCCION & TÉCNICA & ESPAÑOL \\
\hline Snacks & $\ldots$. and snacks & $\ldots$ y pasabocas & $\begin{array}{l}\text { Traducción } \\
\text { literal }\end{array}$ & Regional \\
\hline
\end{tabular}

\begin{tabular}{|l|l|l|l|l|}
\hline Ejemplo 108 & \multicolumn{4}{l|}{ PROGRAMA: THE ODD SQUAD } \\
\hline PAÍS DE DOBLAJE: COLOMBIA & AÑO 2014 \\
\hline TEMPORADA 1 - EPISODIO 2 “Soundcheck - Double Trouble” \\
\hline TÉRMINO & CONTEXTO & TRADUCCION & TÉCNICA & ESPAÑOL \\
\hline Driving & $\begin{array}{l}\text { I'm driving around in } \\
\text { my minivan... }\end{array}$ & $\begin{array}{l}\text { Iba conduciendo mi } \\
\text { minivan... }\end{array}$ & $\begin{array}{l}\text { Traducción } \\
\text { literal }\end{array}$ & Neutro \\
\cline { 4 - 5 } & Préstamo & Regional \\
\hline Minivan
\end{tabular}

\begin{tabular}{|l|c|l|l|l|}
\hline Ejemplo 109 & \multicolumn{1}{l|}{ PROGRAMA: THE ODD SQUAD } \\
\hline PAÍS DE DOBLAJE: COLOMBIA & AÑO 2014 & \multicolumn{1}{l|}{} \\
\hline TEMPORADA 1 - EPISODIO 2 “Soundcheck - Double Trouble” \\
\hline TÉRMINO & \multicolumn{1}{|c|}{ CONTEXTO } & \multicolumn{1}{|l|}{ TRADUCCION } & TÉCNCA & ESPANOL \\
\hline Bagels & $\begin{array}{l}\text { I put } 12 \text { bagels into the } \\
\text { oven... }\end{array}$ & $\begin{array}{l}\text { Puse } 12 \text { panecillos en el } \\
\text { horno... }\end{array}$ & $\begin{array}{l}\text { Traducción } \\
\text { literal }\end{array}$ & Neutro \\
\hline
\end{tabular}

\begin{tabular}{|l|l|l|l|l|}
\hline Ejemplo 110 & \multicolumn{3}{l|}{ PROGRAMA: THE ODD SQUAD } \\
\hline PAÍ́S DE DOBLAJE: COLOMBIA & AÑO 2014 \\
\hline TEMPORADA 1 - EPISODIO 2 “Soundcheck - Double Trouble” \\
\hline TÉRMINO & CONTEXTO & TRADUCCION & TÉCNICA & ESPAÑOL \\
\hline Kiddos & Listen, kiddos... & Escuchen, chicos... & Variación & Regional \\
\hline
\end{tabular}




\begin{tabular}{|l|c|c|c|l|}
\hline Ejemplo 111 & \multicolumn{4}{l|}{ PROGRAMA: THE ODD SQUAD } \\
\hline PAÍS DE DOBLAJE: COLOMBIA & AÑO 2014 & TÉCNICA & ESPAÑOL \\
\hline TEMPORADA 1 - EPISODIO 2 “Soundcheck - Double Trouble” & \multicolumn{2}{l|}{$\begin{array}{l}\text { Regional } \\
\text { (pronunciación } \\
\text { errónea de la J } \\
\text { /S/y } \\
\text { pronunciación } \\
\text { muy marcada } \\
\text { de la primera } \\
(/ \mathrm{t} /)\end{array}$} \\
\hline
\end{tabular}

\begin{tabular}{|l|l|l|l|l|}
\hline Ejemplo 112 & \multicolumn{1}{l|}{ PROGRAMA: THE ODD SQUAD } \\
\hline PAÍS DE DOBLAJE: COLOMBIA & AÑO 2014 \\
\hline \multicolumn{1}{|l|}{ TEMPORADA 1 - EPISODIO 2 “Soundcheck - Double Trouble” } \\
\hline TÉRMINO & CONTEXTO & \multicolumn{1}{|l|}{ TRADUCCION } & TÉCNICA & ESPAÑOL \\
\hline Donuts & $\begin{array}{l}\text { Every morning I make } \\
\text { donuts... }\end{array}$ & $\begin{array}{l}\text { Todas las mañanas hago } \\
\text { panecillos... }\end{array}$ & $\begin{array}{l}\text { Creación } \\
\text { discursiva }\end{array}$ & Neutro \\
\hline
\end{tabular}

\begin{tabular}{|l|c|l|c|c|}
\hline \multicolumn{2}{|l|}{ Ejemplo 113 } & \multicolumn{1}{l|}{ PROGRAMA: THE ODD SQUAD } \\
\hline PAÍS DE DOBLAJE: COLOMBIA & AÑO 2014 \\
\hline \multicolumn{2}{|l|}{ TEMPORADA 1 - EPISODIO 2 “Soundcheck - Double Trouble” } \\
\hline TÉRMINO & CONTEXTO & \multicolumn{1}{|c|}{ TRADUCCION } & TÉCNICA & ESPAÑOL \\
\hline Cool & $\begin{array}{l}\text { How come Olive gets } \\
\text { to do the cool stuff and } \\
\text { I'm stuck here doing } \\
\text { the non-cool stuff? }\end{array}$ & $\begin{array}{l}\text { ¿Por qué Olivia hace las } \\
\text { cosas interesantes y yo estoy } \\
\text { aquí encerrado haciendo lo } \\
\text { aburrido? }\end{array}$ & $\begin{array}{l}\text { Creación } \\
\text { discursiva }\end{array}$ & Neutro \\
\hline
\end{tabular}

\begin{tabular}{|c|c|c|c|c|}
\hline \multicolumn{2}{|l|}{ Ejemplo 114} & \multicolumn{3}{|c|}{ PROGRAMA: THE ODD SQUAD } \\
\hline \multicolumn{2}{|c|}{ PAÍS DE DOBLAJE: COLOMBIA } & \multicolumn{3}{|c|}{ AÑO 2014} \\
\hline \multicolumn{5}{|c|}{ TEMPORADA 1 - EPISODIO 2 "Soundcheck - Double Trouble" } \\
\hline TÉRMINO & CONTEXTO & TRADUCCION & TÉCNICA & ESPAÑOL \\
\hline Y & ...had an older sister... & $\begin{array}{l}\text {...tenía una hermana } \\
\text { mayor... }\end{array}$ & $\begin{array}{l}\text { Traducción } \\
\text { literal }\end{array}$ & $\begin{array}{l}\text { Regional } \\
\text { (pronunciación } \\
\text { muy marcada } \\
\text { de la /3/) }\end{array}$ \\
\hline
\end{tabular}




\begin{tabular}{|c|c|c|c|c|}
\hline \multicolumn{2}{|l|}{ Ejemplo 115} & \multicolumn{3}{|c|}{ PROGRAMA: THE ODD SQUAD } \\
\hline \multicolumn{2}{|c|}{ PAÍS DE DOBLAJE: COLOMBIA } & AÑO 2014 & & \\
\hline \multicolumn{5}{|c|}{ TEMPORADA 1 - EPISODIO 2 "Soundcheck - Double Trouble" } \\
\hline TÉRMINO & CONTEXTO & TRADUCCION & TÉCNICA & ESPAÑOL \\
\hline Hot dog & $\begin{array}{l}\text {...found himself } \\
\text { working at a hot dog } \\
\text { stand... }\end{array}$ & $\begin{array}{l}\ldots y \text { se encontró trabajando } \\
\text { en un carrito de perros } \\
\text { calientes... }\end{array}$ & Calco & Regional \\
\hline
\end{tabular}

\begin{tabular}{|l|l|l|c|c|}
\hline Ejemplo 116 & \multicolumn{1}{l|}{ PROGRAMA: THE ODD SQUAD } \\
\hline PAÍS DE DOBLAJE: COLOMBIA & AÑO 2015 \\
\hline \multicolumn{4}{|l|}{ TEMPORADA 2 - EPISODIO 10 "Not So Splash - By the rule” } \\
\hline TÉRMINO & CONTEXTO & TRADUCCION & TÉCNICA & ESPAÑOL \\
\hline Goop & Any goop & Cosa babosa & Explicitación & Neutro \\
\hline
\end{tabular}

\begin{tabular}{|l|l|l|l|l|}
\hline Ejemplo 117 & \multicolumn{1}{l|}{ PROGRAMA: THE ODD SQUAD } \\
\hline PAÍ́S DE DOBLAJE: COLOMBIA & AÑO 2015 & \multicolumn{1}{l|}{ TÉCNICA } & ESPAÑOL \\
\hline TEMPORADA 2 - EPISODIO 10 "Not So Splash - By the rule” & TRADUCCION & $\begin{array}{l}\text { Traducción } \\
\text { literal }\end{array}$ & Neutro \\
\hline TÉRMINO & CONTEXTO & ¿Cuáles batidos? &
\end{tabular}

\begin{tabular}{|l|c|c|c|c|}
\hline Ejemplo 118 & \multicolumn{1}{l|}{ PROGRAMA: THE ODD SQUAD } \\
\hline PAÍS DE DOBLAJE: COLOMBIA & AÑO 2015 \\
\hline \multicolumn{4}{|l|}{ TEMPORADA 2 - EPISODIO 10 “Not So Splash - By the rule” } \\
\hline TÉRMINO & \multicolumn{1}{|l|}{ CONTEXTO } & TRADUCCION & TÉCNICA & ESPAÑOL \\
\hline $\begin{array}{l}\text { Trick or } \\
\text { treat }\end{array}$ & $\begin{array}{l}\text { I had to take them } \\
\text { trick-or-treating }\end{array}$ & Debí llevarlos a pedir dulces & Explicitación & Neutro \\
\hline
\end{tabular}

\begin{tabular}{|l|l|l|c|c|}
\hline Ejemplo 119 & \multicolumn{1}{l|}{ PROGRAMA: THE ODD SQUAD } \\
\hline PAÍS DE DOBLAJE: COLOMBIA & AÑO 2015 \\
\hline TEMPORADA 2 - EPISODIO 10 “Not So Splash - By the rule” \\
\hline TÉRMINO & CONTEXTO & TRADUCCION & TÉCNICA & ESPAÑOL \\
\hline Halloween & $\begin{array}{l}\text { And it's not } \\
\text { Halloween yet! }\end{array}$ & iY ni siquiera es Halloween! & Préstamo & Neutro \\
\hline
\end{tabular}




\begin{tabular}{|l|l|l|l|l|}
\hline Ejemplo 120 & \multicolumn{1}{l|}{ PROGRAMA: THE ODD SQUAD } \\
\hline PAÍS DE DOBLAJE: COLOMBIA & AÑO 2015 \\
\hline TEMPORADA 2 - EPISODIO 10 “Not So Splash - By the rule” \\
\hline TÉRMINO & CONTEXTO & \multicolumn{1}{l|}{ TRADUCCION } & TÉCNICA & ESPAÑOL \\
\hline Kill & My back is killing me! & $\begin{array}{l}\text { ¡Mi espalda me está } \\
\text { matando! }\end{array}$ & $\begin{array}{l}\text { Traducción } \\
\text { literal }\end{array}$ & Neutro \\
\hline
\end{tabular}

\begin{tabular}{|l|l|l|c|c|}
\hline Ejemplo 121 & \multicolumn{3}{l|}{ PROGRAMA: THE ODD SQUAD } \\
\hline PAÍS DE DOBLAJE: COLOMBIA & AÑO 2015 & \\
\hline TEMPORADA 2 - EPISODIO 10 “Not So Splash - By the rule” \\
\hline TÉRMINO & CONTEXTO & TRADUCCION & TÉCNICA & ESPAÑOL \\
\hline Crackers & With crackers & Con galletas & Generalización & Neutro \\
\hline
\end{tabular}

\begin{tabular}{|l|c|l|l|l|}
\hline Ejemplo 122 & \multicolumn{1}{l|}{ PROGRAMA: THE ODD SQUAD } \\
\hline PAÍS DE DOBLAJE: COLOMBIA & AÑO 2015 \\
\hline TEMPORADA 2 - EPISODIO 10 “Not So Splash - By the rule” \\
\hline TÉRMINO & CONTEXTO & \multicolumn{1}{|l|}{ TRADUCCION } & TÉCNICA & ESPAÑOL \\
\hline Potato & $\begin{array}{l}\text { I saw somebody drop a } \\
\text { potato chip bag }\end{array}$ & $\begin{array}{l}\text { Vi a alguien arrojar una bolsa } \\
\text { de papas fritas }\end{array}$ & $\begin{array}{l}\text { Traducción } \\
\text { literal }\end{array}$ & Neutro \\
\hline
\end{tabular}

\begin{tabular}{|l|c|l|l|l|}
\hline Ejemplo 123 & \multicolumn{1}{l|}{ PROGRAMA: THE ODD SQUAD } \\
\hline PAÍS DE DOBLAJE: COLOMBIA & AÑO 2015 \\
\hline \multicolumn{1}{|l|}{ TEMPORADA 2 - EPISODIO 10 “Not So Splash - By the rule” } \\
\hline TÉRMINO & CONTEXTO & \multicolumn{1}{|l|}{ TRADUCCION } & TÉCNICA & ESPAÑOL \\
\hline Candy & ... candy wrapper... & $\begin{array}{l}\text {...una envoltura de } \\
\text { caramelo... }\end{array}$ & $\begin{array}{l}\text { Traducción } \\
\text { literal }\end{array}$ & Neutro \\
\hline
\end{tabular}

\begin{tabular}{|l|c|l|l|l|}
\hline Ejemplo 124 & \multicolumn{1}{l|}{ PROGRAMA: THE ODD SQUAD } \\
\hline PAÍS DE DOBLAJE: COLOMBIA & AÑO 2015 \\
\hline \multicolumn{5}{|l|}{ TEMPORADA 2 - EPISODIO 10 “Not So Splash - By the rule” } \\
\hline TÉRMINO & CONTEXTO & TRADUCCION & TÉCNICA & ESPAÑOL \\
\hline Banana & $\ldots$.. and a banana peel & $\ldots$ y una cáscara de banana & $\begin{array}{l}\text { Traducción } \\
\text { literal }\end{array}$ & Neutro \\
\hline
\end{tabular}




\begin{tabular}{|l|l|l|l|l|}
\hline \multicolumn{2}{|l|}{ Ejemplo 125 } & \multicolumn{1}{l|}{ PROGRAMA: THE ODD SQUAD } \\
\hline \multicolumn{2}{|l|}{ PAÍS DE DOBLAJE: COLOMBIA } & AÑO 2015 \\
\hline TEMPORADA 2 - EPISODIO 10 “Not So Splash - By the rule” \\
\hline TÉRMINO & \multicolumn{1}{|c|}{ CONTEXTO } & \multicolumn{1}{|l|}{ TRADUCCION } & TÉCNICA & ESPAÑOL \\
\hline Litter & $\begin{array}{l}\text {.. only one of them } \\
\text { littered candy } \\
\text { wrappers... }\end{array}$ & $\begin{array}{l}\text {...solo uno de ellos botó las } \\
\text { envolturas... }\end{array}$ & $\begin{array}{l}\text { Traducción } \\
\text { literal }\end{array}$ & Regional \\
\hline
\end{tabular}

\begin{tabular}{|c|c|c|c|c|}
\hline \multicolumn{2}{|l|}{ Ejemplo 126} & \multicolumn{3}{|c|}{ PROGRAMA: LAB RATS } \\
\hline \multicolumn{2}{|c|}{ PAÍS DE DOBLAJE: MÉXICO } & AÑO 2012 & & \\
\hline \multicolumn{5}{|c|}{ TEMPORADA 1 - EPISODIO 1 "Crush, chop and burn" } \\
\hline TÉRMINO & CONTEXTO & TRADUCCION & TÉCNICA & ESPAÑOL \\
\hline Prom & ...going to the prom... & ...la graduación... & $\begin{array}{l}\text { Explicitación / } \\
\text { Reducción }\end{array}$ & Neutro \\
\hline
\end{tabular}

\begin{tabular}{|l|l|l|l|l|}
\hline Ejemplo 127 & \multicolumn{1}{l|}{ PROGRAMA: LAB RATS } \\
\hline PAÍS DE DOBLAJE: MÉXICO & AÑO 2012 \\
\hline TEMPORADA 1 - EPISODIO 1 “Crush, chop and burn” & TÉCNICA & ESPAÑOL \\
\hline TÉRMINO & CONTEXTO & TRADUCCION & $\begin{array}{l}\text { Traducción } \\
\text { literal }\end{array}$ & Neutro \\
\hline Bra & I got the bra & A mí me dio el sostén &
\end{tabular}

\begin{tabular}{|l|l|l|l|l|}
\hline Ejemplo 128 & PROGRAMA: LAB RATS \\
\hline PAÍS DE DOBLAJE: MÉXICO & AÑO 2012 \\
\hline TEMPORADA 1 - EPISODIO 1 “Crush, chop and burn” & TÉCNICA & ESPAÑOL \\
\hline TÉRMINO & CONTEXTO & TRADUCCION & $\begin{array}{l}\text { Traducción } \\
\text { literal }\end{array}$ & Neutro \\
\hline Girl & I love girls' things & Amo las cosas de niñas &
\end{tabular}

\begin{tabular}{|l|l|l|c|c|}
\hline Ejemplo 129 & PROGRAMA: LAB RATS \\
\hline PAÍS DE DOBLAJE: MÉXICO & AÑO 2012 \\
\hline TEMPORADA 1 - EPISODIO 1 “Crush, chop and burn” & TÉCNICA & ESPAÑOL \\
\hline TÉRMINO & CONTEXTO & TRADUCCION & Neutro \\
\hline Stab & $\begin{array}{l}\text { I can't wait to stab } \\
\text { them in the back }\end{array}$ & Ya tengo que pelear con ellas & Variación & \\
\hline
\end{tabular}




\begin{tabular}{|l|l|l|l|l|}
\hline \multicolumn{2}{|l|}{ Ejemplo 130 } & PROGRAMA: LAB RATS \\
\hline PAÍS DE DOBLAJE: MÉXICO & AÑO 2012 \\
\hline \multicolumn{4}{|l|}{ TEMPORADA 1 - EPISODIO 1 “Crush, chop and burn” } \\
\hline TÉRMINO & CONTEXTO & TRADUCCION & TÉCNICA & ESPAÑOL \\
\hline Bell & It's called a bell & Es una campana & $\begin{array}{l}\text { Traducción } \\
\text { literal }\end{array}$ & Neutro \\
\hline
\end{tabular}

\begin{tabular}{|c|c|c|c|c|}
\hline \multicolumn{2}{|l|}{ Ejemplo 131} & \multicolumn{3}{|l|}{ PROGRAMA: LAB RATS } \\
\hline \multicolumn{2}{|c|}{ PAÍS DE DOBLAJE: MÉXICO } & \multicolumn{3}{|c|}{ AÑO 2012} \\
\hline \multicolumn{5}{|c|}{ TEMPORADA 1 - EPISODIO 1 "Crush, chop and burn" } \\
\hline TÉRMINO & CONTEXTO & TRADUCCION & TÉCNICA & ESPAÑOL \\
\hline Basketball & $\begin{array}{l}\text { So big deal, you can't } \\
\text { play basketball }\end{array}$ & $\begin{array}{l}\text { ¿Qué más da si no juegas } \\
\text { baloncesto? }\end{array}$ & Calco & Regional \\
\hline
\end{tabular}

\begin{tabular}{|l|l|l|l|l|}
\hline Ejemplo 132 & \multicolumn{1}{l|}{ PROGRAMA: LAB RATS } \\
\hline PAÍS DE DOBLAJE: MÉXICO & AÑO 2012 \\
\hline TEMPORADA 1 - EPISODIO 1 “Crush, chop and burn” & \multicolumn{1}{l|}{ TRADUCCION } & TÉCNICA & ESPAÑOL \\
\hline TÉRMINO & \multicolumn{1}{|c|}{ CONTEXTO } & $\begin{array}{l}\text { Traducción } \\
\text { literal }\end{array}$ & Neutro \\
\hline Ball & $\ldots$...the ball & ...el balón &
\end{tabular}

\begin{tabular}{|l|l|l|l|l|}
\hline Ejemplo 133 & \multicolumn{1}{l|}{ PROGRAMA: LAB RATS } \\
\hline PAÍS DE DOBLAJE: MÉXICO & AÑO 2012 \\
\hline TEMPORADA 1 - EPISODIO 1 “Crush, chop and burn” & TÉCNICA & ESPAÑOL \\
\hline TÉRMINO & CONTEXTO & TRADUCCION & $\begin{array}{l}\text { Traducción } \\
\text { literal }\end{array}$ & Neutro \\
\hline Drawers & My drawers! & ¡Mis calzoncillos! &
\end{tabular}

\begin{tabular}{|l|l|l|l|l|}
\hline Ejemplo 134 & \multicolumn{1}{l|}{ PROGRAMA: LAB RATS } \\
\hline \multicolumn{2}{|l|}{ PAÍS DE DOBLAJE: MÉXICO } & AÑO 2012 \\
\hline TEMPORADA 1 - EPISODIO 1 “Crush, chop and burn” & TÉCNICA & ESPAÑOL \\
\hline TÉRMINO & CONTEXTO & \multicolumn{1}{|l|}{ TRADUCCION } & Neutro \\
\hline Wedgie & $\begin{array}{l}\text { There's been a certain } \\
\text { gentleness to my } \\
\text { wedgies }\end{array}$ & $\begin{array}{l}\text { Y hasta he descansado del } \\
\text { calzón chino }\end{array}$ & $\begin{array}{l}\text { Equivalente } \\
\text { acuñado }\end{array}$ \\
\hline
\end{tabular}




\begin{tabular}{|l|c|l|l|l|}
\hline Ejemplo 135 & \multicolumn{3}{l|}{ PROGRAMA: LAB RATS } \\
\hline PAÍS DE DOBLAJE: MÉXICO & AÑO 2012 & \\
\hline TEMPORADA 1 - EPISODIO 1 “Crush, chop and burn” & TÉCNICA & ESPAÑOL \\
\hline TÉRMINO & CONTEXTO & TRADUCCION & Modulación & Neutro \\
\hline Rock & You guys rock! & ¡Los adoro! &
\end{tabular}

\begin{tabular}{|c|c|c|c|c|}
\hline \multicolumn{2}{|l|}{ Ejemplo 136} & \multicolumn{3}{|l|}{ PROGRAMA: LAB RATS } \\
\hline \multicolumn{2}{|c|}{ PAÍS DE DOBLAJE: MÉXICO } & \multicolumn{3}{|l|}{ AÑO 2012} \\
\hline \multicolumn{5}{|c|}{ TEMPORADA 1 - EPISODIO 1 "Crush, chop and burn" } \\
\hline TÉRMINO & CONTEXTO & TRADUCCION & TÉCNICA & ESPAÑOL \\
\hline Steak & $\begin{array}{l}\text {..our first taste of } \\
\text { Salisbury steak, yum! }\end{array}$ & $\begin{array}{l}\text {...conocimos estas deliciosas } \\
\text { hamburguesas... }\end{array}$ & $\begin{array}{l}\text { Creación } \\
\text { discursiva }\end{array}$ & Neutro \\
\hline
\end{tabular}

\begin{tabular}{|l|l|l|l|l|}
\hline Ejemplo 137 & \multicolumn{1}{l|}{ PROGRAMA: LAB RATS } \\
\hline PAÍ́S DE DOBLAJE: MÉXICO & AÑO 2015 \\
\hline TEMPORADA 4 - EPISODIO 1 “Bionic Rebellion Part 1” & TÉCNICA & ESPAÑOL \\
\hline TÉRMINO & CONTEXTO & TRADUCCION & $\begin{array}{l}\text { Traducción } \\
\text { literal }\end{array}$ & Neutro \\
\hline Butt & How to kick your butt & A patear tu trasero &
\end{tabular}

\begin{tabular}{|c|c|c|c|c|}
\hline \multicolumn{2}{|l|}{ Ejemplo 138} & \multicolumn{3}{|c|}{ PROGRAMA: LAB RATS } \\
\hline \multicolumn{2}{|c|}{ PAÍS DE DOBLAJE: MÉXICO } & AÑ̃ 2015 & & \\
\hline \multicolumn{5}{|c|}{ TEMPORADA 4 - EPISODIO 1 "Bionic Rebellion Part 1" } \\
\hline TÉRMINO & CONTEXTO & TRADUCCION & TÉCNICA & ESPAÑOL \\
\hline Winnebago & ...in a Winnebago... & ...y a un Winnebago... & Préstamo & Regional \\
\hline
\end{tabular}

\begin{tabular}{|c|c|c|c|c|}
\hline \multicolumn{2}{|l|}{ Ejemplo 139} & \multicolumn{3}{|c|}{ PROGRAMA: LAB RATS } \\
\hline \multicolumn{2}{|c|}{ PAÍS DE DOBLAJE: MÉXICO } & \multicolumn{3}{|c|}{ AÑO 2015} \\
\hline \multicolumn{5}{|c|}{ TEMPORADA 4 - EPISODIO 1 "Bionic Rebellion Part 1" } \\
\hline TÉRMINO & CONTEXTO & TRADUCCION & TÉCNICA & ESPAÑOL \\
\hline Spoiler & Spoiler alert! & ¡Lo voy a arruinar! & Explicitación & Neutro \\
\hline
\end{tabular}

\begin{tabular}{|l|l|l|l|l|}
\hline Ejemplo 140 & \multicolumn{1}{l|}{ PROGRAMA: LAB RATS } \\
\hline PAÍS DE DOBLAJE: MÉXICO & AÑO 2016 \\
\hline TEMPORADA 4 - EPISODIO 2 “Bionic Rebellion Part 2” & \multicolumn{1}{l|}{ TRADUCCION } & TÉCNICA & ESPAÑOL \\
\hline TÉRMINO & \multicolumn{1}{|l}{ CONTEXTO } & $\begin{array}{l}\text { Traducción } \\
\text { literal }\end{array}$ & Neutro \\
\hline Junk yard & $\begin{array}{l}\text { He kept them in a junk } \\
\text { yard! }\end{array}$ & $\begin{array}{l}\text { ¡Los tenía encerrados en un } \\
\text { basurero! }\end{array}$ &
\end{tabular}




\begin{tabular}{|l|l|l|l|l|}
\hline Ejemplo 141 & \multicolumn{1}{l|}{ PROGRAMA: LAB RATS } \\
\hline PAÍS DE DOBLAJE: MÉXICO & AÑO 2016 \\
\hline \multicolumn{1}{|l|}{ TEMPORADA 4 - EPISODIO 2 “Bionic Rebellion Part 2” } \\
\hline TÉRMINO & \multicolumn{1}{|l|}{ CONTEXTO } & \multicolumn{1}{l|}{ TRADUCCION } & TÉCNICA & ESPAÑOL \\
\hline $\begin{array}{l}\text { Hard-boiled } \\
\text { eggs }\end{array}$ & $\begin{array}{l}\text { If I had hard-boiled } \\
\text { eggs and mayo... }\end{array}$ & $\begin{array}{l}\text { Si tuviera huevos cocidos y } \\
\text { mayonesa... }\end{array}$ & $\begin{array}{l}\text { Traducción } \\
\text { literal }\end{array}$ & Neutro \\
\hline
\end{tabular}

\begin{tabular}{|c|c|c|c|c|}
\hline \multicolumn{2}{|l|}{ Ejemplo 142} & \multicolumn{3}{|l|}{ PROGRAMA: LAB RATS } \\
\hline \multicolumn{2}{|c|}{ PAIIS DE DOBLAJE: MÉXICO } & AÑ̃ 2016 & & \\
\hline \multicolumn{5}{|c|}{ TEMPORADA 4 - EPISODIO 2 "Bionic Rebellion Part 2" } \\
\hline TÉRMINO & CONTEXTO & TRADUCCION & TÉCNICA & ESPAÑOL \\
\hline Cookies & $\begin{array}{l}\text {...those little girls } \\
\text { selling cookies }\end{array}$ & $\begin{array}{l}\text {...de las niñas que vendían } \\
\text { galletas }\end{array}$ & $\begin{array}{l}\text { Traducción } \\
\text { literal }\end{array}$ & Neutro \\
\hline
\end{tabular}

\begin{tabular}{|c|c|c|c|c|}
\hline \multicolumn{2}{|l|}{ Ejemplo 143} & \multicolumn{3}{|c|}{ PROGRAMA: LAB RATS } \\
\hline \multicolumn{2}{|c|}{ PAIÍS DE DOBLAJE: MÉXICO } & AÑ̃ 2016 & & \\
\hline \multicolumn{5}{|c|}{ TEMPORADA 4 - EPISODIO 2 "Bionic Rebellion Part 2" } \\
\hline TÉRMINO & CONTEXTO & TRADUCCION & TÉCNICA & ESPAÑOL \\
\hline Doorbell & $\begin{array}{l}\text { Don't ring my } \\
\text { doorbell! }\end{array}$ & No tocar a mi puerta & Modulación & Neutro \\
\hline
\end{tabular}

\begin{tabular}{|l|l|l|l|l|}
\hline Ejemplo 144 & \multicolumn{1}{l|}{ PROGRAMA: LAB RATS } \\
\hline PAÍS DE DOBLAJE: MÉXICO & AÑO 2016 \\
\hline TEMPORADA 4 - EPISODIO 2 “Bionic Rebellion Part 2" \\
\hline TÉRMINO & CONTEXTO & TRADUCCION & TÉCNICA & ESPAÑOL \\
\hline Rings & Forget the rings & Olviden los anillos & $\begin{array}{l}\text { Traducción } \\
\text { literal }\end{array}$ & Neutro \\
\hline
\end{tabular}

\begin{tabular}{|l|l|l|l|l|}
\hline Ejemplo 145 & \multicolumn{2}{l|}{ PROGRAMA: iCarly } \\
\hline PAÍS DE DOBLAJE: MÉXICO & AÑO 2007 \\
\hline \multicolumn{2}{|l|}{ TEMPORADA 1 - EPISODIO 1 “iPilot” } \\
\hline TÉRMINO & \multicolumn{1}{|l|}{ CONTEXTO } & \multicolumn{1}{l|}{ TRADUCCION } & TÉCNICA & ESPAÑOL \\
\hline God & $\begin{array}{l}\text { Oh God! / Oh my } \\
\text { God! }\end{array}$ & ¡Ay, Dios! ¡Oh, por Dios! & $\begin{array}{l}\text { Traducción } \\
\text { literal }\end{array}$ & Neutro \\
\hline
\end{tabular}

\begin{tabular}{|l|c|l|l|l|}
\hline Ejemplo 146 & \multicolumn{3}{l|}{ PROGRAMA: iCarly } \\
\hline PAÍS DE DOBLAJE: MÉXICO & AÑO 2007 \\
\hline TEMPORADA 1 - EPISODIO 1 “iPilot” & \multicolumn{1}{l|}{ TÉCNICA } & ESPAÑOL \\
\hline TÉRMINO & CONTEXTO & TRADUCCION & $\begin{array}{l}\text { Traducción } \\
\text { literal }\end{array}$ & Neutro \\
\hline Doof & $\ldots$.. you invited the doof & $\ldots$.. invitaste al tonto &
\end{tabular}




\begin{tabular}{|l|l|l|l|l|}
\hline \multicolumn{2}{|l|}{ Ejemplo 147 } & \multicolumn{1}{l|}{ PROGRAMA: iCarly } \\
\hline \multicolumn{2}{|l|}{ PAÍS DE DOBLAJE: MÉXICO } & AÑO 2007 \\
\hline TEMPORADA 1 - EPISODIO 1 “iPilot” & \multicolumn{1}{|l|}{ TÉCNICA } & ESPAÑOL \\
\hline TÉRMINO & \multicolumn{1}{|c|}{ CONTEXTO } & \multicolumn{1}{|c|}{ TRADUCCION } & Regional \\
\hline Boobs & $\begin{array}{l}\text {..he doesn't have } \\
\text { Miss Briggs' crazy } \\
\text { pointy boobs }\end{array}$ & $\begin{array}{l}\text {...no tiene las bubis } \\
\text { puntiagudas de la señorita } \\
\text { Briggs }\end{array}$ & Préstamo \\
\hline
\end{tabular}

\begin{tabular}{|l|l|l|c|c|}
\hline \multicolumn{2}{|l|}{ Ejemplo 148 } & \multicolumn{2}{l|}{ PROGRAMA: iCarly } \\
\hline \multicolumn{2}{|l|}{ PAÍS DE DOBLAJE: MÉXICO } & AÑO 2007 \\
\hline TEMPORADA 1 - EPISODIO 1 “iPilot” & \multicolumn{2}{l|}{ TÉCNICA } & ESPAÑOL \\
\hline TÉRMINO & CONTEXTO & \multicolumn{1}{|l|}{ TRADUCCION } & Neutro \\
\hline Idiots & $\begin{array}{l}\text { We were being all } \\
\text { goofy and acting like } \\
\text { idiots all day! }\end{array}$ & $\begin{array}{l}\text { Hicimos tonterías y actuamos } \\
\text { como tontos }\end{array}$ & Variación \\
\hline
\end{tabular}

\begin{tabular}{|l|c|l|c|c|}
\hline Ejemplo 149 & \multicolumn{2}{l|}{ PROGRAMA: iCarly } \\
\hline PAÍS DE DOBLAJE: MÉXICO & AÑO 2007 \\
\hline \multicolumn{1}{|l|}{ TEMPORADA 1 - EPISODIO 1 “iPilot” } \\
\hline TÉRMINO & CONTEXTO & TRADUCCION & TÉCNICA & ESPAÑOL \\
\hline Bossom & $\begin{array}{l}\text {... with my pointy } \\
\text { bossom }\end{array}$ & $\ldots$ con mis bubis puntiagudas & Variación & Neutro \\
\hline
\end{tabular}

\begin{tabular}{|l|l|l|l|l|}
\hline Ejemplo 150 & PROGRAMA: iCarly \\
\hline PAÍS DE DOBLAJE: MÉXICO & AÑO 2007 \\
\hline TEMPORADA 1 - EPISODIO 1 “iPilot” \\
\hline TÉRMINO & \multicolumn{1}{|c|}{ CONTEXTO } & \multicolumn{1}{l|}{ TRADUCCION } & TÉCNICA & ESPAÑOL \\
\hline Pee & $\begin{array}{l}\text { You always have to } \\
\text { pee }\end{array}$ & Siempre tienes que hacer pipí & $\begin{array}{l}\text { Traducción } \\
\text { literal }\end{array}$ & Neutro \\
\hline
\end{tabular}

\begin{tabular}{|l|l|l|l|l|}
\hline Ejemplo 151 & \multicolumn{3}{l|}{ PROGRAMA: iCarly } \\
\hline PAÍS DE DOBLAJE: MÉXICO & AÑO 2007 \\
\hline TEMPORADA 1 - EPISODIO 1 “iPilot” \\
\hline TÉRMINO & \multicolumn{1}{|l|}{ CONTEXTO } & \multicolumn{1}{|l|}{ TRADUCCION } & TÉCNICA & ESPAÑOL \\
\hline Dorky & $\begin{array}{l}\text {. our dorky friend } \\
\text { Freddie }\end{array}$ & $\begin{array}{l}\text {...nuestro amigo tonto } \\
\text { Freddie }\end{array}$ & $\begin{array}{l}\text { Traducción } \\
\text { literal }\end{array}$ & Neutro \\
\hline
\end{tabular}




\begin{tabular}{|l|c|l|l|l|}
\hline Ejemplo 152 & \multicolumn{1}{l|}{ PROGRAMA: iCarly } \\
\hline PAÍS DE DOBLAJE: MÉXICO & AÑO 2007 \\
\hline TEMPORADA 1 - EPISODIO 1 “iPilot” & \multicolumn{1}{l|}{ TÉCNICA } & ESPAÑOL \\
\hline TÉRMINO & CONTEXTO & TRADUCCION & $\begin{array}{l}\text { Traducción } \\
\text { literal }\end{array}$ & Regional \\
\hline Stupid & Or stupid & O estúpido & & \\
\hline
\end{tabular}

\begin{tabular}{|l|l|l|l|l|}
\hline \multicolumn{2}{|l|}{ Ejemplo 153 } & \multicolumn{1}{l|}{ PROGRAMA: iCarly } \\
\hline PAÍS DE DOBLAJE: MÉXICO & AÑO 2007 \\
\hline TEMPORADA 1 - EPISODIO 1 “iPilot” \\
\hline TÉRMINO & \multicolumn{1}{|l|}{ CONTEXTO } & \multicolumn{1}{|l|}{ TRADUCCION } & TÉCNICA & ESPAÑOL \\
\hline Cupcake & Hey, cupcake & Hola, panquecito & $\begin{array}{l}\text { Traducción } \\
\text { literal }\end{array}$ & $\begin{array}{l}\text { Regional } \\
\text { (diminutivo no } \\
\text { neutro) }\end{array}$ \\
\hline
\end{tabular}

\begin{tabular}{|l|l|l|l|l|}
\hline Ejemplo 154 & \multicolumn{2}{l|}{ PROGRAMA: iCarly } \\
\hline PAÍS DE DOBLAJE: MÉXICO & AÑO 2007 \\
\hline TEMPORADA 1 - EPISODIO 1 “iPilot” & \multicolumn{1}{l|}{ TÉCNICA } & ESPAÑOL \\
\hline TÉRMINO & CONTEXTO & TRADUCCION & $\begin{array}{l}\text { Traducción } \\
\text { literal }\end{array}$ & Neutro \\
\hline Cool & That's so cool & Es genial &
\end{tabular}

\begin{tabular}{|l|l|l|c|c|}
\hline Ejemplo 155 & \multicolumn{2}{l|}{ PROGRAMA: iCarly } \\
\hline PAÍS DE DOBLAJE: MÉXICO & AÑO 2007 \\
\hline \multicolumn{2}{|l|}{ TEMPORADA 1 - EPISODIO 1 “iPilot” } \\
\hline TÉRMINO & \multicolumn{1}{l|}{ CONTEXTO } & TRADUCCION & TÉCNICA & ESPAÑOL \\
\hline Bagel & $\begin{array}{l}\text { I also brought you } \\
\text { juice and a bagel }\end{array}$ & Te traje jugo y un bagel & Préstamo & Regional \\
\hline
\end{tabular}

\begin{tabular}{|c|c|c|c|c|}
\hline \multicolumn{2}{|l|}{ Ejemplo 156} & \multicolumn{3}{|l|}{ PROGRAMA: iCarly } \\
\hline \multicolumn{2}{|c|}{ PAÍS DE DOBLAJE: MÉXICO } & \multicolumn{3}{|l|}{ AÑO 2007} \\
\hline \multicolumn{5}{|c|}{ TEMPORADA 1 - EPISODIO 1 "iPilot" } \\
\hline TÉRMINO & CONTEXTO & TRADUCCION & TÉCNICA & ESPAÑOL \\
\hline \begin{tabular}{l|} 
Waffle \\
cones \\
\end{tabular} & \multirow{2}{*}{$\begin{array}{l}\text { It's like she stuffs } \\
\text { waffle cones in her bra }\end{array}$} & \multirow{2}{*}{$\begin{array}{l}\text { Parece que tuviera conos de } \\
\text { helado en su brassiere }\end{array}$} & \begin{tabular}{|l|}
$\begin{array}{l}\text { Traducción } \\
\text { literal }\end{array}$ \\
\end{tabular} & Neutro \\
\hline Bra & & & Préstamo & Regional \\
\hline
\end{tabular}




\begin{tabular}{|l|l|l|c|c|}
\hline Ejemplo 157 & \multicolumn{4}{l|}{ PROGRAMA: iCarly } \\
\hline PAÍS DE DOBLAJE: MÉXICO & AÑO 2010 \\
\hline \multicolumn{1}{|l|}{ TEMPORADA 3 - EPISODIO 10 “iSaved Your Life” } \\
\hline TÉRMINO & \multicolumn{1}{|l|}{ CONTEXTO } & TRADUCCION & TÉCNICA & ESPAÑOL \\
\hline Bra & $\begin{array}{l}\text { Get out of here, you } \\
\text { bra! }\end{array}$ & ¡Lárgate de aquí, brassiere! & Préstamo & Regional \\
\hline
\end{tabular}

\begin{tabular}{|l|l|l|l|l|}
\hline Ejemplo 158 & PROGRAMA: iCarly \\
\hline PAÍS DE DOBLAJE: MÉXICO & AÑO 2010 \\
\hline TEMPORADA 3 - EPISODIO 10 “iSaved Your Life” & \multicolumn{1}{l|}{} \\
\hline TÉRMINO & CONTEXTO & TRADUCCION & TÉCNICA & ESPAÑOL \\
\hline Assassin & It's called “Assassin” & Se llama “Asesino” & $\begin{array}{l}\text { Traducción } \\
\text { literal }\end{array}$ & Neutro \\
\hline
\end{tabular}

\begin{tabular}{|c|c|c|c|c|}
\hline \multicolumn{2}{|l|}{ Ejemplo 159} & \multicolumn{3}{|l|}{ PROGRAMA: iCarly } \\
\hline \multicolumn{2}{|c|}{ PAÍS DE DOBLAJE: MÉXICO } & \multicolumn{3}{|l|}{ AÑO 2010} \\
\hline \multicolumn{5}{|c|}{ TEMPORADA 3 - EPISODIO 10 "iSaved Your Life" } \\
\hline TÉRMINO & CONTEXTO & TRADUCCION & TÉCNICA & ESPAÑOL \\
\hline Girl & \multirow{2}{*}{$\begin{array}{l}\text {...the girl who tried to } \\
\text { kill my son }\end{array}$} & \multirow{2}{*}{$\begin{array}{l}\text {...la niña que intentó matar a } \\
\text { mi hijo }\end{array}$} & $\begin{array}{l}\text { Traducción } \\
\text { literal }\end{array}$ & Neutro \\
\hline Kill & & & $\begin{array}{l}\text { Traducción } \\
\text { literal }\end{array}$ & Neutro \\
\hline
\end{tabular}

\begin{tabular}{|l|c|l|l|l|}
\hline Ejemplo 160 & \multicolumn{2}{l|}{ PROGRAMA: iCarly } \\
\hline PAÍS DE DOBLAJE: MÉXICO & AÑO 2010 \\
\hline TEMPORADA 3 - EPISODIO 10 “iSaved Your Life” & TRADUCCION & TÉCNICA & ESPAÑOL \\
\hline TÉRMINO & CONTEXTO & $\begin{array}{l}\text { Traducción } \\
\text { literal }\end{array}$ & Neutro \\
\hline Kill & $\begin{array}{l}\text { Get away from me or } \\
\text { I’ll kill you }\end{array}$ & Lárgate de aquí o te mato \\
\hline
\end{tabular}

\begin{tabular}{|l|c|l|c|c|}
\hline Ejemplo 161 & \multicolumn{2}{l|}{ PROGRAMA: iCarly } \\
\hline PAÍS DE DOBLAJE: MÉXICO & AÑO 2010 \\
\hline TEMPORADA 3 - EPISODIO 10 “iSaved Your Life” & TÉCNICA & ESPAÑOL \\
\hline TÉRMINO & CONTEXTO & \multicolumn{1}{l|}{ TRADUCCION } & Neutro \\
\hline Stupid & $\begin{array}{l}\text { If I had seen that } \\
\text { stupid truck coming... }\end{array}$ & $\begin{array}{l}\text { Si hubiera visto a ese tonto } \\
\text { camión venir... }\end{array}$ & Variación \\
\hline
\end{tabular}




\begin{tabular}{|l|l|l|l|l|}
\hline Ejemplo 162 & \multicolumn{3}{l|}{ PROGRAMA: iCarly } \\
\hline PAÍS DE DOBLAJE: MÉXICO & AÑO 2010 \\
\hline TEMPORADA 3 - EPISODIO 10 “iSaved Your Life” & TÉCNICA & ESPAÑOL \\
\hline TÉRMINO & CONTEXTO & TRADUCCION & $\begin{array}{l}\text { Traducción } \\
\text { literal }\end{array}$ & Neutro \\
\hline Come on & Come on! & ¡Ay, por Dios! & & \\
\hline
\end{tabular}

\begin{tabular}{|l|l|l|l|l|}
\hline Ejemplo 163 & \multicolumn{3}{l|}{ PROGRAMA: iCarly } \\
\hline \multicolumn{2}{|l|}{ PAÍS DE DOBLAJE: MÉXICO } & AÑO 2010 & \\
\hline TEMPORADA 3 - EPISODIO 10 “iSaved Your Life” & \multicolumn{1}{l|}{ TRADUCCION } & TÉCNICA & ESPAÑOL \\
\hline TÉRMINO & CONTEXTO & COriación & Neutro \\
\hline Oi & Oi! & ¡Oh! & Varian \\
\hline
\end{tabular}

\begin{tabular}{|l|c|l|l|l|}
\hline Ejemplo 164 & \multicolumn{3}{l|}{ PROGRAMA: iCarly } \\
\hline PAÍS DE DOBLAJE: MÉXICO & \multicolumn{1}{l|}{ AÑO 2010 } & \multicolumn{1}{l|}{} \\
\hline TEMPORADA 3 - EPISODIO 10 “iSaved Your Life” & TRADUCCION & TÉCNICA & ESPAÑOL \\
\hline TÉRMINO & CONTEXTO & $\begin{array}{l}\text { Traducción } \\
\text { literal }\end{array}$ & Neutro \\
\hline Robe & Let me get my robe & Dame mi bata &
\end{tabular}

\begin{tabular}{|l|c|l|c|c|}
\hline Ejemplo 165 & \multicolumn{3}{l|}{ PROGRAMA: iCarly } \\
\hline \multicolumn{2}{|l|}{ PAÍS DE DOBLAJE: MÉXICO } & AÑO 2010 & \multicolumn{2}{l|}{} \\
\hline TEMPORADA 3 - EPISODIO 10 “iSaved Your Life” & TRADUCCION & TÉCNICA & ESPAÑOL \\
\hline TÉRMINO & CONTEXTO & $\begin{array}{l}\text { Traducción } \\
\text { literal }\end{array}$ & Regional \\
\hline Bell & Second bell & Segundo timbre &
\end{tabular}

\begin{tabular}{|l|l|l|l|l|}
\hline Ejemplo 166 & \multicolumn{3}{l|}{ PROGRAMA: iCarly } \\
\hline PAÍS DE DOBLAJE: MÉXICO & AÑO 2010 \\
\hline \multicolumn{1}{|l|}{ TEMPORADA 3 - EPISODIO 10 “iSaved Your Life” } \\
\hline TÉRMINO & \multicolumn{1}{|l|}{ CONTEXTO } & TRADUCCION & TÉCNICA & ESPAÑOL \\
\hline Bacon & $\begin{array}{l}\text { Bacons of the World } \\
\text { Club }\end{array}$ & Club Mundial del Tocino & $\begin{array}{l}\text { Traducción } \\
\text { literal }\end{array}$ & Neutro \\
\hline
\end{tabular}

\begin{tabular}{|l|l|l|c|c|}
\hline Ejemplo 167 & PROGRAMA: iCarly \\
\hline PAÍS DE DOBLAJE: MÉXICO & AÑO 2010 \\
\hline TEMPORADA 3 - EPISODIO 10 “iSaved Your Life” & \multicolumn{1}{l|}{ TRADUCCION } & TÉCNICA & ESPAÑOL \\
\hline TÉRMINO & \multicolumn{1}{|l|}{ CONTEXTO } & $\begin{array}{l}\text { Traducción } \\
\text { literal }\end{array}$ & Neutro \\
\hline Puke up & $\begin{array}{l}\text { Makes me wanna puke } \\
\text { up blood }\end{array}$ & $\begin{array}{l}\text { Me hace querer vomitar } \\
\text { sangre }\end{array}$ \\
\hline
\end{tabular}




\begin{tabular}{|c|c|c|c|c|}
\hline \multicolumn{2}{|l|}{ Ejemplo 168} & \multicolumn{3}{|l|}{ PROGRAMA: iCarly } \\
\hline \multicolumn{2}{|c|}{ PAÍS DE DOBLAJE: MÉXICO } & AÑO 2010 & & \\
\hline \multicolumn{5}{|c|}{ TEMPORADA 3 - EPISODIO 10 "iSaved Your Life" } \\
\hline TÉRMINO & CONTEXTO & TRADUCCION & TÉCNICA & ESPAÑOL \\
\hline Lollipop & A lollipop? & ¿Una paletita? & $\begin{array}{l}\text { Traducción } \\
\text { literal }\end{array}$ & $\begin{array}{l}\text { Regional } \\
\text { (diminutivo) }\end{array}$ \\
\hline
\end{tabular}

\begin{tabular}{|l|l|l|l|l|}
\hline \multicolumn{2}{|l|}{ Ejemplo 169 } & \multicolumn{3}{l|}{ PROGRAMA: iCarly } \\
\hline PAÍS DE DOBLAJE: MÉXICO & AÑO 2010 \\
\hline \multicolumn{1}{|l|}{ TEMPORADA 3 - EPISODIO 10 “iSaved Your Life” } \\
\hline TÉRMINO & \multicolumn{1}{|l|}{ TRADUCCION } & TÉCNICA & ESPAÑOL \\
\hline Geeky & $\begin{array}{l}\text { It's cute and geeky at } \\
\text { the same time }\end{array}$ & $\begin{array}{l}\text { Es muy lindo y raro al mismo } \\
\text { tiempo }\end{array}$ & $\begin{array}{l}\text { Creación } \\
\text { discursiva }\end{array}$ & Neutro \\
\hline
\end{tabular}

\begin{tabular}{|c|c|c|c|c|}
\hline \multicolumn{2}{|l|}{ Ejemplo 170} & \multicolumn{3}{|l|}{ PROGRAMA: iCarly } \\
\hline \multicolumn{2}{|c|}{ PAÍS DE DOBLAJE: MÉXICO } & AÑO 2012 & & \\
\hline \multicolumn{5}{|c|}{ TEMPORADA 6 - EPISODIO 5 "iPear Store" } \\
\hline TÉRMINO & CONTEXTO & TRADUCCION & TÉCNICA & ESPAÑOL \\
\hline \multirow[b]{2}{*}{ Boobies } & $\begin{array}{l}\text { Can't you see her } \\
\text { snow boobies? }\end{array}$ & $\begin{array}{l}\text { ¿No notas sus bubis de } \\
\text { nieve? }\end{array}$ & Préstamo & Regional \\
\hline & $\begin{array}{l}\text { I think one of her } \\
\text { boobies might have } \\
\text { fallen off }\end{array}$ & $\begin{array}{l}\text { Parece que se le cayó un } \\
\text { atributo }\end{array}$ & Generalización & Neutro \\
\hline
\end{tabular}

\begin{tabular}{|l|l|l|l|l|}
\hline Ejemplo 171 & \multicolumn{3}{l|}{ PROGRAMA: iCarly } \\
\hline PAÍS DE DOBLAJE: MÉXICO & AÑO 2012 & \\
\hline TEMPORADA 6 - EPISODIO 5 “iPear Store” & TÉCNICA & ESPAÑOL \\
\hline TÉRMINO & CONTEXTO & TRADUCCION & TÉación & Neutro \\
\hline Idiot & What an idiot & Qué tonto & Variación \\
\hline
\end{tabular}

\begin{tabular}{|l|c|c|c|c|}
\hline Ejemplo 172 & \multicolumn{1}{l|}{ PROGRAMA: iCarly } \\
\hline PAÍS DE DOBLAJE: MÉXICO & AÑO 2012 \\
\hline TEMPORADA 6 - EPISODIO 5 “iPear Store” & \multicolumn{1}{l|}{ TRADUCCION } & TÉCNICA & ESPAÑOL \\
\hline TÉRMINO & CONTEXTO & $\begin{array}{l}\text { Traducción } \\
\text { literal }\end{array}$ & Neutro \\
\hline Ear buds & $\begin{array}{l}\text { I just wanna buy some } \\
\text { ear buds }\end{array}$ & Un par de audífonos &
\end{tabular}




\begin{tabular}{|l|c|l|c|c|}
\hline Ejemplo 173 & \multicolumn{3}{l|}{ PROGRAMA: iCarly } \\
\hline PAÍS DE DOBLAJE: MÉXICO & AÑO 2012 \\
\hline \multicolumn{1}{|l|}{ TEMPORADA 6 - EPISODIO 5 “iPear Store” } \\
\hline TÉRMINO & CONTEXTO & \multicolumn{1}{|l|}{ TRADUCCION } & TÉCNICA & ESPAÑOL \\
\hline Corn & I like caramel corn & $\begin{array}{l}\text { Me gustan las palomitas de } \\
\text { caramelo }\end{array}$ & $\begin{array}{l}\text { Traducción } \\
\text { literal }\end{array}$ & Neutro \\
\hline
\end{tabular}

\begin{tabular}{|c|c|c|c|c|}
\hline \multicolumn{2}{|l|}{ Ejemplo 174} & \multicolumn{3}{|l|}{ PROGRAMA: iCarly } \\
\hline \multicolumn{2}{|c|}{ PAÍS DE DOBLAJE: MÉXICO } & AÑN 2012 & & \\
\hline \multicolumn{5}{|c|}{ TEMPORADA 6 - EPISODIO 5 "iPear Store" } \\
\hline TÉRMINO & CONTEXTO & \begin{tabular}{|l} 
TRADUCCION \\
\end{tabular} & TÉCNICA & ESPAÑOL \\
\hline \multirow[b]{2}{*}{ Nerd } & $\begin{array}{l}\text { What happened to } \\
\text { your nerdiness? }\end{array}$ & ¿Dónde quedó tu lado nerd? & Préstamo & Neutro \\
\hline & $\begin{array}{l}\text { You're a happy little } \\
\text { nerd }\end{array}$ & $\begin{array}{l}\text { Eres como un pequeño nerd } \\
\text { que encontró su hogar }\end{array}$ & Préstamo & Neutro \\
\hline
\end{tabular}

\begin{tabular}{|l|l|l|c|c|}
\hline \multicolumn{2}{|l|}{ Ejemplo 175 } & \multicolumn{1}{l|}{ PROGRAMA: iCarly } \\
\hline \multicolumn{2}{|l|}{ PAÍS DE DOBLAJE: MÉXICO } & AÑO 2012 \\
\hline \multicolumn{2}{|l|}{ TEMPORADA 6 - EPISODIO 5 “iPear Store” } & TÉCNICA & ESPAÑOL \\
\hline TÉRMINO & $\begin{array}{l}\text { TRADUCCION } \\
\text { I hope my foot doesn't } \\
\text { hurt your butt when I } \\
\text { do this }\end{array}$ & $\begin{array}{l}\text { Espero que mi pie no te } \\
\text { lastime cuando haga esto }\end{array}$ & Omisión & -- \\
\hline
\end{tabular}

\begin{tabular}{|l|c|l|l|l|}
\hline \multicolumn{2}{|l|}{ Ejemplo 176 } & \multicolumn{2}{l|}{ PROGRAMA: iCarly } \\
\hline PAÍS DE DOBLAJE: MÉXICO & AÑO 2012 \\
\hline TEMPORADA 6 - EPISODIO 5 “iPear Store” & TÉCNICA & ESPAÑOL \\
\hline TÉRMINO & CONTEXTO & TRADUCCION & $\begin{array}{l}\text { Traducción } \\
\text { literal }\end{array}$ & Regional \\
\hline Lazy & She's lazy & Ella es una haragana &
\end{tabular}

\begin{tabular}{|c|c|c|c|c|}
\hline \multicolumn{2}{|l|}{ Ejemplo 177} & \multicolumn{3}{|l|}{ PROGRAMA: iCarly } \\
\hline \multicolumn{2}{|c|}{ PAÍS DE DOBLAJE: MÉXICO } & \multicolumn{3}{|l|}{ AÑO 2012} \\
\hline \multicolumn{5}{|c|}{ TEMPORADA 6 - EPISODIO 5 "iPear Store" } \\
\hline TÉRMINO & CONTEXTO & TRADUCCION & TÉCNICA & ESPAÑOL \\
\hline Shirt & $\begin{array}{l}\text { But I'm keeping this } \\
\text { Pear Store shirt }\end{array}$ & $\begin{array}{l}\text { Pero conservaré esta camiseta } \\
\text { de la tienda }\end{array}$ & $\begin{array}{l}\text { Traducción } \\
\text { literal }\end{array}$ & Neutro \\
\hline
\end{tabular}




\begin{tabular}{|l|l|l|c|c|}
\hline Ejemplo 178 & \multicolumn{4}{l|}{ PROGRAMA: iCarly } \\
\hline PAÍS DE DOBLAJE: MÉXICO & AÑO 2012 \\
\hline \multicolumn{1}{|l|}{ TEMPORADA 6 - EPISODIO 5 “iPear Store” } \\
\hline TÉRMINO & \multicolumn{1}{|l|}{ CONTEXTO } & \multicolumn{1}{|l|}{ TRADUCCION } & TÉCNICA & ESPAÑOL \\
\hline Sandwich & $\begin{array}{l}\text { I shared my sandwich } \\
\text { with you! }\end{array}$ & $\begin{array}{l}\text { ¡Compartí mi sándwich } \\
\text { contigo! }\end{array}$ & Préstamo & Neutro \\
\hline
\end{tabular}

\begin{tabular}{|l|l|l|l|l|}
\hline Ejemplo 179 & \multicolumn{2}{l|}{ PROGRAMA: iCarly } \\
\hline PAÍS DE DOBLAJE: MÉXICO & AÑO 2012 \\
\hline TEMPORADA 6 - EPISODIO 5 “iPear Store” & TÉCNICA & ESPAÑOL \\
\hline TÉRMINO & CONTEXTO & TRADUCCION & $\begin{array}{l}\text { Traducción } \\
\text { literal }\end{array}$ & Regional \\
\hline Smoothie & This is a smoothie & Es un sorbete &
\end{tabular}

\begin{tabular}{|l|l|l|c|c|}
\hline \multicolumn{2}{|l|}{ Ejemplo 180 } & \multicolumn{2}{l|}{ PROGRAMA: iCarly } \\
\hline PAÍS DE DOBLAJE: MÉXICO & AÑO 2012 \\
\hline \multicolumn{1}{|l|}{ TEMPORADA 6 - EPISODIO 5 “iPear Store” } \\
\hline TÉRMINO & \multicolumn{1}{|l|}{ CONTEXTO } & \multicolumn{1}{l|}{ TRADUCCION } & TÉCNICA & ESPAÑOL \\
\hline Butt & $\begin{array}{l}\text { I’ve been flirting my } \\
\text { butt off }\end{array}$ & Y me he estado esforzando & Variación & Neutro \\
\hline
\end{tabular}

\begin{tabular}{|c|c|c|c|c|}
\hline \multicolumn{2}{|l|}{ Ejemplo 181} & \multicolumn{3}{|l|}{ PROGRAMA: iCarly } \\
\hline \multicolumn{2}{|c|}{ PAÍS DE DOBLAJE: MÉXICO } & AÑO 2012 & & \\
\hline \multicolumn{5}{|c|}{ TEMPORADA 6 - EPISODIO 5 "iPear Store" } \\
\hline TÉRMINO & CONTEXTO & TRADUCCION & TÉCNICA & ESPAÑOL \\
\hline Jerk & $\begin{array}{l}\text { Somebody order a } \\
\text { jerk? }\end{array}$ & ¿Alguien ordenó un tonto? & Variación & Neutro \\
\hline
\end{tabular}

\begin{tabular}{|l|l|l|l|l|}
\hline Ejemplo 182 & \multicolumn{2}{l|}{ PROGRAMA: iCarly } \\
\hline PAÍS DE DOBLAJE: MÉXICO & AÑO 2012 \\
\hline \multicolumn{2}{|l|}{ TEMPORADA 6 - EPISODIO 5 “iPear Store” } \\
\hline TÉRMINO & CONTEXTO & \multicolumn{1}{l|}{ TRADUCCION } & TÉCNICA & ESPAÑOL \\
\hline \multirow{2}{*}{ Jerk } & \multirow{2}{*}{$\begin{array}{l}\text { Would a jerk bring } \\
\text { you guys brownies? }\end{array}$} & $\begin{array}{l}\text { ¿Un tonto les traería } \\
\text { pastelillos? }\end{array}$ & Variación & Neutro \\
\cline { 4 - 5 } & & Generalización & Neutro \\
\hline
\end{tabular}




\begin{tabular}{|l|l|l|l|l|}
\hline Ejemplo 183 & \multicolumn{1}{l|}{ PROGRAMA: iCarly } \\
\hline PAÍS DE DOBLAJE: MÉXICO & AÑO 2012 \\
\hline TEMPORADA 6 - EPISODIO 5 “iPear Store” & \multicolumn{1}{l|}{ TÉCNICA } & ESPAÑOL \\
\hline TÉRMINO & CONTEXTO & TRADUCCION & $\begin{array}{l}\text { Traducción } \\
\text { literal }\end{array}$ & Neutro \\
\hline Fudge nut & Fudge nut & De chocolate & & \\
\hline
\end{tabular}

\begin{tabular}{|c|c|c|c|c|}
\hline \multicolumn{2}{|l|}{ Ejemplo 184} & \multicolumn{3}{|c|}{ PROGRAMA: BIG TIME RUSH } \\
\hline \multicolumn{2}{|c|}{ PAIIS DE DOBLAJE: VENEZUELA } & \multicolumn{3}{|c|}{ AÑO 2009} \\
\hline \multicolumn{5}{|c|}{ TEMPORADA 1 - EPISODIOS 1 y 2 "Big Time Audition" } \\
\hline TÉRMINO & CONTEXTO & TRADUCCION & TÉCNICA & ESPAÑOL \\
\hline Girls & \multirow{2}{*}{$\begin{array}{l}\text { Only the girls won't be } \\
\text { trying to kill me }\end{array}$} & \multirow{2}{*}{$\begin{array}{l}\text { Pero las chicas no trataran de } \\
\text { matarme }\end{array}$} & $\begin{array}{l}\text { Traducción } \\
\text { literal }\end{array}$ & Regional \\
\hline Kill & & & $\begin{array}{l}\text { Traducción } \\
\text { literal }\end{array}$ & Neutro \\
\hline
\end{tabular}

\begin{tabular}{|l|c|l|c|c|}
\hline Ejemplo 185 & \multicolumn{1}{l|}{ PROGRAMA: BIG TIME RUSH } \\
\hline \multicolumn{2}{|l|}{ PAÍ́S DE DOBLAJE: VENEZUELA } & AÑO 2009 \\
\hline TEMPORADA 1 - EPISODIOS 1 y 2 “Big Time Audition” & \multicolumn{1}{l|}{ TÉCNICA } & ESPAÑOL \\
\hline TÉRMINO & CONTEXTO & TRADUCCION & $\begin{array}{l}\text { Traducción } \\
\text { literal }\end{array}$ & Neutro \\
\hline Satan & He’s Satan. & Él es Satán. & \\
\hline
\end{tabular}

\begin{tabular}{|c|c|c|c|c|}
\hline \multicolumn{2}{|l|}{ Ejemplo 186} & \multicolumn{3}{|c|}{ PROGRAMA: BIG TIME RUSH } \\
\hline \multicolumn{2}{|c|}{ PAÍS DE DOBLAJE: VENEZUELA } & \multicolumn{3}{|c|}{ AÑO 2009} \\
\hline \multicolumn{5}{|c|}{ TEMPORADA 1 - EPISODIOS 1 y 2 "Big Time Audition" } \\
\hline TÉRMINO & CONTEXTO & TRADUCCION & TÉCNICA & ESPAÑOL \\
\hline \multirow{3}{*}{ Turd } & Oh, you're such a turd & [canción no traducida] & Omisión & $-{ }_{-}^{-}$ \\
\hline & ...the big turd song & ...la canción del gran cerdo & Variación & Neutro \\
\hline & $\begin{array}{l}\text {... with a giant turd } \\
\text { producer }\end{array}$ & ...con un cerdo productor... & Variación & Neutro \\
\hline
\end{tabular}

\begin{tabular}{|l|c|l|c|c|}
\hline Ejemplo 187 & \multicolumn{3}{l|}{ PROGRAMA: BIG TIME RUSH } \\
\hline PAÍS DE DOBLAJE: VENEZUELA & AÑO 2009 \\
\hline \multicolumn{2}{|l|}{ TEMPORADA 1 - EPISODIOS 1 y 2 “Big Time Audition” } \\
\hline TÉRMINO & \multicolumn{1}{|l|}{ CONTEXTO } & \multicolumn{1}{l|}{ TRADUCCION } & TÉCNICA & ESPAÑOL \\
\hline Jerk & $\begin{array}{l}\text { I don't wanna go to } \\
\text { LA with that jerk }\end{array}$ & $\begin{array}{l}\text { No quiero ir a California con } \\
\text { ese cretino }\end{array}$ & $\begin{array}{l}\text { Traducción } \\
\text { literal }\end{array}$ & Neutro \\
\hline
\end{tabular}




\begin{tabular}{|c|c|c|c|c|}
\hline \multicolumn{2}{|l|}{ Ejemplo 188} & \multicolumn{3}{|c|}{ PROGRAMA: BIG TIME RUSH } \\
\hline \multicolumn{2}{|c|}{ PAÍS DE DOBLAJE: VENEZUELA } & AÑO 2009 & & \\
\hline \multicolumn{5}{|c|}{ TEMPORADA 1 - EPISODIOS 1 y 2 "Big Time Audition" } \\
\hline TÉRMINO & CONTEXTO & TRADUCCION & TÉCNICA & ESPAÑOL \\
\hline \multirow{2}{*}{ Butt } & $\begin{array}{l}\text { The CEO of all of our } \\
\text { butts }\end{array}$ & $\begin{array}{l}\text { El presidente de todos } \\
\text { nuestros traseros }\end{array}$ & $\begin{array}{l}\text { Traducción } \\
\text { literal }\end{array}$ & Neutro \\
\hline & $\begin{array}{l}\text {... and sweat our butts } \\
\text { off... }\end{array}$ & ...y a sudar como cerdos... & $\begin{array}{l}\text { Creación } \\
\text { discursiva }\end{array}$ & Neutro \\
\hline
\end{tabular}

\begin{tabular}{|l|c|l|c|c|}
\hline \multicolumn{2}{|l|}{ Ejemplo 189 } & \multicolumn{1}{l|}{ PROGRAMA: BIG TIME RUSH } \\
\hline \multicolumn{2}{|l|}{ PAÍS DE DOBLAJE: VENEZUELA } & AÑO 2009 \\
\hline TEMPORADA 1 - EPISODIOS 1 y 2 “Big Time Audition” & TÉCNICA & ESPAÑOL \\
\hline TÉRMINO & CONTEXTO & \multicolumn{1}{|l|}{ TRADUCCION } & Neutro \\
\hline Booty & $\begin{array}{l}\text { 'Cause this is the part } \\
\text { where I shake the } \\
\text { booty }\end{array}$ & $\begin{array}{l}\text { Esta es la parte donde meneo } \\
\text { el trasero }\end{array}$ & $\begin{array}{l}\text { Traducción } \\
\text { literal }\end{array}$ \\
\hline
\end{tabular}

\begin{tabular}{|c|c|c|c|c|}
\hline \multicolumn{2}{|l|}{ Ejemplo 190} & \multicolumn{3}{|c|}{ PROGRAMA: BIG TIME RUSH } \\
\hline \multicolumn{2}{|c|}{ PAÍS DE DOBLAJE: VENEZUELA } & AÑO 2009 & & \\
\hline \multicolumn{5}{|c|}{ TEMPORADA 1 - EPISODIOS 1 y 2 "Big Time Audition" } \\
\hline TÉRMINO & CONTEXTO & TRADUCCION & TÉCNICA & ESPAÑOL \\
\hline \multirow{4}{*}{ Idiot } & Idiot! & ¡Tonto! & Variación & Neutro \\
\hline & You're an idiot & Eres un idiota & $\begin{array}{l}\text { Traducción } \\
\text { literal }\end{array}$ & Regional \\
\hline & What an idiot! & ¡Idiota! & $\begin{array}{l}\text { Traducción } \\
\text { literal }\end{array}$ & Regional \\
\hline & Project Idiot? & ¿Proyecto Idiota? & $\begin{array}{l}\text { Traducción } \\
\text { literal }\end{array}$ & Regional \\
\hline
\end{tabular}

\begin{tabular}{|c|c|c|c|c|}
\hline \multicolumn{2}{|l|}{ Ejemplo 191} & \multicolumn{3}{|c|}{ PROGRAMA: BIG TIME RUSH } \\
\hline \multicolumn{2}{|c|}{ PAÍS DE DOBLAJE: VENEZUELA } & \multicolumn{3}{|c|}{ AÑO 2009} \\
\hline \multicolumn{5}{|c|}{ TEMPORADA 1 - EPISODIOS 1 y 2 "Big Time Audition" } \\
\hline TÉRMINO & CONTEXTO & TRADUCCION & TÉCNICA & ESPAÑOL \\
\hline Stupid & $\begin{array}{l}\text {... and that stupid } \\
\text { helmet }\end{array}$ & ...y ese tonto casco & Variación & Neutro \\
\hline
\end{tabular}

\begin{tabular}{|l|c|l|l|l|}
\hline Ejemplo 192 & \multicolumn{1}{l|}{ PROGRAMA: BIG TIME RUSH } \\
\hline \multicolumn{2}{|l|l|l|}{ PAÍS DE DOBLAJE: VENEZUELA } & AÑO 2009 \\
\hline TEMPORADA 1 - EPISODIOS 1 y 2 “Big Time Audition” & TÉCNICA & ESPAÑOL \\
\hline TÉRMINO & CONTEXTO & TRADUCCION & $\begin{array}{l}\text { Traducción } \\
\text { literal }\end{array}$ & Neutro \\
\hline Dork & $\ldots$ has Gustavo Dork... & $\ldots$..el torpe Gustavo... &
\end{tabular}




\begin{tabular}{|c|c|c|c|c|}
\hline \multicolumn{2}{|c|}{ Ejemplo 193} & \multicolumn{3}{|c|}{ PROGRAMA: BIG TIME RUSH } \\
\hline \multicolumn{2}{|c|}{ PAÍS DE DOBLAJE: VENEZUELA } & AÑO 2011 & & \\
\hline \multicolumn{5}{|c|}{ TEMPORADA 2 - EPISODIO 25 "Big Time Contest" } \\
\hline TÉRMINO & CONTEXTO & TRADUCCION & TÉCNICA & ESPAÑOL \\
\hline Smoothie & $\begin{array}{l}\text {... some nice } \\
\text { smoothies... }\end{array}$ & ...unas malteadas... & $\begin{array}{l}\text { Creación } \\
\text { discursiva }\end{array}$ & Regional \\
\hline
\end{tabular}

\begin{tabular}{|l|l|l|c|c|}
\hline Ejemplo 194 & \multicolumn{1}{l|}{ PROGRAMA: BIG TIME RUSH } \\
\hline PAÍS DE DOBLAJE: VENEZUELA & AÑO 2011 \\
\hline TEMPORADA 2 - EPISODIO 25 "Big Time Contest” & TÉCNICA & ESPAÑOL \\
\hline TÉRMINO & CONTEXTO & TRADUCCION & Generalización & Neutro \\
\hline $\begin{array}{l}\text { Meatball } \\
\text { sub }\end{array}$ & Meatball sub! & iSándwich de albóndiga! &
\end{tabular}

\begin{tabular}{|c|c|c|c|c|}
\hline \multicolumn{2}{|l|}{ Ejemplo 195} & \multicolumn{3}{|c|}{ PROGRAMA: BIG TIME RUSH } \\
\hline \multicolumn{2}{|c|}{ PAIIS DE DOBLAJE: VENEZUELA } & AÑO 2011 & & \\
\hline \multicolumn{5}{|c|}{ TEMPORADA 2 - EPISODIO 25 "Big Time Contest" } \\
\hline TÉRMINO & CONTEXTO & TRADUCCION & TÉCNICA & ESPAÑOL \\
\hline Football & $\begin{array}{l}\text {... where BTR plays } \\
\text { football... }\end{array}$ & ...donde jugamos fútbol... & Préstamo & $\begin{array}{l}\text { Regional } \\
\text { (variación } \\
\text { dialectal } \\
\text { /futból/) }\end{array}$ \\
\hline
\end{tabular}

\begin{tabular}{|c|c|c|c|c|}
\hline \multicolumn{2}{|l|}{ Ejemplo 196} & \multicolumn{3}{|c|}{ PROGRAMA: BIG TIME RUSH } \\
\hline \multicolumn{2}{|c|}{ PAÍS DE DOBLAJE: VENEZUELA } & \multicolumn{3}{|l|}{ AÑO 2011} \\
\hline \multicolumn{5}{|c|}{ TEMPORADA 2 - EPISODIO 25 "Big Time Contest" } \\
\hline TÉRMINO & CONTEXTO & TRADUCCION & TÉCNICA & ESPAÑOL \\
\hline Cool & \multirow{2}{*}{..for really cool girls } & \multirow{2}{*}{...para chicas lindas } & \begin{tabular}{|l} 
Creación \\
discursiva \\
\end{tabular} & Neutro \\
\hline Girl & & & $\begin{array}{l}\text { Traducción } \\
\text { literal }\end{array}$ & Regional \\
\hline
\end{tabular}

\begin{tabular}{|c|c|c|c|c|}
\hline \multicolumn{2}{|l|}{ Ejemplo 197} & \multicolumn{3}{|c|}{ PROGRAMA: BIG TIME RUSH } \\
\hline \multicolumn{2}{|c|}{ PAÍS DE DOBLAJE: VENEZUELA } & \multicolumn{3}{|c|}{ AÑO 2011} \\
\hline \multicolumn{5}{|c|}{ TEMPORADA 2 - EPISODIO 25 “Big Time Contest” } \\
\hline TÉRMINO & CONTEXTO & \begin{tabular}{|l} 
TRADUCCION \\
\end{tabular} & TÉCNICA & ESPAÑNL \\
\hline \multirow{2}{*}{ Rush } & \multirow{2}{*}{ Big Time Rush } & \multirow{2}{*}{ Big Time Rush } & -- & $\begin{array}{l}\text { Regional } \\
\text { (pronunciación } \\
\text { /o/) }\end{array}$ \\
\hline & & & -- & $\begin{array}{l}\text { Neutro } \\
\text { (Pronunciación } \\
\text { /a/) }\end{array}$ \\
\hline
\end{tabular}




\begin{tabular}{|l|c|l|l|l|}
\hline Ejemplo 198 & \multicolumn{4}{l|}{ PROGRAMA: PROJECT MC2 } \\
\hline PAÍS DE DOBLAJE: MÉXICO & AÑO 2015 \\
\hline \multicolumn{1}{|l|}{ TEMPORADA 1 - EPISODIO 1 “New Girl in Town” } \\
\hline TÉRMINO & CONTEXTO & TRADUCCION & TÉCNICA & ESPAÑOL \\
\hline Pen & $\ldots$ make a camera pen & ...hacer una cámara pluma & $\begin{array}{l}\text { Traducción } \\
\text { literal }\end{array}$ & Neutro \\
\hline
\end{tabular}

\begin{tabular}{|l|l|l|l|l|}
\hline Ejemplo 199 & \multicolumn{4}{l|}{ PROGRAMA: PROJECT MC2 } \\
\hline PAÍS DE DOBLAJE: MÉXICO & AÑO 2015 \\
\hline \multicolumn{2}{|l|}{ TEMPORADA 1 - EPISODIO 1 “New Girl in Town” } \\
\hline TÉRMINO & \multicolumn{1}{|l|}{ CONTEXTO } & \multicolumn{1}{l|}{ TRADUCCION } & TÉCNICA & ESPAÑOL \\
\hline Slash & $\begin{array}{l}\text {.. forward slash, let's } \\
\text { dash }\end{array}$ & Corre-diagonal-ahora & $\begin{array}{l}\text { Traducción } \\
\text { literal }\end{array}$ & Neutro \\
\hline
\end{tabular}

\begin{tabular}{|l|c|l|l|l|}
\hline Ejemplo 200 & \multicolumn{1}{l|}{ PROGRAMA: PROJECT MC2 } \\
\hline PAÍS DE DOBLAJE: MÉXICO & AÑO 2015 \\
\hline TEMPORADA 1 - EPISODIO 1 “New Girl in Town” & \multicolumn{1}{l|}{ TRADUCCION } & TÉCNICA & ESPAÑOL \\
\hline TÉRMINO & CONTEXTO & $\begin{array}{l}\text { Traducción } \\
\text { literal }\end{array}$ & Neutro \\
\hline Notebook & $\ldots$. your notebook... & $\ldots$..tu libreta... &
\end{tabular}

\begin{tabular}{|c|c|c|c|c|}
\hline \multicolumn{2}{|l|}{ Ejemplo 201} & \multicolumn{3}{|c|}{ PROGRAMA: PROJECT MC2 } \\
\hline \multicolumn{2}{|c|}{ PAÍS DE DOBLAJE: MÉXICO } & AÑO 2015 & & \\
\hline \multicolumn{5}{|c|}{ TEMPORADA 1 - EPISODIO 1 "New Girl in Town" } \\
\hline TÉRMINO & CONTEXTO & TRADUCCION & TÉCNICA & ESPAÑOL \\
\hline Aliens & ... and fight aliens... & ...y pelear con aliens... & Préstamo & $\begin{array}{l}\text { Neutro } \\
\text { (pronunciación } \\
\text { neutra /áliens/) }\end{array}$ \\
\hline
\end{tabular}

\begin{tabular}{|c|c|c|c|c|}
\hline \multicolumn{2}{|l|}{ Ejemplo 202} & \multicolumn{3}{|c|}{ PROGRAMA: PROJECT MC2 } \\
\hline \multicolumn{2}{|c|}{ PAÍS DE DOBLAJE: MÉXICO } & AÑO 2015 & & \\
\hline \multicolumn{5}{|c|}{ TEMPORADA 1 - EPISODIO 1 "New Girl in Town" } \\
\hline TÉRMINO & CONTEXTO & TRADUCCION & TÉCNICA & ESPAÑOL \\
\hline Trusies & Trusies & Es cierto & Variación & Neutro \\
\hline
\end{tabular}




\begin{tabular}{|l|l|l|c|c|}
\hline Ejemplo 203 & \multicolumn{1}{l|}{ PROGRAMA: PROJECT MC2 } \\
\hline PAÍS DE DOBLAJE: MÉXICO & AÑO 2015 \\
\hline \multicolumn{1}{|l|}{ TEMPORADA 1 - EPISODIO 1 “New Girl in Town” } \\
\hline TÉRMINO & CONTEXTO & TRADUCCION & TÉCNICA & ESPAÑOL \\
\hline Totes adorbs & $\begin{array}{l}\text { Which makes him } \\
\text { totes adorbs }\end{array}$ & Que lo hace más adorable & Variación & Neutro \\
\hline
\end{tabular}

\begin{tabular}{|l|l|l|l|l|}
\hline Ejemplo 204 & \multicolumn{1}{l|}{ PROGRAMA: PROJECT MC2 } \\
\hline PAÍS DE DOBLAJE: MÉXICO & AÑO 2015 \\
\hline TEMPORADA 1 - EPISODIO 1 “New Girl in Town” & TÉCNICA & ESPAÑOL \\
\hline TÉRMINO & CONTEXTO & TRADUCCION & $\begin{array}{l}\text { Traducción } \\
\text { literal }\end{array}$ & Neutro \\
\hline Firewall & The firewall is... & La protección es... &
\end{tabular}

\begin{tabular}{|l|c|l|c|c|}
\hline Ejemplo 205 & \multicolumn{1}{l|}{ PROGRAMA: PROJECT MC2 } \\
\hline PAÍS DE DOBLAJE: MÉXICO & \multicolumn{1}{l|}{ AÑO 2015 } \\
\hline \multicolumn{1}{|l|}{ TEMPORADA 1 - EPISODIO 1 “New Girl in Town” } \\
\hline TÉRMINO & \multicolumn{1}{|c|}{ CONTEXTO } & \multicolumn{1}{|l|}{ TRADUCCION } & TÉCNICA & ESPAÑOL \\
\hline Hacker & $\begin{array}{l}\text {... we can find that } \\
\text { sketchy hacker... }\end{array}$ & $\begin{array}{l}\text {...encontraremos a ese } \\
\text { hacker... }\end{array}$ & Préstamo & Neutro \\
\hline
\end{tabular}

\begin{tabular}{|l|c|l|c|c|}
\hline Ejemplo 206 & \multicolumn{1}{l|}{ PROGRAMA: PROJECT MC2 } \\
\hline PAÍS DE DOBLAJE: MÉXICO & AÑO 2015 \\
\hline TEMPORADA 1 - EPISODIO 1 “New Girl in Town” & \multicolumn{1}{|l|}{ TRADUCCION } & TÉCNICA & ESPAÑOL \\
\hline TÉRMINO & \multicolumn{1}{|l}{ CONTEXTO } & $\begin{array}{l}\text { Traducción } \\
\text { literal }\end{array}$ & Regional \\
\hline Girl & $\begin{array}{l}\text { I have to find the girls' } \\
\text { locker room }\end{array}$ & $\begin{array}{l}\text { Debo encontrar el vestidor de } \\
\text { chicas }\end{array}$ \\
\hline
\end{tabular}

\begin{tabular}{|l|l|l|l|l|}
\hline Ejemplo 207 & \multicolumn{1}{l|}{ PROGRAMA: PROJECT MC2 } \\
\hline PAÍS DE DOBLAJE: MÉXICO & AÑO 2015 \\
\hline TEMPORADA 1 - EPISODIO 1 “New Girl in Town” & \multicolumn{1}{|l|}{ TRADUCCION } & TÉCNICA & ESPAÑOL \\
\hline TÉRMINO & \multicolumn{1}{|l}{ CONTEXTO } & $\begin{array}{l}\text { Traducción } \\
\text { literal }\end{array}$ & Neutro \\
\hline Kill & $\begin{array}{l}\text { I don't want curiosity } \\
\text { to kill the Cam }\end{array}$ & $\begin{array}{l}\text { No quiero que la curiosidad } \\
\text { mate a Cam }\end{array}$ &
\end{tabular}

\begin{tabular}{|l|l|l|c|c|}
\hline Ejemplo 208 & \multicolumn{1}{l|}{ PROGRAMA: PROJECT MC2 } \\
\hline PAÍS DE DOBLAJE: MÉXICO & AÑO 2015 \\
\hline TEMPORADA 1 - EPISODIO 1 “New Girl in Town” & TÉCNICA & ESPAÑOL \\
\hline TÉRMINO & CONTEXTO & TRADUCCION & -- \\
\hline Adri & Adri & /ádri/ /éidri/ & -- & -- \\
\hline
\end{tabular}




\begin{tabular}{|l|l|l|c|l|}
\hline Ejemplo 209 & \multicolumn{1}{l|}{ PROGRAMA: PROJECT MC2 } \\
\hline PAÍS DE DOBLAJE: MÉXICO & AÑO 2015 & \multicolumn{1}{l|}{} \\
\hline TEMPORADA 1 - EPISODIO 1 “New Girl in Town” & \multicolumn{1}{l|}{ TRADUCCION } & TÉCNICA & ESPAÑOL \\
\hline TÉRMINO & CONTEXTO & Préstamo & Neutro \\
\hline Churro & $\begin{array}{l}\text { And it’s great for } \\
\text { churros! }\end{array}$ & $\begin{array}{l}\text { ¡Y sirve para hacer } \\
\text { churros! }\end{array}$ & & \\
\hline
\end{tabular}

\begin{tabular}{|l|l|l|l|l|}
\hline Ejemplo 210 & \multicolumn{1}{l|}{ PROGRAMA: PROJECT MC2 } \\
\hline PAÍ́S DE DOBLAJE: MÉXICO & AÑO 2015 \\
\hline TEMPORADA 1 - EPISODIO 1 “New Girl in Town” & TÉCNICA & ESPAÑOL \\
\hline TÉRMINO & CONTEXTO & TRADUCCION & $\begin{array}{l}\text { Creación } \\
\text { discursiva }\end{array}$ & Neutro \\
\hline OMG & OMG! & ¿Qué bueno! &
\end{tabular}

\begin{tabular}{|l|c|l|l|l|}
\hline Ejemplo 211 & \multicolumn{1}{l|}{ PROGRAMA: PROJECT MC2 } \\
\hline PAÍS DE DOBLAJE: MÉXICO & AÑO 2015 \\
\hline TEMPORADA 1 - EPISODIO 1 "New Girl in Town” & TÉCNICA & ESPAÑOL \\
\hline TÉRMINO & CONTEXTO & TRADUCCION & $\begin{array}{l}\text { Traducción } \\
\text { literal }\end{array}$ & Neutro \\
\hline Cool & Cool listening device & ¿Qué buen dispositivo! &
\end{tabular}

\begin{tabular}{|l|l|l|l|l|}
\hline Ejemplo 212 & \multicolumn{1}{l|}{ PROGRAMA: PROJECT MC2 } \\
\hline PAÍ́S DE DOBLAJE: MÉXICO & AÑO 2015 & \multicolumn{1}{l|}{} \\
\hline TEMPORADA 1 - EPISODIO 1 "New Girl in Town” & TRADUCCION & TÉCNICA & ESPANOL \\
\hline TÉRMINO & CONTEXTO & $\begin{array}{l}\text { Traducción } \\
\text { literal }\end{array}$ & Neutro \\
\hline Trending & I'm trending & Soy tendencia &
\end{tabular}

\begin{tabular}{|c|c|c|c|c|}
\hline \multicolumn{2}{|l|}{ Ejemplo 213} & \multicolumn{3}{|c|}{ PROGRAMA: PROJECT MC2 } \\
\hline \multicolumn{2}{|c|}{ PAÍS DE DOBLAJE: MÉXICO } & \multicolumn{3}{|c|}{ AÑO 2016} \\
\hline \multicolumn{5}{|c|}{ TEMPORADA 2 - EPISODIO 1 "Back to Basics" } \\
\hline TÉRMINO & CONTEXTO & TRADUCCION & TÉCNICA & ESPAÑOL \\
\hline Rope & $\begin{array}{l}\text { Focus the light on the } \\
\text { rope }\end{array}$ & Enfoca la luz sobre la cuerda & $\begin{array}{l}\text { Traducción } \\
\text { literal }\end{array}$ & Neutro \\
\hline
\end{tabular}

\footnotetext{
${ }^{170}$ Se consideró en este caso que era posible que se sustituyera la palabra "churros", a pesar de ser española, por otra más general, y por eso se la incluyó en este listado.
} 


\begin{tabular}{|l|l|l|c|c|}
\hline Ejemplo 214 & \multicolumn{1}{l|}{ PROGRAMA: PROJECT MC2 } \\
\hline PAÍS DE DOBLAJE: MÉXICO & AÑO 2016 \\
\hline \multicolumn{1}{|l|}{ TEMPORADA 2 - EPISODIO 1 “Back to Basics” } \\
\hline TÉRMINO & \multicolumn{1}{|l|}{ CONTEXTO } & TRADUCCION & TÉCNICA & ESPAÑOL \\
\hline Trending & $\begin{array}{l}\text { We're so trending } \\
\text { now! }\end{array}$ & iSomos tan trending ahora! & Préstamo & Regional \\
\hline
\end{tabular}

\begin{tabular}{|c|c|c|c|c|}
\hline \multicolumn{2}{|l|}{ Ejemplo 215} & \multicolumn{3}{|c|}{ PROGRAMA: PROJECT MC2 } \\
\hline \multicolumn{2}{|c|}{ PAIIS DE DOBLAJE: MÉXICO } & \multicolumn{3}{|c|}{ AÑO 2016} \\
\hline \multicolumn{5}{|c|}{ TEMPORADA 2 - EPISODIO 1 "Back to Basics" } \\
\hline TÉRMINO & CONTEXTO & TRADUCCION & TÉCNICA & ESPAÑOL \\
\hline \multirow{2}{*}{$\mathrm{BFF}$} & ...my BFF McKeyla & ...mi MAPS McKeyla & \multirow{2}{*}{ Calco } & \multirow{2}{*}{ Regional } \\
\hline & BFF? & ¿MAPS? & & \\
\hline
\end{tabular}

\begin{tabular}{|c|c|c|c|c|}
\hline \multicolumn{2}{|l|}{ Ejemplo 216} & \multicolumn{3}{|c|}{ PROGRAMA: PROJECT MC2 } \\
\hline \multicolumn{2}{|c|}{ PAÍS DE DOBLAJE: MÉXICO } & \multicolumn{3}{|c|}{ AÑO 2016} \\
\hline \multicolumn{5}{|c|}{ TEMPORADA 2 - EPISODIO 1 "Back to Basics" } \\
\hline TÉRMINO & CONTEXTO & TRADUCCION & TÉCNICA & ESPAÑOL \\
\hline Hashtag & Hashtag & Hashtag & Préstamo & Neutro \\
\hline
\end{tabular}

\begin{tabular}{|c|c|c|c|c|}
\hline \multicolumn{2}{|l|}{ Ejemplo 217} & \multicolumn{3}{|c|}{ PROGRAMA: PROJECT MC2 } \\
\hline \multicolumn{2}{|c|}{ PAÍS DE DOBLAJE: MÉXICO } & \multicolumn{3}{|c|}{ AÑO 2016} \\
\hline \multicolumn{5}{|c|}{ TEMPORADA 2 - EPISODIO 1 "Back to Basics" } \\
\hline TÉRMINO & CONTEXTO & TRADUCCION & TÉCNICA & ESPAÑOL \\
\hline Girls & $\begin{array}{l}\text {...four Maywood Glen } \\
\text { Academy girls... }\end{array}$ & $\begin{array}{l}\text {...cuatro chicas de la } \\
\text { Academia Maywood Glen }\end{array}$ & $\begin{array}{l}\text { Traducción } \\
\text { literal }\end{array}$ & Regional \\
\hline
\end{tabular}

\begin{tabular}{|l|c|l|l|l|}
\hline Ejemplo 218 & \multicolumn{1}{l|}{ PROGRAMA: PROJECT MC2 } \\
\hline PAÍS DE DOBLAJE: MÉXICO & AÑO 2016 & \\
\hline TEMPORADA 2 - EPISODIO 1 “Back to Basics” & TÉCNICA & ESPAÑOL \\
\hline TÉRMINO & CONTEXTO & TRADUCCION & $\begin{array}{l}\text { Traducción } \\
\text { literal (uso } \\
\text { despectivo }\end{array}$ & Neutro \\
\hline Girl & Hey, girls! & ¡Oigan, niñas! & \\
\hline
\end{tabular}




\begin{tabular}{|l|l|l|l|l|}
\hline Ejemplo 219 & \multicolumn{1}{l|}{ PROGRAMA: PROJECT MC2 } \\
\hline PAÍS DE DOBLAJE: MÉXICO & AÑO 2016 \\
\hline TEMPORADA 2 - EPISODIO 1 “Back to Basics” & TÉCNICA & ESPAÑOL \\
\hline TÉRMINO & CONTEXTO & TRADUCCION & $\begin{array}{l}\text { Traducción } \\
\text { literal }\end{array}$ & Neutro \\
\hline Kids & Just four kids... & Solo son cuatro niñas... &
\end{tabular}

\begin{tabular}{|l|l|l|l|l|}
\hline Ejemplo 220 & \multicolumn{1}{l|}{ PROGRAMA: PROJECT MC2 } \\
\hline PAÍS DE DOBLAJE: MÉXICO & AÑO 2016 \\
\hline TEMPORADA 2 - EPISODIO 1 “Back to Basics” & \multicolumn{1}{l|}{ TRADUCCION } & TÉCNICA & ESPAÑOL \\
\hline TÉRMINO & \multicolumn{1}{|l}{ CONTEXTO } & $\begin{array}{l}\text { Traducción } \\
\text { literal }\end{array}$ & Neutro \\
\hline Haters & $\begin{array}{l}\text { I'm responding to } \\
\text { haters }\end{array}$ & Respondo a los odiosos \\
\hline
\end{tabular}

\begin{tabular}{|c|c|c|c|c|}
\hline \multicolumn{2}{|l|}{ Ejemplo 221} & \multicolumn{3}{|c|}{ PROGRAMA: PROJECT MC2 } \\
\hline \multicolumn{2}{|c|}{ PAÍS DE DOBLAJE: MÉXICO } & AÑO 2016 & & \\
\hline \multicolumn{5}{|c|}{ TEMPORADA 2 - EPISODIO 1 "Back to Basics" } \\
\hline TÉRMINO & CONTEXTO & TRADUCCION & TÉCNICA & ESPAÑOL \\
\hline Notebook & $\begin{array}{l}\text {...which includes } \\
\text { talking notebooks }\end{array}$ & $\begin{array}{l}\text {...lo que incluye no hablar } \\
\text { con cuadernos }\end{array}$ & $\begin{array}{l}\text { Traducción } \\
\text { literal }\end{array}$ & Neutro \\
\hline
\end{tabular}

\begin{tabular}{|l|l|l|l|l|}
\hline Ejemplo 222 & \multicolumn{1}{l|}{ PROGRAMA: PROJECT MC2 } \\
\hline PAÍS DE DOBLAJE: MÉXICO & AÑO 2016 \\
\hline TEMPORADA 2 - EPISODIO 1 “Back to Basics” & \multicolumn{1}{l|}{ TRADUCCION } & TÉCNICA & ESPAÑOL \\
\hline TÉRMINO & CONTEXTO & $\begin{array}{l}\text { Traducción } \\
\text { literal }\end{array}$ & Regional \\
\hline Jerk & $\begin{array}{l}\text { That guy is such a } \\
\text { jerk! }\end{array}$ & ¡Ese tipo es un idiota! &
\end{tabular}

\begin{tabular}{|c|c|c|c|c|}
\hline \multicolumn{2}{|l|}{ Ejemplo 223} & \multicolumn{3}{|c|}{ PROGRAMA: PROJECT MC2 } \\
\hline \multicolumn{2}{|c|}{ PAÍS DE DOBLAJE: MÉXICO } & \multicolumn{3}{|l|}{ AÑO 2016} \\
\hline \multicolumn{5}{|c|}{ TEMPORADA 2 - EPISODIO 1 "Back to Basics" } \\
\hline TÉRMINO & CONTEXTO & TRADUCCION & TÉCNICA & ESPAÑOL \\
\hline Ball & \multirow[t]{2}{*}{$\begin{array}{l}\text { Can you try and kick } \\
\text { the ball back? }\end{array}$} & \multirow[t]{2}{*}{$\begin{array}{l}\text { ¿Podrían patear la pelota para } \\
\text { acá? }\end{array}$} & $\begin{array}{l}\text { Traducción } \\
\text { literal }\end{array}$ & Neutro \\
\hline Back & & & $\begin{array}{l}\text { Traducción } \\
\text { literal }\end{array}$ & Regional \\
\hline
\end{tabular}




\begin{tabular}{|l|l|l|c|c|}
\hline Ejemplo 224 & \multicolumn{1}{l|}{ PROGRAMA: PROJECT MC2 } \\
\hline PAÍS DE DOBLAJE: MÉXICO & AÑO 2016 \\
\hline TEMPORADA 2 - EPISODIO 1 “Back to Basics" & TÉCNICA & ESPAÑOL \\
\hline TÉRMINO & CONTEXTO & \multicolumn{1}{|c|}{ TRADUCCION } & Neutro \\
\hline Football & $\begin{array}{l}\text { They play a lot of } \\
\text { football }\end{array}$ & Ellos juegan mucho fútbol & Préstamo & \\
\hline
\end{tabular}

\begin{tabular}{|l|l|l|c|c|}
\hline Ejemplo 225 & \multicolumn{4}{l|}{ PROGRAMA: PROJECT MC2 } \\
\hline PAÍS DE DOBLAJE: MÉXICO & AÑO 2016 & \\
\hline TEMPORADA 2 - EPISODIO 1 “Back to Basics” & TÉCNICA & ESPAÑOL \\
\hline TÉRMINO & CONTEXTO & TRADUCCION & Préstamo & Regional \\
\hline Bye & Bye! & ¡Bye! &
\end{tabular}

\begin{tabular}{|l|l|l|l|l|}
\hline Ejemplo 226 & \multicolumn{1}{l|}{ PROGRAMA: PROJECT MC2 } \\
\hline PAÍ́S DE DOBLAJE: MÉXICO & AÑO 2016 \\
\hline TEMPORADA 2 - EPISODIO 1 “Back to Basics” & TRÉCNICA & ESPAÑOL \\
\hline TÉRMINO & CONTEXTO & TRADUCION & TÉcioción & Regional \\
\hline Socks & Burn my socks & Quema mis medias & $\begin{array}{l}\text { Traderal } \\
\text { lital }\end{array}$
\end{tabular}

\begin{tabular}{|c|c|c|c|c|}
\hline \multicolumn{2}{|l|}{ Ejemplo 227} & \multicolumn{3}{|c|}{ PROGRAMA: PROJECT MC2 } \\
\hline \multicolumn{2}{|c|}{ PAÍS DE DOBLAJE: MÉXICO } & \multicolumn{3}{|l|}{ AÑO 2016} \\
\hline \multicolumn{5}{|c|}{ TEMPORADA 2 - EPISODIO 1 "Back to Basics" } \\
\hline TÉRMINO & CONTEXTO & TRADUCCION & TÉCNICA & ESPAÑOL \\
\hline Muffin & \multirow[t]{2}{*}{$\begin{array}{l}\text {...multi-berry } \\
\text { muffin... }\end{array}$} & \multirow[t]{2}{*}{...muffin de multi-frutos... } & Préstamo & $\begin{array}{l}\text { Regional } \\
\text { (pronunciación } \\
\text { /mófin/) }\end{array}$ \\
\hline Berry & & & Generalización & Neutro \\
\hline
\end{tabular}

\begin{tabular}{|l|l|l|l|l|}
\hline Ejemplo 228 & \multicolumn{1}{l|}{ PROGRAMA: PROJECT MC2 } \\
\hline PAÍS DE DOBLAJE: MÉXICO & \multicolumn{1}{l|}{ AÑO 2016 } \\
\hline TEMPORADA 2 - EPISODIO 1 “Back to Basics” & \multicolumn{1}{|l|}{ TRADUCCION } & TÉCNICA & ESPAÑOL \\
\hline TÉRMINO & CONTEXTO & $\begin{array}{l}\text { Traducción } \\
\text { literal }\end{array}$ & Regional \\
\hline Ring (bell) & $\begin{array}{l}\text { That ring takes me } \\
\text { back... }\end{array}$ & $\begin{array}{l}\text { Ese timbre me lleva de } \\
\text { regreso... }\end{array}$ &
\end{tabular}

\begin{tabular}{|l|c|l|c|}
\hline Ejemplo 229 & \multicolumn{1}{l|}{ PROGRAMA: PROJECT MC2 } \\
\hline PAÍS DE DOBLAJE: MÉXICO & AÑO 2016 \\
\hline TEMPORADA 2 - EPISODIO 1 “Back to Basics” & TÉCNICA & ESPAÑOL \\
\hline TÉRMINO & CONTEXTO & TRADUCCION & TÉRA
\end{tabular}




\begin{tabular}{|l|l|}
\hline Ejemplo 230 & PROGRAMA: LOST AND FOUND MUSIC STUDIOS \\
\hline PAÍS DE DOBLAJE: ARGENTINA & AÑO 2016 \\
\hline
\end{tabular}

TEMPORADA 1 - EPISODIO 1 "Lost and Found"

\begin{tabular}{|l|l|l|l|l|}
\hline TÉRMINO & \multicolumn{1}{|c|}{ CONTEXTO } & \multicolumn{1}{|c|}{ TRADUCCION } & TÉCNICA & ESPAÑOL \\
\hline Lipstick & $\begin{array}{l}\text { I can’t even wear } \\
\text { lipstick }\end{array}$ & $\begin{array}{l}\text { Ni siquiera puedo usar lápiz } \\
\text { de labio }\end{array}$ & $\begin{array}{l}\text { Traducción } \\
\text { literal }\end{array}$ & Regional \\
\hline
\end{tabular}

\begin{tabular}{|l|c|l|c|c|}
\hline Ejemplo 231 & \multicolumn{1}{l|}{ PROGRAMA: LOST AND FOUND MUSIC STUDIOS } \\
\hline PAÍS DE DOBLAJE: ARGENTINA & AÑO 2016 \\
\hline TEMPORADA 1 - EPISODIO 1 “Lost and Found” & \multicolumn{1}{|l|}{ TRADUCCION } & TÉCNICA & ESPAÑOL \\
\hline TÉRMINO & CONTEXTO & $\begin{array}{l}\text { Traducción } \\
\text { Aardvark }\end{array}$ & $\begin{array}{l}\text { My cousin just rescued } \\
\text { an ardvaark }\end{array}$ & $\begin{array}{l}\text { Mi primo acaba de rescatar } \\
\text { un cerdo hormiguero }\end{array}$ \\
\hline
\end{tabular}

\begin{tabular}{|l|c|l|l|l|}
\hline Ejemplo 232 & \multicolumn{4}{l|}{ PROGRAMA: LOST AND FOUND MUSIC STUDIOS } \\
\hline PAÍS DE DOBLAJE: ARGENTINA & AÑO 2016 \\
\hline TEMPORADA 1 - EPISODIO 1 “Lost and Found” \\
\hline TÉRMINO & CONTEXTO & TRADUCCION & TÉCNICA & ESPAÑOL \\
\hline Drive & ...to drive this thing & ...para conducir esta cosa & $\begin{array}{l}\text { Traducción } \\
\text { literal }\end{array}$ & Neutro \\
\hline
\end{tabular}

\begin{tabular}{|c|c|c|c|c|}
\hline \multicolumn{2}{|l|}{ Ejemplo 233} & \multicolumn{3}{|c|}{ PROGRAMA: LOST AND FOUND MUSIC STUDIOS } \\
\hline \multicolumn{2}{|c|}{ PAÍS DE DOBLAJE: ARGENTINA } & AÑO 2016 & & \\
\hline \multicolumn{5}{|c|}{ TEMPORADA 1 - EPISODIO 1 "Lost and Found" } \\
\hline TÉRMINO & CONTEXTO & TRADUCCION & TÉCNICA & ESPAÑOL \\
\hline Cool & Cool! & ¡Genial! & $\begin{array}{l}\text { Traducción } \\
\text { literal }\end{array}$ & Neutro \\
\hline
\end{tabular}

\begin{tabular}{|c|c|c|c|c|}
\hline \multicolumn{2}{|l|}{ Ejemplo 234} & \multicolumn{3}{|c|}{ PROGRAMA: LOST AND FOUND MUSIC STUDIOS } \\
\hline \multicolumn{2}{|c|}{ PAÍS DE DOBLAJE: ARGENTINA } & AÑO 2016 & & \\
\hline \multicolumn{5}{|c|}{ TEMPORADA 1 - EPISODIO 1 "Lost and Found" } \\
\hline TÉRMINO & CONTEXTO & TRADUCCION & TÉCNICA & ESPAÑOL \\
\hline God & ... a sign from God & ...una señal de Dios & $\begin{array}{l}\text { Traducción } \\
\text { literal }\end{array}$ & Neutro \\
\hline
\end{tabular}




\begin{tabular}{|l|l|l|l|l|}
\hline Ejemplo 235 & \multicolumn{4}{l|}{ PROGRAMA: LOST AND FOUND MUSIC STUDIOS } \\
\hline PAÍS DE DOBLAJE: ARGENTINA & AÑO 2016 \\
\hline \multicolumn{1}{|l|}{ TEMPORADA 1 - EPISODIO 1 “Lost and Found” } \\
\hline TÉRMINO & \multicolumn{1}{|l}{ CONTEXTO } & TRADUCCION & TÉCNICA & ESPAÑOL \\
\hline Snacks & $\begin{array}{l}\text { I brought you guys } \\
\text { some snacks }\end{array}$ & Les traje unos bocadillos & $\begin{array}{l}\text { Traducción } \\
\text { literal }\end{array}$ & Neutro \\
\hline
\end{tabular}

\begin{tabular}{|l|c|l|c|}
\hline Ejemplo 236 & \multicolumn{4}{l|}{ PROGRAMA: LOST AND FOUND MUSIC STUDIOS } \\
\hline PAÍS DE DOBLAJE: ARGENTINA & AÑO 2016 & TÉCNICA & ESPAÑOL \\
\hline TEMPORADA 1 - EPISODIO 2 "See Through Me” & TRADUCCION & RÉ \\
\hline TÉRMINO & CONTEXTO & Préstamo & Regional \\
\hline Bromance & Like a bromance thing & Como un bromance &
\end{tabular}

\begin{tabular}{|c|c|c|c|c|}
\hline \multicolumn{2}{|l|}{ Ejemplo 237} & \multicolumn{3}{|c|}{ PROGRAMA: LOST AND FOUND MUSIC STUDIOS } \\
\hline \multicolumn{2}{|c|}{ PAÍS DE DOBLAJE: ARGENTINA } & AÑO 2016 & & \\
\hline \multicolumn{5}{|c|}{ TEMPORADA 1 - EPISODIO 2 "See Through Me" } \\
\hline TÉRMINO & CONTEXTO & TRADUCCION & TÉCNICA & ESPAÑOL \\
\hline \multirow{2}{*}{ Cool } & Okay, cool & Okay, genial & \multirow{2}{*}{$\begin{array}{l}\text { Traducción } \\
\text { literal }\end{array}$} & \multirow{2}{*}{ Neutro } \\
\hline & It's such a cool idea... & Es una idea genial & & \\
\hline
\end{tabular}

\begin{tabular}{|c|c|c|c|c|}
\hline \multicolumn{2}{|l|}{ Ejemplo 238} & \multicolumn{3}{|c|}{ PROGRAMA: LOST AND FOUND MUSIC STUDIOS } \\
\hline \multicolumn{2}{|c|}{ PAÍS DE DOBLAJE: ARGENTINA } & AÑO 2016 & & \\
\hline \multicolumn{5}{|c|}{ TEMPORADA 1 - EPISODIO 2 "See Through Me” } \\
\hline TÉRMINO & CONTEXTO & TRADUCCION & TÉCNICA & ESPAÑOL \\
\hline Muffin & $\begin{array}{l}\text { Could you get me a } \\
\text { muffin too? }\end{array}$ & $\begin{array}{l}\text { ¿Me traerías un pastelillo } \\
\text { también? }\end{array}$ & Generalización & Neutro \\
\hline
\end{tabular}

\begin{tabular}{|l|l|l|c|c|}
\hline Ejemplo 239 & \multicolumn{1}{l|}{ PROGRAMA: LOST AND FOUND MUSIC STUDIOS } \\
\hline PAÍS DE DOBLAJE: ARGENTINA & AÑO 2016 \\
\hline TEMPORADA 1 - EPISODIO 2 “See Through Me” & \multicolumn{1}{l|}{ TRADUCCION } & TÉCNICA & ESPAÑOL \\
\hline TÉRMINO & \multicolumn{1}{|c|}{ CONTEXTO } & $\begin{array}{l}\text { Traducción } \\
\text { literal }\end{array}$ & Regional \\
\hline $\begin{array}{l}\text { Fries } \\
\text { (potatoes) }\end{array}$ & $\begin{array}{l}\text { We're going to the } \\
\text { fries }\end{array}$ & Vamos a las patatas &
\end{tabular}




\begin{tabular}{|l|l|}
\hline Ejemplo 240 & \multicolumn{1}{|l|}{ PROGRAMA: VIOLETTA } \\
\hline CANAL: DISNEY CHANNEL & AÑO 2012 \\
\hline ORIGEN DEL PROGRAMA: Argentina \\
\hline \multicolumn{2}{|c|}{ CARACTERÍSTICAS LÉXICAS } \\
\hline ORIGEN DEL ELENCO: Argentina, España, México, Italia, Brasil, Estados Unidos, etc. \\
\hline ¿Eres repartidor? & VARIEDAD DE ESPAÑOL \\
\hline Nena (vocativo) & Regional \\
\hline Niña (vocativo) & Regional \\
\hline Eso me da coraje & Regional \\
\hline Dame tu valija? & Regional \\
\hline ¿Qué os pasa? & Regional \\
\hline Bajá un cambio & Regional \\
\hline \multicolumn{1}{|c|}{ CARACTERÍSTICAS GRAMATICALES } & Regional \\
\hline Tuteo: "No puedo olvidarme de ti" & VARIEDAD DE ESPAÑOL \\
\hline Voseo: "Vos sabés que somos un referente" & Regional \\
\hline ¡Falsa que sos! (estructura sin "qué" & Regional \\
\hline \multicolumn{1}{|c|}{ CARACTERÍSTICAS FONOLÓGICAS } & Regional \\
\hline $\begin{array}{l}\text { Pronunciación marcada que difiere entre los personajes según el } \\
\text { origen del actor. Por ejemplo, la S puede sonar como /s/ o como /z/ } \\
\text { (actor español). Pronunciación a veces incorrecta por parte de los } \\
\text { actores que no tienen el español como lengua materna. }\end{array}$ & VARIEDAD DE ESPAÑOL \\
\hline
\end{tabular}

\begin{tabular}{|l|l|}
\hline Ejemplo 241 & PROGRAMA: YO SOY FRANKY \\
\hline CANAL: NICKELODEON & AÑO 2015 \\
\hline \multicolumn{2}{|c|}{ ORIGEN DEL PROGRAMA: Colombia } \\
\hline \multicolumn{2}{|c|}{ ORIGEN DEL ELENCO: Venezuela, Cuba, Colombia, etc. } \\
\hline Guapa (vocativo) & VARIEDAD DE ESPAÑOL \\
\hline ¿Traes una cubeta? & Regional \\
\hline Bonita (vocativo) & Neutro \\
\hline Sube al carro & Regional \\
\hline ¿Qué rico está! (como sinónimo de "bonito") & Regional \\
\hline \multicolumn{2}{|c|}{ CARACTERÍSTICAS GRAMATICALES } \\
\hline Uso de tuteo exclusivamente & VARIEDAD DE ESPAÑOL \\
\hline Una vez esté mojado el papel (estructura sin "qué") & Neutro \\
\hline Uso generalizado del pretérito perfecto compuesto & Regional \\
\hline \multicolumn{1}{|c|}{ CARACTERÍSTICAS FONOLÓGICAS } & Regional \\
\hline $\begin{array}{l}\text { Pronunciación marcada que difiere entre los personajes según el } \\
\text { origen del actor. Por ejemplo: la G puede sonar /h/ o /x/. }\end{array}$ & Regional \\
\hline
\end{tabular}




\begin{tabular}{|c|c|c|}
\hline Ejemplo 242 & \multicolumn{2}{|l|}{ PROGRAMA: O11CE } \\
\hline CANAL: DISNEY XD & \multicolumn{2}{|l|}{ AÑO 2017} \\
\hline \multicolumn{3}{|c|}{ ORIGEN DEL PROGRAMA: Argentina } \\
\hline \multicolumn{3}{|c|}{ ORIGEN DEL ELENCO: Argentina, México, Colombia, Brasil, Italia, etc. } \\
\hline \multicolumn{2}{|c|}{ CARACTERÍSTICAS LÉXICAS } & VARIEDAD DE ESPAÑOL \\
\hline \multicolumn{2}{|c|}{ Se dedican a hackear } & Neutro \\
\hline \multicolumn{2}{|l|}{ ¿Tienes tu tablet? } & Neutro \\
\hline \multicolumn{2}{|l|}{ Chicos (vocativo) } & Regional \\
\hline \multicolumn{2}{|l|}{ Quédate en la portería } & Neutro \\
\hline \multicolumn{2}{|l|}{ Vengo a platicar } & Regional \\
\hline \multicolumn{2}{|c|}{ No me molesta quedarme en la banca } & Regional \\
\hline \multicolumn{2}{|l|}{ Voy a estar en el banco } & Regional \\
\hline \multicolumn{2}{|l|}{ Apenitas } & Regional \\
\hline \multicolumn{2}{|c|}{ ¿Me habrá comprado la camiseta? } & Neutro \\
\hline \multicolumn{2}{|l|}{ Ya quiero esa playera } & Regional \\
\hline \multicolumn{2}{|c|}{ Aumentativos terminados en azo/aza: "un partidazo" } & Regional \\
\hline \multicolumn{2}{|c|}{$\begin{array}{l}\text { CARACTERÍSTICAS GRAMATICALES } \\
\end{array}$} & VARIEDAD DE ESPAÑOL \\
\hline \multicolumn{2}{|c|}{$\mathrm{C}_{\mathrm{C}} \mathrm{C}$} & Neutro \\
\hline \multicolumn{2}{|c|}{ Voseo: No podés ser tan irresponsable } & Regional \\
\hline \multicolumn{2}{|c|}{ Uso del pretérito perfecto simple y compuesto } & Neutro \\
\hline \multicolumn{2}{|c|}{ CARACTERÍSTICAS FONOLÓGICAS } & VARIEDAD DE ESPAÑOL \\
\hline \multicolumn{2}{|l|}{ Jugar fútbol } & Neutro \\
\hline \multicolumn{2}{|l|}{ Jugar futból } & Regional \\
\hline \multicolumn{2}{|c|}{ Jugar futebol (del portugués) } & Regional \\
\hline \multicolumn{2}{|c|}{$\begin{array}{l}\text { Tanto la pronunciación como la entonación (acento) difieren entre } \\
\text { los personajes según el origen del actor. Por ejemplo: /pesadíjas/ y } \\
\text { /pesadíjas/ }\end{array}$} & Regional \\
\hline
\end{tabular}




\section{ANEXO 2: ESTADÍSTICAS DERIVADAS}

\section{DE LOS DATOS OBTENIDOS}

\section{EN EL ANÁLISIS DEL CORPUS PARALELO}

\section{TÉCNICAS DE TRADUCCIÓN}

\begin{tabular}{|l|r|}
\hline Traducción literal & 127 \\
\hline Equivalente acuñado & 13 \\
\hline Omisión & 13 \\
\hline Modulación & 8 \\
\hline Préstamo & 34 \\
\hline Calco & 4 \\
\hline Creación discursiva & 16 \\
\hline Explicitación & 11 \\
\hline Generalización & 21 \\
\hline Variación & 22 \\
\hline Particularización & 4 \\
\hline & \\
\hline TOTAL & $\mathbf{2 7 3}$ \\
\hline
\end{tabular}


TÉCNICA: TRADUCCIÓN LITERAL

\begin{tabular}{|c|c|c|c|c|c|c|}
\hline SERRE & \multirow[b]{2}{*}{8} & ESTUDDO & \multirow[b]{2}{*}{8} & País & \multirow{2}{*}{\multicolumn{2}{|c|}{ Netflix originals }} \\
\hline Lost and Found Music Studios & & Argentina 1 & & Argentina & & \\
\hline Jessie & 14 & Argentina 2 & 14 & Chile & 11 & Disney Channel \\
\hline Oodd Squad / El escuadrón de lo incréblble & 14 & Colombia & 14 & Colombia & 14 & Disney XD \\
\hline$H 1.5$ & 11 & Chile & 11 & EEVUU. (Miami) & 17 & \begin{tabular}{|l} 
Nickelodeon \\
\end{tabular} \\
\hline Laytown & 17 & EE.UU. (Miami) & 17 & México & 53 & Discovery Kids \\
\hline Project MC2 & 19 & México 1 & 8 & Venezula & 10 & Boomerang \\
\hline Lab Rats & 10 & México 2 & 11 & & & \\
\hline iCarly & 24 & México 3 & 5 & & & \\
\hline Big Time Rush & 10 & México 4 & 5 & & & \\
\hline & & México 5 & 24 & & & \\
\hline & & Venezula & 10 & & & \\
\hline
\end{tabular}




\section{TÉCNICA: EQUIVALENTE ACUÑADO}

SERIE

\begin{tabular}{|l|}
\hline Lost and Found Music Studios \\
\hline Lessie \\
\hline Odd Squad/EE escuadrón de lo increible \\
\hline Hi.5 \\
\hline Laztown \\
\hline Project MC2 \\
\hline Lab Rats \\
\hline iCarly \\
\hline BigTime Rush \\
\hline
\end{tabular}

ESTUDIO

Argentina 1

3

Argentina 2

Colombia

7 chile

2 EE.UU. (Miami)

México 1

1 México?

México 3

México 4

México 5

Venezula
PAÍS

CANAL

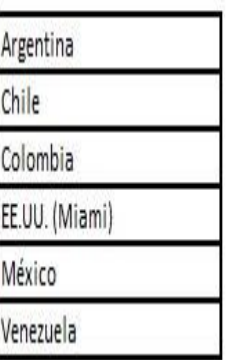

\begin{tabular}{|l|}
\hline Netflix originals \\
\hline Disney Channel \\
\hline Disney XD \\
\hline Nickelodeon \\
\hline Discovery Kids \\
\hline Boomerang \\
\hline
\end{tabular}

\section{TÉCNICA: OMISIÓN}

\section{SERIE}

\begin{tabular}{|l|}
\hline Lost and Found Music Studios \\
\hline Lessie \\
\hline Odd Squad / El escuadrón de lo increible \\
\hline Hi.5 \\
\hline Lazytown \\
\hline Project MC2 \\
\hline Lab Rats \\
\hline CCarly \\
\hline Big Time Rush \\
\hline
\end{tabular}

ESTUDIO

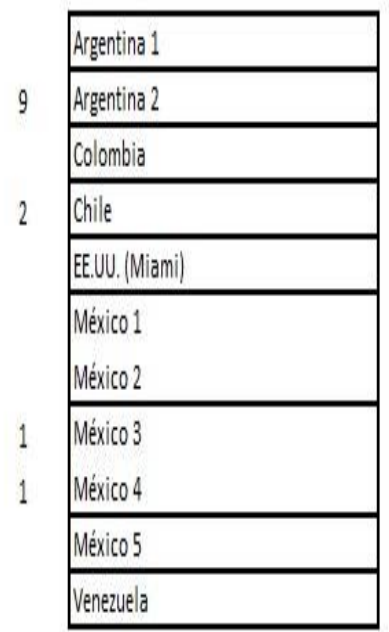

PAÍS

\begin{tabular}{|l|}
\hline Argentina \\
\hline Chile \\
\hline Colombia \\
\hline EE.UU. (Miami) \\
\hline México \\
\hline Venezula \\
\hline
\end{tabular}

\begin{tabular}{l|l|}
9 & Nefflix originals \\
\hline & Disney Channel \\
\hline & Disney XO \\
\hline & Nickelodeon \\
\hline 1 & Discovery Kids \\
\hline 1 & Boomerang \\
\hline
\end{tabular}

CANAL

9 2 2 


\section{TÉCNICA: MODULACIÓN}

SERIE

\begin{tabular}{|l|}
\hline Lost and Found Music Studios \\
\hline lessie \\
\hline Odd Squad/El escuadrón de l lo increible \\
\hline Hi-5 \\
\hline Laztown \\
\hline Project MC2 \\
\hline Lab Rats \\
\hline CCarly \\
\hline Big Time Rush \\
\hline
\end{tabular}

ESTUDIO

\begin{tabular}{|l|}
\hline Argentina 1 \\
\hline Argentina 2 \\
\hline Colombia \\
\hline Chile \\
\hline EE.Uu. (Miami) \\
\hline México 1 \\
México 2 \\
\hline México 3 \\
\hline México 4 \\
\hline México 5 \\
\hline Venezuela \\
\hline
\end{tabular}

PAÍS

CANAL

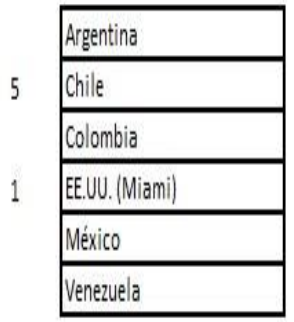

\begin{tabular}{|l|}
\hline Netflix originals \\
\hline Disney Channel \\
\hline Disney XD \\
\hline Nickelodeon \\
\hline Discovery Kids \\
\hline Boomerang \\
\hline
\end{tabular}

\section{TÉCNICA: PRÉSTAMO}

\section{SERIE}

\begin{tabular}{|l|}
\hline Lost and Found Music Studios \\
\hline Jessie \\
\hline Odd Squad/El lescuadrón de l lincreible \\
\hline Hi.5 \\
\hline Lantown \\
\hline Project MC2 \\
\hline Lab Rats \\
\hline iCarly \\
\hline Big Time Rush \\
\hline
\end{tabular}

ESTUDIO

\begin{tabular}{|l|}
\hline Argentina 1 \\
\hline Argentina 2 \\
\hline Colombia \\
\hline Chile \\
\hline EE.UU.(Miami) \\
\hline México1 \\
México2 \\
\hline México3 \\
\hline México 4 \\
\hline México5 \\
\hline Venezuela \\
\hline
\end{tabular}

PAÍS

\begin{tabular}{|l|}
\hline Argentina \\
\hline Chile \\
\hline Colombia \\
\hline EE.Uu. (Miami) \\
\hline México \\
\hline Venezuela \\
\hline
\end{tabular}

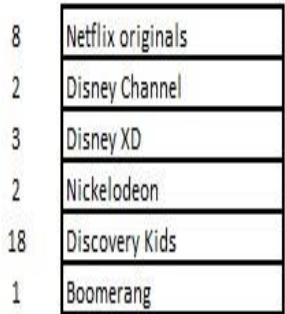

CANAL

10

.

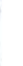

6

2




\section{TÉCNICA: CALCO}

SERIE

\begin{tabular}{|l|}
\hline Lost and Found Music Studios \\
\hline Lessie \\
\hline Odd Squad/EE escuadrón de lo incréble \\
\hline Hi.5 \\
\hline Lazytown \\
\hline Project MC2 \\
\hline Lab Rats \\
\hline CCarly \\
\hline Big Time Rush \\
\hline
\end{tabular}

ESTUDIO

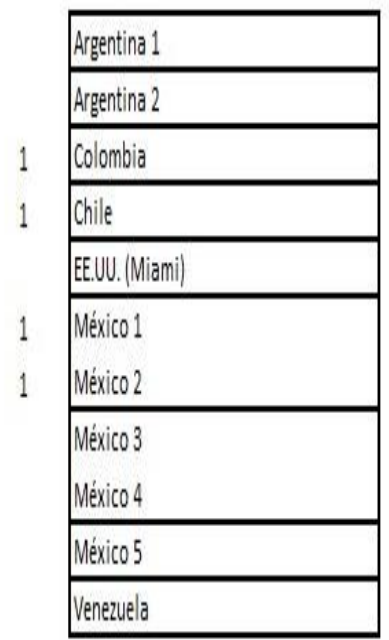

PAÍS

\begin{tabular}{|l|}
\hline Argentina \\
\hline Chile \\
\hline Colombia \\
\hline EE.UU.(Miami) \\
\hline México \\
\hline Venezuela \\
\hline
\end{tabular}

CANAL

\begin{tabular}{|l|}
\hline Netflix originals \\
\hline Disney Channel \\
\hline DisneyXD \\
\hline Nickelodeon \\
\hline Discovery Kids \\
\hline Boomerang \\
\hline
\end{tabular}

\section{TÉCNICA: CREACIÓN DISCURSIVA}

\section{SERIE}

\begin{tabular}{|l|}
\hline Lostand Found Music Studios \\
\hline Jessie \\
\hline Odd Squad/El escuadrón del lo increible \\
\hline Hi.5 \\
\hline Lantown \\
\hline ProjectMC2 \\
\hline Lab Rats \\
\hline Carly \\
\hline Big Time Rush \\
\hline
\end{tabular}

ESTUDIO

\begin{tabular}{|c|}
\hline \begin{tabular}{|l|} 
Argentina 1 \\
\end{tabular} \\
\hline Argentina 2 \\
\hline Colombia \\
\hline Chile \\
\hline EEEUU. (Miami) \\
\hline México 1 \\
\hline México 2 \\
\hline México 3 \\
\hline México 4 \\
\hline México 5 \\
\hline Venezula \\
\hline
\end{tabular}

PAÍS

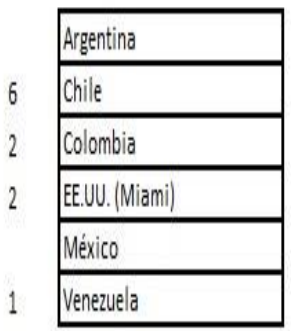

CANAL

\begin{tabular}{|l|}
\hline Nefflix originals \\
\hline Disney Channel \\
\hline Disney XD \\
\hline Nickelodeon \\
\hline Discovery Kids \\
\hline Boomerang \\
\hline
\end{tabular}


TÉCNICA: EXPLICITACIÓN

SERIE

\begin{tabular}{|l|}
\hline Lost and Found Music Studios \\
\hline Jessie \\
\hline Odd Squad / El escuadrón de lo increible \\
\hline Hi.5 \\
\hline Lazytown \\
\hline Project MCL \\
\hline Lab Rats \\
\hline iCarly \\
\hline BigTime Rush \\
\hline
\end{tabular}

ESTUDIO

\begin{tabular}{|c|}
\hline Argentina 1 \\
\hline Argentina 2 \\
\hline Colombia \\
\hline Chile \\
\hline EE.UU. (Miami) \\
\hline México 1 \\
\hline México 2 \\
\hline México 3 \\
\hline México 4 \\
\hline México 5 \\
\hline Venezuela \\
\hline
\end{tabular}

PAÍS

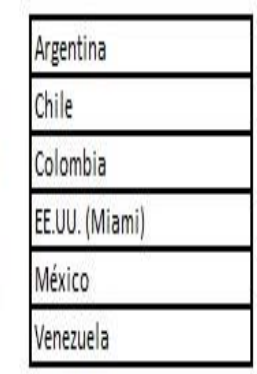

CANAL

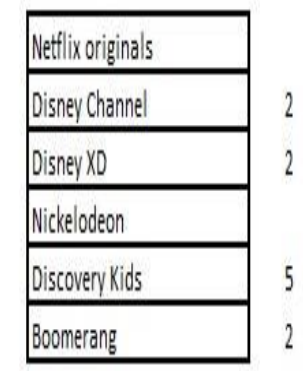

\section{TÉCNICA: GENERALIZACIÓN}

\section{SERIE}

\begin{tabular}{|l|}
\hline Lost and Found Music Studios \\
\hline Jessie \\
\hline Odd Squad / El escuadrón de lo increible \\
\hline Hi-5 \\
\hline Lazytown \\
\hline Project MC2 \\
\hline Lab Rats \\
\hline CCarly \\
\hline Big Time Rush \\
\hline
\end{tabular}

ESTUDIO

\begin{tabular}{|l|}
\hline Argentina 1 \\
\hline Argentina 2 \\
\hline Colombia \\
\hline Chile \\
\hline EE.UU. (Miami) \\
\hline México 1 \\
\hline México 2 \\
\hline México 3 \\
\hline México 4 \\
\hline México 5 \\
\hline Venezuela \\
\hline
\end{tabular}

PAÍS

\begin{tabular}{|l|}
\hline Argentina \\
\hline Chile \\
\hline Colombia \\
\hline EE.Uu. (Miami) \\
\hline México \\
\hline Venezuela \\
\hline
\end{tabular}

CANAL

\begin{tabular}{|c|}
\hline Netflix originals \\
\hline Disney Channel \\
\hline Disney XD \\
\hline Nickelodeon \\
\hline Discovery Kids \\
\hline Boomerang \\
\hline
\end{tabular}


TÉCNICA: VARIACIÓN

SERIE

\begin{tabular}{|l|}
\hline Lost and Found Music Studios \\
\hline lessie \\
\hline Odd Squad / El escuadrón de lo increible \\
\hline Hi-5 \\
\hline Lazytown \\
\hline Project MC2 \\
\hline Lab Rats \\
\hline iCarly \\
\hline Big Time Rush \\
\hline
\end{tabular}

ESTUDIO

Argentina 1

Argentina 2

Colombia

\begin{tabular}{|l|}
\hline Chile \\
\hline EE.UU. (Miami) \\
\hline
\end{tabular}

México 1

México 2

México 3

México 4

\begin{tabular}{|l|}
\hline México5 \\
\hline Venezuela \\
\hline
\end{tabular}
PAÍS

CANAL

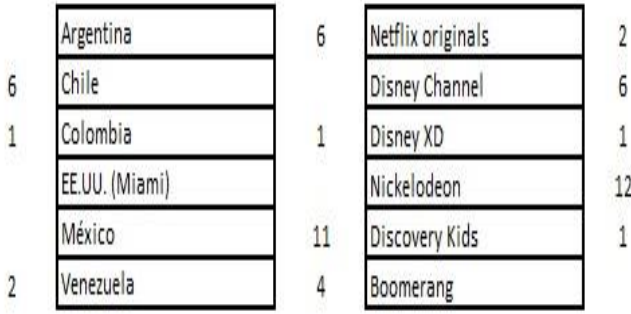

4

\section{TÉCNICA: PARTICULARIZACIÓN}

\section{SERIE}

\begin{tabular}{|l|}
\hline Lost and Found Music Studios \\
\hline Jessie \\
\hline Odd Squad / El escuadrón de lo incréble \\
\hline Hi-5 \\
\hline Lazytown \\
\hline Project MC2 \\
\hline Lab Rats \\
\hline iCarly \\
\hline BigTime Rush \\
\hline
\end{tabular}

ESTUDIO

\begin{tabular}{|c|}
\hline Argentina 1 \\
\hline Argentina 2 \\
\hline Colombia \\
\hline Chile \\
\hline EE.UU. (Miami) \\
\hline \multirow{2}{*}{$\begin{array}{l}\text { México } 1 \\
\text { México } 2\end{array}$} \\
\hline \\
\hline \multirow{2}{*}{$\begin{array}{l}\text { México } 3 \\
\text { México } 4 \\
\end{array}$} \\
\hline \\
\hline México 5 \\
\hline Venezuela \\
\hline
\end{tabular}

PAÍS

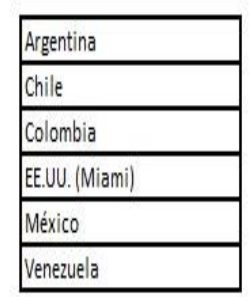

CANAL

\begin{tabular}{|l|}
\hline Netflix originals \\
\hline Disney Channel \\
\hline Disney XD \\
\hline Nickelodeon \\
\hline Discovery Kids \\
\hline Boomerang \\
\hline
\end{tabular}




\section{TÉCNICAS UTILIZADAS SEGÚN EL PROGRAMA}

PROGRAMA

Lost and Found Music Studios Traducción literal

Total analizado: 10

Jessie

Total analizado: 65

Odd Squad

Total analizado: 28
TÉCNICA

Equivalente acuñado

Omisión

Modulación

Préstamo

Calco

Creación discursiva

Explicitación

Generalización

Variación

Particularización

Traducción literal

Equivalente acuñado

Omisión

Modulación

Préstamo

Calco

Creación discursiva

Explicitación

Generalización

Variación

Particularización

Traducción literal

Equivalente acuñado

Omisión

Modulación

Préstamo

Calco

Creación discursiva

Explicitación

Generalización

Variación

Particularización
CANTIDAD PORCENTAJE

8

80,00

10,00

1

1

10,00

14

21,54

4,62

13,85

7,69

10,77

7

9,23

3,08

15,38

9,23

34,62

14

50,00

10,71

$1 \quad 3,57$

$2 \quad 7,14$

$4 \quad 14,29$

$3 \quad 10,71$

$1 \quad 3,57$ 
Hi-5

Total analizado: 30

Lazytown

Total analizado: 24

Project MC2

Total analizado: 33
Traducción literal

36,67

Equivalente acuñado

23,33

Omisión

6,67

Modulación

Préstamo

6,67

Calco

Creación discursiva

3,33

6,67

Explicitación

3,33

Generalización

Variación

Particularización

1

3,33

Traducción literal

70,83

Equivalente acuñado

17

8,33

Omisión

Modulación

Préstamo

8,33

Calco

Creación discursiva

Explicitación

Generalización

4,17

Variación

Particularización

Traducción literal

19

57,58

Equivalente acuñado

Omisión

Modulación

Préstamo

27,27

Calco

9

3,03

Creación discursiva

1

3,03

Explicitación

Generalización

Variación

1

3,03

Particularización 
Lab Rats

Total analizado: 19

iCarly

Total analizado: 44

Big Time Rush

Total analizado: 20
Traducción literal

10

52,63

Equivalente acuñado

1

Omisión

Modulación

10,53

Préstamo

5,26

Calco

Creación discursiva

5,26

Explicitación

5,26

Generalización

Variación 5,26

Particularización

Traducción literal

Equivalente acuñado

Omisión

Modulación

Préstamo

18,18

Calco

Creación discursiva

Explicitación

Generalización

Variación

4,55

Particularización

Traducción literal

Equivalente acuñado

Omisión

1

5,00

Modulación

Préstamo 5,00

Calco

Creación discursiva

15,00

Explicitación

Generalización

Variación

1

5,00

Particularización 


\section{ESPAÑOL NEUTRO VERSUS ESPAÑOL REGIONAL}

\begin{tabular}{|l|c|c|c|c|c|c|}
\hline \multirow{2}{*}{ PROGRAMA } & \multicolumn{2}{|c|}{ ESPAÑOL NEUTRO } & \multicolumn{2}{c|}{ ESPAÑOL REGIONAL } & \multirow{2}{*}{} \\
\cline { 2 - 6 } & CASOS & $\mathbf{\%}$ & CASOS & $\mathbf{\%}$ & \multirow{2}{*}{ TOTAL } & OMISIONES \\
\hline $\begin{array}{l}\text { Lost and Found } \\
\text { Music Studios }\end{array}$ & 6 & $60 \%$ & 4 & $40 \%$ & 10 & \\
\hline Jessie & 47 & $84 \%$ & 9 & $16 \%$ & 56 & 9 \\
\hline Odd Squad & 20 & $69 \%$ & 9 & $31 \%$ & 29 & \\
\hline Hi-5 & 20 & $71 \%$ & 8 & $29 \%$ & 28 & 2 \\
\hline Lazytown & 18 & $75 \%$ & 6 & $25 \%$ & 24 & \\
\hline Project MC2 & 23 & $70 \%$ & 10 & $30 \%$ & 33 & \\
\hline Lab Rats & 17 & $89 \%$ & 2 & $11 \%$ & 19 & \\
\hline iCarly & 32 & $74 \%$ & 11 & $26 \%$ & 43 & 1 \\
\hline Big Time Rush & 14 & $64 \%$ & 8 & $36 \%$ & 22 & 1 \\
\hline
\end{tabular}




\section{ANEXO 3: CUESTIONARIO \\ PARA LOS ENTREVISTADOS}

Mi nombre es Gabriela Scandura, soy estudiante de Doctorado en la Universitat Jaume I, y estoy realizando un proyecto de investigación para mi tesis, titulada "Estudio descriptivo del español neutro de doblaje de series de ficción infantiles y juveniles: ¿estandarización, políticas lingüísticas o censura?" Se trata de una tesis doctoral sin fines comerciales, y le estaría muy agradecida si pudiera responder brevemente las preguntas que figuran a continuación. Su participación será anónima, y los datos que me brinde se utilizarán únicamente con fines investigadores y estarán a su disposición una vez concluida la tesis. ¡Muchas gracias por su colaboración!

Pregunta número 1: ¿Sus clientes tienen una lista de palabras que usted no puede usar en el doblaje?

Pregunta número 2: Si tienen prohibido usar ciertas palabras, ¿son similares o varían mucho entre cliente y cliente?

Pregunta número 3: ¿Varían según el país de origen del cliente o entre estudios del mismo país?

Pregunta número 4: ¿En todos los casos son palabras relacionadas con el español neutro? ¿O también tienen que ver con cuestiones culturales? (Por ejemplo, nombres de comidas o verbos problemáticos versus groserías o referencias muy locales o específicas)

Pregunta número 5: ¿Notó algún cambio con el correr de los años en este aspecto?

Pregunta número 6: ¿Hay diferencias en las pronunciaciones del español neutro que le piden los distintos clientes? 
Pregunta número 7: ¿Diría que algún cliente ejerce algún tipo de censura sobre la traducción?

Pregunta número 8: ¿Todos los estudios tienen una guía de estilo? De tenerla, ¿hablan específicamente de temas de español neutro, o solo indican que "hay que usar un español neutro"? 


\title{
ANEXO 4: TÉRMINOS UTILIZADOS
}

\author{
EN EL ESPAÑOL NEUTRO \\ Y EN LOS DISTINTOS PAÍSES
}

LATINOAMERICANOS ${ }^{171}$

\begin{tabular}{|c|c|c|}
\hline Término en inglés & $\begin{array}{l}\text { Término usado } \\
\text { generalmente en } \\
\text { español neutro }^{172}\end{array}$ & $\begin{array}{c}\text { Términos en los distintos países } \\
\text { latinoamericanos }\end{array}$ \\
\hline Apricot & Albaricoque & $\begin{array}{l}\text { Albaricoque (CO), chabacano (MX), damasco (AR, } \\
\mathrm{CH})\end{array}$ \\
\hline Artichoke & Alcachofa & Alcachofa (MX, CH), alcaucil (AR) \\
\hline Avocado & Aguacate & $\begin{array}{l}\text { Palta (AR, CH, PE, UY, VE), aguacate (MX), cura } \\
\text { o curo }(\mathrm{CO})\end{array}$ \\
\hline Baby bottle & Biberón & $\begin{array}{l}\text { Mamadera (AR, CH, UY), biberón (MX), tetero } \\
(\mathrm{CO}) \text {, bibí (PR) }\end{array}$ \\
\hline Bacon & Tocino & Tocino (PR, MX), panceta (AR, PE), tocineta (CO), \\
\hline Banana & Banana & Plátano (CH, CO, MX), banana (AR, UY), \\
\hline Bermuda shorts & $\begin{array}{l}\text { (Pantalón) } \\
\text { bermudas }\end{array}$ & Bermudas (AR), pantalones (PR) \\
\hline Boy & Niño / Adolescente & $\begin{array}{l}\text { Pibe, chico (AR), chamo (VE), guambra (EC), } \\
\text { chirís (GU, solo niño), chavo (MX, GU), chango } \\
\text { (BO), chamaco (RD, SA, MX), chiquilín (UY), lolo }\end{array}$ \\
\hline
\end{tabular}

${ }^{171}$ Esta lista no pretende ser exhaustiva. Solo contiene los términos hallados en las páginas de Internet mencionadas en esta tesis, por eso no siempre se han podido incluir todas las versiones. La finalidad es simplemente demostrar que un mismo concepto recibe distintos nombres en los diferentes países. En los casos en que hay más de una versión del mismo país, se debe a que se encontraron ambas en los folletos en línea.

${ }^{172}$ Este listado se confeccionó con términos sobre los cuales la autora debió consultar a sus supervisores en las empresas de doblaje o que fueron corregidos por el Departamento de Compliance o el director de doblaje. 


\begin{tabular}{|c|c|c|}
\hline & & $\begin{array}{l}\text { (CH, solo adolescente), chino (CO), gurí (UY), } \\
\text { botija (MX, UY), mitaí (PAR), patojo (GU) }\end{array}$ \\
\hline Bra & Sostén & $\begin{array}{l}\text { Corpiño (AR, UY), brasier (MX, CO), sostén }(\mathrm{CH}) \text {, } \\
\text { sujetador (MX), soutien (AR) }\end{array}$ \\
\hline Breaded & Empanizado & $\begin{array}{l}\text { Apanado }(\mathrm{CH}) \text {, rebozado }(\mathrm{AR}) \text {, empanizado }(\mathrm{CU}, \\
\mathrm{MX}, \mathrm{HO}, \mathrm{CR})\end{array}$ \\
\hline Bucket & Cubeta & $\begin{array}{l}\text { Balde (AR, UY, CO, PE, CH), cubo (PR), cubeta } \\
(\mathrm{MX})\end{array}$ \\
\hline Butter & Mantequilla & Manteca (AR, UY), mantequilla (CO, MX) \\
\hline Cake & Pastel & $\begin{array}{l}\text { Torta (AR, } \mathrm{CO}, \mathrm{CH}), \text { bizcochuelo (AR), bizcocho } \\
(\mathrm{PR}) \text {, pastel (MX) }\end{array}$ \\
\hline Chicken thigh & Muslo de pollo & $\begin{array}{l}\text { Pata / muslo (AR, CO), trutro (largo o corto) }(\mathrm{CH}) \text {, } \\
\text { / pierna / pernil / muslo }(\mathrm{CO}, \mathrm{MX}), \text { pierna / } \\
\text { encuentro }(\mathrm{PE})\end{array}$ \\
\hline Coctail sauce & Salsa de cóctel & $\begin{array}{l}\text { Salsa golf (AR, UY), mayoketchup (PR), salsa mil } \\
\text { islas (MX) }\end{array}$ \\
\hline Computer & Computadora & Computadora (AR, MX), computador (CO) \\
\hline Cooler & Conservadora & $\begin{array}{l}\text { Neverita (PR), heladerita (AR), cooler / nevera } \\
(\mathrm{CH})\end{array}$ \\
\hline Croissant & $\begin{array}{l}\text { Croissant / } \\
\text { Medialuna }\end{array}$ & $\begin{array}{l}\text { Croissant (PR, CO), medialuna (AR), cuernito } \\
(\mathrm{MX})\end{array}$ \\
\hline Cupcake & Cupcake & Cupcake (AR, PR, MX) \\
\hline Dish soap & Lavavajillas & $\begin{array}{l}\text { Detergente lavavajilla (AR, PE), lavalozas }(\mathrm{CH} \text {, } \\
\mathrm{CO}) \text {, lavatrastes (MX) }\end{array}$ \\
\hline Dishcloth & Paño & $\begin{array}{l}\text { Repasador (AR, UY), secador (MX, PE), limpión } \\
\text { (CO) }\end{array}$ \\
\hline Disposable & Desechable & Desechable (PR, CO, CH, MX), descartables (AR) \\
\hline Eggplant & Berenjena & Berenjena $(\mathrm{CH}, \mathrm{CO}, \mathrm{UY}, \mathrm{AR})$ \\
\hline Fan & Ventilador & Ventilador (AR, UY, CH, PE), abanico (PR) \\
\hline Freezer & Congelador & Freezer (AR), congeladora $(\mathrm{PE})$ \\
\hline Fridge & Refrigerador & $\begin{array}{l}\text { Refrigerador }(\mathrm{CH}, \mathrm{MX}, \mathrm{EC}) \text {, heladera }(\mathrm{AR}, \mathrm{UY}) \text {, } \\
\text { nevera }(\mathrm{PR}, \mathrm{CO}, \mathrm{VE})\end{array}$ \\
\hline Headphones & Auriculares & Audífonos (CO, CH, MX), auriculares (AR) \\
\hline
\end{tabular}




\begin{tabular}{|c|c|c|}
\hline Home appliance & Electrodoméstico & Electrodoméstico (AR, CO, MX) \\
\hline Infant / Baby car seat & Silla de niño & $\begin{array}{l}\text { Silla para auto }(\mathrm{AR}, \mathrm{CH}, \mathrm{UY}) \text {, autoasiento }(\mathrm{MX}) \text {, } \\
\text { silla para carro }(\mathrm{CO})\end{array}$ \\
\hline Jacket & Chaqueta & $\begin{array}{l}\text { Chamarra (MX), campera (AR, UY), chaqueta } \\
\text { (UY), jacket (PR) }\end{array}$ \\
\hline Kétchup & Kétchup & Kétchup (AR, PR, CH, UY), cátsup (MX) \\
\hline Light bulb & Foco / Bombilla ${ }^{173}$ & $\begin{array}{l}\text { Lamparita (AR, UY), ampolleta (CH), foco (PE, } \\
\mathrm{MX})\end{array}$ \\
\hline Mouthrinse & Enjuague bucal & $\begin{array}{l}\text { Enjuague bucal (AR, CH, MX), enjuagador bucal } \\
\text { (PR) }\end{array}$ \\
\hline Notebook / Laptop & Laptop & Laptop (AR, UY), portátil (CO) \\
\hline Panties & $\begin{array}{l}\text { Pantis / Ropa } \\
\text { interior }\end{array}$ & $\begin{array}{l}\text { Calzón, pantaleta }(\mathrm{CH}), \text { bombacha }(\mathrm{AR}, \mathrm{UY}) \text {, panty } \\
(\mathrm{MX}) \text {, ropa interior }(\mathrm{PR})\end{array}$ \\
\hline Peach & Durazno & $\begin{array}{l}\text { Durazno, (AR, MX, CH, VE, UY), melocotón } \\
(\mathrm{VE}) \text {, nectarin }(\mathrm{CO})\end{array}$ \\
\hline Peanut & $\begin{array}{l}\text { Maní (solo si es } \\
\text { mantequilla) / } \\
\text { Cacahuate }\end{array}$ & $\begin{array}{l}\text { Maní (AR, CO, UY, CH), cacahuate / cacahuete } \\
(\mathrm{MX})\end{array}$ \\
\hline Pillow & Cojín & Cojín (CH, CO), almohadón (AR) \\
\hline Pineapple & Piña & Pina $(\mathrm{CH}, \mathrm{CO}, \mathrm{MX})$, ananá (AR, UY) \\
\hline Polo shirt & (Camiseta) polo & Chomba (AR), polo (PR), remera cuello polo (UY), \\
\hline Pork chops & Chuletas de cerdo & $\begin{array}{l}\text { Costillitas de cerdo (AR), chuleta de cerdo (MX), } \\
\text { costeleta de cerdo (AR) }\end{array}$ \\
\hline Potato & Papa & Papa (AR, PR, CH, CO, MX, VE, UY) \\
\hline Potty & Bacinica & $\begin{array}{l}\text { Pelela (AR, UY), bacinica }(\mathrm{CH}) \text {, baño entrenador } \\
(\mathrm{MX}) \text {, vasenilla }(\mathrm{CO})\end{array}$ \\
\hline Rottisserie chicken & $\begin{array}{l}\text { Pollo asado o } \\
\text { rostizado }\end{array}$ & $\begin{array}{l}\text { Pollo asado }(\mathrm{CH}) \text {, pollo al spiedo (AR), rostizado } \\
(\mathrm{MX}, \mathrm{HO}, \mathrm{SAL})\end{array}$ \\
\hline Sausage / Hot Dog & Salchicha & $\begin{array}{l}\text { Salchicha (AR, MX, VE), salchicha / frankfurter } \\
\text { (UY, PE), vienesas }(\mathrm{CH}) \text {, salchicha perro caliente } \\
\text { (CO) }\end{array}$ \\
\hline
\end{tabular}

${ }^{173}$ Significa "sorbete" en Argentina 


\begin{tabular}{|c|c|c|}
\hline Shaving foam & Espuma para afeitar & Espuma de afeitar (AR, $\mathrm{CH}, \mathrm{CO}, \mathrm{MX})$ \\
\hline Shoelaces & Cintas & $\begin{array}{l}\text { Cordones }(\mathrm{AR}) \text {, trenzas }(\mathrm{VE}) \text {, pasadores }(\mathrm{EC}, \mathrm{PE}) \text {, } \\
\text { agujetas }(\mathrm{MX}, \mathrm{CO}) \text {, guatos }(\mathrm{BO})\end{array}$ \\
\hline Shorts & Shorts & Shorts (AR, MX, UY), pantalones cortos (PR) \\
\hline Skateboard & Skate / Skateboard & $\begin{array}{l}\text { patineta / patinete }(\mathrm{CU}, \mathrm{HO}, \mathrm{VE}) \text {, monopatín (SAL, } \\
\mathrm{VE}) \text {, patineta }(\mathrm{AR}, \mathrm{CO})\end{array}$ \\
\hline Sleeping bag & Saco de dormir & $\begin{array}{l}\text { Sleeping bag (MX), sobre de dormir (UR), bolsa de } \\
\text { dormir (AR) }\end{array}$ \\
\hline Snacks & Snacks / bocadillos & $\begin{array}{l}\text { Snacks (AR), botanas (MX), aperitivo (AR), } \\
\text { bocadillo }^{174} \text {, pasabocas }(\mathrm{CO})\end{array}$ \\
\hline Sneakers & Calzado deportivo & $\begin{array}{l}\text { Zapatillas }^{175} \text { (AR, CO, PE CH,) championes (UY), } \\
\text { tenis (MX), }\end{array}$ \\
\hline Sock & Calcetín / Media & Media (AR, UY), calceta (MX, CO), calcetín $(\mathrm{CH})$ \\
\hline Soda (water) & Gaseosa & Gaseosa (AR, CO, PE), refresco (MX, VE, UY) \\
\hline Soya & Soya & Soya $(\mathrm{CH}, \mathrm{VE})$, soja (AR) \\
\hline Steak & Filete o bistec & $\begin{array}{l}\text { Bife (AR, CH, PE, UY), bistec (MX), filete (UY), } \\
\text { churrasco (AR), churrasco de res (PR) }\end{array}$ \\
\hline Strawberry & Fresa & Fresa $(\mathrm{CO}, \mathrm{PE}, \mathrm{MX})$, frutilla $(\mathrm{AR}, \mathrm{CH})$ \\
\hline Stroller & Carrito & $\begin{array}{l}\text { Coche para bebé (CO, UY), carriola (MX), } \\
\text { cochecito de bebé (AR) }\end{array}$ \\
\hline Sweatshirt & $\begin{array}{l}\text { Sudadera } \\
\text { Suéter/abrigo } \\
\text { deportivo / con } \\
\text { capucha }\end{array}$ & $\begin{array}{l}\text { Buzo (AR, UY) (en UY puede ser también un } \\
\text { suéter), polerón }(\mathrm{CH}) \text {, sudadera (MX, UY), hoodie } \\
\text { (PE) }\end{array}$ \\
\hline Toilet bowl & Sanitario & $\begin{array}{l}\text { Inodoro (AR, PE, UY), retrete / WC }(\mathrm{PE}) \text {, poceta } \\
\text { (VE) }\end{array}$ \\
\hline Toilet paper & Papel sanitario & $\begin{array}{l}\text { Papel higiénico (AR, CH, UY, CO, MX, PE), } \\
\text { confort }(\mathrm{CH}) \text {, papel toilet (VE) }\end{array}$ \\
\hline Toilet seat & $\begin{array}{l}\text { Asiento del } \\
\text { sanitario }\end{array}$ & Asiento del inodoro (AR, PE, UY) \\
\hline
\end{tabular}

\footnotetext{
${ }^{174}$ Es un dulce en Colombia, México y Venezuela.

${ }^{175}$ Significa "zapatos" en México.
} 


\begin{tabular}{|l|l|l|}
\hline Trash can & Cubo de basura & $\begin{array}{l}\text { Papelera (CO), tacho de basura (AR), bote de } \\
\text { basura (MX), cesto de basura (MX) }\end{array}$ \\
\hline Turtleneck & Cuello de tortuga & $\begin{array}{l}\text { Polera (AR, UY), suéter cuello de tortuga (MX, } \\
\text { VE, CO) }\end{array}$ \\
\hline Wallet & Billetera & Billetera (AR, CO, UY, CH), cartera (MX) \\
\hline Watermelon & Sandía & Sandía (AR, MX, PE, UY), patilla (CO) \\
\hline Yogurt & Yogurt & Yogurt (PR, CO), yoghurt (CH, MX), yogur (AR) \\
\hline
\end{tabular}


Nombre dado al mismo producto en Argentina, Uruguay y España ${ }^{176}$

\begin{tabular}{|l|l|l|}
\hline \multicolumn{1}{|c|}{ Argentina } & \multicolumn{1}{|c|}{ Eruguay } & Pspaña \\
\hline Ananá & Piña & Bañera \\
\hline Bañera (de bebé) & Bañito & Saco de dormir \\
\hline Bolsa de dormir & Sobre de dormir & $\begin{array}{l}\text { Vinoteca, enfriador de } \\
\text { botellas }\end{array}$ \\
\hline Cava & Enfriadora de vino & Polo \\
\hline Chomba & Remera cuello polo & Baby, bata escolar \\
\hline Delantal & Túnica & Periódico/Diario \\
\hline Diario & Periódico & Refresco de cola \\
\hline Gaseosa & Refresco & Papelería \\
\hline Librería & Papelería & Lazo escolar \\
\hline Moño & Moña & Plato llano \\
\hline Plato playo & Plato llano & Palomitera, palomitero \\
\hline Pochoclera & Popera & Tersey \\
\hline Remera & T-shirt & Catre \\
\hline Reposera & & Tumbona, hamaca \\
\hline
\end{tabular}

\footnotetext{
${ }^{176}$ A pesar de que muchos productos que se venden en Uruguay son de origen argentino, el catálogo de Tienda Inglesa, un conocido supermercado de Uruguay, incluye 10 productos que en Argentina reciben otro nombre.
} 


\section{ANEXO 5: LEYES Y DECRETOS ARGENTINOS RELACIONADOS CON EL DOBLAJE}

\section{DOBLAJE}

\section{LEY $N^{\circ} 23.316$ [fragmento]}

Establécese su obligatoriedad en la televisación de películas y/o tapes de corto o largometraje, la presentación fraccionada de ellas con fines de propaganda, la publicidad, la prensa y las denominadas 'series' que sean puestas en pantalla por dicho medio.

Sancionada: Mayo 7 de 1986.

Promulgada: Mayo 23 de 1986.

ARTICULO $1^{\circ}$ - El doblaje para la televisación de películas y/o tapes de corto o largometraje, la presentación fraccionada de ellas con fines de propaganda, la publicidad, la prensa y las denominadas 'series' que sean puestas en pantalla por dicho medio y en los porcentajes que fija esta ley, deberá ser realizado en idioma castellano neutro, según su uso corriente en nuestro país, pero comprensible para todo el público de la América hispano hablante.

Tal obligación alcanza a todo el territorio argentino y comprende toda clase de exhibición -sea ella emitida de manera directa, diferida o por video grabación ('video tape')-; en blanco y negro o en color; para su transmisión indiscriminada para el público televidente, o en el caso de emisión por el llamado 'circuito cerrado' y, asimismo, para las que sólo se dirijan a personas de existencia real o ideal abonadas a programación.

La prescripción de esta ley abarca las emisiones de los canales de televisión públicos y privados y a sus repetidoras, así como las transmitidas por conducto de satélites o cables coaxiales, o cualquier otro medio creado o a crearse.

ARTICULO $2^{\circ}$ - Las empresas privadas, estatales o mixtas importadorasdistribuidoras de material fílmico o en video grabación de ficción dramática, hablado originalmente en idioma extranjero y destinado a su televisación en la República Argentina, quedan obligadas a realizar su doblaje en el país en las siguientes proporciones: Doce y Medio por Ciento $(12,5 \%)$ del metraje de filmación, dentro de los ciento ochenta (180) días de la vigencia de la presente ley, porcentaje que se incrementará progresivamente hasta alcanzar el Veinticinco por Ciento $(25 \%)$ dentro de los trescientos sesenta (360) días y, como mínimo, el Cincuenta por Ciento $(50 \%)$ a partir de los tres (3) años. Los organismos del Estado nacional, 
provincial y municipal y entes autárquicos o descentralizados que introduzcan al país estos materiales, quedan obligados por las disposiciones de esta ley que les resulten aplicables.

ARTICULO $3^{\circ}$ - Entiéndese por ficción dramática el material que desarrolla historias interpretadas por un mínimo de cuatro (4) actores. Quedan equiparados a esta categoría los materiales documentales, periodísticos o especiales donde hablen por lo menos cuatro (4) personas distintas. En todos los supuestos contemplados en este artículo, el doblaje deberá estar a cargo, según el caso, de actores egresados del seminario de Doblaje de la Asociación Argentina de Actores y/o locutores del Curso de Capacitación para Doblaje del Instituto Superior de Enseñanza Radiofónica, o de los establecimientos educativos especializados a crearse por el Estado o la iniciativa privada con reconocimiento oficial de sus títulos.

ARTICULO $4^{\mathbf{0}}$ - Las empresas importadoras-distribuidoras de material fílmico o en video-grabación de no ficción (documentales, periodístico, musicales, especiales) destinados a su televisación en la República Argentina que requieran de uno (1) a tres (3) relatores, quedan obligadas a realizar el doblaje en castellano del Veinticinco por Ciento $(25 \%)$ de su metraje dentro de los ciento ochenta (180) días de la vigencia de esta ley. En todos los casos contemplados en este artículo, el doblaje deberá estar a cargo de locutores egresados del Curso de Locución del Instituto Superior de Enseñanza Radiofónica o de los establecimientos educativos especializados en locución a crearse por el Estado o a iniciativa privada con reconocimiento oficial de sus títulos.

ARTICULO $5^{\circ}$ - Todos los canales de televisión abierta, circuito cerrado, televisión por cable y televisión por suscripción de la República Argentina, cualesquiera sean las formas en que emitan sus señales, quedan obligados a que su programación de material fílmico y de video grabación doblado en castellano, incluya programas doblados en la Argentina en los mismos porcentajes y plazos que se fijan en los artículos $2^{\circ}$ y $4^{\circ}$ para las empresas importadoras-distribuidoras.

ARTICULO $6^{\circ}$ - Las empresas a que se refieren los arts. $2^{\circ}$ y $4^{\circ}$ deberán inscribirse en el Registro de Empresas Importadoras-Distribuidoras de Programas Envasados para Televisión, con funcionamiento en el Instituto Nacional de Cinematografía. Dichas empresas no podrán hacer el despacho aduanero de los materiales que importen sin contar con el certificado que les extenderá el Instituto Nacional de Cinematografía.

ARTICULO $7^{0}$ - Los estudios y laboratorios de doblaje deberán inscribirse en el Registro de Estudios y Laboratorios de Doblaje del Instituto Nacional de Cinematografía, previa aprobación por dicho organismo de la calidad del trabajo que realizan. A los fines de este control de calidad, deberán presentar por lo menos quince (15) minutos de una ficción dramática que hayan doblado en castellano con intervención de actores autorizados al efecto por la presente ley. El Instituto Nacional de Cinematografía otorgará 
a las empresas a las que se hace referencia en el artículo anterior el 'certificado de libre deuda' y, eventualmente, podrá denegar o revocar su inscripción en el Registro por falta de cumplimiento de las obligaciones contractuales.

ARTICULO $8^{\mathbf{0}}$ - No podrá televisarse en ningún canal abierto o cerrado del país, materiales importados y/o doblados por empresas no registradas en el Instituto Nacional de Cinematografía según las prescripciones de los artículos $6^{\circ}$ y $7^{\circ}$.

ARTICULO $9^{\circ}$ - Las empresas importadoras-distribuidoras registradas en el Instituto Nacional de Cinematografía deberán presentar trimestralmente a dicho organismo una declaración jurada con una lista de material fílmico y en video grabación que importaron durante el período, y otra lista del material que doblaron en castellano o cuyo doblaje contrataron en el mismo lapso. En todos los casos deberán especificar la duración de cada material, su categoría (ficción dramática o no ficción) y certificaciones de los estudios y/o laboratorios donde hicieron o contrataron los doblajes. Hechas las comprobaciones, el Instituto Nacional de Cinematografía extenderá un permiso de televisación para cada material del listado (películas, capítulos de series, horas de miniseries, documentales, periodísticos, musicales, dibujos animados, especiales). Ningún canal abierto o cerrado del país podrá televisar materiales fílmicos o en video grabación que no cuenten con el permiso de televisación del Instituto Nacional de Cinematografía.

ARTICULO 10. - Los materiales doblados en Argentina antes y después de sancionada esta ley, recibirán el permiso de televisación por tiempo ilimitado.

ARTICULO 11. - Si un canal que se proponga estrenar un material doblado en el país, lo rechazara por considerar que el doblaje es deficiente, deberá comunicar esta decisión al Instituto Nacional de Cinematografía y éste procederá a un control de calidad mediante una comisión formada por un representante del canal en cuestión, uno del Instituto Nacional de Cinematografía y uno de la Asociación Argentina de Actores especializado en doblaje (interpretación, sincronismo, castellano neutro) si se tratara de ficción dramática -tal cual se especifica en el artículo $3^{\circ}$-, o uno del Instituto Superior de Enseñanza Radiofónica especializado en doblaje (interpretación, sincronismo, castellano neutro) -según lo establecido en el artículo $4^{\circ}$ - si lo fuese de no ficción. En los casos en que el dictamen resultare desfavorable, deberá rehacerse el doblaje o reemplazárselo por otro de igual duración a los efectos de esta ley.

ARTICULO 12. - Quedan exceptuados de la obligatoriedad del doblaje que determina la presente ley:

a) Las letras de composiciones musicales;

b) Los programas destinados a la enseñanza de lenguas extranjeras; 
c) Los programas para colectividades extranjeras;

d) Las ceremonias de cualquier credo, con libre empleo de la lengua propia de sus ritos;

e) La intercalación de palabras o frases en idioma extranjero que hayan sido acuñadas por la literatura clásica o por la retórica internacional;

f) Mensajes orales de personalidades extranjeras o miembros de organismos internacionales, que podrán ser traducidos, si así se lo prefiere, mediante leyendas sobre-impresas claramente legibles o en traducción simultánea;

g) Las emisiones destinadas a áreas pobladas por aborígenes, las que podrán ser bilingües y con eventual empleo de leyendas sobre-impresas claramente legibles;

h) La mención de marcas registradas;

i) Las noticias de origen extranjero, con las que se podrá proceder como en el inciso f);

j) Los materiales fílmicos y en video grabación extranjeros hablados originariamente en idioma castellano, aunque incluyan palabras de dialectos y/o jergas o modismos locales.

ARTICULO 13. - Los canales de televisión podrán operar como operadores-distribuidores, cumpliendo con todas las prescripciones de esta ley.

ARTICULO 14. - El Poder Ejecutivo nacional dentro del término de seis (6) meses de la vigencia de esta ley reglamentará el otorgamiento de crédito de fomento para el doblaje destinado a poblaciones aborígenes.

ARTICULO 15. - El incumplimiento de las obligaciones impuestas por esta ley, será sancionado de acuerdo con la reglamentación que dictará el Poder Ejecutivo Nacional, dentro del término de seis (6) meses de la vigencia de esta ley.

\section{SERVICIOS DE COMUNICACION AUDIOVISUAL}

\section{Ley 26.522 [fragmento]}

Regúlanse los Servicios de Comunicación Audiovisual en todo el ámbito territorial de la República Argentina.

Sancionada: Octubre 10 de 2009. 
Promulgada: Octubre 10 de 2009.

ARTICULO $9^{\mathbf{0}}$ - Idioma. La programación que se emita a través de los servicios contemplados por esta ley, incluyendo los avisos publicitarios y los avances de programas, debe estar expresada en el idioma oficial o en los idiomas de los Pueblos Originarios ${ }^{21}$, con las siguientes excepciones:

a) Programas dirigidos a públicos ubicados fuera de las fronteras nacionales;

b) Programas destinados a la enseñanza de idiomas extranjeros;

c) Programas que se difundan en otro idioma y que sean simultáneamente traducidos o subtitulados;

d) Programación especial destinada a comunidades extranjeras habitantes o residentes en el país;

e) Programación originada en convenios de reciprocidad;

f) Las letras de las composiciones musicales, poéticas o literarias.

g) Las señales de alcance internacional que se reciban en el territorio nacional.

ARTICULO 10. - Autoridad de aplicación. Créase como organismo descentralizado y autárquico en el ámbito del Poder Ejecutivo nacional, la Autoridad Federal de Servicios de Comunicación Audiovisual, como autoridad de aplicación de la presente ley.

ARTICULO 66. - Accesibilidad. Las emisiones de televisión abierta, la señal local de producción propia en los sistemas por suscripción y los programas informativos, educativos, culturales y de interés general de producción nacional, deben incorporar medios de comunicación visual adicional en el que se utilice subtitulado oculto (closed caption), lenguaje de señas y audio descripción, para la recepción por personas con discapacidades sensoriales, adultos mayores y otras personas que puedan tener dificultades para acceder a los contenidos. La reglamentación determinará las condiciones progresivas de su implementación ${ }^{80}$.

ARTICULO 67. - Cuota de pantalla del cine y artes audiovisuales nacionales ${ }^{81}$. Los servicios de comunicación audiovisual que emitan señales de televisión deberán cumplir la siguiente cuota de pantalla:

Los licenciatarios de servicios de televisión abierta deberán exhibir en estreno televisivo en sus respectivas áreas de cobertura, y por año calendario, ocho (8) películas de largometraje nacionales, pudiendo optar por incluir en la misma cantidad hasta tres (3) telefilmes nacionales, en ambos casos producidos mayoritariamente por productoras independientes 
nacionales, cuyos derechos de antena hubieran sido adquiridos con anterioridad a la iniciación del rodaje.

Todos los licenciatarios de servicios de televisión por suscripción del país y los licenciatarios de servicios de televisión abierta cuya área de cobertura total comprenda menos del veinte por ciento (20\%) de la población del país, podrán optar por cumplir la cuota de pantalla adquiriendo, con anterioridad al rodaje, derechos de antena de películas nacionales y telefilmes producidos por productoras independientes nacionales, por el valor del cero coma cincuenta por ciento $(0,50 \%)$ de la facturación bruta anual del año anterior.

Las señales que no fueren consideradas nacionales, autorizadas a ser retransmitidas por los servicios de televisión por suscripción, que difundieren programas de ficción en un total superior al cincuenta por ciento $(50 \%)$ de su programación diaria, deberán destinar el valor del cero coma cincuenta por ciento $(0,50 \%)$ de la facturación bruta anual del año anterior a la adquisición, con anterioridad a la iniciación del rodaje, de derechos de antena de películas nacionales.

\section{DOBLAJE}

Decreto 933/2013 [fragmento]

\section{Ley N²3.316. Reglamentación.}

Bs. As., 15/7/2013

\section{LA PRESIDENTA DE LA NACION ARGENTINA DECRETA:}

Artículo $1^{\circ}$ - La programación que sea emitida a través de los servicios de radiodifusión televisiva contemplados por la Ley $\mathrm{N}^{\circ} 26.522$, incluyendo los avisos publicitarios y los avances de programas, debe estar expresada, en el idioma oficial o en los idiomas de los Pueblos Originarios, con las excepciones previstas en el artículo $9^{\circ}$ de dicha ley.

Art. $2^{\circ}$ - A los fines del cumplimiento de lo dispuesto en el artículo anterior y cuando por el origen de la producción sea necesario el doblaje de programas, películas, series o telefilmes de corto o largo metraje, éste se deberá realizar en las proporciones, términos y condiciones previstos en el artículo $2^{\circ}$ de la Ley $\mathrm{N}^{\circ} 23.316$.

Art. $3^{\circ}$ - Se considera como idioma oficial al castellano neutro según su uso corriente en la REPUBLICA ARGENTINA, pero garantizando su comprensión para todo el público de la América hispanohablante. Asimismo se establece que su utilización no deberá desnaturalizar las obras, particularmente en lo que refiere a la composición de personajes que requieran de lenguaje típico. 
Art. $4^{\circ}$ - Se encuentran alcanzadas por la presente reglamentación las personas físicas o jurídicas de gestión estatal, gestión privada con fines de lucro y gestión privada sin fines de lucro titulares de licencias o autorizaciones de servicios de televisión abierta, así como los titulares de señales de radiodifusión televisiva que se emitan por vínculo físico o satelital en la REPUBLICA ARGENTINA.

Art. $5^{\circ}$ - Establécese la obligatoriedad de la inscripción en el Registro de "Empresas Importadoras Distribuidoras de Programas Envasados para Televisión y de Estudios y Laboratorios de Doblaje", en la órbita del INSTITUTO NACIONAL DE CINE Y ARTES AUDIOVISUALES (INCAA), de las empresas importadoras-distribuidoras de programas, películas, series y telefilmes de ficción dramática hablada en idioma extranjero; y destinados a su emisión mediante radiodifusión televisiva en la REPUBLICA ARGENTINA y de los Estudios y Laboratorios de Doblaje, respectivamente.

Art. $6^{\circ}$ - Las empresas importadoras-distribuidoras y los laboratorios de doblaje que a la fecha se encontraren inscriptos, deberán renovar las pertinentes inscripciones, a las que se les asignará un nuevo número de registro.

Art. $7^{\circ}$ - A los fines de su inscripción, los Estudios y Laboratorios de Doblaje, deberán presentar junto con la solicitud de registro, el material que prevé e artículo $7^{\circ}$ de la Ley $\mathrm{N}^{\circ} 23.316$, a efectos del debido control de calidad.

\section{Art. $9^{\circ}$ - La AUTORIDAD FEDERAL DE SERVICIOS DE COMUNICACION} AUDIOVISUAL (AFSCA) verificará el cumplimiento de lo dispuesto en el artículo $2^{\circ}$ de la presente medida y aplicará a los servicios de radiodifusión televisiva las sanciones correspondientes por su incumplimiento de conformidad con lo dispuesto en el TITULO VI de Ley $\mathrm{N}^{\mathrm{o}} 26.522$ y su normativa reglamentaria.

Art. 10. - Instrúyese al INSTITUTO NACIONAL DE CINE Y ARTES AUDIOVISUALES (INCAA) para que en el plazo de SESENTA (60) días apruebe un régimen de sanciones para las Empresas Importadoras Distribuidoras de Programas envasados para Televisión y para los Estudios y Laboratorios de Doblaje que infrinjan lo dispuesto en la normativa vigente en la materia y en el presente decreto.

Art. 11. - La AUTORIDAD FEDERAL DE SERVICIOS DE COMUNICACION AUDIOVISUAL (AFSCA) y el INSTITUTO NACIONAL DE CINE Y ARTES AUDIOVISUALES (INCAA) podrán iniciar, en el ámbito de sus respectivas competencias, los sumarios por infracciones a la normativa vigente en materia de doblaje, de oficio o por denuncia de terceros. 
Ley 23.316 - Normas que la modifican

07-05-1986

Normativa /

Fecha

Número

publicación Descripción

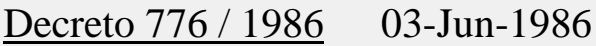

LEY N $^{\circ} 23316$ - SU PROMULGACION

PODER

TENGASE POR LEY DE LA NACION N ${ }^{\circ}$

EJECUTIVO

23.316

NACIONAL

(P.E.N.)

Decreto

$\underline{\text { Reglamentario }}$

$\underline{1091 / 1988}$

PODER

EJECUTIVO

NACIONAL

(P.E.N.)
25-Ago-

1988

\section{LEY $\mathbf{N}^{\circ} 23316$ - SU REGLAMENTACION}

REGLAMENTACION DE LA LEY N 23.316
Decreto

Reglamentario 933

/ 2013

PODER

EJECUTIVO

NACIONAL

(P.E.N.)
17-Jul-2013

LEY 23.316 - REGLAMENTACION

REGLAMENTACION DE LA LEY N ${ }^{\circ}$

23.316. DEROGANSE EL DECRETO $\mathrm{N}^{\circ}$ 1091/88 Y LA RESOLUCION DEL ENTONCES INSTITUTO NACIONAL DE CINEMATOGRAFIA No 344/92.
Resolución 3100 / 04-Nov-

2013

2013

INSTITUTO

NACIONAL DE

CINE Y ARTES

AUDIOVISUALES
CONTROL DE CALIDAD DEL DOBLAJE

EL CONTROL DE CALIDAD DEL DOBLAJE EFECTUADO POR ESTUDIOS Y LABORATORIOS, A LOS FINES QUE DETERMINAN LOS ARTICULOS $7^{\circ} \mathrm{Y} 11^{\circ}$ DE LA LEY 23.316, SERA EFECTUADO POR LA COMISION ASESORA DE EXHIBICIONES CINEMATOGRAFICAS (C.A.E.C.) QUE FUNCIONA EN LA ORBITA DE LA GERENCIA GENERAL DE ESTE INSTITUTO NACIONAL DEL CINE Y ARTES AUDIOVISUALES, Y DEBERA INCORPORAR PARA ESTA TAREA A UN REPRESENTANTE DE LA ASOCIACION 
Normativa /

Número
Fecha

publicación Descripción

ARGENTINA DE ACTORES Y OTRO DEL INSTITUTO SUPERIOR DE ENSEÑANZA RADIOFONICA.

\begin{tabular}{|c|c|c|}
\hline & $\begin{array}{l}\text { Resolución 1368 / } \\
2013 \\
\text { AUTORIDAD } \\
\text { FEDERAL DE } \\
\text { SERVICIOS DE } \\
\text { COMUNICACION } \\
\text { AUDIOVISUAL }\end{array}$ & $\begin{array}{l}\text { TITULARES DE SERVICIOS DE } \\
\text { RADIODIFUSION TELEVISIVA } \\
\text { ABIERTA - INFORMACION } \\
\text { A PARTIR DE LA FECHA DE ENTRADA } \\
\text { EN VIGENCIA DE LA PRESENTE, LOS } \\
\text { TITULARES DE SERVICIOS DE } \\
\text { RADIODIFUSION TELEVISIVA ABIERTA, } \\
\text { DEBERAN CONSIGNAR EN FORMA } \\
\text { CONJUNTA CON LA INFORMACION A } \\
\text { QUE SE HALLAN OBLIGADOS POR } \\
\text { APLICACION DE LO DISPUESTO EN EL } \\
\text { ARTICULO 1 DE LA RESOLUCION No } \\
\text { 1348-AFSCA/12, LOS PROGRAMAS, } \\
\text { PELICULAS, SERIES O TELEFILMES DE } \\
\text { CORTO O LARGO METRAJE, HABLADOS } \\
\text { ORIGINALMENTE EN IDIOMA } \\
\text { EXTRANJERO, QUE HAN SIDO OBJETO } \\
\text { DE DOBLAJE EN LA REPUBLICA } \\
\text { ARGENTINA, EN LOS TERMINOS DE LO } \\
\text { PREVISTO POR LA LEY No } 23.316 \text { Y EL } \\
\text { DECRETO No 933/13. ASIMISMO } \\
\text { DEBERAN INDIVIDUALIZAR: A) EL } \\
\text { TOTAL DE DICHO MATERIAL EMITIDO, } \\
\text { A CUYO EFECTO DEBERA } \\
\text { IDENTIFICARSE CLARAMENTE EL } \\
\text { TITULO Y DURACION DE CADA OBRA; } \\
\text { B) LOS SUPUESTOS QUE SE } \\
\text { ENCUENTRAN EXCEPTUADOS EN LOS } \\
\text { TERMINOS DEL ART. 9 DE LA LEY } 26.522 \\
\text { Y C) EN CASO DE TRATARSE DE UNA } \\
\text { OBRA DE NO FICCION, DEBERAN } \\
\text { CONSIGNAR EL NUMERO DE } \\
\text { RELATORES PARTICIPANTES. }\end{array}$ \\
\hline
\end{tabular}

Resolución 872/ 23-Abr$\underline{2014} \quad 2014$

REGLAMENTO DE LA CAEC DOBLAJE - APROBACION 
Normativa /

Número
Fecha

publicación Descripción
INSTITUTO

NACIONAL DE

CINE Y ARTES

AUDIOVISUALES
APRUEBESE EL REGLAMENTO DE LA CAEC DOBLAJE.

\section{$\frac{\text { Resolución } 3126 /}{2014}$ 01-Dic-2014 FORMULARIOS - APRUEBENSE \\ INSTITUTO \\ APRUEBENSE LOS FORMULARIOS QUE \\ NACIONAL DE \\ CINE Y ARTES OBRAN AGREGADOS A LA PRESENTE COMO ANEXOS. \\ AUDIOVISUALES}

\section{Resolución 796/ \\ 2015 \\ AUTORIDAD \\ FEDERAL DE \\ SERVICIOS DE \\ COMUNICACION \\ AUDIOVISUAL}

16-Sep-2015

TITULARES DE SERVICIOS DE RADIODIFUSION TELEVISIVA ABIERTA - INFORMACION

LOS TITULARES DE SERVICIOS DE RADIODIFUSION TELEVISIVA ABIERTA, LOS TITULARES DE LICENCIAS DE SERVICIOS DE COMUNICACION AUDIOVISUAL POR SUSCRIPCION, POR SU CANAL DE GENERACION PROPIA, Y LOS TITULARES DE SEÑALES NO EXCEPTUADAS POR EL ARTICULO $9^{\circ} \mathrm{DE}$ LA LEY N ${ }^{\circ}$ 26.522, DEBERAN CONSIGNAR EN FORMA CONJUNTA CON LA INFORMACION A QUE SE HALLAN OBLIGADOS POR APLICACION DE LO DISPUESTO EN LA RESOLUCION N ${ }^{\circ} 465$ AFSCA/10 -MODIFICADA POR RESOLUCION N ${ }^{\circ} 1348$-AFSCA/12 Y RESOLUCION $\mathrm{N}^{\circ} 1322$-AFSCA/14 - LAS EMISIONES HABLADAS ORIGINALMENTE EN IDIOMA EXTRANJERO, QUE HAN SIDO OBJETO DE DOBLAJE EN LA REPUBLICA ARGENTINA, EN LOS TERMINOS DE LO PREVISTO POR LA LEY N ${ }^{\circ} 23.316$ Y EL DECRETO N ${ }^{\circ}$ 933/13. 
Normativa /

Número
Fecha

publicación Descripción

\begin{abstract}
Resolución 3935 / 09-Dic-2015
$\underline{2015}$

INSTITUTO

NACIONAL DE

CINE Y ARTES

AUDIOVISUALES

DEPARTAMENTO DE CONTROL INTERNO - CREACION
SUPRIMASE EL AREA DE
COORDINACION DE FISCALIZACION
INTERNA, PREVISTA EN LA
RESOLUCION N ${ }^{\circ}$ 1314/13-INCAA. CREASE
EN EL AMBITO DE LA GERENCIA DE
FISCALIZACION DEL INSTITUTO
NACIONAL DE CINE Y ARTES
AUDIOVISUALES EL DEPARTAMENTO
DE CONTROL INTERNO QUE
DEPENDERA DE LA COORDINACION DE
FISCALIZACION.

Fuente: https://www.argentina.gob.ar/normativa/nacional/ley-23316-23775/normas-modifican 


\section{ANEXO 6: CANCIONES EN RADIO DISNEY}

\section{Nacionalidad de los cantantes cuyas canciones se transmitieron por Radio Disney}

Se analizaron 4 horas de programación de un viernes por la tarde ( 2 horas) y un sábado por la tarde ( 2 horas) de febrero de 2018 y, con excepción de las canciones en inglés (aproximadamente un 20\% del total de canciones), las cantadas en español provenían de los siguientes países:

\begin{tabular}{|c|c|}
\hline CANTANTE & PAÍS \\
\hline Shakira & Colombia \\
\hline David Bisbal & España \\
\hline Tini Stoessel & Argentina \\
\hline Ricky Martin feat. Maluma & Puerto Rico / Colombia \\
\hline Cali y el Dandee & Colombia \\
\hline Sebastián Yatra & Colombia \\
\hline Maite Perroni feat. Cali y el Dandee & México / Colombia \\
\hline Luis Fonsi y Demi Lovato & Puerto Rico / EE.UU. (Nuevo México) \\
\hline Anitta & Brasil \\
\hline Jesse \& Joy feat. Gente de Zona & México / Cuba \\
\hline Luis Fonsi, Daddy Yankee y Justin Bieber & Puerto Rico / Puerto Rico / Canadá \\
\hline $\mathrm{CNCO}$ & Estados Unidos (Miami) \\
\hline Morat y Juanes & Colombia \\
\hline Tini Stoessel y Nacho & Argentina / Venezuela \\
\hline Abraham Mateo, Farruko y Christian Daniel & España / Puerto Rico / Puerto Rico \\
\hline Maxi Trusso & Argentina \\
\hline Anitta y J Balvin & Brasil / Colombia \\
\hline Karol Sevilla & México \\
\hline Luciano Pereyra & Argentina \\
\hline
\end{tabular}

